Taxonomic Tapestries The Threads of Evolutionary, Behavioural and Conservation Research 



\section{Taxonomic Tapestries The Threads of Evolutionary, Behavioural and Conservation Research}

Edited by Alison M Behie and Marc F Oxenham

Chapters written in honour of Professor Colin P Groves

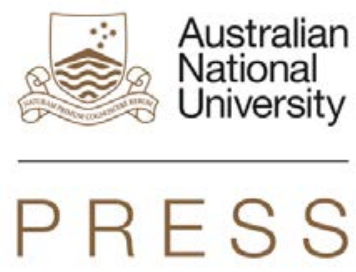




\section{ANU \\ PRESS}

Published by ANU Press

The Australian National University

Acton ACT 2601, Australia

Email: anupress@anu.edu.au

This title is also available online at http://press.anu.edu.au

National Library of Australia Cataloguing-in-Publication entry

Title: Taxonomic tapestries : the threads of evolutionary,

behavioural and conservation research /

Alison M Behie and Marc F Oxenham,

editors.

ISBN:

9781925022360 (paperback) 9781925022377 (ebook)

Subjects: Biology--Classification.

Biology--Philosophy.

Human ecology--Research.

Coexistence of species--Research.

Evolution (Biology)--Research.

Taxonomists.

Other Creators/Contributors: Behie, Alison M., editor.

Oxenham, Marc F., editor.

Dewey Number:

578.012

All rights reserved. No part of this publication may be reproduced, stored in a retrieval system or transmitted in any form or by any means, electronic, mechanical, photocopying or otherwise, without the prior permission of the publisher.

Cover design and layout by ANU Press

Cover photograph courtesy of Hajarimanitra Rambeloarivony

Printed by Griffin Press

This edition (C) 2015 ANU Press 


\section{Contents}

List of Contributors . . . . . . . . . . . . . . . . . . . . . . . vii List of Figures and Tables. . . . . . . . . . . . . . . . ix

\section{PART I}

1. The Groves effect: 50 years of influence on behaviour, evolution and conservation research .................... 3 Alison M Behie and Marc F Oxenham

\section{PART II}

2. Characterisation of the endemic Sulawesi Lenomys meyeri (Muridae, Murinae) and the description of a new species of Lenomys . . . . . . . . . . . . . . . . . . . . . . . . . . 13 Guy G Musser

3. Gibbons and hominoid ancestry. . . . . . . . . . . . . . . . . . 51 Peter Andrews and Richard J Johnson

4. Hurricanes and coastlines: The role of natural disasters in the speciation of howler monkeys . . . . . . . . . . . . . 75 Alison M Behie, Travis S Steffens, Tracy M Wyman, Mary SM Pavelka

5. Adolf Remane: Notes on his work on primates . . . . . . . . . 93 Prof Ulrich Welsch

6. Retouch intensity on Quina scrapers at Combe Grenal: A test of the reduction model . . . . . . . . . . . . . . . . 103 Peter Hiscock and Chris Clarkson

7. What are species and why does it matter? Anopheline taxonomy and the transmission of malaria . . . . . 129 Robert Attenborough

\section{PART III}

8. Lamarck on species and evolution . . . . . . . . . . . . . . 155 Marc F Oxenham 
9. Naming the scale of nature . . . . . . . . . . . 171 Juliet Clutton-Brock

10. Changes in human tooth-size and shape with the Neolithic transition in Indo-Malaysia . . . . . . . . . . . . . 183 David Bulbeck

11. Variation in the Early and Middle Pleistocene: The phylogenetic relationships of Ceprano, Bodo, Daka, Kabwe and Buia . . 215 Debbie Argue

12. Human evolution in Sunda and Sahul and the continuing contributions of Professor Colin Groves . . . . . . . . . . 249 Michael C Westaway, Arthur Durband and David Lambert

\section{PART IV}

13. The domestic and the wild in the Mongolian horse and the takhi . . . . . . . . . . . . . . . . . . 279 Natasha Fijn

14. Rhino systematics in the times of Linnaeus, Cuvier, Gray and Groves. . . . . . . . . . . . . . . . . . . . . . . 299 Kees Rookmaaker

15. Conservation consequences of unstable taxonomies: The case of the red colobus monkeys . . . . . . . . . . 321 John Oates and Nelson Ting

16. The phylogenetic species concept and its role in Southeast Asian mammal conservation . . . . . . . . . . . . 345 Erik Meijaard and Benjamin Rawson

17. Conserving gorilla diversity . . . . . . . . . . . 361 Angela Meder

18. The warp and weft: Synthesising our taxonomic tapestry . . . 373 Marc F Oxenham and Alison M Behie

Index . . . . . . . . . . . . . . . . . 381 


\section{List of Contributors}

Peter Andrews Natural History Museum, Cromwell Road, London, UK SW7 5BD

Debbie Argue School of Archaeology and Anthropology, The Australian National University, Canberra, Australia, 2601

Robert Attenborough School of Archaeology and Anthropology, The Australian National University, Canberra, Australia, 2601; Division of Biological Anthropology, Department of Archaeology \& Anthropology, University of Cambridge, Pembroke Street, Cambridge, UK, CB2 3DZ

Alison M Behie School of Archaeology and Anthropology, The Australian National University, Canberra, Australia, 2601

David Bulbeck Department of Archaeology and Natural History, School of Culture, History and Language, College of Asia and the Pacific, The Australian National University, Canberra, Australia, 2601

Chris Clarkson Department of Archaeology, School of Social Sciences, The University of Queensland, Brisbane, St Lucia, QLD, Australia, 4072

Juliet Clutton-Brock Natural History Museum, Cromwell Road, London, UK, SW7 5BD

Arthur Durband Department of Sociology, Anthropology and Social Work, Kansas State University, 204 Waters Hall, Manhattan, KS, 66502

Natasha Fijn School of Archaeology and Anthropology, The Australian National University, Canberra, Australia, 2601

Peter Hiscock Department of Archaeology, School of Philosophical and Historical Inquiry | Faculty of Arts and Social Sciences, The University of Sydney, Sydney, Australia, 2006

Richard J Johnson University of Colorado, Denver Aurora, USA, CO 80045

David Lambert Griffith School of Environment, Nathan campus, Griffith University, 170 Kessels Road Nathan, QLD, Australia, 4111

Angela Meder Berggorilla \& Regenwald Direkthilfe c/o Rolf Brunner Lerchenstr. 545473 Muelheim, Germany

Erik Meijaard People and Nature Consulting International, Country Woods house no. 306, JL WR Supratman, Pondok-Ranji-Rengas, Ciputat, Jakarta 15412, Indonesia 
Taxonomic Tapestries

Guy G Musser Division of Vertebrate Zoology (Mammalogy), American Museum of Natural History, New York, NY 10024

John Oates Department of Anthropology, Hunter College, City University of New York, 695 Park Avenue, New York, NY 10065

Marc F Oxenham School of Archaeology and Anthropology, The Australian National University, Canberra, Australia, 2601

Mary SM Pavelka Department of Anthropology, The University of Calgary, 2500 University Drive NW, Calgary, Alberta, T2N 1N4

Benjamin Rawson Vietnam Programme, Fauna \& Flora International, 340, Nghi Tam, Hanoi, Vietnam

Kees Rookmaaker Department of Biological Sciences, National University of Singapore, 14 Science Drive 4 Singapore 117543; Rhino Resource Centre

Travis S Steffens Department of Anthropology, University of Toronto, 19 Russell Street, Toronto, Ontario, M5S 2S2

Nelson Ting 308 Condon Hall, Department of Anthropology, 1218 University of Oregon, Eugene, OR 97403

Ulrich Welsch Ludwig Maximilians University Munich, Institute for Anatomy and Cell Biology Schillerstr. 4280336 München Germany

Michael C Westaway Griffith School of Environment, Nathan campus, Griffith University, 170 Kessels Road, Nathan, QLD, Australia, 4111

Tracy M Wyman Department of Anthropology, The University of Calgary, 2500 University Drive NW, Calgary, Alberta, T2N 1N4 


\section{List of Figures and Tables}

\section{Figures}

Figure 2.1 An adult Bunomys chrysocomus skull illustrating limits 14 of cranial and dental measurements employed.

Figure 2.2a Collection localities for modern and subfossil samples of $\quad 17$ Lenomys meyeri.

Figure 2.2b Collection localities for modern and subfossil samples of $\quad 18$ Lenomys meyeri.

$\begin{array}{lll}\text { Figure 2.3 Holotype of Mus meyeri. } & 21\end{array}$

$\begin{array}{lll}\text { Figure 2.4 Skull of the holotype of Mus meyeri. } & 21\end{array}$

Figure 2.5 Young adult female Lenomys meyeri from tropical lowland 25 evergreen rainforest near Tomado, $1000 \mathrm{~m}$.

Figure 2.6 Length of distal white tail segment relative to total 25 length of tail in the sample of Lenomys meyeri.

Figure 2.7 Cranium and left dentary of Lenomys meyeri lampo, 26 an adult female collected at $2200 \mathrm{~m}$ on Gunung Lompobatang.

Figure 2.8 Nomenclature of dental structures using right upper and lower molars of Lenothrix canus.

Figure 2.9 Occlusal views of right maxillary and mandibular molar 28 rows of Lenomys meyeri from Gunung Lompobatang.

Figure 2.10 Specimen scores representing modern examples of Lenomys meyeri projected on first and second principal components.

Figure 2.11 Hillside primary forest along Sungai Sadaunta in area near where Lenomys meyeri was caught.

Figure 2.12 Ground cover over terrace where burrow of Lenomys 33 meyeri was located.

Figure 2.13 Burrow system of Lenomys meyeri excavated on a stream terrace adjacent to Sungai Sadaunta, $915 \mathrm{~m}$.

Figure 2.14 Dentaries from Lenomys obtained in the southwest peninsula. 
Taxonomic Tapestries

Figure 2.15 Occlusal views of subfossil mandibular molar rows from 43 two species of Lenomys.

Figure 2.16 Scores representing specimens of modern and subfossil Lenomys meyeri and subfossil L. grovesi projected on first and second principal components.

Figure 4.1a Total number of storms that crossed through the ranges of Alouatta pigra and Alouatta palliata from 1851 to 2007.

Figure $4.1 \mathrm{~b}$ Total number of hurricanes that crossed through the ranges of Alouatta pigra and Alouatta palliata from 1851 to 2007 .

Figure 5.1 Photograph of Professor Remane.

Figure 6.1 Examples of specimens classified into each of the four scraper classes.

Figure 6.2 Diagrammatic representation of the staged reduction 105 model proposed by Dibble.

Figure 6.3 Notional illustration of the relationship of blank cross109 section and extent of reduction for dorsally retouched Quina scrapers.

Figure 6.4 Illustration of the measurements of reduction used multiple values of Kuhn's (1990) unifacial reduction index and a count of the number of zones.

Figure 6.5 Relationship between Kuhn GIUR and the percentage of original flake mass lost through retouching in the experimental dataset.

Figure 6.6 Histogram of the Kuhn GIUR values for single scrapers from Layer 21.

Figure 6.7 Examples of different levels of reduction on scrapers.

Figure 6.8 Histogram showing differences in the distribution of retouch on specimens classified as single scrapers and transverse scrapers.

Figure 6.9 Illustration of the typological status and reduction history of flakes retouched to different degrees.

Figure 8.1 Diagram 'Showing the Origin of the Various Animals'.

Figure 8.2 This is a modification of Ruse following Bowler's interpretation of Lamarck's scheme. 
Figure 10.1 Dental metrics, Penrose size statistics comparisons.

Figure 10.2 Dental metrics, Penrose shape distances, 17 male samples, 194 32 diameters, seriated average-linkage dendrogram.

Figure 10.3 Dental metrics, Penrose shape distances, 18 male 196 samples, 16 buccolingual diameters, seriated averagelinkage dendrogram.

Figure 10.4 Dental metrics, Penrose shape distances, 19 bisexual 199 samples, 32 diameters, seriated average-linkage dendrogram.

Figure 10.5 Dental metrics, Penrose shape distances, 19 bisexual samples, 16 buccolingual diameters, seriated averagelinkage dendrogram.

Figure 10.6 Dental metrics, Penrose shape distances, 23 bisexual samples, up to 32 diameters, seriated average-linkage dendrogram.

Figure 11.1a Three shortest trees.

Figure 11.1b Three shortest trees.

Figure 11.1c Three shortest trees.

Figure 11.2 Bootstrap analysis.

Figure 11.3 Bodo and H. rhodesiensis.

Figure 11.4 Bodo and H. erectus.

Figure 11.5 Daka and H. erectus.

Figure 11.6 Daka and KNMs.

Figure 11.7 Ceprano and H. erectus.

Figure 11.8 Preferred phylogeny.

Figure 12.1a The extreme thickness of Sangiran 6 is compared to that of Sangiran $1 b$.

Figure 12.1b The very thick corpus of Sangiran 6 is similar to that seen in the Peninj Paranthropus mandible.

Figure 12.1c The posterior view of Sangiran 31 showing the extreme robusticity of the occipital torus.

Figure 12.1d Lateral view of Sangiran 31 showing the extreme robusticity of the occipital torus.

Figure 12.2 Liang Bua 1, the type specimen of Homo floresiensis. 
Taxonomic Tapestries

Figure 12.3a Autapomorphic characters identified in the Ngandong 259 series.

Figure 12.3b Autapomorphic characters identified in the Ngandong 259 series.

Figure 12.4a Robust and gracile Australian fossils often discussed in 261 the Aboriginal origins debate.

Figure 12.4b Robust and gracile Australian fossils often discussed in 262 the Aboriginal origins debate.

Figure 12.5 Theorised representation of the emergence of cranial 263 robusticity associated with the onset of the Last Glacial Maximum.

Figure 13.1 Takhi herd with stallion to the right, Hustai Nuruu National Park.

Figure 13.2 Individual takhi at Hustai Nuruu National Park.

Figure 13.3 A Mongolian horse herd in a snowstorm in spring, 285 Arkhangai Province.

Figure 13.4 A prized Mongolian horse with elaborate saddle and 287 bridle and wild-type characteristics.

Figure 13.5 Mongolian herder with Mongolian horse.

Figure 13.6 A saddled piebald (kharlag) Mongolian horse.

Figure 13.7 Mongolians greeting by passing snuff.

Figure 14.1 Black rhinoceros and skull, sketched by Anders 302 Sparrman.

Figure 14.2 The famous Indian rhinoceros 'Clara', shown all around 303 Europe between 1741 and 1758, depicted behind a human skeleton.

Figure 14.3 A rhinoceros skull drawn by the English physician 304 James Parsons.

Figure 14.4 The first description of the double horned rhinoceros of 305 Sumatra by William Bell.

Figure 14.5 Broadside published by the Dutch professor Petrus 306 Camper to show the differences between skulls of a black rhinoceros obtained from the Cape of Good Hope and of a rhinoceros from Java. 
Figure 14.6 Depiction of a rhino hunt at Chué Spring (Heuningvlei) 306 in South Africa by William Burchell in 1812.

Figure 14.7 Skeleton of the 'Rhinoceros unicorne de Java' in the 307 Paris Museum of Natural History.

Figure 14.8 Lateral view of black rhinoceros called 'Rhinoceros 308 keitloa' drawn by Gerald Ford.

Figure 14.9 Images of the female Sumatran rhino 'Begum' shown in 310 London Zoo from 15 February 1872 to 31 August 1900.

Figure 14.10 Nile rhino from the Lado Enclave in Sudan. Plate drawn by J. Terrier and printed by J. Pitcher.

Figure 15.1 Distribution of 18 allopatric populations of red colobus 326 monkeys that have been given taxonomic names of subspecies or species rank.

Figure 15.2 Geographical distribution of red colobus monkeys 334 according to nine-species arrangement of Groves.

Figure 15.3 Geographical distribution of red colobus monkeys 334 according to 16-species arrangement of Groves.

Figure 15.4 Geographical distribution of red colobus monkeys 335 according to five-species arrangement of Ting.

Figure 16.1 Change over time of the number of South-East Asian pig 347 species described and generally recognised.

Figure 16.2 Change over time of the number of gibbon species 351 described and generally recognised. 
Taxonomic Tapestries

\section{Tables}

Table 2.1 Descriptive statistics for measurements of lengths of head and body, tail, hind foot, and ear, and for weight, derived from modern samples of Lenomys meyeri

Table 2.2 Age, sex, number of teats, and external, cranial, and dental measurements for holotypes associated with Lenomys meyeri

Table 2.3 Descriptive statistics for cranial and dental measurements derived from modern samples of Lenomys meyeri

Table 2.4 Results of principal-components analysis comparing modern specimens of Lenomys meyeri

Table 2.5 Summary of microhabitats at trapping sites and other relevant information for two specimens of Lenomys meyeri collected in Central Sulawesi, 1974-1975

Table 2.6 Subfossil fragments of Lenomys meyeri from the southwest peninsula of Sulawesi

Table 2.7 Measurements of mandibular molars from subfossil and modern samples of Lenomys meyeri and the subfossil specimen of Lenomys grovesi

Table 2.8 Subfossil representatives of murids excavated from Leang Burung 1

Table 2.9 Murid species represented by middle and late Holocene subfossils excavated from caves and rock shelters on the southern end of the southwestern peninsula of Sulawesi

Table 2.10 Results of principal-components analysis comparing modern and subfossil samples of Lenomys meyeri with the subfossil specimen of Lenomys grovesi

Table 3.1 Morphological features of proconsulids related to their form of locomotion

Table 4.1 Howler species (Genus Alouatta) as recognised by Colin Groves in Primate Taxonomy (2001)

Table 4.2 Studies included in behavioural comparisons of Alouatta pigra and A. palliata

Table 6.1 Sample of complete retouched flakes from Layer 21 used in this analysis, presented by implement type.

Table 6.2 Descriptive statistics for the Kuhn GIUR, Retouched zone index, and surface area/platform area ratio of four implement classes in Layer 21 of Combe Grenal.

Table 7.1 Key features of the primary Pacific malaria vectors 
Table 7.2 Selected contrasts in variables relevant to malaria transmission between selected cryptic species in the An. punctulatus and An. gambiae species complexes

Table 10.1 Recent/historical samples used in the comparisons 185

Table 10.2 Historical Sulawesi dental metrics 186

$\begin{array}{lll}\text { Table 10.3 Prehistoric samples used in the comparisons } & 187\end{array}$

$\begin{array}{lll}\text { Table } 10.4 & \text { Early Sulawesi dental metrical data } & 188\end{array}$

Table 10.5 First analysis: square roots of Penrose shape distances (top 193

Table 10.6 Second analysis: square roots of Penrose shape distances 195 (top right) and after calibration and seriation (bottom left)

Table 10.7 Third analysis: square roots of Penrose shape distances (top 198 right) and after calibration and seriation (bottom left)

Table 10.8 Fourth analysis: square roots of Penrose shape distances 200 (top right) and after calibration and seriation (bottom left)

Table 10.9 Fifth analysis, four additional samples: square roots of 202 Penrose shape distances (left) and after calibration and seriation (right)

Table 10.10 Comparative data on major limb-bone lengths ${ }^{(\mathrm{A})}$ in Java 206

Table 10.11 Comparison of Indo-Malaysian tooth size and cranial 207 index

Table 15.1 Taxonomic arrangements of red colobus forms by different authors

Table 15.2 Selected threat status listings of red colobus taxa by IUCN 

PART I 



\title{
1. The Groves effect: 50 years of influence on behaviour, evolution and conservation research
}

\author{
Alison M Behie and Marc F Oxenham
}

This volume explores the complexity, diversity and interwoven nature of taxonomic pursuits primarily within the context of explorations of humans and related species, although it also delves into more distantly related species to show how taxonomy has impacted fields outside of human research. Essentially we are interested in showcasing recent research into that somewhat unique species we call humankind through the theoretical and conceptual approaches afforded by the discipline of biological anthropology. Structurally, our approach to understanding human uniqueness is tripartite in focusing on: (1) the evolution of the human species, (2) the behaviour of primates and other species, and (3) how humans affect the distribution and abundance of other species through anthropogenic impact. In this manner we weave together these three key areas of bio-anthropological endeavour and scrutinise how changes in taxonomic theory and methodology, including our fluctuating understanding of speciation, have recrafted the way in which we view animal behaviour, human evolution and conservation studies.

Taxonomy forms perhaps the most fundamental structural principle of arguably all biological knowledge and research. Indeed, taxonomy is the epistemological cornerstone of the biological sciences. In this context it is somewhat astonishing to note that within the last 20 years significant gaps in taxonomic knowledge have appeared, ostensibly due to a dearth of adequately trained taxonomists in the current generation of scholars. This lacuna, referred to as the taxonomic impediment, is in our view exacerbated by a recent over reliance on 'geno-hype' (Holtzmann, 1999), which refers to our scientific love affair with genetic-based approaches, at the expense of traditional taxonomic principles. Taxonomy, however, is more than its constituent parts, with DNA but one piece of the taxonomic fabric.

While the invention of improved and non-invasive ways to collect DNA has resulted in its resurgence in the field of taxonomy, this reliance on genetics to define species is nothing new. The Biological Species Concept defines species as 'groups of actually or potentially interbreeding natural populations, which are reproductively isolated from other such groups' (Mayr, 1940: 256). This concept, which relies heavily on interbreeding, or lack thereof, to define species, 
has been a mainstream way to view and define species for decades. Despite its common acceptance, there are controversies surrounding it, many of which were brought to the forefront by Professor Colin Groves. One major criticism is that this concept can only be applied to species with overlapping ranges, meaning we cannot differentiate species that do not have the opportunity to attempt breeding due to non-overlapping ranges. In addition, our ability to analyse the genetics of many wild populations has allowed us to see that in some groups hybrid animals may actually be more numerous than the parent species, suggesting that reproductive isolation may not in fact separate species (Groves, 2012).

Up to 24 species concepts have been proposed over the years, but in the interest of brevity, just a few major players will be described here. The Ecological Species Concept proposes that species are groups of animals 'evolving separately from others with its own evolutionary role and tendencies' (Simpson, 1963: 153), which by anyone's definition is a vague concept that would be nearly impossible to apply in practice. The Genetic Species Concept defines species based on the amount of genetic variation both within and between species, assuming more variation between than within species. While simple and logical, it is nearly impossible to determine a cut off point for determining too much (multiple species) or too little (single species) genetic variation. The Phylogenetic Species Concept provides a more encompassing view of species in that they are defined by their possession of unique features and/or characteristics, either primitive or derived, that separate them from other groups (Nixon and Wheeler, 1990). It does not ignore genetics, but does not require different species be genetically incompatible, while also taking into account other features such as morphological similarities (Kimbel and Martin, 1993). It is this concept that has been strongly supported by Colin Groves throughout his career.

To date, debate over the definition of species continues, creating uncertainty for any researcher using species as their basic taxonomic unit of study. While this is an important issue, no volume has yet attempted to examine how changing views on the nature and processes of taxonomy have shaped modern research agendas and interpretations in the key areas of biological anthropology. It is, however, an issue with profound implications and one may ask: Does it matter if different scientists take different approaches to defining species? Will our understanding of evolution and behaviour, or the way in which we attempt to conserve species, really be impacted by the taxonomic classification system we choose to use? Important questions such as these are what this volume explores by using new data to interpret how a fluid and ever changing understanding of taxonomy has led to diverse and disparate research outcomes. The chapters in this volume will explore the significant impacts that these changes have had by investigating both historical perspectives relating to taxonomy and employing 
new data to uncover how the taxonomic impediment has influenced research processes and outcomes, with particular emphasis on humans and our close primate relatives.

\section{Colin Groves}

As one of the world's leading taxonomists, this volume pays tribute to Colin Groves. Professor of Biological Anthropology at The Australian National University, where he has worked for the past 40 years, Colin's influence has spread through multiple disciplines including, but certainly not limited to, animal morphology, animal behaviour, human evolution and conservation. Colin sees himself as a taxonomist above all else, and his dedication to taxonomic pursuits stems directly from his true love of animals, which can perhaps be traced back to his childhood when his grandfather bought him a book on animals. This fascination grew in his teen years, which would see him heading to the London Natural History Museum and requesting access to their bone collections. When it was time to attend university, it is no surprise Colin wanted to study zoology, but as his father had a preference for him to undertake a degree in linguistics, he settled on anthropology as a compromise between the two. And the rest, as they say, is history.

Immediately following his undergraduate years, Colin entered the $\mathrm{PhD}$ program at the University of London under the tutelage of the esteemed John Napier, who was at the time regarded as the leader in primate taxonomy. His doctoral research, completed in 1966, involved a large-scale survey of gorilla skulls. Somewhat serendipitously Colin's work led to a meeting with Dian Fossey, who invited him to Karisoke to see the population of mountain gorillas she is now so famous for studying. Colin's work with gorillas resulted in numerous high impact publications at a very young age, vastly expanding our knowledge of gorilla ecology, biology and morphology. The influence these early years had on Colin can still be seen today in his passion for and involvement in gorilla conservation.

Colin's doctoral research success not only fuelled his future academic pursuits, such as his two-year postdoctoral fellowship at Berkeley and his fixed-term appointment at Cambridge, but also beat a path to his wife of more than 40 years, Phyll. As Colin had studied with John Napier, who worked at the Royal University Hospital at the University of London, it was not surprising that when Colin fell ill in the fall of 1973 he was admitted to that hospital with a request to be put in a private ward due to the fact he was suspected of having tuberculosis, which luckily he did not. He did, however, get placed in a ward where the Ward Sister was one Phyll Dance. She would watch Colin taking the tea cart 
around, not realising it may have been because he wanted a cuppa himself, and playing chess with the elderly patients. Their connection rapidly grew into a whirlwind romance leading to Phyll packing her bags and moving to Australia with Colin just a short four months later when, in January 1973, Colin took up a position at The Australian National University. This is where he has been ever since, supervising scores of Honours, Masters, Doctoral and other graduate students in addition to collaborating with myriad scientists from around the globe, resulting in close to 200 peer-reviewed publications. Lest we forget the opportunities to travel: it also gave him the opportunity to continue to conduct field work expeditions in places such as Tanzania, Indonesia, Rwanda, Kenya and Iran.

Colin's field work adventures have included trips to museums and national parks around the globe, allowing him to study hundreds of species of animal, including every species of rhinoceros, which is still one of his greatest personal achievements. This love of the rhinoceros may have its genesis in the work he did as an undergraduate, which resulted in his first publication, entitled 'On the Rhinoceroses of South-East Asia'. This connection to rhinoceroses remains strong, which would be apparent to anyone who entered the Groves' home and noticed the vast collection of rhinoceros paraphernalia crowding the shelves and walls. When Phyll first met Colin and realised she may too have to participate in these trips, she asked him 'Do you get chased by wild animals?' to which Colin replied 'No. Animals don't chase people.' An answer he may now regret considering they have been chased by lions, a herd of banteng, as well as by a rhinoceros in Ujung Kulon. We might add that this was a rhinoceros they had been cautioned not to get too close to, but Colin with his ever inquisitive nature began to follow, not realising it would soon be following them.

Despite these close calls, Colin has always been a true conservationist. In this respect he was well ahead of his time in understanding the impact of humans on the environment. Phyll can recall when she first took Colin to her home town shortly after they met, he refused a plastic bag from a shop keeper. Although she was embarrassed by this at the time, it just goes to show that he has always been ahead of the game in his devotion to conservation - a devotion that quickly becomes apparent to anyone who has ever heard Colin speak about the plight of wild animals and the need to conserve them. He is avidly involved with conservation organisations, and right here in Canberra he often speaks at fundraising events where he is never shy about voicing his opinion on controversial topics such as the boycotting of products containing palm oil due to the impact palm oil plantations have on Asian wildlife. As taxonomy is the basis for conservation and as 'threats to the natural world and its biodiversity are ubiquitous and accelerating, it affects conservation strategies'. After all, 
how can we know what to conserve if we don't know what species are out there? Links such as these, tying taxonomy to practical and real research outputs, are what have set Colin apart.

Colin has also devoted much of his career to refining mammalian taxonomy, which has resulted in his naming more than 40 taxa, including species of rats, civets, possums and, most famously, the human ancestor, Homo ergaster, which was undertaken with colleague Vratislav Mazák in 1975. This is likely the thing he is most remembered for, but his contributions to the field of human evolution certainly do not end there. As a renowned skeptic and a 30-year member of the Australian Skeptics, Colin is always pushing the boundaries and looking for new ways to understand the world and challenge those around him. This has led to him arguably making more contributions to mammalian taxonomy than any other modern scientist, including the addition of his two influential books Primate Taxonomy and Ungulate Taxonomy, which are now used as landmark taxonomy guides. More recently, Colin has also been a major player in the recent debate surrounding Homo floresiensis and its relationship to modern humans. Never shy to turn away from a debate, he gets great pleasure in educating young people about many things including the truth behind creationism, which is one of the only things he seems to take offence to.

Colin has undoubtedly influenced, directly or indirectly, thousands of people far and wide, which embodies what he truly is: a teacher. Having students in his lab or speaking in schools and getting young people excited about behaviour, morphology, evolution or conservation, or any other topic of interest, makes Colin happy. He is an educator on every level, whether working as a supervisor, mentor or even simply by taking the time to write numerous letters to newspapers to discuss topics of interest. There is no doubt his many undergraduate students enjoy hearing him lecture, his graduate students appreciate his support, supervision and insight, and the staff he has mentored welcome his helpful nature and encyclopaedic knowledge of the discipline.

Despite everything Colin has obviously achieved, what might make him the most endearing to those who know him is his humility. Just recently he was made an honorary member of the American Society of Mammalogists, something which has been bestowed on less than 100 people. He was also the 2014 recipient of an award from the Margot Marsh Biodiveristy Fund for Excellence in Contribution to Primate Conservation. Both awards were a surprise, and to hear Colin tell the story, he didn't even realise that the great person being described as they began the ceremonies was himself. This is not the first time that we have heard Colin say such things. His gentle spirit and true passion for what he does leave no room for ego or arrogance, and all of us who have had the pleasure to work with or even briefly chat with Colin Groves are the better for it. 
Taxonomic Tapestries

\section{Volume structure}

This volume is broken down into four main sections, prefaced by this introduction as Part I. Part II, Chapters 2 through 7, explores the influence of changing taxonomic and speciation mechanisms on studies of behaviour and morphology. Chapter 2 describes a new species of murid rodent endemic to the island of Sulawesi, Lenomys grovesi, a genus that up until now has been thought to be monotypic. Chapters 3 to 5 focus on primatology, with Chapter 3 providing new insights into the evolution of gibbons through consideration of the morphology of their last common ancestor. Chapter 4 considers how natural disasters may play a role in the speciation of New World monkeys, while Chapter 5 summarises, for the first time, the influence of the primatologist Adolf Remane on primatological studies. Chapter 6 turns to the hominid lineage by using new ways of thinking about lithic technology to weigh in on current debates about hominid and Neanderthal cognition. Finally, Chapter 7 explores how changes to the taxonomy of anopheline (malarial) mosquitoes have contributed to our understanding of human malaria transmission.

Part III shifts focus to studies of evolution, starting with Chapter 8, which revisits the contributions of Lamarck's ideas on the nature of species, re-evaluating his contributions to the field of biological evolution. Chapter 9 investigates the changing nature of taxonomy from Aristotle to the current day, with a focus on what this has meant to studies of domestication. The remainder of this section focuses on human evolution, starting with Chapter 10, followed by reviews of how relationships between diet, farming and cooking techniques with reductions in tooth size and corresponding cranial changes can affect evolution in the Holocene human skeletal record. Chapter 11 uses cladistic analyses to test existing hypotheses regarding the phylogenetic relationships of Ceprano, Daka, Kabwe and Bodo in the Early and Middle Pleistocene. Chapter 12 focuses on important new insights that studies of ancient DNA (aDNA) can contribute to our rewriting of the human evolutionary narrative in Sunda and Sahul.

Part IV moves from studying species themselves, to studies that consider how to conserve them. Chapter 13 describes how Mongolians have cooperated with western conservation organisations to enable the takhi to be released back on the Mongolian steppe from a captive existence in zoos and reserves. Chapter 14 describes the history of systematic research of the small group of currently existing species of rhinoceros to better understand rhinoceros conservation needs and plans. Chapters 15 through 17 consider primate conservation. Chapter 15 examines how the ever changing taxonomy of red colobus monkeys has impacted conservation efforts in Africa, while Chapter 16 evaluates the claim that use of the phylogenetic species concept undermines conservation efforts by focusing on two groups of Southeast Asian mammals, pigs (Suidae) 
and gibbons (Hylobatidae). Chapter 17 tries to make sense of the complexity of gorilla conservation in light of ever changing species designations as well as threats. Finally, Chapter 18 synthesises our taxonomic tapestry.

\section{References}

Groves CP. 2012. Species concepts in primates. Am J Primatol 74:687-691.

Holtzman N. 1996. Are Genetic Tests Adequately Regulated? Science 286:409.

Kimbel WH, Martin LB, editors. 1993. Species, species concepts, and primate evolution. New York: Plenum Press.

Mayr E. 1940. Speciation Phenomena in Birds. The American Naturalist 74:249278.

Nixon KC, Wheeler QD. 1990. An amplification of the phylogenetic species concept. Cladistics 6:211-223.

Simpson GG. 1961. Principles of animal taxonomy. Columbia University Press. p. 247. 

PART II 



\title{
2. Characterisation of the endemic Sulawesi Lenomys meyeri (Muridae, Murinae) and the description of a new species of Lenomys
}

\author{
Guy G Musser
}

\section{Introduction}

In 1969, DJ Mulvaney sent me a batch of subfossils excavated by him and his colleagues from caves and rock-shelters in the Makassar region of Sulawesi (Mulvaney and Soejono, 1970). Among them are samples from a cave (Leang Burung 1) containing examples of Lenomys meyeri, a large-bodied rat endemic to Sulawesi, and a single right dentary with an intact molar row that is from a smaller-bodied Lenomys, which represents a new species. The small Lenomys along with specimens of $L$. meyeri were excavated from a level with a radiocarbon date of $2820 \pm 210 \mathrm{BP}$, and other examples of L. meyeri were found in an underlying stratum dated at $3420 \pm 400 \mathrm{BP}$ (Mulvaney and Soejono, 1970: 171).

Here I name and describe the new Lenomys within the context of first characterising L. meyeri by briefly summarising external, cranial, dental, and other traits, sketching its geographic and elevational distributions based upon the small available samples, looking into geographic variation of cranial and dental morphometrics, and providing notes on ecology. The phylogenetic relationships of Lenomys to other murids will not be explored here.

\section{Materials and methods}

Specimens examined (mostly museum study skins and their associated skulls) are stored in the following institutions: the American Museum of Natural History, New York (AMNH); Natural History Museum (formerly British Museum of Natural History), London (BMNH); Museum Zoologicum Bogoriense, Cibinong, Java (MZB; now the Indonesian National Museum of Natural History); Naturhistorisches Museum Basel, Switzerland (NMB); Nationaal Museum of 
Natural History Naturalis (formerly the Rijksmuseum van Natuurlijke Historie), Leiden (RMNH); and National Museum of Natural History, Smithsonian Institution, Washington, DC (USNM).

External measurements were either taken by me or transcribed from collector's notations on skin labels: total length; length of tail (LT); length of hind foot, including claw (LHF); length of ear, from notch to crown (LE); and body weight or mass (W). Length of head and body (LHB) was derived by subtracting tail length from total length.
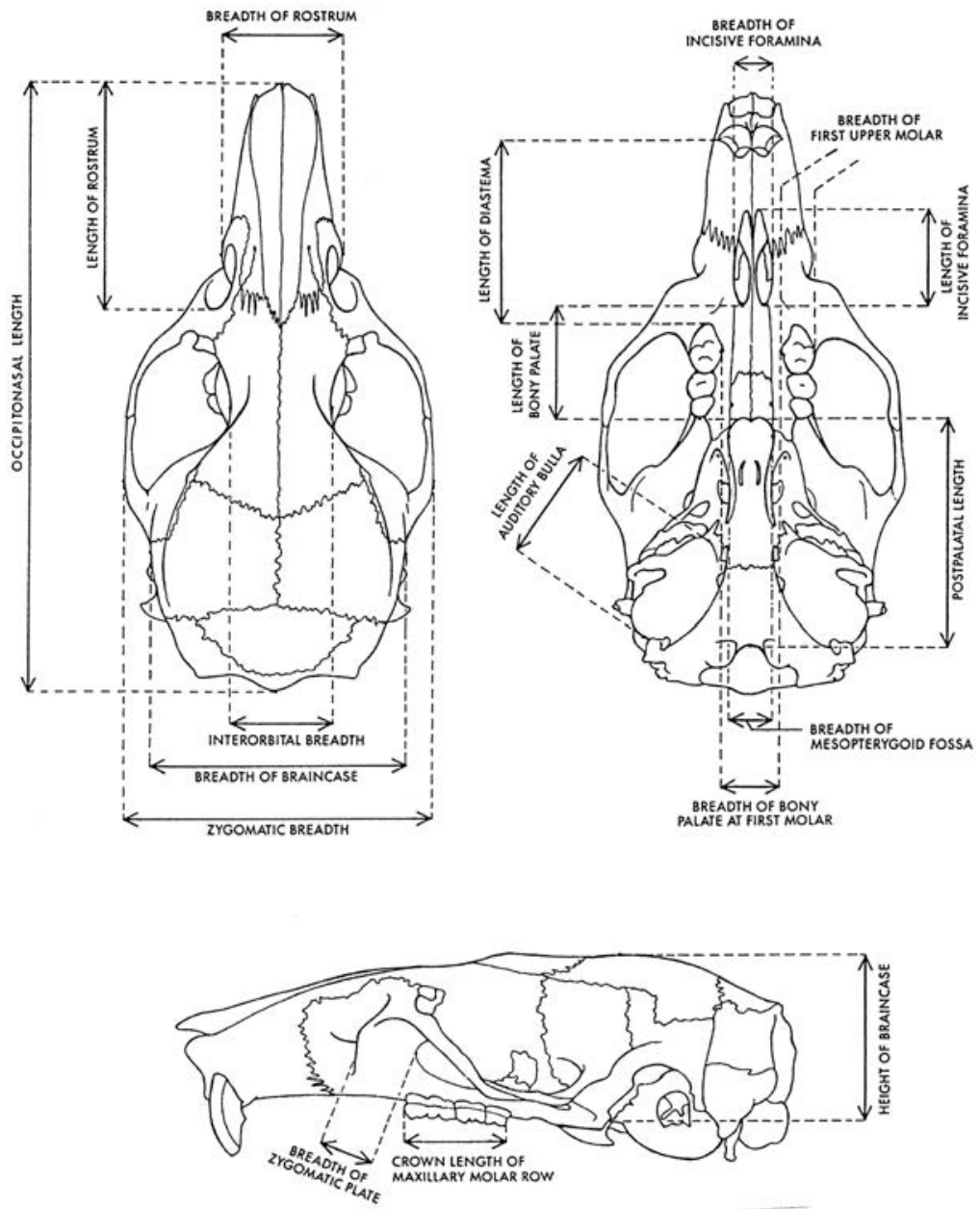

Figure 2.1: An adult Bunomys chrysocomus skull illustrating limits of cranial and dental measurements employed. See text for additional definitions.

Source: Drawing by Patricia Wynne. 
Using dial calipers graduated to tenths of a millimetre, I measured the following cranial and dental dimensions (illustrated in Figure 2.1):

$O N L=$ occipitonasal length (greatest length of skull; distance from tip of nasals to posterior margin of occiput)

$Z B=$ zygomatic breadth (greatest breadth across zygomatic arches)

$I B=$ interorbital breadth (least distance across the frontal bones between the orbital fossae)

$L R=$ length of rostrum (from tip of nasal bones to posterior margin of zygomatic notch)

$B R=$ breadth of rostrum (greatest breadth across rostrum, including bony nasolacrimal capsules)

$B B C=$ breadth of braincase (measured from just above the squamosal root of each zygomatic arch)

$H B C=$ height of braincase (from top of braincase to ventral surface of basisphenoid)

$B Z P=$ breadth of zygomatic plate (distance between anterior and posterior edges of zygomatic plate)

$L D=$ length of diastema (distance from posterior alveolar margins of upper incisors to anterior alveolar margin of $\mathrm{Ml}$ )

$P P L=$ postpalatal length (distance from posterior margin of palatal bridge to posterior edge of basioccipital - ventral lip of foramen magnum)

$L B P=$ length of bony palate (distance from posterior edge of incisive foramina to posterior margin of bony palate)

$B B P=$ breadth of bony palate at Ml (least distance between lingual alveolar margins of first molars)

$L I F=$ length of incisive foramina (distance from anterior to posterior margins)

$B I F=$ breadth across incisive foramina (greatest distance across both foramina)

$B M F=$ breadth of mesopterygoid fossa (distance from one edge of mesopterygoid fossa to the other)

$L B=$ length of ectotympanic (auditory) bulla (greatest length of bullar capsule, excluding the bony eustachian tube) 
CLM1-3 = crown length of maxillary molar row (from anterior enamel face of M1 to posterior enamel face of M3)

alm1-3 = alveolar length of mandibular molar row (from anterior alveolar rim of $\mathrm{ml}$ to posterior alveolar rim of $\mathrm{m} 3$ )

clm1-3 = crown length of mandibular molar row (from anterior enamel face of $\mathrm{ml}$ to posterior enamel face of $\mathrm{m} 3$ )

$B M 1=$ breadth of first maxillary (upper) molar (taken across widest part of molar)

$b m 1, b m 2, b m 3=$ breadths of first, second and third mandibular (lower) molars (taken across widest part of molar).

$M=$ maxillary (upper) molars

$M=$ mandibular (lower) molars

Cranial and dental measurements were obtained only from adults: animals clothed in adult pelage with occlusal surfaces of molars expressing the range from slight (young adults) to moderate (adults) to well worn where cusp patterns are nearly obliterated (old adults). Sexes were not separated in any of the statistical analyses because of the small number of specimens in each geographic sample. Furthermore, weak sexual dimorphism in cranial and dental variables generally characterises nongeographic sexual variation among muroid rodents (Musser, 2014; Musser and Durden, 2014).

Standard univariate descriptive statistics (mean, standard deviation, and observed range) were calculated for samples containing modern and fossil examples of $L$. meyeri and the new species. Principal-component analyses were computed using original cranial and dental measurements transformed to natural logarithms. Principal components were extracted from a variancecovariance matrix; loadings (correlations) of the variables are given as Pearson product-moment correlation coefficients of the extracted principal components. Probability levels denoting significance of the correlations are unadjusted. The statistical packages in SYSTAT 11 for Windows, Version 11 (2005), were used for all analytical procedures. 


\section{Gazetteer and specimens}

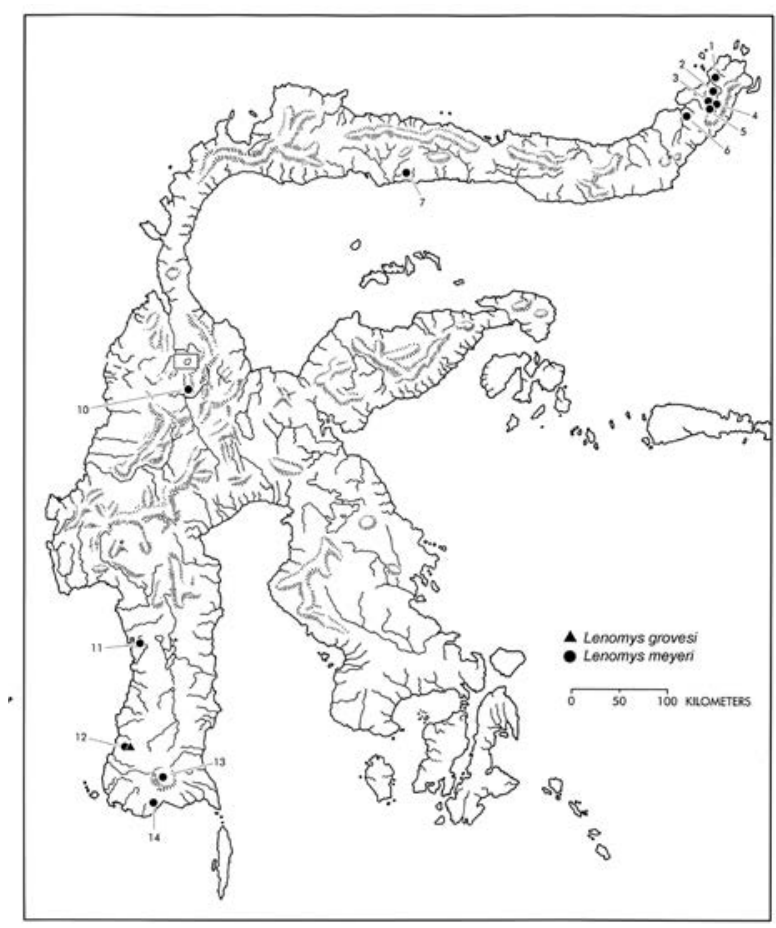

Figure 2.2a: Collection localities for modern and subfossil samples of Lenomys meyeri. Numbers key to localities described in the gazetteer. The map in Figure 2.2b contains collection localities 8 and 9. Locality 12 designates Leang Burung 1, the cave where subfossil dentaries of $L$. meyeri and $L$. grovesi $\mathrm{n}$. sp. were excavated (see gazetteer); the other subfossils come from caves and rock-shelters at locality 14. The Tempe Depression mentioned in text is at about the level of Parepare (locality 11).

Notes: Sulawesi consists of a central region from which four arms or peninsulas radiate: the northern peninsula, which ends in a northeastern jog; the eastern peninsula; the southeastern peninsula; the southwestern peninsula. I use these informal labels when describing the distribution of Lenomys, and refer to the central portion as Sulawesi's core. I also use the Indonesian names for mountain (Gunung), stream or river (Sungai), and lake (Danau).

Source: Drawing by Patricia Wynne. 


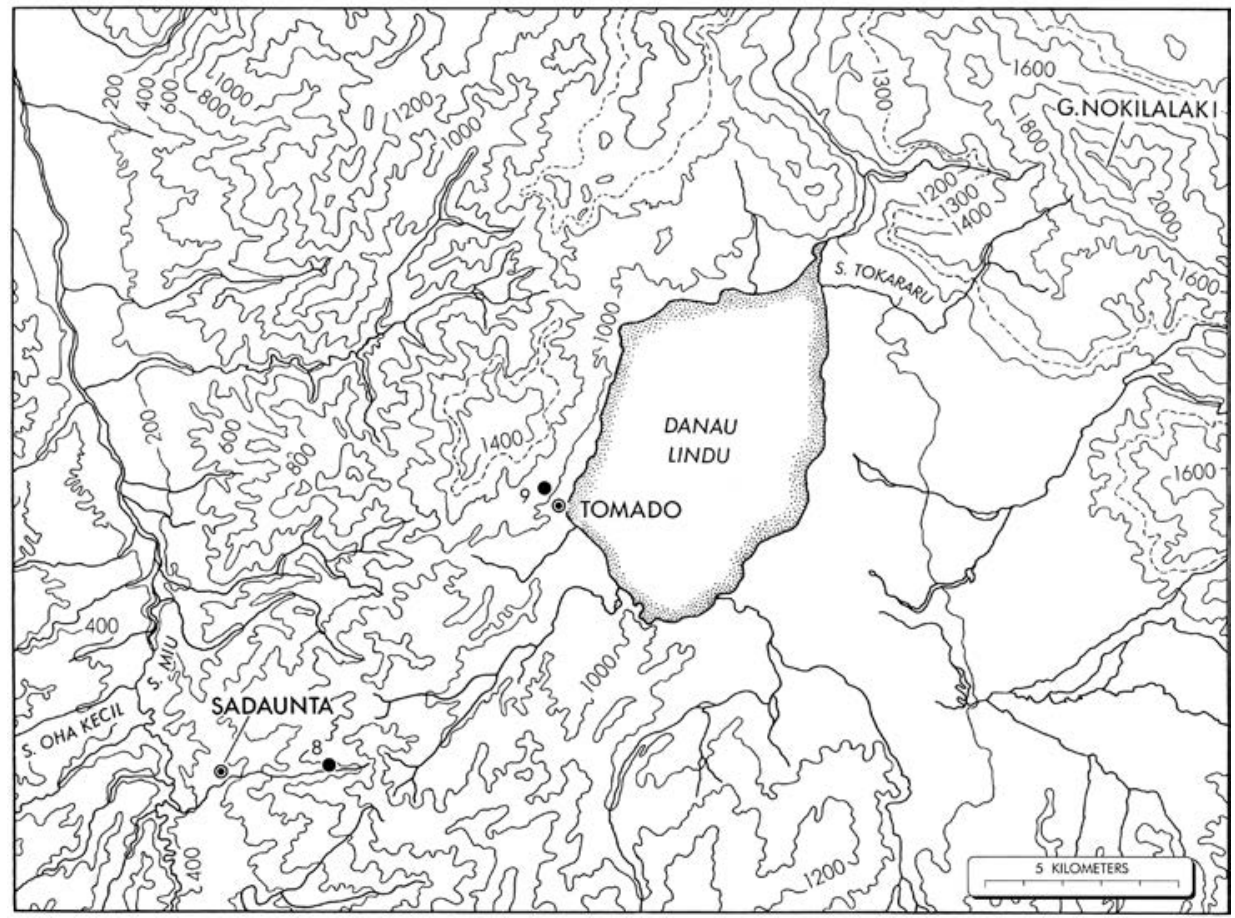

Figure 2.2b: Collection localities for modern and subfossil samples of Lenomys meyeri. Numbers key to localities described in the gazetteer. The map in Figure 2.2b contains collection localities 8 and 9; dashed contour line at $1300 \mathrm{~m}$ marks approximate boundary between tropical lowland evergreen and tropical lower montane rainforests.

Notes: Sulawesi consists of a central region from which four arms or peninsulas radiate: the northern peninsula, which ends in a northeastern jog; the eastern peninsula; the southeastern peninsula; the southwestern peninsula. I use these informal labels when describing the distribution of Lenomys, and refer to the central portion as Sulawesi's core. I also use the Indonesian names for mountain (Gunung), stream or river (Sungai), and lake (Danau).

Source: Drawing by Patricia Wynne.

Listed below are the localities at which the 27 modern and 20 subfossil specimens of Lenomys meyeri I examined were collected. The number preceding each place keys to the same numbered locality on the maps in Figures 2.2a and 2.2b. Cartographic and gazetteer sources for latitudes, longitudes, and spellings are referenced in Musser and others (2010).

1. Manado, $01^{\circ} 30^{\prime} \mathrm{N}, 124^{\circ} 50^{\prime} \mathrm{E}$, coastal plain near sea level: RMNH 21233 .

2. Rurukan, $01^{\circ} 21^{\prime} \mathrm{N}, 124^{\circ} 52^{\prime} \mathrm{E}, 3500 \mathrm{ft}(1067 \mathrm{~m})$ : BMNH 97.1.2.19.

3. Gunung Masarang, $01^{\circ} 19^{\prime} \mathrm{N}, 124^{\circ} 51^{\prime} \mathrm{E}, 3800 \mathrm{ft}(1159 \mathrm{~m})$ : BMNH 97.1.2.20. 
4. Tomohon, $01^{\circ} 19^{\prime} \mathrm{N}, 124^{\circ} 49^{\prime} \mathrm{E}, 700-800 \mathrm{~m}$ BMNH 99.10.1.9; NMB 1208, 3326, $3327,1110 / 4759$.

5. Langoon, $01^{\circ} 09^{\prime} \mathrm{N}, 124^{\circ} 50^{\prime} \mathrm{E}, 700-800 \mathrm{~m}$ : RMNH 18302 (holotype of Mus meyeri).

6. Amurang, $01^{\circ} 11^{\prime} \mathrm{N}, 124^{\circ} 35^{\prime} \mathrm{E}$, coastal plain near sea level: BMNH 21.2.9.4; MZB 384, 5810 .

7. Bumbulan, $00^{\circ} 29^{\prime} \mathrm{N}, 122^{\circ} 04^{\prime} \mathrm{E}$, coastal plain near sea level: AMNH 153011 .

8. Valley of Sungai Miu, Sungai Sadaunta, $01^{\circ} 23^{\prime} \mathrm{S}, 119^{\circ} 58^{\prime} \mathrm{E}, 3000 \mathrm{ft}(915 \mathrm{~m})$ : AMNH 226813, 226814.

9. Valley of Danau Lindu, forest near Tomado (a village on western shore of Danau Lindu), $01^{\circ} 19^{\prime} \mathrm{S}, 120^{\circ} 03^{\prime} \mathrm{E}, 1000 \mathrm{~m}$ : AMNH 224317.

10. Gimpu, $01^{\circ} 36^{\prime} \mathrm{S}, 120^{\circ} 02^{\prime} \mathrm{E}, 400 \mathrm{~m}$ : USNM 219712 (holotype of Lenomys longicaudus).

11. Parepare, $04^{\circ} 01^{\prime} \mathrm{S}, 119^{\circ} 38^{\prime} \mathrm{E}$, coastal plain near sea level: RMNH 18303. This is the cranium discussed, figured, and identified as Mus callitrichus by Jentink (1890: pl. 10, Figures 4-6, Plate 120).

12. Leang Burung 1, a cave near the village of Pakalu, 'about $2 \mathrm{~km}$ north of the main road from Maros, $10 \mathrm{~km}$ to the west' (Mulvaney and Soejono, 1970: 169), less than 100 m: AMNH 265022-265028 (subfossils). The dentary of Lenomys grovesi n. sp. was also collected here (Table 2.8).

13. Wawokaraeng, Gunung Lompobatang, an extinct volcanic mountain near the tip of the southwestern peninsula, 05 ${ }^{\circ} 20^{\prime} \mathrm{S}, 1^{\circ} 9^{\circ} 55^{\prime} \mathrm{E}$ : $2200 \mathrm{~m}$, AMNH 101125 , 101127, 101128 (holotype of Lenomys meyeri lampo), 101129; 2300 m, AMNH $101126 ; 2400$ m, ANMH 101124.

14. Panganreang Tudea, a rock shelter at the southern tip of the southwestern peninsula (see description and map in Mulvaney and Soejono, 1970: 166): subfossil Specimen Numbers 2-10 documented by Musser (1984). Batu Ejaja, a cave 'a few hundred meters distant' from Panganreang Tudea (Mulvaney and Soejono, 1970: 166), 275 m: subfossil Specimen Number 1 documented by Musser (1984). Batu Edaja 2, a rock shelter near Batu Edjaja (see description Mulvaney and Soejono, 1970): AMNH 265029-265031 (subfossils).

The following specimens were examined but their provenances were not mapped:

A. Minahassa, Warumbungan: RMNH 2797. 
B. RMNH 18304; a skull listed as specimen 'c' under 'Mus giganteus' in Jentink's 'Catalogue Ostéologique des Mammifères', published in 1887 (p. 210); 'Java' is listed as provenance, but the skull is Lenomys meyeri.

\section{Lenomys (Thomas, 1898)}

The mounted skin and partial skull shown in Figures 2.3 and 2.4 are the basis for Jentink's (1879: 12-13) short and undiagnostic description of Mus meyeri. Later, Thomas (1898: 409) recognised the distinctive attributes of meyeri, proposed the genus Lenomys to contain it, and provided a diagnosis that applies to the genus and to L. meyeri. The characterisation of L. meyeri follows.

\section{Lenomys meyeri (Jentink, 1879)}

Mus meyeri Jentink, 1879: 12.

Lenomys longicaudus Miller and Hollister, 1921b: 5.

Lenomys meyeri lampo Tate and Archbold, 1935b: 5.

\section{Holotype and type locality}

The holotype is RMNH 18302; the skin and skull of an adult (sex not determined) obtained in September 1875 by SCIW van Musschenbroek, and is listed as specimen ' $a$ ' in Jentink's (1888: 65) 'Catalogue Systématique des Mammifères'. External, cranial, and dental measurements, along with other relevant data, are listed in Table 2.2.

The skin is mounted in a pose meant to simulate the living rat (Figure 2.3); the fur is discoloured, a straw-brown. The cranium is incomplete: pieces of nasals and right zygomatic arch, and ventral and occipital portions of the braincase are missing (Figure 2.4). Except for worn angular processes, the mandible is intact. All incisors and molars are present and undamaged.

The type locality is Langoon $\left(01^{\circ} 09^{\prime} \mathrm{N}, 124^{\circ} 50^{\prime} \mathrm{E}\right), 700-800 \mathrm{~m}$ (locality 4 in gazetteer and Figure 2.2a), northeastern tip of the northern peninsula, Propinsi Sulawesi Utara, Indonesia. Jentink (1879: 13) noted the 'habitat' to be 'Celebes, Menado', but information attached to the holotype indicates it came from 'Menado, Langowan' (now spelled Langoon). 


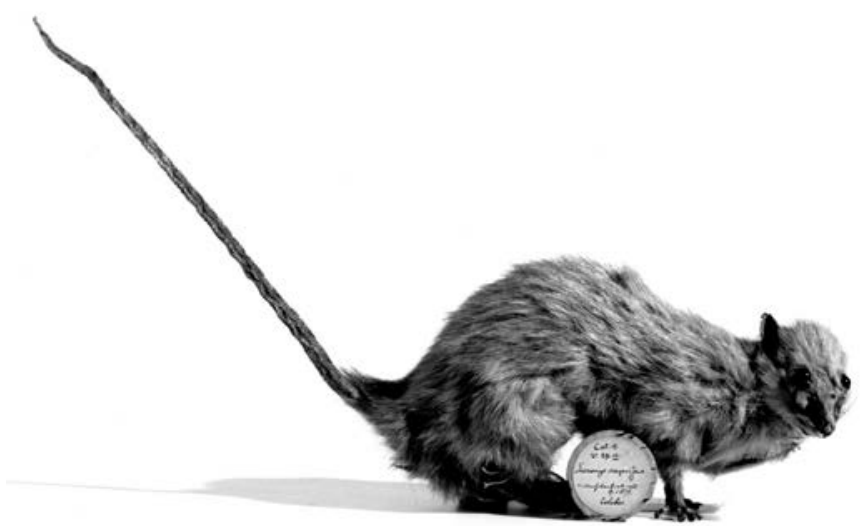

Figure 2.3: Holotype of Mus meyeri (RMNH 18302; listed as specimen ' $a$ ' in Jentink's [1888: 65] 'Catalogue Systématique des Mammifères'). Measurements are listed in Table 2.2.

Source: Photograph by Peter Goldberg.
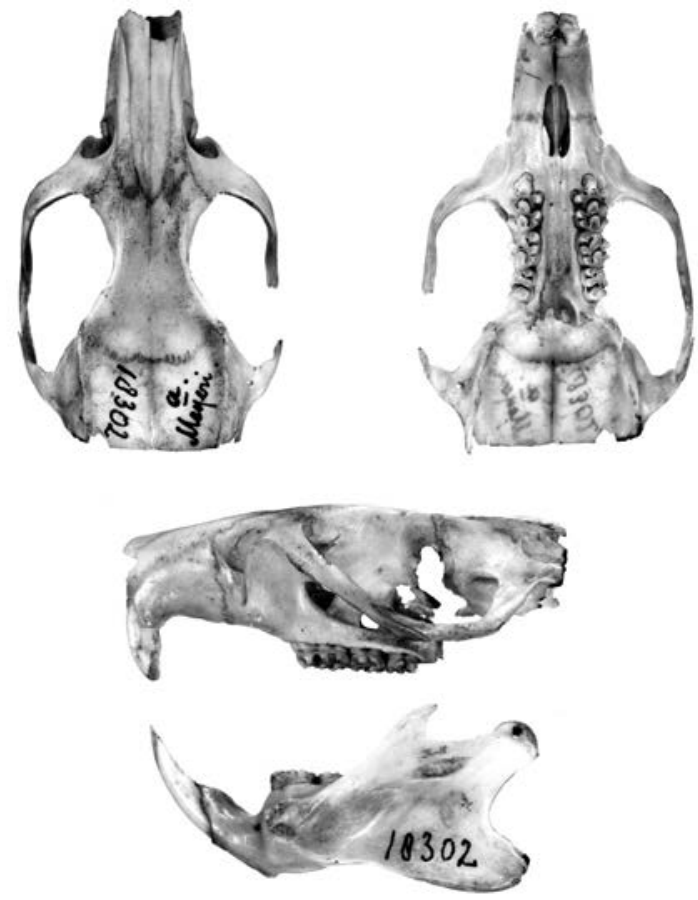

Figure 2.4: Skull of the holotype of Mus meyeri (RMNH 18302. See Table 2.2 where measurements are listed. X2

Source: Photograph by Peter Goldberg. 


\section{Geographic and elevational distributions}

Because provenances of specimens are few and scattered, the actual range of $L$. meyeri is unknown; most samples are from the northeastern tip of the northern peninsula and the southern end of the southwestern peninsula (Figure 2.2a). While broad swaths of Sulawesi, including all of the eastern and southeastern peninsulae as well as most of the central portion, are without records of L. meyeri, I suspect its range extends over most of Sulawesi wherever suitable forest habitats remain.

Modern specimens from north of the southwestern peninsula have been collected from the coastal plain near sea level to 1,159 m, an elevational range in which tropical lowland evergreen rainforests dominate, or at least did in the past (I use Whitmore's [1984] terminology for forest formations). Maryanto and others (2009: 47) record a specimen of 'Lenomys meyeri' from about 2,100 $\mathrm{m}$ in 'cloud forest' in Lore Lindu National Park, which is in the northern section of central Sulawesi. I had worked in the same region but obtained L. meyeri only at lower elevations in tropical lowland evergreen rainforest, and Eropeplus canus, which externally closely resembles Lenomys, only high in mountain forest; I suspect their specimen is an example of E. canus.

South of the Tempe Depression (the swampy and lake-filled lowlands bisecting the peninsula at its northern margin at about the latitude of Parepare), examples of $L$. meyeri are represented by subfossils excavated from caves in lowlands (100-275 m) and modern samples obtained in montane forest at 2,200-2,400 m on Gunung Lompobatang - the only place where the species is accurately recorded from montane forest habitats.

Table 2.1: Descriptive statistics for measurements of lengths of head and body, tail, hind foot, and ear, and for weight, derived from modern samples of Lenomys meyeri.

\begin{tabular}{|l|r|r|r|r|}
\hline \multicolumn{1}{|c|}{ Variable } & \multicolumn{1}{|c|}{ Northeast } & Northcentral & Core & Southwest Peninsula \\
\hline LHB & $\begin{array}{r}281.5 \pm 13.63 \\
(270-301) 4\end{array}$ & 256 & $\begin{array}{r}253.3 \pm 16.80 \\
(235-268) 3\end{array}$ & $\begin{array}{r}265.7 \pm 11.34 \\
(245-275) 6\end{array}$ \\
\hline LT & $\begin{array}{r}277.4 \pm 2.51 \\
(275-280) 5\end{array}$ & 242 & $\begin{array}{r}270.7 \pm 10.07 \\
(260-280) 3\end{array}$ & $\begin{array}{r}277.3 \pm 19.74 \\
(240-298) 6\end{array}$ \\
\hline LT/LHB (\%) & 99 & 95 & 107 & 104 \\
\hline LHF & $\begin{array}{r}47.2 \pm 0.84 \\
(46-48) 5\end{array}$ & 47 & $\begin{array}{r}47.7 \pm 1.53 \\
(46-49) 3\end{array}$ & $\begin{array}{r}48.2 \pm 1.72 \\
(46-50) 6\end{array}$ \\
\hline LE & - & 28 & $\begin{array}{r}27.0 \pm 1.41 \\
(26-28) 2\end{array}$ & $\begin{array}{r}26.3 \pm 1.51 \\
(24-28) 6\end{array}$ \\
\hline W & - & - & $\begin{array}{r}322.5 \pm 3.54 \\
(320-325) 2\end{array}$ & - \\
\hline
\end{tabular}


Notes: Measurements are in millimetres, weight in grams. Mean $\pm 1 \mathrm{SD}$, observed range (in parentheses), and size of sample are listed. Mean values were used to compute LT/LHB. Variable abbreviations are defined in the text. Specimens measured are listed below:

Northeast - Amurang: BMNH 21.2.9.4, MZB 5810. Gunung Masarang: BMNH 97.1.2.20. Rurukan: BMNH 97.1.2.19. Langowan: RMNH 18302 (holotype of Mus meyeri). All were measured by collectors other than me.

Northcentral - Bumbulan: AMNH 153011 (measured by JJ Menden).

Core - Sadaunta: AMNH 226813. Tomado: AMNH 224317 (these two were measured by me). Gimpu: USNM 219712 (holotype of Lenomys longicaudus; measured by HC Raven).

Southwest Peninsula - Gunung Lompobatang: AMNH 101124-27, 101128 (holotype of Lenomys meyeri lampo), 101129 (all measured by G Heinrich)

Source: Author's data.

Table 2.2: Age, sex, number of teats, and external, cranial, and dental measurements for holotypes associated with Lenomys meyeri.

\begin{tabular}{|c|c|c|c|}
\hline & $\begin{array}{l}\text { Mus meyeri } \\
\text { RMNH } \\
18302 \\
\end{array}$ & $\begin{array}{c}\text { Lenomys longicaudus } \\
\text { USNM } \\
219712 \\
\end{array}$ & $\begin{array}{c}\text { Lenomys meyeri lampo } \\
\text { AMNH } \\
101128 \\
\end{array}$ \\
\hline Age & Adult & Adult & Adult \\
\hline Sex & $?$ & Female & Female \\
\hline LHB & 275 & 235 & 275 \\
\hline$\overline{L T}$ & 280 & 260 & 276 \\
\hline LT/LHB (\%) & 102 & 111 & 100 \\
\hline LWS & 128 & 82 & 145 \\
\hline LWS/LT (\%) & 46 & 32 & 53 \\
\hline TSR/CM & 7 & 7 & 7 \\
\hline LHF & 46 & 48 & 47 \\
\hline$\overline{\mathrm{LE}}$ & - & - & 25 \\
\hline LDF & $20-25$ & $25-30$ & $25-30$ \\
\hline Teats & $?$ & 2 inguinal pairs & 2 inguinal pairs \\
\hline$\overline{O N L}$ & - & 56.2 & 57.2 \\
\hline $\mathrm{ZB}$ & 27.5 & 27.1 & 28.2 \\
\hline IB & 7.5 & 7.3 & 7.0 \\
\hline LR & - & 15.7 & 17.4 \\
\hline$\overline{B R}$ & 10.1 & 10.3 & 9.6 \\
\hline $\mathrm{BBC}$ & - & 19.3 & 18.7 \\
\hline $\mathrm{HBC}$ & - & 14.4 & 13.5 \\
\hline BZP & 6.5 & 5.6 & 6.1 \\
\hline LD & 13.1 & 13.9 & 16.0 \\
\hline PPL & - & 19.2 & 19.0 \\
\hline LBP & 14.4 & 14.4 & 14.8 \\
\hline $\mathrm{BBP}$ & 2.6 & 2.8 & 3.1 \\
\hline BMF & 3.5 & 3.3 & 3.0 \\
\hline LIF & 7.3 & 6.9 & 9.1 \\
\hline $\mathrm{BIF}$ & 2.8 & 2.8 & 3.0 \\
\hline LB & - & 7.8 & 8.8 \\
\hline CLM1-3 & 12.1 & 10.8 & 11.0 \\
\hline BM1 & 3.5 & 3.2 & 3.3 \\
\hline
\end{tabular}

Notes: Measurements are in millimetres. Unless otherwise indicated, I copied from skin tags the values for external measurements; I measured the cranial and dental dimensions. Variable acronyms are defined in the text. 
Taxonomic Tapestries

For the holotype of meyeri, I measured lengths of head and body, tail, and white tail segment on the mounted skin. In the original description of RMNH 18302, Jentink listed $290 \mathrm{~mm}$ and $270 \mathrm{~mm}$, respectively, for lengths of head and body and tail. For the holotype of longicaudus, I measured lengths of tail, white tail segment, and hind foot on the stuffed museum study skin; $280 \mathrm{~mm}$ for the tail and $45 \mathrm{~mm}$ for the hind foot are recorded on the skin label.

Number of scale rings per centimetre on the tail (TSR/CM) was counted about one-third the distance from its base.

To measure lengths of overfur and guard hairs on the dorsum (LDF), I placed a ruler at a right angle to the skin surface on the back near the rump and recorded the approximate mark where ends of the bunched hairs rested.

Source: Author's data.

\section{Description}

Adult Lenomys meyeri are physically large with a short and wide head, stocky body, small ears, and moderately long tail (LHB $=235-301 \mathrm{~mm}, \mathrm{LT}=240$ $298 \mathrm{~mm}, \mathrm{LHF}=46-50 \mathrm{~mm}, \mathrm{LE}=24-28 \mathrm{~mm}, \mathrm{~W}=320-325 \mathrm{~mm}$; Figure 2.5, Table 2.1). Fur covering upperparts is dense, woolly, soft, and long (length of underfur $=15-30 \mathrm{~mm}$, depending on elevation of provenance), with guard hairs extending 5-10 $\mathrm{mm}$ beyond the underfur layer; overall colour ranges from grayish brown to dark brownish gray and is without patterning except for brownish black areas at the base of the mystacial vibrissae. The dark dorsal coat extends onto the basal 50-55 $\mathrm{mm}$ of the tail. The small ears are dark gray or brownish gray and finally haired on the margins. Ventral coat is short (10$15 \mathrm{~mm}$ ) and grayish white (hairs with gray bases and unpigmented tips) or whitish gray. Tail is bicoloured, scantily haired, and ranges from being slightly shorter than length of head and body to slightly longer (LT/LHB $=95-107 \%$ ); scale hairs are moderately large (Table 2.2), each scale bearing three short hairs; basal portion of tail is dark brownish gray, distal $32-63 \%$ is white (Figure 6). Front and hind feet are short and broad; all dorsal surfaces (tarsal, metatarsal, and digital) are dark brown, claws are stout and unpigmented. Palmar and plantar surfaces are naked, unpigmented and adorned with large fleshy pads (three interdigitals, thenar and hypothenar on palmar surface; four interdigitals, thenar and hypothenar on plantar surfaces).

Females have two pairs of inguinal teats.

The cranium is large and stocky (Figure 2.7). Characteristic features are its short rostrum; stout zygomatic arches that bow widely out from sides of the rostrum and braincase; strong supraorbital ridges that transform posteriorly into postorbital shelves that extend posteriorly as pronounced temporal ridges all the way to the occiput where they fuse with the lamboidal ridges; trapezoidshaped interparietal; wide zygomatic plate; large premaxillary foramen, 
moderately short and wide incisive foramina; long, deeply scored bony palate; wide mesopterygoid region with moderately long and wide sphenopalatine vacuities; large ectotympanic bulla; and no alisphenoid strut.

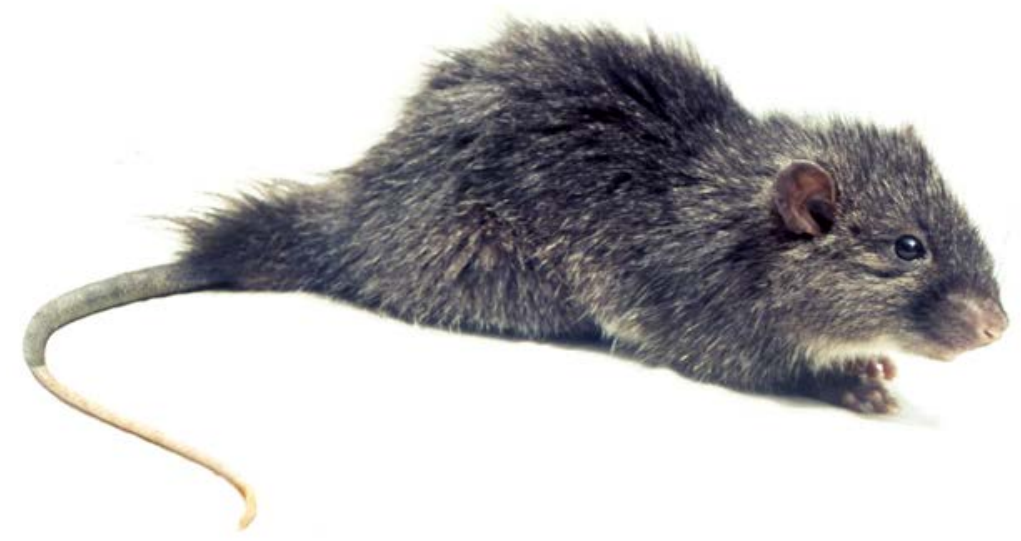

Figure 2.5: Young adult female Lenomys meyeri (AMNH 224317) from tropical lowland evergreen rainforest near Tomado, $1000 \mathrm{~m}$. Collected May 16, 1974.

Source: Photograph by Author.

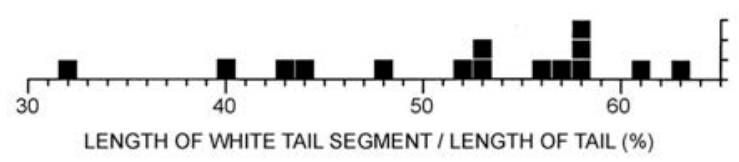

Figure 2.6: Length of distal white tail segment relative to total length of tail in the sample of Lenomys meyeri. I measured the distal white segment (in $\mathrm{mm}$ ) on freshly caught rats in the field and on dry museum preparations.

Source: Drawing by Patricia Wynne.

A carotid arterial circulation that is derived for muroid rodents in general but primitive for members of subfamily Murinae (character-state 2 of Carleton, 1980; pattern 2 described by Voss, 1988; diagrammed for Oligoryzomys by Carleton and Musser, 1989), is present in L. meyeri as indicated by the presence of a large stapedial foramen in the petromastoid fissure, a deep groove extending from the middle lacerate foramen to the foramen ovale on the ventral posterolateral surface of each pterygoid plate, and no sphenofrontal foramen or squamosalalisphenoid groove. Each robust dentary has a pronounced coronoid process and stout condyloid and angular processes; the ramus anterior to the molar row is short and thick. 
Incisors are broad and robust, enamel layers are orange in the uppers and pale orange in the lowers; uppers emerge from the rostrum at either a right angle or curve slightly back.

Maxillary (upper) and mandibular (lower) molars are robust, moderately highcrowned, with sharply defined large and high angular cusps, and only slight overlapping occurs between molars in each row (Figure 2.9). Typically, Ml is anchored by five roots, M2 by four, and M3 by three. The same pattern of roots is found on the lower molars, with the exception of AMNH 265022, in which $\mathrm{m} 4$ has five roots and $\mathrm{m} 3$ has four.

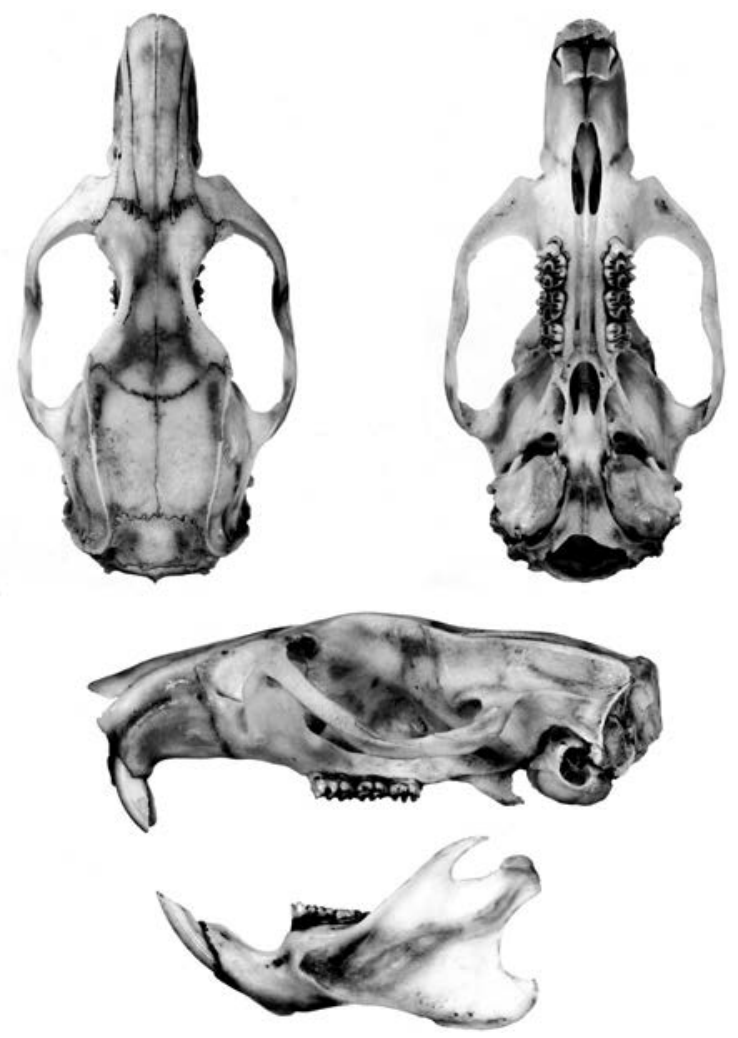

Figure 2.7: Cranium and left dentary of Lenomys meyeri lampo (AMNH 101128, the holotype), an adult female collected at $2200 \mathrm{~m}$ on Gunung Lompobatang. X2.

Source: Photograph by Peter Goldberg. 


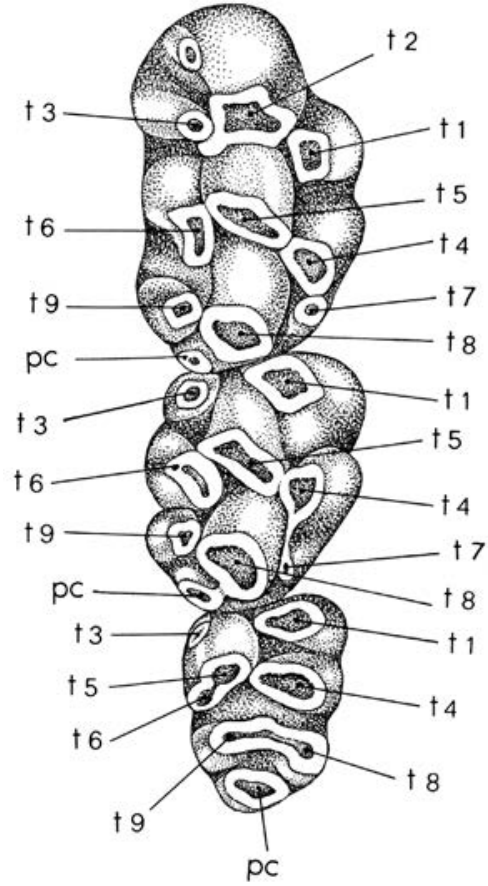

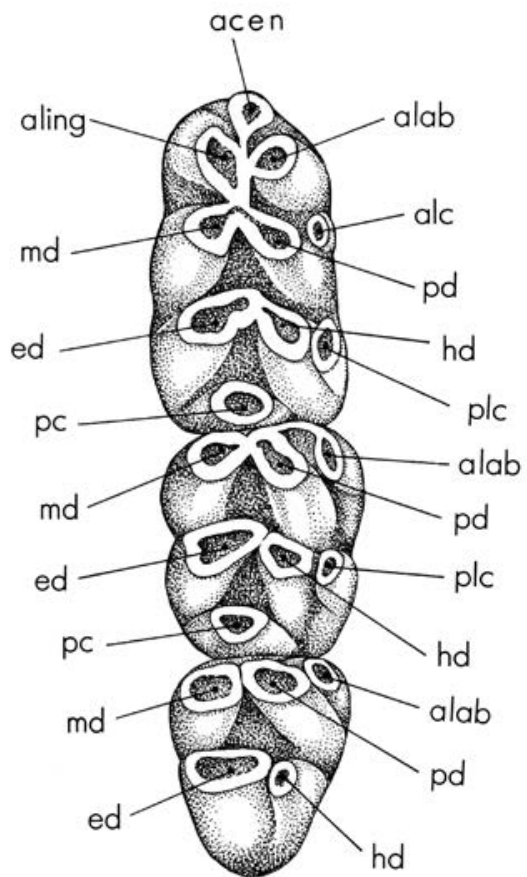

Figure 2.8: Nomenclature of dental structures using right upper and lower molars of Lenothrix canus. Maxillary molars: Cusps are numbered according to Miller's (1912) scheme and are referred to in the text with the prefix ' $t$ '; pc, posterior cingulum. Mandibular molars: The anterocentral cusp (acen), anterolabial cusp (alab), and anterolingual cusp (aling) form the anteroconid; an anterior labial cusplet (alc) is present on the first molar and posterior labial cusplets (plc) occur on all three teeth; primary cusp rows are formed by the protoconid (pd) and metaconid (md), and the hypoconid (hd) and entoconid (ed); a posterior cingulum (pc) sits at the back of first and second molars (adapted from van de Weerd, 1976: 44).

Source: Drawing by Patricia Wynne.

Occlusal cusp patterns seen in Lenomys are unique among endemic Sulawesi murids. Distinctive features of the maxillary molars, in addition to the tall and discrete cusps, are a prominent cusp $\mathrm{t} 7$ on all molars (indistinct on M3 in some specimens because it has partially fused with the adjacent cusp t8); a prominent cusp t3 on M2 and M3; a posterior cingulum that is a moderately large and discrete cusp on all molars of many specimens, but an enamel ridge or bump on other specimens; prominent crests (enamel and dentine) extending backwards from cusps $t 1$ and $t 3$ on M1, from cusp tl on M2, from cusps $t 4$ and t6 on Ml 
and M2 (stephanodonty; see Misonne, 1969: 55). In some specimens, the crests extending from cusps $t 4$ and $t 6$ merge with the anterior faces of cusps $t 7$ and t9 to form a circle consisting of cusps and crests on M1 and M2.
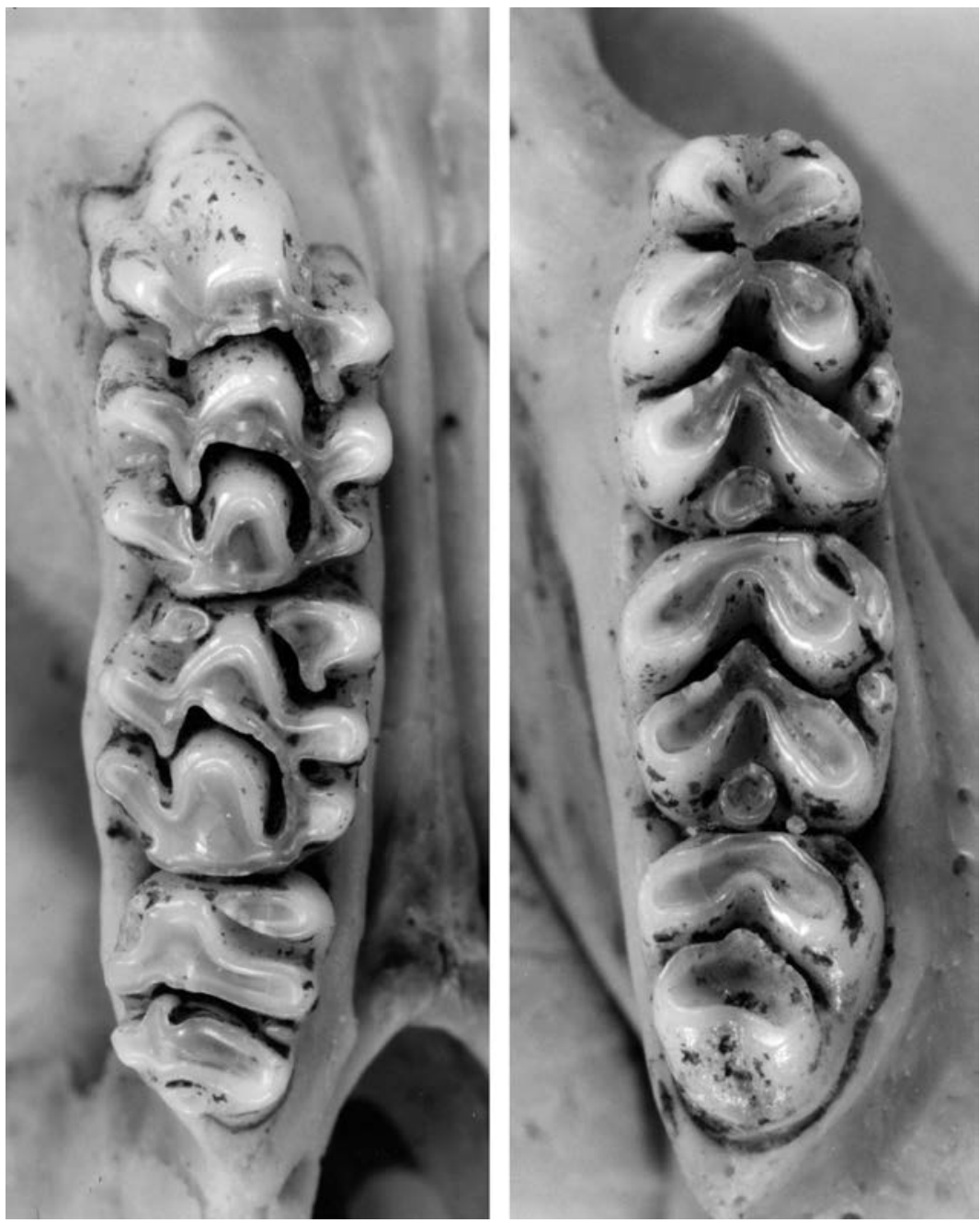

Figure 2.9: Occlusal views of right maxillary (left image) and mandibular (right image) molar rows of Lenomys meyeri (AMNH 101127) from Gunung Lompobatang. X10. See Figure 2.8 for cusp labels.

Source: Photograph by Peter Goldberg.

Occlusal cusp patterns of mandibular molars are equally distinctive (Figures 2.9, 2.15). In many specimens, a mid-sagittal enamel crest connects the anteroconid and the second cusp row, and that row is also connected with the posterior cusp row by a mid-sagittal crest in some specimens. In all specimens, the anteroconid 
is formed by two large and discrete cusps, and a small anterocentral cusp is present on some molars (Figure 2.15, centre) but absent from other specimens (Figure 2.15, right). Additional elaborations are anterior and posterior cusplets on $\mathrm{m} 1$, an anterolabial cusp and posterior labial cusplet on $\mathrm{m} 2$, an anterolabial cusp on $\mathrm{m} 3$, and prominent posterior cingula on $\mathrm{ml}$ and $\mathrm{m} 2$.

In addition to the cranial and dental traits summarised here, there is information covering spermatozoan morphology. The sperm head is symmetrical without hooks, and the spermatozoan tail is attached to the midbasal region of the head (Breed and Musser, 1991). Among the Sulawesian species of murines surveyed by Breed and Musser, only Eropeplus canus and Taeromys celebensis share similar morphologies.

\section{Geographic variation}

If there is more than one species in Lenomys, it is not clearly evident in the modern material at hand, which consists of small samples ( $1-6$ specimens) from widely separated localities (Figure 2.2). Variation in fur colour (upper parts range from grayish brown to dark brownish gray, underparts whitish gray to grayish white, dorsal fur thick and woolly to thinner and harsher) forms no apparent geographic pattern. Cranial and dental measurements suggest a pattern that must be substantiated by measurements from larger samples. The montane sample from Gunung Lompobatang averages a longer and wider skull (ONL and ZB), zygomatic plate (BZP) and bony palate (BBP); longer diastema (LD) and incisive foramina (LIF); and larger bullae (LB) than other geographic samples (Table 2.3). The variation is summarised by the distribution of specimen scores projected on first and second principal components in Figure 2.10. Size influences spread of the scores along the first axis (largest to the right), with loadings of the variables noted above being most forceful $(r=0.62-0.88)$ - the three scores for the Gunung Lompobatang series are farthest to the right. Long incisive foramina and large bullae were among the traits used by Tate and Archbold (1935: 5) to distinguish L. m. lampo. The cranium from Parepare (at the southern margin of the Tempe Depression) also has long incisive foramina (8.7 $\mathrm{mm}$ according to Hooijer, 1950: 76), thus falling within the range of the Lompobatang sample. Scatter of scores for the other specimens likely reflect individual and age variation within adults. For example, the points for specimens from the northeast (filled circle) are scattered along the first component and all are adults. Aside from the possible separation of the Gunung Lompobatang sample, no other apparent geographic pattern emerges from the analysis; samples, however, are small. A principal-component analysis (not illustrated) employing only dental variables, which allowed me to use the subfossil material, revealed no significant geographic pattern in dental measurements, and no separation of the Lompobatang toothrows. 
Taxonomic Tapestries

Table 2.3: Descriptive statistics for cranial and dental measurements derived from modern samples of Lenomys meyeri.

\begin{tabular}{|c|c|c|c|c|}
\hline Variable & $\begin{array}{l}\text { Northeast } \\
N=5\end{array}$ & $\begin{array}{l}\text { Northcentral } \\
N=1\end{array}$ & $\begin{array}{l}\text { Core } \\
N=2\end{array}$ & $\begin{array}{l}\text { Southwest Peninsula } \\
N=3\end{array}$ \\
\hline ONL & $\begin{array}{r}53.8 \pm 1.70 \\
(52.3-56.4)\end{array}$ & 54.8 & $\begin{array}{r}54.7 \pm 2.12 \\
(53.2-56.2)\end{array}$ & $\begin{array}{r}55.4 \pm 2.02 \\
(53.2-57.2)\end{array}$ \\
\hline ZB & $\begin{array}{r}27.0 \pm 1.06 \\
(25.8-28.4)\end{array}$ & 27.2 & $\begin{array}{r}26.6 \pm 0.71 \\
(26.1-27.1) \\
\end{array}$ & $\begin{array}{r}27.5 \pm 0.64 \\
(27.0-28.2)\end{array}$ \\
\hline IB & $\begin{array}{r}8.0 \pm 0.21 \\
(7.8-8.3)\end{array}$ & 8.0 & $\begin{array}{r}7.1 \pm 0.28 \\
(6.9-7.3)\end{array}$ & $\begin{array}{r}7.2 \pm 0.29 \\
(7.0-7.5)\end{array}$ \\
\hline LR & $\begin{array}{r}15.6 \pm 0.38 \\
(15.2-16.2)\end{array}$ & 16.1 & $\begin{array}{r}15.4 \pm 0.42 \\
(15.1-15.7) \\
\end{array}$ & $\begin{array}{r}15.9 \pm 1.50 \\
(14.4-17.4)\end{array}$ \\
\hline BR & $\begin{array}{r}10.1 \pm 0.30 \\
(9.7-10.4)\end{array}$ & 10.5 & $\begin{array}{r}10.2 \pm 0.14 \\
(10.1-10.3)\end{array}$ & $\begin{array}{r}9.6 \pm 0.25 \\
(9.4-9.9)\end{array}$ \\
\hline BBC & $\begin{array}{r}19.3 \pm 0.18 \\
(19.1-19.5)\end{array}$ & 18.9 & $\begin{array}{r}18.9 \pm 0.64 \\
(18.4-19.3)\end{array}$ & $\begin{array}{r}19.0 \pm 0.35 \\
(18.7-19.4)\end{array}$ \\
\hline $\mathrm{HBC}$ & $\begin{array}{r}13.4 \pm 0.45 \\
(12.8-14.0)\end{array}$ & 13.5 & $\begin{array}{r}14.1 \pm 0.49 \\
(13.7-14.4)\end{array}$ & $\begin{array}{r}13.7 \pm 0.25 \\
(13.5-14.0)\end{array}$ \\
\hline BZP & $\begin{array}{r}5.9 \pm 0.30 \\
(5.5-6.3) \\
\end{array}$ & 6.5 & $\begin{array}{r}5.8 \pm 0.28 \\
(5.6-6.0)\end{array}$ & $\begin{array}{r}6.2 \pm 0.36 \\
(5.9-6.6) \\
\end{array}$ \\
\hline LD & $\begin{array}{r}13.8 \pm 0.84 \\
(13.0-15.1)\end{array}$ & 15.1 & $\begin{array}{r}13.7 \pm 0.35 \\
(13.4-13.9)\end{array}$ & $\begin{array}{r}14.9 \pm 1.15 \\
(13.7-16.0)\end{array}$ \\
\hline PPL & $\begin{array}{r}19.8 \pm 0.35 \\
(19.4-20.2)\end{array}$ & 19.1 & $\begin{array}{r}19.5 \pm 0.42 \\
(19.2-19.8)\end{array}$ & $\begin{array}{r}19.7 \pm 1.02 \\
(19.0-20.9)\end{array}$ \\
\hline LBP & $\begin{array}{r}13.6 \pm 0.38 \\
(13.1-14.0)\end{array}$ & 13.0 & $\begin{array}{r}13.3 \pm 1.56 \\
(12.2-14.4)\end{array}$ & $\begin{array}{r}14.3 \pm 0.44 \\
(14.0-14.8)\end{array}$ \\
\hline BBP & $\begin{array}{r}2.7 \pm 0.29 \\
(2.3-3.1) \\
\end{array}$ & 2.8 & $2.8 \pm 0.00$ & $\begin{array}{r}3.0 \pm 0.31 \\
(2.7-3.3) \\
\end{array}$ \\
\hline BMF & $\begin{array}{r}3.1 \pm 0.17 \\
(3.0-3.4)\end{array}$ & 3.5 & $\begin{array}{r}3.3 \pm 0.07 \\
(3.2-3.3)\end{array}$ & $3.0 \pm 0.00$ \\
\hline LIF & $\begin{array}{r}7.6 \pm 0.31 \\
(7.1-7.9)\end{array}$ & 8.5 & $\begin{array}{r}7.4 \pm 0.71 \\
(6.9-7.9)\end{array}$ & $\begin{array}{r}8.9 \pm 0.47 \\
(8.4-9.3)\end{array}$ \\
\hline BIF & $\begin{array}{r}3.1 \pm 0.16 \\
(2.9-3.3) \\
\end{array}$ & 3.2 & $\begin{array}{r}3.2 \pm 0.49 \\
(2.8-3.5) \\
\end{array}$ & $\begin{array}{r}3.1 \pm 0.07 \\
(3.0-3.3) \\
\end{array}$ \\
\hline LB & $\begin{array}{r}8.3 \pm 0.39 \\
(7.9-8.7)\end{array}$ & 8.1 & $\begin{array}{r}7.8 \pm 0.07 \\
(7.7-7.8)\end{array}$ & $\begin{array}{r}8.9 \pm 0.21 \\
(8.7-9.1)\end{array}$ \\
\hline CLM1-3 & $\begin{array}{r}11.8 \pm 0.34 \\
(11.3-12.2)\end{array}$ & 10.5 & $\begin{array}{r}11.1 \pm 0.42 \\
(10.8-11.4)\end{array}$ & $\begin{array}{r}11.5 \pm 0.56 \\
(11.0-12.1)\end{array}$ \\
\hline BM1 & $\begin{array}{r}3.5 \pm 0.23 \\
(3.3-3.8)\end{array}$ & 3.2 & $\begin{array}{r}3.5 \pm 0.35 \\
(3.2-3.7)\end{array}$ & $\begin{array}{r}3.4 \pm 0.23 \\
(3.3-3.7) \\
\end{array}$ \\
\hline
\end{tabular}

Notes: Measurements are in millimetres. Mean \pm 1 SD and observed range (in parentheses) are listed. Specimens measured are indicated below.

Northeast-Gunung Masarang: BMNH 97.1.2.20. Tomohon: NMB 3327, 4759. Amurang: BMNH 21.2.9.4; MZB 5810.

Northcentral - AMNH 153011.

Core - Tomado: AMNH 224317. Gimpu: USNM 219712 (holotype of Lenomys longicaudus).

Southwest Peninsula - Gunung Lompobatang: AMNH 101125, 101126, 101128 (holotype of Lenomys meyeri lampo).

Source: Author's data. 
2. Characterisation of the endemic Sulawesi Lenomys meyeri (Muridae, Murinae)

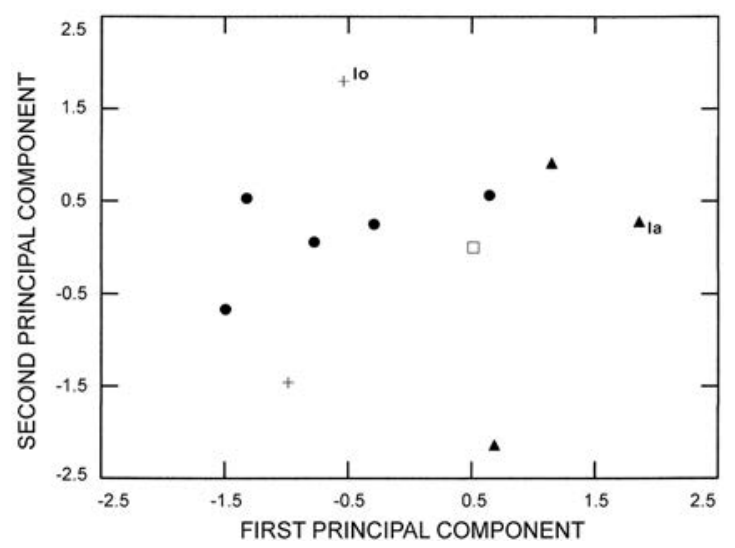

Figure 2.10: Specimen scores representing modern examples of Lenomys meyeri projected on first and second principal components extracted from principalcomponents analysis of 16 cranial and two dental log-transformed variables. Symbols: filled circle $=$ northern peninsula east of Gorontalo region $(N=5$; Amurang, Gunung Masarang, Tomohon); empty square = Bumbulan, west of Gorontalo region $(N=1)$; cross $=$ central region $(N=2$; Gimpu, Tomado); filled triangle $=$ southwest peninsula ( $N=3$; Gunung Lompobatang). Abbreviations identify scores for holotypes: la = Lenomys meyeri lampo; lo = Lenomys longicaudus. See Table 2.4 for correlations of variables and percent variance.

Source: Author's data.

Table 2.4: Results of principal-components analysis comparing modern specimens of Lenomys meyeri.

\begin{tabular}{|l|r|r|}
\hline \multicolumn{1}{|c|}{ Variable } & \multicolumn{2}{|c|}{ Correlations } \\
\hline & PC1 & PC2 \\
\hline ONL & $0.70(\mathrm{C})$ & 0.23 \\
\hline ZB & $0.71(\mathrm{C})$ & 0.40 \\
\hline IB & -0.43 & 0.35 \\
\hline LR & 0.45 & -0.08 \\
\hline BR & -0.26 & 0.09 \\
\hline BBC & -0.14 & 0.21 \\
\hline HBC & 0.19 & 0.23 \\
\hline BZP & $0.62(\mathrm{C})$ & -0.40 \\
\hline LD & $0.88(\mathrm{~A})$ & -0.03 \\
\hline PPL & -0.11 & $-0.66(\mathrm{C})$ \\
\hline LBP & 0.56 & 0.43 \\
\hline BBP & $0.76(\mathrm{~B})$ & 0.40 \\
\hline BMF & -0.43 & 0.22 \\
\hline LIF & $0.82(\mathrm{~B})$ & -0.52 \\
\hline BIF & -0.23 & $-0.85(\mathrm{~A})$ \\
\hline LB & $0.64(\mathrm{C})$ & -0.19 \\
\hline CLM1-3 & -0.16 & -0.43 \\
\hline BM1 & -0.44 & $-0.63(\mathrm{C})$ \\
\hline Eigenvalue & 0.022 & 0.012 \\
\hline \% Variance & 38.4 & 19.9 \\
\hline
\end{tabular}

Notes: Correlations (loadings) of log-transformed values for 16 cranial and 2 dental variables are based on 11 specimens; see Figure 2.10.

(A) $\mathrm{P} \leq 0.001$; (B) $\mathrm{P} \leq 0.01$; (C )P $\leq 0.05$. 
The specimen from Gimpu is the holotype of L. longicaudus, which Miller and Hollister (1921: 95) thought was distinctive because its tail is longer than length of head and body, but they had no comparative material at hand, and among the specimens I examined tail length ranges from slightly shorter to slightly longer than length of head and body (Table 2.1). The dental traits they highlighted in their diagnosis are not diagnostic and fall within the range of variation seen in larger samples of L. meyeri.

\section{Ecological notes}

Observations provided here come from my capture of a young adult male from Tomado (AMNH 224317) and an adult female from Sungai Sadaunta (AMNH 226813) in lowland tropical evergreen rainforest (see Table 2.5 for details).

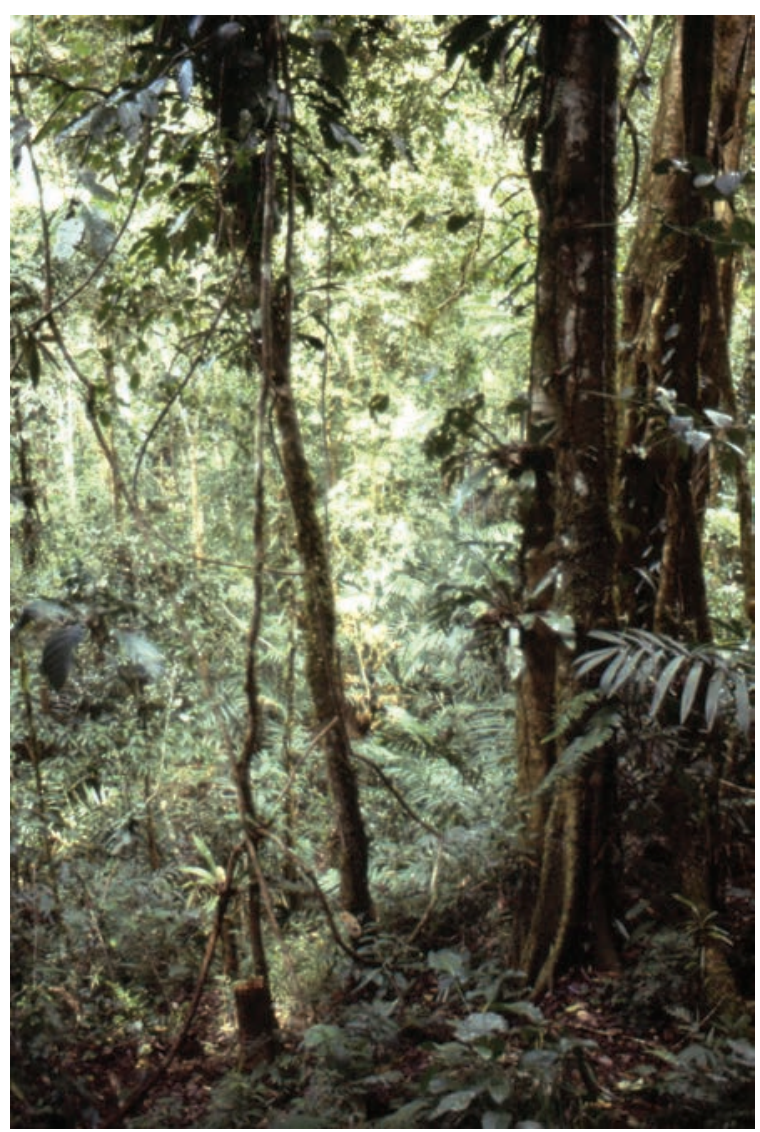

Figure 2.11: Hillside primary forest along Sungai Sadaunta in area near where Lenomys meyeri was caught. Photographed in 1976.

Source: Photograph by Author. 


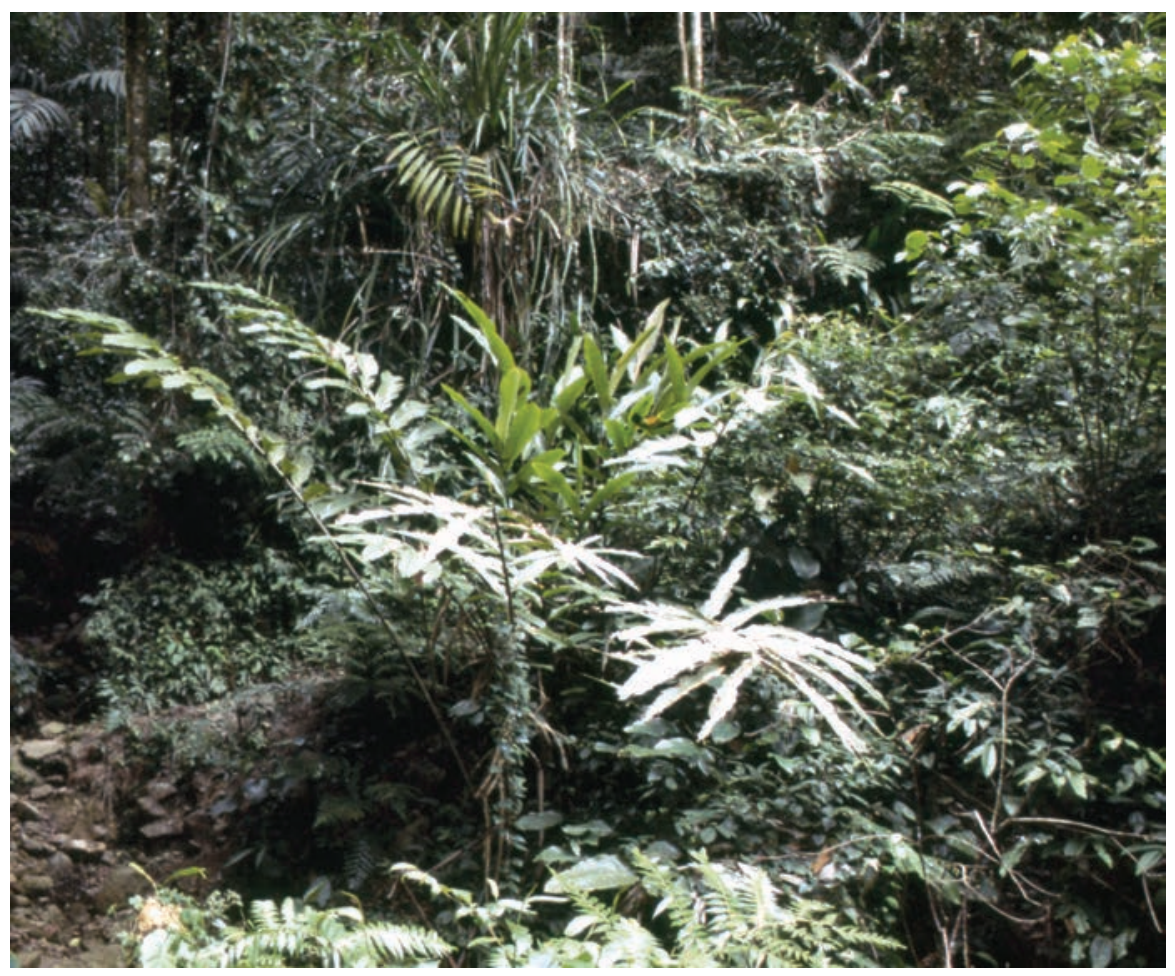

Figure 2.12: Ground cover over terrace where burrow of Lenomys meyeri was located. Burrow system was in a stable area near edge of a gently sloping terrace above and back from a stream. Dry leaves and broken branches covered the ground beneath a moderately dense undergrowth of shrubs, palm and tree seedlings, ferns, and gingers. Surrounding forest was tall second-growth regenerating over clearing made by a fallen canopy tree. Primary forest covered slopes back of this disturbed area; see Table 2.5. Photographed in 1976.

Source: Photograph by Author.

Most ecological information comes from the rat collected on Sungai Sadaunta, which I kept captive for about a month. It eagerly accepted and consumed katydids, grasshoppers, and moths (usually eating everything except legs and wings); large and small fruit from several species of figs (Ficus spp.); small and young tender green plants, tips of fern fronds, palm heart (mostly the thin embryonic leaves); and bait (peanut butter, raisins, oatmeal, and bacon ground into a mash). Tougher leaves of sapling or understorey trees were rejected as were several other kinds of non-fig fruits. It also required a constant source of drinking water. 
Table 2.5: Summary of microhabitats at trapping sites and other relevant information for two specimens of Lenomys meyeri collected in Central Sulawesi, 1974-1975.

\begin{tabular}{|c|c|c|c|}
\hline $\begin{array}{l}\text { Locality, AMNH } \\
\text { and (ASE-field) } \\
\text { numbers }\end{array}$ & $\begin{array}{l}\text { Elevation } \\
\text { (m) }\end{array}$ & Date & Trap site and other information \\
\hline $\begin{array}{l}\text { Tomado } 224317 \\
\text { (1612) }\end{array}$ & 1000 & $\begin{array}{l}\text { May } \\
1974\end{array}$ & $\begin{array}{l}\text { Caught during the night on decaying, moss and } \\
\text { vine-covered trunk bridging narrow stream about } \\
2 \mathrm{~m} \text { above water level. On one bank of stream is } \\
\text { tall primary forest that has been slightly disturbed } \\
\text { by removal of a tree for lumber, some rattan and } \\
\text { occasionally a sugar palm. The opposite bank is } \\
\text { scrubby, consisting of a few coffee trees next to } \\
\text { scrub and low second-growth forest, which abuts a } \\
\text { grassy meadow; ground cover here is mostly grass, } \\
\text { shrubs, and ferns. Minimum and maximum ambient } \\
\left.\text { temperatures ( }{ }^{\circ} \mathrm{F}\right) \text { during a } 30 \text {-day period were } 65.0 \\
(56-67) \text { and } 80.9 \text { (70-94), respectively. }\end{array}$ \\
\hline $\begin{array}{l}\text { Sungai } \\
\text { Sadaunta } \\
226813 \text { (4401a) }\end{array}$ & 915 & $\begin{array}{l}\text { April } \\
1976\end{array}$ & $\begin{array}{l}\text { Dug out of burrow near edge of a gently sloping } \\
\text { terrace about } 1.5 \text { m above a stream and } 2.5 \mathrm{~m} \\
\text { back from it. The area was stable, the soil firmly } \\
\text { held in place by roots, and the ground covered with } \\
\text { dry leaves and litter from rotting small branches } \\
\text { and rattan. Undergrowth was knee-to-waist high } \\
\text { consisting of shrubs, palm and tree seedlings, } \\
\text { ferns, gingers, and rattan rosettes. Forest shading } \\
\text { this spot was tall second-growth festooned with } \\
\text { woody vines in the understorey and represented } \\
\text { regenerating growth over an area where a large } \\
\text { canopy tree fell, marked now only by the decaying } \\
\text { base of its trunk on the terrace edge near the } \\
\text { burrow and the remainder of the trunk lying on } \\
\text { the terrace partially covered by undergrowth. Tall } \\
\text { primary forest surrounded this disturbed spot. } \\
\text { Minimum and maximum ambient temperatures ( }{ }^{\circ} \mathrm{F} \text { ) } \\
\text { during a } 4 \text {-month period was } 66.9 \text { ( } 62-70 \text { ) and } \\
75.2 \text { (70-86), respectively. See the habitat images } \\
\text { in Figures } 2.11 \text { and } 2.12 \text {. }\end{array}$ \\
\hline
\end{tabular}

Notes: Descriptions of the trapping sites are summarised from my field journals (in Mammalogy archives at AMNH). ASE designates Archbold Sulawesi Expedition field numbers. Both sites were in lowland tropical evergreen rainforest (as defined by Whitmore, 1984).

Source: Author's data.

Both the Tomado and Sadaunta rats consumed their own faeces (coprophagous), either picking the pellets from the cage floor or taking them directly from the anus.

The Sadaunta animal gave birth to one young: the pup began uncoordinated movements and ears opened on day 17, pup actively wandered around cage and climbed on supports by day 21 at which time the eyes opened and although still nursing the pup nibbled on bait and palm heart. 
The Tomado and Sadaunta animals slept in a leaf nest during the day and were active only at night. They could also move along branches; their short and wide feet with huge fleshy pads and curved claws are fit for climbing - this species nests in ground burrows and likely forages during the night on substrates above ground in the understorey.

A diagram of the burrow and other details are provided in Figure 2.13. During the night the burrow entrance was open but in the morning had been sealed by a plug of dry leaves.

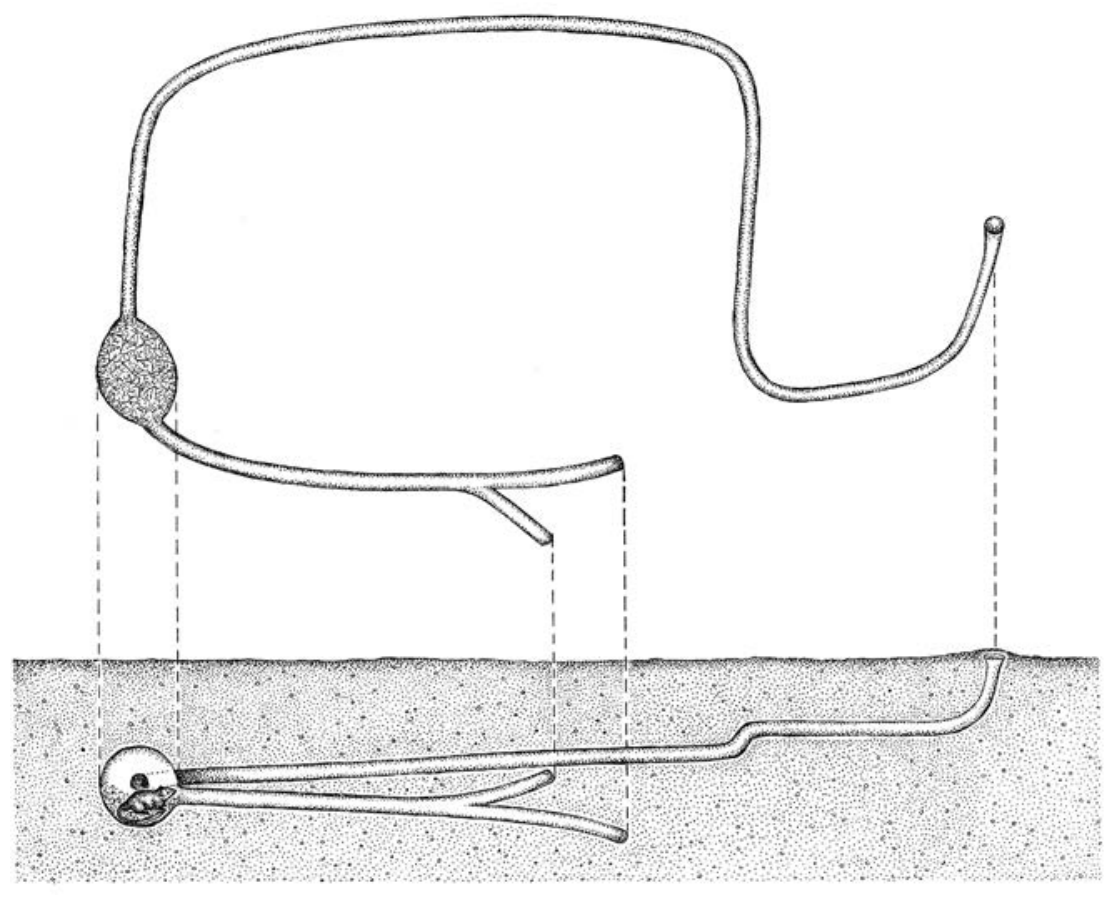

Figure 2.13: Burrow system of Lenomys meyeri excavated on a stream terrace adjacent to Sungai Sadaunta, 915 m (3 April 1976). Tunnel system was $5.6 \mathrm{~m}$ long $(90 \mathrm{~cm}$ at its widest and $248 \mathrm{~cm}$ at its longest, tunnels were $7-10 \mathrm{~cm}$ in diameter) with a single entrance and two blind passages; entire structure lay about $45 \mathrm{~cm}$ below ground surface. The oval chamber was $30 \mathrm{~cm}$ long and $20 \mathrm{~cm}$ in diameter and partially filled with compacted dry leaves forming a shallow bowl-shaped nest. An adult female (AMNH 226813) was found in the burrow.

Source: Drawing by Patricia Wynne. 
Taxonomic Tapestries

\section{Subfossils}

Subfossil specimens of L. meyeri are identified and documented in Table 2.6.

Table 2.6: Subfossil fragments of Lenomys meyeri from the southwest peninsula of Sulawesi.

\begin{tabular}{|c|c|c|}
\hline Cave and specimen & Age & Description \\
\hline \multicolumn{3}{|l|}{ BATU EJAJA } \\
\hline Specimen 1 & adult & Most of left dentary, molar row intact, incisor missing. \\
\hline AMNH 272963 & adult & Small fragment of right pelvic girdle. \\
\hline \multicolumn{3}{|l|}{ BATU EJAJA 2} \\
\hline AMNH 265029 & adult & Fragment of left dentary containing $\mathrm{m} 2$ and portion of incisor. \\
\hline AMNH 265030 & adult & Incomplete right upper incisor. \\
\hline AMNH 265031 & adult & Distal tip of right upper incisor. \\
\hline Specimen 2 & adult & Most of right dentary, molar row intact, incisor missing. \\
\hline Specimen 3 & adult & Piece of right dentary, $\mathrm{m} 1$ and $\mathrm{m} 2$ present, incisor intact. \\
\hline Specimen 4 & adult & Fragment of right dentary, basal piece of incisor, no molars. \\
\hline Specimen 5 & adult & Piece of left dentary, $\mathrm{m} 1$ and $\mathrm{m} 2$ present, incisor intact. \\
\hline Specimen 6 & adult & Fragment of left dentary, molar row intact, incisor missing. \\
\hline Specimen 7 & adult & Fragment of left dentary, molar row intact, incisor missing. \\
\hline Specimen 8 & adult & Piece of right dentary, $\mathrm{m} 1$ and $\mathrm{m} 2$ present, incisor intact. \\
\hline Specimen 9 & adult & Fragment of right dentary, $\mathrm{m} 1$ and basal half of incisor present. \\
\hline Specimen 10 & adult & Piece of left dentary, all molars present, basal piece of incisor. \\
\hline \multicolumn{3}{|l|}{ LEANG BURUNG 1} \\
\hline AMNH 265022-A & adult & Most of left dentary, molar row and incisor intact (Figure 2.14). \\
\hline AMNH 265023-A & adult & Anterior fragment of left dentary, molars and incisor missing. \\
\hline AMNH 265028-B & young & Fragment of left dentary, most of incisor present, molars gone. \\
\hline AMNH 265024-B & adult & Most of right lower incisor. \\
\hline AMNH 265025-A & adult & Distal piece of right upper incisor. \\
\hline AMNH 265026-A & adult & Distal fragment of right upper incisor. \\
\hline AMNH 265027-A & adult & Nearly complete left pelvic girdle. \\
\hline AMNH 272961 & adult & Intact left femur. \\
\hline AMNH 272962 & adult & Distal portion of right tibia. \\
\hline
\end{tabular}

Note: Identities of Specimens 1-10 from Batu Ejaja 2 were discussed more fully elsewhere (Musser, 1984).

Source: Author's data. 


\section{Lenomys grovesi, new species}

\section{Holotype and type locality}

The holotype and only example of the species is AMNH 265021, a subfossil right dentary from an adult collected on 26 July 1969 by members of the AustralianIndonesian Archaeological Expedition to Sulawesi under the leadership of DJ Mulvaney and RP Soejono. The dentary is mostly undamaged except for the missing tip of the coronoid process; all molars are intact; root of the incisor is embedded within the dentary, the rest of the incisor is missing (Figures 2.14 and 2.15). Dental measurements are listed in Table 2.7 .

The type locality is Leang Burung 1, a cave near the village of Pakalu, 'about $2 \mathrm{~km}$ north of the main road from Maros, $10 \mathrm{~km}$ to the west' (Mulvaney and Soejono, 1970: 169 and map on p. 170; the site is also mapped by Bulbeck [2004: 130]), less than $100 \mathrm{~m}$ (locality 12 in Figure 2.2a), in the southeastern portion of the southwestern peninsula, Propinsi Sulawesi Tengah, Indonesia.

Mulvaney and Soejono (1970) identified the cave as 'Leang Burung' but it has been designated 'Leang Burung $1^{\prime}$ in subsequent literature to distinguish it from the nearby 'Leang Burung 2' (Glover, 1981; Bulbeck, 2004). The subfossil was excavated from 'Trench A'. Mulvaney and Soejono (1970: 170) wrote that

Most of Trench A cut through recent limestone rubble that reached to bedrock. Just inside the line of overhang, however, bedrock dipped vertically, and excavation showed that beneath the rubble lay a zone of disturbed occupation material, and underneath, undisturbed deposit. The depth reached in our test trench was $4 \mathrm{~m}$, at which depth excavation became impossible because of massive fallen rocks.

Mulvaney and Soejono (1970: 171) indicated that charcoal from a depth of about $270 \mathrm{~cm}$ in Trench A was dated at $2820 \pm 210(2,360-3,460)$ years BP, and D. Bulbeck (in a letter to me, 1997; 2004: 136) indicated that 3,000-2,000 years BP are the outside limits for Trench A; the time frame is late Holocene. 
Taxonomic Tapestries

Table 2.7: Measurements of mandibular molars from subfossil and modern samples of Lenomys meyeri and the subfossil specimen of Lenomys grovesi.

\begin{tabular}{|c|c|c|c|c|c|}
\hline $\begin{array}{l}\text { Species, } \\
\text { locality and specimen }\end{array}$ & clm1-3 & alm1-3 & bm1 & bm2 & bm3 \\
\hline \multicolumn{6}{|l|}{ L. meyeri } \\
\hline \multicolumn{6}{|l|}{ SUBFOSSIL } \\
\hline \multicolumn{6}{|l|}{ Southwest Peninsula } \\
\hline \multicolumn{6}{|l|}{ Leang Burung 1} \\
\hline AMNH 265022 & 11.5 & 11.9 & 3.0 & 3.1 & 2.7 \\
\hline \multicolumn{6}{|l|}{ Batu Ejaja } \\
\hline AMNH 265029 & - & - & - & 3.1 & -Batu Ejaja \\
\hline \multicolumn{6}{|l|}{$\begin{array}{l}\text {-Batu Ejaja } \\
\text { Panganreang Tudea }\end{array}$} \\
\hline $\begin{array}{l}\text { Specimens 1-10 } \\
\text { (Musser, 1984: 69) }\end{array}$ & $\begin{array}{r}11.2 \pm 0.47 \\
(10.7-11.9) 5\end{array}$ & $\begin{array}{r}11.7 \pm 0.82 \\
(10.9-13.1) 8 \\
\end{array}$ & $\begin{array}{l}3.1 \pm 0.11 \\
(3.0-3.3) 8\end{array}$ & $\begin{array}{l}3.1 \pm 0.08 \\
(3.0-3.2) 8\end{array}$ & $\begin{array}{l}2.8 \pm 0.14 \\
(2.6-2.9) 5\end{array}$ \\
\hline \multicolumn{6}{|l|}{ MODERN } \\
\hline Northeast & $\begin{array}{r}11.2 \pm 0.34 \\
(10.7-11.6) 7\end{array}$ & $\begin{array}{r}11.6 \pm 0.51 \\
(10.9-12.2) 5\end{array}$ & $\begin{array}{l}3.2 \pm 0.17 \\
(3.0-3.4) 7\end{array}$ & $\begin{array}{l}3.2 \pm 0.22 \\
(2.9-3.5) 7\end{array}$ & $\begin{array}{l}2.8 \pm 0.16 \\
(2.6-3.0) 7\end{array}$ \\
\hline Northcentral & 10.0 & 9.9 & 2.9 & 2.9 & 2.7 \\
\hline \multicolumn{6}{|l|}{ Core } \\
\hline AMNH 224317 & 11.0 & 11.4 & 3.3 & 3.3 & 3.0 \\
\hline USNM 219712 & 10.4 & 10.5 & 3.0 & 3.1 & 2.7 \\
\hline Southwest Peninsula & $\begin{array}{r}10.7 \pm 0.38 \\
(10.3-11.2) 5 \\
\end{array}$ & \begin{tabular}{|r|}
$11.3 \pm 0.43$ \\
$(10.7-11.8) 5$ \\
\end{tabular} & $\begin{array}{l}3.1 \pm 0.18 \\
(2.9-3.3) 5\end{array}$ & \begin{tabular}{|l|}
$3.1 \pm 0.16$ \\
$(2.9-3.3) 5$ \\
\end{tabular} & $\begin{array}{l}2.8 \pm 0.16 \\
(2.6-3.0) 5 \\
\end{array}$ \\
\hline \multicolumn{6}{|l|}{ Lenomys grovesi } \\
\hline \multicolumn{6}{|l|}{ SUBFOSSIL } \\
\hline \multicolumn{6}{|l|}{ Southwest Peninsula } \\
\hline \multicolumn{6}{|l|}{ Leang Burung I } \\
\hline AMNH 265021 & 9.3 & 9.6 & 2.7 & 2.6 & 2.3 \\
\hline
\end{tabular}

Notes: Measurements are in millimeters. Mean $\pm 1 \mathrm{SD}$, observed range (in parentheses), and size of sample is listed. Modern specimens measured are identified below:

Northeast - Gunung Masarang: BMNH 97.1.2.20. Tomohon: NMB 3326, 3327, 4759. Langoon: RMNH 18302, holotype of Mus meyeri. Amurang: (BMNH 21.2.9.4). 'Minahassa': RMNH 21233.

Northcentral-Bumbulan: AMNH 153011.

Core - Tomado and Gimpu (holotype of Lenomys longicaudus).

Southwest peninsula - Gunung Lompobatang: AMNH 101124-28 (includes holotype of Lenomys meyeri lampo).

Source: Author's data. 


\section{Diagnosis}

In morphology of the dentary and molars, and the occlusal patterns formed by molar cusps, Lenomys grovesi is a diminutive version of the larger-bodied L. meyeri, with the added distinction that $\mathrm{m} 3$ is relatively narrower as contrasted with the dental proportions in L. meyeri.

\section{Etymology}

The patronym honours Colin Groves, a professional colleague and friend who over the years has consistently impressed me with his unique intellect and the breadth of his scholarship - his impact on the study of mammalian diversity will influence the nature of research long after the rest of us disappear into that place where the winds begin and the sky reflects infinity.

\section{Geographic distribution and habitat}

Leang Burung 1 is located on the western coastal plain at about $100 \mathrm{~m}$ in the Maros karst region at the southern end of the southwestern peninsula of Sulawesi (see the map in Simons and Bulbeck, 2004: 168). Forest cover on the coastal plain during middle and late Holocene times likely consisted of tropical lowland evergreen or semi-evergreen rainforest formations. Based upon analyses of the vertebrate faunal composition excavated from caves and rock shelters, Simons and Bulbeck (2004: 178) speculate that the environment in this region '... consisted of a mosaic of copses of primary forest, expanses of secondary forest, and possibly more open habitats between about 7000 and 2000 BP.' I strongly suspect $L$. grovesi to be restricted to forested terrain; the mosaic landscape suggested by Simons and Bulbeck would support populations of L. grovesi and the other murids represented by subfossils excavated at Leang Burung 1 (Table 2.8), and from other caves in the Maros region (Table 2.9). During my trapping in the central part of Sulawesi, I found Lenomys meyeri, Paruromys dominator, Maxomys hellwaldii, and Rattus hoffmanni, which are represented by subfossils from Leang Burung 1 (Table 2.8), to inhabit primary forest or secondary growth that had nearly assumed the structure of old-growth formations. 
Taxonomic Tapestries

Table 2.8: Subfossil representatives of murids excavated from Leang Burung 1.

\begin{tabular}{|c|c|c|}
\hline Species & $\begin{array}{l}\text { Trench A } \\
(2820 \pm 210 \mathrm{BP})\end{array}$ & $\begin{array}{l}\text { Trench B } \\
(3420 \pm 400 \mathrm{BP})\end{array}$ \\
\hline Lenomys grovesi & AMNH 265021 & \\
\hline Lenomys meyeri & $\begin{array}{r}\text { AMNH } 265022 \\
265023,265025- \\
265027\end{array}$ & AMNH 265024,265028 \\
\hline Paruromys dominator & $\begin{array}{r}\text { AMNH } 265002- \\
265004\end{array}$ & $\begin{array}{r}\text { AMNH } 265005,265006, \\
269960,269962\end{array}$ \\
\hline Maxomys hellwaldii & - & AMNH 265016 \\
\hline Rattus bontanus & AMNH 265032 & AMNH 269957 \\
\hline Rattus hoffmanni & AMNH 265032 & - \\
\hline Rattus tanizumi & - & AMNH 265040 \\
\hline
\end{tabular}

Notes: Radiocarbon dates are from Mulvaney and Soejono (1970); also see Figure 2 in Bulbeck (2004: 133).

Of the seven species listed, all are endemic to Sulawesi except for Rattus tanizumi, which is a member of the geographically broadly distributed Rattus rattus complex (Aplin et al., 2011), and represents an unintended anthropogenic introduction to the endemic Sulawesi murid fauna.

Results from analysis of external traits and morphometric data from skull and dental measurements in population samples (Musser, unpublished data) coupled with analyses of DNA sequences (Achmadi et al., 2013) indicate that Maxomys hellwaldii as listed here will likely prove to be a complex of species, reminiscent of the diversity uncovered in populations of Maxomys surifer and M. whiteheadi from mainland Indochina and islands on the Sunda Shelf, each previously considered as a single species (Gorog et al., 2004).

Source: Author's data.

Whether L. grovesi is extinct or still occurs on the southwestern peninsula is unknown. Most of the lowland forest was long ago removed and the region converted to agriculture (Fraser and Henson, 1996; Whitten et al., 1987), which comprises much of the present landscape south of the Tempe Depression (see map 8d in Mackinnon, 1997); however, remnant tracts of lowland forest are present, especially in karst areas (Whitten et al., 1987: 102; Froehlich and Supriatna, 1996). Unfortunately, these patches have never been adequately, if it all, surveyed for endemic species of murids. Most samples of modern specimens come from the flanks of the volcano Gunung Lompobatang in either montane or mid elevational forests, which have yielded Lenomys meyeri, Paruromys dominator, Maxomys hellwaldii and M. musschenbroekii, Rattus hoffmanni and $R$ bontanus, but not L. grovesi (Musser, ms). 
Table 2.9: Murid species represented by middle and late Holocene subfossils excavated from caves and rock shelters on the southern end of the southwestern peninsula of Sulawesi.

\begin{tabular}{|l|l|l|l|l|l|l|l|l|}
\hline Species & $\begin{array}{l}\text { Batu } \\
\text { Ejaja }\end{array}$ & $\begin{array}{l}\text { Bola } \\
\text { Batu }\end{array}$ & $\begin{array}{l}\text { Panganreang } \\
\text { Tudea }\end{array}$ & $\begin{array}{l}\text { Panisi } \\
\text { Ta'batu }\end{array}$ & $\begin{array}{l}\text { Leang } \\
\text { Burung 1 }\end{array}$ & $\begin{array}{l}\text { Ulu } \\
\text { Leang 1 }\end{array}$ & PattaE & $\begin{array}{l}\text { Leang } \\
\text { Karassa }\end{array}$ \\
\hline Lenomys grovesi & & & & & + & & & \\
\hline Lenomys meyeri & + & + & + & & + & & & \\
\hline Paruromys dominator & + & + & + & & + & + & & + \\
\hline Taeromys celebensis & & & + & & & & & \\
\hline Taeromys punicans & + & + & & & & & + & \\
\hline Maxomys hellwaldii & + & & & & + & & & \\
\hline $\begin{array}{l}\text { Maxomys } \\
\text { musschenbroekii }\end{array}$ & & + & & & & & & \\
\hline $\begin{array}{l}\text { Bunomys } \\
\text { chrysocomus }\end{array}$ & & & & & & + & & \\
\hline Bunomys andrewsi & + & & & & & + & & \\
\hline Rattus bontanus & + & + & + & + & + & + & & + \\
\hline Rattus hoffmanni & + & & & & + & & & \\
\hline Rattus tanezumi & & & & + & + & + & & \\
\hline
\end{tabular}

Notes: The sites are mapped and described in Mulvaney and Soejono (1970), Bulbeck (2004), and Simons and Bulbeck (2004).

My identifications of the samples are documented in Musser (1984, in press), Simons and Bulbeck (2004), and in unpublished manuscripts either being prepared by me or submitted for publication. Some of the names in the table differ from those recorded in the publications. The specimens of Bunomys andrewsi were originally identified by me as $B$. heinrichi (listed in tables by Simons and Bulbeck, 2004), which is the name available for the population of $B$. andrewsi occurring on the southwestern peninsula. The Rattus bontanus have been documented as either $R$. xanthurus foramineus (Musser, 1984) or $R$. foramineus (Simons and Bulbeck, 2004), but foramineus is a synonym of $R$. bontanus, a southwestern peninsular endemic (Musser and Carleton, ms). Examples determined as Rattus tanezumi have either been referred to as $R$. rattus (Musser, 1984) or R. tanezumi (Simons and Bulbeck, 2004); see note to Table 2.8.

Results from analysis of external traits and morphometric data from skull and dental measurements in population samples (Musser, unpublished data) coupled with analyses of DNA sequences (Achmadi et al., 2013) indicate that Maxomys hellwaldii and M. musschenbroekii as listed here will likely prove to be a complex of species, reminiscent of the diversity uncovered in populations of Maxomys surifer and M. whiteheadi from mainland Indochina and islands on the Sunda Shelf, each previously considered as one species (Gorog et al., 2004).

Source: Author's data. 

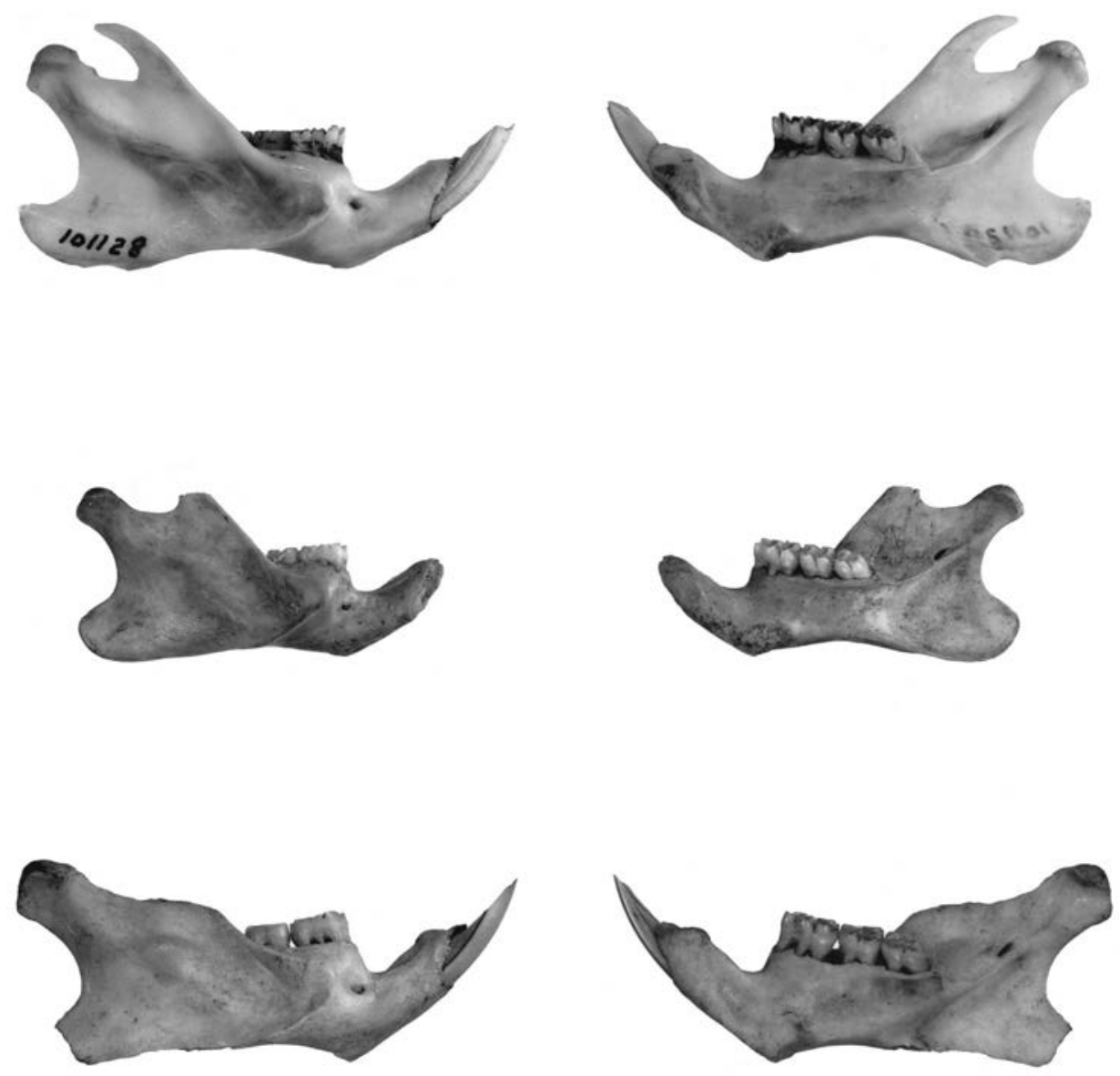

Figure 2.14: Dentaries from Lenomys obtained in the southwest peninsula. Upper row: right dentary of modern Lenomys meyeri (AMNH 101128, holotype of $L$. $m$. lampo) from Gunung Lompobatang, 2,200 m. Middle row: right dentary of subfossil $L$. grovesi (AMNH 265021) from Leang Burung 1 on coastal plain. Lower row: left dentary (image was flipped for comparison with the two other specimens) of subfossil L. meyeri (AMNH 265022) from Leang Burung 1. X2.

Source: Photograph by Peter Goldberg. 

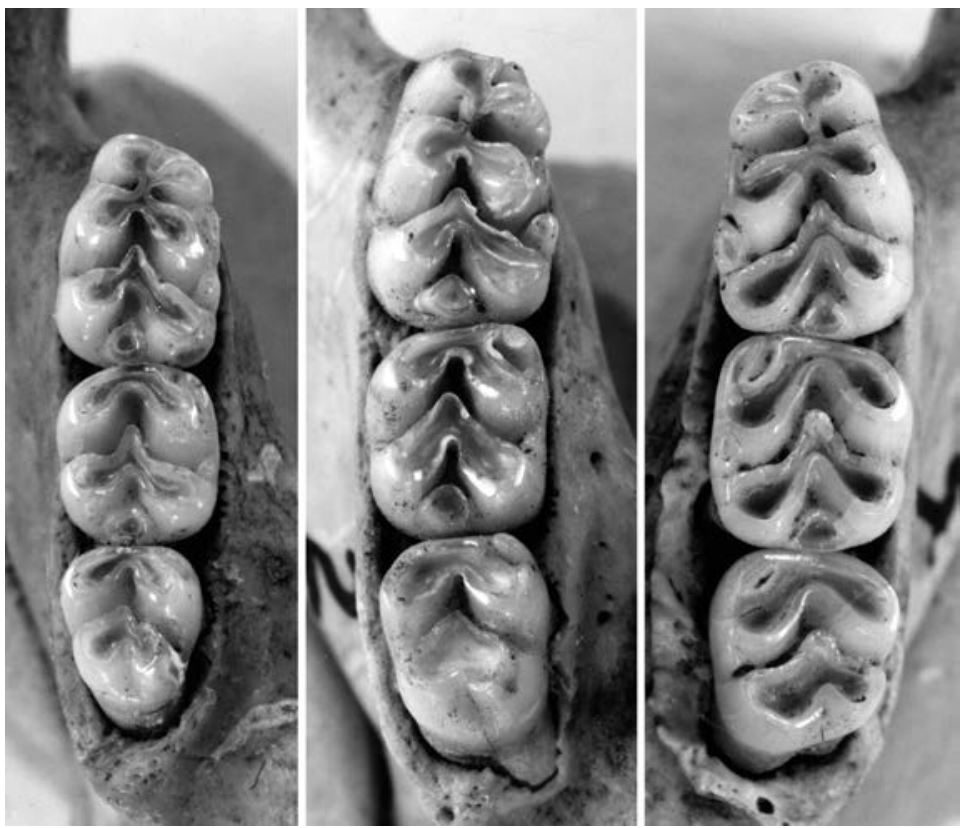

Figure 2.15: Occlusal views of subfossil mandibular molar rows from two species of Lenomys. Left, L. grovesi (AMNH 265021; clm1-3 = $9.3 \mathrm{~mm}$; right toothrow) from Leang Burung I; Middle, L. meyeri, (Specimen 2; clm1-3 = $11.3 \mathrm{~mm}$; right toothrow) from Panganreang Tudea; Right, $L$. meyeri, (Specimen 1; clm1-3 = $10.7 \mathrm{~mm}$; left toothrow) from Batu Ejaja.

Source: Photograph by Peter Goldberg.

\section{Description and comparisons}

Lenomys grovesi is a miniature version of L. meyeri, assuming size of dentary and molars reflect overall physical size of the animals; no other examples of L. meyeri at hand, either subfossil or modern, matches the smaller dimensions characteristic of L. grovesi. Configuration of the dentary in L. grovesi conforms to that described previously for L. meyeri, but is simply much smaller (Figure 2.14). So are the molars, a difference evident visually (Figure 2.15), by measurements (Table 2.7), and quantitatively by the distribution of specimen scores for samples of $L$. grovesi and $L$. meyeri projected on first and second principal components extracted from principal-components analysis (Figure 2.16). Along the first component, covariation among all variables isolates the score for $L$. grovesi, reflecting its smaller molars and shorter toothrow, and the greater size of these dental elements in L. meyeri ( $r=0.84-0.94$; Table 2.10). Position of the score for $L$. grovesi along the second axis indicates its relatively narrower $\mathrm{m} 3(r=-0.53)$ compared with the proportion in L. meyeri. 


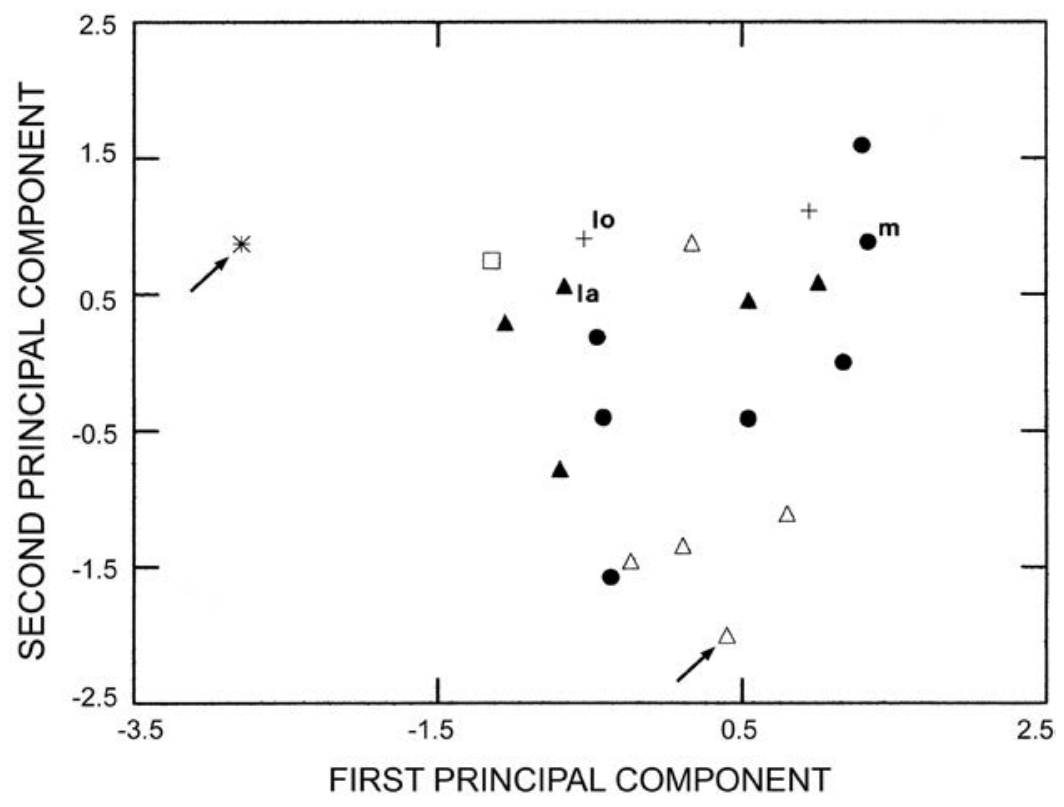

Figure 2.16: Scores representing specimens of modern and subfossil Lenomys meyeri and subfossil $L$. grovesi projected on first and second principal components extracted from principal-components analysis of four log-transformed dental variables. Symbols for Lenomys meyeri: filled circle $=$ northern peninsula east of Gorontalo region ( $N=7$; Amurang, Gunung Masarang, Tomohon, Langoon); empty square = Bumbulan, west of Gorontalo region ( $N=1)$; cross $=$ central region $(\mathbf{N}=2$;

Gimpu, Tomado); filled triangle = southwest peninsula ( $N=5$; Gunung Lompobatang); open triangle = southwest peninsula $(\mathrm{N}=5$; subfossils from Batu Ejaja, Panganreang Tudea, and Leang Burung 1). Symbol for L. grovesi: asterisk = southwest peninsula ( $\mathbf{N}=1$; Leang Burung 1 ). Abbreviations identify scores for holotypes: la = Lenomys meyeri lampo; lo = Lenomys longicaudus; $\mathrm{m}=$ Mus meyeri. Arrows point to scores for subfossils from Leang Burung 1, the holotype of L. grovesi (asterisk) and AMNH 265022 representing $L$. meyeri (empty triangle). See Table 2.10 for correlations of variables and per cent variance. 
Table 2.10: Results of principal-components analysis comparing modern and subfossil samples of Lenomys meyeri with the subfossil specimen of Lenomys grovesi.

\begin{tabular}{|l|r|r|}
\hline \multicolumn{1}{|c|}{ Variable } & \multicolumn{2}{|c|}{ Correlations } \\
\hline & PC 1 & \multicolumn{1}{|c|}{ PC 2 } \\
\hline $\mathrm{clm} 1-3$ & $0.94^{(\mathrm{A})}$ & 0.19 \\
\hline $\mathrm{bm} 1$ & $0.94^{(\mathrm{A})}$ & 0.23 \\
\hline $\mathrm{bm} 2$ & $0.94^{(\mathrm{A})}$ & 0.02 \\
\hline $\mathrm{bm} 3$ & $0.84^{(\mathrm{A})}$ & $-0.53^{(\mathrm{B})}$ \\
\hline Eigenvalue & 0.013 & 0.001 \\
\hline \% Variance & 83.8 & 8.8 \\
\hline
\end{tabular}

Note: (A) P $\leq 0.001$; (B) $\mathrm{P} \leq 0.01$. Correlations (loadings) of four dental log-transformed variables are based on 21 specimens; see Figure 2.16 .

Source: Author's data.

Except for size, other traits are shared by the two species. In both, $\mathrm{ml}$ is typically anchored by five roots, $\mathrm{m} 2$ by four, and $\mathrm{m} 3$ by three. Occlusal patterns formed by molar cusps are closely similar in both (Figure 2.15): major cusps are large and sharply defined; the anteroconid and cusp row behind it are joined by a mid-sagittal ridge; an anterocentral cusp is absent in L. grovesi, but is either present or absent in samples of $L$. meyeri; anterior and posterior labial cusplets adorn $\mathrm{ml}$, an anterolabial cusp is on $\mathrm{m} 2$ and $\mathrm{m} 3$, and a posterior labial cusplet sits on $\mathrm{m} 2$ but is absent from $\mathrm{m} 3$.

Three examples of L. meyeri are represented by molar and dental elements also excavated from level A in Leang Burung 1, as well as upper incisor fragments and a pelvic girdle (Table 2.8).

\section{Conclusion: Hypotheses}

\section{Lenomys meyeri}

That the samples of $L$. meyeri analysed here represent one widely geographically spread species is a hypothesis that has to be tested by analyses of more specimens from a broader coverage of Sulawesi than is now available, and the use of DNA sequences as well as qualitative anatomical and morphometric data. The most likely candidate for separation is the population inhabiting montane forest habitats on Gunung Lompobatang at the south end of the southwestern peninsula (locality 13 in Figure 2.2a). Presently, I assume the montane animals and those from the adjacent lowlands are members of the same population; 
dental measurements support this view, but thorough documentation remains elusive without intact modern specimens from the lowlands south of the Tempe Depression.

\section{Lenomys grovesi}

That the single small dentary and associated molars I designate L. grovesi represent a species and not just a genetic aberration in a population of $L$. meyeri seems a reasonable hypothesis set against the background of size variation in mandibular and dental elements documented for available samples of that larger-bodied species. It is also reasonable to postulate that L. grovesi is another murid endemic to the southwestern peninsula south of the Tempe Depression; Bunomys coelestis, Rattus mollicomulus, and Rattus bontanus are other members of that endemic group.

Future search in subfossil samples from the southwestern peninsula may undercover additional specimens of L. grovesi. Clason (1976: 66), for example, listed 65 fragments identified only as 'rodent' that were excavated from Ulu Leang I; this material bears critical reexamination.

\section{Colin Groves}

'Guy, this is Colin Groves,' explained Paul Ryan as he brought a thin, bespectacled Englishman sporting a Beatles-style haircut over to where I was standing, which happened to be next to a row of specimen cabinets extending the length of the rodent range in the Mammal Division of the National Museum of Natural History in Washington, DC. Colin and I shook hands and he expounded in his understated way on his research interests; I then countered with my reasons for rummaging through the trays of Asian rodents. That was in the late 1960s. Colin was then focusing on primates and I mistakenly pigeonholed him as a primatologist. Between then and now and through many visits with one another at museums in the United States and England, over dinners of Indian delicacies and standard British fare, and in one of my forest camps in Sulawesi, I came to understand the intellectual acuity of this man and the depth and range of Colin's interest and expertise in all mammal groups, their taxonomy, biogeography, and evolutionary history. Yes, he was deeply interested in primates, including fossil humans, but he also published on other groups, extending from monotremes and marsupials to rodents and ungulates. Perissodactyls and artiodactyls, however, were his first love. While sharing tea with John Hill at the British Museum, John reminisced about the time a young Colin Groves appeared in the Mammal Section to show him a thick manuscript revising ungulate taxonomy, asking about the next steps to publication, absolutely dumbfounding all the curators. 
And he never quit gathering data for his ungulate research. I fondly remember one of his visits to the American Museum when he merrily disappeared with his huge set of wooden calipers into the depths of the rhinoceros collection to emerge later with measurements of not just some but all the specimens - his eyes sparkled merrily.

Applying the honorary patronym to the small-bodied Lenomys endemic to Sulawesi also serves as a tribute to Colin for his numerous contributions to the science of mammalogy, for his friendship, for his glittering intelligence, and dedication to his profession. I would like to think that my contributions are much better than they would have been without Colin's influence.

\section{Acknowledgements}

My fieldwork in Sulawesi was supported by the former Celebes Fund of the American Museum of Natural History and Archbold Expeditions, Inc.; I was sponsored in Indonesia by the Lembaga Ilmu Pengetahuan Indonesia (LIPI) and the Museum Zoologicum Bogoriense (MZB), and also assisted by members of United States Navy Medical Research Unit No. 2 (NAMRU-2) in Jakarta. The drawings in Figures 2.1 , 2.2, 2.6, 2.8, and 2.13 are the work of Patricia Wynne; photographic prints of the skulls, molar rows, dentaries, and habitats were produced by Peter Goldberg. Curators and supporting staff attached to the various institutions I visited provided access to specimens and archival data. Without the assistance of artist, photographer, and museum staffs, I could not have accomplished my research goals.

\section{References}

Achmadi AS, Esselstyn JA, Rowe KC, Maryanto I, Abdullah MT. 2013. Phylogeny, diversity, and biogeography of Southeast Asian spiny rats (Maxomys). $J$ Mammal 94(6):1412-1423.

Aplin KP, Suzuki H, Chinen AA, Chesser RT, Ten Have J, Donnellan SC, Austin J, Frost A, Gonzalez JP, Herbreteau Y, Catzeflis F, Soubrier J, Fang Y-P, Robins J, Matisoo-Smith E, Bastos ADS, Maryanto I, Sinaga MH, Denys C, Van Den Bussche RA, Conroy C, Rowe K, Cooper A. 2011. Multiple geographic origins of commensalism and complex dispersal history of black rats. PLoS ONE 6(11):e26357, doi:10.1371/journal.pone.0026357. 
Taxonomic Tapestries

Breed WG, Musser GG. 1991. Sulawesi and Philippine rodents (Muridae): A survey of spermatozoa morphology and its significance for phylogenetic inference. Am Mus Novit 3003:1-15.

Bulbeck D. 2004. Divided in space, united in time: The Holocene prehistory of South Sulawesi. In: Keates SG, Pasveer JM, editors. Quaternary research in Indonesia. Mod Quat Re 18:129-166.

Carleton MD. 1980. Phylogenetic relationships in Neotomine-Peromyscine rodents (Muroidea) and a reappraisal of the dichotomy within New World Cricetinae. Miscellaneous Publications Museum of Zoology, University of Michigan 157:1-146.

Carleton MD, Musser GG. 1989. Systematic studies of oryzomyine rodents (Muridae, Sigmodontinae): A synopsis of Microryzomys. Bull Am Mus Nat Hist 191:1-83.

Clason AT. 1976. A preliminary note about the animal remains from the Leang I Cave, South Sulawesi, Indonesia. Mod Quat Re 2:53-67.

Fraser BJ, Henson SM. 1996. Survai jenis-jenis burung endemik di Gunung Lompobattang, Sulawesi Selatan [Survey of endemic bird species on Gunung Lompobattang, south Sulawesi]. Bogor: PHPA/BirdLife InternationalIndonesia Programme, Technical Memorandum No. 12.

Froehlich JW, Supriatna J. 1996. Secondary intergradation between Macaca maurus and $M$. tonkeanus in south Sulawesi, and the species status of $M$. togeanus. In: Fa JE and Lindburg DG, editors. Evolution and ecology of macaque societies, Cambridge: Cambridge University Press. pp. 43-70.

Glover IC. 1981. Leang Burung 2: An Upper Palaeolithic rock shelter in South Sulawesi, Indonesia. Mod Quat Re 6:1-38.

Gorog AJ, Sinanga MH, Engstrom MD. 2004. Vicariance or dispersal? Historical biogeography of three Sunda shelf murine rodents (Maxomys surifer, Leopoldamys sabanus and Maxomys whiteheadi). Biol J Linn Soc Lond 81:91109.

Hooijer DA. 1950. Man and other mammals from Toalian sites in Southwestern Celebes. Koninklije Nederlandsche Akademie van Wetenschappen, Verhandelingen Afdeling. Natuurkunde (Tweede Sectie) 46(2):1-164.

Jentink FA. 1879. On various species of Mus, collected by S. C. I. van Musschenbroek Esq. in Celebes. Notes of the Royal Zoological Museum of the Netherlands, Leyden 1(note 2):7-13. 
Jentink FA. 1887. Catalogue ostéologique des Mammifères. Muséum d'Histoire Naturelle des Pays-Bas, Tome 9. Leide: E.J. Brill. pp. 1-360.

Jentink FA. 1888. Catalogue systématique des Mammifères. Museum d'Histoire Naturelle des Pays-Bas, Tome 12. Leide: E.J. Brill. pp. 1-280.

Jentink FA. 1890. Mammalia from the Malay Archipelago. II. Rodentia, Insectivora, Chiroptera. In: Weber $\mathrm{M}$, editor. Zoologische Ergebnisse einer Reise in Niederländisch Ost-Indien. Leiden: E.J. Brill. Erster Band. pp. 115130, pls VIII-XI.

MacKinnon J, editor. 1997. Protected areas systems review of the Indo-Malayan Realm (prepared on behalf of the World Bank by the Asian Bureau for Conservation in collaboration with the World Conservation Monitoring Centre). Canterbury: Asian Bureau for Conservation Limited.

Maryanto I, Prijono S, Yani M. 2009. Distribution of rats at Lore Lindu National Park, Central Sulawesi, Indonesia. J Trop Biol Conserv 5:43-52.

Miller GS, Jr. 1912. Catalogue of the mammals of Western Europe (Europe exclusive of Russia) in the collection of the British Museum. London: British Museum (Natural History).

Miller GS Jr, Hollister N. 1921. Descriptions of sixteen new murine rodents from Celebes. Proc Biol Soc Wash 34:93-104.

Misonne X. 1969. African and Indo-Australian Muridae: Evolutionary trends. Ann Musée Roy Afr Centr Ser 8 Sci Zool 172:1-219.

Mulvaney J and Soejono RP. 1970. The Australian-Indonesian expodition to Suwalesi. AP 13:163-177.

Musser GG. 1984. Identities of subfossil rats from caves in southwestern Sulawesi. Mod Quat Re 8:61-94.

Musser GG. 2014. A systematic review of Sulawesi Bunomys (Muridae, Murinae) with the description of two new species. Bull Am Mus Nat Hist 392:1-313.

Musser GG, Durden LA. 2014. Morphological and geographic definitions of the sulawesian shrew rats Echiothrix leucura and E. centrosa (muridae, murinae), and description of a new species of sucking louse (Phthiraptera: Anoplura). Bull Am Mus Nat Hist 871:1-87.

Musser GG, Durden LA, Holden ME, Light JE. 2010. Systematic review of endemic Sulawesi squirrels (Rodentia, Sciuridae), with descriptions of new species of associated sucking lice (Insecta, Anoplura), and phylogenetic and zoogeographic assessments of sciurid lice. Bull Am Mus Nat Hist 339:1-260. 
Taxonomic Tapestries

Simons A, Bulbeck D. 2004. Late quaternary faunal successions in South Suwalesi, Indonesia. Mod Quat Re 18:167-190.

Tate GHH, Archbold R. 1935. Results of the Archbold Expeditions. No. 3. Twelve apparently new forms of Muridae (other than Rattus) from the IndoAustralian region. Am Mus Novit 803:1-9.

Thomas O. 1898. VIII. On the mammals collected by Mr. John Whitehead during his recent expedition to the Philippines with field notes by the collector. Trans Zool Soc Lond 14:377-414.

Van de Weerd A. 1976. Rodent faunas of the Mio-Pliocene continental sediments of the Teruel-Alhambra region, Spain. Utrecht Micropaleontol Bull, Special Publication 2:1-218.

Voss RS. 1988. Systematics and ecology of ichthyomyine rodents (Muroidea): Patterns of morphological evolution in a small adaptive radiation. Bull Am Mus Nat Hist 188:259-493.

Whitmore TC. 1984. Tropical rainforests of the Far East. Second edition. Oxford: Clarendon Press.

Whitten AJ, Mustafa M, Henderson GS. 1987. The ecology of Sulawesi. Yogyakarta: Gadjah Mada University Press. 


\title{
3. Gibbons and hominoid ancestry
}

\author{
Peter Andrews and Richard J Johnson
}

\section{Introduction}

Gibbons form a monophyletic group that differs from other hominoid primates, both in behaviour and anatomy. They are found exclusively in eastern Asia, and although evidence from DNA suggests their lineages diverged close to the time of hominoid origins (Goodman et al., 1998), the species array seen today in Asia did not speciate until closer to 6 Mya (Hayashi et al., 1995; Groves, 2001). Their taxonomy has been clarified by the work of Groves (2001), but their evolutionary history is still poorly understood. There is next to no fossil evidence to show when and where the gibbon lineage emerged and speciated, but comparisons with the great apes provide evidence of their shared common ancestor. Gibbon locomotor morphology, which formed the basis of our shared work with Colin Groves (Andrews and Groves, 1976), is unique in the animal world, but attempts to link gibbon anatomy with that of the great apes has generated much confusion not only in ape evolution but also in human evolution. The question 'were human ancestors brachiators?' provides a good instance of this, and it seriously retarded evolutionary interpretations of human evolution during the middle part of the twentieth century (and is still with us today). We will review this evidence here, followed by the fossil evidence for gibbon evolution, little as it is, and attempt to reconstruct the gibbon common ancestor. Three evolutionary scenarios will be presented based on these two lines of evidence, with a third based on the evolutionary significance of the loss of the uricase gene during gibbon evolution (Johnson and Andrews, 2010).

\section{Hylobatid taxonomy and morphology}

Gibbons (family Hylobatidae) share some characters with the great apes, including the relatively large size and the configuration of the brain; the morphology of the teeth; long clavicle; the orientation and dorsal positioning of the scapula; the cranial orientation and shape of the head of the humerus; the free rotatory movements of the radioulnar joints; the mobility of the wrist and hand, in particular the meniscus development of the wrist; the shortened caudal and lengthened sacral regions of the vertebral column; the expanded ilium; the loss of the tail; the shape of the thorax; the presence of a vermiform appendix; 
and the disposition of the abdominal viscera (Napier, 1960, 1963; Lewis, 1971, 1989; Groves, 1972, 1986; Preuschoft et al., 1984). They have many adaptations for below branch suspensory locomotion, or brachiation, for example their elongated arms and the automatic hook formed by their hands when they extend their arms - they literally cannot extend their fingers when their arms are extended, an excellent device for hanging securely on to branches. They may move bipedally on larger branches of trees (Avis, 1962), and their legs are relatively long compared with the size of their bodies. They are strictly arboreal, living in tropical rainforest, with a diet consisting mainly of fruit, and they are 5 to 12 kilograms in body weight. In all of these morphological characters, gibbons appear to be derived relative to monkeys and other primates.

In many characters, gibbons are also derived relative to the earliest known fossil apes, so that they may have branched off from the other apes soon after the appearance of this fossil group. The earliest fossil that can be shown to share hominoid synapomorphies is Proconsul heseloni (Ward et al., 1991, 1993), which is from $18 \mathrm{Ma}$ deposits on Rusinga Island, Kenya, but other species of the genus extend back in time to 20 to $22 \mathrm{Ma}$. There is also a fossil monkey from similar aged deposits, and recently a monkey-like tooth has been described from the Rukwa rixft in southern Tanzania dated to 25 Ma (Stevens et al., 2013). From the same site at Rukwa is a fossil tooth row showing a remarkable degree of similarity to Rangwapithecus gordoni (Stevens et al., 2013), but it should be pointed out that there are no characters that establish either this species or the new Rukwapithecus fleaglei as members of the hominoid lineage. Their elongated molars and adaptations for more folivorous diets (Kay, 1977) are shared with monkeys rather than apes, and it may be that $R$. gordoni and $R$. fleaglei should be distinguished as a separate family, together with 'nyanzapithecines' and separate from hominoids (Harrison, 2002). Be that as it may, there is also evidence for gibbon divergence prior to the loss of the uricase gene (see below), a loss common to all living hylobatids, before 13.1 Ma (Keebaugh and Thomas, 2010) or 9.8 Ma (Oda et al., 2002).

The family is divided into four genera and as many as 14 to 18 species (Groves, 2001; Brandon-Jones et al., 2004; Thinh et al., 2010). Genus Hylobates (named as subgenera in Groves, 2001) is the most widespread with seven species; Bunopithecus hoolock and Symphalangus syndactylus are monospecific genera, and Nomascus has six species. They live exclusively in tropical and subtropical forests of eastern Asia where they have a unique form of locomotion, brachiation, which is common to all 14 species (Napier, 1963; Avis, 1962; Lewis, 1971). At the time when Colin and lead author, PA, wrote their paper on gibbon locomotion, there was much discussion about brachiation, what it is and how common it is in other primates. Much of this was the result of anatomical studies of the primate shoulder and forearm (Napier, 1963; Ashton and Oxnard, 1963, 1964), 
of the skeleton (Schultz, 1973) and of the hand (Lewis, 1971), and following in this tradition we undertook a series of anatomical dissections of the gibbon shoulder and forearm. Colin and PA found that:

The most striking thing, perhaps, about the musculature of the gibbon is the prevalence of interlinked muscle systems; indeed Hylobates lar may be crudely characterised as a mass of muscle chains. A long chain runs from pectoralis major via biceps brachii to flexor digitorum sublimis, and this is reinforced by a chain from latissimus dorsi via dorsoepitrochlearis to biceps. Further cleidodeltoideus (in the lar group only) inserts into pectoralis major. Separate from this multified chain is a second linking the caudal head of subscapularis with the deep fibres of teres major. Functionally a muscle chain acts to transmit the contraction of one muscle to the action of a second. (Andrews and Groves, 1976: 207)

There are variations within the hylobatids, as we and others have pointed out (references in Andrews and Groves, 1976), but these are minor compared with the species of great apes and humans. Even the spider monkey, which comes closest to gibbons in its form of locomotion and in its specialisations for below-branch locomotion, lacks the specialised interlinked muscle systems so characteristic of gibbons. They are absent in the great apes, and we concluded that characters for brachiation, and for suspensory locomotion in general, must be tied to the hylobatids, and the absence of these characters in great apes suggests a nonsuspensory evolutionary history. Characters such as the broad thorax, which are sometimes put forward as evidence of suspensory function in the great apes, together with associated characters of elongated clavicle and position of the scapula, are rather allometrically associated with increase in body size within primates, and the broad thorax in hylobatids is an exception to this allometric gradient (Andrews and Groves, 1976). This is consistent with fossil evidence (see below), which shows that for the first eight million years of the known fossil record of apes, the thorax was narrow and deep like that of monkeys. The same argument applies to the 'long' arms in gibbons and great apes; in the latter, their length in the African apes is on the same allometric gradient as that of monkeys (and humans), and while orangutan arms are slightly longer than expected for their body size, it is only the gibbons that have arm lengths outside the allometric gradient (Biegert and Maurer, 1972; Aiello, 1981; Jungers, 1984). We concluded by saying:

Where differences in morphology occur between gibbons and Great Apes, we conclude that, potentially, the condition seen in gibbons is that adaptive for brachiation. In many cases the functional interpretation significantly relates the condition to brachiation, but in some cases the features can be interpreted as adaptive for upright posture of mobility of forelimb, both necessary but not exclusive attribute of brachiation. It is 
in these features that Great Apes resemble gibbons, and it is concluded that they share a common feeding adaptation, despite their very different habitats, involving feeding in a stationary upright posture by reaching all round with the mobile forelimbs. (Andrews and Groves 1976: 213)

References to and justifications of these conclusions are set out in full in our long 1976 article and cannot be repeated here. The message we wish to convey here is that the gibbons formed a monophyletic group marked by unique behaviour and morphology that are shared to a great extent by all hylobatid species. It has also become apparent from molecular studies that gibbon speciation was both recent and sudden, either as a vicariant event or a rapid radiation at the end of the Miocene period (Israfil et al., 2011). We will now look to the fossil record to see if any of the features present today in living hylobatids may be seen in any known fossil ape.

\section{Fossil evidence}

It is a remarkable thing that despite their origin in the Miocene, hylobatids are not known in the fossil record earlier than the Middle Pleistocene. There are isolated teeth from Middle Pleistocene deposits in China and Indonesia, and Matthews and Granger (1923) described Bunopithecus sericus from Szechuan, which is indistinguishable from hoolock gibbons. Delson (1977) described a number of isolated teeth, but without attributing them to species, and Hooijer (1960) described numerous siamang teeth from Middle to Late Pleistocene sites in Indonesia. All are indistinguishable from living species of hylobatid and tell us nothing about the evolution of the lineage.

There are several reasons that might explain why the fossil record is so poor. Gibbons did not differentiate until relatively late in hominoid evolution, about the same time as the African ape and human clade, but while there is a good fossil record for early humans there is almost none for the great apes. DNA evidence shows that gibbons split off from the other apes and humans well before the orangutan divergence, but it may be that early species of fossil gibbon were extremely rare, and the sparse fossil record of fossil apes has so far failed to recover any. It is possible, even likely, that early gibbons did not look anything like modern gibbons, the characteristics of which almost certainly appeared late in their evolution, and it may be that some fossil gibbons are already known, but since they are not recognisable as gibbons they are not generally accepted as such. Finally, it might be also that gibbons were restricted to dense tropical forest, unlike the majority of fossil apes (see below), and the rarity of fossil sites representing forest habitats means that no fossil gibbons have been recovered. 
It is also the case with the great apes that few fossil apes can definitively be assigned to any of the great ape lineages. There is a fossil orangutan skeleton from middle Pleistocene deposits in Vietnam (Bacon and Long, 2001), fragmentary remains of chimpanzees in Africa, also from the Middle Pleistocene (McBrearty and Jablonsky, 2005; Pickford and Senut, 2005), and no fossil gorillas are known at all. It is the human lineage that is by far the best represented in the fossil record.

\section{Morphology of fossil apes}

We will first briefly review the evidence for morphological variation in fossil apes. Fossil apes span the last 20 million years, restricted initially to Africa in the early Miocene and spreading into Europe and Asia during the middle Miocene.

The earliest known apes are the proconsulids from the early Miocene, and they are characterised by the following key morphologies (described in Table 3.1).

Table 3.1: Morphological features of proconsulids related to their form of locomotion.

\begin{tabular}{|l|}
\hline Torsion of the humeral head \\
\hline Mobile shoulder joint \\
\hline Mobile elbow joint \\
\hline Narrow chest \\
\hline Long curved back \\
\hline Relatively long thumb \\
\hline Opposable thumb, non-rotatory \\
\hline Non-weight-bearing wrist and hand \\
\hline Relatively short hand \\
\hline Narrow gripping foot \\
\hline Powerful flexor muscles for gripping branches \\
\hline Molars had low degrees of shearing \\
\hline
\end{tabular}

Source: Compiled from sources on proconsulid morphology. All sources in reference list.

The conclusion to be drawn from the morphology of proconsulids is that they were arboreal climbers, moving on the tops of branches, but they were not habitual leapers rather moved slowly and powerfully in the trees. They were mainly fruit eaters with body sizes varying from $9-11 \mathrm{~kg}$ to $63-83 \mathrm{~kg}$, from siamang size to larger than chimpanzees, and some degree of terrestrial activity is indicated, particularly for the larger species, which were as big as chimpanzees or even bigger (Le Gros Clark and Leakey, 1951; Napier and Davis, 1959; Napier, 1960; Andrews, 1978, 1992; Walker and Pickford, 1983; Walker et al., 1983, 
1993; Rose, 1983, 1984; Beard et al., 1986; Gebo et al., 1988; Rafferty, 1988; Lewis, 1989; Walker and Teaford, 1988, 1989; Ward, 1993; Begun et al., 1994; Teaford, 1994; Rafferty et al., 1995; Ward et al., 1995; Harrison, 2002; Gebo et al., 2009). Primates at the upper end of the size range and living in woodland (non-forest) environments, must have been partly terrestrial, as in chimpanzees and gorillas today, for they were too large to move easily between arboreal pathways. Mike Rose has made a particularly telling point when he said: When I look at the postcranial bones from the Miocene apes, I get a fairly consistent pattern from many species, but it is nothing like what we see in modern apes. Maybe we should consider the ones that survived as the bizarre ones.

Dendropithecus macinnesi, an early Miocene ape from the same sites and levels as the proconsulids, was described originally by Le Gros Clark and Thomas (1951), who showed its similarities to hylobatids based on the gracile limb bones, which were taken to indicate suspensory locomotion in trees. Limb proportions were not gibbon-like, however, but more similar to those of spider monkeys. Andrews and Simons (1977) agreed with this interpretation, placing the new genus Dendropithecus in Hylobatidae, but in many respects it was shown that the morphology of the limb bones was more like that of colobine monkeys, the most arboreal of Old World monkeys.

There is also increasing evidence that early Miocene apes did not, for the most part, live in tropical forests but are mostly found associated with woodland habitats. The proconsulids (and Dendropithecus) at Rusinga Island are associated with a flora, which preserved a rich plant assemblage (Collinson et al., 2009) dominated by deciduous woodland tree species. There were very few twigs with thorns such as are found on more arid adapted species of Acacia or Balanites, and there was no evidence of forest trees. Broadleaved deciduous woodland is therefore indicated by the Rusinga flora. Evidence of large forest trees is known from Mfwangano Island, and the faunas from a few levels at Songhor and Koru suggest localised forest as well (Collinson et al., 2009).

Early in the middle Miocene, apes emigrated from Africa, initially in small numbers but later in the middle Miocene in greater numbers. Three groups are known at this stage, afropithecines, kenyapithecines and griphopithecines, and they share the following characters: relatively broad upper central incisors; lower crowned and relatively robust canines; enlarged premolars that are relatively long; molars with thick enamel, low dentine relief; long curved back; forelimbs adapted for both climbing and terrestrial locomotion; stiffer lower back (than proconsulids) analogous but not homologous to the condition in the living great apes; hand proportions indicate both arboreal and terrestrial locomotion; the foot was adapted for powerful grasping. 
Body sizes were within the range seen in the proconsulid species, estimated at 35 to $55 \mathrm{~kg}$, and environments were mainly woodland or even open woodland in Africa and subtropical woodlands in Europe (Harrison, 2002). Clearly, primates of this size, living in relatively open canopy woodlands, would have had to spend part of their time on the ground. The thick enamel of their teeth suggest a harder, coarser fruit and nut diet compared with proconsulids (Tekkaya, 1974; Alpagut et al., 1990, 1996; Teaford, 1988, 1991; Harrison, 1992; McCrossin and Benefit, 1997; McCrossin et al., 1998; Nakatsukasa et al., 1998, 2007; Begun and Güleç, 1998; King et al., 1999; Ishida et al., 1999, 2004; Ward, 1993; Ward et al., 1995; Kelley et al., 2000, 2002, 2008; Kelley, 2002, 2008; Ungar, 2007; Ersoy et al., 2008; Nakatsukasa, 2008).

During the second half of the middle Miocene and extending into the late Miocene, there was a greater proliferation of fossil apes in Europe and Asia. There are also a few genera and species known in Africa. The taxonomic status of subfamily Dryopithecinae has passed through several stages in its history, from the time when it included almost all known fossil apes, after the 1965 revision by Elwyn Simons and David Pilbeam (Simons and Pilbeam, 1965), to the later part of the twentieth century when almost everything except Dryopithecus itself had been removed (Begun, 2002). This situation will certainly change in the future, with some of the species and genera perhaps being combined and new ones found. Their characters are as follows: skulls with lightly built crania with relatively prominent brow ridges; variable prognathism from low to high; strong angle between face and skull (klinorhynchy) in Hispanopithecus laietanus; reduced maxillary sinus; broad triangular nose; broad palate; high zygomatic root; primitive teeth in $D$. fontani, molars with broad basins between cusps elongated molars and premolars in Pierolapithecus; teeth with thick enamel in Anoiapithecus and Pierolapithecus; reduced M3 in the three earlier species but not in $H$. laietanus and $R$. hungaricus; orthograde (upright) posture; broad chest region; long clavicle; scapula shifted on to back; stiff lumbar region; mobile elbow joint, stable at full extension; mobile wrist; long slender hand phalanges (short and less curved in some); femur head above greater trochanter; femur neck steeply angled.

Not all these characters are known for all species, but where they are known for two or more species the characters are consistent, with the conclusion that upright posture, and/or suspensory locomotion had evolved in some species of dryopithecines, particularly in Hispanopithecus laietanus (Crusafont-Pairo and Hurzeler, 1961; Pilbeam and Simons, 1971; Kretzoi, 1975; Morbeck, 1983; Begun et al., 1990, 2003; Moyà-Solà et al., 1993, 2004, 2009a, 2009b; Kordos, 1991; Begun and Kordos, 1993; Moyà-Solà S. and Köhler, 1993, 1995, 1996, 1997; Kordos and Begun 1997; Ungar and Kay 1995; Kordos and Begun, 1997; Kordos and Begun, 1997; Begun, 2002, 2009; Ungar, 2005; Alba et al., 2010; Begun et al., 
2012). Some of the characters supposedly indicating suspensory locomotion are absent in gibbons, the most suspensory of the apes, for example the stiff lower back. Similarly, the combination of mobility and stability in the elbow joint is seen as far back in time as the early Miocene in Proconsul heseloni, which had no suspensory adaptations. Crompton et al. (2008) points out that the adaptations of the trunk are related to upright posture, not necessarily to suspensory activity in trees, although it may be a pre-adaptation to the specialised brachiation in living gibbons. The large and elongated hand and cranial orientation of the head of the humerus are the two major adaptations that can be related to overhead suspension during locomotion, and these would certainly be pre-adaptations to gibbon-style locomotion.

The smaller dryopithecine species (15 to $35 \mathrm{~kg}$, Begun, 2002) have been found associated with subtropical to warm temperate swamp forests, with mesophytic broadleaved trees and deciduous conifers. These forests are deciduous and have open canopy, but there may have been a lower canopy of evergreen sclerophyllous bushes such as palms and laurels (Kretzoi et al., 1974; Axelrod, 1975; Myers and Ewel, 1990; Kovar-Eder et al., 1996; Kordos and Begun, 2002; Andrews and Cameron, 2010; Merceron et al., 2007; Marmi et al., 2012). There is no indication that these species of fossil ape were terrestrial.

More generally, all five dryopithecine species share some characters with the living great apes, and can be grouped with them in Hominidae. Some characters are shared only with the African great apes and others only with the orangutan. None are shared exclusively with gibbons, although the characters of the shoulder joint and hand are most similar to those of gibbons and orangutans, and it does not seem possible to link dryopithecines with one or other of the extant apes. The mosaic nature of evolutionary change depicted by the dryopithecines suggests that many of the cranial and dental similarities shared by the great apes evolved independently and should not be expected to be present in their common ancestor.

Mosaic evolution is also shown by the morphology of Oreopithecus bambolii, a late Miocene ape from Italy. It also had long arms, a broad thorax, short trunk, mobile hindlimbs, and powerful grasping hands and feet, and, like Hispanopithecus, it was adapted for forelimb suspension and arboreal climbing (Harrison, 1991; Harrison and Rook, 1997), but its skull and dental morphology show it to be different from the dryopithecines and probably an aberrant side branch of ape evolution.

Late Miocene fossil apes are less well known. A few fragmentary specimens have been recovered in Africa, but they are best known in Asian deposits, from Pakistan and India to Southeast Asia. Their associated habitats appear to be subtropical to tropical woodland (Badgley, 1984, 1989). Some of the species 
extend back into the middle Miocene, for example Sivapithecus sivalensis, and they are similar functionally to middle Miocene European apes, with relatively robust jaws and thick-enamelled teeth. Some have similarities of the skull with the orangutan, but the few postcrania show no suspensory adaptations and indicate a strong element of terrestriality in their locomotion (Pilbeam, 1982, 1996, 2004; Pilbeam et al., 1990; Rose, 1984, 1986, 1988, 1989, 1994, 1997). Laccopithecus robustus from late Miocene deposits in China is an ape similar to hylobatids in its skull and dental formation, but a single proximal phalanx is long and curved, like that of Hispanopithecus and gibbons (Wu and Pan, 1984; Meldrum and Pan, 1988; Begun, 2002).

In summary, the spectrum of fossil apes as known at present appears to have little or no bearing on the evolution of gibbons and nor, for that matter, to the great apes and humans. In 2006, Terry Harrison and PA tried to define the common ancestor between apes and humans by looking at the full extent of this spectrum, and we found that the last common ancestor of apes was probably not great-ape-like at all (Andrews and Harrison, 2006), and we suggest here that, similarly, the ancestral gibbons for most of their evolutionary history also did not look anything like recent gibbons.

\section{Divergence date of gibbons}

In the absence of fossil evidence, it has been proposed that the divergence of genera within the hylobatid clade was about $6 \mathrm{Ma}$. This is based in large part on the similarities in sequence diversity in mtDNA within the hylobatid clade and the African ape and human clade (Hayashi et al., 1995). Hylobatids are accepted as the outgroup to Hominidae (Hylobatidae(Hominidae(Ponginae(Ho mininae)))), and so, clearly, their separation from hominids must have predated the earliest divergence within Hominidae, that of the orangutan, and this gives a minimum age for the emergence of hylobatids. It has already been observed that the divergence of hylobatids from the great ape and human clade after that of the proconsulids does not itself give a maximum age of divergence. A minimum date is also provided by the uricase mutation mentioned above (and see below) of 13.1 to 9.8 Ma (Keebaugh and Thomas, 2010; Oda et al., 2002).

There are many unresolved issues in determining divergence ages. For a start, the calibration point from which molecular phylogenies are generated from DNA trees is that of the separation between monkeys and apes, and this is commonly taken to be about $30 \mathrm{Ma}$ (Raaum et al., 2005; Locke et al., 2011; Disotell, 2013). However, as Disotell points out, the earliest fossil apes or monkeys date to about $20 \mathrm{Ma}$, and there is no real basis for assuming a date much earlier than this. It is on the basis of a $30 \mathrm{Ma}$ split between monkeys and apes that the orangutan lineage is thought to have diverged at 12 to $13 \mathrm{Ma}$, but if the monkey/ape split 
was closer to $20 \mathrm{Ma}$, the orangutan divergence would have been closer to 9 or $10 \mathrm{Ma}$ and the separation of the gibbon lineage from other apes not much earlier than that.

The other main problem with the divergence of the orangutan lineage is that two species of fossil ape could be implicated. One is the Indian ape Sivapithecus sivalensis, the earliest record for which is about $12 \mathrm{Ma}$, and which gives a minimum age for the origin of the orangutan lineage (Pilbeam, 1996; Pilbeam et al., 1990). However, the postcranial skeleton of this fossil ape is nothing like that of the orangutan (Rose, 1984, 1986, 1989), whereas the skeleton and some aspects of the skull of Hispanopithecus laietanus from nine-million-year-old deposits in Spain have many similarities with the orangutan (Moyà-Solà and Köhler, 1996; Moyà-Solà et al., 2004, 2009a, 2009b). There is little likelihood, however, that $S$. indicus and $H$. laietanus are closely related, and it is clear that one or the other is converging on the orangutan, but which one? The fossils provide a range of dates of 9 to $12 \mathrm{Ma}$, and all we can say at present is that the gibbons branched off earlier.

\section{Hylobatid common ancestor}

To truly reflect evolutionary history, phylogenies must be based on characters inherited from recent ancestors, that is, homologous characters, and convergent, or non-homologous, homoplasies must be discarded. Further to this, the characters shared between two species are only significant in evolutionary terms if they were uniquely shared with their common ancestor, so that they are both homologous and derived relative to other species. Homology can sometimes be clearly evident, as for instance in the loss of the tail in all apes, but they can be difficult to distinguish from primitive retentions from an anthropoid ancestor. As new data are introduced into the analysis, the potential for error is compounded once the individual traits are combined into an ancestral morphotype. With this in mind, it is important to view ancestral morphotypes as approximations with relatively low resolution, rather than precise and accurate formulations of the ancestral condition. This is particularly important in stem forms where the proportion of potentially phylogenetically meaningful characters is small in relation to the number of primitive features, and the level of resolution may, therefore, exceed the capability to confidently differentiate their preserved anatomy from the ancestral morphotypes. If this is the case, there is a serious danger that the outcome of phylogenetic analyses might be influenced or skewed by the introduction of a few characters of uncertain or dubious utility.

From a theoretical perspective it may be argued that any common ancestor is essentially unknowable, because the characters by which it may be linked with its descendant species are not yet present. Closely related species are certain 
to share many characters as well as having developed different characters after their separation, but by the time that any one of these characters are present in a putative ancestor, it is no longer the common ancestor but belongs to one or other of the descendent lineages. For example, one of the most visible morphologies distinguishing living apes from all other primates is the loss of the tail, and any fossil primate lacking a tail, such as Proconsul, cannot be the common ancestor between monkeys and apes but must already be considered an ape. On the other hand, the common ancestor of apes and monkeys could have had a tail without being placed on the line leading to monkeys, for all other primates have tails, and this is the ancestral condition for all primates, primitively retained by monkeys. It is likely, therefore, that the common ancestor of apes and monkeys had a tail, but this does not help to identify it, just as lack of tail would disqualify it as the common ancestor.

Similarly with the gibbons: they share a whole suite of characters relating to their suspensory locomotion and orthograde posture, and this shows them to be a monophyletic group. Absence of some or even most of these characters would not exclude any fossil ape from being ancestral to gibbons before they began to speciate, and several possible scenarios for gibbon ancestry can be suggested and potentially tested against future fossil evidence. One such scenario is that the gibbon lineage will show the progressive acquisition of suspensory characters. In this scenario, it is suggested that early gibbon ancestors retained mainly primitive catarrhine characters, with a gradually developing suite of suspensory and orthograde adaptations, most of which were almost certainly acquired independently of the great apes and humans. Two examples illustrate this. Dendropithecus macinnesi from $18 \mathrm{Ma}$ in Africa had clear suspensory adaptations, but they were analogous with those of colobine or ateline monkeys, and they cannot be identified with any certainty as being homologous with gibbons. Evidence is lacking to show if the fossil species was orthograde or not. Similarly, the late Miocene Laccopithecus robustus from China combined primitive skull morphology with a single phalanx that also showed tantalising evidence of suspensory locomotion. Either or both could be ancestral to gibbons, but it is also the case that there were many other small-sized catarrhine primates in the Miocene, any one of which could have given rise to the gibbons.

An alternative scenario is that the gibbon lineage arose out of one of the lineages already known to have well developed suspensory adaptations, for example from Hispanopithecus laietanus. The adaptations of the upper arm and shoulder, the greatly elongated hand and the cranial orientation of the head of the femur could all be precursors to the highly specialised suspensory adaptations in living gibbons. Reduction in size, with increasingly gracile skulls, is not a major evolutionary step. Shea (2013) has shown that many of the apparent differences in the skull between great apes and gibbons is due 
to their size differences, characters such as palate depth, naso-alveolar clivus morphology, nasal aperture size and shape and the height of the zygomatic root. It is apparent that reduction in body weight by about 50 per cent of a fossil ape such as Hispanopithecus laietanus would leave its skull close to the morphology of gibbon skulls. The apparent adaptation of this dryopithecine, together with that of Rudapithecus hungaricus, to below branch suspensory locomotion in warm temperate to subtropical swamp forests in southern Europe (Merceron et al., 2007; Andrews and Cameron, 2010; Marmi et al., 2012) could have led to increasing specialisation to life in tropical rainforests.

A third scenario can be based on evidence of the mutation leading to the shutting down of the uricase gene. Uricase is an enzyme that breaks down uric acid, and exists in all mammals except the hominoids. There is evidence that the uricase enzyme progressively lost its activity in hominoids during the early Miocene due to mutations in its promoter region (Oda et al., 2002). However, complete silencing of the uricase gene occurred separately in the great ape-human clade (in codon 33 of exon 2) and in the hylobatids (in codon 18 of exon 2) during the midMiocene. The timing of the uricase mutations is not known with certainty, but it has been calculated in the great ape-human clade to have occurred either 12.9 Ma (Keebaugh and Thomas, 2010), 15.4 Ma (Oda et al., 2002), or between 15.7 and $20 \mathrm{Ma}$ (Eric Gaucher, pers. comm.), respectively. The silencing mutation in the hylobatid lineage has been estimated to occur at 13.1 Ma (Keebaugh and Thomas, 2010) or 9.8 Ma (Oda et al., 2002) based on proposed separations of the hominoids and Old World monkeys at $23 \mathrm{Ma}$ and of the Catarrhini and hominoids at $35 \mathrm{Ma}$, respectively. The presence of a monkey-like tooth in 25 Ma deposits of the Nsungwe Formation (Stevens et al., 2013) suggests an earlier divergence of monkeys and apes. These data are also consistent with a separation of hylobatids from the great ape-human lineage between 15 and 20 Ma.

It has been hypothesised that the loss of the uricase gene had a positive adaptive function in the great ape and human clade (Johnson and Andrews, 2010). For fruit eaters such as gibbons, this might appear to be a serious matter, for fructose, the primary sugar present in fruit, stimulates fat synthesis and accumulation due in part to an increase in intracellular and serum uric acid that occurs as a consequence of its unique metabolism (Lanaspa et al., 2012). The ability of fructose to stimulate fat accumulation in the liver is enhanced when uricase is inhibited (Tapia et al., 2013). The uric acid generated by fructose also has an important role in driving the elevations in serum triglycerides, induction of insulin resistance, and elevations in blood pressure in response to fructose (Nakagawa et al., 2006). Therefore, the loss of uricase may have enhanced the ability of gibbons and other ancestral apes to increase their fat stores from the ingestion of ripe fruits rich in fructose that could aid survival through the adverse conditions in seasonal habitats (Johnson and Andrews, 2010). In this 
scenario, it may be that the late Miocene gibbon ancestors passed through a traumatic phase in increasingly hostile environments before ending up in the rich tropical rainforests of Asia.

Whichever of these scenarios proves to be correct, or any other not so far proposed, it is evident from molecular studies that the gibbon radiation was recent and rapid, either as a vicariant event or extremely rapid radiation (Thinh et al., 2010; Israfil et al., 2011; Disotell, 2013). The trigger for this was probably the rise and fall of sea levels, combined with expansion and contraction of the Southeast Asian rainforests during the glaciations (Geissmann, 1995; BrandonJones, 1998). This diversification, however, probably took place during the last two to three million years, and it does not answer the question of what prompted the emergence of the highly specialised gibbon adaptations.

\section{Acknowledgements}

We are grateful to the organisers and editors of the book to honour the many contributions made by Colin Groves. Working with Colin has always been enjoyable and stimulating, both in the field on the Tana River project, and in the laboratory, when we did our work on gibbon morphology. PA benefited greatly from the association and owes much to Colin during a crucial stage of his career.

\section{References}

Aiello LC. 1981. The allometry of primate body proportions. In: Stringer CB, editor. Aspects of human evolution. London: Taylor \& Francis. pp. 331-358.

Alba DM, Fortuny J, Moyà-Solà S. 2010. Enamel thickness in the middle Miocene great apes Anoiapithecus, Pierolapithecus and Dryopithecus. Proc R Soc Lond 277:2237-2245.

Alpagut B, Andrews P, Martin L. 1990. New hominoid specimens from the middle Miocene site at Paşalar, Turkey. J Hum Evol 19:397-422.

Alpagut B, Andrews P, Fortelius M, Kappelman J, Temizsoy I, Celebi H, Lindsay W. 1996. A new specimen of Ankarapithecus meteai from the Sinap Formation of central Anatolia. Nature 382:349-351.

Andrews P. 1978. A revision of the Miocene Hominoidea of East Africa. Bull $\mathrm{Br}$ Mus Nat Hist (Geol) 30:85-224. 
Taxonomic Tapestries

Andrews P. 1992. Evolution and environment in the Hominoidea. Nature 360:641-646.

Andrews P, Cameron D. 2010. Rudabànya: Taphonomic analysis of a fossil hominid site from Hungary. Palaeogeog, Palaeoclimat, Palaeoecol 297:311329.

Andrews P, Groves CP. 1976. Gibbons and brachiation. In: Rumbaugh D, editor. Gibbon and Siamang, Vol. 4. Basel: Karger. pp. 167-218.

Andrews P, Harrison T. 2005. The last common ancestor of apes and humans. In: Lieberman DE, Smith RJ, Kelley J, editors. Interpreting the past: Essays on human, primate, and mammal evolution in honor of David Pilbeam. Boston: Brill Academic Publishers. pp. 103-121.

Andrews P, Simons EL. 1977. A new African gibbon-like genus Dendropithecus (Hominoidea, Primates) with distinctive postcranial adaptations: Its significance to origin of Hylobatidae. Folia Primatol 28:161-169.

Ashton EH, Oxnard CE. 1963. The musculature of the primate shoulder. Trans Zool Soc Lond 29:553-650.

Ashton EH, Oxnard CE. 1964. Locomotor patterns in primates. Proc Zool Soc Lond 142:1-28.

Avis V. 1962. Brachiation: The crucial issue for man's ancestry. Southwestern J Anthrop 18:119-148.

Axelrod DI. 1975. Evolution and biogeography of the Madrean-Tethyan sclerophyll vegetation. Ann Miss Bot Garden 62:280-334.

Bacon A-M, Long VT. 2001. The first discovery of a complete skeleton of a fossil orang-utan in a cave of the Hoa Binh Province, Vietnam. J Hum Evol 41:227241.

Badgley C. 1984. The palaeoenvironment of South Asian Miocene hominoids, In: White RD, editor. The evolution of East Asian environments. Hong Kong: Centre for Asian Studies. pp. 796-811.

Badgley C. 1989. Community analysis of Siwalik mammals from Pakistan. $J$ Vert Paleont 9:11A.

Beard KC, Teaford MF, Walker A. 1986. New wrist bones of Proconsul africanus and P. nyanzae from Rusinga Island, Kenya. Folia Primatol 47:97-118.

Begun DR. 2002. European hominoids. In: Hartig WC, editor. The primate fossil record. Cambridge: Cambridge University Press. pp. 339-368. 
Begun DR. 2009. Dryopithecins, Darwin, de Bonis and the European origin of the African apes and human clade. Geodiversitas 31:789-816.

Begun DR, Geraads D, Guleç E. 2003. The Çandır hominoid locality: Implications for the timing and pattern of hominoid dispersal events. Courier Forsch Senckenberg 240:251-265.

Begun DR, Güleç E. 1998. Restoration of the type and palate of Ankarapithecusmeteai: Taxonomic and phylogenetic implications. Am J Phys Anthrop 105:279-314.

Begun DR, Kordos L. 1993. Revision of Dryopithecus brancoi Schlosser, 1910, based on the fossil hominid material from Rudabanya. J Hum Evol 25:271286.

Begun DR, Moyá-Sola S, Köhler M. 1990. New Miocene hominoid specimens from Can Llobateres (Valles Penedes, Spain) and their geological and paleoecological context. J Hum Evol 9:255-268.

Begun DR, Nargolwalla MC, Kordos L. 2012. European Miocene hominids and the origin of the African ape and human clade. Evol Anthrop 21:10-23.

Begun DR, Teaford MF, Walker A. 1994. Comparative and functional anatomy of Proconsul phalanges from the Kaswanga primate site, Rusinga Island, Kenya. J Hum Evol 26:89-165.

Biegert J, Maurer R. 1972. Rumpfskelettlange, Allometrien und Korperproportionen bei catarrhinen Primaten. Folia Primatol 17:142-156.

Brandon-Jones D. 1998. Pre-glacial Bornean primate impoverishment and Wallace's line. In: Hall R, Holloway JD, editors. Biogeography and geological evolution of SE Asia. Leiden: Blackhuys Publishers. pp. 393-403.

Brandon-Jones D, Eudey AA, Geissmann T, Groves CP, Melnick DJ, Morales JC, Shekelle M, Stewart C-B. 2004. Asian primate classification. Int J Primatol 25:97-164.

Collinson ME, Andrews P, Bamford M. 2009. Taphonomy of the early Miocene flora, Hiwegi Formation, Rusinga Island, Kenya. J Hum Evol 57:149-162.

Crompton RH, Vereeke EE, Kalb JE. 2008. Locomotion and posture from the common hominoid ancestor to fully modern hominins, with special reference to the common Panin/Hominin ancestor. J Anat 212:501-543.

Crusafont-Pairó M, Hürzeler J. 1961. Les pongidés fossilles d'Espagne. Comptes Rendus bebdomadaires d l'Academie des Sciences Paris 254:582-584. 
Delson E. 1977. Vertebrate paleontology, especially of non-human primates from China. In: Howells WW, Tsuchitani PJ, editors. Paleoanthropology in the People's Republic of China. Washington: National Academy of Sciences, pp. 40-65.

Disotell TR. 2013. Genetic perspectives on ape and human evolution. In: Begun DR, editor. A companion to paleoanthropology. Oxford: Wiley-Blackwell. pp. 291-305.

Ersoy A, Kelley J, Andrews P, Alpagut B. 2008. Hominoid phalanges from the middle Miocene site of Paşalar, Turkey. J Hum Evol 54:518-529.

Gebo DL, Beard KC, Teaford MF, Walker A, Larson SG, Jungers WL, Fleagle JG. 1988. A hominoid proximal humerus from the early Miocene of Rusinga Island, Kenya. J Hum Evol 17:393-401.

Gebo DL, Malit NR, Nengo IO. 2009. New proconsuloid postcranials from the early Miocene of Kenya. Primates 50:311-319.

Geissmann T. 1995. Gibbon systematics and species identification. Zoo News 42:467-501.

Goodman M, Porter CA, Czelnusiak J, Page SL, Schneider H, Shoshani J, Gunnell G, Groves CP. 1998. Towards a phylogenetic classification of primates based on DNA evidence complemented by fossil evidence. Mol Phyl Evol 9:585598.

Groves CP. 1972. Systematics and phylogeny of gibbons. In: Rumbaugh D, editor. Gibbon and Siamang, Vol. 1. Basel: Karger. pp. 1-89.

Groves CP. 2001. Primate taxonomy. Washington, DC: The Smithsonian Institution.

Harrison T. 1991. The implications of Oreopithecus for the origins of bipedalism. In: Coppens Y, Senut B, editors. Origine(s) de la Bipédie Chez les Hominidés. Paris: Cahiers de Paléoanthropologie, CNRS. pp. 235-244.

Harrison T. 1992. A reassessment of the taxonomic and phylogenetic affinities of the fossil catarrhines from Fort Ternan, Kenya. Primates 33:501-522.

Harrison T. 2002. Late Oligocene to middle Miocene catarrhines from AfroArabia. In: Hartwig WC, editor. The primate fossil record. Cambridge: Cambridge University Press. pp. 311-338. 
Harrison T, Rook L. 1997. Enigmatic anthropoid or misunderstood ape? The phylogenetic status of Oreopithecus bambolii reconsidered. In: Begun, DR, Ward CV, Rose MD, editors. Function, phylogeny, and fossils: Miocene hominoid evolution and adaptations. New York: Plenum Press. pp. 327-362.

Hayashi S, Hayasaka K, Takenaka O, Horai S. 1995. Molecular phylogeny of gibbons inferred from mitochondrial DNA sequences: Preliminary report. $J$ Mol Evol 41:359-365.

Hooijer DA. 1960. Quaternary gibbons from the Malay archipelago. Zool Verh Mus Leiden 46:1-42.

Ishida H, Kunimatsu Y, Nakatsukasa M, Nakano Y. 1999. New hominoid genus from the middle Miocene of Nachola. Anthropological Science 107:189-191.

Ishida H, Kunimatsu Y, Takano T, NakanoY, Nakatsukasa M. 2004. Nacholapithecus skeleton from the Middle Miocene of Kenya. J Hum Evol 46:69-103.

Israfil H, Zehr SM, Mootnick AR, Ruvolo M, Steiper ME. 2011. Unresolved molecular phylogenies of gibbons and siamangs (Family Hylobatidae) based on mitochondrial, Y-linked and X-linked loci indicate a rapid Miocene radiation or sudden vicariance event. Mol Phyl Evol 58:447-455.

Johnson RJ, Andrews P. 2010. Fructose, uricase, and the back to Africa hypothesis. Evol Anthrop 19:250-257.

Jungers WL. 1984. Aspects of size and scaling in primate biology with special reference to the locomotor skeleton. Yrbk Phys Anthrop 27:73-97.

Keebaugh AC, Thomas JW. 2010. The evolutionary fate of the genes encoding the purine catabolic enzymes in hominoids, birds, and reptiles. Mol Biol Evol 27:1359-1369.

Kay, RF. 1977. Diet of early Miocene African hominoids. Nature 268:628-630.

Kelley J. 2002. The hominoid radiation in Asia. In: Hartwig WC, editor. The primate fossil record. Cambridge: Cambridge University Press. pp. 339-368.

Kelley J. 2008. Identification of a single birth cohort in Kenyapithecus kizili and the nature of sympatry between K. kizili and Griphopithecus alpani at Paşalar. J Hum Evol 54:530-537.

Kelley J, Andrews P, Alpagut B. 2008. A new hominoid species from the middle Miocene site of Paşalar, Turkey. J Hum Evol 54:455-479.

Kelley J, Ward S, Brown B, Hill A, Downs W. 2000. Middle Miocene hominoid origins: Response. Science 287:2375a. 
Taxonomic Tapestries

Kelley J, Ward S, Brown, B, Hill A, Duren DL. 2002. Dental remains of Equatorius africanus from Kipsaramon, Tugen Hills, Baringo District, Kenya. J Hum Evol 42:39-62.

King T, Aiello L, Andrews P. 1999. Dental microwear of Griphopithecus alpani. J Hum Evol 36:3-31.

Kordos L. 1991. Le Rudapithecus hungaricus de Rudabànya (Hongrie). L'Anthropologie 95:343-362.

Kordos L, Begun DR. 1997. A new reconstruction of RUD 77, a partial cranium of Dryopithecus brancoi from Rudabánya, Hungary. Am J Phys Anthrop 103:277-294.

Kordos L, Begun DR. 2002. Rudabánya: A late Miocene subtropical swamp deposit with evidence of the origin of the African apes and humans. Evol Anthrop 11:45-57.

Kovar-Eder J, Kvacek Zastawniak E, Givulescu R, Hably L, Mihajlovic D, Teslenko J, Walther H. 1996. Floristic trends in the vegetation of the Paratethys surrounding areas during Neogene times. In: Bernor RL, Fahlbusch V, Mitmann H-W, editors. The evolution of Western Eurasian Neogene mammal faunas. New York: Columbia University Press. pp. 395-413.

Kretzoi M. 1975. New ramapithecines and Pliopithecus from the lower Pliocene of Rudabànya in northeastern Hungary. Nature 257:578-581.

Kretzoi M, Krolopp E, Lorincz H, Palfalvy I. 1974. A Rudabanyai Alsopannonai prehominidas lelohely floraja, faunaja es retegtani helyzete. M All Foldtani Intezet Evi Jelentezi 1974:365-394.

Lanaspa MA, Sanchez-Lozada LG, Choi YJ et al. 2012. Uric acid induces hepatic steatosis by generation of mitochondrial oxidative stress: Potential role in fructose-dependent and -independent fatty liver. J Biol Chem 287:40732-44.

Le Gros Clark WE, Leakey LSB. 1951. The Miocene Hominoidea of East Africa. London: British Museum (Natural History).

Le Gros Clark WE, Thomas DP. 1951. Associated jaws and limb bones of Limnopithecus macinnesi. London: British Museum (Natural History).

Lewis OJ. 1971. Brachiation and the early evolution of the Hominoidea. Nature 203:577-579.

Lewis OJ. 1989. Functional morphology of the evolving hand and foot. Oxford: Clarendon Press. 
Locke DP, Hillier LW, Warren WC, Worley KC, Nazareth LV, Muzny DM, Yang S-P, Wang Z, Chinwall AT, Minx P. 2011. Comparative and demographic analysis of orang utan genomes. Nature 469:529-533.

McBrearty S, Jablonsky NG. 2005. First fossil chimpanzee. Nature 437:105-108.

McCrossin ML, Benefit BR. 1997. On the relationships and adaptations of Kenyapithecus, a large-bodied hominoid from the middle Miocene of eastern Africa. In: Begun DR, Ward CV, Rose MD, editors. Function, phylogeny and fossils: Miocene hominoid evolution and adaptations. New York: Plenum Press. pp. 241-267.

McCrossin ML, Benefit BR, Gitau SN, Palmer AK, Blue KT. 1998. Fossil evidence for the origin of terrestriality among Old World higher primates. In: Strasser E, Fleagle J, Rosenberger A, McHenry H, editors. Primate locomotion: Recent advances. New York: Plenum Press. pp. 353-396.

Marmi J, Casanovas-Vilar I, Robles JM, Moyá-Sola S, Alba DM. 2012. The paleoenvironment of Hispanopithecus laietanus as revealed by paleobotanical evidence from the late Miocene of Can Llobateres 1 (Catalonia, Spain). J Hum Evol 62:412-423.

Matthews WD, Granger W. 1923. New fossil mammals from the Pliocene of Szechuan, China. Bull Amer Mus Nat Hist 48:563-598.

Meldrum DJ, Pan Y. 1988. Manual proximal phalanx of Laccopithecus robustus from the latest Miocene site of Lufeng. J Hum Evol 17:719-731.

Merceron G, Schulz E, Kordos L Kaiser TM. 2007. Paleoenvironment of Dryopithecus brancoi at Rudabánya, Hungary: Evidence from dental mesoand micro-wear analyses of large vegetarian mammals. J Hum Evol 53:331349

Morbeck ME. 1983. Miocene hominoid discoveries from Rudabánya: Implications from the postcranial skeleton. In: Ciochon RL, Corruccini RS, editors, New interpretations of ape and human ancestry. New York: Plenum Press. pp. 369-404.

Moyà-Solà S, Alba DM, Almecija S, Casanovas-Vilar I, Köhler M, EstebanTrivigno S de, Robles JM, Galindo J, Fortuny J. 2009a. A unique middle Miocene European hominoid and the origins of the great ape and human clade. PNAS 106:1-6.

Moyà-Solà S, Köhler M. 1993. Recent discoveries of Dryopithecus shed new light on evolution of great apes. Nature 365:543-545. 
Taxonomic Tapestries

Moyà-Solà S, Köhler M. 1995. New partial cranium of Dryopithecus Lartet, 1863 (Hominoidea, Primates) from the upper Miocene of Can Llobateres, Barcelona, Spain. J Hum Evol 29:101-139.

Moyà-Solà S, Köhler M. 1996. The first Dryopithecus skeleton: Origins of great ape locomotion. Nature 379:156-159.

Moyà-Solà S, Köhler M. 1997. The phylogenetic relationships of Oreopithecus bambolii Gervais, 1872. C R Acad Sciences 324:141-148.

Moyà-Solà S, Köhler M, Alba DM, Casanovas-Vilar I, Galindo J. 2004. Pierolapithecus catalaunicus, a new middle Miocene great ape from Spain. Science 306:1339-1344.

Moyà-Solà S, Köhler M, Alba DM, Casanovas-Vilar I, Galindo J, Robles JM, Cabrera L, Garces M, Almecija S, Beamud E. 2009b. First partial face and upper dentition of the middle Miocene hominoid Dryopithecus fontani from Abocador de Can Mata (Valles-Penedes Basin, Catalonia, NE Spain): Taxonomic and phylogenetic implications. Am J Phys Anthrop 139:126-145.

Myers RL, Ewel JJ. 1990. Ecosystems of Florida. Gainesville: University of Central Florida Press.

Nakagawa T, Hu H, Zharikov S et al. 2006. A causal role for uric acid in fructoseinduced metabolic syndrome. Am J Physiol Renal Physiol 290:F625-631.

Nakatsukasa M. 2008. Comparative study of Moroto vertebral specimens. $J$ Hum Evol 55:581-588.

Nakatsukasa M, Kunimatsu Y, Nakano Y, Ishida H. 2007. Vertebral morphology of Nacholapithecus kerioi based on KNM-BG 35250. J Hum Evol 52:347-369.

Nakatsukasa M, Yamanaka A, Kunimatsu Y, Shimizu D, Ishida H. 1998. A newly discovered Kenyapithecus skeleton and its implications for the evolution of positional behaviour in Miocene East African hominoids. J Hum Evol 34:657-664.

Napier JR. 1960. Studies of the hands of living primates. Proc Zool Soc Lond 134:647-657.

Napier JR. 1963. Brachiation and brachiators. Symp Zool Soc Lond 10:183-195.

Napier JR, Davis PR. 1959. The fore-limb skeleton and associated remains of Proconsul africanus. London: British Museum (Natural History).

Oda M, Satta Y, Takenaka O, Takahata N. 2002. Loss of urate oxidase activity in hominoids and its evolutionary implications. Mol Biol Evol 19(5):640-653. 
Pickford M, Senut B. 2005. Hominoid teeth with chimpanzee- and gorilla-like features from the Miocene of Kenya: Implications for the chronology of apehuman divergence and biogeography of Miocene hominoids. Anthrop Sci 113:95-102.

Pilbeam DR. 1982. New hominoid skull material from the Miocene of Pakistan. Nature 295:232-234.

Pilbeam DR. 1996. Genetic and morphological records of the Hominoidea and hominid origins: A synthesis. Mol Phyl Evol 5:155-168.

Pilbeam DR. 2004. The anthropoid postcranial axial skeleton: Comments on development, variation and evolution. J Experiment Zool 302:241-267.

Pilbeam DR, Rose MD, Barry JC, Shah MI. 1990. New Sivapithecus humeri from Pakistan and the relationship of Sivapithecus and Pongo. Nature 348:237-239.

Pilbeam DR, Simons EL. 1971. Humerus of Dryopithecus from Saint Gaudens, France. Nature 229:406-407.

Preuschoft H, Chivers DJ, Brockelman WY, Creel N. 1984. The Lesser Apes: Evolutionary and Behavioural Biology. Edinburgh: Edinburgh University Press.

Raaum R, Sterner KN, Noviello CM, Stewart C-B, Disotel DR. 2005. Catarrhine primate divergence dates estimated from complete mitochondrial genomes: Concordance with fossil and nuclear DNA evidence. J Hum Evol 48:237-257.

Rafferty KL. 1998. Structural design of the femoral neck in primates. J Hum Evol 34:361-383.

Rafferty K, Walker A, Ruff C, Rose M, Andrews P. 1995. Postcranial estimates of body weight in Proconsul, with a note on a distal tibia of P. major from Napak, Uganda. Am J Phys Anthrop 97:391-402.

Rose MD. 1983. Miocene hominoid postcranial morphology: Monkey-like ape-like, neither, or both? In: Ciochon RL, Corruccini RS, editors. New interpretations of ape and human ancestry. New York: Plenum Press. pp. 405417.

Rose MD. 1984. Hominoid postcranial specimens from the middle Miocene Chinji Formation, Pakistan. J Hum Evol 13:503-516.

Rose MD. 1986. Further hominoid postcranial specimens from the late Miocene Nagri Formation of Pakistan. J Hum Evol 15:333-367.

Rose MD. 1988. Another look at the anthropoid elbow. J Hum Evol 17:193-224. 
Rose MD. 1989. New postcranial specimens of catarrhines from the middle Miocene Chinji Formation, Pakistan: Descriptions and a discussion of proximal humeral functional morphology in anthropoids. J Hum Evol 18:131-162.

Rose MD. 1994. Quadrupedalism in some Miocene catarrhines. J Hum Evol 26:387-411.

Rose MD. 1997. Functional and phylogenetic features of the forelimb in Miocene hominoids. In: Begun DR, Ward CV, Rose MD, editors. Function, phylogeny and fossils: Miocene hominoid evolution and adaptations. New York: Plenum Press. pp. 79-100.

Schultz AH. 1973. The skeleton of the Hylobatidae and other observations on their morphology. In: Rumbaugh DM, editor. Gibbon and Siamang, Vol. 2. Basel: Karger. pp. 1-54.

Simons EL, Pilbeam DR. 1965. A preliminary revision of the Dryopithecinae. Folia Primatol 3:81-152.

Stevens, NJ, Seiffert ER, O'Connor PM, Roberts EM, Schmitz, MD, Krause C, Gorscak E, Ngasala S, Hieronymus TL, Temu J. 2013. Palaeontological evidence for an Oligocene divergence between Old World monkeys and apes. Nature, published online 15 April 2013.

Tapia E et al. 2013. Synergistic effect of uricase blockade plus physiological amounts of fructose-glucose on glomerular hypertension and oxidative stress in rats. Am J Physiol Renal Physiol 304:F727-36.

Teaford MF. 1988. A review of dental microwear and diet in modern mammals. Scanning Microsc 2:1149-1166.

Teaford MF. 1991. Dental microwear: What can it tell us about diet and dental function? In: Else J, Lee P, editors. Advances in dental anthropology. New York: Wiley-Liss Inc. pp. 341-356.

Teaford MF. 1994. Dental microwear and dental function. Evol Anthrop 3:17-30.

Tekkaya I. 1974. A new species of anthropoid (Primates, Mammalia) from Anatolia. Bull Min Explor Inst, Ankara (MTA) 83:148-165.

Thinh VN, Mootnick AR, Geissmann T, Li M, Ziegler T, Agil M, Moisson P, Nadler T, Walter L, Roos C. 2010. Mitochondrial evidence for multiple radiations in the evolutionary history of small apes. BMC Evol Biol 10: 74. 
Ungar PS. 2005. Dental evidence for the diets of fossil primates from Rudabánya, Northeastern Hungary with comments on extant primate analogs and 'noncompetitive' sympatry. Palaeont Ital 90:97-112.

Ungar PS, editor. 2007. Evolution of the human diet. Oxford: Oxford University Press.

Ungar PS, Kay RF. 1995. The dietary adaptations of European Miocene catarrhines. PNAS 93:5479-5481.

Walker AC, Falk D, Smith R, Pickford M. 1983. The skull of Proconsul africanus: Reconstruction and cranial capacity. Nature 305:525-527.

Walker A, Pickford M. 1983. New postcranial fossils of Proconsul africanus and Proconsul nyanzae. In: Ciochon RL, Corruccini RS, editors. New interpretations of ape and human ancestry. New York: Plenum Press. pp. 325-351.

Walker A, Teaford M. 1988. The hunt for Proconsul. Scient Am 260:76-82.

Walker A, Teaford M. 1989. The Kaswanga primate site: An early Miocene hominoid site on Rusinga Island, Kenya. J Hum Evol 17:539-544.

Walker A, Teaford M, Martin L, Andrews P. 1993. A new species of Proconsul from the early Miocene of Rusinga/Mwangano Islands, Kenya. J Hum Evol 25:43-56.

Ward CV. 1993. Torso morphology and locomotion in Proconsul nyanzae. Am J Phys Anthrop 92:291-328.

Ward CV, Ruff CB, Walker A, Teaford MF, Rose MD, Nengo IO. 1995. Functional morphology of Proconsul patellas from Rusinga Island, Kenya, with implications for other Miocene-Pliocene catarrhines. J Hum Evol 29:1-19.

Ward CV, Walker A, Teaford MF. 1991. Proconsul did not have a tail. J Hum Evol 21:215-220.

Ward CV, Walker A, Teaford MF, Odhiambo I. 1993. Partial skeleton of Proconsul nyanzae from Mfangano Island, Kenya. Am J Phys Anthrop 90:77-111.

Wu R, Pan Y. 1984. A late Miocene gibbon-like primate from Lufeng, Yunnan Province. Acta Anthrop Sin 3:185-194. 



\title{
4. Hurricanes and coastlines: The role of natural disasters in the speciation of howler monkeys
}

\author{
Alison M Behie, Travis S Steffens, Tracy M Wyman, \\ Mary SM Pavelka
}

In his highly influential book Primate Taxonomy, Colin Groves discusses the importance of having an accurate account of primate taxa in order to understand evolutionary relationships that exist between species. This includes understanding genetic and morphological similarities between species as well as the processes of speciation. As the most widely ranging Neotropical monkey, the evolutionary relationships of the genus Alouatta have been examined from behavioural, morphological and most recently genetic data. According to Groves (2001) there are nine or 10 species of Alouatta and up to 19 subspecies (Table 4.1). Of these species, three are found in Mesoamerica: A. palliata, A. pigra and A. coibensis, with the rest located in South America. However, a more recent study of the molecular genetics of these species revealed $A$. coibensis to be indistinct from $A$. palliata, leaving $A$. pigra and $A$. palliata as the two remaining species in the Mesoamerican clade of howlers (Cortes-Ortiz et al., 2003). In 2012, while at a conference in Mexico, the lead author asked Colin what his thoughts were on the potential role of severe weather in speciation events, and more specifically on the biogeographical distribution on these two closely related species. He admitted he had never given it much thought, but was intrigued by the idea. This chapter further investigates this idea, by pulling together an array of evidence for both $A$. pigra and $A$. palliata in an attempt to add another piece to the puzzle of what factors are important in defining species.

Until 1970 A. pigra was considered a subspecies of $A$. palliata, when they were separated into two distinct species by Smith. This distinction was based on differences in their cranial size and morphology, characteristics of the upper molar dentition as well as the colour and texture of the pelage. Horwich and Johnson (1986) later noted that testes descend much earlier in A. pigra, and that $A$. pigra lives in consistently smaller social groups. The taxnomonic separation of A. pigra and A. palliata was genetically confirmed by Cores-Ortiz and others (2007) who showed them to have a $5.7 \%$ difference in mitochondrial DNA. 
Taxonomic Tapestries

Table 4.1: Howler species (genus Alouatta) as recognised by Colin Groves in Primate Taxonomy (2001).

\begin{tabular}{|c|c|c|}
\hline \multicolumn{3}{|l|}{ Alouatta palliata group } \\
\hline & \multicolumn{2}{|l|}{ Alouatta palliata } \\
\hline & \multicolumn{2}{|l|}{ Alouatta pigra } \\
\hline & \multicolumn{2}{|l|}{ Alouatta coibensis } \\
\hline \multicolumn{3}{|c|}{ Alouatta seniculus group } \\
\hline \multicolumn{3}{|c|}{ Alouatta seniculus } \\
\hline & & Alouatta seniculus arctoidea \\
\hline & & Alouatta seniculus juara \\
\hline \multicolumn{3}{|c|}{ Alouatta macconnelli } \\
\hline \multicolumn{3}{|c|}{ Alouatta sara } \\
\hline \multicolumn{3}{|c|}{ Alouatta belzebul } \\
\hline & \multicolumn{2}{|l|}{ Alouatta nigerrima } \\
\hline & \multicolumn{2}{|l|}{ Alouatta guariba } \\
\hline & & Alouatta guariba guariba \\
\hline & & Alouatta guariba clamitans \\
\hline \multicolumn{3}{|l|}{ Alouatta caraya group } \\
\hline \multicolumn{3}{|c|}{ Alouatta caraya } \\
\hline
\end{tabular}

Note: This chapter considers only the first group, which is the Central American group.

Source: After Groves (2001).

The dominant view of the colonisation of Mesoamerica by South American primate species revolves around the barrier created by the Andes, which limited the ability of taxa to move out of South America (Ford, 2006). When a land bridge formed between the two regions 3.5 million years ago, the only genera that were able to migrate were those already across this boundary in the northwest of South America. This included the genera Alouatta, Ateles, Aotus, Cebus and Saguinus. The divergence of the Mesoamerican Alouatta species into $A$. pigra and $A$. palliata could have occurred in one of two ways: colonisation by a single species that later split or speciation pre-colonisation and a first wave of A. pigra followed later by A. palliata (Smith, 1970). Cores-Ortiz and others' (2007) genetic data suggest a split of three million years ago for the two species, which coincides with the formation of the Panamanian land bridge. This is consistent with either the pre or post colonisation split. Ford (2006) supports a pre-colonisation speciation followed by four to five waves after the formation of the land bridge, however, cautions that due to the poorly resolved phylogenies of Mesoamerican primate species, the data do not support firm conclusions about this.

It has been suggested that $A$. palliata may not have been able to colonise areas where $A$. pigra are found due to the ability of $A$. pigra to live in a wider range of habitat types including swamps, mangroves and dry deciduous forests (Reid, 
1997). Further, A. pigra is mainly found in lowland coastal regions of less than $500 \mathrm{~m}$ (Horwich and Johnson, 1986; Baumgarten, 2006). Coastal forests of low elevation have an increased vulnerability to storms and severe stochastic weather patterns (Ford, 2006). As part of the Northern Atlantic Cyclone Basin, the Caribbean along with Central and South America are frequently hit by hurricanes, averaging six hurricanes and two tropical storms per year (www.noaa.com). Most of these, however, pass through the northern part of the hurricane basin in the Yucatan region. This type of regular exposure to severe weather events should have profound effects on the animals living in the area and, depending on frequency of exposure, could have influenced their behaviour and demographic profile (Ford, 2006). This is certainly the case in Madagascar, where the history of regular cyclones has resulted in changes to lemur behaviour and morphology including, small group size, high degrees of energy conserving behaviours (including torpor), and a limited number of species that are dedicated frugivores (Wright, 1999).

In this chapter we explore the possible role of severe weather events in determining the biogeographical distribution of A. pigra and A. palliata through a study of the forest characteristics that predict the occurrence of $A$. pigra in Belize. We also conduct an examination of group size and evidence of energy conservation in A. pigra and A. palliata to determine if $A$. pigra show any of the behavioural features associated with living in a stochastic environment. Finally we look for evidence of different levels of environmental stochasticity faced by $A$. pigra as compared to $A$. palliata by comparing the frequency of hurricanes and other tropical storms making landfall in the regions populated by each species. While we acknowledge that Colin Groves considers $A$. coibensis a separate species (Table 4.1), in this paper we focus on A. palliata and A. pigra due to limited data available on $A$. coibensis as well as the fact that its distribution is limited to the island of Coiba, which is located outside of a hurricane belt (Rylands et al., 2006).

\section{Materials and methods}

\section{Forest characteristics associated with A. pigra}

We used satellite imagery, local informants, guides, and published literature to identify areas that might contain $A$. pigra populations or be suitable habitat for A. pigra in Belize. To determine A. pigra presence or absence, and relative abundance, areas that were accessible were surveyed on foot using existing trails, logging roads, new trails or by boat along rivers. When a group of $A$. pigra was spotted, location data were collected using a hand held Global Positioning System device (Garmin GPSmap 60CSx). When possible this included the exact location of the 
group, but when it was not possible we recorded our location and a compass bearing towards the group and a visual estimate of the distance to the group in metres. We also recorded the group size and composition, height in the canopy and group activity. When a group was heard vocalising we estimated the distance in metres and direction of the group. In previous studies (Pavelka et al., 2007), we found this overestimated the distance by 0.5 to $1.0 \mathrm{~km}$, therefore we took this into account in our analysis here. All spatial data (visual and vocal contacts, confirmations of presence from local informants, and track information) were entered into ArcMap software (v.10.1). Relative abundance was calculated by dividing the number of monkeys sighted by the total distance $(\mathrm{km})$ walked, in that patch.

To assess forest characteristics associated with $A$. pigra, we measured its presence or absence and relative abundance in relation to anthropogenic disturbance (road density, number of settlements, human population density, amount of edge, and presence of agriculture), natural disturbance (hurricanes), and patch characteristics (patch size, patch type, river density, and elevation). We used ArcMap GIS (v.10.1) software to measure road density, the number of settlements within a patch, human population density of the patch, amount of edge to area ratio of a patch, how many hurricanes of category 1-4 have occurred within a patch, patch size, patch type, river density, and mean area-weighted patch elevation. The data to measure the above variables were acquired from BERDS (Biodiversity and Environmental Resource Data System) for all variables except the number of hurricanes, which was acquired from the National Oceanic and Atmospheric Administration (NOAA, 2006).

\section{Behavioural comparisons between $A$. pigra and $A$. palliata}

We surveyed the available literature on A. pigra and A. palliata to determine the average and mean group size of each species as well as to determine the influence of fruit consumption on activity budgets to look for indications of energy minimising behaviour. For the behavioural studies, we only included studies that were done over greater than six months to allow for seasonal variation in fruit availability and consumption to be considered. This resulted in the inclusion of three studies for A. pigra and 13 for A. palliata (Table 4.2). Due to this limited sample size, no statistical analyses could be performed on the behavioural changes associated with seasonal fruit scarcity, however, these data were compared qualitatively. 
Table 4.2: Studies included in behavioural comparisons of Alouatta pigra and $A$. palliata.

\begin{tabular}{|c|c|c|c|c|}
\hline $\begin{array}{c}\text { Behavioural response } \\
\text { to fruit shortage }\end{array}$ & Species & Study site & $\begin{array}{c}\text { Group size } \\
\text { (\# individuals) }\end{array}$ & Reference \\
\hline \multirow[t]{4}{*}{$\begin{array}{l}\text { Decrease time spent } \\
\text { travelling/ranging }\end{array}$} & $\begin{array}{l}\text { Alouatta } \\
\text { palliata }\end{array}$ & $\begin{array}{l}\text { Los Tuxlas, } \\
\text { Mexico }\end{array}$ & 14 & Estrada, 1984 \\
\hline & & $\begin{array}{l}\text { Arroyo Liza, } \\
\text { Mexico }\end{array}$ & 6 & Asensio et al., 2007 \\
\hline & $\begin{array}{l}\text { Alouatta } \\
\text { pigra }\end{array}$ & Monkey River & 6.6 & $\begin{array}{l}\text { Pavelka and Knopff, } \\
2004\end{array}$ \\
\hline & & $\begin{array}{l}\text { Cockscomb } \\
\text { Basin Wildlife } \\
\text { Sanctuary, Belize }\end{array}$ & 6.5 & $\begin{array}{l}\text { Silver and Marsh, } \\
2003\end{array}$ \\
\hline Group fission & $\begin{array}{l}\text { Alouatta } \\
\text { palliata }\end{array}$ & $\begin{array}{l}\text { Agaltepec Island, } \\
\text { Mexico }\end{array}$ & 59 & Asensio et al., 2007 \\
\hline \multirow[t]{2}{*}{$\begin{array}{l}\text { Increase time spent } \\
\text { feeding }\end{array}$} & $\begin{array}{l}\text { Alouatta } \\
\text { palliata }\end{array}$ & $\begin{array}{l}\text { Los Tuxlas, } \\
\text { Mexico }\end{array}$ & 4 & $\begin{array}{l}\text { Sheddon-Gonzalez } \\
\text { and Rodriguez-Luna, } \\
2010\end{array}$ \\
\hline & & $\begin{array}{l}\text { La Pacifica, } \\
\text { Costa Rica }\end{array}$ & 13 & Glander 1978 \\
\hline \multirow[t]{7}{*}{$\begin{array}{l}\text { Increased time spent } \\
\text { travelling/ranging }\end{array}$} & $\begin{array}{l}\text { Alouatta } \\
\text { palliata }\end{array}$ & $\begin{array}{l}\text { La Pacifica, } \\
\text { Costa Rica }\end{array}$ & 25 & $\begin{array}{l}\text { Williams-Guillen, } \\
2003\end{array}$ \\
\hline & & $\begin{array}{l}\text { La Pacifica, } \\
\text { Costa Rica }\end{array}$ & 15 & $\begin{array}{l}\text { Williams-Guillen, } \\
2003\end{array}$ \\
\hline & & $\begin{array}{l}\text { La Pacifica, } \\
\text { Costa Rica }\end{array}$ & 20 & $\begin{array}{l}\text { Williams-Guillen, } \\
2003\end{array}$ \\
\hline & & $\begin{array}{l}\text { La Pacifica, } \\
\text { Costa Rica }\end{array}$ & 13 & Glander, 1978 \\
\hline & & $\begin{array}{l}\text { Agaltepec Island, } \\
\text { Mexico }\end{array}$ & 10 & $\begin{array}{l}\text { Rodriguez Luna et } \\
\text { al., } 2003\end{array}$ \\
\hline & & $\begin{array}{l}\text { Agaltepec Island, } \\
\text { Mexico }\end{array}$ & 27 & $\begin{array}{l}\text { Rodriguez Luna et } \\
\text { al., } 2003\end{array}$ \\
\hline & & $\begin{array}{l}\text { Barro Colorado } \\
\text { Island, Panama }\end{array}$ & & Milton, 1980, 1981 \\
\hline \multirow[t]{6}{*}{$\begin{array}{l}\text { No change in } \\
\text { behaviour }\end{array}$} & $\begin{array}{l}\text { Alouatta } \\
\text { palliata }\end{array}$ & $\begin{array}{l}\text { Los Tuxlas, } \\
\text { Mexico }\end{array}$ & 7 & $\begin{array}{l}\text { Estrada and Coates- } \\
\text { Estrada, } 1999\end{array}$ \\
\hline & & La Selva, Mexico & 20 & Stoner, 1996 \\
\hline & & La Selva, Mexico & 11 & Stoner, 1996 \\
\hline & & $\begin{array}{l}\text { Santa Rosa, } \\
\text { Costa Rica } \\
\end{array}$ & 40 & $\begin{array}{l}\text { Chapman, 1987, } \\
1988\end{array}$ \\
\hline & & $\begin{array}{l}\text { Playo Escondida, } \\
\text { Mexico }\end{array}$ & 7 & Asensio et al., 2007 \\
\hline & $\begin{array}{l}\text { Alouatta } \\
\text { pigra }\end{array}$ & $\begin{array}{l}\text { Community } \\
\text { Baboon } \\
\text { Sanctuary, Belize }\end{array}$ & 5.9 & Silver et al., 1998 \\
\hline $\begin{array}{l}\text { Increase in time } \\
\text { spent inactive }\end{array}$ & $\begin{array}{l}\text { Alouatta } \\
\text { pigra }\end{array}$ & $\begin{array}{l}\text { Cockscomb } \\
\text { Basin Wildlife } \\
\text { Sanctuary, Belize }\end{array}$ & 6.5 & $\begin{array}{l}\text { Silver and Marsh, } \\
2003\end{array}$ \\
\hline
\end{tabular}

Source: Data compiled from behavioural and diet studies of at least nine months in duration to account for seasonality. This resulted in three studies for A. pigra and 13 for A. palliata. See reference list for full references of studies included. 
Taxonomic Tapestries

\section{Hurricane-to-coastline ratios}

In order to calculate the number of hurricanes in relation to length of coastline (a hurricane to coastline ratio) for A. pigra and A. palliata, species distribution maps based on Rylands and others (2006) and hurricane tracks obtained from the National Oceanic and Atmospheric Administration (NOAA) in digital format, were plotted in ArcGIS 10.1 (ESRI, 2012). Political boundary data of all Central American countries consisted of datasets from the Digital Chart of the World (Defence Mapping Agency, 1992). These datasets have a standard 1:1,000,000 scale and were used as the base for coastline measures. For the purpose of this study we chose to use a method that would be easily repeatable yet still provide a valid measure of coastline length with respect to the potential distance that tropical storms could cross. Coastline lengths for A. pigra and A. palliata ranges were calculated using the 'detailed hull' function in the extension XTools Pro 9.2 (Data East, 2012) in ArcGIS. The detailed hull function creates a 'contour' around outer points similar to that of a standard convex hull, except that it does include some concave angles when consecutive line segments fall below a certain length - the result of this detailed hull function is a 'finer scaled convex hull'. If the actual length of coastline was used, it would overestimate length due to undulations caused by major inlets and bays along the actual coastline. These are especially apparent along the coast of Belize.

The complete dataset of hurricane tracks included hurricanes from Category 1 to 5, tropical storms, and tropical depressions of all known and recorded storms from the years 1851 to 2007. Because hurricane strength often changes once hitting land, it was not possible to calculate a reasonable comparative measure of number of hurricanes by species range area. Thus we calculated a ratio of the number of hurricanes crossing the coastline for each of the species' range. Coastline measurements were clipped to create a measure for the two species ranges' separately. Hurricane track data were filtered so that two measures could be performed: (1) all tropical depressions, tropical storms, and hurricanes Category 1 to 5 ; (2) hurricanes only (all categories).

\section{Results}

\section{Forest patch characteristics of $A$. pigra in Belize}

We recorded a total of 83 visual and 110 vocal contacts of $A$. pigra within Belize and collected another 284 confirmations of presence from other reliable sources. All patches were sampled in lowland habitat and a chi square test for independence $(\mathrm{p}=0.05)$ found that $A$. pigra were more likely to be present in 
a patch classified as lowland broad-leaf moist and wet forest, and more likely to be absent from patches classified as agriculture, lowland savannah, shrubland, or wetland. The area-weighted mean elevation of all patches ranged between sea level and $222 \mathrm{~m}$ ASL with the highest confirmation of an A. pigra group at $700 \mathrm{~m}$ and the highest reported sighting of a group at $289 \mathrm{~m} \mathrm{ASL}$. When considering factors influencing the relative abundance of $A$. pigra, only the amount of edge was positively associated $(r=0.545 ; \mathrm{p}=0.006)$ accounting for $30 \%$ of the variation in relative abundance $\left(r^{2}=0.297\right)$.

We found a significant positive relationship between the number of settlements in a patch and the presence of $A$. pigra, with more settlements in present patches (1.19) than absent patches (0.14). There was also a significant relationship between $A$. pigra presence and patch size. Patches ranged in size from $0.13 \mathrm{~km}^{2}$ to over $1256 \mathrm{~km}^{2}$ with the largest patch occurring in the Rio Bravo and Gallon Jug region and the smallest patches $\left(<1.0 \mathrm{~km}^{2}\right)$ adjacent to the Belize River. We found present patches to be, on average, larger $\left(117.24 \mathrm{~km}^{2}\right)$ than absent patches $\left(27.29 \mathrm{~km}^{2}\right)$.

\section{Behavioural comparisons of $A$. pigra and $A$. palliata}

Our literature review found $A$. pigra to live in significantly smaller groups than A. palliata with $A$. pigra living in groups ranging from 5.9 to 9 individuals $(\overline{\mathrm{x}}=6.83, \mathrm{CV}=19.55)$ and $A$. palliata living in groups ranging from 4 to 59 individuals $(\overline{\mathrm{X}}=15.37, \mathrm{CV}=79.78)$. Group size in $A$. palliata was more variable, which may be due to the increased sample size for the comparatively well studied mantled howler or reflect group size constraints that may be present in A. pigra due to the stochastic nature of their environment.

When examining the relationship between fruit consumption and activity patterns we found no consistent differences within or between species in how populations adjust behaviour during periods of fruit shortage. Populations of A. pigra either decreased time spent travelling (from $9.52 \%$ to $5.45 \%$ ), increased time spent inactive (from $69 \%$ to $77 \%$ ) or did not adjust activity patterns in response to seasonal reductions in fruit intake (Behie and Pavelka, 2005; Silver et al., 1998; Pavelka and Knopff, 2004). While some groups of $A$. palliata also did not show changes in activity that correspond to fruit production, the most common response reported in the literature is an increase in either travel time (from 18.6\% to $35.8 \%$ in A. palliata in Nicaragua, Williams-Guillen, 2003) or ranging distance (from $114.05 \mathrm{~m}$ to $502.88 \mathrm{~m}$ for a population in Mexico, Estrada, 1984), which is a response that has never been reported for a population of $A$. pigra. 


\section{Severe weather events in the ranges of $A$. pigra and A. palliata}

The method described above resulted in a coastline length of $893 \mathrm{~km}$ for $A$. pigra and $1372 \mathrm{~km}$ for A. palliata. Since 1851, 118 Atlantic hurricanes, depressions or tropical storms have crossed into coastal regions populated by $A$. pigra, where only 40 have crossed into the range of $A$. palliata. There is a significantly higher storm to coastline ratio of 0.132 for $A$. pigra than the 0.0292 for $A$. palliata $\left(X^{2}\right.$ $=37.52, \mathrm{df}=1, \mathrm{p}<0.0001$ ) (Figure 4.1a). When considering hurricanes only, the difference is still evident. Many more hurricanes crossed the coastal regions of A. pigra $(\mathrm{N}=49)$ compared to A. palliata $(\mathrm{N}=19)$ (Figure $4.1 \mathrm{~b})$. The hurricane to coastline ratios ( 0.551 for $A$. pigra and 0.0138 for $A$. palliata) were significantly different $\left(\mathrm{X}^{2}=12.36, \mathrm{df}=1, \mathrm{p}=0.0004\right)$.

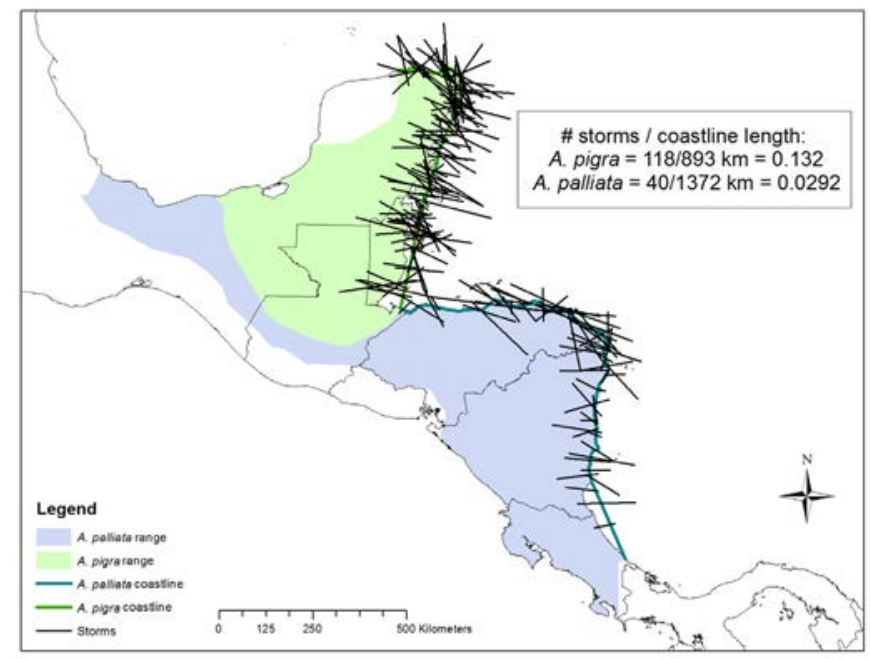

Figure 4.1a: Total number of storms that crossed through the ranges of Alouatta pigra and Alouatta palliata from 1851 to 2007.

Source: Data were obtained from the National Oceanic and Atmospheric Administration (NOAA) and plotted in ArcGIS 10.1 (ESRI, 2012). Political boundary data of all Central American countries consisted of datasets from the Digital Chart of the World (Defence Mapping Agency, 1992). These datasets have a standard 1:1,000,000 scale and were used as the base for coastline measures. 
4. Hurricanes and coastlines

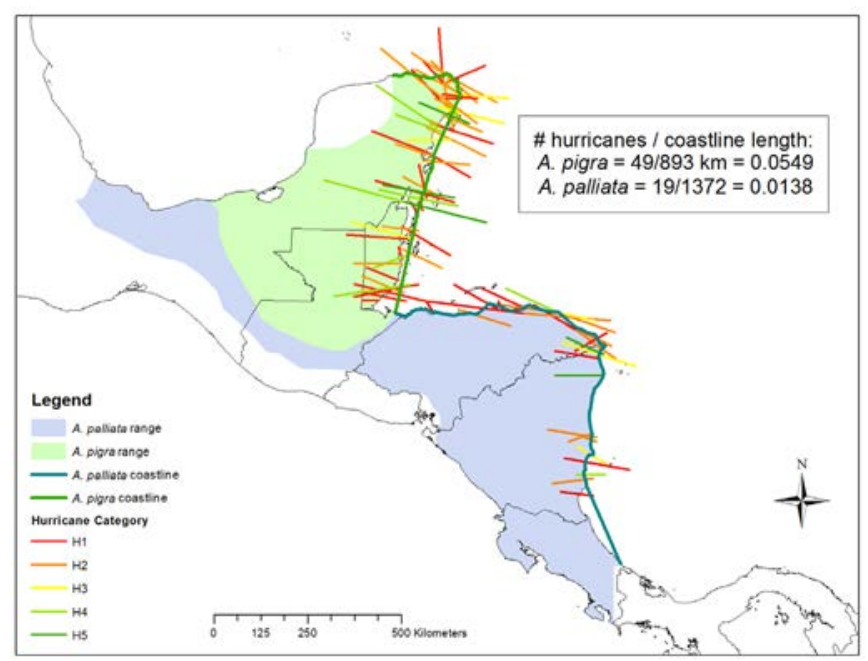

Figure 4.1b: Total number of hurricanes that crossed through the ranges of Alouatta pigra and Alouatta palliata from 1851 to 2007.

Source: Data were obtained from the National Oceanic and Atmospheric Administration (NOAA) and plotted in ArcGIS 10.1 (ESRI, 2012). Political boundary data of all Central American countries consisted of datasets from the Digital Chart of the World (Defence Mapping Agency, 1992). These datasets have a standard 1:1,000,000 scale and were used as the base for coastline measures.

\section{Discussion}

The evolutionary history of $A$. pigra and $A$. palliata in Mesoamerica is not entirely understood. Colonisation of Mesoamerica by South American species took place after the formation of a land bridge between the two regions approximately 3.5 million years ago (Ford, 2006), and genetic data suggest that the two Alouatta species diverged from one another close to 3.0 Mya (CoresOrtiz et al., 2007). Whether they colonised Mesoamerica before or after this speciation event, A. pigra is currently limited to a small geographic range in the Yucatan Peninsula compared to a relatively wide distribution of $A$. palliata. The aim of this paper was to investigate the potential role of environmental stochasticity in the geographic distribution and possibly speciation of $A$. pigra and $A$. palliata through: an examination of the forest characteristics that predict the presence of $A$. pigra; a comparison of the behavioural traits of $A$. pigra and $A$. palliata that might suggest an evolutionary history shaped by living in a stochastic environment; and finally a comparison of the prevalence of severe weather events, such as hurricanes, in the ranges of the two species. 
In terms of patch characteristics, we found a higher relative abundance of A. pigra in Belize in lowland broad-leaf moist and wet forest, in line with previous reports that $A$. pigra inhabit primarily lowland riverine coastal forests (Horwich and Johnson, 1986; Reid, 1997). The highest published densities reported for $A$. pigra have been at the Community Baboon Sanctuary (CBS) near the Belize River (257 ind/ $\mathrm{km}^{2}$, Ostro et al., 1999) and at Monkey River (102 ind/ $\mathrm{km}^{2}$, Pavelka, 2003). Seasonally flooded forests create localised disturbance which may improve soil quality and thus the quality of the howler food supply (Peres, 1997). We also found a significant positive relationship between both human settlements and patch size and the occurrence of A. pigra and between the amount of edge and the relative abundance of $A$. pigra. This suggests that $A$. pigra is tolerant of disturbance and may even prefer disturbed forest patches. One reason for such a preference may be that disturbed areas are colonised by fast growing pioneer species that invest little in chemical defence, thus produce leaves high in protein and low in fibre and secondary compounds (Coley, 1983). Folivores are able to take advantage of this and maintain a high quality diet despite an overall reduction in stem density. We found this to be the case following hurricane Iris in Monkey River where A. pigra shifted their leaf consumption to include up to $75 \%$ Cecropia peltata, which had the highest protein to fibre ratio and the third highest concentration of sugar of all ingested species (Behie et al., 2014).

Living in disturbed forest patches may improve the food supply for folivores in the long term, but immediately following a severe natural disaster there would be substantial reductions in the available food supply. Many trees regenerate new leaves immediately following a hurricane (Klinger, 2006; Zimmerman and Covich, 2007; Waide, 1991), while other food sources such as fruit or flowers take longer to return (Waide, 1991; Behie and Pavelka, 2005; Ratsimbazafy et al., 2002). After Hurricane Iris hit Monkey River there was a 52 per cent loss of major fruit trees and an 18 month absence in all fruit production forcing resident A. pigra groups to rely on a completely folivorous diet (Behie and Pavelka, 2005; Behie and Pavelka, in press). Following natural disturbances ring-tailed lemurs (Lemur catta; LaFleur and Gould, 2009; Ratsambazafy et al., 2002), ruffed lemurs (Varecia v. editorium; Ratzimbazafy, 2006) lion-tailed macaques (Macaca silenus; Menon and Poirer, 1996) and black howlers (Alouatta pigra; Behie and Pavelka, 2005) altered their diets to include plant parts and species not previously ingested, some of which were exotic to the region or were located outside of the regular forest habitat.

Such changes in food supply would be expected to result in demographic and behavioural changes to deal with an unpredictable and irregular food supply. One such mechanism to cope with this would be to reduce group size to deal with increased feeding competition. The average group size of black-and- 
white lemurs decreased from seven individuals before Cyclone Gretelle to 2.5 individuals after (Ratsimbazafy et al., 2002) and after wildfires moved through Borneo, the number of gibbon groups of more than five members significantly decreased, while the number of pairs increased (O'Brien et al., 2004). Group size in A. pigra in Monkey River following Hurricane Iris fell from 6.32 individuals before the storm to less than five in the first year following the storm. This suggests that animals exposed to severe disturbance adapt in the short term by reducing group size.

If exposed to severe environmental change on a regular basis, it stands to reason that group size may be constrained, placing upper limits on how many animals could live in a group without suffering the ill effects of increased competition at times of food scarcity. This was suggested by Wright (1999) who noted that lemur populations affected by frequent cyclones lived in smaller groups than groups not impacted by severe weather. In our comparison with A. palliata we found that $A$. pigra have significantly smaller and less variable group sizes than do A. palliata. Mean group size in A. palliata is 15.37 (Glander, 1978; Estrada, 1982, 1984; Chapman, 1987; Larose, 1996; Stoner, 1996; Estrada et al., 1999; Serio-Silva et al., 1999; Solano et al., 1999; Rodriguez-Luna, 2003; Williams Guillen, 2003; Munoz et al., 2006; Asensio et al., 2007; Dunn et al., 2009; Dunn et al., 2010) and mean group size in A. pigra is 6.83 (Silver et al., 1998; Silver and Marsh, 2003; Pavelka and Knopff, 2004; Pozo-Montuy and Serio-Silva, 2006). Considering the hurricane activity that occurs in the range of A. pigra, low group size could very well represent an adaptation to living in a stochastic environment. James et al. (1997) studied groups of $A$. pigra living at Bermudian Landing, Belize that were subjected to population declines from hurricanes in 1931, 1954 and 1978 as well as from a yellow fever epidemic which occurred in 1971. Each of these severe weather events caused a drastic decline in population numbers, and although they have recovered, the average group size in this region is only 4.6 individuals, lower than most other species of howlers. In 1999 this number increased to between four to 10 individuals, which although larger, is still smaller than other howler species (Ostro et al., 1999). A similar decline in group size was recorded in Monkey River following Hurricane Iris where group size remains smaller than before the storm even after more than a decade has passed.

We also found differences in activity patterns between A. pigra and A. palliata during periods of fruit scarcity. The prolonged fruit shortage following Hurricane Iris resulted in differences in activity levels between periods when fruit was not available (2002-mid-2004; mean fruit intake 4.93\%) and when it was available at close to pre-hurricane levels (mid-2004-2007; mean fruit intake $28.75 \%$ ). When fruit consumption was absent or very low, animals spent more time inactive and less time feeding and locomoting, probably minimising energy 
expenditure in response to low energy intake. An increase in time spent inactive and a reduction in time spent feeding has also been seen in howler monkeys following translocation to an unfamiliar environment (Silver and Marsh, 2003) and in lemurs in response to unpredictable resource availability and dramatic and prolonged shortages in fruit production in Madagascar (Wright, 1999). In lemurs this is also associated with a lower basal metabolic rate, which varies in response to changing fruit production, allowing them to maximise energy conservation (Pereira, 1993; Jolly, 1966). Increasing inactivity in the howlers at Monkey River in response to prolonged fruit shortage likely serves a similar function allowing howlers to conserve energy at times when higher quality resources (e.g. fruit) are not ingested. This however is not the response seen in A. palliata who have been reported to increase travel time (Williams-Guillen, 2003) or ranging distance (Estrada, 1984) when fruit is less available. This may be reflective of increased scramble competition in the larger groups of $A$. palliata, however, it may also be a result of $A$. palliata living in regions that show more predictability in fruit production with less need to conserve energy for long periods of food scarcity.

This successful dispersal of $A$. palliata may have resulted in their outcompeting A. pigra in most areas, pushing them up into their currently restricted range of southern Mexico, Belize and northern Guatemala (Ford, 2006). If this is true, and $A$. palliata were able to outcompete $A$. pigra and push them out of many regions, then the current range of $A$. pigra must represent areas that are not tolerated by A. palliata. There is no denying that exposure to hurricanes would create a selective pressure for animals living in hurricane belts, an idea that Colin himself agrees may have influenced speciation and/or current biogeographical distributions. Data presented here show that significantly more hurricanes pass into the range of $A$. pigra than the range of $A$. palliata. This may have been one reason why $A$. palliata did not extend their range into the hurricane belt of the Yucatan Peninsula, leaving A. pigra as the only Alouatta species to colonise the area. This is supported by the fact that $A$. pigra are commonly found in and may actually prefer disturbed forests and live in small groups who exhibit energy conservation strategies with regards to their activity budgets. Such adaptations to environmental stochasticity are also seen in lemurs regularly exposed to cyclones in Madagascar (Wright, 1999) suggesting they are necessary adaptive mechanisms to cope with high degrees of environmental perturbations. $A$. palliata may be less able to tolerate hurricane activity and unable to colonise the hurricane belt of the Yucatan Peninsula. While there may be other reasons contributing to the range separation of $A$. pigra and $A$. palliata, we argue that the role of hurricane activity cannot be ruled out as a possible explanation for the current biogeographical separation and potentially of speciation in these two species and potentially other species exposed to severe weather conditions. 
This is an idea rarely considered in theories of primate speciation or when considering current biogeographical ranges, but as severe weather events become more frequent and intense is one that warrants further investigation.

\section{Acknowledgements}

We wish to thank the Belize Government for granting us permission to conduct this research. The Monkey River Research Project could not be done without the assistance of guides and research assistants who aid in the collection of data and monitoring of the monkey population. Financial support for this research was received from The Natural Sciences and Engineering Council of Canada, The International Primatological Society, Sigma Xi, The Department of Anthropology, Faculty of Social Sciences and Graduate Studies at the University of Calgary. All data collection met the principles of the ethical treatment for animals and were approved by the Life and Environmental Sciences Animal Care Committee at the University of Calgary.

\section{References}

Asensio N, Cristobal-Azkarate J, Dias PAD, Vea JJ, Rodriguez-Luna E. 2007. Foraging habits of Alouatta palliata mexicana in three forest fragments. Folia Primatol 78:141-153.

Baumgarten A. 2006. The distribution and biogeography of Central American howling monkeys (Alouatta pigra and A. palliata). Masters Thesis, Louisiana State University.

Behie AM, Pavelka MSM. 2005. The short-term effect of Hurricane Iris on the diet and activity of black howlers (Alouatta pigra) in Monkey River, Belize. Folia Primatol 76:1-9.

Behie AM, Pavelka MSM. 2013. The interacting roles of nutrition, stress and parasitism in determining population density of howler monkeys living in a hurricane disturbed forest fragment. Chapter to be included in the book Primates infragments: Complexity and resilence. March LK, editor. Springer Press.

Behie AM, Kutz S, Pavelka SMS. 2014. Cascading effects of climate change: How do hurricane-damaged forests increase exposure to parasies. Biotropica. $46: 25-34$. 
Behie AM, Pavelka MSM. In press. Fruit as a key factor in howler monkey population density: Conservation implications. In: Kowalewski M, Garber PA, Cortes-Ortiz L, Urbani B, Youlatos D, editors. Howler monkeys: Examining the biology, adaptive radiation, and behavioral ecology of the most widely distributed genus of Neotropical primate. New York: Springer Press.

Chapman CA. 1987. Flexibility in diets of three Costa Rican primates. Folia Primatol 49:90-105.

Coley PD. 1983. Herbivory and defensive characteristics of tree species in a lowland tropical forest. Ecol Monographs 53(2):209-234.

Cortes-Oritz L, Bermingham E, Rico C, Rodriguez-Luna E, Sampaio I, RuizGarcia M. 2003. Molecular systematics and biogeography of the Neotropical monkey genus, Alouatta. Mol Phyl Evol 26:64-81.

Data East. 2012. XTools Pro for ArcGIS Desktop. 9.2. Data East, LLC.

Defense Mapping Agency. 1992. Digital Chart of the World. Fairfax, VA: Defense Mapping Agency.

Dunn JC, Asensio N, Arroyo-Rodriguez V, Schnitzer S, Cristobal-Azkarate J. 2009. The ranging costs of a fallback food: Liana consumption supplements diet but increases foraging effort in howler monkeys. Biotropica 43:612-618.

Dunn JC, Cristobal-Azkarate J, Vea JJ. 2010. Seasonal variations in the diet and feeding effort of two groups of howlers in different sized forest fragments. Int J Primatol 31:887-903.

Environmental Systems Resource Institute (ESRI). 2012. ArcGIS 10.1. Redlands, California: ESRI.

Estrada AR. 1982. Survey and census of howler monkeys (Alouatta palliata) in the rainforest 'Lox Tuxlas' Veracruz, Mexico. Am J Primatol 2:363-372.

Estrada A. 1984. Resource use by howler monkeys (Alouatta palliata) in the rainforest of 'Los Tuxlas', Veracruz, Mexico. Int J Primatol 5:105-131.

Estrada A, Anzures A, Coates-Estrada R. 1999. Tropical rainforest fragmentation, howler monkeys (Alouatta palliata), and dung beetles at Los Tuxlas, Mexico. Am J Primatol 48:253-262.

Ford SM. 2006. The biogeographic history of Mesoamerican primates. In: Estrada, A, Garber PA, Pavelka MSM, Luecke L, editors. New perspectives in the study of Mesoamerican primates: Distribution, ecology, behavior, and conservation. New York: Springer. pp. 81-120. 
Glander KE. 1978. Howling monkey feeding behavior and plant secondary compounds: A study of strategies. In: Montgomery GG, editor. The ecology of arboreal folivores. Washington, DC: Smithsonian Press. pp. 561-573.

Groves CP. 2001. Primate taxonomy. Washington, DC: Smithsonian Books.

Horwich RH, Johnson ED. 1986. Geographic distribution of the black howler (Alouatta pigra) in Central America. Primates 2:53-62.

James R, Leberg PL, Quattro JM, Vrijenhoek RC. 1997. Genetic diversity in black howler monkeys (Alouatta pigra). Am J Phys Anthropol 102:329-336.

Jolly A. 1966. Lemur behaviour: A Madagascar field study. Chicago: University of Chicago Press.

Klinger R. 2006. The interaction of disturbances and small mammal community dynamics in a lowland forest in Belize. J Anim Ecol 75:1227-1238.

LaFleur M, Gould L. 2009. Feeding outside the forest: The importance of crop raiding and an invasive weed in the diet of gallery forest ring-tailed lemurs (Lemur catta) following a cyclone at the Beza Mahafaly Special Reserve, Madagascar. Folia Primatol 80:233-246.

Larose F. 1996. Foraging strategies, group size and food competition in the mantled howler monkey, Alouatta pigra. PhD thesis, University of Alberta.

Menon S, Poirer FE. 1996. Lion-tailed macaques (Macaca silenus) in a disturbed forest fragment: Activity patterns and time budget. Int J Primatol 17:969985.

Milton K. 1980. The foraging strategy of howler monkeys: A study in primate economics. New York: Columbia University Press.

Milton K. 1981. Food choices and digestive strategies of two sympatric species. Amer Nat 117:496-505.

Munoz D, Estrada A, Naranjo E, Ochoa S. 2006. Foraging ecology of howler monkeys in a cacao (Theobroma cacao) plantation in Comalcalco, Mexico. Am J Primatol 68:127-142.

National Oceanic and Atmospheric Administration (NOAA). 2006. Historical North Atlantic and East-Central North Pacific tropical cyclone tracks, 18512005. www.csc.noaa.gov/hurricane_tracks (accessed September 2006).

O'Brien TG, Kinnaird MF, Nurcahyo A, Iqbal M, Rusmanto M. 2004. Abundance and distribution of sympatric gibbons in a threatened Sumatran rainforest. Int J Primatol 25:267-284. 
Taxonomic Tapestries

Ostro LET, Silver SC, Koontz FW, Young TP, Horwich RH. 1999. Ranging behavior of translocated and established groups of black howler monkeys Alouatta pigra in Belize, Central America. Biol Conserv 87:181-190.

Pavelka MSM. 2003. Population, group, and range size and structure in black howler monkeys $(A$. pigra) at Monkey River in southern Belize. Neotrop Primates 11:187-189.

Pavelka MSM, Behie AM. 2005. The effect of hurricane Iris on the food supply of black howlers (Alouatta pigra) in southern Belize. Biotropica 37:102-108.

Pavelka MSM, Knopff KH. 2004. Diet and activity in black howler monkeys (Alouatta pigra) in southern Belize: Does degree of frugivory influence activity level? Primates 45:105-111.

Pavelka MSM, McGoogan KC, Steffens TS. 2007. Population size and characteristics of Alouatta pigra before and after a major hurricane. Int $J$ Primatol 28:919-929.

Pereira ME. 1993. Seasonal adjustment of growth rate and adult body weight in ringtailed lemurs. In Kappeler PM, Ganzhorn JU, editors. Lemur social systems and their ecological basis. New York: Plenum Press. pp. 205-221.

Peres CA. 1997. Primate community structure at twenty western Amazonia flooded and un-flooded forests. J Trop Ecol 13:381-405.

Pozo-Montuy G, Serio-Silva JC. 2006. Comportamiento alimentario de monos aulladores negros (Alouatta pigra Lawrence, Cebidae) en habitat fragmentado en Balancan, Tabasco, Mexico. Acta Zoologica Mexicana 22:53-66.

Ratsimbazafy JH. 2006. Diet composition, foraging and feeding behavior in relation in habitat disturbance: Implications for the adaptability of ruffed lemurs (Varecia V. editorium) in Manombo forest, Madagascar. In: Gould L, Sauther ML, editors. Lemurs: Ecology and adaptation. New York: Springer Press. pp. 403-422.

Ratsimbazafy JH, Ramarosandratana HV, Zaonarivelo RJ. 2002. How do blackand-white ruffed lemurs survive in a highly disturbed habitat? Lemur News 7:7-10.

Reid FA. 1997. A field guide to the mammals of Central America and Southeast Mexico. New York: Oxford University Press.

Rodriguez-Luna E, Dominguez-Dominguez LE, Morales MJ, Martinez-Morales M. 2003. Foraging strategy changes in Alouatta palliata mexicana troop released on an island. In: Marsh LK, editor. Primates in fragments: Ecology and conservation. New York: Kluwer. 
Rylands AB, Groves CP, Mittermeier RA, Cortés-Ortíz L, Hines JJH. 2006. Taxonomy and distribution of Mesoamerican primates. In: Estrada A, Garber PA, Pavelka MSM, Luecke L, editors. New perspectives in the study of Mesoamerican primates: Distribution, ecology, behavior, and conservation. New York: Springer. pp. 29-81.

Serio-Silva JC, Hernandez-Salazar LT, Rico-Gray V. 1999. Nutritional composition of the diet of Alouatta palliata mexicana females in different reproductive states. Zoo Biol 18:507-513.

Sheddon-Gonzalez A, Rodriguez-Luna E. 2010. Responses of a translocated howler monkey Alouatta palliata group to new environmental conditions. Endang Sp Res 12:25-30.

Silver SC, Marsh LK. 2003. Dietary flexibility, behavioural plasticity, and survival in fragments: Lessons from translocated howlers. In: Marsh LK, editor. Primates in fragments: ecology and conservation. New York: Kluwer.

Silver SC, Ostro LET, Yeager CP, Horwich R. 1998. Feeding ecology of the black howler monkey (Alouatta pigra) in northern Belize. Am J Primatol 45:263279.

Smith JD. 1970. The systematic status of the black howler monkey, Alouatta pigra Lawrence. J Mammal 51:358-369.

Solano SJ, Martinez T, Estrada A, Coates-Estrada R. 1999. Uso de plantas como alimento por Alouatta palliata en un fragemento de selva en Los Tuxlas, Mexico. Neotrop Primates 7:8-11.

Stoner KE. 1996. Habitat selection and seasonal patterns of activity and foraging of mantled howling monkeys (Alouatta palliata) in north-eastern Costa Rica. Int J Primatol 17:1-30.

Waide RB. 1991. The effect of Hurricane Hugo on bird populations in the Luquillo Experimental Forest, Puerto Rico. Biotropica 23:475-480.

Williams-Guillen K. 2003. The behavioral ecology of mantled howling monkeys (Alouatta palliata) living in a Nicaraguan shade coffee plantation. Doctoral Dissertation, New York University.

Wright PC. 1999. Lemur traits and Madagascar ecology: Coping with an island environment. Am J Phys Anthropol 110:31-72.

Zimmerman JKH, Covich AP. 2007. Damage and recovery of riparian Sierra palms after hurricane Georges: Influence of topography and biotic characteristics. Biotropica 39:43-49. 



\title{
5. Adolf Remane: Notes on his work on primates
}

\author{
Prof Ulrich Welsch
}

I met Colin Groves for the first time in the Anthropological Institute of the University of Zürich in 1964, where I did some of my PhD thesis research under the supervision of Professor Adolf Remane (1898-1976). The conversations I had with Colin were based on our common enthusiasm for morphology, comparative anatomy, phylogeny and theoretical ideas about the 'natural system', as I called it, following Professor Remane. Key elements of the natural system are the terms homology and analogy, which enabled scientists, even before the time of Charles Darwin, to establish the natural relationships among organisms. This concept was followed up much later with phylogenetic research. Based on my dealings with both scholars, I am convinced that there is a deep similarity between the minds of Adolf Remane and Colin Groves. Both were/are exceptionally gifted morphologists and both authored numerous high quality publications including entire books. In addition, primates were/are the main target of their interests. On a more personal note, to me both were/are very modest, yet at the same time show a sympathetic and friendly self-confidence, without a dogmatic attitude. Both scholars also worked/work with reliable and never failing consistancy, diligence and concentration, in a harmonious way that included uniting fieldwork with theory. They were/are also deeply interested in the historical dimensions of present-day concepts and had/have acquired a truly unusual knowledge in this field. Remane frequently read original texts (e.g. of Aristotle, Goethe and Cuvier), which is also the case of Colin whose own works are based in the classic texts of Buffon and many European authors of the nineteenth century. Both enjoyed/enjoy to share their knowledge freely with students and colleagues and in doing so they often showed/show a good sense of humour. Finally, both were/are outstanding university-academics, with a search for truth guiding their way of thinking.

Of course there are also differences of opinion between the two men. Remane condensed his experience and concepts in the book Foundations of the Natural System, Comparative Anatomy and Phylogenetics in 1952. I am sure that Colin Groves does not agree with every sentence in that book, but I am also sure that he has an understanding for Remane's arguments and logic. While Remane's interest in the scientific theory of taxonomy did not run very deep, I feel sure that he would have wholeheartedly joined in any discussion on Colin's Primate Taxonomy (2001) and that he would have followed in all probability Colin's 'Putting Primate Taxonomy into Practice' even if - deeply in his heart - he may have had reservations in one or the other case. The rest of this chapter will focus 
on the works of Robert Gustav Adolf Remane, which were published in German, thus underappreciated and largely unknown amongst many primatologists. As Colin himself is able to translate German works into English, it is fitting not only because the two men are so similar, but because Colin would appreciate the way that Remane's work was held back by the language in which it was written.

As alluded to above, Professor Robert Gustav Adolf Remane (1898-1976) was a multifaceted and stimulating zoologist. During his career he created a tremendous amount of scientific work including more than 300 publications ranging from unsurpassed monographs on single invertebrate groups (e.g. rotifers), to a broader field of marine biological and ecological topics, to more theoretical work on the foundations of the natural system, comparative anatomy and phylogeny and on practical and theoretical reflections on the phenomenon of homology. One important aspect in this coherent mosaic is Remane's primatological studies which dominated two periods of his career, the first at the beginning (19211928) and the second towards the end (1951-1965). His publications in this field concerned mainly the functional morphology of teeth and dentition of almost all extant and many extinct primate species and the methodological problems of hominoid phylogeny and theoretical problems of primate systematics.

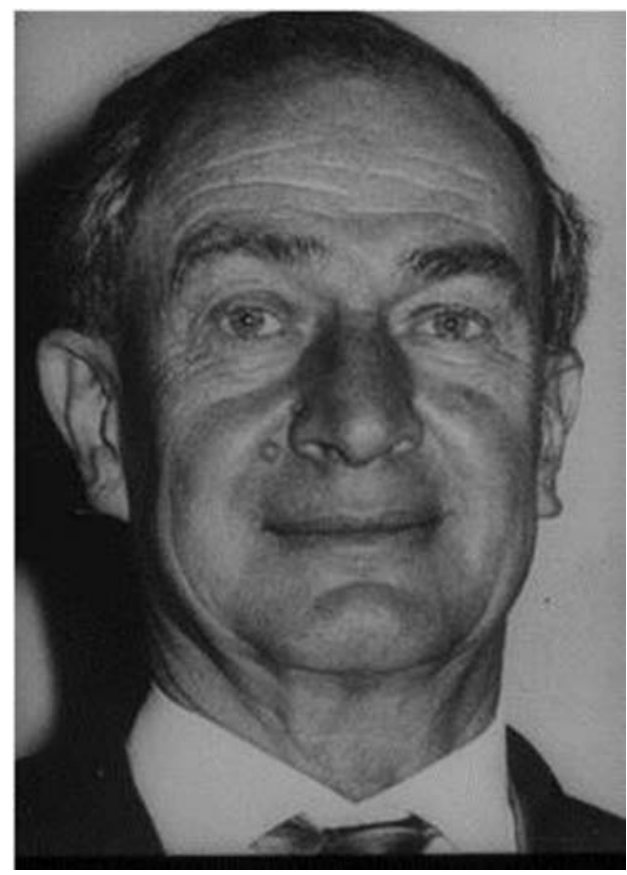

Figure 5.1: Photograph of Professor Remane, at the age of 65.

Source: Given to author as a private gift from the Institute of Zoology in 1967. Photo was taken by the Institute in 1962. 
It was the striking diversity of opinions on fossil teeth, which led him in 1921 to conduct his first thorough study of more than 900 dentition specimens of extant gibbons and apes. Apart from valuable, careful and very detailed descriptions, his work is always marked by a specific sober spirit, guided by an immense knowledge, and by enlightening comparative statements which always create a pleasant intellectual feeling while reading all his papers and articles, not unlike reading one of Colin's papers. He had a gift to not feel compelled to give all problems definitive answers, but was content to ask further questions based on preliminary conclusions. He found particular pleasure in finding the complexity of situations, for example of the possibility of reversibility of phylogenetic trends, of the simultaneous presence of very advanced specialisations and of primitive characters in one animal species (e.g. in Tarsius or in Alouatta).

Reading Remane's texts you always have the impression that you are not wasting your time with boring dental details but that you have gained new general biological insights, both on single primate species and on the interrelationships among primates. For example, in one instance he was able to compare the molar patterns of Apidium, Oreopithecus, Pongo and of human milk molars with interesting results in just a few sentences. The vividness of his thoughts was even more present when he spoke in the lecture hall. In his lectures, the wealth of his knowledge made it easy for him to reflect meaningfully on a variety of topics. He could easily discuss the specific morphological details of human canines or discuss topics considered by Georges Cuvier or Goethe, who on this or that subject had objected to Cuvier's viewpoint, then adding a sentence in ancient Greek, that this or that ambiguity had already been touched by Aristotle, all this quite naturally and without any pretentious attitude. One has to know that he was at home in the entire world of arts, philosophy and natural science in order to understand certain lines of argument in his work. In discussions he was unbeatable, logically thinking with an immense knowledge of all fields of zoology, anthropology, ecology, botany and philosophy, possibly only being rivalled by Colin himself. All his profound primatological - and other - work is free of any personal vanity and is marked by a rare solidity; it was created under often difficult circumstances which were caused by the absurd ups and downs of Central European history in the twentieth century and sometimes by strong personal discomfort due to migraines.

In order to understand Remane's complex theoretical work on the natural system, comparative anatomy and phylogenetics in depth, it is important to be familiar with the, in-part, pre-Darwinian developments of comparative anatomy, mainly in France, England and Germany. Georges Cuvier (1769-1832), Johann Wolfgang Goethe (1749-1832) and Carl Gegenbaur (1826-1903) were constants of orientation. For Cuvier he had a lifelong sympathy. In his lectures, which I had the privilege to hear from 1961-66, he additionally often referred to 
Richard Owen (1804-1892), Etienne Geoffroy Saint-Hilaire (1772-1844), Ernst Haeckel (1834-1919) and William King Gregory (1876-1970), AS Romer (18941832) and to GG Simpson (1902-1984). Of course, he was fully aware of the unique significance of Charles Darwin (1809-1882) for the entire development of modern biology, but now and then slight 'mental reservations' became visible, especially against dogmatic followers of Darwin and those who claimed to be in the possession of 'the' Darwinian truth. Remane knew, that particularly eager protagonists could be good specialists, but could at the same time lack in depth of insight into the entire kingdom of organisms with its endless diversity, and contradictions. He was quite against absolute statements and also saw opaque spots in the 'synthetic evolutionary theory', which ideologically minded debaters did not want to see. The unobtrusive, ever present reference to the scientists of the past was not only an expression of personal modesty but was also of great educational significance for his students. Remane never saw natural science as an anti-thesis to other fields of the human mind such as art, philosophy or religion.

He had a unique gift to analyse and understand morphology, and he was openminded to theoretical questions, but he could also become silent in view of the endless complexity of life. He was also an enthusiastic outdoor biologist with unbeatable knowledge of plants and animals, again similar to Colin's knowledge of most things flora and fauna.

His primatological work was based on the knowledge of several thousand teeth, which he studied personally in all important European museum collections and by careful and serious reading of all relevant literature. Gifted by an obviously inborn feeling for morphology, supported by a unique power of memory and guided by an unusual intelligence, he wrote more than 30 publications and handbook articles with primatological contents, including:

1. Individual topics, such as e.g. the unique morphology of the human canines (Remane, 1924a); or the critical discussion of R. Fourtaus' Prohylobates tandyi and Dryopithecus mogharensis (Remane, 1924b); or the interpretation of the dentition of Oreopithecus (Remane, 1952a) in which he showed that the attempt to derive the pattern of human upper molars from those of Oreopithecus and thus placing Oreopithecus into the hominids, is theoretically possible but only by help of a transitory form on paper and by using a specific variant of human molars; or the presumable phylogenetic position of Gigantopithecus (Remane, 1953), or the origin of bilophodont molars in Cercopithecidae (Remane, 1951); or aberrant morphologies of teeth and skulls.

2. Critical reviews, including those on primate systematics or the 'natural history' of primates (Remane 1956a, 1956b, 1960a, 1965), which due to their original and critical thoughts, are by no means outdated. 
3. Handbook articles, in particular in the Handbook of Primatology (Primatologia) and comparable articles (Remane 1921a, 1921b, 1952b, 1955), which are not word-rich elaborations but concise intelligent compositions full of facts, accompanied by clear line drawings or photomicrographs. The facts are usually condensed into useful tables, e.g. on measurements and proportions of teeth. Already his first publication (1921) on teeth of gibbons and apes is based on the analysis of the skulls of 322 gorillas, 287 chimpanzees, 160 orangutans and 145 gibbons. Such a rich background renders particular weight on specific papers, for example on the dentition of Oreopithecus (Remane, 1952a) or Australopithecus (Remane, 1952b). This analysis also opened his eyes to the remarkable variability of morphological characters of primate teeth, which for him remained a life-long warning not to make definite statements on single fossil teeth or jaw fragments. He gave many important examples for the variability of skull and mandible shape, for example of Pan, of measurements of teeth and of crown patterns (Remane, 1952a), and he took this fact seriously. However, he analysed also single fossil teeth as far as one can go, but never crossed the borders of serious and objective science. The quantitative and qualitative analyses always comprises crown, roots and alveoli and usually details of maxilla and mandible. Of course most information can be extracted from the dental crown, for example patterns of cusps, crests and furrows, including patterns of attrition (Remane 192lab). He was aware that different scientists use different methods, for example when measuring length and width of teeth, which can make it impossible to compare corresponding data. Therefore he suggested application of the same measuring techniques for primate teeth (Remane, 1927). In his contribution on methodic problems of hominid phylogeny II (Remane, 1954), he discusses not only the variability of all types of teeth in apes and man, but also of many cranial characters. Furthermore he carefully discusses pitfalls when not considering variability, which can lead to wrong simplifications and wrong phylogenetic reconstructions. Finally his discussion on species, subspecies and populations, also in regard of fossil findings, is of significance.

What makes Remane's texts and analyses always interesting and often helpful are his often surprising functional correlations, the comparative aspects and of course the always present phylogenetic background. Unfortunately it became a considerable drawback that Remane published almost exclusively in German. As he himself read with ease and pleasure in a multitude of languages including ancient Greek and Latin, French and English he possibly subconsciously expected a similar versatility in English and French-speaking scientists. This language barrier kept many of his publications unknown and underrepresented, but this is a real tragedy due to the fact that his work:

a) contains an invaluable treasure of facts (e.g. dental measurements and evaluations of crown patterns, illustrated by clear drawings) 
b) opens eyes beyond the facts

c) includes, especially in his 1956, 1960 and 1962 handbook articles, all the older European and North-American literature (1900 until about 1960)

d) helps to avoid repetitive work

e) is written in a relatively simple, grammatically correct German.

What also makes such articles valuable even today is that the data can be used for studies not foreseen when they were compiled; primarily they can be transferred into computers for further mathematical evaluations.

When a character was particularly variable, for example the morphology of upper outer incisors or the molar crown patterns of chimpanzees or the morphology of human milk molars, Remane formed groups by which he tried to give some order to the variability. This, today, could be refined by computer analysis. But, it may be added, Remane always remarked, that the best discriminator for visible morphological characters are the human retina (with its many millions of neurons) and brain. In addition he used to say that although large numbers are important to give weight to statements, statements only make sense when the characters are evaluated and not only counted. In this he followed of course the great French comparative anatomists around 1800 and in the early years of the nineteenth century.

His statements were always sober and clear, e.g. 'fossil material too scanty for final statements', 'a well-founded evaluation can be made only when more fossil material is available', 'the XY-index as used in this study for the evaluation of fossil material is almost without any worth', in regard of the inner cusp of $\mathrm{P}_{3}$ : 'since there are regularly variations in regard of the presence of single structures in meristic organs (here the lower premolars) this question has no great significance', etc.

His analysis (1965) of teeth and the fragments of the mandibles of Gigantopithecus blacki are sober and careful and consider not only details of the Pleistocene strata but, in fairness, also the suggestions of other scientists in regard of the systematic position of this big ape (Remane et al., 1960; Remane, 1960a, 1965). He convincingly excludes Gigantopithecus from any lineage towards Homo, as had been suggested before. He carefully excludes Gigantopithecus from any close relationship with Pongo (and Pan); he describes similarities with Gorilla and overlap of teeth sizes with Gorilla beringei. The similarities with Gorilla are common primitive features. He clearly works out specific characters, for example the high hypsodont crowns and the specific morphology of the lower P3 and lower canines and concludes that Gigantopithecus was a herbivore and represents an own lineage of apes rooting probably in the 'Sivalik-pongids'. 
Interesting and worth considering is his 1965 evaluation of the 'SivalikPongiden' - the fossil remains of apes as found in the Sivalik hills (Remane, 1965). He discusses at length all findings and 'species' as described by Lydekker, Pilgrim, Gregory and Hellman, Lewis, von Koenigswald, Hooijer, and Dehm. He mentions among others that the size of the teeth varies from those of Gorilla (Dryopithecus giganteus) to those of a small Pan. The teeth are generally typical for apes. The 'species' are more similar among each other than among extant apes. Single teeth show rather specific agreements with those of Pongo, for example the P3 of 'Sivapithecus himalayensis' (Pilgrim, 1927). Some of these P3-similarities are also to be found in Indopithecus (Hooijer, 1951). The M2 of Dryopithecus giganteus is marked by a pattern of furrows reminding those of Pongo molars. This and additional observations lead him to speculate that ancestors of Pongo may be present among the Sivalik pongids. These possible ancestors, however, have in general more primitive characters than modern Pongo (clearer defined cusps, bigger M3, more rounded symphysis). However, it would be premature to ascribe all Sivalik apes to Pongo and possible relatives. For example, Dryopithecus pilgrimi has rather narrow incisors as can be seen in Gorilla and Dryopithecus fontani. Individual teeth have a high length-widthindex, as to be seen in Gigantopithecus and the closer relationship of Homo. Such individual evaluations take a large part of this contribution. Remane finally gives long arguments against a closer relationship between Ramapithecus and the Homo-lineage.

Today, Remane's most useful work may be his 209-page 'Zähne und Gebiß' (teeth and dentition) in Primatologia III/2, (1960b). It is probably the best introduction for a beginner in primate dental morphology and for the advanced beginner an always helpful reference. It deals with all genera and all important species. It includes much of his older publications, occasionally with more differentiated interpretations. Valuable is the chapter on deciduous teeth, which often give hints to the origin of structures on the permanent teeth. Unique are the crossreferences and cross-comparisons among all primate groups, enlightening and convincing are the argumentations for homology or analogy. Fine examples of a sovereign mind are many specific paragraphs, for example on the detailed comparisons between Pan and Homo, and the parallel development of bilophodont molars in primates (e.g. in Cebus, Cercopithecoidea, Symphalangus, Archaeolemuridae and in part Indriidae). Almost every page has at least one clear illustration; the great trends in the development of primate dentitions are summarised in the last chapter, with summaries on the specific families and genera (e.g. Hylobates, Gorilla, Pongo, Pan and Homo). 
Taxonomic Tapestries

\section{References}

Heydemann B. Zum Tode von Professor Dr.Dr.'.c. Adolf Remane (1977). FaunÖkol Mitt 5:85-91.

Hooijer, DA. 1951. Questions relating to a new large anthropoid ape from the Mio-Pliocene of the Siwaliks. Am J Phys Anthropol 9: 79-95.

Pilgrim GE, 1927. A Sivapithecus palate and other primate fossils from India. Memoirs of the Geological Survey of India (Palaeontologica Indica), NS(14):126.

Remane A. 1921. Beiträge zur Morphologie des Anthropoidengebisses. Archivf. Naturgeschichte, Abt. A 87:1-179.

Remane A. 1921. Zur Beurteilung der fossilen Anthropoiden. Centralblatt für Mineralogie, Geologie und Paläontologie 11:335-339.

Remane A. 1924a. Einige Bemerkungen über Prohylobates Tanyi R. Fourtau und Dryopithecus mogharensis R. Fourtau. Centralblatt f. Mineralogie, Geologie und Paläontologie 7:220-223.

Remane A. 1924b. Einige Bemerkungen zur Eckzahnfrage. Anthropolog Anz $1: 35-40$.

Remane A. 1927. Methoden zur Untersuchung der Primaten. Zur Meßtechnik der Primatenzähne. Handbuch biologischer Arbeitsmethoden. Abt. 7:609-635 Berlin, Wien.

Remane A. 1951. Die Entstehung der Bilophodontie bei den Milchmolaren oft phylogenet. Vorstufe Cercopithecidae. Anat Anz 98:161-165.

Remane A. 1952a. Methodische Probleme der Hominiden-Phylogenie I. Z Morph Anthrop 44:188-200.

Remane A. 1952b. Der vordere Prämolar (P3) von Australopithecus prometheus und die morphologische Stellung des Australopithecinengebisses. Z Morph Anthropol 43:288-310.

Remane A. 1953. Die primitivsten Menschenformen (Australopithecinae) und das Problem der tertiären Menschen. Schriften Naturwiss. Verein. Schleswig Holstein 29:3-10.

Remane A. 1954. Methodische Probleme der Hominiden Phylogenie II. Z Morph Anthrop 46:225-268. 
Remane A. 1955. Ist Oreopithecus ein Hominide? Abh. Math.-Naturw. Kl. Akad. Wiss. Mainz N.R. 12:469-497.

Remane A. 1956a. Paläontologie und Evolution der Primaten, besonders der Nicht-Hominoiden. Primatologia I(8). Basel, New York: S. Karger. pp. 267378.

Remane A. 1956b. Die Grundlagen des Natürlichen Systems, der Vergleichenden Anatomie und der Phylogenetik. 2. Aufl. Leipzig: Akademische Verlagsgesellschaft.

Remane A. 1960a. Die Stellung von Gigantopithecus. Anthropol Anz 24:146-159.

Remane A. 1960b. Zähne und Gebiss. Primatologia III(2). Basel, New York: S. Karger. pp. 637-846.

Remane A. 1961. Probleme der Systematik der Primaten. Z wiss Zool 165:1-34.

Remane A. 1962. Masse und Proportionen des Milchgebisses der Hominoidea. Bibl. Primatl. 1. Basel, New York: S. Karger. pp. 229-238.

Remane A. 1965. Die Geschichte der Menschenaffen. Hrsg. Gerhard Heberer. Menschliche Abstammungslehre. Stuttgart: Gustav Fischer Verlag. pp. 249309. 



\title{
6. Retouch intensity on Quina scrapers at Combe Grenal: A test of the reduction model
}

\author{
Peter Hiscock and Chris Clarkson
}

\section{Introduction}

There have been extensive discussions about whether hominids other than $H$. sapiens had the cognitive capacity to plan and conceptualise elaborate tool forms in advance of use and to transmit those conceptual systems to others. Outside Africa such discussions have been most extensive for questions of what cognitive capacities were possessed by Neanderthals and how their approach to planning and tool use differed from the subsequent $H$. sapiens. A core concern of these questions has been how morphological variation is understood and how that variation can usefully be expressed in classificatory systems that are capable of revealing evolutionary change. Such considerations have been critical in biological debates about the nature of species as well as about specific species boundaries. Similar deliberations are pursued in studies of lithic artefacts, as archaeologists explore how morphological transformations within individual artefacts as well as evolutionary transitions in populations of artefacts, are represented in metrical indices and classifications.

One intensively debated issue in lithic analysis concerns whether conventional practices of analysing retouched flakes by classifying them into a number of tool types is valid or problematic, and whether those types represent tools of distinctly different designs or alternatively arbitrary divisions between objects that display continuous morphological variation. Inferences about these issues have formed the basis of different explanations for the Mousterian facies, and the opposing claims about whether Neanderthals conceived of a large number of tool designs or not (e.g. Bordes, 1972; Binford, 1973; Binford and Binford, 1966; Bourguignon, 1997; Dibble, 1984, 1988b; Dibble and Rolland, 1992; Rolland and Dibble, 1990; Hiscock and Attenbrow, 2005; Hiscock et al., 2009; Holdaway et al., 1996; Mellars, 1996; Turq, 1992, 2000). Debates about the nature of economy, technology and cognition in ancient hominids are both significant and exciting, but they rest on the accuracy and clarity of depictions of artefact patterning and the meaning of morphological and technological diversity. 
Although much has been written on the characterisation of retouched flake variability in Middle Palaeolithic assemblages, key aspects of the archaeological patterns remain unresolved.

In recent decades, two different hypotheses have competed as the best explanation for the variability observed in Mousterian implements from the Dordogne. One model advocates the primacy of retouch intensity in models explaining morphological diversity in ancient tools, with some researchers arguing this is the sole significant factor creating typological variation. The second model argues that intensity of retouch is only one of many factors creating variation and that others are often more significant. In this chapter we test these competing models by presenting a detailed, quantitative analysis of the relationship between different types of Quina scrapers and the extent of retouching that they have undergone in one level of Combe Grenal.

\section{The question of Quina scrapers and reduction}

A well-known model for Middle Palaeolithic scraper reduction was proposed by Harold Dibble (1984, 1987a, 1987b, 1988a, 1988b, 1995). He hypothesised the transformation of scrapers from one typological class to another as they received additional reduction. Dibble argued that extent of reduction was the key factor causing differences between four implement classes with retouch onto their dorsal surface: (1) single-edged side scrapers with retouch on one lateral margin (Bordes types 9-11); (2) double scrapers with two separate retouched edges (Bordes types 12-17); (3) convergent scrapers which have two retouched edges that touch (Bordes types 8, 18-21); and (4) transverse scrapers which have retouch across the distal end of the flake (Bordes types 22-24). Examples of these classes are provided in Figure 6.1. Dibble interpreted these four kinds of implement as a result of different amounts of reduction, in which all specimens began as single scrapers, but with additional retouching were either transformed into transverse scrapers or alternatively into double and eventually convergent scrapers. This model, schematically shown in Figure 6.2, notionally positions each of these four classes along a continuum of greater or lesser amounts of retouch, and reveals the proposition that there were two branches along which individual scrapers could travel from the same starting point. Dibble (1988b: 49; 1995: 319) suggested that those individual single scrapers that were further retouched were either worked at the distal end to become transverse forms or on the second lateral margin to become double/convergent implements. He suggested that the sequence followed by any individual specimen may have depended on the shape of the flake, with short/broad flakes being worked into transverse scrapers while longer, narrow flakes were retouched laterally to become double and convergent scrapers. However, Dibble (1995: 319) argued 
that much of the variation between implement classes, and specifically the morphology diagnostic of different types, was a product of differences in the level of retouching and the length of time they had been used and maintained: single scrapers had undergone little retouching while both transverse and convergent scrapers were more intensively retouched. In a series of papers he argued that the smaller average size of convergent and transverse scrapers, both in absolute terms and relative to their platform size, was evidence that this model was correct for Quina assemblages from southwest France and elsewhere.

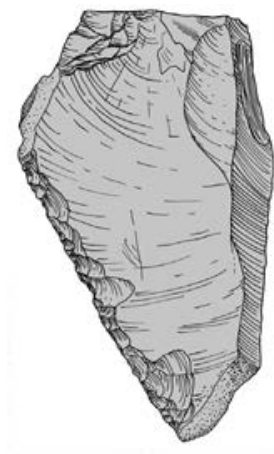

A) Single Scraper

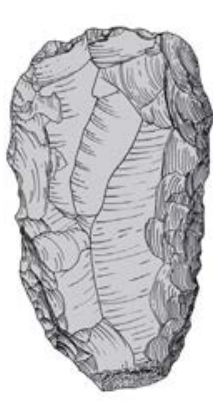

B) Double Scraper

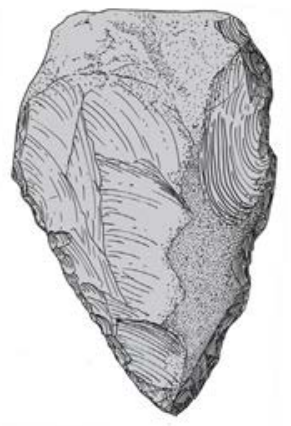

C) Convergent Scraper

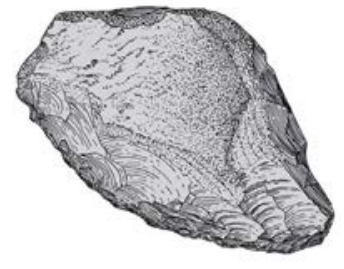

D) Transverse Scraper

Figure 6.1: Examples of specimens classified into each of the four scraper classes: A) Single scraper, B) Double scraper, C) Convergent scraper, and D) Transverse scraper. All specimens are from Combe Grenal, Layer 21.

Source: Authors' original work depicting artefacts from Combe General.

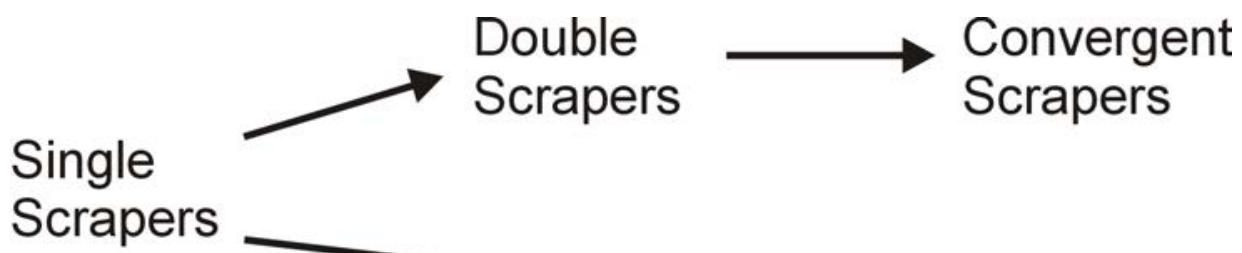

Transverse Scrapers Low $\quad$ Amount of mass removed by retouching High

Figure 6.2: Diagrammatic representation of the staged reduction model proposed by Dibble. 
This conclusion implies and necessitates particular interpretations of Mousterian variability. For example, although Dibble believed that the typology of Bordes still had value, he argued that the different types were a continuum created by differing extents of edge resharpening and that the implement classes therefore represented coherent stages in the continuum of retouch (Dibble and Rolland 1992: 11). Consequently Dibble (1988b: 52) stated that traditional implement types were best employed as a proxy for the extent of tool maintenance/ resharpening in archaeological assemblages.

One interpretation that has followed from Dibble's model of flake retouching is that differences between implement types and industries reflect differences in the intensity of tool use (and by implication the nature of land use); they do not reflect mental constructions of Neanderthals, nor do they reveal specific differences in design or function. For instance, Dibble and Rolland (1992: 17) argued that the production of industries dominated by convergent or transverse scrapers were a consequence of economic practices that encouraged more intensive tool use, such as the intensive maintenance of tools during cold palaeo-climatic phases in which there were long winter residence and patterns of settlement based on the interception of migratory herds, situations in which provisioning of stone for tools could have proved difficult. They contrast this with the contexts of industries dominated by side scrapers (and denticulates), which they hypothesised resulted from less intensive tool and site use that occurred under milder climatic phases in which Neanderthal economy was focused on the pursuit of dispersed, mobile game. The value of these kinds of interpretations depends on the veracity of the characterisation of traditional implement types as comparable units primarily reflecting differences in the extent of tool resharpening.

A number of commentaries and further studies have followed the publication of Dibble's model, many supporting his argument of the value of traditional implement types for studies of the extent of implement reduction (e.g. Gordon, 1993; Holdaway et al., 1996). However, significant reconsiderations of the factors involved in implement creation have been offered. The most potent is the proposition that the extent of retouching is not a function of the intensity of edge maintenance alone, but was often a reflection of the size and morphology of the flake to which retouch had been applied. For instance, Dibble (1991: 266), Gordon (1993: 211), and Holdaway and others (1996) all argued that larger flakes typically had greater potential for edge resharpening, and consequently in extensively reduced assemblages those larger specimens received more retouching than smaller ones. One result of the continued reduction of larger specimens, but not smaller ones, is that extensively retouched flakes were sometimes still larger when discarded than less extensively retouched ones made on smaller flakes (Dibble, 1991). While this proposition has been applied 
to notched types (e.g. Holdaway et al., 1996; Hiscock and Clarkson, 2007), its implications for the interpretation of other implement types and for the value of typology as a measure of the extent of retouching has received less attention. One obvious implication is that the amount of retouching applied to a specimen cannot be judged by its size (Dibble, 1991), a realisation that encouraged the development and growth of several methods for measuring retouch intensity on Middle Palaeolithic tools (see Dibble, 1995; Hiscock and Clarkson, 2005). However, the existence of a strong relationship between flake form and retouch has been argued to create problems for the interpretation of implement types as reduction stages.

For example, if retouching is a response to flake morphology and there is variation in the size and shape of flakes being retouched, an almost inevitable reality in most prehistoric contexts, then the amount of mass removed during retouching may vary substantially between specimens assigned to any implement type. This appears to be the case in the data presented by Dibble (1987b: 113) for the La Quina scrapers, which display extraordinarily high levels of intra-type variability in reduction measures, such as flake area/ platform area ratios which show coefficients of variation of $125 \%$ for single scrapers, $49 \%$ for double scrapers, $91 \%$ for convergent scrapers and $182 \%$ for transverse scrapers. Although Dibble still found statistically significant differences between the means of these four implement classes, the measured variability probably reflects very great differences in the amount of retouching between specimens in a single implement class. In such circumstances the value of conventional types as units measuring the extent of reduction may be questioned, and Hiscock (1994) argued that analysts would be better able to discuss differences in amounts of retouching if they focused on measuring the manufacture of individual specimens rather than merely the contrast between types (also Hiscock and Clarkson, 2005; Clarkson and Hiscock, 2008).

Furthermore, many researchers have argued that intensity of retouch is not the most important factor affecting the form of retouched flakes. For instance, Kuhn (1992) has argued that if flake form played a significant role in determining the position and amount of retouch on each object then typological composition is not principally affected by the intensity of tool use and so industrial variation may not directly correspond to different patterns of settlement and mobility. Instead, Kuhn argues the typological composition of an assemblage would reflect the size and shape of available flakes, which in turn would reflect the form and availability of raw material and the tactics of core reduction. While raw material procurement and core reduction may also be linked to economic and settlement patterns, the connection with the abundance of each implement type would be remote and indistinct. While Kuhn did not deny the proposition that intensity of retouch may be an indicator of settlement/mobility systems, he argued that 
types are not reliable indicators of intensity of retouch, and that archaeologists will require dedicated measurements of retouch intensity prior to developing inferences about the land-use from lithic artefacts.

Long-term archaeological research in southwest France has yielded much evidence for the complex articulation of core reduction systems and the patterns of retouched tools made on the flakes produced in those systems (e.g. Bisson, 2001; Bourguignon, 1997; Bourguignon et al., 2004; Thiébaut, 2003; Turq, 2000; Verjux, 1988; Verjux and Rousseau, 1986), reinforcing the possibility that flake form may have an important role in the construction of morphological diversity amongst Mousterian implements. Many discussions of flake-retouch relationships have posited a simple relationship between flake elongation and the position of retouch, suggesting that long flakes were often retouched on their lateral margins, whereas short, wide flakes were often worked at the distal end (e.g. Bordes, 1961: 806, 1968: 101; Turq, 1989; Mellars, 1992). A number of researchers have argued that the flakes on which single and transverse scrapers were made are very different, and that regular production, and/or selection, of flakes with particular characteristics was a significant factor in the formation of the typological composition of any assemblage (e.g. Turq, 1989, 1992). As a consequence, Turq (1989) argued that there were clear morphological discontinuities in the form of single and transverse scrapers in the Dordogne, evidence that would not be conformable with Dibble's reduction hypothesis. The hypothesised connection of flake form and systems of core reduction has also been argued to be evidence for deliberate and planned acts of selection/ production (e.g. Boëda, 1988; Turq, 1989, 1992).

Some models of the way the morphology of flakes strongly influenced the nature, and typological category of implements have hypothesised complex interactions between multiple characteristics that affected the nature of retouching. An example is Alain Turq's proposal that scrapers in Quina industries reflected a regular pattern of flake selection and retouching. He suggested that transverse scrapers, unlike single side scrapers, were made on flakes that were thick relative to their length and ventral surface area; a proposition that would account for differences between types in the relationship of platform and ventral areas, which Dibble (1984, 1987a, 1987b, 1995) had employed as evidence for different degrees of reduction. Furthermore, Turq argues that scrapers were typically made on flakes with asymmetrical cross-sections and retouch was located on the flake margin furthest from the maximum thickness (Turq, 1992: 75). In a diagram, presented here as Figure 6.3, Turq (1992: 77) implied that the potential for resharpening was related to the asymmetry of each flake selected for retouching, with symmetrical ones having little mass removed before steep retouching came close to reaching the thickest part of the flake while asymmetrical flakes could have considerably more mass removed 
through retouching before reaching the same state. This proposition linked variation in scraper morphology with flake morphology as well as extent of reduction, implying that flake shape and selection were the proximate factors creating variation in both the location/orientation of retouch and the amount of mass removed by retouching on different specimens, and consequently the typological category into which each specimen was placed. Turq's model not only contrasts with Dibble's in the emphasis given to flake form rather than extent of reduction, but also implies that there may be a great deal of difference in the extent of reduction of specimens with similar cross-sections and placed in the same typological category.

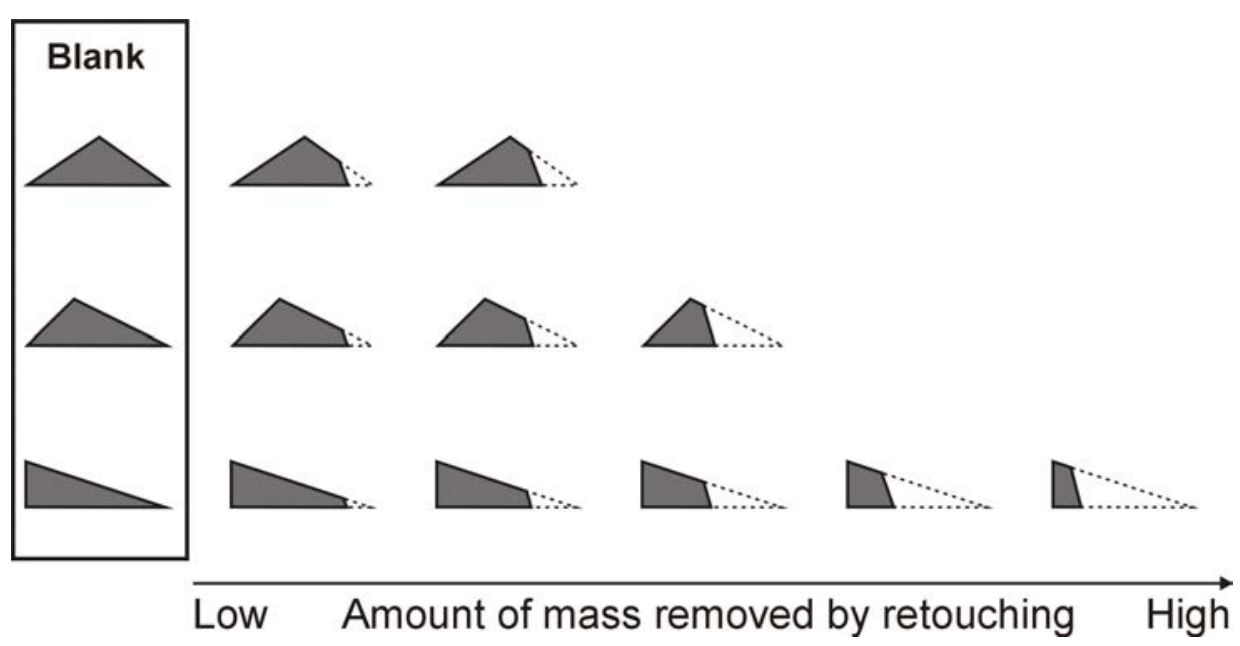

Figure 6.3: Notional illustration of the relationship of blank cross-section and extent of reduction for dorsally retouched Quina scrapers.

Source: After Turq (1992: Figure 6.2).

Considered in this way, the distinctions between two different models of Quina scraper variability are clear. On the one hand Dibble's 'scraper reduction model', posits a single branching scheme and asserts that traditional typological categories represent different points/stages along a continuum of greater or lesser amounts of retouch. The frequency of specimens in each type may therefore be used as a proxy for the intensity of reduction that an assemblage has undergone. From this perspective intensity of reduction is the primary cause of typological variation, and although differences in flake morphology exist, their effect on typological variation is minimal. Consequently typological diversity through time and space can be directly interpreted as a result of access to raw material and settlement/economic activities. On the other hand, what Hiscock and Clarkson (2008) have called the 'blank-retouch interaction hypothesis' proposes that traditional typological categories represent complex patterns of 
morphological variation created by several factors, particularly differences in the distribution and intensity of retouch in response to flake form. Distinctions between conventional implement types may therefore have little coherent covariation with intensity of retouch, and should not necessarily be treated as representing different points along a reduction continuum. This hypothesis implies that the frequency of specimens in each type may not be a reliable indicator of the intensity of retouching that an assemblage has undergone, and that typological diversity through time and space is difficult to directly interpret in terms of settlement/economic activities. Instead, this hypothesis asserts that Borde's typology reflects morphological patterns created by a constellation of factors including flake morphology, material cost, tool design, as well as amount of uselife/resharpening, and that the resulting typological patterns are not necessarily sensitive to variation in the intensity of retouch.

Our goal here is to examine the applicability of these two opposing models to one Quina assemblage, recovered from Layer 21 in Combe Grenal. Although these models predict different behavioural processes, they both invoke extent of retouching as a mechanism constructing morphological variation; the two models differ in the way retouching is articulated to other technological and economic factors. We emphasise that there is no reason to expect that one will inevitably be the most appropriate in all situations. It is possible for the 'reduction hypothesis' to be correct for some assemblages and the 'blankretouch interaction hypothesis' to be correct for others. In this way these opposing models are not competitors in a search for a universal truth but are actually expressions of the variable operation of multiple factors that may have created morphological variation in Mousterian implements. Consequently our examination of these two models for Layer 21 at Combe Grenal is not a test of the general veracity of either model, but actually an assessment of what kinds of processes were operating in the Neanderthal technological system in the Perigord Noir at the time that layer formed.

\section{Our approach to measuring the extent of retouching}

Our sample of artefacts comes from Combe Grenal, excavated by François Bordes (1972) and now held at the Musèe National de Prèhistoire des Eyzies. The following analysis uses measurements of complete dorsally retouched flakes from Layer 21, a Quina level. Technological cores and unretouched flakes, broken specimens, and a small number of burins, end scrapers, Mousterian points and a truncated-faceted piece were excluded from the analysis. For this paper our sample consists of 306 objects, representing all specimens in each of 
the major typological categories: single scrapers $(\mathrm{N}=172)$, double scrapers $(\mathrm{N}$ $=28)$, convergent scrapers $(\mathrm{N}=40)$, transverse scrapers $(\mathrm{N}=66)$. The number of specimens in each of the Bordes type classes used in our analysis is listed in Table 6.1.

Table 6.1: Sample of complete retouched flakes from Layer 21 used in this analysis, presented by implement type.

\begin{tabular}{|l|r|}
\hline \multicolumn{1}{|c|}{ Implement types } & N \\
\hline Single & 50 \\
\hline 9 Single straight scraper & 112 \\
\hline 10 Single convex scraper & 10 \\
\hline 11 Single concave scraper & 14 \\
\hline Double & 7 \\
\hline 12 Double straight scraper & 2 \\
\hline 13 Double straight-convex scraper & 4 \\
\hline 14 Double straight-concave scraper & 2 \\
\hline 15 Double convex scraper & 3 \\
\hline 16 Double concave scraper & 5 \\
\hline Convergent & 30 \\
\hline 8 Limace & 14 \\
\hline 18 Straight convergent scraper & 49 \\
\hline 19 Convex convergent scraper & \\
\hline 21 Dejete scraper & \\
\hline Transverse & \\
\hline 22 Straight transverse scraper & \\
\hline 23 Convex transverse scraper & \\
\hline 24 Concave transverse scraper & \\
\hline
\end{tabular}

Source: Author's data.

Our analysis of these implements employs two measures of the position of retouching on each specimen and the amount of mass removed through retouching (Figure 6.4). The first is a version of the Geometric index of unifacial reduction (GIUR), a measure we have experimentally verified (Hiscock and Clarkson, 2005, 2009; Clarkson and Hiscock, 2008). Our experiments showed that scar height ratios, taken at multiple points around a retouched flake, yield an average GIUR value which has a non-linear relationship with the mass removed by retouching (Hiscock and Clarkson 2005: 1019). Experimental retouching of flakes demonstrated that there was a strong log-linear relationship between the calculated Kuhn GIUR and the percentage of original flake weight that has been lost (Figure 6.5). This relationship appears to hold irrespective of whether retouching is applied to the lateral or distal margin (Hiscock and Clarkson, 
2005), or to one or more than one edge (Clarkson and Hiscock, 2008; Hiscock and Clarkson, 2009). For instance, when we experimentally retouched flakes on one lateral margin, producing items similar to single side scrapers, there was a strong positive relationship between the index value and the mass removed by retouching $\left(\mathrm{r}=0.933, \mathrm{r}^{2}=0.871\right)$. When we experimentally retouched flakes on two lateral margins the Kuhn GIUR was still strongly and significantly correlated with the proportion of mass lost from each flake $\left(r=0.88, r^{2}=0.778\right)$. We have argued elsewhere that while variations in the GIUR/mass-lost relationship occurred as a consequence of differences in the shape and size of flake blanks, a strong relationship exists for most flakes that are dorsally retouched, and consequently we take the Kuhn GIUR to be a reliable measure of the extent of dorsal, unifacial retouch in most instances, including the specimens discussed in this analysis, irrespective of the nature of the flake (Hiscock and Clarkson, 2005: 1022). Furthermore, the high coefficient of determination $\left(\mathrm{r}^{2}\right)$ allows us to use the regression line and 95\% confidence intervals shown in Figure 6.5 to estimate the approximate amount of mass removed during retouching.

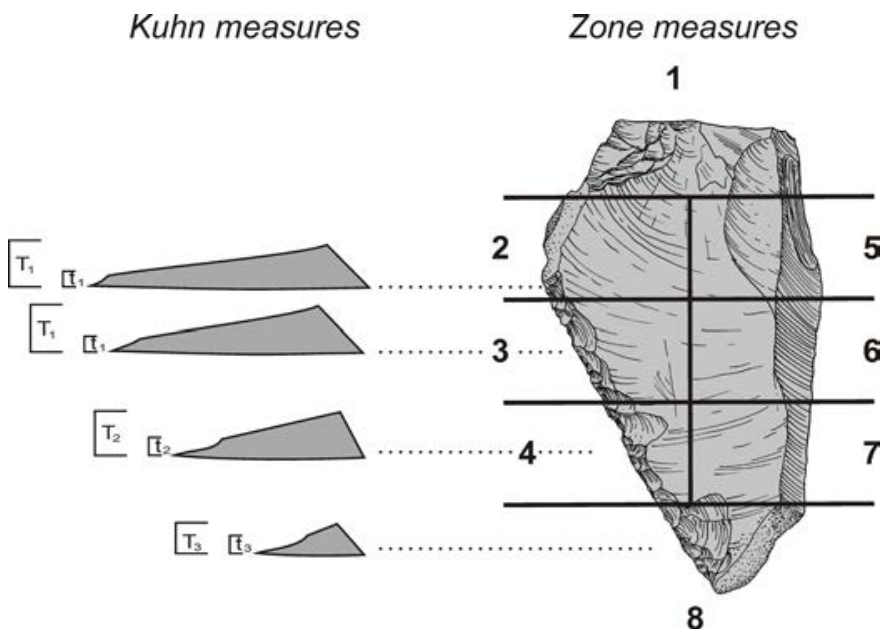

Figure 6.4: Illustration of the measurements of reduction used: multiple values of Kuhn's (1990) unifacial reduction index and a count of the number of zones which have been retouched.

Source: Hiscock and Clarkson (2005). 


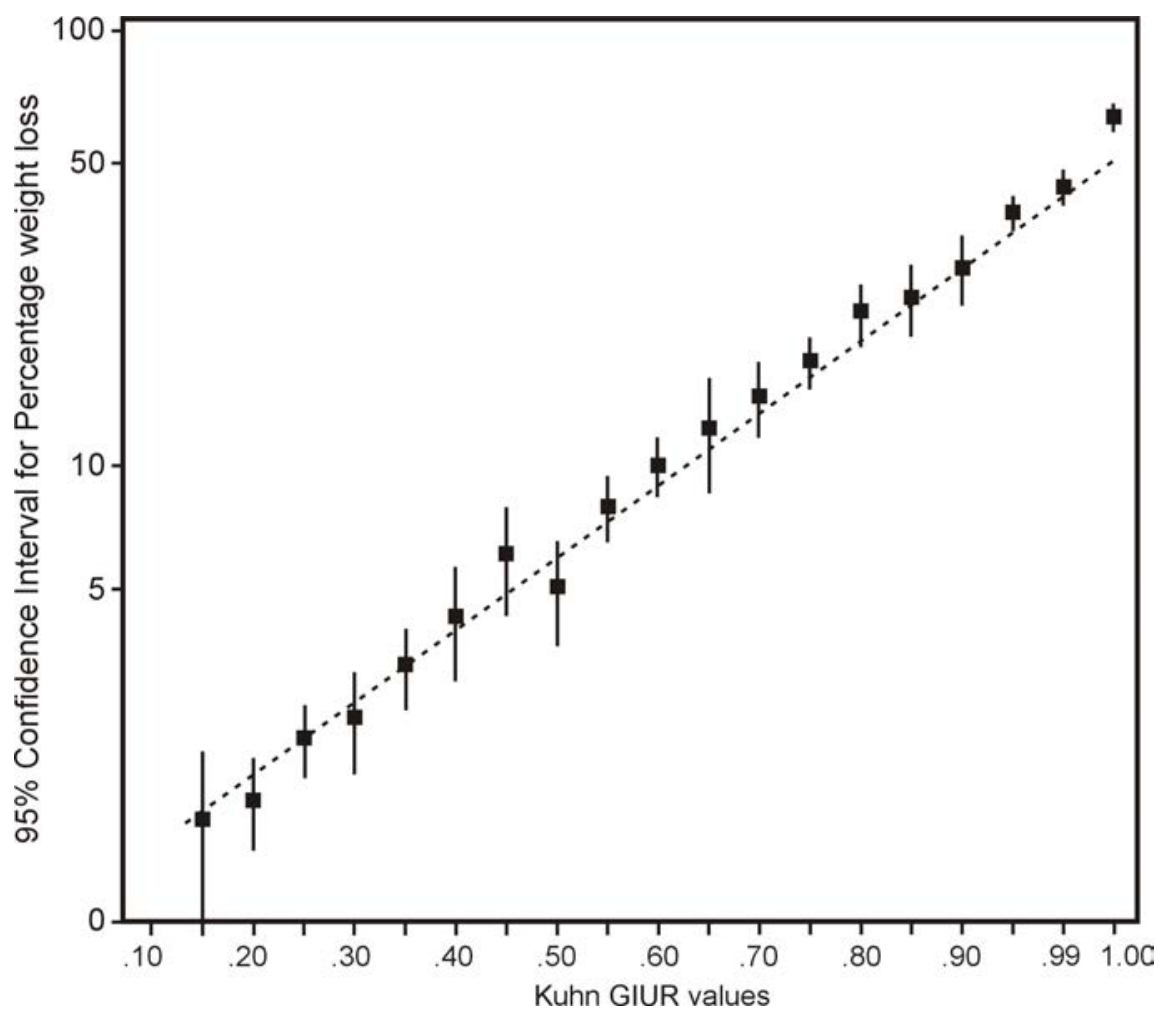

Figure 6.5: Relationship between Kuhn GIUR (as 0.05 intervals) and the percentage of original flake mass lost through retouching (shown with 95\% confidence intervals) in the experimental dataset (Hiscock and Clarkson 2005). Broken line is the regression line $\left(r=0.933, r^{2}=0.871\right)$ published by Hiscock and Clarkson (2009).

Source: Hiscock and Clarkson (2009).

A second measure of retouching was the distribution of retouch on the margins of each flake. This measure provides an indication of the lateral expansion of retouching around the specimen; complementing the GIUR, which measures how far retouch has penetrated into the centre of a flake (Hiscock and Attenbrow, 2005: 59). This 'Retouched zone index' was obtained by observing which of eight zones, illustrated in Figure 6.4, were retouched. The zones were defined in terms of five equal divisions of the percussion length, but with the left and right margins being separated to create eight locations (proximal, distal, three zones on the right margin and three on the left). The face on which scars occurred was not relevant for this measure, giving retouched flakes values between 1 and 8 zones. This recording system was not only used to measure the amount of retouch around the flake margin, but also served as a way to compare the location of retouch on different specimens. 
Other measures of flake retouching, such as Clarkson's (2002) invasiveness index or Holdaway, McPherron and Roth's (1996) surface area/platform thickness ratio were considered to be of lesser value on the steeply, unifacially retouched flakes in our sample and are not presented here. Although we have previously expressed doubt about the sensitivity of Dibble's (1987) surface area/platform area ratio as a measure of reduction we have calculated this below as a comparison to published data that has been used to discuss models of Quina retouch.

\section{The extent of retouching and implications for reduction}

With these measurements of the amount of retouching, we are able to evaluate whether the different implement categories (single, double, convergent, transverse scrapers) actually represent clusters of specimens that have been reduced to different extents, as hypothesised by Dibble. Descriptive statistics for the reduction indices in our sample, presented in Table 6.2, show a pattern somewhat similar to that reported by Dibble (1987: 113) for the La Quina site, and which he used in support of his reduction model. For instance, the mean surface area/platform area values are higher for single scrapers than double and convergent ones, and transverse scrapers display the smallest mean; with the means being very similar to those Dibble found at La Quina. This offers support for the proposition that, on average, single scrapers were less reduced that the other three scraper categories. Average values for the Kuhn GIUR and retouched zone index could also be used to suggest that single scrapers were on average less reduced than double or convergent scrapers; giving support to the idea of a single-double-convergent sequence of scraper transformations in Layer 21. ANOVA treatment of our data reveals statistically significant differences between the implement classes in the Kuhn GIUR $(\mathrm{F}=5.485$, d.f. $=4, \mathrm{p}=0.001$, with the index broken into five groups: $0.01-0.19,0.20-0.39,0.40-0.59,0.60-0.79$, and $0.8-1.0)$ and in the retouched zone index $(\mathrm{F}=10.112$, d.f. $=7, \mathrm{p}<0.001)$; but not in the surface area/platform area ratio $(\mathrm{F}=0.295$, d.f. $=4, \mathrm{p}=0.881)$, with the index broken into five groups: 0.01-4.99, 5-9.99, 10-49.99, 50-99.99, and $>100$. These statistics all indicate that there is patterned variation in the central tendencies for retouching intensity between the four classes of implement.

However, the relationship of transverse and single scrapers is not consistent with the predictions of Dibble's reduction model. Differences in mean Kuhn GIUR alone $(\mathrm{t}=3.239$, d.f. $=236, \mathrm{p}=0.001)$ conform with the predictions of Dibble's (1987) model, although the question of how to interpret the large variation in each class is discussed below. Average surface area / platform area values were not significantly different for transverse and single scrapers $(t=-0.892$, d.f. $=208$, 
$\mathrm{p}=0.373)$, and the retouched zone index indicates that transverse scrapers have significantly less extensively retouched margins than single scrapers $(\mathrm{t}=-4.185$, d.f. $=97.8, \mathrm{p}<0.001$ ), a finding that is not compatible with Dibble's model in which the addition of distal retouch converted single scrapers into transverse ones. These statistics imply a difference between single and transverse scrapers in intensity and location of reduction, but not necessarily as sequential stages as Dibble argued in model of his single-transverse sequences.

Table 6.2: Descriptive statistics for the Kuhn GIUR, Retouched zone index, and surface area/platform area ratio of four implement classes in Layer 21 of Combe Grenal.

\begin{tabular}{|c|c|c|c|}
\hline & Kuhn GIUR & $\begin{array}{l}\text { Retouched zone } \\
\text { index }\end{array}$ & $\begin{array}{c}\text { Surface area/platform } \\
\text { area }\end{array}$ \\
\hline $\begin{array}{l}\text { Single } \\
(N=150)\end{array}$ & $\begin{array}{r}0.49 \pm 0.20 \\
0.15-1.00\end{array}$ & $\begin{array}{r}4.05 \pm 1.42 \\
1-8\end{array}$ & $\begin{array}{r}14.59 \pm 31.10 \\
1.0-297.4\end{array}$ \\
\hline $\begin{array}{l}\text { Double } \\
(N=23)\end{array}$ & $\begin{array}{r}0.60 \pm 0.16 \\
0.31-0.91\end{array}$ & $\begin{array}{r}6.61 \pm 1.12 \\
2-8\end{array}$ & $\begin{array}{r}11.86 \pm 7.20 \\
2.9-31.2\end{array}$ \\
\hline $\begin{array}{l}\text { Convergent } \\
(\mathrm{N}=31)\end{array}$ & $\begin{array}{r}0.61 \pm 0.16 \\
0.26-0.98\end{array}$ & $\begin{array}{r}6.26 \pm 1.59 \\
2-8\end{array}$ & $\begin{array}{r}11.81 \pm 20.32 \\
1.2-105.8\end{array}$ \\
\hline $\begin{array}{l}\text { Transverse } \\
(\mathrm{N}=60)\end{array}$ & $\begin{array}{r}0.61 \pm 0.21 \\
0.17-1.00\end{array}$ & $\begin{array}{r}2.97 \pm 1.78 \\
1-7\end{array}$ & $\begin{array}{r}10.79 \pm 17.78 \\
0.5-102.7\end{array}$ \\
\hline
\end{tabular}

Note: Top line is mean and standard deviation, lower line is the minimum and maximum value.

Source: Authors' calculation.

These data document differences between these implement classes in the average degree of reduction, but such differences may not constitute evidence of the transformation of specimens from one implement class to another. An examination of the variation found within each implement class reveals that the assemblage from Layer 21 does not conform to Dibble's reduction model. Each of implement class displays high levels of variation in the reduction measures. In particular single and transverse scrapers show large ranges of reduction indices. For example, on single scrapers the coefficient of variation for Kuhn GIUR is $41 \%$ and for the retouched zone index it is 35\%, while transverse scrapers have a coefficient of variation for Kuhn GIUR of $34 \%$ and for the retouched zone index $60 \%$. This indicates that each of those typological groupings contain specimens with very different levels of retouch. Using the Kuhn GIUR to estimate the proportion of original flake mass removed through retouching shows that single scrapers lost $2-66 \%$ of their weight, double scrapers 3-30\%, convergent scrapers $5-35 \%$, and transverse scrapers $4-66 \%$ of blank weight. When intensity of reduction is expressed in this way it is clear that Dibble's reduction models do not account for all of the specimens in Layer 21. For instance, some single scrapers are extensively reduced; some more than twice as reduced as any 
double or convergent scrapers. The existence of single scrapers with very high amounts of mass removed through retouching, and that were not converted into double or convergent forms, demonstrates that specimens typologically classified as single scrapers were not all 'early stage', with only little retouch. Conversely the existence of double, convergent and transverse scrapers with less than $5-10 \%$ of mass removed through retouching, representing the initial creation of the edge and perhaps one resharpening episode, demonstrates that such forms were not always more heavily retouched than single scrapers. Similarly, many transverse scrapers were not noticeably more reduced than many single scrapers, as might be expected if they were created at a later stage. However, other transverse scrapers have been extensively retouched, probably losing more than $50 \%$ of their original mass. This illustrates that the intensity of reduction within each implement class is highly variable. Further evidence for this within class variation in retouching intensity, and its implications, is provided in the following sections.

\section{Single Scrapers}

The striking characteristic of single scrapers in Layer 21, besides the strong pattern of retouch positioned on one lateral margin, is the great difference in the extent of reduction that different specimens had undergone. Some of the variation in the extent of retouching is displayed by the retouched zone index. The majority of single scrapers were retouched along much of one lateral margin, resulting in retouch scars in four or five zones (Figure 6.6). However, a few specimens had retouch restricted to a small portion of the lateral margin, only one or two zones; and some specimens also had small occurrences of retouch elsewhere on the flake, in more than five zones. The distribution of retouch around the flake margin was clearly related to blank characteristics, such as edge angle, cross-section and distribution of cortex.

Another dimension of retouch intensity, measured by the Kuhn GIUR, also displays extreme variation. Figure 6.6 shows a histogram of the abundance of specimens with different levels of the Kuhn GIUR. Almost $20 \%$ of single scrapers had a GIUR less than 0.3 , equating to less than about $5 \%$ of the original flake mass removed by retouching. Most single scrapers had GIUR values of $0.3-$ 0.8 , representing about $5-20 \%$ of mass loss. Some single scrapers, about $10 \%$ of those in Layer 21, had GIUR values greater than 0.8 , representing retouch that removed approximately $30 \%$ to more than $60 \%$ of the original mass. While conversion of GIUR values to mass lost through retouching in this way is only an estimate, it expresses the large differences in retouch intensity that are evident on different single scrapers. 

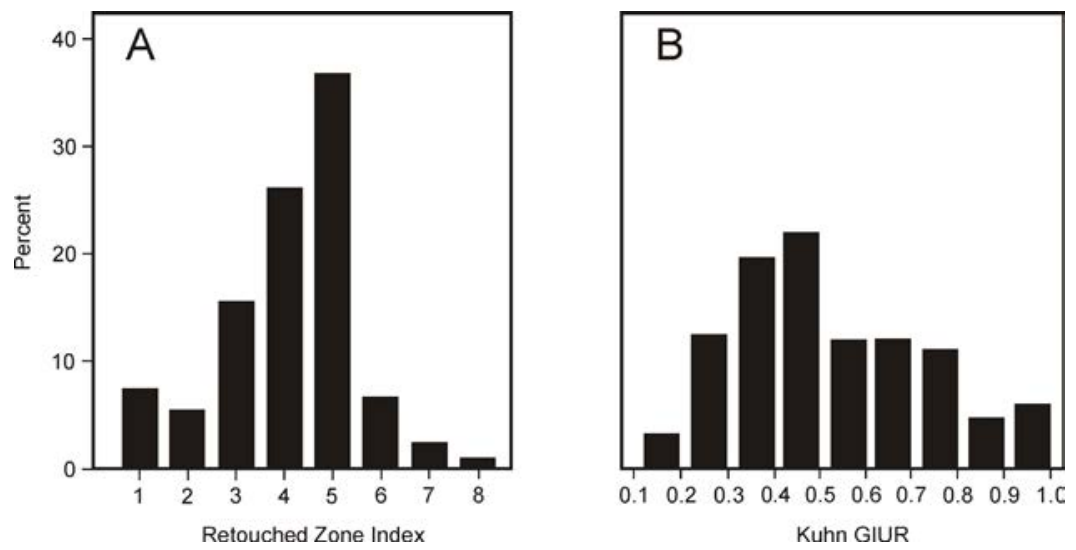

Figure 6.6: Histogram of the Kuhn GIUR values for single scrapers from Layer 21.

Source: Authors' calculations.

Single scrapers
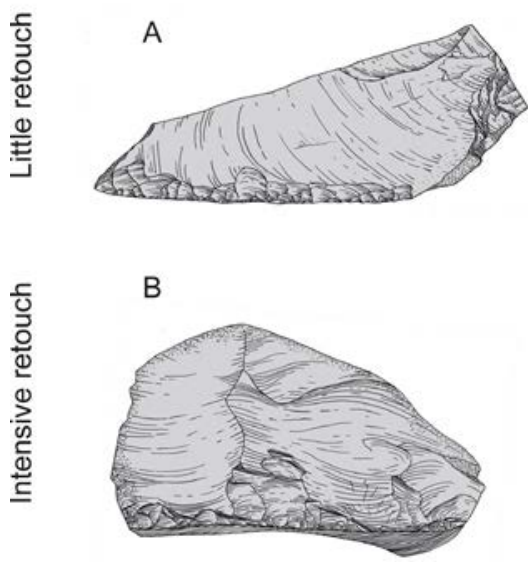

Transverse scrapers

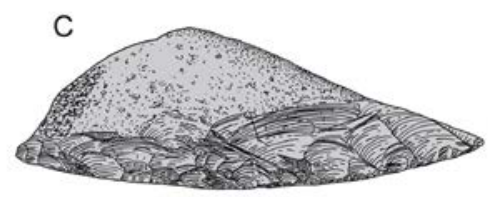

D

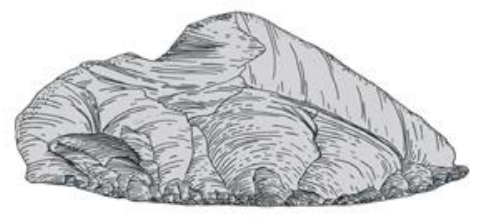

Figure 6.7: Examples of different levels of reduction on scrapers: A-B = Single scrapers, $C-D=$ Transverse scrapers; $A$ and $C=$ little mass removed, $B$ and $D=$ extensive mass removed. $A=$ Single scraper with a Kuhn index of $0.44 ; B=$ Single scraper with a GIUR index of 1.00 . $C=$ Transverse scraper with a Kuhn index of 0.56; $D=$ Transverse scraper with a Kuhn index of 0.91 .

Source: Authors' calculations.

Differences in the extent of retouching on single scrapers are illustrated in Figure 6.7, which presents two single scrapers: one with a small amount of material removed by retouching and the other with a large amount. The first specimen is a long flake with a series of small retouch scars, mostly about $3 \mathrm{~mm}$ 
long, on three zones of the left lateral margin (Figure 6.7A). The Kuhn GIUR of 0.44 recorded for this specimen, in association with low unretouched edge angles of $20-25^{\circ}$ in the retouched zones, is consistent with less than $5-10 \%$ of the original flake mass being removed by retouching. The other specimen (Figure 6.7B) was the remnant of a wide, thick flake which has been extensively reduced through the removal of large flakes from along the entire right lateral margin (retouch in five zones). This specimen has a GIUR of 1.00, with the retouch scars having removed the thickest part of the flake; a pattern consistent with the removal of approximately $45-65 \%$ or more of the original flake mass by retouching. Together these two illustrations exemplify the different levels of reduction present amongst single scrapers in Layer 21 .

In conjunction with the statistics, these specimens demonstrate that some single scrapers in Layer 21 were minimally retouched while others were heavily retouched. The heavily retouched specimens, as indicated by the GIUR, typically have retouch scars only on one lateral margin and had always been a single scraper throughout the retouching process. The evidence from such specimens shows that some single scrapers became very intensively retouched but that the level of reduction did not alter their typological status.

\section{Double and convergent scrapers}

Double and convergent scrapers are almost certainly made from single scrapers that had appropriate sizes and shapes, since one retouched margin must have been created before the other. The higher mean and minimum GIUR values for both classes, in comparison to single scrapers, are consistent with that interpretation, but do not prove it. However, the evidence for Layer 21 does not conform to Dibble's proposed single-double-convergent sequence of type stages. We have already discussed the observation that single scrapers were sometimes very intensively retouched and so specimens in that typological class do not always represent a stage of minimal reduction. This demonstrates that double/ convergent scrapers are not always highly retouched and single scrapers were not always minimally retouched.

Furthermore, in the collection from Layer 21 there is no difference in the intensity of reduction of the double and convergent scrapers. There is no significant difference between these two classes for any measure of retouching intensity: Kuhn GIUR ( $\mathrm{t}=-0.566$, d.f. $=66, \mathrm{p}=0.573)$, retouched zone index $(\mathrm{t}=0.995$, d.f. $=66, \mathrm{p}=0.323)$, and platform surface/platform area index $(\mathrm{t}=-0.010$, d.f. $=$ $52, \mathrm{p}=0.992)$. The ranges and distribution of values are also comparable for these measures; evidence that indicates specimens in both groups show varied but comparable levels of retouch intensity. Since convergent scrapers in this 
assemblage are not more reduced than double scrapers the notion that double scrapers were regularly converted into convergent scrapers is unlikely to be correct.

Instead, it seems likely that double and convergent scrapers are made on different kinds of flakes. A number of features of the flake are preserved on these retouched specimens and show statistically significant differences between the two classes. For example, the mean platform thickness of double scrapers is significantly lower than for convergent scrapers $(\mathrm{t}=-3.318$, d.f. $=$ $49, \mathrm{p}=0.002$ ). This evidence indicates that the relative positioning of retouched edges in double and convergent scrapers, leading them to be assigned to different types, may reflect the knapper's response to dissimilarities in flake form rather than extent of retouch. Hence, it is possible to conclude that more specimens classified as double and convergent scrapers were reworked single scrapers, but that many of the convergent scrapers are not more intensively retouched than double scrapers, the typological distinction largely reflects the influence of the different flake blanks from which they were made.

\section{Transverse scrapers}

Transverse scrapers also display large differences in the extent of retouching. Nearly $60 \%$ of transverse scrapers had a GIUR less than 0.6 , probably indicating less than $10 \%$ mass lost through retouching; but $20 \%$ of specimens had values of 1.0 , indicating they had more than $40-50 \%$ of their initial mass removed. These differences can also be illustrated using specific implements as exemplars (Figure 6.7). For instance, Figure 6.7C shows a transverse scraper made on a primary decortication flake, which has had a series of small retouch scars at the distal end. The Kuhn GIUR of 0.56 recorded for this specimen, in association with a low unretouched edge angle of $34^{\circ}$ at the distal end, is consistent with less than $10 \%$ of the original flake mass being removed by retouching. In contrast, another transverse scraper shown in Figure 6.7D had a series of large flake scars at the distal end, with retouch removing the thickest part of the flake along one half of the edge to give a GIUR of 0.91. This pattern is consistent with the removal of at least $30-35 \%$ of the original flake mass by retouching. These two illustrations exemplify the different levels of reduction present amongst transverse scrapers in this layer.

Large differences in retouch intensity between specimens classified as transverse scrapers also reflect flake characteristics: specimens with GIUR of less than 0.6 have, on average, significantly smaller platform thickness $(\mathrm{t}=2.094$, d.f. $=$ $59, \mathrm{p}=0.041)$, smaller flake thickness $(\mathrm{t}=3.616$, d.f. $=64, \mathrm{p}=0.001)$ and lower unretouched edge angles $(t=3.240$, d.f. $=64, p=0.002)$. Reduction 
intensity was therefore connected to the size and morphology of flakes, with larger flakes being more extensively retouched. However, despite the great variation in retouch between specimens in Layer 21, retouch intensity did not alter the typological status of transverse scrapers. That inference is inconsistent with the notion that transverse scrapers were once single side scrapers that had subsequently had additional retouch added to the distal end. Instead this evidence indicates that many or all transverse scrapers had always been transversely retouched, throughout their entire production and re-sharpening history.

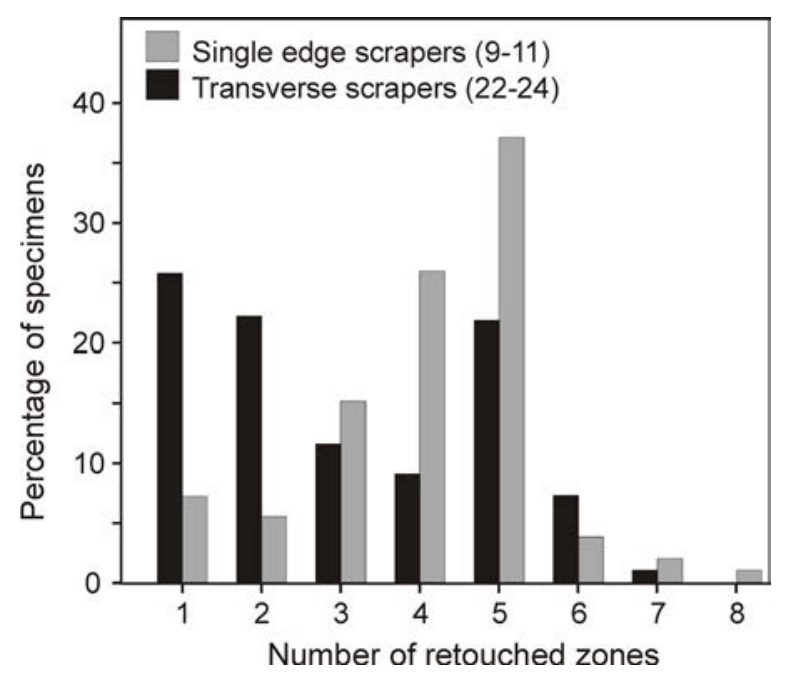

Figure 6.8: Histogram showing differences in the distribution of retouch on specimens classified as single scrapers and transverse scrapers.

Source: Author's data.

This conclusion is reinforced by information about the distribution of retouch around the perimeter of flakes (Figure 6.8). Distribution of retouch around flake perimeters is not consistent with all transverse specimens originally being single scrapers. More than $50 \%$ of transverse scrapers have retouch only toward the distal end ( $<3$ retouched zones). These specimens were never single scrapers, and we conclude that at least half the transverse scrapers began as transverse scrapers. Those with $4-6$ retouched zones may once have been single side scrapers that had retouch added to the distal end, or they may have begun as transverse scrapers that subsequently had retouch added to a lateral margin. While it is possible that in Layer 21 Dibble's hypothesised transformation of single into transverse scrapers sometimes occurred, this must have been 
infrequent compared to the common process creating transverse scrapers, in which knappers began to retouch at the distal end and continued to retouch in that location.

The initiation and maintenance of restricted patterns of retouch, at either the distal end or on a margin, probably reflects the influence of blank form. Transverse and single scrapers were regularly made on different flake blanks. For example, flakes which received retouch at their distal end (transverse scrapers) were thicker $(\mathrm{t}=1.929$, d.f. $=236, \mathrm{p}=0.055)$ and had higher unretouched edge angles $(t=2.249$, d.f. $=99, p=0.027)$ than those worked only the lateral margin. Differences in flake shape and thickness are therefore hypothesised to have been factors affecting the decision of knappers to begin working flakes laterally or distally.

\section{A retouching scheme for Layer 21}

The evidence presented here is consistent with a retouching scheme that is more elaborate and less stage-based than the one proposed by Dibble (1984, 1987b, 1995). Our interpretation of the retouching processes that created typological scraper groups in Layer 21 of Combe Grenal is represented in Figure 6.9. Most frequently, single side scrapers were retouched only on one margin for their entire history of production and maintenance. Some of those specimens were discarded after only a small amount of retouching but others were very intensively retouched on the same margin but remained, in typological terms, single scrapers. Some single side scrapers were retouched on additional margins to produce specimens classified as either double or convergent scrapers. Single scrapers were typically converted into either a double scraper or a convergent scraper, but there is little evidence for double scrapers being reworked to form convergent ones. Double and convergent scrapers have comparable levels of retouch, and are not sequential stages of retouch; they represent alternative strategies applied to single scrapers with subtly different sizes and shapes. The choice of whether to continue retouching one margin or to begin working a second, and in the latter case to retouch parallel or converging edges, appears to be related to differences in flake size and morphology. The precise interaction of blank form and retouch intensity will be pursued in future publications. 
Taxonomic Tapestries

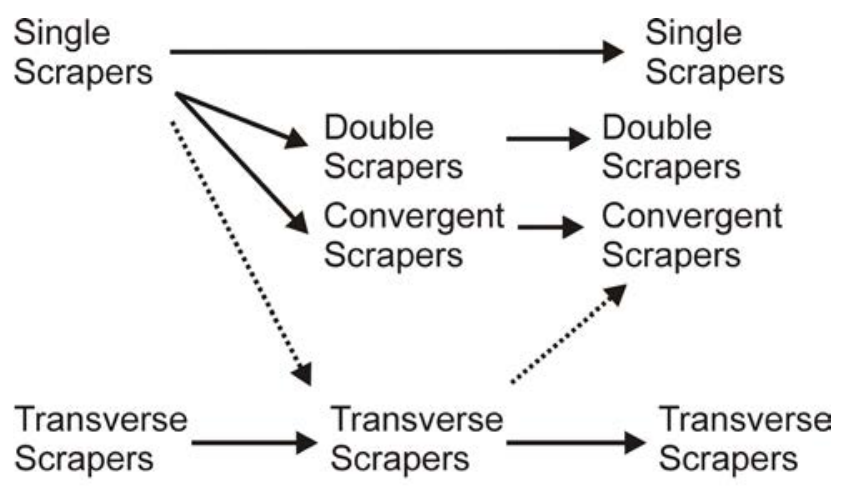

Low Amount of mass removed by retouching $\quad \mathrm{High}$

Figure 6.9: Illustration of the typological status and reduction history of flakes retouched to different degrees, using the same graphical conventions as Figure 6.1.

Source: Author's original figure.

Retouching of flakes to produce transverse scrapers appears to have been largely separate to patterns of lateral retouching leading to single, double and convergent scrapers (see Figure 6.9). Some transformations of single side scrapers to transverse scrapers, or the reworking of transverse scrapers into double/ convergent scrapers, may have occurred but in Layer 21 this was infrequent. Our interpretation of the evidence is that the majority of transverse scrapers were distally retouched throughout their 'life-span' and they had never been single side scrapers. Transverse scrapers therefore principally represent the result of a parallel pattern of production that is separate from, and constitutes an alternative to, the retouching strategy that created single side scrapers.

\section{Implications for the interpretation and analysis of Mousterian variability}

We note that while our analysis demonstrates the non-sequential structure of Quina scrapers at Combe Grenal Layer 21, and the incorrectness of Dibble's reduction model for that assemblage, the application of our analytical approach to Denticulate retouched flakes in Layers $11-12$ revealed that notched tool types did follow a sequence as predicted by the reduction model (Hiscock and Clarkson, 2007). This contrast shows that models of tool production may be correct for one site, or one level within a site, but not another, and arguments 
that one model is universally correct are not valuable. Additionally this finding reinvigorates questions of whether there is a distinct difference in tool production between Quina and Denticulate industries.

Furthermore, our interpretation of Quina scraper retouching in Layer 21 of Combe Grenal has a number of implications. Evidence presented indicates implement production was not simply a series of stages, it was multi-linear, and flake morphology was an important influence on the pattern of retouch distribution and intensity. Dibble's model of the implement classes, as stages of reduction, is not a viable depiction of the retouching technology represented in Layer 21. Our reconstruction of retouching processes conforms to many of the propositions contained in the 'blank-retouch interaction hypothesis' advocated by Turq and others.

Each of the Bordes' types examined here had multiple histories of retouching. Within each implement type some specimens received little retouch while others were intensively retouched. Perhaps retouch sometimes changed a specimen to such an extent that the type into which it would be classified was altered, but many specimens remained typologically stable even though they received additional retouch. Because different specimens belonging to each type had different histories, in particular very different amounts of retouch, the Bordes typology is not a reliable system for measuring retouch intensity. In assemblages such as this, Bordesian types tend to record the pattern and character of retouch preserved on flakes at the time they were discarded, but intensity of retouch cannot be accurately inferred from the type classification alone. Consequently, studies of spatial and temporal changes in retouch intensity will be more reliable when made on the basis of dedicated and experimentally verified systems of measurement, such as the Kuhn GIUR. In this context it is likely that robust models of land use and provisioning will not be able to be built on typological counts alone, and that long standing questions about the relationship between industrial variation and broader-scale organisational patterns can only be based on understandings of the technological processes that underpin differences in retouched flakes.

This is the first time that detailed quantitative measurements of reduction intensity have been used to assess the applicability of Dibble's 'reduction model' to Quina assemblages, and to do so by not only employing the same measures as Dibble had used but also other independent, and we argue more accurate, measurements of the retouch intensity. Our analysis reveals that the traditional typological groups are a complex product of multiple processes and not principally a signal of differing levels of retouch, even though retouch intensity is undoubtedly one of a number of factors creating morphological variation between specimens. Our conclusion that at Combe Grenal, and perhaps for many Mousterian assemblages, there is a strong interaction between 
blank and the nature of retouch which knappers applied to the blank also invites consideration of broad questions about the interpretation of implement patterns. The retouching scheme we have inferred for Layer 21 implies that sequential transformation of retouched flakes from one implement type to another was rare, and instead there were multiple, albeit branching, pathways of reduction. Demonstrating that retouching often maintained relatively stable tool forms need not indicate that Mousterian knappers had a specific design. In the instance of Combe Grenal the strong connection of retouch location, form and extent with blank form may provide a mechanism for creating regular and stable implement shapes over the reduction process, even if no well-defined, formal design was in place. Habitual application of production rules to blanks of different shapes may maintain stability in the appearance and location of a retouched edge during extended reduction. However, as Turq, Boëda and others have proposed, such production rules connecting blank form and retouching process to produce regularity in implement form might be considered a kind of design system for Middle Palaeolithic hominids. Debates of how we should think of goal-oriented behaviours in the Mousterian, and indeed the nature of technological and cogntive processes that were involved and their articulation with economic and ecological contexts, still require exploration in the quest to understand the construction of morphological diversity in Middle Palaeolithic implements. The evaluation of what constitute meaningful and valuable units of measurement, and how they may or may not be connected to traditional implement types, is not resolved; on the contrary, this discussion is merely beginning.

\section{Acknowledgements}

We offer this paper in reference to Colin Groves' significant work on classification, units of measurement, and of course hominin evolution. Both authors have enjoyed our interactions with Colin at all points through our careers, and we thank him for his support and engagement.

We acknowledge and appreciate the permission to examine the collection granted by Dr J-J Cleyet-Merle, the Director of the Musèe National de Prèhistoire des Eyzies. We thank Dr Cleyet-Merle and the Musèe National de Prèhistoire des Eyzies for providing their facilities for the prolonged duration of our project. For assistance and discussions at the Musèe National de Prèhistoire des Eyzies we thank Alain Turq, Andre Morala, and Jean-Philippe Faivre. Additionally we thank both Harold Dibble and Shannon McPherron for their advice and their generous help. A preliminary version of this paper analysing a sample of artefacts from Layer 21 was published as Hiscock and Clarkson (2008), but this paper presents an analysis of all relevant specimens from the layer and 
supersedes that earlier depiction. This research was funded by an Australian Research Council Discovery Grant (DP0451472 - A reappraisal of Western European Mousterian tools from Australian perspectives).

\section{References}

Binford LR. 1973. Interassemblage variability - the Mousterian and the 'functional' argument. In: Renfrew $\mathrm{C}$, editor. The explanation of culture change. London: Duckworth. pp. 227-254.

Binford LR. 1989. Isolating the transition to cultural adaptations: An organizational approach. In: Trinkaus, E, editor. The emergence of modern humans: Biocultural adaptations in the later Pleistocene. Cambridge: Cambridge University Press. pp. 18-41.

Binford LR, Binford SR. 1966. A preliminary analysis of functional variability in the Mousterian of Levallois Facies. Am Antiq 68:238-295.

Bisson MS. 2001. Interview with a Neanderthal: An experimental approach for reconstructing scraper production rules, and their implications for imposed form in Middle Palaeolithic tools. Cambridge Archaeol J 11:165-84.

Boëda E. 1988. Le concept laminare: Rupture et filiation avec le concept Levallois. In: Kozlowski J, editor. L'Homme Neanderthal, vol. 8, La Mutation. Liège: Etudes et Recherches Archéologique de l'Université de Liege (ERAUL). pp. $41-60$.

Bordes F. 1968. The Old Stone Age. New York: McGraw-Hill.

Bordes F. 1972. A tale of two caves. New York: Harper and Row.

Bordes F. 1961. Typologie du Paléolithique Ancien et Moyen. Mémoires de l'Institut Préhistoriques de l'Université de Bordeaux 1, Delmas: Bordeaux.

Bordes F, De Sonneville-Bordes D. 1970. The significance of variability in Palaeolithic assemblages. World Archaeol 2:61-73.

Bourguignon L. 1997. Le Moustérien de type Quina: Définition d'une nou-velle entité technique. Thèse de Doctorat de l'Université de Paris X, Nanterre.

Bourguignon L, Faivre J-P, Turq A. 2004. Ramification des chaînes opératoires: Une spécificité du Moustérien? Paléo 16:37-48. 
Clarkson C. 2002. An Index of Invasiveness for the measurement of unifacial and bifacial retouch: A theoretical, experimental and archaeological verification. J Archaeol Sci 29:65-75.

Clarkson C, Hiscock P. 2008. Tapping into the past: Exploring the extent of Palaeolithic retouching through experimentation. J Lithic Tech 33:1-15.

Close A. 1991. On the validity of Middle Paleolithic tool types: A test case from the Eastern Sahara. J Field Archaeol 18:256-264.

Debenath A, Dibble HL. 1994. Handbook of Paleolithic typology, Volume One. Lower and Middle Paleolithic of Europe. Philadelphia: University Museum, University of Pennsylvania.

Dibble HL. 1984. Interpreting typological variation of Middle Paleolithic scrapers: Function, style, or sequence of reduction? J Field Archaeol 11:431436.

Dibble HL. 1987a. Reduction sequences in the manufacture of Mousterian implements of France. In: Soffer, $\mathrm{O}$, editor. The Pleistocene Old World regional perspectives. New York: Plenum Press. pp. 33-45.

Dibble HL. 1987b. The interpretation of Middle Paleolithic scraper morphology. Am Antiq 52:109-117.

Dibble HL. 1988a. Typological aspects of reduction and intensity of utilization of lithic resources in the French Mousterian. In: Dibble H, Montet-White A, editors. Upper Pleistocene prehistory of Western Eurasia. Philadelphia: University Museum, University of Pennsylvania. pp. 181-194.

Dibble HL. 1988b. The interpretation of middle Paleolithic scraper reduction patterns. In: L'Homme de Néandertal, vol. 4, La Technique. Actes du Colloque International de Liége, L'Homme de Neandertal. pp. 49-58.

Dibble HL. 1991. Rebuttal to Close. J Field Archaeol 18:264-269.

Dibble HL. 1995. Middle Paleolithic scraper reduction: Background, clarification, and review of evidence to date. J Archaeol Meth Th 2:299-368.

Dibble HL, Rolland N. 1992. On assemblage variability in the Middle Paleolithic of Western Europe: History, perspectives, and a new synthesis. In: Dibble HL, Mellars P, editors. The Middle Paleolithic: Adaptation, behavior, and variability. Philadelphia: University Museum, University of Pennsylvania. pp. 1-28.

Gordon D. 1993. Mousterian tool selection, reduction and discard at Ghar, Israel. J Field Archaeol 20:205-218. 
Hiscock P. 1994. The end of points. In: Sullivan M, Brockwell S, Webb A, editors. Archaeology in the north. Darwin: North Australia Research Unit, The Australian National University. pp. 72-83.

Hiscock P. 2004. Slippery and Billy: Intention, selection and equifinality in lithic artefacts. Cambridge Archaeol J 14:71-77.

Hiscock P, Attenbrow V. 2005. Australia's Eastern Regional Sequence revisited: Technology and change at Capertee 3. British Archaeological Reports. International Monograph Series 1397. Oxford: Archaeopress.

Hiscock P, Clarkson C. 2005. Experimental evaluation of Kuhn's Geometric Index of Reduction and the flat-flake problem. J Archaeol Sci 32:1015-1022.

Hiscock P, Clarkson C. 2007. Retouched notches at Combe Grenal (France) and the Reduction Hypothesis. Am Antiq 72:176-190.

Hiscock P, Clarkson C. 2008. The construction of morphological diversity: A study of Mousterian implement retouching at Combe Grenal. In: Andrefsky $\mathrm{W}$, editor. Artifact life-cycle and the organization of lithic technologies. Cambridge: Cambridge University Press. pp. 106-135.

Hiscock, P, Clarkson C. 2009. The reality of reduction experiments and the GIUR: reply to Eren and Sampson. J Archaeol Sci 36:1576-1581.

Hiscock P, Turq A, Faivre J-P, Bourguignon L. 2009. Quina procurement and tool production. In: Adams B, Blades B, editors. Lithic materials and Paleolithic societies. Blackwell. pp. 232-246.

Holdaway S, Mcpherron S, Roth B. 1996. Notched tool reuse and raw material availability in French Middle Paleolithic sites. Am Antiq 61:377-387.

Kuhn S. 1990. A geometric index of reduction for unifacial stone tools. J Archaeol Sci 17:585-593.

Kuhn S. 1992. Blank morphology and reduction as determinants of Mousterian scraper morphology. Am Antiq 57:115-128.

Mellars P. 1965. Sequence and development of Mousterian traditions in southwest France. Nature 205:626-627.

Mellars P. 1986. A new chronology for the French Mousterian period. Nature 322:410-411. 
Taxonomic Tapestries

Mellars P. 1988. The chronology of the south-west French Mousterian: A review of the current debate. In: Otte M, editor. L'Homme de Néanderthal, vol. 4: La technique. Liege: Etudes et recherches Archaéologiques de l'Université de Liége. p. 97-120.

Mellars P. 1992. Technological change in the Mousterian of southwest France. In: Dibble HL, Mellars P, editors. The Middle Paleolithic: Adaptation, behavior, and variability. Philadelphia: University Museum, University of Pennsylvania. pp. 29-43.

Mellars P. 1996. The Neanderthal legacy. New York: Princeton University Press.

Rolland N. 1981. The interpretation of Middle Paleolithic variability. Man 16:15-42.

Rolland N. 1988. Observations on some Middle Paleolithic time series in southern France. In: Dibble H, Montet-White A, editors. Upper Pleistocene prehistory of Western Eurasia. University Museum Monograph 54. Philadelphia: University Museum, University of Pennsylvania. pp. 161-180.

Rolland N, Dibble HL. 1990. A new synthesis of Middle Paleolithic assemblage variability. Am Antiq 55:480-499.

Thiebaut C. 2003. L'industrie lithique de la couche III du Roc de Marsal: Le probléme de l'attribution d'une série lithique au Moustérien à Denticulés. Paléo 15:141-168.

Turq A. 1989. Approche technologique et économique du facies Moustérien de type Quina: Etude préliminaire. Bull Soc Préhist Fr 86:244-56.

Turq A. 1992. Raw material and technological studies of the Quina Mousterian in Perigord. In: Dibble HL, Mellars P, editors. The Middle Paleolithic: Adaptation, behavior, and variability. Philadelphia: University Museum, University of Pennsylvania. pp. 75-85.

Turq A. 2000. Paléolithique inférieur et moyen entre Dordogne et Lot. Paléo, Supplément 2.

Verjux C. 1988. Les Denticules Mousteriens. In: L'Homme de Néandertal, vol. 4, La Technique. Actes du Colloque International de Liége, L'Homme de Neandertal. pp. 197-204.

Verjux C, Rousseau D-D. 1986. La retouche Quina: Une mise au point. Bull Soc Préhist Fr 11-12:404-415. 


\title{
7. What are species and why does it matter? Anopheline taxonomy and the transmission of malaria
}

\author{
Robert Attenborough
}

\section{Introduction}

By the mid-twentieth century, taxonomy had, like many things Victorian, become unfashionable. When Washburn (1951: 298) argued for a 'new physical anthropology', he described the discipline's dominant approach of that period as 'static, with emphasis on classification based on types', though he did qualify that characterisation as 'oversimplified'. The change he wanted to encourage was one of emphasis, bringing genetics in without totally rejecting systematics. Even so, it must have seemed to many readers that a viewpoint centred on taxonomy would be allied, not to the new, but to the 'old physical anthropology' (see also Fuentes, 2010; Little and Collins, 2012).

From this period onwards, an antipathy to taxonomy was almost palpable in some quarters, even if manifested more in neglect than in critique. The typological mentality underlying the enterprise was seen as akin to that of stamp-collecting; it was predicated on a static, almost pre-Darwinian view of biological variation; too much was left to the subjective judgment of the taxonomist; some industrious practitioners had taken 'splitting' to absurd and chaotic extremes; the rules of nomenclature were arcane and obfuscatory. Above all, the work necessary and sufficient to label the entities out there in nature had essentially been done by then. Further fiddling with categories and names was mere finicky detail; and when it led to changes in an approved taxonomic name, that was more a nuisance than a scientific advance.

Since the 1980s or so, however, the tide has been turning, even if taxonomists of some groups (e.g. plants) still fear that their trade is itself an endangered species. Colin Groves must long have been amongst those who sensed that earlier critiques had thrown out both baby and bathwater. In much of his work from the 1960s to the present, he has addressed taxonomic issues both directly (e.g. Groves, 2001a; Groves and Grubb, 2011) and indirectly, through the taxonomic underpinning he has brought to other work (e.g. Groves, 1989; Groves, 2008). I draw on some of his arguments here. 
It says much for the adaptability of Linnaean taxonomy that a pre-evolutionary system for classifying biological diversity should have weathered the intellectual shocks of Darwinism, Mendelian genetics, 1930s population genetics, and in our own time molecular genetics. A further shock came from within taxonomy itself, in the form of a challenge to make taxonomy conform more rigorously to phylogeny. The cladistic school of taxonomy emerged in 1950 with the publication in German of Hennig's major theoretical work; though by 1966, when it appeared in English, other pioneers were already thinking along comparable lines (Cain and Harrison, 1960; Groves, 2001a). Hennig insisted that taxonomic groups should be monophyletic, which many traditional taxonomic groups were not; and he even wanted to have each taxonomic group's rank linked systematically to its antiquity, at least within higher-order taxa. Cladistic taxonomy was indeed a 'bombshell' and initiated a 'scientific revolution' (Groves 2001a: 8, 18).

Since the mid-century 'new synthesis' of evolution with genetics (Huxley, 1942), one particular taxonomic rank - the species - has been a focus of special interest and intensive analysis amongst cladistic and more traditional taxonomists. Why are species special? Part of the answer, as Groves puts it, is that species are 'kinds of animals (and other organisms)' as the lay public generally understands them (2001a: 26). A happy example was provided by Mayr from his fieldwork in the Arfak Mountains of the Vogelkop Peninsula, now in West Papua, Indonesia. He found that local people had 136 vernacular names for the 137 bird species that museum taxonomists recognised as occurring in the area. Their classification conflated just two of the museum taxonomists' species. This, said Mayr, was 'an indication that both groups of observers deal with the same, non-arbitrary discontinuities of nature' (1963: 17). Indeed: the observation vividly illustrates why species are special, and not purely artificial. But Mayr did not claim - nor would Godfrey and Marks (1991) for example, nor Groves - that it provides all the answers to the role of species in evolutionary theory, or solves all the taxonomists' day-to-day practical problems.

So what, then, are species, and why does it matter? The double-barrelled question comes verbatim from Colin Groves himself in recent conversation. But the first part is also the question with which he began a much earlier major theoretical work (Groves, 1989). He has reviewed this long-standing concern several more times, both in detail (Groves, 2001a: Part I) and more succinctly (Groves and Grubb, 2011: 1-10); see also Groves (2001b, 2004, 2012). In this chapter, I start from the solid ground that he established in these reviews (confounding his lament to Mittermeier and Richardson [2008: ii] that 'nobody ever reads Part I' of Primate Taxonomy). Then I shall set off in a quite different direction. 


\section{What are species?}

In introducing the taxonomy of the primates, Groves (2001a) reviewed 11 main concepts of what a species is (amongst sexually reproducing organisms). Importantly, he divided them into two groups: theoretical concepts, dealing with 'what a species is in essence'; and operational concepts dealing with 'how you can recognize one when you meet one' (2001a: 26). Here I only consider one concept from each group.

Mayr's Biological Species Concept (BSC) originated with the neo-Darwinian 'new synthesis', and became part of the prevailing orthodoxy along with it, cited innumerable times now. Under this theoretical concept, species are 'groups of actually or potentially interbreeding natural populations which are reproductively isolated from other such groups' (Mayr, 1963: 19). Reacting against the preceding Typological Species Concept, Mayr and like-minded thinkers were concerned to emphasise species as units of evolution - populations or sets of populations sharing a common gene pool. Reproductive continuity was central under the BSC. Morphology and phenotype played no part in defining species, although Mayr did allow that 'where the taxonomist applies morphological criteria, he uses them as secondary indications of reproductive isolation' (1963: 16-17).

The BSC still fits well with modern evolutionary thinking, and remains important at that level. Groves cited it approvingly in earlier work (e.g. Groves, 1989: 1-3). But his position has become more sceptical (e.g. Groves, 2001a; Groves and Grubb, 2011); and this has much to do with the weaknesses of the BSC as a guide to a working taxonomist. For one thing, if the test is which sets of populations are 'actually or potentially interbreeding' and which are 'reproductively isolated' in nature, that raises visions of the taxonomist as naturalist field-worker, binoculars at the ready, watching interbreeding not happening. Not only is such negative evidence hard to gather and inherently unlikely to convince; often the reality is that the taxonomist works mainly in the museum or the laboratory, on preserved specimens rather than observations in life, providing evidence that bears only inferentially at best on reproductive isolation.

Furthermore, even field observational evidence cannot determine which noninterbreeding populations might potentially interbreed (Groves, 2001a: 26-27; Groves and Grubb, 2011); nor, as Mayr himself rightly insisted (1963: 92), can evidence from captivity settle the question either. The classic, common instance of this problem arises where populations or sets of populations are allopatric. Populations might be separated by geographical barriers or unsuitable habitat, 
so that there is little or no actual interbreeding. But could the separated populations potentially, naturally, interbreed? The BSC provides no clear, evidence-based way of answering that question.

Groves also draws attention to a simpler, more factual problem with the BSC. With extensive genetic evidence from wild populations now available, we can see that good species, recognised by everyone as such, do actually interbreed, at least on occasion. There are both primate and ungulate examples of this (Groves, 2001a; Groves and Grubb, 2011: 2).

Groves concludes that, for all the great merits of Mayr's work, the BSC is irreparably flawed as a basis for practical taxonomy. Even taxonomists professing to implement it have often only paid it lip service, and 'it can be claimed that the BSC had made very little difference in how practicing taxonomists actually practiced' (Groves, 2001a: 27; Groves and Grubb, 2011). One effect that it did have, however, was an ill-effect: a bias arose amongst some workers under the BSC against the recognition of allopatric species, which tended to be 'lumped', even where sympatric species may have been correctly diagnosed (Groves, 2001a: 27).

Amongst the 10 concepts competing to succeed the BSC, Groves' reviews identify a clear winner: the operational Phylogenetic Species Concept (PSC), due principally to Cracraft (e.g. 1983), though further developed by others (Groves, 2001a: 30-32; 2004). Species are seen as evolutionary lineages - units of evolution and biodiversity. The concept is 'based on the results of evolution (on pattern), not on the processes by which these results may or may not have come about' (Groves, 2001a: 31). Cracraft's formal definition of the PSC includes reference to 'patterns of ancestry and descent', a reference which for practical purposes Groves strips out. Like reproductive isolation, it would lead us off towards the untestable. For operational purposes, he defines a species simply as: 'a diagnosable entity' (Groves, 2001a: 32). 'Diagnosable' here means 'identifiable $100 \%$ of the time, having fixed genetic differences from all others' (Groves, 2001a: 313). This is still a demanding definition. Species diagnoses on this basis may admittedly be based on plausible assumptions as to the heritable basis of diagnostic characters (rather than clear demonstrations), and on the indications of small samples as to their prevalence. But at least there is a reasonably objective basis on which to reach a conclusion that can be defended as the best supported one in the current state of knowledge. And it is a concept that is compatible with Hennigian cladistics (Nixon and Wheeler, 1990). Groves does not claim that there are no uncertainties or drawbacks to the PSC; only that they are fewer and less serious than for the competing concepts.

Put in a nutshell, 'the advantage of the PSC is that it depends entirely on the evidence to hand; there is no extrapolation' (Groves and Grubb, 2011: 1). And 'this is as close as we can come to putting a finger on the units of biodiversity. 
The next level ... is where the excitement begins for many workers ... But first we have to determine what the units actually are' (Groves and Grubb, 2011: 2). I agree; and I propose to proceed on that basis.

\section{Why does it matter?}

Does all this make a difference? Indeed it does. It has been precisely the PSC's power to make a real difference to accepted classifications that has made it unwelcome where a high value is placed on taxonomic stability. The difference it can make, simply in terms of the number of species recognised, is illustrated by Cracraft's own work as an avian taxonomist. Cracraft (1992) applied the PSC to the birds of paradise (Paradisaeidae) with dramatic results. A family previously thought to comprise 40-43 species could now boast some 90 of them. The contrast with the taxonomic stability found in the New Guinea example cited earlier - Mayr's from the Arfak Mountains - is instructive. If one's first thought is that perhaps Mayr's finding was simply an outrageous fluke, a second thought, and a third one, show that it is more complex.

While Mayr supplied few details, Bulmer's (1970) ethnotaxonomic research elsewhere in New Guinea provided a case study with more nuance. His work was amongst the Kalam (now the standard spelling, though Bulmer spelt it 'Karam': Pawley, 2011) of the Schrader Mountains. Bulmer estimated that only about $60 \%$ of Kalam terminal taxa for vertebrates correspond well with species as recognised zoologically. This does not, however, conflict with his main argument, that Kalam are like zoologists in being 'concerned with, and to a large extent aware of, the discontinuities which define biological species, even where their folk-taxa do not correspond one-to-one to these' (1970: 1082). The mismatches are explained partly as cases where Kalam are less familiar with those forms, and partly as either Kalam 'lumping' of zoological species (e.g. five microhylid frog species which, unlike all other frogs, they regard as inedible) or Kalam 'splitting' (e.g. where mature male birds of paradise, with their different plumage and behaviour, are placed in a different terminal taxon from females and immature males, even though Kalam know that this is what they are).

The essence of both Mayr's and Bulmer's examples, however, was that they were local. Presumably the species in question were mostly or all sympatric. Cracraft, on the other hand, in surveying a whole radiating family dispersed across the broad New Guinea region, was assessing the taxonomic status of population sets that included many instances of allopatry. What Cracraft had done was not primarily to collect new specimens, and certainly not to find new evidence about reproductive isolation. It was primarily to restore species status to numerous 'operational taxonomic units' (Groves, 2001a: 7), which under 
the BSC had been regarded as subspecies: allopatric, by definition, therefore. 'Restore' because, ironically, many of these taxonomic units had had species status until it became the trend under the BSC to relegate allopatric species to subspecies status where they were similar enough descriptively for that to be plausible. Cracraft's treatment of the evidence was quite traditional, analysing morphological variation in relation to geographical distribution, though his analysis was guided by the criteria of the PSC. The shock was in the outcome. Although Cracraft actually recognised fewer 'terminal taxonomic units' than the 100-115 that had been recognised under the BSC, he more than doubled the number recognised at species, as opposed to subspecies, level. Such a large disturbance of the previously accepted order can make readers uncomfortable. We ourselves are, after all, a classifying species, and sometimes classifications and their anomalies are strongly marked culturally (Douglas, 1966).

The PSC has brought similar, sometimes equally dramatic, changes to mammalian taxonomy. Madagascan primates supply several examples. Louis and others (2006) reviewed the genus Lepilemur (sportive lemurs), a group of 'superficially indistinguishable' (p. 2) primates, and argued on the basis of both molecular and phenotypic data that the true species diversity of the genus was 22 , double that previously recognised. Andriantomphohavana and others (2007) similarly reviewed the taxonomy of the genus Avahi (woolly lemurs), supporting the five species already recognised, and proposing the elevation of two subspecies to species status and the recognition of a further entirely new species. In both genera, the taxa in question are separated by rivers as well as sheer distance: see also this volume (Chapter 15) for a catarrhine case.

A recent and dramatic illustration of the difference that a different species concept can make - and the controversy it can cause - comes from Groves' own work. Groves and Grubb (2011) and Groves and Leslie (2011) have presented a revised scheme for the classification of the ungulates in which, amongst other things, they recognised 279 extant bovid species where only 143 had been recognised previously. This was too much for Zachos and others (2013), who launched a strongly worded critique of authors promoting 'species inflation and taxonomic artefacts'; to which Groves (2013) duly responded.

Their exchange is instructive. The parties are agreed on certain points. Sometimes, traditional classifications do underestimate diversity at the species level. This diversity is worth uncovering and recognising. In this task, genetic data can usefully supplement morphological data. A categorical taxonomic system is not fully adequate to reflecting a continuous evolutionary process, so whether a speciation process is sufficiently advanced to justify formal recognition for an incipient species may sometimes be moot. There can be real-world consequences to recognising more or fewer species. 
But for Zachos et al., the splitting of, for example, one klipspringer species (Oreotragus oreotragus) into 11 species is simply unacceptable: 'spectacular ... taxonomic inflation' (Groves and Grubb, 2011: 275-279; Zachos et al., 2013: 3). Their principal criticisms, across this and other examples, appear to be two: that the PSC has been inappropriately applied; and that there are insufficient data. Despite passing mention of the Genetic Species Concept ('a group of genetically compatible interbreeding natural populations that is genetically isolated from other such groups'), Zachos and others make no clear case as to what species concept or what method of implementing one they would have preferred to see. The very fact of major divergence from tradition in the resulting number of species recognised seems to be a fault perceived in the PSC. As for the data, Groves (2013) concedes the small samples but points out that no more data were available; and he argues that one should draw the conclusion that follows from the available data, while remaining open to testing it against more data once available. Zachos and others make similar criticisms in relation to other examples, e.g. the recognition of six mainland serow (Capricornis) species in place of one (Groves and Grubb, 2011: 255-261; Zachos et al., 2013: 3), even though the data are more abundant in that case. Groves, lacking their trust in traditional species diagnoses, is correspondingly more willing to advance claims based on the PSC.

All these examples - birds of paradise, lemurs, klipspringers and serows concern instances where authors applying the PSC have recognised more species than previously. This does not in itself show that the higher number is either correct or incorrect. Many but not all are taxa previously deemed to be subspecies. All, I believe, are allopatric - often not even parapatric but well separated geographically - with respect to other populations with which they had been or might have been considered conspecific. Allopatry is not invariably central, however, to cases where species diagnosis is affected by subtleties of detail and concept. Among insects and some other invertebrates, sympatric sibling or cryptic species have long been reported, separated reproductively, genetically, ecologically or chronologically (Mayr, 1963). Behaviour and ecology are often important as distinguishing characters, where the morphological differences are slight.

Overall, the species concept deployed not only makes a difference - potentially a large difference - to the classification one comes up with; it is also a difference that matters greatly to taxonomists. To Groves, for one, it matters to make the most scientific, most evidence-based estimate one can of the species-level diversity in nature; and, even if the answer that comes up is unexpected or inconvenient, to take it seriously. But, taxonomists apart, does it matter more widely? 
There is at least one further, and very practical, respect in which it matters. Conservation work risks being misdirected unless it is operating on the best available understanding of the evolutionary lineages it is dealing with. Without that understanding, the rich biodiversity of what survives may be underestimated; but so may the extent and nature of the need for action. The lineages and habitats in direst danger of extinction - or conversely, on a conservation triage approach, those viable enough to benefit from intervention - may not be correctly identified to conservation agencies. Thus, excessive 'lumping' carries an undisputed risk of concealing conservation needs; while Zachos and others add a countervailing concern that excessive 'splitting' may provide additional targets for taxonomically minded trophy hunters and collectors.

In the remainder of this chapter, I shall attempt to explore a quite different practical reason why it is helpful to do as Groves and like-minded scholars have done with the taxa of interest to them: to consider and refine species concepts very carefully and to work from them towards the best attainable empirical determinations and characterisations of species.

\section{Anopheline taxonomy}

Flies of the family Culicidae (Diptera) - mosquitoes - are divided into two subfamilies, Culicinae and Anophelinae; and Anophelinae into three genera, including Anopheles (Krzywinski and Besansky, 2003). By virtue of the blood meals that they imbibe from their hosts - mammal, bird and reptile - the females of many culicid species transmit infections between them, including, in the human case, arboviruses, filariasis and malaria. Because it is only anophelines, specifically Anopheles, of certain species only, that transmit human malaria, there is a disproportionate focus on anophelines in the literature; and they will be my focus too. The number of anopheline species recognised, including cryptic species, has increased substantially in recent years. Below I explore some implications of this development. My debt especially to three recent reviews (Beebe et al., 2013; Sinka et al., 2012; White et al., 2011), which draw on much wider literatures than I shall do directly, will be very apparent.

Anopheles is a very speciose genus, with a near worldwide distribution, containing six subgenera and hundreds of species. Four of the subgenera are endemic to South America, where the genus is likely to have originated, at least 50 million years ago (Reidenbach et al., 2009). Their current distribution includes many regions where malaria does not normally occur endemically nowadays, such as southern Australia and northern Europe - though islands in the Remote Pacific, beyond Buxton's Line which runs east and south of Vanuatu, remain Anopheles-free. In the 1980s, around 400 species of Anopheles were recognised (Bruce-Chwatt, 1985). Now, after much further work in genetics to supplement 
the morphology, 465 species are formally recognised and there are also over 50 unnamed members of species complexes (Sinka et al., 2012). Only a minority of all anopheline species have the capacity to transmit the five malaria parasites that normally infect people (Plasmodium falciparum, P. vivax, P. malariae, $P$. knowlesi and P. ovale), and fewer still do so frequently.

The global distribution of Anopheles species involves complex regionally contrasted patterns of allopatry and sympatry. The southwest Pacific region - lying between Weber's Line in the west (running through the Moluccas) and Buxton's Line in the east, and centred on the islands and archipelagos of New Guinea, the Bismarcks, the Solomons, Vanuatu and Australia - may serve to illustrate this complexity. At best current reckoning, at least 56 Anopheles species occur in this region (Beebe et al., 2013; Foley et al., 2007). Most of these belong to one of five species groups endemic to the Australian Faunal Region (the An. punctulatus, An. longirostris, An. lungae, An. bancroftii and An. annulipes groups). There are also four ungrouped endemic species, and eight species from the Oriental Faunal Region which have dispersed eastwards into the Moluccas or further into the Australian Faunal Region. There are elements of allopatry in their distribution: for example, the An. lungae group occurs only in the Solomons including Bougainville, whereas the $A n$. longirostris and An. bancroftii groups occur only in New Guinea, and the An. annulipes group mainly in Australia though with two representatives in New Guinea. On the other hand, An. farauti (in the An. punctulatus group) occurs throughout the tropical parts of the region, though rarely far from the coast, and is thus sympatric with many other species (Beebe et al., 2013).

The best studied species group in the region is the An. punctulatus group (subgenus Cellia). In the 1980s this group had five recognised member species, of which just three - An. punctulatus, An. koliensis and An. farauti (or An. farauti 1) - were known from Papua New Guinea. Research undertaken around this time was reported in these terms (e.g. Attenborough et al., 1997; Charlwood et al., 1986). Since the 1990s it has become apparent that the situation is more complex. The biodiversity of this species group, and the extent to which it is made up of morphologically similar cryptic species, is only now becoming fully appreciated (Beebe et al., 2013). This is because genetic data have allowed further species-level distinctions to be made where morphological data alone are uninformative or (as it turns out) unreliable. The An. punctulatus group now consists of 13 species. Most of the more recently diagnosed ones were previously included in An. farauti, and some still await a formal name. They have been distinguished via observations on chromosomal inversions, allozyme variation, variation under species-specific genomic DNA probes, and PCR-RFLP variation in ribosomal DNA (rDNA), especially its internal transcribed spacer 2 (ITS2) region. Species status for these taxa was further confirmed in some cases by cross-mating experiments demonstrating sterility, and by lack of hybridity 
at the rDNA locus even in large samples of field-collected specimens. The 13 species appear to be organised as two main clades: most of the An. farauti-like species in one; the An. punctulatus-like species plus An. farauti 4 in the other; with the position of $A n$. koliensis indeterminate (Beebe et al., 2013).

At a broad level, there is much co-occurrence amongst the An. punctulatus group species. Three of the 13 species occur in the Moluccas; four in New Britain; formerly five in the Solomons (including Bougainville), though fewer now; 11 in one or another part of the New Guinea island. In more fine-grained biogeographical terms, there is less true sympatry of these species, especially in New Guinea where different species occupy different regions; and there is also some ecological separation e.g. in breeding habitats. Nonetheless, there is some true sympatry: for example, An. koliensis, An. hinesorum (formerly An. farauti 2) and An. farauti 4 have not only overlapping distributions, especially in New Guinea's inland northern lowlands, but also similar larval habitats, including transient ones created by human and pig activity. They are also not reliably distinguishable on morphological criteria only. The latter two are thus instances of cryptic species-level biodiversity uncovered through genetic research. That they are - unlike the newly recognised vertebrate species discussed earlier sympatric is very interesting. Beebe and others (2013) do not explicitly discuss the species concept that has been applied in diagnosing these and other species in the group; but their methods and findings appear to conform to the PSC.

Similar statements could be made about the other four Anopheles species groups endemic to the region, in which some 25 new species overall have emerged through recent research. These groups are, however, all less well known than the An. punctulatus group.

For a second example, the most thoroughly researched of all, I turn to subSaharan Africa and the An. gambiae species group. For this group we can see research well advanced in some directions that currently still remain in the future for the southwest Pacific anophelines. The major African malaria vector An. gambiae was originally taken to be a single species. Then crossmating experiments showed that sterile male progeny resulted from crossing, first western and eastern coastal saltwater breeding populations with each other or with freshwater breeding populations, and then certain freshwater populations with each other (White et al., 2011). We now have an An. gambiae species complex consisting of some seven well recognised species: the western coastal species An. melas; the eastern coastal species An. merus; a third salttolerant species, An. bwambae, found near hot springs in Uganda; at least two widespread freshwater species, An. gambiae sensu stricto and An. arabiensis, which are extensively but not wholly sympatric; and two allopatric species of more restricted distribution, both originally included in An. quadriannulatus but now separated, again on the strength of crossing experiments, as 
An. quadriannulatus A and B (White et al., 2011) (see also maps of Sinka et al., 2012). Fixed genetic differences between these species were discovered, first karyologically, as banding patterns and paracentric chromosomal inversions, and then at the DNA level, again primarily in the intergenic spacer of rDNA. The species in the An. gambiae complex remain morphologically indistinguishable (White et al., 2011): that is, no morphological differences that are fixed and therefore diagnostic have been identified. Here, then we have a species group smaller than the An. punctulatus one but similarly complex, with at least seven, sometimes sympatric, well studied sibling members clearly recognised as such despite their phenotypic similarity. Species hybrids have been found in the wild and may be fertile if female; but are extremely rare and do not alter the diagnosis of these good species, whose phylogeny and history of ecological interaction with humans are discussed by White and others (2011).

The complexity goes to another level too in this case. A great deal of complexly patterned chromosomal and molecular variation has been discovered within $A n$. gambiae s.s. (hereafter, An. gambiae), and these two modes of variation are not simply related to each other. It transpires that the molecular level is the more fundamental one reproductively. The molecular forms labelled M and S, identified by fixed single-nucleotide differences in rDNA, have been widely considered to be examples of 'incipient speciation', but recently some workers have gone further and accorded them species status, as An. coluzzii and An. gambiae respectively (Coetzee et al., 2013). Though sympatric, they are ecologically differentiated at a micro level, especially in larval habitat. S characteristically breeds in ephemeral rain puddles and its larvae grow fast. $M$ tends to breed in longer-lasting artificial habitats associated with irrigated agriculture; its larvae grow more slowly and are outcompeted by $\mathrm{S}$ in the absence of predators, but are better at predator avoidance - they become more inactive in their presence (White et al., 2011). A recent study in Burkina Faso confirmed strong assortative mating of the forms, whereby: first, most mating swarms were of one form only, temporally or spatially separated from the other; second, even in mixed-form swarms, a large majority of pairs collected were of the same form; and third, even in the tiny number of mixed-form pairs, all the females had sperm of their own form in their spermothecae, not of the males they were caught with, presumably having mated recently with males of their own form (Dabiré et al., 2013). This supports the evidence of Pennetier and others (2010) for close-range mate-type recognition, based specifically on auditory flight-tone matching via difference tones. It also supports their recognition as species. Despite the existence of pre-mating barriers and probably post-mating barriers too, hybridisation of $\mathrm{M}$ and $\mathrm{S}$ does occur, at low but non-negligible and regionally variable levels, and genetic evidence indicates continuing gene flow between forms (White et al., 2011). Most authors prior to Coetzee and others (2013) recognised a strong evolutionary differentiation but did not go beyond calling the forms 'incipient 
species'. As both Groves (2013) and Zachos and others (2013) would presumably agree, in the continuous process whereby species come into existence, there will be instances in which it is moot where we draw any categorical line; and this appears to be one of them. We seem to have an excellent example of speciation under way; and interestingly it is happening sympatrically. The possible future discovery of further complexity and differentiation is not ruled out.

In the two limited examples of anopheline taxonomy chosen for discussion here, then, we can see that, although neither the PSC nor any of its competitor concepts is explicitly invoked, molecular technology and more in-depth research tend to uncover more complexity and greater biodiversity, both unambiguously at the species level and emergent amongst sets of populations, both allopatric and sympatric. Positive and statistically convincing identification of reproductive isolation mechanisms, often by experimentation, has more often been practical with insects than with birds or mammals, but is compatible with the PSC; and the primary criterion of 'fixed genetic differences' (White et al., 2011: 114) captures its essence.

\section{The transmission of malaria}

There are, then, many more anopheline species, and differentiable subpopulations within the formally named species (not always meeting the criteria for subspecies), than were recognised a few years or decades ago. Probably very few concerns have arisen that any anopheline taxa might need conservation. But there is a different practical reason why we should be interested in getting anopheline taxonomy right, and specifically in not underestimating their species biodiversity. That lies in the potential that a better understanding of malaria's vectors should have in combatting the transmission of the Plasmodium parasite. One simple illustration lies in a mistargeted malaria control campaign in Vietnam against a non-vector species misidentified as a vector (Krzywinski and Besansky, 2003; van Bortel et al., 2001). The more fine-grained our knowledge of each species or form, even those that are cryptic, the better guided our interventions should be. As Beebe and others (2013) put it: 'effectiveness of malaria control interventions depends on the biology of the [Anopheles] species present.'

Given the multiplicity of the factors required for human malaria transmission, there are many points at which the cycle might in principle fail or be interrupted. Depending on her proclivities and opportunities, a mosquito's first blood meal might or might not be from a human host; that blood meal might or might not be infected with the gametocytes of one of the plasmodia that cause human malaria; the mosquito might or might not be a competent vector (i.e. susceptible to infection); she might or might not live long enough for the malaria sporozoites to develop and reach her salivary glands; her next blood meal may or, depending 
on similar factors, may not be from another human host, and may or may not start up a new infection in that person; the mosquito may or may not proceed to high levels of reproductive success.

Mosquito survivorship, density and anthropophily are the basis of vectorial capacity, which is thus a matter of numbers and probabilities. Since the proportion of anophelines that have the potential to transmit a malarial infection is typically only a few per cent, quantitative reductions in abundance and biting rates, however these arise, may bring appreciable gains. Current efforts to achieve this amount principally to indoor residual insecticide spraying and (often long-lasting) insecticide-treated bed-nets. Used effectively, these can lead to large reductions in biting rates. A genetic study in Equatorial Guinea has shown large reductions in anopheline populations subject to these measures (Athrey et al., 2012). In addition, larval control measures have, but only lately, been shown to be effective where coverage of larval habitats is high enough (Tusting et al., 2013). And anti-malarial medications, where effective, must reduce the opportunities for mosquitoes to be infected.

The key point here is that the different variables affecting malaria transmission frequently vary in a species-specific way, and sometimes in a populationspecific way. Anopheles species are not all equal in their importance for malaria epidemiology; nor are their roles as malaria vectors simply a function of their global distribution or local abundance. And, as White and others (2011: 112) say, 'the rare species that possess all four of these traits [strong preference for human blood, physiological competence to parasite infection, long life, high population density] are not clustered phylogenetically but rather are interdigitated with nonvector species in four of six subgenera and even in sibling species complexes'. This statement applies globally (Sinka et al., 2012), in Africa (White et al., 2011), and in the Pacific (Beebe et al., 2013). It has long been known that anopheline species vary in their ecology, demography and behaviour as well as their distribution, in ways that affect malaria transmission patterns and the overall importance of each as malaria vectors (Bruce-Chwatt, 1985). But this is true of newly distinguished Anopheles species and populations, too. Important questions now for renewed malaria control or even local elimination efforts include: what are the details of these patterns of variation? And how can malaria transmission interventions best be designed on the basis of that knowledge? I only discuss, selectively, the first question here.

Some 70 Anopheles species, worldwide, out of $\sim 500$, can transmit the Plasmodium parasites; and Sinka and others (2012) designate 41 of those as dominant vector species or species complexes (DVS). In Africa, they designate three species (An. gambiae and An. arabiensis, both in the An. gambiae complex; plus An. funestus) as the most dominant of the continent's DVSs; and a further three species (including two more members of the An. gambiae complex, An. melas 
and An. merus) and one species complex as secondary DVSs. The recognition by some authors of An. coluzzii (see above) brings the list of most dominant DVSs to four.

Of the 56 species in the Pacific region, Beebe and others (2013) divide the 38 which occur in New Guinea, the Bismarcks, the Solomons and/or Vanuatu into four vector status categories: 3 primary vectors (all in the An. punctulatus group); 18 secondary vectors (including 4 in the An. punctulatus group); 8 possible vectors (including 1 in the An. punctulatus group), pending more extensive research; and 9 non-vectors (including 5 in the An. punctulatus group).

The three primary Pacific vectors of malaria go by the names longest-known in the An. punctulatus group: An. farauti s.s., An. koliensis and An. punctulatus itself. All are widespread in the region and can be locally abundant. Some key features of their species-specific distribution, ecology and behaviour, relevant to their vectorial capacity, are summarised in broad terms in Table 7.1.

Table 7.1: Key features of the primary Pacific malaria vectors.

\begin{tabular}{|c|c|c|c|c|c|}
\hline Species & Distribution & Environment & Breeding sites & Longevity & Anthropophily \\
\hline An. farauti & $\begin{array}{l}\text { Moluccas } \\
\text { New Guinea } \\
\text { Bismarcks } \\
\text { Solomons } \\
\text { Vanuatu } \\
\text { N. Australia }\end{array}$ & $\begin{array}{l}\text { Seldom far } \\
\text { from coasts }\end{array}$ & $\begin{array}{l}\text { Small ground } \\
\text { pools to } \\
\text { large coastal } \\
\text { swamps \& } \\
\text { lagoons. } \\
\text { Larvae tolerate } \\
\text { brackish water }\end{array}$ & Variable & $\begin{array}{l}\text { Adaptable } \\
\& \text { variable: } \\
\text { readily feeds } \\
\text { on humans } \\
\text { but in many } \\
\text { places also } \\
\text { pigs, dogs } \\
\& \text { probably } \\
\text { native birds \& } \\
\text { mammals; in } \\
\text { the Solomons } \\
\text { strongly } \\
\text { anthropophilic }\end{array}$ \\
\hline An. koliensis & $\begin{array}{l}\text { New Guinea } \\
\text { New Britain } \\
\text { Buka } \\
\text { Formerly } \\
\text { most of } \\
\text { Solomons }\end{array}$ & $\begin{array}{l}\text { Inland } \\
\text { lowlands \& } \\
\text { river flood } \\
\text { plains to } \\
300 \mathrm{~m} \text { a.s.l. }\end{array}$ & $\begin{array}{l}\text { Wheel tracks, } \\
\text { drains, natural } \\
\text { pools, swamps }\end{array}$ & Medium & $\begin{array}{l}\text { Prefers } \\
\text { humans; will } \\
\text { feed on pigs \& } \\
\text { dogs }\end{array}$ \\
\hline $\begin{array}{l}\text { An. } \\
\text { punctulatus }\end{array}$ & $\begin{array}{l}\text { Moluccas } \\
\text { New Guinea } \\
\text { Bismarcks } \\
\text { Buka } \\
\text { Formerly } \\
\text { Solomons }\end{array}$ & $\begin{array}{l}\text { Lowlands, } \\
\text { foothills, } \\
\text { mountain } \\
\text { valleys. } \\
\text { Clay soils, } \\
\text { perennial } \\
\text { rainfall }\end{array}$ & $\begin{array}{l}\text { Rock pools in } \\
\& \text { near rivers } \\
\text { \& streams, } \\
\text { wheel ruts, } \\
\text { foot \& hoof } \\
\text { prints, pig } \\
\text { wallows, } \\
\text { transient } \\
\text { water. Eggs } \\
\text { can survive } \\
\text { desiccation }\end{array}$ & $\begin{array}{l}\text { Most } \\
\text { long lived } \\
\text { of its } \\
\text { species } \\
\text { group }\end{array}$ & $\begin{array}{l}\text { Most } \\
\text { anthropophilic } \\
\text { of its species } \\
\text { group }\end{array}$ \\
\hline
\end{tabular}


Relative to the primary vectors, other species play smaller roles, or no role, in malaria transmission, for reasons generally related to the criteria set out by White and others (2011). At the extreme, several New Guinea species including An. farauti 5 are rare, An. clowi so rare that it has only been found twice since 1946; An. rennellensis only occurs on Rennell Island (Solomons) where there is little or no malaria transmission; the three members of the An. lungae complex (endemic to Solomons) bite humans but have never been found infected with human malaria parasites, and at least one of them is short-lived, so their capacity to transmit malaria is unconfirmed; An. irenicus (formerly An. farauti 7) is not only restricted to Guadalcanal (Solomons) but also has never been recorded as biting humans, despite local abundance as indicated by larval collections. Thus these species and some others play nil, negligible or unproven roles in malaria transmission (Beebe et al., 2013).

This leaves, however, a number of secondary vectors, including newly recognised species, which may play significant malaria transmission roles on top of those of the primary vectors, at least locally where they occur or are abundant. Within the An. punctulatus group, for instance, An. farauti 6 is quite common in the cool moist highlands valleys of New Guinea over $1000 \mathrm{~m}$ a.s.l., to which it appears adapted; and it probably plays a major role in the now worsening problem of highlands malaria transmission. An. farauti 4, An. hinesorum (formerly An. farauti 2) and An. koliensis all transmit malaria, but are hard to distinguish morphologically, and are all sympatric in lowland New Guinea; so more field research is still required to characterise sharply the abundance, ecology and vectorial properties of the first two especially. An. hinesorum in New Guinea readily bites humans but is highly zoophilic in Buka, Bougainville and the Solomons. Similarly, mosquitoes of the An. longirostris complex transmit malaria but have been found to be zoophilic in some areas and anthropophilic in others; whether reflecting species-specific behavioural differences between the cryptic species in this complex remains to be seen following further research (Beebe et al., 2013).

As with taxonomy, so also with vectorial capacity, more research has been undertaken in Africa than in the Pacific. Within the morphologically homogeneous An. gambiae complex, An. gambiae is usually considered the most anthropophilic, though there are grounds to see the situation as more complex. An. gambiae thrives in many different environments, but appears specialised in its association with humans in all those environments and at all stages of its life cycle (White et al., 2011). Ayala and Coluzzi (2005) argue that An.gambiae is a very young species (or, now, species pair), descended from an An. quadriannulatuslike ancestor; and thence ultimately, like other complex members, from an An. arabiensis-like ancestor. The proposed selection pressures were principally those produced by human population density and environmental impacts, beginning in the African late Neolithic, less than 4,000 years ago; resulting, for 
example, in heliophilic larvae. Along with its anthropophily, An. gambiae is also endophagic and endophilic, with implications for intervention (White et al., 2011). The highly anthropophilic incipient species M and S, or An. coluzzii and An. gambiae, show a partial but marked ecological differentiation as described above, with $\mathrm{M}$ predominant in more urbanised, more polluted environments with longer-lasting, more predator-infested breeding habitats; whereas S predominates in more rural settings (Kamdem et al., 2012).

Where sympatric, An. gambiae and An. arabiensis compete, with An. gambiae prevailing in rainforests and other relatively well watered habitats, and An. arabiensis in drier ones. An. arabiensis possibly dispersed from the Middle East over 6,000 years ago, probably as a zoophilic and exophilic species, acquiring anthropophily secondarily, and being now second in that respect only to An. gambiae in East Africa - though it remains zoophilic and exophilic in Madagascar, perhaps on account of historically lower population density (Ayala and Coluzzi, 2005).

At the opposite extreme of anthropophily, still within the same superficially homogeneous species complex, An. quadriannulatus is generally reported to be highly zoophilic and therefore a non-vector of human malaria. It has never been found naturally infected with Plasmodium falciparum malaria, though it has been shown in the laboratory to be a competent vector of it (White et al., 2011).

Another pressure driving the recent and rapid radiation of the An. gambiae complex has apparently been the adaptation permitting larval physiological tolerance of brackish water - twice independently, with one lineage, more closely related to An. quadriannulatus, leading to An. bwambae and the western coastal species An. melas, and the other, more closely related to An. gambiae, leading to the eastern coastal species $A n$. merus. This adaptation would appear to be the dominant differentiating factor for these species, given their still saltwater-focused distribution (Ayala and Coluzzi, 2005).

Anopheline mosquitoes' role as malaria vectors brings them no known evolutionary advantage. That there are variations amongst species, populations and individual mosquitoes in genes conferring immune resistance to malarial infection might suggest that there is some evolutionary cost. Laboratory genetic lines of An. gambiae more refractory to infection are able to kill many immature Plasmodium parasites - though $P$. falciparum least, and African P. falciparum least of all. These findings may not be transferable to field-collected mosquitoes, whose median parasite density is typically very low. But if they are transferable, an evolutionary 'arms race' might be hypothesised, whereby An. gambiae has evolved a degree of resistance to infection with the Plasmodium species and strains that naturally infect it, but in turn those plasmodia most exposed to this selection pressure have evolved the ability to evade the mosquitoes' immune 
defences. White and others (2011) review the now substantial evidence now available on immune gene variation affecting their vector competence. The net result is great variation, even within malaria-endemic zones, between and within species, in the likelihood that an individual mosquito's bite will be infective.

The processes that direct that individual mosquito's bite to a human host, rather than some other vertebrate (for which it may not be infective), are also crucial epidemiologically; and they vary according partly to anopheline species or population. As a variable, however, anthropophily can be problematic. Mosquito preferences for particular host species do not necessarily translate directly into biting rates on those species, as hosts may differ in their numbers, accessibility, presence in particular micro-environments, and defensive behaviour. Thus true host preferences unbiased by these factors are generally unmeasurable in uncontrolled field conditions. Consequently, descriptions such as anthropophilic or zoophilic are frequently based on less than satisfactory evidence. Nonetheless, it is clear that anophelines do have preferences amongst hosts, that these preferences vary between species, and that they play a part in explaining the different biting rate patterns of different species: indeed population differences within An. gambiae have been demonstrated (Lefèvre et al., 2009). Of the multiple cues thought to guide mosquitoes' activation, anemotaxis, close-range approach to hosts, and landing behaviour, some are non-specific (warmth, humidity, carbon dioxide); but others are species-specific - human or cattle odours, for example, eliciting different responses according to the anthropophily/zoophily of the anopheline species. Amongst anthropophilic species there is also differential attraction to different individual humans, and one factor which exacerbates this in An. gambiae - one further risk factor for malaria, in other words - is beer consumption (Lefèvre et al., 2010).

Field estimates of population density are generally derived from mosquito landing rates at human, animal or artificial baits, and are therefore subject to the extent of their attraction to those baits. The abundance of more zoophilic mosquitoes is likely to be underestimated in situations where most of the data come from human landing rates. Nonetheless, despite biases affecting the estimates, species differences in population density are clearly real and sometimes very large.

An illustrative picture of some more recently diagnosed anopheline species, reviewed in relation to White and others' (2011) four criteria for vectorial efficiency, is presented in Table 7.2. As this table shows, there are potentially major malariological implications to making taxonomic distinctions amongst anophelines, including between species previously not distinguished. 
Taxonomic Tapestries

Table 7.2: Selected contrasts in variables relevant to malaria transmission between selected cryptic species in the An. punctulatus and An. gambiae species complexes.

\begin{tabular}{|c|c|c|c|c|c|}
\hline $\begin{array}{l}\text { Species } \\
\text { complex }\end{array}$ & Species & $\begin{array}{l}\text { Anthropophily/ } \\
\text { zoophily* }\end{array}$ & $\begin{array}{l}\text { Estimated } \\
\text { population } \\
\text { density* }\end{array}$ & Longevity & $\begin{array}{l}\text { Vector } \\
\text { competence }\end{array}$ \\
\hline \multirow{4}{*}{$\begin{array}{l}\text { An. } \\
\text { punctulatus } \\
\text { (Pacific) }\end{array}$} & punctulatus & $\begin{array}{l}\text { Most } \\
\text { anthropophilic } \\
\text { in complex but } \\
\text { ranges from } \\
\text { total to modest } \\
\text { dependence on } \\
\text { human blood }\end{array}$ & High & Long-lived & Yes \\
\hline & farauti & Highly variable & High & Variable & Yes \\
\hline & hinesorum & $\begin{array}{l}\text { Variable } \\
\text { geographically }\end{array}$ & $\begin{array}{l}\text { Variable } \\
\text { geographically }\end{array}$ & & Yes \\
\hline & irenicus & Highly zoophilic & $\begin{array}{l}\text { Common } \\
\text { locally }\end{array}$ & & No? \\
\hline \multirow{3}{*}{$\begin{array}{l}\text { An. } \\
\text { gambiae } \\
\text { (Africa) }\end{array}$} & gambiae & $\begin{array}{l}\text { Highly } \\
\text { anthropophilic }\end{array}$ & High & & Yes \\
\hline & arabiensis & $\begin{array}{l}\text { Second most } \\
\text { anthropophilic }\end{array}$ & High & & Yes \\
\hline & quadriannulatus & Highly zoophilic & & & $\begin{array}{l}\text { Shown in } \\
\text { lab only }\end{array}$ \\
\hline
\end{tabular}

Note: *See text for discussion of difficulties in making unbiased estimates of these variables.

Source: Summarised from Beebe and others (2013); White and others (2011).

Research on anopheline demography, ecology and behaviour clearly has important potential implications - not pursued here - for interrupting malaria transmission. Suffice it to say that, to the (substantial) extent that these characteristics vary along taxonomic lines, especially species-specific lines, a fine-grained taxonomy of anophelines too has an important role in fresh approaches in the field to the still huge problem of malaria. The recent recognition of An. coluzzii as a species distinct from An. gambiae only strengthens this point.

To counterbalance optimism with a necessary caution, it also needs to be noted that we also have evidence for: phenotypic adaptability according to circumstances; variation within currently recognised species and even incipient species due either to such adaptability or genetic differentiation of subpopulations; and rapid changes in these traits due to either evolutionary or behavioural change. 


\section{Conclusion}

The circle that I have attempted to square in this piece has been to seek a perspective, from my own angle as a biological anthropologist interested above all in one particular species (ourselves), on a central interest of Colin Groves: that is, on species concepts, species diagnosis, species biodiversity, and indeed the origin of species. My approach has been to review, first, species concepts, and thence, selected recent developments in the taxonomy of Anopheles, the mosquito genus that, by transmitting malaria, still wreaks enormous havoc upon human life and health. This review supports the proposition that a fine-grained taxonomy, based on the PSC criterion of fixed inherited differences, and including recognition of cryptic and incipient species that are barely distinguishable or indistinguishable morphologically, is an important prerequisite of further fundamental biological research on these mosquito populations. Optimum practical intervention also depends upon it: in this case, not in a conservation context but to improve human health in the tropical Western Pacific, subSaharan Africa and other places still greatly afflicted by this scourge.

\section{Acknowledgements}

This piece is written out of my appreciation of an almost career-long collaboration with the acute, polymathic, formidably industrious, frequently humorous, ever equable Colin Groves, my closest colleague in the School of Archaeology and Anthropology at The Australian National University. To Tom Burkot of James Cook University, I owe not only my long-ago introduction to malarial entomology but also my extreme gratitude for valuable guidance before this piece was written and a critical reading of it afterwards. Nigel Beebe of the University of Queensland and Nora Besansky of the University of Notre Dame were also most helpful entomologically. Andrew Pawley of ANU drew my attention to a most useful reference. Any remaining errors are of course my own responsibility. I thank the volume editors, Alison Behie and Marc Oxenham of ANU, for their advice and forbearance.

\section{References}

Andriantomphohavana R, Lei R, Zaonarivelo JR, Engberg SE, Nalanirina G, McGuire SM, Shore GD, Andrianasolo J, Herrington K, Brenneman RA et al. 2007. Molecular phylogeny and taxonomic revision of the woolly lemurs, genus Avahi (Primates: Lemuriformes). Lubbock, TX: Museum of Texas Tech University. 
Athrey G, Hodges TK, Reddy MR, Overgard HJ, Matias A, Ridl FC, Kleinschmidt I, Caccone A, Slotman MA. 2012. The effective population size of malaria mosquitoes: Large impact of vector control. PLoS Genetics 8(12):e1003097.

Attenborough RD, Burkot TR, Gardner DS. 1997. Altitude and the risk of bites from mosquitoes infected with malaria and filariasis among the Mianmin people of Papua New Guinea. Trans R Soc Trop Med Hyg 91:8-10.

Ayala FJ, Coluzzi M. 2005. Chromosome speciation: Humans, Drosophila, and mosquitoes. Proc Natl Acad Sci U S A 102(Suppl 1):6535-6542.

Beebe NW, Russell TL, Burkot TR, Lobo NF, Cooper RD. 2013. The systematics and bionomics of malaria vectors in the southwest Pacific. In: Manguin S, editor. Anopheles mosquitoes: New insights into malaria vectors. New York: Intech Publishing.

Bruce-Chwatt LJ. 1985. Essential Malariology. London: William Heinemann Medical Books.

Bulmer R. 1970. Which came first, the chicken or the egg-head? In: Pouillon J, Maranda P, editors. Échanges et Communications: Mélanges offerts à Claude Lévi-Strauss à L'Occasion de son 60ème Anniversaire. The Hague: Mouton.

Cain AJ, Harrison GA. 1960. Phyletic weighting. Proc Zool Soc Lond 135(1):1-31.

Charlwood JD, Graves PM, Alpers MP. 1986. The ecology of the Anopheles punctulatus group of mosquitoes from Papua New Guinea: A review of recent work. P N G Med J 29(1):19-26.

Coetzee M, Hunt RH, Wilkerson RC, della Torre A, Coulibaly MB, Besansky NJ. 2013. Anopheles coluzzii and Anopheles amharicus, new members of the Anopheles gambiae complex. Zootaxa 3619(3):246-274.

Cracraft J. 1983. Species concepts and speciation analysis. In: Johnston RF, editor. Current Ornithology. New York: Plenum Press. pp. 159-187.

Cracraft J. 1992. The species of the birds-of-paradise (Paradisaeidae): Applying the phylogenetic species concept to a complex pattern of diversification. Cladistics 8:1-43.

Dabiré KR, Sawadodgo S, Diabate A, Toe KH, Kengne P, Ouari A, Costantini C, Gouagna C, Simard F, Baldet T et al. 2013. Assortative mating in mixed swarms of the mosquito Anopheles gambiae s.s. M and S forms, in Burkina Faso, West Africa. Med Vet Entomol 27:298-312. 10.1111/mve.2013.27. issue-3. 
Douglas M. 1966. Purity and danger: An analysis of concepts of pollution and taboo. London: Routledge \& Kegan Paul.

Foley DH, Wilkerson RC, Cooper RD, Volovsek ME, Bryan JH. 2007. A molecular phylogeny of Anopheles annulipes (Diptera: Culicidae) sensu lato: The most species-rich anopheline complex. Mol Phylogenet Evol 43(1):283-297.

Fuentes A. 2010. The new biological anthropology: Bringing Washburn's New Physical Anthropology into 2010 and beyond - the 2008 AAPA luncheon lecture. Yearb Phys Anthropol 53:2-12.

Godfrey L, Marks J. 1991. The nature and origins of primate species. Yearb Phys Anthropol 34:39-68.

Groves CP. 1989. A theory of human and primate evolution. Oxford: Clarendon Press.

Groves CP. 2001a. Primate taxonomy. Washington, DC: Smithsonian Institution Press.

Groves CP. 2001 b. Why taxonomic stability is a bad idea, or why are there so few species of primates (or are there?). Evol Anthropol 10:192-198.

Groves CP. 2004. The what, why, and how of primate taxonomy. Int J Primatol 25:1105-1126.

Groves CP. 2008. Extended family: Long-lost cousins. A personal look at the history of Primatology. Arlington, VA: Conservation International.

Groves CP. 2012. Species concept in primates. Am J Primatol 74:687-691.

Groves CP. 2013. The nature of species: A rejoinder to Zachos et al. Mamm Biol 78(1):7-9.

Groves CP, Grubb P. 2011. Ungulate taxonomy. Baltimore: Johns Hopkins University Press.

Groves CP, Leslie DM. 2011. Family Bovidae (Hollow-horned ruminants). In: Wilson DE, Mittermeier RA, editors. Handbook of the mammals of the world. Barcelona: Lynx Edicions.

Huxley JS. 1942. Evolution: The modern synthesis. London: Allen \& Unwin.

Kamdem C, Tene Fossog B, Simard F, Etouna J, Ndo C, Kengne P, Boussès P, Etoa F-X, Awono-Nkondjio C, Besansky NJ et al. 2012. Anthropogenic habitat disturbance and ecological divergence between incipient species of the malaria mosquito Anopheles gambiae. PLoS ONE 7(6):e39453. 
Taxonomic Tapestries

Krzywinski J, Besansky NJ. 2003. Molecular systematics of Anopheles: From subgenera to subpopulations. Annu Rev Entomol 48:111-139.

Lefèvre T, Gouagna L-C, Dabiré KR, Elguero E, Fontenille D, Costantini C, Thomas F. 2009. Evolutionary lability of odour-mediated host preference by the malaria vector Anopheles gambiae. Trop Med Int Health 14(2):228-236.

Lefèvre T, Gouagna L-C, Dabiré KR, Elguero E, Fontenille D, Renaud F, Costantini C, Thomas F. 2010. Beer consumption increases human attractiveness to malaria mosquitoes. PLOS ONE 5(3):e9546.

Little MA, Collins KJ. 2012. Joseph S. Weiner and the foundation of post-WWII human biology in the United Kingdom. Yearb Phys Anthropol 55:114-131.

Louis EE, Engberg SE, Lei R, Geng H, Sommer JA, Andriantomphohavana R, Randria G, Prosper, Ramaromilanto B, Rakotoarisoa G et al. 2006. Molecular and morphological analyses of the Sportive Lemurs (family Megaladapidae: genus Lepilemur) reveals 11 previously unrecognized species. Special Publications. Lubbock, TX: Museum of Texas Tech University.

Mayr E. 1963. Animal species and evolution. Cambridge, Mass: Belknap Press of Harvard University Press.

Mittermeier RA, Richardson M. 2008. Foreword. In: Groves CP, Extended family: Long-lost cousins. A personal look at the history of Primatology. Arlington, VA: Conservation International.

Nixon KC, Wheeler QD. 1990. An amplification of the phylogenetic species concept. Cladistics 6:211-223.

Pawley A. 2011. A dictionary of Kalam with ethnographic notes. Canberra: Pacific Linguistics.

Pennetier C, Warren B, Dabiré KR, Russell IJ, Gibson G. 2010. 'Singing on the wing' as a mechanism for species recognition in the malarial mosquito Anopheles gambiae. Curr Biol 20:131-136.

Reidenbach KR, Cook S, Bertone MA, Harbach RE, Wiegmann BM, Besansky NJ. 2009. Phylogenetic analysis and temporal diversification of mosquitoes (Diptera: Culicidae) based on nuclear genes and morphology. BMC Evol Biol 9:298.

Sinka ME, Bangs MJ, Manguin S, Rubio-Palis Y, Chareonviriyaphap T, Coetzee M, Mbogo CM, Hemingway J, Patil AP, Temperley WH et al. 2012. A global map of dominant malaria vectors. Parasit Vectors 5(69):1-11. 
Tusting LS, Thwing J, Sinclair D, Fillinger U, Gimnig J, Bonner KE, Bottomley C, Lindsay SW. 2013. Mosquito larval source management for controlling malaria. Cochrane Database of Syst Rev 2013(8).

van Bortel, W, Harbach, RE, Trung HD, Roelants, P, Backeljau, T, Coosemans M. 2001. Confirmation of Anopheles varuna in Vietnam, previously misidentified and mistargeted as the malaria vector Anopheles minimus. Am J Trop Med Hyg 65(6):729-732.

Washburn SL. 1951. The new physical anthropology. Trans N Y Acad Sci 13(7):298-304.

White BJ, Collins FH, Besansky NJ. 2011. Evolution of Anopheles gambiae in relation to humans and malaria. Annu Rev Ecol Evol Syst 42:111-132.

Zachos FE, Apollonio M, Barmann EV, Festa-Bianchet M, Golich U, Habel JC, Haring E, Kruckenhauser L, Lovari S, McDevitt AD, Pertoldi C, Rossner GE, Sanchez-Villagra MR, Scandura M, Suchentrunk F. 2013. Species inflation and taxonomic artefacts - a critical comment on recent trends in mammalian classification. Mammalian Biology 78:1-6. 

PART III 



\title{
8. Lamarck on species and evolution
}

\author{
Marc F Oxenham
}

\section{Introduction}

For the last decade I have lived three doors down from Colin's office, in the bowels of the AD Hope building at The Australian National University. However, my first contact with Colin was indirect, in as much as he was an examiner of my Honours thesis ('Progress and Evolution: A re-evaluation of some ideas, devices and scholars in the study of human evolution to 1950') back in 1995 . Those familiar with the Australian and New Zealand university systems will realise that Honours is where undergraduates start to play with the big kids, and examiner's reports can be a rude entree to the world of academia. Colin's positive comments inspired me to think about publishing from my Honours research, and while my PhD quickly got in the way of that, this chapter is in fact a reworked early version of a paper drafted just after my Honours year. While my research interests have developed in very different directions since then, I have maintained a strong 'armchair' interest in the history of evolutionary thought and hope this contribution will excite others to revisit the works of the early evolutionary theorists. Much of my discussion concerns the nature of and the role of species in Lamarck's theory of evolution. Many readers are no doubt aware of Colin's own particular interest in species (see the discussion by Robert Attenborough, this volume, particularly with respect to the phylogenetic species concept) and while Colin may not necessarily agree with my interpretations of Lamarck on species, I am sure he would see it a most appropriate topic for this volume.

In popular and scientific mythology Darwin is reified as the founder of modern evolutionary theory and Lamarck lampooned as that 'odd chap' who believed in the inheritance of acquired characteristics. While not of concern here, the inheritance of acquired characteristics (what is now termed transgenerational epigenetic inheritance) would now seem to be a reality (see Morris, 2012 for an overview of recent developments in this area). The purpose of this chapter is not to bring Darwin 'down a peg', and in fact Darwin hardly gets a mention, but to entreat the reader to see Lamarck in an alternative light.

The role and influence of the French naturalist Jean-Baptiste Pierre Antoine de Monet, Chevalier de Lamarck (1744-1829) with regard to the development of evolutionary theory has been extensively researched over the past 50 years 
or so (Cannon, 1959; Gillispie, 1959; Lovejoy, 1959; Burkhardt, 1977, 1984; Hull, 1984; Lovtrup, 1987; Corsi, 1988) and is not pursued here. In this chapter I wish to review Lamarck's ideas on the nature of species, which directly relates to his evolutionary model, and then re-evaluate what I will argue are misinterpretations of two central aspects of this model: first, the view that Lamarck's theory was strictly vertical in nature and lacked a crucial horizontal component; secondly, that his evolutionary model is best viewed as a collection of multiple, independent lineages and is inconsistent with a theory of descent. Both of these themes are generally considered evidence of pivotal differences between Lamarck's and Darwinian, or modern, evolutionary theory. While I am not proposing that Darwin's theory of evolution be seen as resting on the foundations of Lamarck's theorising, I am asking that Lamarck at least be given a fair go in light of a close reading of his actual works.

\section{Zoological philosophy}

Coming from a background in botany Lamarck assumed the position of professor of invertebrates at the Museum National d'Histoire Naturelle in Paris in 1793 at 50 years of age. At the turn of the nineteenth century Lamarck made a seemingly abrupt ideological change with his conversion to evolutionism (Lamarck, 1800, 1802). Less than a decade later he became the first scholar (Lamarck, 1809) to publish a detailed theory of bio-evolution or transmutation. While neither of these terms were used by Lamarck, contemporary synonymous concepts such as 'changed', 'converted', 'mutation' and 'transformed' were used in their stead. Lamarck was also to a large extent responsible for integrating the threads of an emerging nineteenth century bio-evolutionary theory with the notion of progress.

Lamarck's most famous work, published in 1809 (the year of Darwin's birth), Zoological Philosophy, was not only a treatise on evolution but a system of biology treating three broad areas of study: (1) zoological classification and evolution; (2) the nature and causes of life; and (3) the nature and causes of intelligence, emotions and so forth. While the first part of this work dealt specifically with his evolutionary ideas, some sections on the origin of life in the second part of the work are important in understanding Lamarck's evolutionary model.

In his own lifetime Lamarck's views were essentially either ignored or actively disparaged (Cannon, 1959; Bowler, 1984, 2003; Burkhardt, 1984; Hull, 1984), although he received support in some quarters, the French naturalist Henri de Blainville for instance (see Appel, 1987). Perhaps one reason for Lamarck's dearth of support was related to his lack of compunction in seeing humanity as a creature of the evolutionary process. Cannon (1959) has also suggested that 
Georges Cuvier, a younger highly influential contemporary of Lamarck's, was the central cause of Lamarck's problems whilst living and dead. During his time at the Museum of Natural History Lamarck came into conflict with Cuvier over both geological gradualism and transmutation, both concepts to which Cuvier was totally antagonistic. The power and influence Cuvier wielded during these years (Coleman, 1964) did nothing for Lamarck's cause. Cannon (1959) has even suggested that nineteenth and twentieth century interpretations of Lamarck and his ideas stem from Cuvier's reinterpretations or misrepresentations. Indeed, in Cuvier's Biographical Memoir (Cuvier, 1831: 434) of Lamarck, he contrasted him to men of true genius:

[Those], with minds not less ardent, nor less adapted to seize new relations, have been less severe in scrutinizing the evidence; with real discoveries with which they have enriched science, they have mingled many fanciful conceptions; and, believing themselves able to outstrip both experience and calculation, they have laboriously constructed vast edifices on imaginary foundations, resembling the enchanted palaces of our old romances, which vanished into air on the destruction of the talisman to which they owed their birth.

Notwithstanding, Cuvier was one man and insufficient to the task of countering all materialist thought at the time (see Corsi, 1988). Burkhardt (1984) has outlined three additional reasons why Lamarck was so unsuccessful in his own time. In brief these are the materialist overtones of his work; his reputation for wild speculation; and the fact that he was 'unable to cultivate a circle of capable naturalists willing to champion his views' (Burkhardt, 1984: xxxiv). Moreover, less than three decades after his death, Lamarck was to present 'a serious public relations problem for Darwin and the Darwinians' (Hull, 1984: xlvi). Lamarck was perceived as Darwin's scientific precursor in a sense. Lyell even went as far as to describe Darwin's theory of evolution as a modification of Lamarck's views, much to the annoyance of Darwin (Hull, 1984). A perception of Darwinian evolution as Lamarckian evolution revisited (Lovtrup, 1987) would not have been an idea that would have sat well in the Darwin camp. Unfortunately, only Lamarck's mechanism for change survives as his legacy to the history of evolutionary thought. Furthermore, it is unlikely that Lamarck would recognise what was understood and presented as Lamarckism after his death (see Bowler, 1992).

\section{Lamarck on species}

Lamarck's particular understanding of species impacts on the two principal themes of this chapter and it is necessary to outline his ideas on this subject. 
Lamarck argued for the ability of species to change, and while not in itself ground breaking at the time, he presented his case by positing that species form a continuum:

I do not mean that existing animals form a very simple series, regularly graded throughout; but I do mean that they form a branching series, irregularly graded and free from discontinuity, or at least once free from it. For it is alleged that there is now occasional discontinuity, owing to some species being lost. (Lamarck, 1809: 37)

In his view species changed or transformed very gradually, that is by way of extremely small changes or micro-mutations over time. Because of this Lovtrup (1987) has argued that Lamarck was in fact the first micro-mutationist. Lamarck needed evolution to be gradual to fit with his understanding of deep geological time and views of environmental change.

As compared to the periods which we look upon as great in our ordinary calculations, an enormous time and wide variation in successive conditions must doubtless have been required to enable nature to bring the organization of animals to that degree of complexity and development in which we see it at its perfection. (Lamarck, 1809: 50)

Lamarck, like those after him who subscribed to the view of gradual species change, had a problem with species recognition. How does one separate a temporally and physically continuous entity into discrete units or species? Lamarck's solution was unique: species for him did not actually become extinct, although he noted the exception of recent cases of non-natural human induced extinctions. The fossil evidence in his time indicated many forms with no known contemporary representatives. Lamarck forwarded two explanatory arguments. The first, it was likely the living counterparts existed in the vast unexplored regions of the earth; the second and more important, species did not become extinct but they change over time by way of the accumulation of tiny mutations into new or different forms.

May it not be possible ... that the fossils [apparently representing extinct species] ... belonged to species still existing, but which have changed since that time and become converted into the similar species that we now actually find. (Lamarck, 1809: 45).

Species for Lamarck could encompass both broad levels of variation and temporal depth. In modern evolutionary terms Lamarck was describing the model of phyletic (anagenetic) evolution. This particular conceptualisation of what defined species allowed him to see them both change through time and retain their essential identity. 
There is, perhaps, an additional reason for Lamarck's subscription to this particular notion of species. It may have been a reaction to an interpretation of extinction events as the result of the non-viability of transmutated organisms. Such a view, if sustained, would constitute direct evidence against evolution. There is some evidence for this view when one considers opposition to transmutationism from Cuvier. Coleman (1964) and Bowler (1984) have noted that Cuvier, through his studies in comparative anatomy, had come to the conclusion that biological organisms were too complex to hold to the view transmutation could result in different viable organisms. For Cuvier species were fixed (implying species had a creationist and/or saltational origin). Lamarck saw transumtation occurring very gradually and there was certainly no place for useful monsters (the expected common result of large mutations as opposed to tiny unnoticed ones) in his scheme.

\section{Vertical and lateral evolution}

A number of scholars have either denied (Mayr, 1982, 1991) the idea of lateral, as opposed to vertical, evolutionary change in Lamarck's evolutionary model, or else seen this idea as having limited significance (Ruse, 1981, 1982; Bowler, 1984). It is Darwin who is generally credited with this ostensibly novel dichotomisation of evolutionary theory. For example, Mayr (1991: 17) argues that:

For Lamarck, evolution was a strictly vertical phenomenon, proceeding in a single dimension, that of time. Evolution for him was a movement from less perfect to more perfect, from the most primitive infusorians up to the mammals and man.

and

The problem of how these new species and incipient species came into being was clarified for Darwin by the Galapagos mockingbirds. These specimens showed that new species can originate by what we now call geographical (or allopatric) speciation...By this thought Darwin founded a branch of evolutionism which, for short, we might designate as horizontal evolutionism, in contrast with the strictly vertical evolutionism of Lamarck. (Mayr, 1991: 20)

Moreover, both Bowler $(1984,2003)$ and Ruse $(1981,1982)$ have tended to stress the idea that Lamarck was redeveloping the Medieval classificatory construct of a scale of being or scala natura, albeit a dynamic scale rather than a static one. Traditionally this scale concept was a hierarchical device that encompassed all 
life from the worms in the ground through to the angels themselves and even God. Each life form was ordered and ranked in such a manner as to create a continuous, unbroken but graduated chain of life (Hodgen, 1964).

Indeed, the concept of a scale of life is prominent in Lamarck's work. He outlined 14 classes of animals which were ranked or arranged from the single celled infusorian through to the most 'perfect' class mammals. Notwithstanding, Lamarck's understanding and use of the scala natura concept needs some explanation. For instance, what did Lamarck mean by the concept arrangement? Arrangement related to the order of his scale, in distinction to classification which referred specifically to the divisions within it. For example, Lamarck (1809: 56) defined arrangement as:

[A]n order in that list [referring to his classes] which represents as nearly as possible the actual order followed by nature in the production of animals; an order conspicuously indicated by the affinities which she has set between them.

However, this was not a simple continuous unilinear scale with evolution being represented by change over time (refer to the Lamarck, 1809: 37 quotation above) and Lamarck's views can be seen to be quite modern. Most evolutionary biologists today would accept some sort of loose macro-historical trend of less to more complex, mediated by the observation that the evolution of $B$ from $A$ is constrained by the nature of $A$ itself (see Mayr, 1982; Eldridge, 1985). Further, there are controversies and difficulties with current species concepts (e.g. Paterson, 1981; Eldridge, 1985; Tattersall, 1986), a topic to which Colin has also made important contributions (e.g. Groves, 2001). The point is that Lamarck was not simply reviving the scala natura in newer and more dynamic garb.

If not a simple unilineal scale what then was Lamarck's evolutionary scheme? In a summary of his own evolutionary views Lamarck notes:

Nature has produced all the species of animals in succession, beginning with the most imperfect or simplest, and ending her work with the most perfect, so as to create a gradually increasing complexity in their organization; these animals have spread at large throughout all the habitable regions of the globe, and every species has derived from its environment the habits that we find in it and the structural modifications which observation shows us. (Lamarck, 1809: 126)

Two themes are clearly presented here by Lamarck: the first is an implicit law of nature which causes the vertical progression from simple to complex organisation, based on the scala natura already spoken of; the second theme is the lateral secondary transformation of species due to the effects of environment, habit 
and so forth. Although this bi-directional scale of vertical continuity and lateral change was a major intellectual conceptualisation of the Renaissance theistic model of Adamitic origins and subsequent diffusion (see Hodgen, 1964), it is Lamarck who was responsible for appropriating it into an evolutionary model.

Lamarck's advocacy of lateral, or non-progressive, evolutionary change is further illustrated in his evolutionary diagram (see Figure 8.1). For instance there is an initial lateral branching from the worms into an annelids-cirrhipedes-molluscs evolutionary sequence on the one hand and an insects-arachnids-crustaceans sequence on the other. There is a similar major branching event at the reptiles. Further, there are a series of lateral bifurcations from an ancestral amphibian stock. That this is the manner in which Lamarck viewed evolutionary history, and not simply an interpretation seen through the lens of a modern understanding of evolution, is evident in his own comments concerning this diagram:

It is there shown that in my opinion the animal scale begins by at least two separate branches, and that as it proceeds it appears to terminate in several twigs in certain places. (Lamarck, 1809: 178)

The importance of this concept in his evolutionary model is further reinforced by other such specific references in his work:

As we continue to examine the probable origin of the various animals, we cannot doubt that the reptiles, by means of two distinct branches, caused by the environment, have given rise, on the one hand, to the formation of the birds and, on the other hand, to the amphibian mammals, which have in their turn given rise to all the other mammals. (Lamarck, 1809: 176; italics added)

The environment was the causal agent for Lamarck's other secondary, or lateral, component of his evolutionary model. It is evident that environmental influence played an important role in influencing evolutionary direction. Lamarck devoted a chapter (VII: 106-127) to his secondary evolutionary causal agent.

It is obvious then that as regards the character and situation of the substances which occupy the various parts of the earth's surface, there exits a variety of environmental factors which induces a corresponding variety in the shapes and structures of animals, independent of that special variety which necessarily results from the progress of the complexity of organisation in each animal. (Lamarck, 1809: 112)

Lamarck (1809: 127, italics added) went on in concluding his chapter on the role of environmental influence to state that:

[I]t is not the shape either of the body or its parts which give rise to the habits of animals and their mode of life; but that it is, on the contrary, 
the habits, mode of life and all the other influences of the environment which have in course of time built up the shape of the body and of the parts of animals. With new shapes, new faculties have been acquired, and little by little nature has succeeded in fashioning animals such as we actually see them.

It is clear that not only should Lamarck be given credit for the first comprehensive development of this vertical-lateral dichotomy within an evolutionary model, but that it was a fundamental component of his theory. Lamarck's answer to the riddle of specific diversity was a function of his lateral thinking.

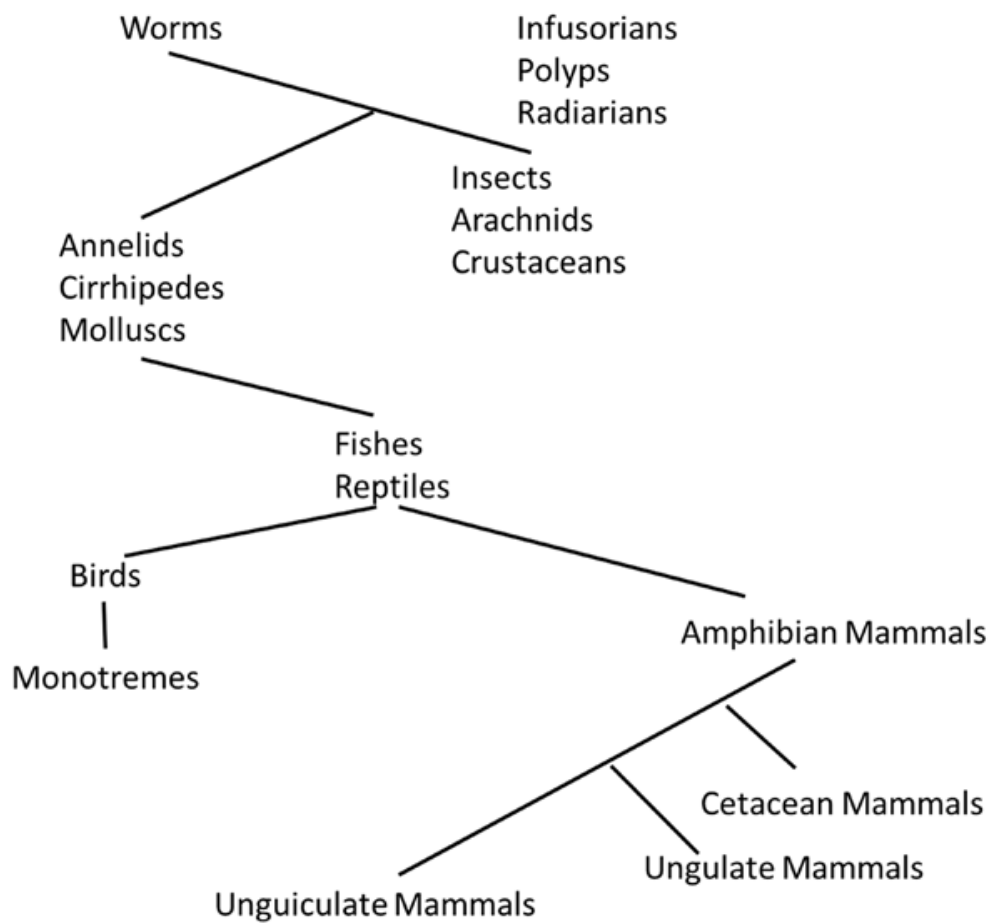

Figure 8.1: Diagram 'Showing the Origin of the Various Animals'.

Source: After Lamarck 1809: 179

\section{The multiple independent lineage view}

Giving precedence to Lamarck for first developing a vertical-lateral evolutionary model would not be accepted by Ruse $(1981,1982)$ and Bowler (1984), both of whom have argued that Lamarck's evolutionary model cannot be viewed 
as encompassing a theory of common descent. In fact Bowler claimed that the crucial difference between modern, or Darwinian, evolutionary theory and Lamarck's evolutionary views was that Lamarck '... did not suppose all forms alive to have evolved from a common ancestry' (Bowler, 1984: 80). For Lamarck complexity equated with temporal depth of lineage. Humans, for example, are the longest lived lineage which arose at the earliest period in time, relative to other lineages, from a separate spontaneous generation event (see Bowler, 1984 Fig. 10; 2003 Fig. 9). ${ }^{1}$ Lamarck is interpreted to be advocating multiple parallel lineages through time, each lineage having its roots in a separate and progressively later point of spontaneous generation (Bowler, 1984; Ruse, 1981, 1982). The most primitive species belong to the youngest lineages and in fact spontaneous generation is still occurring (Bowler, 1984; Ruse, 1981, 1982). However, I would argue that only the last point is partially correct.

Lamarck (1809: 247) devotes an entire chapter to the topic of spontaneous generation, which in summary is that:

[I]t appears to me certain that nature does herself carry out spontaneous or direct generations, that she has this power, and that she utilises it at the anterior extremity of each organic kingdom, where the most imperfect living bodies are found; and that it is exclusively through their medium that she has given existence to all the rest.

Note that in Lamarck's scheme there are only two organic kingdoms: the plants and animals. This is Lamarck's principal view regarding the origins and subsequent development or evolution of plant and animal life. However, Lamarck does pose the question that is apparently the cause of the (mis)interpretation of his main thesis representing multiple and independent evolutionary lineages through time:

[I]s it certain that she [nature] does not give rise to similar generations at any other point of these scales? (Lamarck 1809: 247)

When posing this question Lamarck (1809: 247) notes that he had hitherto held the view that:

[I]n order to give existence to all living bodies, it was enough for nature to have formed directly the simplest and most imperfect of animals and plants.

It is in this context that he (1809: 247) expands on his question:

\footnotetext{
1 Bowler (1984: fig. 10; 2003: fig. 9) does not provide an argument or evidence for this particular interpretation. Presumably his view is based on arguments by Ruse (e.g. 1982) who produces a very similar schematic (1982: fig. 1.4) to Bowler. As will be come apparent later in the chapter, Ruse (1982), has misinterpreted Lamarck on this issue.
} 
Why indeed should nature not give rise to direct generations at various points in the first half of the animal and plant scales, and even the origin of certain separate branches of these scales? Why should she not establish, in favourable circumstances, in these diverse rudimentary living bodies, certain physical systems of organisation, different from those observed at the points where the animal and vegetable scales appear to begin?

Having posed these questions they are then put aside as aspects worthy of further investigation, but not in any way central to his main thesis. He (1809: 248 , italics added) goes on to conclude this section thus:

Whether the kind of direct generations, here referred to, do or do not actually take place, as to which at present I have no settled opinion, it seems to me certain at all events that nature actually carries out such generations at the beginning of each kingdom of living bodies, and that she could never, except through this medium, have brought into existence the animals and plants which live on our earth.

Lamarck spent the majority of the first part of his book arguing that the dual agents of natural progress (vertical change) and environmental influence (lateral branching) acting on spontaneous generation events at the base of the plant and animal kingdoms are sufficient causes in and of themselves for producing the present variety and complexity of life. For Lamarck spontaneous generation is clearly important for the establishment of the animal and plant kingdoms, while the environment played a crucial role in subsequent branching events.

Not only has the direct formation of the simplest living bodies actually occurred [spontaneous generation], as I am about to show, but the following principles proves that such formations must still be constantly carried out and repeated where the conditions are favourable, in order that the existing state of things may continue. (Lamarck, 1809: 245)

The maintenance of the existing order Lamarck refers to is a reference to animals such as his infusorians (see Figure 8.1), which would become extinct, and thus disrupt the existing state of things, without continuous acts of spontaneous generation. In referring to the ephemeral and seasonal nature of these simplest of animals he goes on to state:

$[\mathrm{H}]$ ow fragile their existence, from what or in what way do they regenerate in the season when we again see them? Must we not think that these simple organisms, these rudiments of animality, so delicate and fragile, have been newly and directly fashioned by nature rather than have regenerated themselves? (Lamarck, 1809: 245) 
With the exception of the generation of the original plant and animal progenitors, these acts of continuous spontaneous generation were not seen by Lamarck as the starting points for new independent lineages. Except for fleetingly toying with the possibility of such a scenario, the idea of multiple separate and independent lineages was certainly not part of Lamarck's evolutionary model as substantively outlined in Zoological Philosophy.

Ruse (1981: 10) has argued that (and it is worth quoting him at length):

[O]ne must note that Lamarck's theory was in no way a theory of common descent, supposing that all organisms descended from one or a few common origins. We know that he thought simple forms of life are constantly being spontaneously generated through the action of heat, light, electricity and moisture on the inorganic world (Philosophie: 236248). Then organic development continues on essentially the same path it started on. Lamarck believed that lions and so on, if destroyed, would be replaced in the course of time (Philosophie: 187). There is therefore no reason to believe, for example, that today's mammals and today's fish have common ancestors- they are merely at different stages on the scale of being [see Figure 8.2].

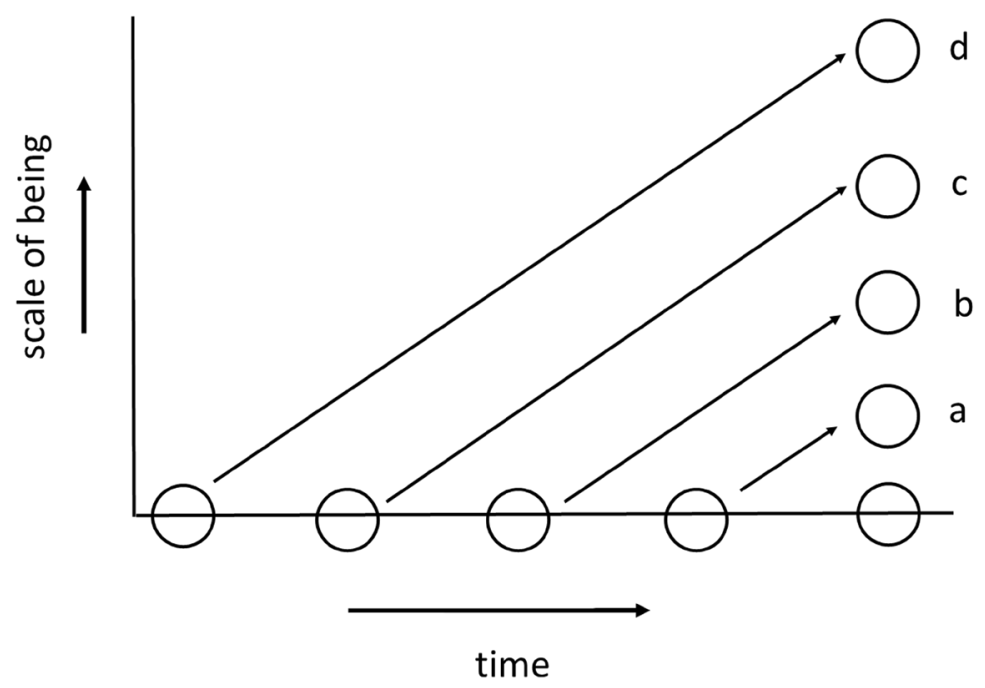

Figure 8.2: This is a modification of Ruse (1982: 8) following Bowler's (1984: Figure 10) interpretation of Lamarck's scheme. The circles along the $X$ axis represent the spontaneous generation events of the 'simplest' organisms, while the circles on the right hand side of the $\mathrm{Y}$ axis represent progressively more complex ( $d$ being the most complex) organisms that have unilinearly evolved from separate original spontaneous generation events. 
Whilst I have already addressed the majority of points raised in this statement, it is necessary to examine the reference to the lions and other animals, as this is clearly an important component of Ruse's argument for multiple, independent lineages. Lamarck has been taken out of context, and this is not a piece of evidence supporting the multiple independent lineage interpretation. In fact, this quote is taken from the introductory section of part two of Zoological Philosophy, dealing specifically with the physical causes, effects and manifestations of life, and not his evolutionary model per se.

After recognising the necessity for these acts of direct creation [spontaneous generation], we must enquire which are the living bodies that nature may produce spontaneously, and distinguish them from those which only derive their existence indirectly from her. Assuredly the lion, eagle, butterfly, oak, rose, do not derive their existence immediately from nature; they derive it as we know from individuals like themselves who transmit it to them by means of reproduction; and we may be sure that if the entire species of the lion or oak chanced to be destroyed in those parts of the earth where they are now distributed, it would be long before the combined powers of nature could restore them. (Lamarck, 1809: 186-187)

Lamarck is making two important points here, neither of which can be attributed to subscription to a model of multiple, independent lineages: (1) complex animals (e.g. lions and oaks) derive [descend] from other complex forms and are not the product of spontaneous generation; (2) enormous periods of time are involved in the complex process of evolution.

A final point before concluding concerns Bowler's $(1984,2003)$ view that the multiple, independent lineage model is the only one able to explain why, in Lamarck's world view, the scala natura is still visible. Lamarck provided two mechanisms to explain the continued existence of his scale. The first relates to his ideas on extinction: generally it does not happen. His understanding of the concept of species, examined previously, did not encompass the idea of extinction and this is why we still see life at all levels of organisational complexity. Secondly, and related to the first point, is the role of environmental influence again. In outlining his aims for the first part of Zoological Philosophy Lamarck (1809: 15, italics added) noted:

I shall [also] show the influence of environment and habit on the organs of animals, as being the factors which favour or arrest their development.

An example of this arrest in development can be seen in the way he dealt with an anti-evolutionary argument that used mummified Egyptian cats amongst other things. It was argued that as these cats, which were several thousand 
years old, were essentially identical to modern forms this proved that species did not change. Lamarck invoked the environmental argument to claim that the climate and environment in Egypt had not changed to any degree over the past several thousand years and thus one would not expect to see any change in Egyptian cats over this time. Progress, his vertical evolutionary component, would tend to cause all life to advance toward perfection. However, environmental influence, his lateral component, would serve to redirect and also arrest progressive advance. Lamarck's understanding of species and the role of the environment in his evolutionary model were sufficient in themselves to explain the apparent preservation of the arrangement of life as diagrammatically represented in Figure 8.1.

\section{Conclusions}

Ruse (1981) remarked that Lamarck was a very confusing writer and suggested this may have been because Lamarck was confused himself. True, Zoological Philosophy is written in a generally unclear and confusing style, but it is also apparent that he was struggling with a number of novel ideas and concepts. Even without an equivalent set of 'Darwin note books' it is clear that Zoological Philosophy has been through a number of drafts and alterations in theoretical orientation. Lamarck even noted in the preface to this work that this was a new, corrected and enlarged version of Recherches sur les corps vivants (Lamarck, 1802). Perhaps it is the clutter of these vestiges of changes in point of view that facilitated some of the misinterpretations of his work dealt with in this chapter.

Notwithstanding such concerns, Lamarck clearly and successfully grappled with the concepts of vertical and lateral evolutionary change. The view that he supported and promulgated a model of multiple, independent lineages all catalysed with their own independent spontaneous origin events is clearly not supported by a close reading of Lamarck's own words. Moreover, the development of the vertical and lateral dichotomy in Lamarck's model prefigured, at least, its appearance in Darwin's (1859) published model half a century later. What Lamarck gave us, whether anyone was listening or not, was a phylogentic model with two fundamental bifurcations, plant and animal, these in turn provided a multitude of environmentally induced branching events: a model of vertical and lateral evolutionary change.

Some 200 years after Lamarck published Zoological Philosophy, Colin Groves (Groves and Grubb, 2011; Gippoliti and Groves, 2012) was criticised for his own views on species (e.g. Zachos and Lovari, 2013). While I am sure Colin will be vindicated with time and, indeed, has made a stellar progress on this front (e.g. Gippoliti et al., 2013), I am not so sure about Lamarck. 
Taxonomic Tapestries

\section{References}

Appel TA. 1987. The Cuvier-Geoffroy debate: French biology in the decades before Darwin. New York: Oxford University Press.

Bowler PJ. 1984. Evolution: The history of an idea. Berkeley: University of California Press.

Bowler PJ. 1992. Lamarckism. In: Keller EV and Lloyd EA, editors. Keywords in evolutionary biology. Cambridge, MA: Harvard University Press. pp. 188-193.

Bowler PJ. 2003. Evolution: The history of an idea. Third edition. Berkeley: University of California Press.

Burkhardt RW Jr. 1977. The spirit of system: Lamarck and evolutionary biology. Cambridge: Cambridge University Press.

Burkhardt RW Jr. 1984. The zoological philosophy of J.B. Lamarck. In: Lamarck JB. Zoological philosophy: An exposition with regard to the natural history of animals. Translation of the 1809 edition by H Elliot. Chicago: The University of Chicago Press. p. xv-xxxix.

Cannon HG. 1959. Lamarck and modern genetics. Manchester: Manchester University Press.

Coleman W. 1964. Georges Cuvier, zoologist: A study in the history of evolution theory. Cambridge, MA: Harvard University Press.

Corsi P. 1988. The age of Lamarck: Evolutionary theories in France 1790-1830. Berkeley: University of California Press.

Cuvier G. 1831 [1984]. Biographical Memoir of M. De Lamarck. In: Lamarck JB. Zoological philosophy: An exposition with regard to the natural history of animals. Translation of the 1809 edition by H Elliot. Chicago: The University of Chicago Press. pp. 434-453.

Darwin C. 1859 [1985]. The origin of species by means of natural selection. Edited with an introduction by J.W. Burrow. Penguin Books.

Eldredge N. 1985. Unfinished synthesis: Biological hierarchies and modern evolutionary thought. New York: Oxford University Press.

Gillispie C. 1959. Lamarck and Darwin in the history of science. In: Glass B, Temkin O, and Straus W Jr., editors. Forerunners of Darwin: 1745-1859. Baltimore: Johns Hopkins University Press. pp. 265-291. 
Gippoliti S, Cotterill FPD, Groves CP. 2013. Mammal taxonomy without taxonomists: A reply to Zachos and Lovari. Hystrix 24(2):145-147.

Gippoliti S, Groves CP., 2012. "Taxonomic inflation" in the historical context of mammalogy and conservation. Hystrix 23(2):8-11.

Groves CP. 2001. Primate taxonomy. Washington, DC: Smithsonian Institution Press.

Groves CP, Grubb P. 2011. Ungulate taxonomy. Baltimore: Johns Hopkins University Press.

Hodgen MT. 1964. Early anthropology in the sixteenth and seventeenth centuries. Philadelphia: University of Pennsylvania Press.

Hull DL. 1984. Lamarck among the Anglos. In: Lamarck JB. Zoological philosophy: An exposition with regard to the natural history of animals. Translation of the 1809 edition by $\mathrm{H}$ Elliot. Chicago: The University of Chicago Press. p. xl-lxvi.

Lamarck JB. 1800. Introductory Lecture for 1800. In: Lamarck JB. Zoological philosophy: An exposition with regard to the natural history of animals. Translation of the 1809 edition by $\mathrm{H}$ Elliot. Chicago: The University of Chicago Press. pp. 407-433.

Lamarck JB. 1802. Recherches sur L'organisation Des Corps Vivants. Paris: Maillard.

Lamarck JB. 1809 [1984]. Zoological philosophy: An exposition with regard to the natural history of animals. Translated by $\mathrm{H}$ Elliot. Chicago: The University of Chicago Press.

Lovejoy AO. 1959. The argument for organic evolution before the origin of species, 1830-1858. In: Glass B, Temkin O, and Straus W Jr, editors. Forerunners of Darwin: 1745-1859. Baltimore: Johns Hopkins University Press. pp. 356-414.

Lovtrup S. 1987. Darwinism: The refutation of a myth. New York: Croom Helm in association with Methuen.

Mayr E. 1982. The growth of biological thought: Diversity, evolution, and inheritance. Cambridge, MA: Belknap Press.

Mayr E. 1991. One long argument: Charles Darwin and the genesis of modern evolutionary thought. Allen Lane: The Penguin Press.

Morris KV. 2012. Lamarck and the Missing Lnc. The Scientist 26(10):29-33. 
Taxonomic Tapestries

Paterson HEH. 1981. The continuing search for the unknown and unknowable: A critique of contemporary ideas on speciation. S Afr J Sci 77:113-119.

Ruse M. 1981. The Darwinian revolution: Science red in tooth and claw. Chicago: University of Chicago Press.

Ruse M. 1982. Darwinism defended: A guide to the evolution controversies. London: Addison-Wesley Publishing.

Tattersall I. 1986. Species recognition in human paleontology. J Hum Evol 15:165-175.

Zachos FE, Lovari S. 2013. Taxonomic inflation and the poverty of the Phylogenetic Species Concept - a reply to Gippoliti and Groves. Hystrix 24(2):142-144. 


\title{
9. Naming the scale of nature
}

\author{
Juliet Clutton-Brock
}

\section{Introduction}

As an archaeozoologist and mammalogist, I spent 30 years in the Osteology Room of the British Museum (Natural History), later named the Natural History Museum, and for a number of those years the visits of Colin and Phyll Groves enlivened the Mammal Section, not only with taxonomic discussions but also with memorable lunches in the nearby Bute Street cafés. It was the period during which the analysis of animal remains from archaeological sites was developing into a multidisciplinary science, and arguments and discussions on nomenclature prevailed in many international conferences. At the seminal conference on 'Equids in the Ancient World' held in Tübingen University in 1984 Colin's knowledge of equid taxonomy led the discussions (Groves, 1986).

In the context of archaeozoology and proposals for standardising the nomenclature of domestic animals that I have participated in with Colin, I give below a summary of the ways in which organisms in the animal kingdom have been named. This begins with the first written records in the prehistoric period, and progresses through the methods of Aristotle to the naturalists of the eighteenth century, Linnaeus, and modern taxonomy. The summary is followed with an outline of the suggestions and arguments for and against the formal naming of domestic animals that surrounded the development of archaeozoology in the twentieth century.

\section{The beginnings}

Since early hominins first began to use words to describe their surroundings they must have had names for the plants and animals around them, and these names would have been distinctive in the myriad languages that evolved around the world. However, it is only since the invention of written records that names could live on and be transcribed from ancient languages that have become extinct.

It is in the third millennium BC that the first written records of animal names begin to appear, and it is evident that elaborate systems of nomenclature already existed. To take an example from the 1984 Tübingen conference, the 
names for the different species and hybrids of equids, which were known to the Sumerians and Akkadians in ancient Mesopotamia, were decoded, as follows, from cuneiform texts by Nicholas Postgate (1986):

$$
\begin{array}{ll}
\text { anse } & =\text { generic term for equid, or E. asinus } \\
\text { anse-DUN.GI or anse-LIBIR } & =E \text {. asinus } \\
\text { anse-eden-na } & =E \text {. hemionus } \\
\text { anse-BARxAN } & =E \text {. asinus } x \text { E. hemionus } \\
\text { anse-zi-zi or anse-kur-ra } & =E \text {. caballus }
\end{array}
$$

By the time that Genesis is believed to have been first recorded in writing, probably during the first millennium BC there must have been fully developed nomenclatures for every living and non-living thing in a people's environment. So it is not surprising that the Hebrew legend of creation included an explanation for the origin of animal names: 'and out of the ground the Lord God formed every beast of the field, and every fowl of the air; and brought them unto Adam to see what he would call them: and whatsoever Adam called every living creature, that was the name thereof' (Genesis 2, 19).

Furthermore, after the Flood had retreated, the Hebrew God

[B]lessed Noah and his sons and said unto them, Be fruitful and multiply, and replenish the earth.

And the fear of you and the dread of you shall be upon every beast of the earth, and upon every fowl of the air, upon all that moveth upon the earth, and upon all the fishes of the sea, into your hand are they delivered.

Every moving thing that liveth shall be meat for you; even as the green herb have I given you all things (Genesis 9, 1-3).

This belief that everything in the world had been created by God for the benefit of humans seems not to have been inherited so rigidly by the ancient Egyptians but it certainly was by the ancient Greeks and its spread to Christianity was due in great part to the enormous influence of Aristotle's great works. This lasted in Western Europe until the time of Darwin, although doubts set in after the spread of new animals and plants (unknown to the classical world) from the Americas in the sixteenth century.

Aristotle was born in $384 \mathrm{BC}$ and he died, aged 63 in $322 \mathrm{BC} .{ }^{1}$ His approach to the natural world was teleological, that is, he believed that everything in Nature

\footnotetext{
1 The sections on Aristotle and Linnaeus, in this chapter, were previously given as part of a paper presented to a conference, In the Company of Animals, held at the New School for Social Research, New York, in April
} 
had a purpose, and this purpose was for the benefit of mankind (Clutton-Brock, 1999a). He wrote, 'plants are evidently for the sake of animals, and animals for the sake of Man; thus Nature, which does nothing in vain, has made all things for the sake of Man' (Peck, 1970: xli).

Aristotle's investigations into zoology are compiled into a series of books (authoritatively translated in the Loeb Library), known as the History of Animals (Peck, 1965, 1970; Balme, 1991) the Generation of Animals (Peck, 1990), and the Parts of Animals, the Movement of Animals, and the Progression of Animals (Peck and Forster, 1983). He wrote about more than 500 species including shellfish, insects, birds, reptiles, and quadrupeds, with humans being treated in the same way as all other animals. Aristotle's descriptions of animals were much quoted in the later classics, such as Pliny's Natural History (c. AD 77-79) and Aelian's (AD 175-235) On Animals, and it is from the classical writers on natural history that the long tradition of naming animals and plants in Latin was inherited.

Division of the animal kingdom is older than Aristotle; in Plato's philosophy the highest genus was divided by means of differentiae into subsidiary genera and each of these was then divided and subdivided by dichotomy, until the ultimate species was reached. At the upper end of Aristotle's scale he had main groups such as birds and fish, which were his genera, and at the lower end the commonly named animals such as dog, cat, eagle, etc., which were his species, but normally the intermediate stages are missing.

Aristotle did recognise a Scale of Nature but the rungs of his ladder were not the stages of a taxonomic scheme, and there is no evidence that he felt they should be. His purpose was not to construct a taxonomic system, but to collect data for ascertaining the Causes of observed phenomena; and this was to be done by looking to see whether certain characteristics were regularly found in combination: this was how the clues to the Causes would be brought to light. Aristotle believed that human beings were animals but at the same time he was certain that all other animals existed for the sake of Man. He asserted that it was impossible to produce a neat hierarchical order on the basis of obvious physical differences because these cut across each other.

Like the ancient civilisations of Mesopotamia and Egypt, that of classical Greece was a stratified society ruled by powerful hierarchies and in which all manual work was carried out by slaves. It is therefore only to be expected that the Greek philosophers would view the natural world as a gradation from the lowest to the highest, or as a scale of perfection, which was to become known as the Scale of Nature or the Great Chain of Being (Lovejoy, 1936).

1995. The proceedings were published in Clutton-Brock (1999a). 
Taxonomic Tapestries

\section{The Five Predicables}

In the European-speaking world, until well into the eighteenth century, the method of classification of all organisms was based on the Five Predicables. This was a hierarchical system that had been adapted from Aristotle's classification of logic, as written in his work known as the Topics. The Five Predicables were genus, species, differentia, property, and accident. They were clearly defined by Simpson (1961: 24).

\section{Linnaeus and binomial classification}

Carl Linnaeus (1707-1778) was clearly an obsessional organiser who classified not only the plant and animal kingdoms but also the minerals and the kinds of diseases known in his day. Since the time of Aristotle, animals and plants had been named in Latin by using the genus and the differentia from the Five Predicables of classification. The two together made up the definition, which could be used as the name. However, with the classification and naming of more and more species over time, the differentia often became very long. The great innovation of Linnaeus was in creating the binomial or binary system by taking the old name for the genus and adding a single name from the many that had been used in the differentia, as the species.

Linnaeus's definitive tenth edition of his Systema Naturae (1758) was written in Latin and the long introduction has been seldom translated, although it is full of fascinating comments on eighteenth century attitudes to animals, as well as the first use of the term Mammalia. The translation of Robert Kerr (1792) has the title The Animal Kingdom or Zoological System of the Celebrated Sir Charles Linnaeus. After the short introduction there is a chapter translated as, 'The Empire of Nature', which begins with quotations from Aristotle on the Causes, and from the Roman writers Seneca (4 BC-AD 65) and Pliny the Elder (AD 2379). Linnaeus followed Aristotle in believing that the three kingdoms of nature: minerals, vegetables, and animals met together in the Order of Zoophytes, and also in the belief from Genesis that everything in the world was created for Man, for he wrote: 'Hence one great employment of man, at the beginning of the world, must have been to examine created objects, and to impose on all the species names according to their kinds'.

Unlike his predecessors, Linnaeus saw that the unit of classification had to be the species, and he produced a strict hierarchical classification that ended at its summit with the Kingdom. Linnaeus summarised his ideas as follows (Kerr, 1792: 22-23): 
Classes and Orders are the creatures of human invention, while the division of these into Genera and Species is the work of Nature. All true knowledge refers finally to the species of things, while at the same time, what regards the generic divisions is substantial in its Nature.

... God, beginning from the most simple terrestrial elements, advances through Minerals, Vegetables, and Animals, and finishes with Man. Man on the contrary, reversing this order, begins with himself, and proceeds downwards to the materials of the earth. The framer of a systematic arrangement begins his study by the investigation of particulars, from which he ascends to more universal proportions; while the teacher of this method, taking a contrary course, first explains the general propositions, and then gradually descends to particulars.

\section{Vernacular names and early modern classifications}

While the naturalists wrestled with trying to produce meaningful classifications of the natural world, the general population of each country of course had their own vernacular names for every living thing, and these names could be enormously complicated. This was especially so when the animal was part of a ritual such as the royal hunts of Medieval Europe. In modern English a male red deer is a stag, but in the Laws of Venery the red deer was a beast of the chase and the stag had many names, depending on its age. In its first year it was a calf, in its second, a brocket, in its third a spayard, in its fourth a staggard, in its fifth a hart of ten, and in its sixth a hart (Clutton-Brock, 1984). When the meat of an animal was to be eaten it also had a separate name and it was from the Normans that the English names, venison, beef, and pork were adopted.

Throughout the Medieval and early modern periods animals and plants were named according to their uses to humans and this applied to domestic animals as much as to wild ones. Thomas (1983: 55) quotes the sixteenth century book Of English Dogges, by Dr John Caius in which there were three categories of dogs: a 'generous' kind, used in hunting or by fine ladies; a 'rustic' kind used for necessary tasks, and a 'degenerate', currish kind, used as turnspits and for other menial purposes. This way of classifying dogs by their uses to humans was echoed by Linnaeus who 200 years later divided the dog (Canis familiaris) into 11 separate species, which included the sheep dog (Canis domesticus) and the turnspit (Canis vertagus). 
Taxonomic Tapestries

\section{After Linnaeus: Modern taxonomy and nomenclature}

The fundamental unit of all classifications, including those of Aristotle and Linnaeus, is the species, which is composed of a population of interbreeding organisms. To Linnaeus, and to most biologists until the second half of the twentieth century, a species was considered to be a group of animals all of which were supposed to be identical with a type, officially recognised as such and preserved in a public institution. Following the growth of modern taxonomy, however, it was soon realised that a species comprises a population that is inherently variable in morphology and therefore the type specimen can have no special role in identifying other specimens. As explained in Simpson (1961: 31), 'A nomenclatural type is simply something to which a name is attached by purely legalistic convention'.

There is a commonly held view that the separation of two species can be determined by whether or not they will produce fertile offspring when interbred. However, on its own, the state of fertility of hybrid offspring is an inadequate means of defining a species. Many mammals that are normally considered to be good species will interbreed, although, because of a behavioural barrier, they may not usually do so in the wild, and their offspring will be fertile, for example the dog, wolf, jackal, coyote, and dingo will all interbreed and produce fertile offspring (Gray, 1972).

How then is the species to be defined? Since first proposed by Mayr (1940) an often-used definition has been the 'biological species concept'. This has gone through several revisions and expansions in the last 60 years, not least by Mayr himself, but remains essentially the same and is: a species is a group of interbreeding natural populations that is genetically isolated from other such groups as a result of physiological or behavioural barriers. However, Colin Groves argues (pers. comm., 27 July 2012) that:

The Biological Species Concept gives no guidance in the case of allopatric forms; it does not satisfactorily cover cases where two parapatric taxa, which are homogeneous within their ranges, nonetheless interbreed where their ranges meet; and DNA studies show that there has been far, far more interbreeding between perfectly 'good' species, even sympatric ones, than we would have guessed.

Groves prefers the Phylogenetic Species Concept of Cracraft (1983) who described his views thus:

As the 'biological species concept' really doesn't work, let us define species as being populations which are 'diagnosable', meaning that they 
differ $100 \%$ from each other; you can always recognise individuals as belonging to a particular species (except in the case of demonstrable hybrids); they have fixed heritable differences between them; they are (in cladistic terms) the terminals on a cladogram - however one wishes to put it. ${ }^{2}$

Until well into the twentieth century there were no fixed concepts of what constituted or distinguished species, subspecies, or breeds. Linnaeus believed there were several species of domestic dogs and even Darwin was not sure of the distinctions. The subspecies is the lowest unit that may be included in zoological taxonomy and subspecies are designated with a trinomial, e.g. Canis lupus arabs (in botany, variations can also be given a Latin name). The status of the subspecies has been discussed at length by Simpson (1945: 16; 1961: 171). The modern definition that I consider most useful states: a subspecies is a distinctive, geographical segment of a species, that is it comprises a group of wild animals that is geographically and morphologically separate from other such groups within a single species.

Today, it is generally agreed that the end product of animal domestication is the breed and not the species or subspecies, and breeds are not given Latin names. My definition of a breed is: a group of animals that has been bred by humans to possess uniform characters that are heritable and distinguish the group from other animals within the same species. A breed parallels a subspecies, except that, whereas a subspecies is restricted to a geographical region a breed is not (Clutton-Brock, 1999b: 40).

But how should domestic forms be named? Up to the time of Linnaeus and beyond, there were no problems - domestic breeds were seen as species or subspecies in their own right, and the nineteenth and early twentieth century archaeozoologists were happy to allocate the bones they found associated with human settlements to taxa with Linnaean binomials and trinomials. Sheep remains were called Ovis aries studeri or Ovis longipes egyptius, while dog remains were Canis poutiatini or Canis familiaris matris-optimae.

The central difficulty for the naming of domestic species hangs on whether or not they should be considered as conspecific with their wild progenitors. To Linnaeus it was obvious that the dog was a separate species from the wolf, but to archaeozoologists who work on the identification of sub-fossil animal remains at the interface between the wild species and their earliest domesticated descendents there may be little or no evidence of an osteological and therefore a taxonomic distinction. In order to try to overcome this problem and with a widespread view that domesticates should be treated as conspecific with their

2 Their position as terminals on a cladogram is the origin of the 'phylogenetic' part of the name (Groves, pers. comm., 4 March 2013). 
assumed progenitors, several different systems of nomenclature have been devised for domestic mammals, as reviewed by Gautier (1993). Although none has received international recognition, the most widely accepted system was that proposed by Bohlken (1961). Bohlken's solution was to call the domestic form by the first available name for the wild species, followed by the linking word 'forma' (f.) and then by the earliest name, according to the rule of priority, for the domestic animal. In this way we would have Canis lupus $\mathrm{f}$. familiaris $\mathrm{L}$. for the dog and Capra aegagrus f. hircus L. for the domestic goat. This arrangement is, however, clumsy and it has the disadvantage that it assumes certain identification of the wild progenitor, which for some domestic animals, for example the ferret, may never be established.

At one time, I also proposed that domestic species should be excluded from formal nomenclature but I have come to believe that domestication is an evolutionary process and if the domestic form of an animal is for all intents and purposes separated reproductively from the wild form then it should be classified as a separate species. It is then valid to use the Linnaean names, which have the great benefit of being widely known and in general usage.

If the Linnaean names are used for domestic mammals there has been a problem with certain wild species that were given the same names as the domestic by Linnaeus. When he was familiar with both the wild and the domestic form of a species and they looked alike, as with his native reindeer, Linnaeus gave them the same name, Cervus tarandus, now called Rangifer tarandus. On the other hand because he failed to see the relationship between the wolf and the dog he gave them the separate species names, Canis lupus and Canis familiaris. With yet others, for example the goats and sheep, he had no knowledge of the wild ancestor and so he named only the domestic form (see Clutton-Brock, 2012, Appendix, for the list of relevant species). In order to get over the difficulty of using say the Linnaean name Equus asinus for the African wild ass as well as for the donkey it has become usual to use the next available name according to the International Code of Zoological Nomenclature (ICZN) for the wild species, which is Equus africanus.

As a convention among zoologists and archaeozoologists this system of nomenclature worked well but it was not in accord with the rules of the ICZN and in the chapters on the Perissodactyla and Artiodactyla in the 1993 edition of the influential Mammal Species of the World edited by Wilson and Reeder, names were used for wild species irrespective of whether they were first described on a wild or a domestic form. Thus the Linnaean names Equus asinus and Equus caballus were used for both the wild and domestic forms of ass and horse respectively. It was clearly time to stabilise the nomenclature of the 15 wild species that Linnaeus had named on domestic forms. Accordingly, Anthea Gentry, Colin and I put a Case to the ICZN to conserve the usage of specific 
names for wild animals that are antedated by or are contemporary with names based on domestic animals (Gentry et al., 1996). Case 3010 was presented and for six years Comments for and against the Proposal went to the ICZN. Finally, the Commission voted on the Case - the names were to be conserved and the ruling was published (ICZN, 2003).

The controversy surrounding the ruling on these names may seem arcane to non-taxonomists, but in fact it is of considerable importance. For example the extinct aurochs would, strictly, have to be named Bos taurus primigenius, as indeed it still is in the latest edition of Wilson and Reeder (2005: 692-693), thus making it a subspecies of the domestic ox. It must be emphasised, however, that this ruling on the conservation of these names is for wild species and it does not affect the taxonomic status and nomenclature of domestic forms.

So what should be done to settle the continuing discussion about naming the domestic forms? After 40 years of consideration and several changes of view I now believe that if the domestic form of an animal is for all intents and purposes separated reproductively from the wild form then it should be classified as a separate species. It is for this reason that I, together with other mammalogists, including Colin, have argued that domestic animals should not be excluded from formal zoological nomenclature and that the traditional Latin binomial names such as Capra hircus and Ovis aries should hold (Clutton-Brock, 1999b, 2012; Gentry et al., 2004).

Nomenclature is the backbone of taxonomy, but I think it is important to remember its subjective element, and to support my view on this I will discuss the different formal names that have been given to the dingo over the past 50 years. Until the 1970s the dingo was generally known as the wild dog of Australia and it was not paid taxonomic attention, but then its depredations on livestock turned the sheep farmers against it and biologists and pest controllers were called in to study its behaviour. In 1973 Alan Newsome and colleagues published an account of the dingo in the Australian Meat Research Committee Review in which they named it Canis familiaris dingo. The aim of the work was, 'to provide the basic biological data to devise rational and effective control programs'. And by naming the dingo as a subspecies of domestic dog (C. familiaris) the biologists were justifying its control.

This justification was increased by the work of Laurie Corbett who with his morphological study of dingoes and Thai dogs claimed that 'dingo-like canids' were widespread throughout Southeast Asia (Corbett, 1985). The dingoes of Australia thereby lost their unique status and they could be classified as pests. Then in the 1990s, and after the notoriety of the Azaria Chamberlain Case (1980), the dingo began to be named Canis lupus dingo, and this trinomial remains today in numerous online publications and on the latest IUCN Red List of Vulnerable 
Species. As a subspecies of wolf and a wild carnivore, it may be controlled when considered necessary but also conserved. However, genetic studies have now shown that the dingo was introduced to Australia possibly from South China and possibly at a single occasion, before the Neolithic expansion from Taiwan (Savolainen et al., 2004; Oskarsson et al., 2012). Since humans brought these first dogs to Australia, they have lived, bred and undergone natural selection in the wild, isolated from other canids until the arrival of Europeans. The case is clear to me that this unique dog should be recognised as part of the living heritage of Australia and it should revert to its first Latin name of Canis dingo Meyer, 1793, as argued by Crowther and others (2014). And finally I am pleased to learn online that the Merigal Dingo Sanctuary in Bargo (New South Wales), which I visited with Colin in 1987, is still active and promoting the conservation of dingoes.

\section{References}

Balme DM. [Transl.] 1991. Aristotle Historia Animalium. Books VII-X. Loeb Classical Library. Cambridge, MA and London: Harvard University Press.

Bohlken H. 1961. Haustiere und zoologische Systematik. Zeitschrift für Tierzüchtung und Züchtungsbiologie 76:107-113.

Clutton-Brock J. 1984. The master of game: The animals and rituals of Medieval venery. Biologist 31(3):167-171.

Clutton-Brock J. 1999a. Aristotle, the scale of nature, and modern attitudes to animals. In: Mack A, editor. Humans and other animals. Columbus: Ohio State University Press. pp. 5-24.

Clutton-Brock J. 1999b. A natural history of domesticated mammals. 2nd edition. Cambridge: Cambridge University Press \& The Natural History Museum.

Clutton-Brock J. 2012. Animals as domesticates a world view through history. Michigan: Michigan State University Press.

Corbett LK. 1985. Morphological comparisons of Australian and Thai dingoes: A reappraisal of dingo status, distribution and ancestry. Proc Ecol Soc Australia 13:277-291.

Cracraft J. 1983. Species concepts and speciation analysis. Current Ornithology $1: 159-187$.

Crowther MS, Fillios M, Colman N, Letnic M. 2014. An updated description of the Australian dingo (Canis dingo Meyer, 1793). J Zool 293(3):192-203. 
Gautier A. 1993. 'What's in a name?' A short history of the Latin and other labels proposed for domestic animals. In: Clason A, Payne S, Uerpmann H-P, editors. Skeletons in her cupboard Festschrift for Juliet Clutton-Brock. Oxbow Monograph 34, Oxford: Oxbow Books.

Gentry A, Clutton-Brock J, Groves CP. 1996. Case 3010. Proposed conservation of usage of 15 mammal specific names based on wild species which are antedated by or contemporary with those based on domestic animals. Bull Zool Nomencl 53(1):28-37.

Gentry A, Clutton-Brock J, Groves CP. 2004. The naming of wild animal species and their domestic derivatives. J Archaeol Sci 31:645-651.

Gray AP. 1972. Mammalian hybrids. Commonwealth Agricultural Bureau.

Groves CP. 1986. The taxonomy, distribution, and adaptations of Recent equids. In: Meadow RH, Uerpmann H-P, editors. Equids in the Ancient World I. Wiesbaden: Beihefte zum Tübinger Atlas des Vorderen Orients. pp. 11-65.

International Commission on Zoological Nomenclature (ICZN). 2003. Opinion 2027 (Case 3010). Usage of 17 specific names based on wild species which are predated by or contemporary with those based on domestic animals: conserved. Bull Zool Nomencl 60(1):81-84.

Kerr R. 1792. The animal kingdom or zoological system of the celebrated Sir Charles Linnaeus; Class I Mammalia. London: J. Murray.

Linnaei C. 1758 [1956]. Systema Naturae. A photographic facsimile of the first volume of the tenth edition (1758) Regnum Animale. London: British Museum (Natural History).

Lovejoy AO. 1936. The great chain of being. Cambridge, MA: Harvard University Press.

Mack A, editor. 1999. Humans and other animals. Columbus: Ohio State University Press.

Mayr E. 1940. Speciation Phenomena in Birds. The American Naturalist 74:249278.

Newsome AE, Corbett LK, Best LW, Green B. 1973. Australian Meat Research Committee Review, No. 14.

Oskarsson MCR, Klütsch CFC, Boonyaprakob U, Wilton A, Tanabe Y, Savolainen P. 2012. Mitochondrial DNA data indicate an introduction through mainland Southeast Asia for Australian dingoes and Polynesian domestic dogs. Proc Royal Soc Lond B 279(1730): 967-974. 
Peck AL. [Transl.] 1965. Aristotle Historia Animalium. Books I-III. Loeb Classical Library. Cambridge, Mass.: Harvard University Press \& London: Heinemann.

Peck AL. [Transl.] 1970. Aristotle Historia Animalium. Books IV-VI. Loeb Classical Library. Cambridge, MA and London: Harvard University Press.

Peck AL. [Transl.] 1990. Aristotle Generation of animals. Loeb Classical Library. Cambridge, MA and London: Harvard University Press.

Peck AL, Forster ES. [Transl.] 1983. Aristotle Parts of animals, movement of animals, progression of animals. Loeb Classical Library. Cambridge, MA: Harvard University Press \& London: Heinemann.

Postgate, JN. 1986. The equids of Sumer, again. In: Meadow RH, Uerpmann H-P, editors. Equids in the Ancient World I. Wiesbaden: Beihefte zum Tübinger Atlas des Vorderen Orients. pp. 194-206.

Savolainen P, Leitner T, Wilton AN, Matisoo-Smith E, Lundeberg J. 2004. A detailed picture of the origin of the Australian dingo, obtained from the study of mitochondrial DNA. Nat Proc Acad Sci 101:12837-12890.

Simpson GG. 1945. The principles of classification and a classification of mammals. Bull Am Mus Nat Hist 85: vii-xvi, 1-350.

Simpson GG. 1961. Principles of animal taxonomy. New York and London: Columbia University Press.

Thomas K. 1983. Man and the natural world: Changing attitudes in England 1500-1800. London: Allen Lane.

Wilson DE, Reeder DAM, editors. 2005. Mammal species of the world: A taxonomic and geographic reference. 2 vols. 3rd edition. Baltimore. 


\title{
10. Changes in human tooth-size and shape with the Neolithic transition in Indo-Malaysia
}

\author{
David Bulbeck
}

\section{Introduction}

During my Master of Arts studies on Holocene human remains from Indonesia and Malaysia, I was the beneficiary of excellent supervision from Colin Groves and the late Alan Thorne. At the time, the general view was that the 'Mongoloid' features of most Southeast Asians reflect the late Holocene immigration of their ancestors from Northeast Asia into a region previously inhabited by largetoothed 'Australoids' (e.g. Jacob, 1967a; Howells, 1973; Bellwood, 1978). At the same time, Christy Turner was developing an alternative perspective of long-term continuity in Southeast Asia of a 'Sundadont' dental morphology complex, distinguished from the 'Sinodont' complex of Northeast Asia and the New World by features such as less marked incisor shovelling (e.g. Turner, 1983). Also, some biological anthropologists were developing a model that explained post-Neolithic craniodental changes in terms of biological adaptation to changed selection pressures (e.g. Carlson and van Gerven, 1977). The driving force, according to this model, was the reduced demand on the masticatory apparatus associated with the Neolithic transition, as people now grew crops low in fibrous content, and often cooked their food in pots to soften it further. Hence, my MA thesis proposed that Southeast Asia's late Holocene transition to smaller teeth and jaws, and broader and less robust crania, reflected local adaptation to the reduced need for large tooth mass (Bulbeck, 1981, 1982).

Colin Groves was very supportive of this 'Neolithic tooth-size reduction' model, and indeed highlighted it in his contribution at a major symposium (Groves, 1989). On the other hand, as I belatedly discovered, Loring Brace (1976) had already rejected the model's applicability for Southeast Asia. Brace accepted it for China, but argued that the retention of larger teeth in Southeast Asia pointed to a later onset of the Neolithic there, attributable, moreover, to immigration from South China (see also Brace and Hinton, 1981). Subsequently, Hirofumi Matsumura produced a series of studies that emphasised morphological similarities between Southwest Pacific and early Southeast Asian cranial remains. A critical aspect was Matsumura's removal of sheer tooth-size from 
the comparisons, allowing him to argue that the relative sizes of the different tooth diameters ('tooth shape') also pointed to Neolithic immigration from China into Southeast Asia (e.g. Matsumura and Hudson, 2004). These views accorded with a growing consensus amongst historical linguists that the Austroasiatic and Austronesian languages, which dominate Southeast Asia ethnographically, trace their origins to the north.

Other biological anthropologists have presented analyses that support longterm population continuity in Southeast Asia (e.g. Hanihara, 1994; Storm, 1995; Manser, 2005; Demeter, 2006; Pietrusewsky, 2006). However, only Manser's study found the Neolithic tooth-size reduction model useful. Indeed, Storm instead preferred an alternative explanation of body-size reduction related to post-Pleistocene warming.

The task of this contribution is to rigorously test whether biological adaptations to agriculture, and the use of pottery for cooking, could explain late Holocene craniodental change in Indo-Malaysia - the part of Southeast Asia where my specialisation lies. There are now enough well-dated burial series from Sulawesi, Borneo, Java and Malaya to test two main predictions of the Neolithic tooth-size reduction model:

1. Indo-Malaysian tooth-size should show continual reduction over time, not only between the pre-Neolithic and the Neolithic, but also continuing into the Early Metal Phase (EMP) and modern times.

2. Pre-Neolithic and late Holocene Indo-Malaysians should have similar tooth shape.

Depending on the obtained results, the discussion will also briefly examine the efficacy of tooth-size reduction as a driver for late Holocene change in IndoMalaysian cranial shape, and review recent insights from human genetic and osteological comparisons.

\section{Materials and methods}

The dental metrical analyses presented here include male and bisexual samples. The male analyses cater for the critical Late Pleistocene Java sample, which is exclusively male. The bisexual analyses enable the inclusion of archaeological teeth that are difficult to sex - for instance, loose teeth, and teeth from subadults - and also cater for series where both males and females, on their own, are sparsely documented. In these analyses, tooth-size comparisons (but less so shape comparisons - Bulbeck, 1981; Bulbeck et al., 2005) are prone to distortion due to the samples' variable sex composition, given that male teeth 
are on average larger than female teeth. However, many of the prehistoric IndoMalaysian samples are dominated by specimens that cannot be sexed, and so they can be analysed only as bisexual samples.

The present coverage of recent Indo-Malaysian populations focuses on Indonesia and the Orang Asli ('aboriginal people') of Malaya, including the Semang 'Negritos'. Several Southwest Pacific and Northeast Asian samples are also included so as to provide a regional context (Table 10.1). Most of the samples included here are based on dental casts from living subjects or anatomical collections of skulls from persons of known sex. Two exceptions are the ethnohistorical Motu cemetery on Motupore Island, Papua New Guinea (PNG), and the Euston cemetery on the Murray Valley, with an estimated age between 2,000 and 6,000 years ago (Pardoe, 1988). Postcranial material was available to assist sexing the Motupore skulls (Brown, 1978) but sexing of the Euston skulls relied on cranial size and robustness (Brown, 1981). A third exception is the 'historical Sulawesi' sample, which mainly comprises geographically dispersed archaeological finds (Table 10.2). Many of these remains cannot be reliably sexed and so the sample is best treated as bisexual.

Table 10.1: Recent/historical samples used in the comparisons.

\begin{tabular}{|c|c|c|c|}
\hline Sample & Male sample size & Bisexual composition & Source \\
\hline Shanghai Chinese & $14-104$ & $\delta$ and $q$ about equal & $\begin{array}{l}\text { Brace et al. } \\
1984\end{array}$ \\
\hline Historical Sulawesi & Not applicable & More $\delta$ than $q$ (probably) & $\begin{array}{l}\text { See Table } \\
10.2\end{array}$ \\
\hline Jahai Semang, Malaya & $13-19$ & \multirow[t]{2}{*}{$\begin{array}{l}\text { Pooled into Semang sample, } \\
\text { more } \delta \text { than }+\end{array}$} & $\begin{array}{l}\text { Bulbeck et } \\
\text { al. } 2005\end{array}$ \\
\hline Batek Semang, Malaya & $8-12$ & & $\begin{array}{l}\text { Bulbeck et } \\
\text { al. } 2005\end{array}$ \\
\hline Temiar Senoi, Malaya & $6-30$ & $\delta$ and $q$ about equal & $\begin{array}{l}\text { Bulbeck et } \\
\text { al. } 2005\end{array}$ \\
\hline Temuan, Malaya & $9-16$ & \multirow[t]{2}{*}{$\begin{array}{l}\text { Pooled into Aboriginal Malay } \\
\text { sample, } \delta \text { and } q \text { about equal }\end{array}$} & $\begin{array}{l}\text { Bulbeck et } \\
\text { al. } 2005\end{array}$ \\
\hline Semelai, Malaya & $14-22$ & & $\begin{array}{l}\text { Bulbeck et } \\
\text { al. } 2005\end{array}$ \\
\hline Batawi, Java & $96-139$ & More $\delta$ than $q$ & Snell 1938 \\
\hline Surabaya Javanese & $35-63$ & Not available & Snell 1938 \\
\hline Motupore Island, PNG & $9-11$ & $\hat{\sigma}$ and $q$ about equal & Brown 1978 \\
\hline Eastern Highlands, PNG & $32-53$ & Not available & $\begin{array}{l}\text { Doran and } \\
\text { Freedman } \\
1974\end{array}$ \\
\hline Walbiri, Central Australia & $29-136$ & Not used & $\begin{array}{l}\text { Barrett et al. } \\
1963,1964\end{array}$ \\
\hline Euston, Murray Valley & $14-27$ & $\widehat{\partial}$ and $q$ about equal & Brown 1978 \\
\hline
\end{tabular}

Source: All sources listed in the table and cited fully in the references. 
Taxonomic Tapestries

Table 10.2: Historical Sulawesi dental metrics. ${ }^{(A)}$

\begin{tabular}{|c|c|c|c|c|c|c|}
\hline \multirow[t]{2}{*}{ Tooth } & \multicolumn{3}{|c|}{ Mesiodistal (MD) diameters } & \multicolumn{3}{|c|}{ Buccolingual (BL) diameters } \\
\hline & $\begin{array}{l}\text { Sample } \\
\text { size }\end{array}$ & Mean & $\begin{array}{l}\text { Standard } \\
\text { deviation }\end{array}$ & $\begin{array}{l}\text { Sample } \\
\text { size }\end{array}$ & Mean & $\begin{array}{l}\text { Standard } \\
\text { deviation }\end{array}$ \\
\hline Upper medial incisor $\left(I^{1}\right)$ & 11 & 8.3 & 0.90 & 14 & 7.2 & 0.45 \\
\hline Upper lateral incisor $\left(I^{2}\right)$ & 10 & 7.3 & 0.66 & 13 & 6.7 & 0.34 \\
\hline Upper canine (ㅁ) & 20 & 7.9 & 0.54 & 21 & 8.2 & 0.66 \\
\hline Upper first premolar $\left(\mathrm{P}^{3}\right)$ & 28 & 7.5 & 0.68 & 27 & 9.5 & 0.90 \\
\hline Upper second premolar $\left(\mathrm{P}^{4}\right)$ & 21 & 7.2 & 0.45 & 21 & 9.5 & 0.60 \\
\hline Upper first molar $\left(\mathrm{M}^{1}\right)$ & 23 & 10.7 & 0.72 & 23 & 11.7 & 0.59 \\
\hline Upper second molar $\left(\mathrm{M}^{2}\right)$ & 25 & 9.8 & 0.69 & 24 & 11.8 & 0.80 \\
\hline Upper third molar $\left(\mathrm{M}^{3}\right)$ & 19 & 9.4 & 0.64 & 19 & 11.9 & 0.75 \\
\hline Lower medial incisor $\left(I_{1}\right)$ & 11 & 5.8 & 0.57 & 12 & 6.3 & 0.49 \\
\hline Lower lateral incisor $\left(\mathrm{I}_{2}\right)$ & 16 & 6.0 & 0.49 & 20 & 6.2 & 0.42 \\
\hline Lower canine $(\mathrm{C})$ & 14 & 7.3 & 0.47 & 16 & 8.0 & 0.40 \\
\hline Lower first premolar $\left(\mathrm{P}_{3}\right)$ & 20 & 7.1 & 0.46 & 20 & 8.1 & 0.55 \\
\hline Lower second premolar $\left(\mathrm{P}_{4}\right)$ & 24 & 7.4 & 0.64 & 24 & 8.3 & 0.61 \\
\hline Lower first molar $\left(\mathrm{M}_{1}\right)$ & 31 & 11.5 & 0.57 & 33 & 10.8 & 0.48 \\
\hline Lower second molar $\left(\mathrm{M}_{2}\right)$ & 34 & 11.3 & 0.71 & 35 & 10.4 & 0.54 \\
\hline Lower third molar $\left(\mathrm{M}_{3}\right)$ & 25 & 11.3 & 0.94 & 25 & 10.7 & 0.75 \\
\hline
\end{tabular}

Note: A. The sample includes teeth dated to the second millennium CE from the Talaud Islands in North Sulawesi (Bulbeck, 1981), teeth from ethnohistorical burials near Lake Towuti in central Sulawesi (laboratory notes), colonial period Bugis skulls (museum notes), seventeenth to twentieth-century Makassar teeth from Batu Ejaya in southwest Sulawesi (Bulbeck, 2004), and teeth from seventeenth to nineteenth century 'Macassan' skulls in the Northern Territory (museum notes).

Source: All sources listed in the notes section.

Numerous prehistoric samples from Indo-Malaysia are also available, dating between the Late Pleistocene and the EMP (Table 10.3). Where the sex composition of the bisexual samples could be assessed, they may have more males than females (the Gua Cha samples), approximately equal numbers of males and females (Mesolithic Java, Gilimanuk) or more females than males (the Niah samples). Some of the samples are composite, especially the 'Early Sulawesi' sample (Table 10.4). Early Sulawesi, along with Melanta Tutup in Sabah, and Neolithic and EMP Java, lack observations (as placed in the public domain) on some of their tooth diameters. Included for comparison are Khok Phanom Di, Thailand, with burial goods similar to those from Neolithic Malaya (Bellwood, 1993), and the terminal Pleistocene cemetery from Coobool Creek, in Australia's Murray Valley, for which only buccolingual diameters are available (Brown, 1989). 
10. Changes in human tooth-size and shape with the Neolithic transition in Indo-Malaysia

Table 10.3: Prehistoric samples used in the comparisons.

\begin{tabular}{|c|c|c|c|c|c|}
\hline Site(s) & Location & Age & Comparisons & Data source & Dating source \\
\hline $\begin{array}{l}\text { Khok } \\
\text { Phanom Di }\end{array}$ & $\begin{array}{l}\text { Southern } \\
\text { Thailand }\end{array}$ & $\begin{array}{l}\text { Neolithic, } \\
4-3.5 \mathrm{ka}\end{array}$ & $\begin{array}{l}\text { Bisexual ( } \hat{\imath}, q \\
+ \text { children) }\end{array}$ & Tayles 1999 & Tayles 1999 \\
\hline See Table 10.4 & $\begin{array}{l}\text { Early } \\
\text { Sulawesi }\end{array}$ & mid-Holocene & Bisexual & See Table 10.4 & See Table 10.4 \\
\hline Leang Buidane & $\begin{array}{l}\text { Talauds, } \\
\text { North } \\
\text { Sulawesi }\end{array}$ & $\begin{array}{l}\text { EMP, 700- } \\
1200 \mathrm{CE}\end{array}$ & Bisexual & Bulbeck 1981 & Bellwood 1976 \\
\hline Leang Codong & $\begin{array}{l}\text { Southwest } \\
\text { Sulawesi }\end{array}$ & EMP, 2-1 ka & Bisexual & Jacob 1967a & Bulbeck 1996-97 \\
\hline Pre-Neolithic Niah & Sarawak & $20-8 \mathrm{ka}$ & Bisexual & Manser 2005 & Manser 2005 \\
\hline Neolithic Niah & Sarawak & $\begin{array}{l}\text { Neolithic, } \\
3.5-2 \text { ka }\end{array}$ & $\begin{array}{l}\text { Males, } \\
\text { bisexual }\end{array}$ & Manser 2005 & Manser 2005 \\
\hline Melanta Tutup & Sabah & $\begin{array}{l}\text { Neolithic/EMP, } \\
\text { 3.5-1 ka }\end{array}$ & Bisexual & Chia et al. 2005 & Chia 2008 \\
\hline $\begin{array}{l}\text { Gua Cha } \\
\text { Hoabinhian }\end{array}$ & Malaya & $\begin{array}{l}\text { mid-Holocene, } \\
7-3 \mathrm{ka}\end{array}$ & \begin{tabular}{|l} 
Males, \\
bisexual
\end{tabular} & Bulbeck 2005a & Bulbeck 2005a \\
\hline Gua Cha Neolithic & Malaya & $\begin{array}{l}\text { Late Neolithic, } \\
3-2 \mathrm{ka}\end{array}$ & \begin{tabular}{|l} 
Males, \\
bisexual
\end{tabular} & Bulbeck 2005a & Bulbeck 2005a \\
\hline Guar Kepah & Malaya & \begin{tabular}{|l|} 
Transitional \\
Neolithic $\sim 6 \mathrm{ka}$
\end{tabular} & Bisexual & Jacob 1967a & Tieng $2010^{(\mathrm{A})}$ \\
\hline Gua Harimau & Malaya & $\begin{array}{l}\text { Neolithic/EMP, } \\
\text { 3-2 ka }\end{array}$ & Bisexual & Bulbeck 2001 & Bulbeck 2001 \\
\hline $\begin{array}{l}\text { Wajak, Gua Lawa } \\
1\end{array}$ & Java & $\begin{array}{l}\text { Pleistocene, } \\
\sim 30-20 \mathrm{ka}\end{array}$ & Males & $\begin{array}{l}\text { Storm 1995; } \\
\text { Détroit } 2002\end{array}$ & $\begin{array}{l}\text { Storm et al. in } \\
\text { press; Détroit } \\
2002\end{array}$ \\
\hline Mesolithic Java(B) & Java & $\begin{array}{l}\text { Pleistocene to } \\
\text { mid-Holocene, } \\
13-4 \text { ka }\end{array}$ & $\begin{array}{l}\text { Males, } \\
\text { bisexual }\end{array}$ & $\begin{array}{l}\text { Jacob 1967a; } \\
\text { Détroit 2002; } \\
\text { Noerwidi } \\
2011-12\end{array}$ & $\begin{array}{l}\text { Jacob 1967a; } \\
\text { Détroit } 2002\end{array}$ \\
\hline Neolithic Java ${ }^{(\mathrm{C})}$ & Java & $\begin{array}{l}\text { Neolithic, } \\
3.5-2.5 \mathrm{ka}\end{array}$ & Bisexual & $\begin{array}{l}\text { Storm 1995; } \\
\text { Détroit 2002; } \\
\text { Noerwidi } \\
2011-12\end{array}$ & $\begin{array}{l}\text { Storm 1995; } \\
\text { Détroit 2002; } \\
\text { Noerwidi 2011- } \\
12\end{array}$ \\
\hline EMP Java & Java & $\sim 2-1 \mathrm{ka}$ & Bisexual & $\begin{array}{l}\text { Snell 1938; } \\
\text { Jacob 1964; } \\
\text { Noerwidi } \\
\text { 2011-12 }\end{array}$ & $\begin{array}{l}\text { Jacob 1967a; } \\
\text { Noerwidi } \\
2011-12\end{array}$ \\
\hline Gilimanuk & Bali & EMP, 2-1 ka & Bisexual & Jacob 1967b & Anggraeni 1999 \\
\hline Coobool Creek & $\begin{array}{l}\text { Murray } \\
\text { Valley, } \\
\text { Australia }\end{array}$ & $\begin{array}{l}\text { Pleistocene, } \\
\sim 15 \text { ka }\end{array}$ & $\begin{array}{l}\text { Only males } \\
\text { used }\end{array}$ & Brown 1989 & Brown 1989 \\
\hline
\end{tabular}

Notes: A. Tieng reports a radiocarbon date on marine shell of $5700 \pm 50 \mathrm{BP}$ for the Guar Kepah shell middens. The calibrated date (Intcal 09), allowing a delta R correction of $15 \pm 38$ (Singapore), would be 5967-6269 BP ( 2 sigma). The age of the shell middens serves as a maximum age for the burials. Pot sherds from all levels in the middens, and betelnut staining of the burials' teeth (Bulbeck, 2005b), indicate the burials are Neolithic.

B. Sampung; Pawon; Song Keplek 1 and 4; Song Terus 1; Gua Braholo 1, 4, 5,7 and /H8.

C. Hoekgroet ${ }^{\prime}$; Gua Jimbe; Gua Kecil; Song Keplek 5 q ; Gua Braholo loose teeth; Song Tritis.

D. Puger $\delta^{\Uparrow}$; Anjar Lor $\$$; Batujaya and Plawangan for lower premolars, $M_{1}$ and $M_{2}$.

Source: Includes data from all sources listed in the table and cited fully in reference list. 
Taxonomic Tapestries

Table 10.4: Early Sulawesi dental metrical data.

\begin{tabular}{|c|c|c|c|c|c|}
\hline Diameter & $\begin{array}{l}\text { Leang } \\
\text { Buidane } \\
\text { Pre-ceramic, } \\
\text { Talaud } \\
\text { Islands(A) }^{(A)}\end{array}$ & $\begin{array}{l}\text { Gua Mo'o } \\
\text { Hono, Lake } \\
\text { Towuti(B) }\end{array}$ & $\begin{array}{l}\text { Leang Burung } \\
1 \text { Trench } B \text {, } \\
\text { southwest } \\
\text { Sulawesi }^{(C)}\end{array}$ & $\begin{array}{l}\text { Bola Batu, } \\
\text { southwest } \\
\text { Sulawesi } i^{\left({ }^{2}\right)}\end{array}$ & $\begin{array}{l}\text { Overall } \\
\text { average }\end{array}$ \\
\hline$I^{1} \mathrm{MD}$ & & & 8.4 & & 8.4 \\
\hline $\mathrm{I}^{1} \mathrm{BL}$ & & & 6.8 & & 6.8 \\
\hline$\underline{\mathrm{C}} \mathrm{MD}$ & 8.2 & & & & 8.2 \\
\hline C BL & 8.9 & & & & 8.9 \\
\hline $\mathrm{P}^{3} \mathrm{MD}$ & 8.0 & & & & 8.0 \\
\hline $\mathrm{P}^{3} \mathrm{BL}$ & 10.0 & & & 8.6 & 9.3 \\
\hline $\mathrm{P}^{4} \mathrm{MD}$ & 7.4 & 8.5 & & 6.5 & 7.5 \\
\hline $\mathrm{P}^{4} \mathrm{BL}$ & 9.9 & 9.3 & & 7.8 & 9.0 \\
\hline $\mathrm{M}^{1} \mathrm{MD}$ & 11.95 & & & 9.9 & 11.3 \\
\hline $\mathrm{M}^{1} \mathrm{BL}$ & 12.3 & & & 10.6 & 11.45 \\
\hline $\mathrm{M}^{2} \mathrm{MD}$ & 11.3 & & 9.5 & 10.4 & 10.6 \\
\hline $\mathrm{M}^{2} \mathrm{BL}$ & 12.5 & & 11.6 & 10.0 & 11.7 \\
\hline $\mathrm{I}_{2} \mathrm{MD}$ & & & & 6.8 & 6.8 \\
\hline $\mathrm{I}_{2} \mathrm{BL}$ & & & & 6.1 & 6.1 \\
\hline $\mathrm{C} \mathrm{BL}$ & & & & 7.0 & 7.0 \\
\hline $\mathrm{P}_{3} \mathrm{MD}$ & & & & 7.0 & 7.0 \\
\hline $\mathrm{P}_{3} \mathrm{BL}$ & & & & 7.4 & 7.4 \\
\hline $\mathrm{P}_{4} \mathrm{BL}$ & & & & 7.7 & 7.7 \\
\hline $\mathrm{M}_{1} \mathrm{MD}$ & & & & 12.3 & 12.3 \\
\hline $\mathrm{M}_{1} \mathrm{BL}$ & & & & 11.2 & 11.2 \\
\hline $\mathrm{M}_{2} \mathrm{MD}$ & & 11.0 & & & 11.0 \\
\hline $\mathrm{M}_{2} \mathrm{BL}$ & & 10.15 & & 9.5 & 9.9 \\
\hline $\mathrm{M}_{3} \mathrm{BL}$ & & & & 8.4 & 8.4 \\
\hline
\end{tabular}

Notes: A. Unsexed adolescent stratified beneath the EMP cemetery (Bulbeck, 1981).

B. Teeth from spits 19 to 26, perhaps female, associated with 6-8 ka radiocarbon dates (Bulbeck et al., 2013). Data exclude teeth too worn for even their buccolingual diameters to be recorded.

C. Primary burial, perhaps male, directly radiocarbon dated to $4610 \pm 220 \mathrm{BP}$ (Bulbeck, 2004).

D. Slightly mineralised remains, some probably male, from pre-ceramic levels (Bulbeck, 2004).

Source: Includes data from all sources listed in notes and fully cited in reference section.

The statistical application employed in this study is Penrose's (1954) size and shape statistic, which divides Pearson's 'Coefficient of Racial Likeness' (CRL) into size and shape components. Like the CRL, Penrose's size and shape statistics are based on calculating a grand standard deviation for all the samples entered for analysis, dividing the samples' means by this grand standard deviation, and calculating the differences between the standardised means. I have developed 
an Approach database template that manages these steps, but only for up to 17 samples, which places a limit on how many samples with a reasonable sample size can be included in any analysis. However, I can freely add samples of very small sample size, because their variance would have minimal effect on the grand standard deviation, and so samples like these can be simply entered as mean values to be standardised. (More sophisticated statistical techniques that require individual specimens, with original measurements as observed or estimated for every analysed variable, are inappropriate for this study. This is because the dental metrical data are publicly available mainly in the form of means and standard deviations, and because most samples are dominated by incomplete dentitions or even loose teeth.)

Penrose's size component has the advantage that, when the calculated statistic is expressed as its square root, it is additive along a single dimension. For instance, if $\mathrm{A}$ is $\mathrm{x}$ larger than $\mathrm{B}$, and $\mathrm{B}$ is $\mathrm{y}$ larger than $\mathrm{C}$, then $\mathrm{A}$ is $(\mathrm{x}+\mathrm{y})$ larger than C. A second advantage is that the size difference tracks the average difference between samples in terms of grand standard deviations. So, for instance, if we assign $\mathrm{C}$ a size value of 0 (being smallest), and we then compute B's size as 0.5 and A's size as 1.0, we can state that $\mathrm{A}$ is on average one standard deviation larger than C, while B is half a standard deviation from both A and C.

Penrose's shape component essentially captures the variance that cannot be attributed to size. To make the shape distances more intuitive, two transformations are performed here. The first transformation is to express the calculated shape distances as their square roots, to convert them to Euclidean distances. The second transformation involves dividing each inter-sample shape distance by the square root of the product (or geometric average) of the average shape distances of the two samples being compared. For instance, if A has an average shape distance of 0.4 from the other samples, and B an average shape distance of 1.6, and their shape distance from each other is 0.8, their transformed (calibrated) shape distance would be $0.8 / 0.8$ (the geometric average of 0.4 and 1.6), or 1. A value of 1 can be thought of as the 'expected' shape distance between any two samples, while values less than 1 (greater than 1) reflect cases of samples that are more similar (less similar) in shape than would be expected. In addition to relating shape differences to a benchmark of 1 , this calibration process enables relatively small shape distances between a pair of samples to stand out, whether these samples' shape distances are on average large or small. (This calibration process also accommodates shape distances computed from different selections of variables in the same analysis, as later described for the analysis concerned.) 
To present an overall view of the obtained shape distances, the samples are clustered into dendrograms using average linkage. In addition, two refinements are included, to the degree permitted by the dendrogram structure. (The calculations, performed using Excel spreadsheets, are available from the author on request.)

The first refinement involves seriating the samples along a single dimension. The samples most unlike each other are placed at the two extremes, and the other samples are positioned to the degree that they approach one or the other extreme. The success of the seriation can be calculated as the coefficient of variation between the seriated distances and the most similar, perfect seriation of those distances (see footnotes to Tables 10.5 to 10.8).

The second refinement is to vary the dendrogram's branch lengths according to the represented distances. A long branch in the dendrogram reflects a considerable shape disjunction, and a sample that accumulates great branch length with respect to the analysed samples' final joining distance (represented as 0 in the dendrogram) stands out as generally different from the other samples. The distance between any two samples is represented by the minimum horizontal distance that has to be traversed in tracing a path, through the dendrogram, that connects the two samples. How successful the traversed horizontal distances are in representing the shape distances can also be calculated in terms of their coefficient of variation. (The algorithm to calculate branch lengths is based on the average within-distance compared with the average outside-distance. For instance, if $\mathrm{A}$ and $\mathrm{B}$ cluster together at a distance of 0.5 , but $\mathrm{A}$ is 0.1 farther from the other samples than $B$ is, then the stem length of $A$ is calculated as $0.5 / 2$ $+0.1 / 2=0.3$, while the stem length of $B$ is calculated as $0.5 / 2-0.1 / 2=0.2$.)

Five Penrose size and shape analyses are presented here. The first includes all of the male samples for all tooth diameters. The second analysis also focuses on male samples but is restricted to buccolingual diameters. Buccolingual diameters are not susceptible to reduction through interstitial wear, whereas, when mesiodistal diameters are included, there is a risk that the calculated size and shape distances mainly reflect differences in interstitial wear rates (but see Results). The third analysis includes the bisexual samples for all tooth diameters. The fourth comparison focuses on the same bisexual samples, but only on their buccolingual diameters, for the same reason as with the second analysis. Finally, the fifth analysis includes the four prehistoric Indo-Malaysian samples that are lacking data for some of the tooth diameters (see Results section).

Principal Components Analysis (PCA) was also undertaken of all of the analyses presented here, with the sample means submitted to PCA. In each case, the first principle component captured size, as would be expected of biological data (Joliffe 2002). The implications barely differ from the implications of the Penrose 
size analyses, and so it would be redundant to also present the PCA size results. After the $45-84 \%$ of variance accounted for by size was removed, the second, third and other principle components captured a maximum of $15 \%$ of variance. In most cases, this was too low to allow for ready interpretation. Accordingly, the PCA results are excluded from this contribution.

\section{Results}

\section{First analysis: 17 male samples, all 32 diameters}

The Penrose size comparisons are presented at the top of Figure 10.1 (Figure 10.1a). The results would be consistent with a scenario of pronounced toothsize reduction in Indo-Malaysia between the Pleistocene and early Holocene, with continuing tooth-size reduction during the Neolithic and recent times. Surabaya males from Java show the smallest teeth, whereas the Late Pleistocene Java sample has the largest teeth, on average 2.3 standard deviations larger than Surabaya Javanese. The two pre-Neolithic Indo-Malaysian samples have larger teeth than the two Neolithic Indo-Malaysian samples, whose teeth are of above average size by recent Indo-Malaysian standards. Also of interest, Shanghai Chinese, and the Motupore males from Papua New Guinea, both resemble recent Indo-Malaysians in their tooth-size, whereas the other three Southwest Pacific samples have teeth that are much larger.

The Penrose shape distances (square roots) are presented at Table 10.5, both before and after calibration. The order of the samples reflects their order after seriation of the average-linkage dendrogram, which is illustrated in Figure 10.2. As shown there, the recent Southwest Pacific samples are all placed at one half of the seriated order and the recent Indo-Malaysian (and Chinese) samples toward the other half. Thus, seriation of the dendrogram appears to identify a distinction between 'Australoids' and 'Mongoloids' in their tooth shape, with the two Semang Negrito samples intermediate between the Australoids and the Mongoloids. The only Indo-Malaysian samples that cluster with the Australoids are the pre-Neolithic samples, including Pleistocene Java. The Neolithic samples, for their part, fall at the polar opposite from the Australoids. This result is consistent with the conventional wisdom (e.g. Bellwood, 1997) of a pre-Neolithic occupation of Indo-Malaysia by Australoid foragers, prior to the immigration of newcomers who introduced the Neolithic to the region. 
1a: 17 male samples, 32 diameters

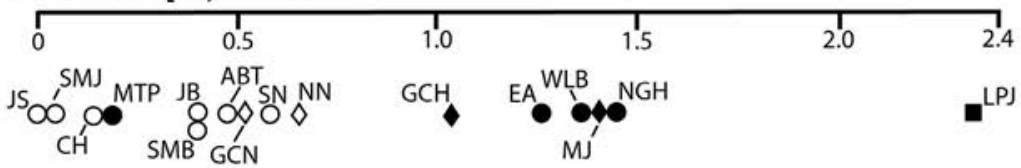

1b: 18 male samples, 16 buccolingual diameters

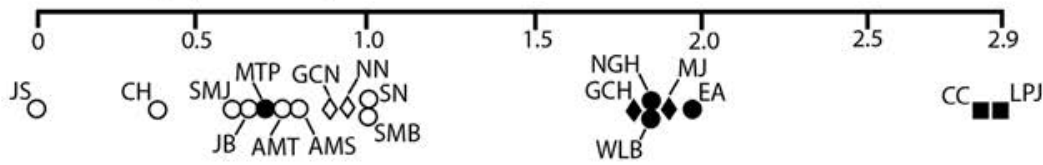

1c: 19 bisexual samples, 32 diameters
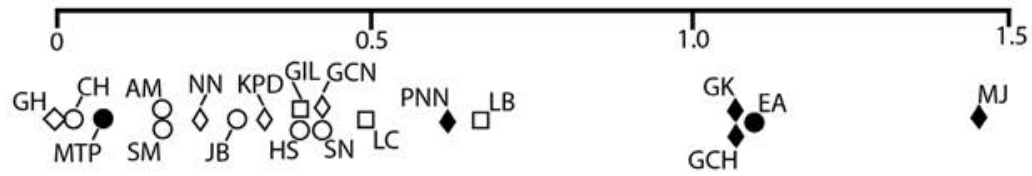

1d: 19 bisexual samples, 16 buccolingual diameters

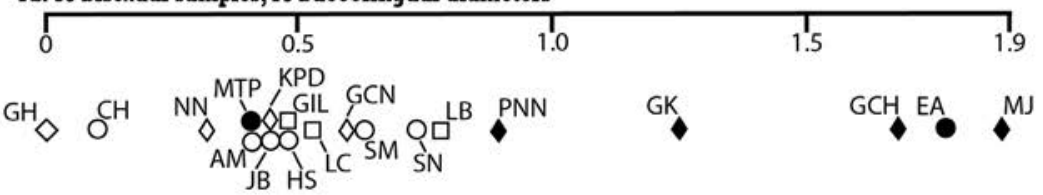

1e: 23 bisexual samples, up to 30 diameters

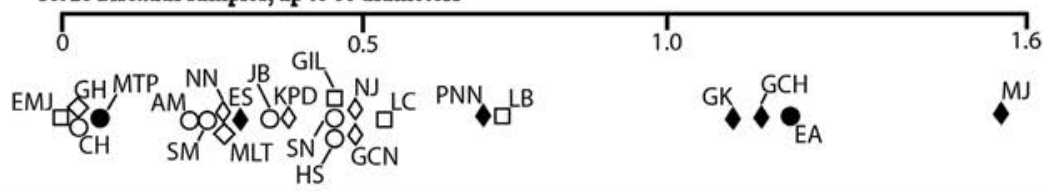

\begin{tabular}{|c|c|c|c|c|}
\hline LEGEND & $\begin{array}{l}\text { LPJ: Late Pleistocene } \\
\text { Java }\end{array}$ & NN: Neolithic Niah & $\begin{array}{l}\text { EMJ: Early Metal } \\
\text { Phase Java }\end{array}$ & AM: $\begin{array}{l}\text { Aboriginal } \\
\text { Malays }\end{array}$ \\
\hline - Late Pleistocene & $\begin{array}{l}\text { CC: Coobool Creek, } \\
\text { Australia }\end{array}$ & NJ: Neolithic Java & HS: Historical & JB: Batawi, \\
\hline $\begin{array}{l}\text { Other mid-Holocene / } \\
\text { earlier Indo-Malaysia }\end{array}$ & MJ: Mesolithic Java & GCN: Gua Cha & $\begin{array}{l}\text { SMB: Batek } \\
\text { Semang }\end{array}$ & JS: Surabaya, \\
\hline $\begin{array}{l}\text { Late Holocene } \uparrow \\
\text { lithic Southeast }\end{array}$ & PNN: Pre-Neolithic & GH: Gua Harimau & SMJ: Jahai & $\mathrm{CH}: \begin{array}{l}\text { Shanghai, } \\
\text { China }\end{array}$ \\
\hline $\begin{array}{l}\text { Early Metal Phase } \\
\text { Indo-Malaysia }\end{array}$ & GCH: Gua Cha & MLT: Melanta Tutup & SM: Semang & $\mathrm{EA}: \mathrm{Eu}$ \\
\hline$\diamond \begin{array}{l}\text { Neolithic/Early } \\
\text { Metal Phase }\end{array}$ & ES: Early Sulawesi & GIL: Gilimanuk & SN: & WLB: Walbiri, \\
\hline O Recent East Asia & GK: Guar Kepah & LC:Leang Codong & $\begin{array}{l}\text { AMT: Temuan Abo- } \\
\text { riginal Malays }\end{array}$ & 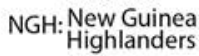 \\
\hline $\begin{array}{l}\text { Recent Southwest } \\
\text { Pacific }\end{array}$ & $\begin{array}{l}\text { KPD: Khok Phanom } \\
\text { Di }\end{array}$ & LB: Leang Buidane & 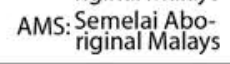 & $\begin{array}{l}\text { MTP: Motupore, } \\
\text { PNG }\end{array}$ \\
\hline
\end{tabular}

Figure 10.1: Dental metrics, Penrose size statistics comparisons.

Sources: Snell 1938; Barrett et al. 1963, 1964; Jacob 1964; Jacob 1967a, 1967b; Doran and Freedman 1974; Brown 1978; Bulbeck 1981; Brace et al. 1984; Brown 1989; Tayles 1989; Storm 1995; Bulbeck 2001; Détroit 2002; Bulbeck 2004; Bulbeck 2005a; Bulbeck et al. 2005; Chia et al. 2005; Manser 2005; Noerwidi 2011-12; Bulbeck et al. 2013; this paper. 
10. Changes in human tooth-size and shape with the Neolithic transition in Indo-Malaysia

등

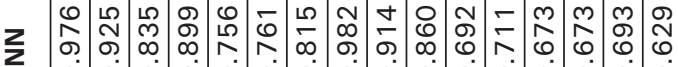

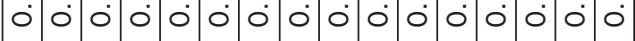

z

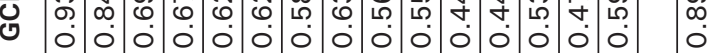

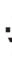

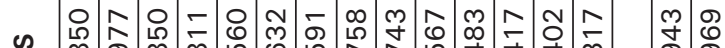

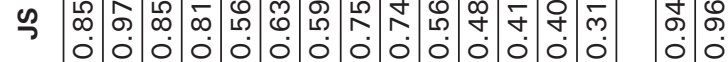

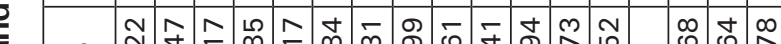

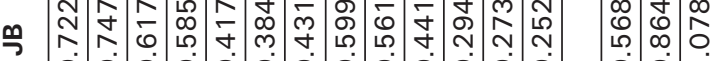

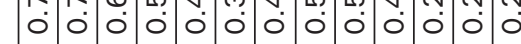

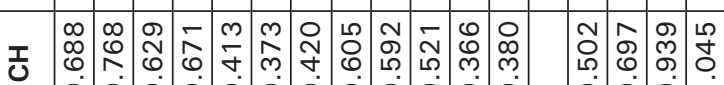

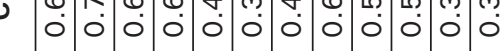

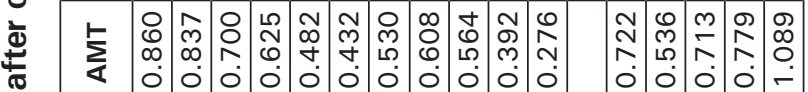

음

든

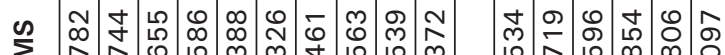

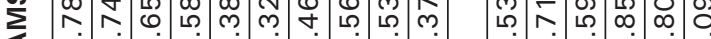

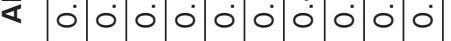

은

மீ

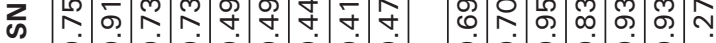

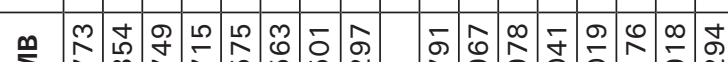

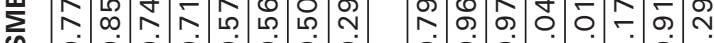

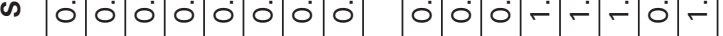

ᄀ

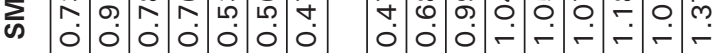

ฮิ

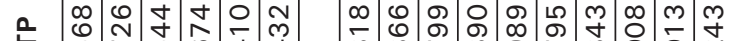

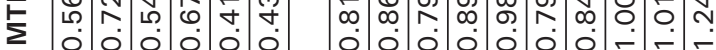

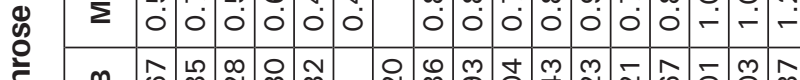

อับ

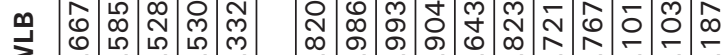

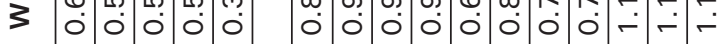

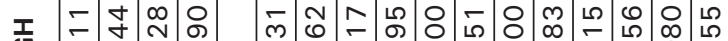

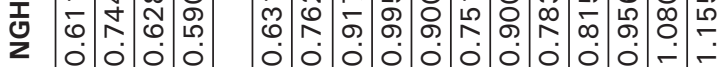

人ิ

ᄀ

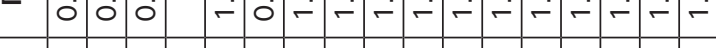

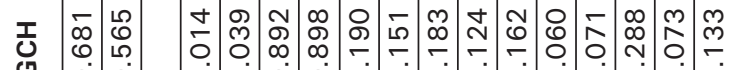

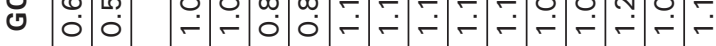

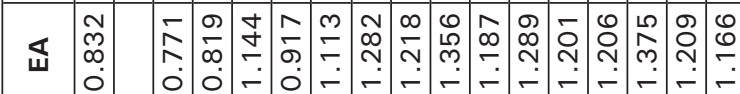

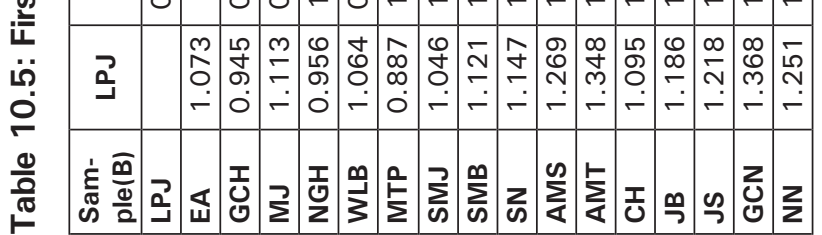

可

ป

要昰

范

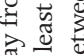

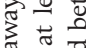

هิ

के

\&

드

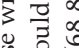

के 3

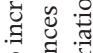

유

음

శี

ZII $\frac{\pi}{\pi}$

: శ్రేี

छ

क

ส

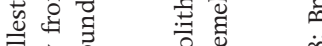

苋 穴

कू

용 क्ष

गे $\quad \therefore \dot{0}$

वृ.

ปี

ส ठิ

उㅍㅀㅇ

के

苟

节矛

壱吉

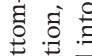

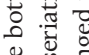

¿

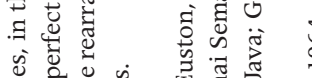

व

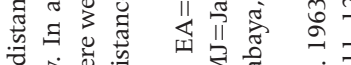

ठ

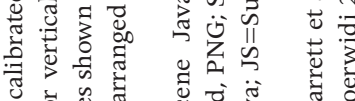

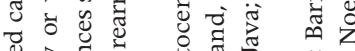

营芯芯志

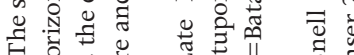

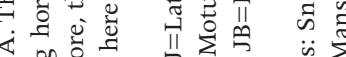

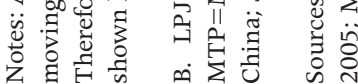




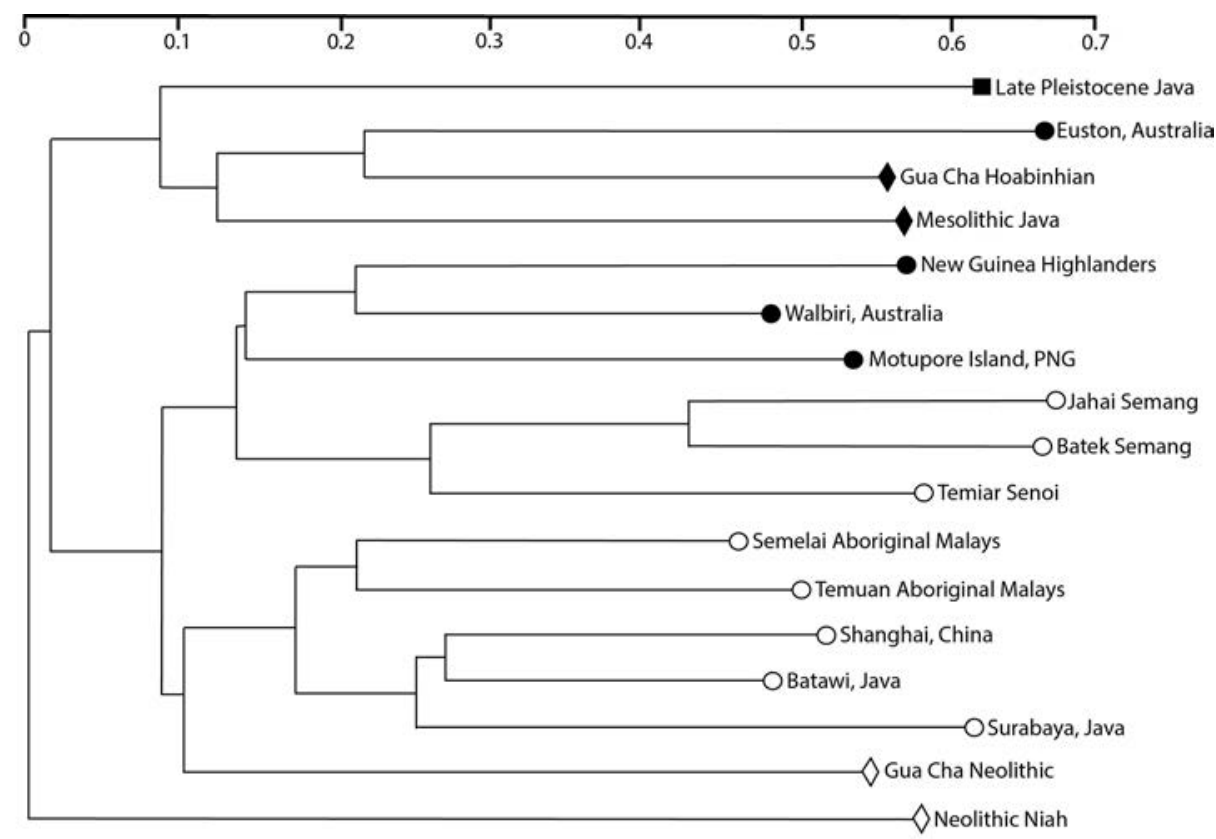

Coefficient of variation with a perfect seriation $68.8 \%$. Branch lengths' coefficient of variation with distances $74.4 \%$.

For explanation of symbols, see Figure 1.

Figure 10.2: Dental metrics, Penrose shape distances, 17 male samples, 32 diameters, seriated average-linkage dendrogram.

Sources: Snell 1938; Barrett et al. 1963, 1964; Jacob 1967a; Doran and Freedman 1974; Brown 1978; Brace et al. 1984; Storm 1995; Détroit 2002; Bulbeck 2005a; Bulbeck et al. 2005; Manser 2005; Noerwidi $2011-12$.

\section{Second analysis: 18 male samples, 16 buccolingual diameters}

The Penrose size comparisons are presented at Figure 10.1b. The results essentially echo those obtained for males using all diameters, with a clear indication of continual tooth-size reduction in Indo-Malaysia from the Pleistocene through the early Holocene, into the Neolithic and recent times. However, the inclusion of Coobool Creek (Late Pleistocene Australia) in the comparison offers two additional insights. First, the Coobool Creek teeth are larger than those of Holocene Australian Aborigines, as emphasised by Brown (1989). Secondly, Pleistocene Java and Australian teeth appear very similar in size, just as Mesolithic Java tooth-size appears very similar to Holocene Australian tooth-size. 


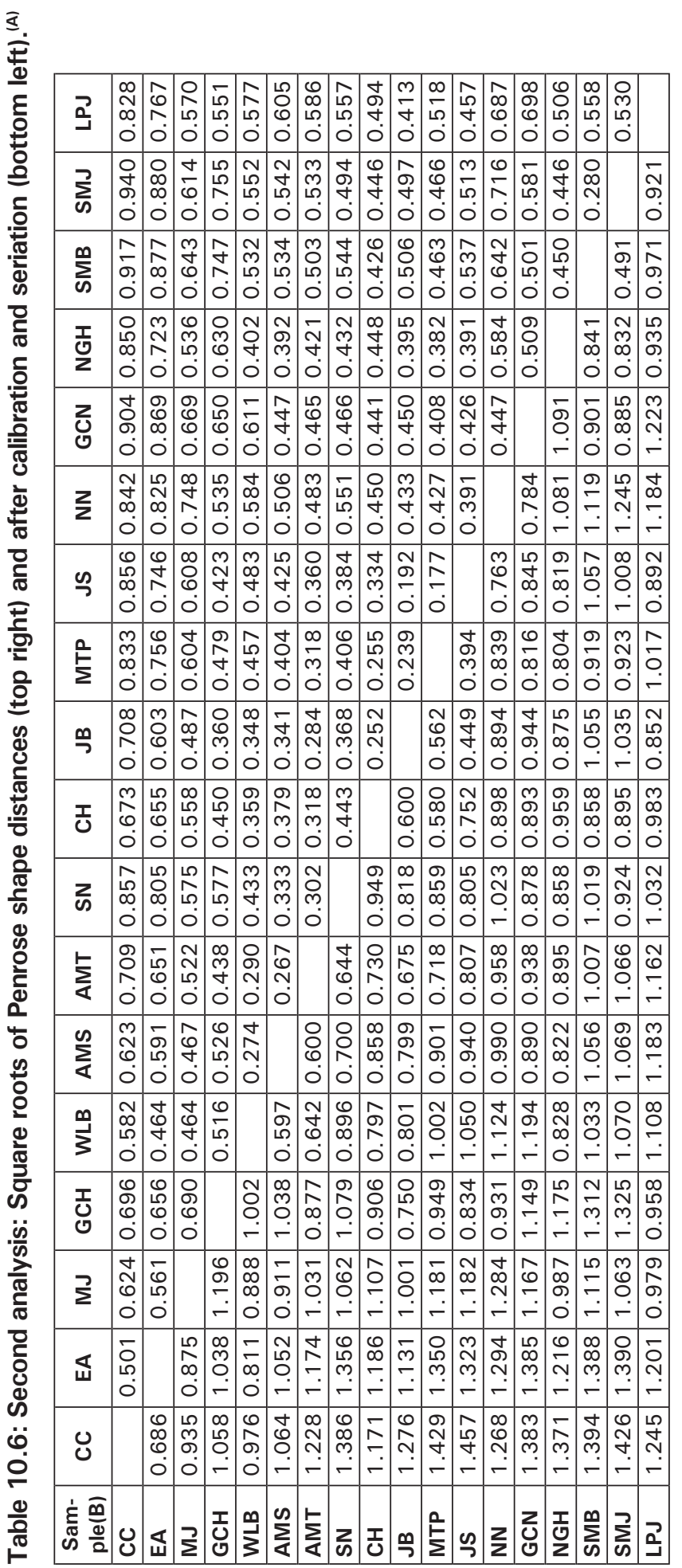

局焉

表苟学

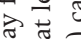

完 这

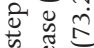

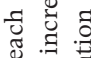

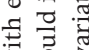

3

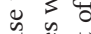

苞

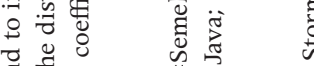

สี สี

동ํำ

; $:$ :

$\Xi \Xi$

串

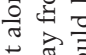

范

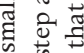

ำ

赵赵

है

记

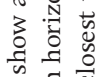

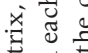

害起

त्త घं व

过击

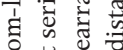

政

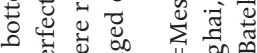

\&

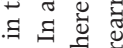

过

$\frac{0}{4} \frac{1}{1}$

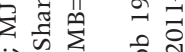

类 11 is

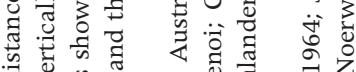

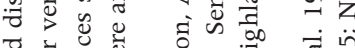

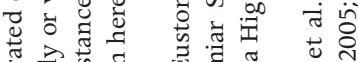

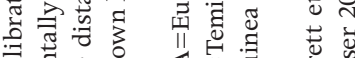

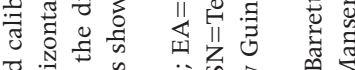

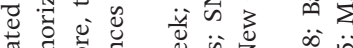

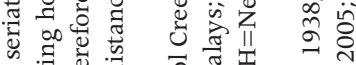

施

ख च के

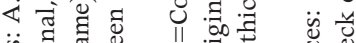

षैं

记 :

๓ « \&

范 


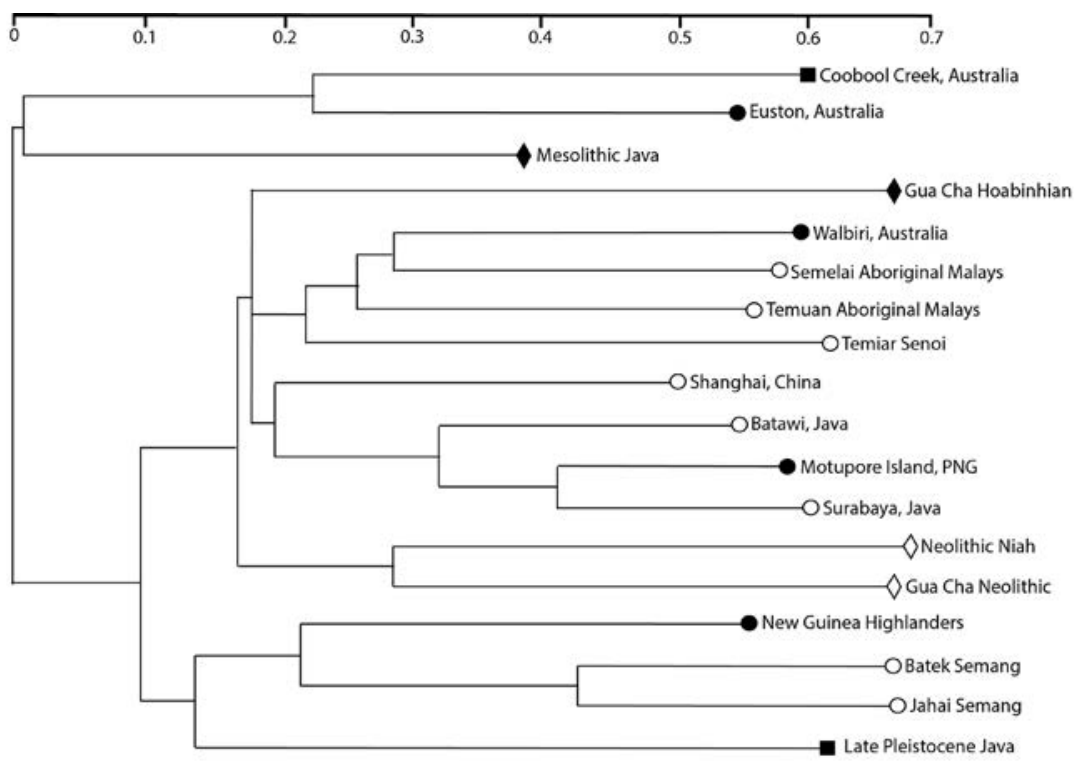

Coefficient of variation with a perfect seriation $73.2 \%$. Branch lengths' coefficient of variation with distances $70.7 \%$. For explanation of symbols, see Figure 1.

Figure 10.3: Dental metrics, Penrose shape distances, 18 male samples, 16 buccolingual diameters, seriated average-linkage dendrogram.

Sources: Snell 1938; Barrett et al. 1964; Jacob 1967a; Doran and Freedman 1974; Brown 1978; Brace et al. 1984; Brown 1989; Storm 1995; Détroit 2002; Bulbeck 2005a; Bulbeck et al. 2005; Manser 2005; Noerwidi 2011-12.

However, when the calibrated shape distances (Table 10.6) are clustered and seriated, the results differ from Figure 10.2 (the first analysis). The Southwest Pacific samples now split between Australian samples (including Coobool Creek) at one half of the seriation, and New Guinea samples at the other half of the seriation (Figure 10.3). Mesolithic Java and Gua Cha Hoabinhians align with the Australian samples, whereas Late Pleistocene Java takes up a polar position away from Australians. There is however one concordance between Figures 10.2 and 10.3: the two Neolithic samples fall closer to recent Indo-Malaysians than to the pre-Neolithic Indo-Malaysian samples.

The similarity between Australian and New Guinea samples in Figure 10.2, lacking from Figure 10.3, suggests the existence of a 'Southwest Pacific tooth shape' based on mesiodistal diameters and their relation to buccolingual diameters. This similarity cannot be attributed to interstitial wear. The Euston Aboriginal teeth were affected by much greater interstitial wear than the Motupore teeth (personal observation). Hence, if interstitial wear were at stake, any Euston-Motupore similarity should be evident in Figure 10.3, not Figure 10.2 - the reverse of what we find. Accordingly, the dentition as a whole 
apparently reflects a genetically based difference between 'Australoids' and 'Mongoloids', detectable notwithstanding differences between populations in their interstitial wear rates.

\section{Third analysis: 19 bisexual samples, all 32 diameters}

In the Penrose size comparisons (Figure 10.1c), the Neolithic/EMP sample from Gua Harimau shows the smallest teeth. The Niah samples also appear relatively small-toothed, with Neolithic Niah smaller than Neolithic Gua Cha, and preNeolithic Niah smaller than Gua Cha Hoabinhians and Mesolithic Java. This however may be affected by the greater representation of females than males in the Niah samples. Another complication is that the Guar Kepah sample, while qualifying as Neolithic, is of similar mid-Holocene antiquity to the Gua Cha Hoabinhians, and indeed their teeth are similarly large. The late Holocene Neolithic samples, for their part, tend to have slightly smaller teeth than the EMP samples. For all that, we can safely conclude that mid-Holocene and earlier Indo-Malaysian teeth appear to have been larger than their late Holocene counterparts.

The shape distances (Table 10.7), upon analysis, produce a pattern similar to that observed for the male samples with all 32 diameters included. The top half of the dendrogram (Figure 10.4) features Southwest Pacific samples, along with mid-Holocene and earlier Indo-Malaysian samples, as well as the Semang and Temiar Senoi from Malaya. The bottom half of the dendrogram includes recent Indo-Malaysians (except the Semang and Senoi), Shanghai Chinese and the late Holocene prehistoric samples. The extreme examples are Gua Harimau and Neolithic Niah, whereas Neolithic Gua Cha now tends towards the middle of the dendrogram. The simplest interpretation of Figure 10.4 may be that it points to broadly 'Australoid' (Euston Aborigines to Motupore) and 'Mongoloid' (Gua Harimau to Aboriginal Malay) groupings, with pre-Neolithic Niah, Guar Kepah and Gua Cha Neolithic intermediate. 


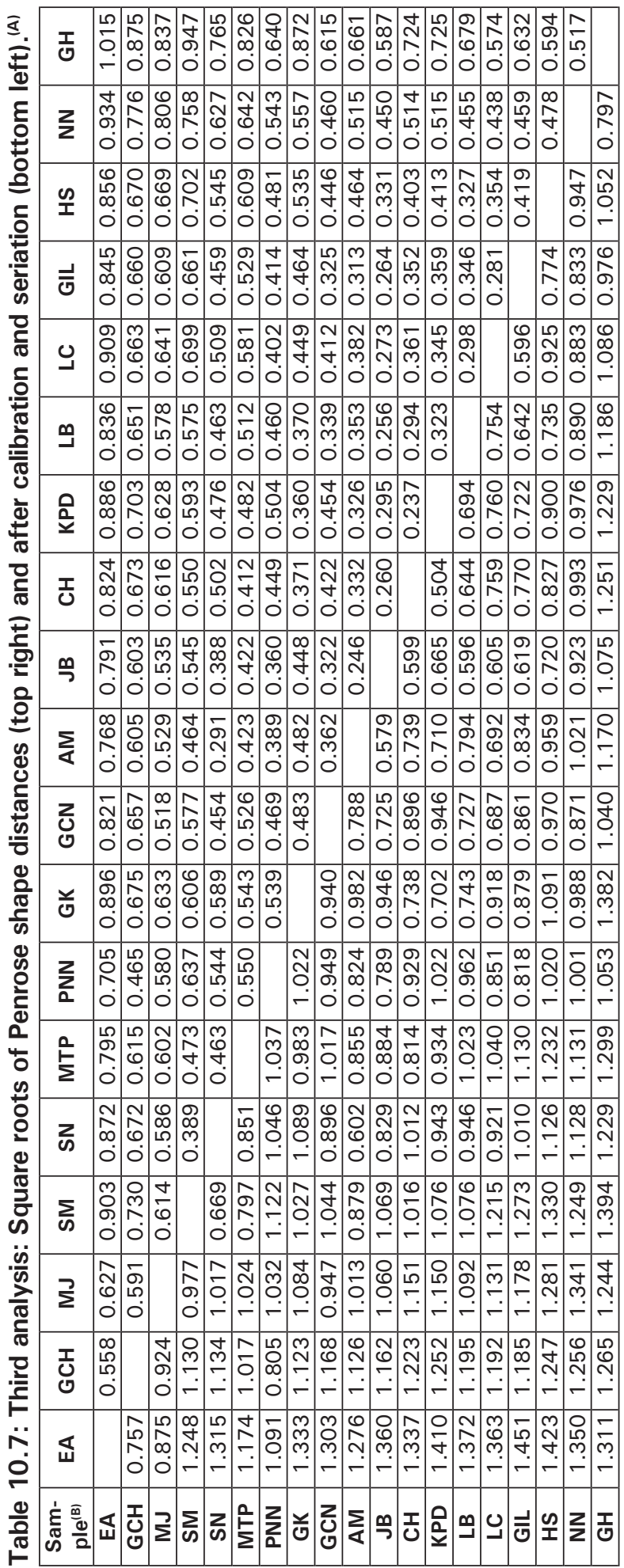

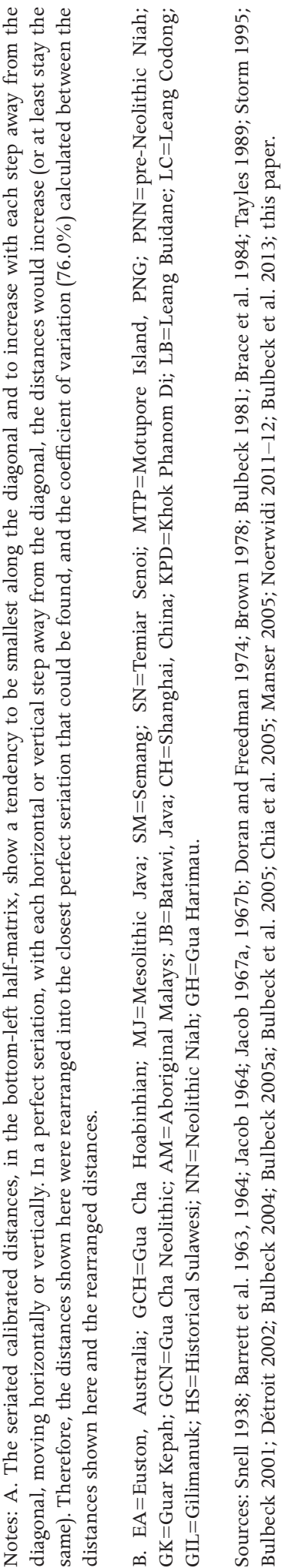




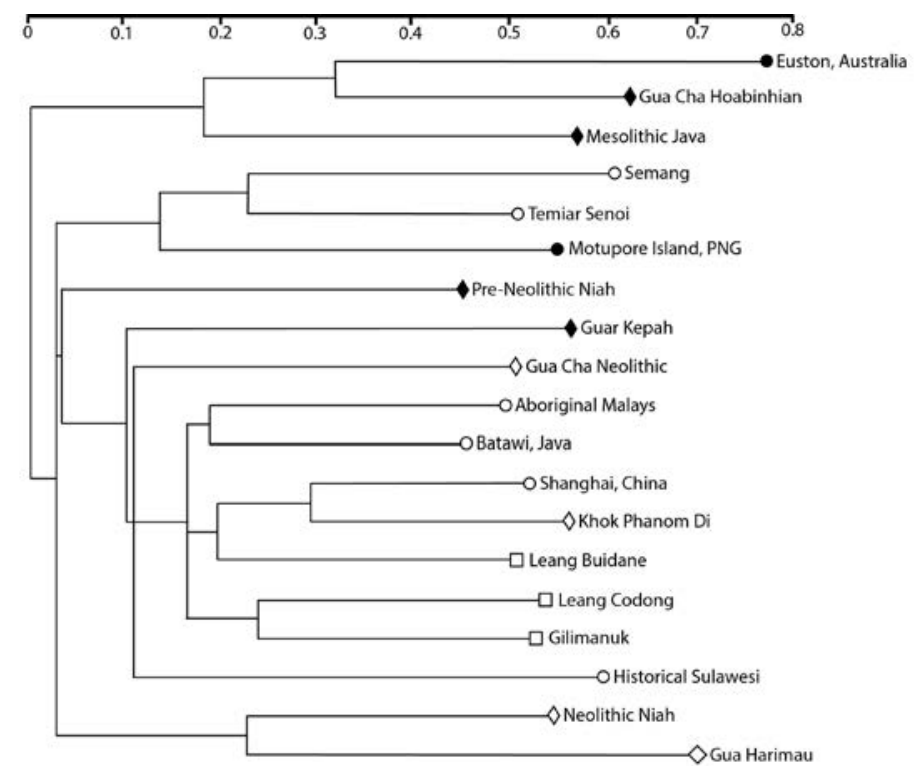

Coefficient of variation with a perfect seriation $76.0 \%$. Branch lengths' coefficient of variation with distances $79.2 \%$. For explanation of symbols, see Figure 1.

\section{Figure 10.4: Dental metrics, Penrose shape distances, 19 bisexual samples, 32 diameters, seriated average-linkage dendrogram.}

Sources: Snell 1938; Barrett et al. 1963, 1964; Jacob 1964; Jacob 1967a, 1967b; Doran and Freedman 1974; Brown 1978; Bulbeck 1981; Brace et al. 1984; Tayles 1989; Storm 1995; Bulbeck 2001; Détroit 2002; Bulbeck 2004; Bulbeck 2005a; Bulbeck et al. 2005; Chia et al. 2005; Manser 2005; Noerwidi 2011-12; Bulbeck et al. 2013; this paper.

\section{Fourth analysis: 19 bisexual samples, 16 buccolingual diameters}

When the Penrose size distances for bisexual samples are limited to buccolingual diameters, the resulting graph (Figure 10.1d) can be viewed as a clarification of Figure 10.1c. There is now no overlap in tooth-size between the late Holocene and the mid-Holocene and earlier samples. Moreover, the lack of a systematic size distinction, comparing the Neolithic, EMP and recent/historical samples with each other, is very apparent. (The small size of the Gua Harimau teeth is even more apparent than in Figure 10.1c.)

The structure of the shape distances (Table 10.8; Figure 10.5) is difficult to interpret. The extreme positions of the seriated dendrogram are taken up by Euston Aborigines and Gua Harimau, as in the third analysis. However, the three pre-Neolithic Indo-Malaysian samples now split between Mesolithic Java, which clusters with Euston Aborigines, and pre-Neolithic Niah and Gua Cha Hoabinhians, which seriate adjacently to Gua Harimau. The Neolithic samples (including Guar Kepah) lie in the same half of the dendrogram as Mesolithic Java. 


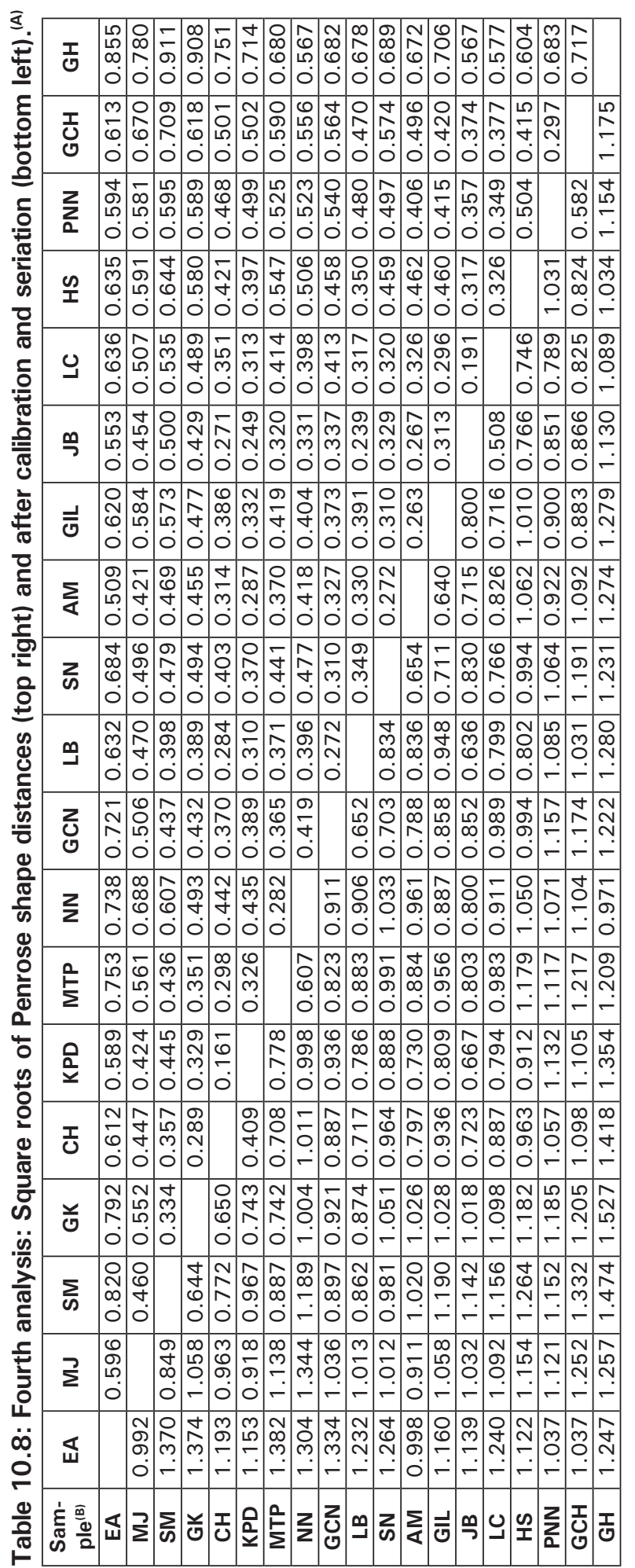

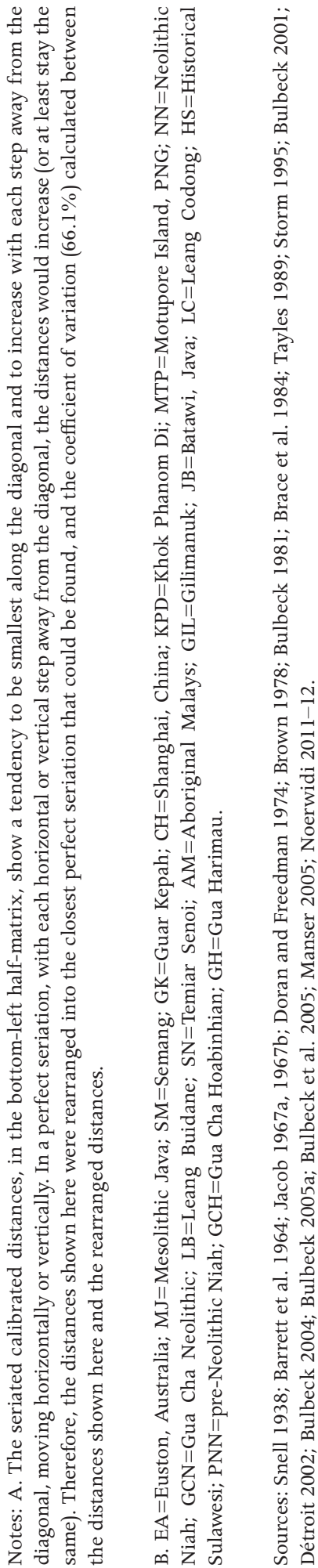


10. Changes in human tooth-size and shape with the Neolithic transition in Indo-Malaysia

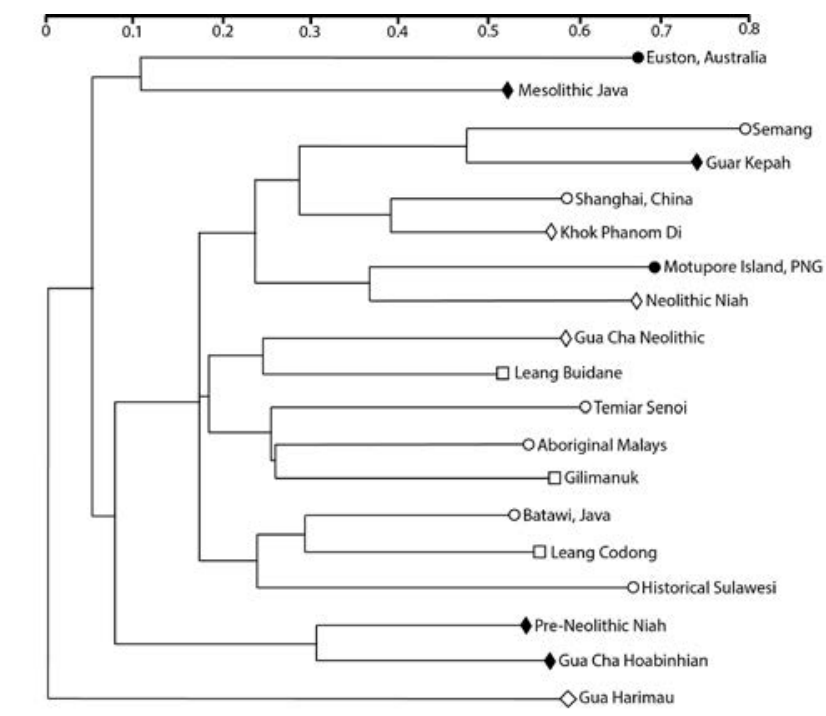

Coefficient of variation with a perfect seriation $66.1 \%$. Branch lengths' coefficient of variation with distances $66.6 \%$. For explanation of symbols, see Figure 1.

Figure 10.5: Dental metrics, Penrose shape distances, 19 bisexual samples, 16 buccolingual diameters, seriated average-linkage dendrogram.

Sources: Snell 1938; Barrett et al. 1964; Jacob 1967a, 1967b; Doran and Freedman 1974; Brown 1978; Bulbeck 1981; Brace et al. 1984; Tayles 1989; Storm 1995; Bulbeck 2001; Détroit 2002; Bulbeck 2004; Bulbeck 2005a; Bulbeck et al. 2005; Manser 2005; Noerwidi 2011-12.

\section{Fifth analysis: 23 bisexual samples, up to 32 diameters}

The fifth analysis has the complication that it includes four samples lacking data for some of the diameters. The available data for these samples cover 30 diameters (EMP Java), 24 diameters (Neolithic Java and Melanta Tutup) and 23 diameters (Early Sulawesi). Further, when these samples are compared with each other, the number of diameters they have in common may be further reduced, to as few as 16 (Neolithic Java compared with Melanta Tutup). The approach adopted here to missing data is to base the pair-wise comparisons on as many diameters as there are data available.

For the size comparisons, each of the additional four samples was individually compared with the 19 samples (those in the third analysis) on all of the diameters for which the individual sample has data. Of these, EMP Java was found to have smaller teeth than Gua Harimau. Therefore, with EMP Java established as the new 'ground zero' for the size comparisons, the tooth-size of the other samples is represented by their distance from EMP Java for as many diameters as they have in common with EMP Java, up to 30 (Figure 10.1e). 
Table 10.9: Fifth analysis, four additional samples: Square roots of Penrose shape distances (left) and after calibration and seriation (right). ${ }^{\text {(A) }}$

\begin{tabular}{|c|r|c|c|c|c|c|c|c|}
\hline Sample $^{(\mathbf{B})}$ & NJ & MLT & EMJ & ES & ES & EMJ & MLT & NJ \\
\hline EA & 1.140 & 1.517 & 1.240 & 1.563 & 1.694 & 1.464 & 1.630 & 1.230 \\
\hline GCH & 0.927 & 1.414 & 1.119 & 1.312 & 1.733 & 1.552 & 1.637 & 1.166 \\
\hline MJ & 1.049 & 1.191 & 0.943 & 1.223 & 1.663 & 1.274 & 1.423 & 1.301 \\
\hline MTP & 0.948 & 1.168 & 0.967 & 1.324 & 1.832 & 1.368 & 1.472 & 1.250 \\
\hline SM & 1.037 & 1.158 & 1.024 & 1.318 & 1.620 & 1.355 & 1.436 & 1.251 \\
\hline SN & 0.887 & 1.059 & 0.851 & 1.280 & 1.733 & 1.231 & 1.444 & 1.182 \\
\hline PNN & 0.894 & 1.121 & 0.852 & 1.042 & 1.472 & 1.274 & 1.462 & 1.239 \\
\hline GK & 1.118 & 1.005 & 0.898 & 1.156 & 1.594 & 1.285 & 1.318 & 1.503 \\
\hline GCN & 0.992 & 0.951 & 0.637 & 1.162 & 1.692 & 1.141 & 1.287 & 1.411 \\
\hline AM & 0.915 & 0.988 & 0.752 & 1.163 & 1.796 & 1.201 & 1.451 & 1.347 \\
\hline JB & 0.840 & 0.941 & 0.698 & 1.044 & 1.694 & 1.153 & 1.386 & 1.276 \\
\hline KPD & 1.019 & 0.911 & 0.748 & 1.109 & 1.659 & 1.177 & 1.231 & 1.472 \\
\hline CH & 0.999 & 0.938 & 0.745 & 1.060 & 1.613 & 1.169 & 1.328 & 1.425 \\
\hline LB & 0.936 & 0.965 & 0.735 & 1.057 & 1.622 & 1.160 & 1.364 & 1.367 \\
\hline GIL & 1.017 & 0.875 & 0.808 & 1.057 & 1.568 & 1.254 & 1.235 & 1.460 \\
\hline LC & 0.933 & 0.879 & 0.686 & 0.989 & 1.466 & 1.061 & 1.201 & 1.312 \\
\hline HS & 0.807 & 1.014 & 0.748 & 1.105 & 1.623 & 1.117 & 1.377 & 1.113 \\
\hline NN & 1.031 & 0.989 & 0.840 & 1.214 & 1.663 & 1.167 & 1.233 & 1.296 \\
\hline GH & 0.920 & 1.079 & 0.854 & 1.234 & 1.411 & 1.066 & 1.184 & 1.079 \\
\hline NJ & & 1.650 & 1.230 & 1.570 & 1.357 & 1.401 & 1.475 & \\
\hline MLT & & & 0.934 & 1.163 & 1.112 & 0.979 & & \\
\hline EMJ & & & & 0.897 & 0.837 & & & \\
\hline ES & Square roots of & & & & Calibrated & & & \\
& shape distances & & & & shape & & & \\
\hline
\end{tabular}

Notes: A. The calibrated distances in the top 19 rows were calculated from four separate 20 by 20 half-matrices of shape distances based on all of the tooth diameters recorded for the sample named in the column heading. For instance, to compare EMJ (EMP Java) with the 19 samples from the third analysis (EA to GH), a 20 by 20 halfmatrix of shape distances was calculated based on the 30 diameters recorded for EMJ. The calibrated distance of EMJ from EA (for instance) is 1.240 divided by the geometric average of the average distances obtained for EMJ and for EA. However, the calibrated distances comparing NJ (Neolithic Java), Melanta Tutup (MLT), EMJ and Early Sulawesi (ES) with each other were calculated from six separate, 21 by 21 half-matrices. For instance, to compare NJ and MLT, the 21 compared samples included the 19 samples from the third analysis (EA to GH) as well as NJ and MLT. The shape distances in the 21 by 21 half-matrix were calculated from the 16 diameters NJ and MLT have in common. Their calibrated distance is 1.650 divided by the geometric average of the average distances now obtained for NJ and MLT.

B. EA=Euston, Australia; $\mathrm{GCH}=\mathrm{Gua}$ Cha Hoabinhian; $\mathrm{MJ}=$ Mesolithic Java; $\mathrm{MTP}=$ Motupore Island, PNG; SM=Semang; SN=Temiar Senoi; PNN=pre-Neolithic Niah; GK=Guar Kepah; GCN=Gua Cha Neolithic; $\mathrm{AM}=$ Aboriginal Malays; JB=Batawi, Java; $\mathrm{KPD}=$ Khok Phanom Di; $\mathrm{CH}=$ Shanghai, China; LB=Leang Buidane; GIL=Gilimanuk; LC=Leang Codong; HS=Historical Sulawesi; NN=Neolithic Niah; GH=Gua Harimau; NJ=Neolithic Java; MLT=Melanta Tutup; EMJ=Early Metal Phase Java; ES=Early Sulawesi.

Sources: Snell 1938; Barrett et al. 1963, 1964; Jacob 1964; Jacob 1967a, 1967b; Doran and Freedman 1974; Brown 1978; Bulbeck 1981; Brace et al. 1984; Tayles 1989; Storm 1995; Bulbeck 2001; Détroit 2002; Bulbeck 2004; Bulbeck 2005a; Bulbeck et al. 2005; Chia et al. 2005; Manser 2005; Noerwidi 2011-12; Bulbeck et al. 2013; this paper. 


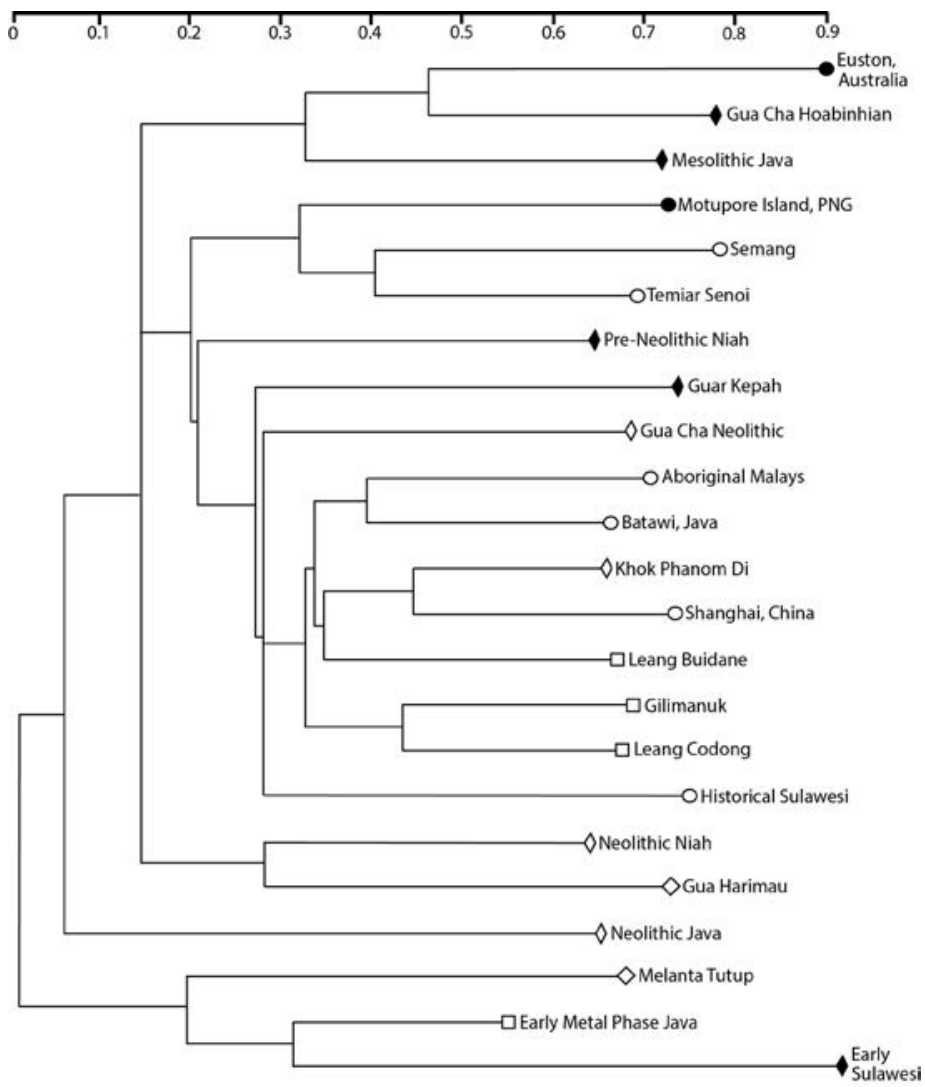

Coefficient of variation with a perfect seriation $79.5 \%$

Branch lengths' coefficient of variation with distances $82.7 \%$.

For explanation of symbols see Figure 1.

Figure 10.6: Dental metrics, Penrose shape distances, 23 bisexual samples, up to 32 diameters, seriated average-linkage dendrogram.

Sources: Snell 1938; Barrett et al. 1963, 1964; Jacob 1964; Jacob 1967a, 1967b; Doran and Freedman 1974; Brown 1978; Bulbeck 1981; Brace et al. 1984; Tayles 1989; Storm 1995; Bulbeck 2001; Détroit 2002; Bulbeck 2004; Bulbeck 2005a; Bulbeck et al. 2005; Chia et al. 2005; Manser 2005; Noerwidi 2011-12; Bulbeck et al. 2013; this paper.

As shown there, the Early Sulawesi teeth are small (as previously noted by Bulbeck, 2004), smaller than EMP (Leang Codong, Leang Buidane) and historical Sulawesi teeth. The Neolithic Java and Melanta Tutup teeth are small, and the EMP Java teeth are very small. Caution should be exercised in the use of these results, given that they are based on very small sample sizes and incomplete coverage of the dentition. Nonetheless, it is interesting that the late Holocene tooth-size reduction indicated for Java, Borneo and Malaya appears to be reversed for Sulawesi. 
Turning to the shape comparisons, we first note that the calibrated shape distances from the third analysis (Table 10.7) were migrated wholesale to the fifth analysis, supplemented here by the calibrated shape distances that involve the four additional samples. As explained in footnote A to Table 10.9, the calibrated shape distances in the fifth analysis vary in terms of the tooth diameters used to generate them, but they are comparable in that the value of 1 serves as the benchmark for the 'expected' shape distance in each cell.

Figure 10.6 shows the seriated dendrogram that results from the calibrated shape distances in Tables 10.7 and 10.9. The same general structure emerges as for Figure 10.4. Euston Aborigines, Gua Cha Hoabinhians, Mesolithic Java, Motupore and pre-Neolithic Niah fall towards one pole, while Gua Harimau, Niah Neolithic and historical Sulawesi fall towards the other pole. The four additional samples take up the extreme position at the latter pole. In other words, Neolithic Java, Melanta Tutup, EMP Java and especially Early Sulawesi (but not the Chinese sample) appear particularly non-Australoid. Thus, the Early Sulawesi sample differs from the other mid-Holocene and earlier Indo-Malaysian samples not just by its smaller teeth but also its distinct dental metrical shape.

\section{Discussion}

The first assignment for this study was to test the hypothesis that the advent of agriculture and pottery selected for smaller teeth. The expectation required to confirm this hypothesis was evidence for continual tooth-size reduction in Indo-Malaysia throughout the late Holocene. The male comparisons are broadly consistent with this expectation. However, only two late Holocene, prehistoric samples from Indo-Malaysia qualified for inclusion in these comparisons. Further, one of them, Gua Cha Neolithic males, had slightly smaller teeth than Temiar males, even though Temiar ancestry may have included the population represented by the Gua Cha Neolithic burials (Bulbeck, 2011: 237). Certainly, when analysis included the bisexual samples, evidence for continual tooth-size reduction throughout that late Holocene was hard to find. For instance, in the fifth analysis, the Neolithic and recent samples overlap comprehensively in toothsize, both falling centrally within the EMP range of variation (Figure 10.1e). Similarly, Brace and others (1984) could find no evidence for late Holocene toothsize reduction in north China, while in mainland Southeast Asia, the Neolithic teeth from Ban Kao in Thailand are smaller than those of recent Thais, and the Iron Age Dong Son teeth smaller than those of recent Vietnamese (Matsumura and Hudson, 2005: Figure 3). Therefore, detailed comparisons appear to falsify the 'Neolithic tooth-size reduction' model. 
Keeping to a local evolutionary paradigm, we turn to an alternative possible explanation for the tooth-size reduction which characterises Java, Malaya and Borneo, when late Holocene samples are compared with older samples. This explanation, general body-size reduction, is the one preferred by Brown (1989) for the smaller size of Holocene Murray Valley teeth compared to Coobool Creek. It is also Storm's (1995) proposed explanation for the differences between the Wajak and recent Javanese skulls in their general morphology. However, the available data, sparse as they are, would suggest very large body size in Java right up to the Neolithic (Table 10.10), despite the small teeth as currently documented for Neolithic Java. As for Malaya, Bulbeck (2011) finds evidence for around $10 \%$ reduction in stature between the early Holocene and recent times (with reference to the Orang Asli). However, according to Bulbeck's data, this stature reduction continued throughout the late Holocene, whereas, as shown here, the Gua Cha Neolithic and Gua Harimau teeth appear no larger than those of the Orang Asli. Finally, Zuraina and Pfister (2005) find evidence for a circa $10 \mathrm{~cm}$ increase in stature of the Niah Neolithic burials compared to the preNeolithic Niah burials. While the small stature estimated for the pre-Neolithic Niah burials ( $154 \mathrm{~cm}$ for males, $145 \mathrm{~cm}$ for females) is consistent with the modest size of their teeth, Neolithic Niah appears to combine stature increase with tooth-size reduction. In summary, while a broad correlation between tooth-size and general body size would be expected, general body-size reduction fails as an explanation for late Holocene tooth-size reduction in Borneo, Malaya and Java.

With the falsification of the two mooted, local evolutionary explanations for tooth-size changes in late Holocene Indo-Malaysia, the incursion of 'new people' with smaller teeth is left as the default explanation. Although this study was not designed to investigate the source of any such newcomers, the fifth analysis did identify a potential candidate - Early Sulawesi. On the available data, the circa mid-Holocene teeth from Sulawesi are of very typical size by the standards of late Holocene teeth across Indo-Malaysia (Figure 10.1e). The Early Sulawesi teeth also stand at the polar extreme from Australoids in their shape (Figure 10.6), and so would serve as an appropriate precursor for the markedly non-Australoid tooth shape recorded for late Holocene samples from other locations (notably Neolithic and EMP Java, Melanta Tutup, Gua Harimau and Neolithic Niah). The status of Sulawesi as a donor region is reasonable in view of mitochondrial DNA evidence that it was a centre for the dispersal of the E1a, E2a, M7clc and D5 haplogroups, which together constitute a substantial proportion of recent Indo-Malaysians' mitochondrial DNA (Hill et al., 2007; Soares et al., 2008). 
Taxonomic Tapestries

Table 10.10: Comparative data on major limb-bone lengths ${ }^{(A)}$ in Java.

\begin{tabular}{|l|l|l|l|l|}
\hline \multicolumn{1}{|c|}{ Specimen/series } & \multicolumn{1}{|c|}{$\begin{array}{c}\text { Femur length } \\
(\mathbf{m m})\end{array}$} & \multicolumn{1}{|c|}{$\begin{array}{c}\text { Tibia length } \\
(\mathbf{m m})\end{array}$} & $\begin{array}{l}\text { Humerus length } \\
\text { (mm) }\end{array}$ & \multicolumn{1}{|c|}{ Source } \\
\hline Wajak (male) & $\begin{array}{l}\text { Larger than } \\
\text { Hoekgroet }\end{array}$ & $\begin{array}{l}\text { Too fragmentary } \\
\text { to assess }\end{array}$ & $\begin{array}{l}\text { Too fragmentary } \\
\text { to assess }\end{array}$ & Storm 1995 \\
\hline $\begin{array}{l}\text { Song Terus 1 } \\
\text { (Mesolithic male) }\end{array}$ & $470 \mathrm{~mm}$ (right) & Not reported & Not reported & $\begin{array}{l}\text { Détroit } \\
2002: 224\end{array}$ \\
\hline $\begin{array}{l}\text { Song Keplek 5 } \\
\text { (Neolithic female) }\end{array}$ & $\begin{array}{l}\text { Too fragmentary } \\
\text { to assess }\end{array}$ & $390 \mathrm{~mm}$ (right) & $346 \mathrm{~mm}$ (left) & $\begin{array}{l}\text { Noerwidi } \\
2011-12\end{array}$ \\
\hline $\begin{array}{l}\text { Hoekgroet } \\
\text { (Neolithic, female?) }\end{array}$ & $\sim 450 \mathrm{~mm}$ & $\sim 390 \mathrm{~mm}$ & $\begin{array}{l}\text { Too fragmentary } \\
\text { to assess }\end{array}$ & Storm 1995 \\
\hline $\begin{array}{l}\text { Recent Surabaya } \\
\text { males }\end{array}$ & $\begin{array}{l}414.3 \pm 23.0 \\
\text { (right) }\end{array}$ & $\begin{array}{l}348.0 \pm 21.0 \\
\text { (right) }\end{array}$ & $\begin{array}{l}296.6 \pm 16.2 \\
\text { (left) }\end{array}$ & $\begin{array}{l}\text { Bergman and } \\
\text { The 1955 }\end{array}$ \\
\hline
\end{tabular}

Note: A. Femur length in natural position (Martin 2), total tibia length (Martin 1) and maximum humerus length (Martin 1) are the definitions employed by Bergman and The (1955), and also by Noerwidi (201112). Détroit (2002) and Storm (1995) do not define their measurements.

Source: All listed in notes section.

At the same time, the evidence relating tooth-size reduction to broader cranial shape is ambiguous, at best. Table 10.11 focuses on the 'cranial index' (cranial breadth as a percentage of cranial length) as this is one of the most widely reported observations for prehistoric remains from Indo-Malaysia. The comparison between Wajak and early to mid-Holocene Indo-Malaysians suggests a transition to smaller teeth associated with more elongated, not broader, crania. Late Holocene Indo-Malaysians, for their part, can generally be distinguished from early to mid-Holocene Indo-Malaysians both by their smaller teeth and their broader crania. However, there are exceptions, such as the Puger skull (EMP Java), which combines a narrow braincase with very small teeth.

The dental metrical results outlined here are at variance with recently presented results on the same burial series. Manser (2005) was unable to distinguish between the pre-Neolithic and Neolithic Niah remains on their facial shape, cranial non-metric traits and dental morphology, finding that both resemble recent Southeast Asians, Polynesians and Australian Aborigines. Here, however, we find that the Neolithic teeth from Niah are not only smaller than the preNeolithic teeth, as noted by Manser (2005), but also different in shape. As for Gua Cha, Bulbeck (2005a) supported earlier findings of population continuity between the Hoabinhian and Neolithic series, consistent with the decision by Matsumura and Hudson (2004) to pool them into a single 'Gua Cha' sample. However, tooth shape analysis would be compatible with a scenario in which the Gua Cha Neolithic burials reflect admixture between the Gua Cha Hoabinhians and Neolithic immigrants from the north, as represented by Khok Phanom Di (Figures 10.4 to 10.6; cf. Bellwood, 1993). Finally, the Java Mesolithic burials appear to be more homogeneous in their cranial shape (Table 10.11) and their dental metrics, and more distinct from the Java Neolithic burials, than Détroit (2002) inferred - although this discrepancy may reflect Détroit's reliance on a now superseded, pre-Neolithic dating for the critical Song Keplek 5 burial. 
10. Changes in human tooth-size and shape with the Neolithic transition in Indo-Malaysia

Table 10.11: Comparison of Indo-Malaysian tooth-size and cranial index.

\begin{tabular}{|c|c|c|c|c|}
\hline Location/Age & Series/specimen & Tooth size $\mathrm{A}^{(\mathrm{A})}$ & Cranial index ${ }^{(\mathrm{B})}$ & $\begin{array}{c}\text { Cranial index data } \\
\text { source }\end{array}$ \\
\hline Java, Late Pleistocene & Wajak & Very large & Mesocranic (75.5) & Storm 1995 \\
\hline $\begin{array}{l}\text { Java, Pleistocene/ } \\
\text { Holocene junction }\end{array}$ & Gua Braholo & Large & $\begin{array}{l}\text { Dolichocranic } \\
(70.3,73.9)\end{array}$ & Détroit 2002 \\
\hline Malaya, Early Holocene & Gua Peraling 4 & Small & Dolichocranic (74.7) & $\begin{array}{l}\text { Bulbeck and Adi } \\
2005\end{array}$ \\
\hline Java, mid-Holocene & Song Keplek 4 & Large & Mesocranic (77.8) & Détroit 2002 \\
\hline Java, mid-Holocene & Sampung & Large & Dolichocranic & Jacob 1967a \\
\hline Malaya, mid-Holocene & $\begin{array}{l}\text { Gua Cha } \\
\text { Hoabinhian }\end{array}$ & Large & $\begin{array}{l}\text { Dolichocranic } \\
(72.8,73.1)\end{array}$ & Bulbeck 2005a \\
\hline Malaya, mid-Holocene & Guar Kepah & Large & Dolichocranic (63.6) & Jacob 1967a \\
\hline $\begin{array}{l}\text { Sulawesi, } \\
\text { mid-Holocene }\end{array}$ & $\begin{array}{l}\text { Leang Buidane } \\
\text { Pre-ceramic }\end{array}$ & $\begin{array}{l}\text { Medium } \\
\text { (Table 10.4) }\end{array}$ & Dolichocranic (66.8) & Bulbeck 1981 \\
\hline Java, Neolithic & Song Keplek 5 & Medium & Brachycranic & Noerwidi 2011-12 \\
\hline Java, Neolithic & Hoekgroet & Small & Brachycranic (80.5) & Storm 1995 \\
\hline Malaya, Neolithic & $\begin{array}{l}\text { Gua Cha } \\
\text { Neolithic }\end{array}$ & Small & $\begin{array}{l}\text { Mesocranic }(76.0) \text {, } \\
\text { brachycranic }(>80)\end{array}$ & Bulbeck 2005a \\
\hline Sulawesi, EMP & Leang Buidane & Medium & Mesocranic & Bulbeck 1981 \\
\hline Java, EMP & Puger & Very small & Dolichocranic (73.9) & Snell 1938 \\
\hline Sulawesi, Recent & $\begin{array}{l}\text { Historical } \\
\text { Sulawesi }\end{array}$ & Small & Brachycranic (80.6) & $\begin{array}{l}\text { Pietrusewsky } \\
1981^{(C)}\end{array}$ \\
\hline Malaya, Recent & Semang & Small & Mesocranic & $\begin{array}{l}\text { Bulbeck and Lauer } \\
2006\end{array}$ \\
\hline Malaya, Recent & Senoi & Small & Mesocranic & $\begin{array}{l}\text { Bulbeck and Lauer } \\
2006\end{array}$ \\
\hline Malaya, Recent & $\begin{array}{l}\text { Aboriginal } \\
\text { Malays }\end{array}$ & Small & Mesocranic & $\begin{array}{l}\text { Bulbeck and Lauer } \\
2006\end{array}$ \\
\hline Java, Recent & $\begin{array}{l}\text { Surabaya, } \\
\text { Batawi }\end{array}$ & $\begin{array}{l}\text { Small to } \\
\text { very small }\end{array}$ & Brachycranic (81.0) & \begin{tabular}{|l} 
Pietrusewsky \\
$1981^{(C)}$
\end{tabular} \\
\hline
\end{tabular}

Notes: A. Tooth-size from this paper except for Gua Peraling 4, from Bulbeck and Adi (2005), and Song Keplek 5, from Noerwidi (2011-12).

B. A cranial index below 75 corresponds to narrow braincases (dolichocrany), while a cranial index above 80 corresponds to broad braincases (brachycrany). Mesocrany (cranial index between 75 and 80) is intermediate.

C. Calculated from the male means for maximum cranial length and cranial breadth.

Sources: Snell 1938; Jacob 1964; Jacob 1967a; Bulbeck 1981; Pietrusewsky 1981; Storm 1995; Détroit 2002; Bulbeck 2004; Bulbeck 2005a; Bulbeck and Adi 2005; Bulbeck et al. 2005; Bulbeck and Lauer 2006; Noerwidi 2011-12; Bulbeck et al. 2013; this paper. 
Détroit (2002) hypothesised that Indo-Malaysia was a region of population movements, from the terminal Pleistocene onwards, with links to what is now mainland East Asia to the north and New Guinea (and the Northern Territory) to the southeast. The population history of Indo-Malaysians was more of a swirl in all directions of the compass than a two-layer sequence involving indigenous Australoid foragers and immigrant Neolithic farmers. This hypothesis is consistent with Sulawesi's possible status as a source for the small teeth and non-Australoid tooth shape found widely across late Holocene Indo-Malaysia. Détroit's hypothesis is also consistent with the mtDNA findings of Martin Richards and his associates. These findings include significant population movements from Taiwan into Indonesia and from Mainland Southeast Asia into Malaya associated with the introduction of the Neolithic, but also numerous other dispersals into, within and out from Indo-Malaysia's 'entangled bank' (Hill et al., 2007; Soares et al., 2008; Soares et al., 2011; Bulbeck, 2011).

Colin Groves $(1976,1980)$ developed a strong interest in the macaques and other mammals of Sulawesi, which he explored in the context of both the natural (Groves, 1984) and human-mediated (Groves, 1985, 1995) dispersal of mammals across Indo-Malaysia. Of particular relevance to this paper are his proposals for a sea-borne dispersal of early dogs through Indonesia into New Guinea, and the eastward transport of the Sulawesi warty pig (Sus celebensis) as a domesticate or game animal, prior to the introduction of the dog and pig breeds that could be reasonably associated with the late Holocene migration of Austronesian speakers from Taiwan to Indo-Malaysia. Without reviewing the considerable information now available for human-mediated dispersals of mammals across Indo-Malaysia, we can note that it broadly justifies and indeed extends Colin's open-minded, exploratory perspective on this topic. Colin taught his students to follow the evidence wherever it leads, an approach which this contribution hopefully illustrates.

\section{Conclusion}

Analysis of dental metrical data from Indo-Malaysia suggests a three-stage sequence: very large teeth in the Late Pleistocene; large teeth (except for Sulawesi) between the terminal Pleistocene and mid-Holocene; and small teeth during the late Holocene. Evidence for tooth-size reduction between the Neolithic and recent times was hard to find. This falsifies the model that attributes the small size of late Holocene teeth in Indo-Malaysia to changed selection pressures associated with agriculture and cooking in pots. Also, body-size reduction fails as an explanation for late Holocene tooth-size reduction in Borneo, Java and Malaya. Thus, the change appears to reflect the influx of newcomers, whose teeth were not only smaller than those of their mid-Holocene counterparts but 
also different in 'shape'. Although the study was not designed to investigate the origins of these newcomers, mid-Holocene Sulawesi emerged as a possibility, admittedly based on a small sample with incomplete coverage of the dentition.

\section{Acknowledgements}

The author's data collection from Sulawesi skulls in museums was funded by a large Australian Research Council grant to the author and Colin Groves for the 'Contribution of South Asia to the Peopling of Australasia' project. The author's study of teeth from Lake Towuti in Sulawesi was funded by a large Australian Research Council grant (DP 110101357) to Sue O'Connor, Jack Fenner, Janelle Stevenson (Australian National University) and Ben Marwick (University of Washington). The author thanks Marc Oxenham and an anonymous reviewer for their comments on this paper.

\section{References}

Anggraeni. 1999. The introduction of metallurgy to Indonesia. MA thesis, The Australian National University. Available from: ANU Library.

Barrett MJ, Brown T, Arato G, Ozols IV. 1964. Dental observations on Australian Aborigines: Buccolingual crown diameters of deciduous and permanent teeth. Aust Dent J 9:280-285.

Barrett MJ, Brown T, MacDonald MR. 1963. Dental observations on Australian Aborigines: Mesiodistal crown diameters of permanent teeth. Aust Dent J 8:150-155.

Bellwood P. 1976. Archaeological research in Minahasa and the Talaud Islands, northeastern Indonesia. AP 19:240-288.

Bellwood P. 1978. Man's conquest of the Pacific. Sydney: Collins.

Bellwood P. 1993. Cultural and biological differentiation in Peninsular Malaysia: The last 10,000 years. AP 32:37-60.

Bellwood P. 1997. Prehistory of the Indo-Malaysian Archipelago. Revised edition. Honolulu: University of Hawai'i Press.

Bergman RAM, The TH. 1955. The length of the body and long bones of the Javanese. Doc Med Geogr Trop 7:197-214.

Brace CL. 1976. Tooth reduction in the Orient. AP 19:203-219. 
Brace CL, Hinton RJ. 1981. Oceanic tooth-size variation as a reflection of biological and cultural mixing. Curr Anthropol 22:549-659.

Brace CL, Shao X-q, Zhang Z-b. 1984. Prehistoric and modern tooth-size in China. In: Smith FH, Spencer, F, editors. The origins of modern humans: A world survey of the fossil evidence. New York, NY: Alan R. Liss. pp. 485-516.

Brown PJ. 1978. The ultrastructure of dental abrasion: Its relationship to diet. BA Hons thesis, The Australian National University.

Brown P. 1981. Sex determination of Aboriginal crania from the Murray River Valley: A reassessment of the Larnach and Freedman technique. Archaeol Ocean 16:53-63.

Brown P. 1989. Coobool Creek. Terra Australis 13. Canberra: The Australian National University.

Bulbeck FD. 1981. Continuities in Southeast Asian evolution since the Late Pleistocene. Some new material described and some old questions reviewed. MA thesis, The Australian National University. Available from: ANU Library.

Bulbeck FD. 1982. A re-evaluation of possible evolutionary processes in Southeast Asia since the late Pleistocene. Bull Indo Pac Pre hi 3:1-21.

Bulbeck D. 1996-97. The Bronze-Iron Age of South Sulawesi, Indonesia: < ortuary traditions, metallurgy and trade. In: Bulbeck FD, Barnard N, editors. Ancient Chinese and Southeast Asian Bronze Age cultures. Taipei: Southern Materials Center Inc. Vol II, pp. 1007-1076.

Bulbeck D. 2001. Human remains from Gua Harimau, West Malaysia. Report to the Department of Museums and Antiquity, Kuala Lumpur, Malaysia. Available from: the author on request.

Bulbeck D. 2004. South Sulawesi in the corridor of island populations along East Asia's Pacific rim. In: Keates SG, Pasveer JM, editors. Quaternary research in Indonesia. Mod Quat Re 18. Leiden: A.A. Balkema. pp. 221-258.

Bulbeck FD. 2005a. The Gua Cha burials. In: Zuraina M, editor. The Perak Man and other prehistoric skeletons of Malaysia. Penang: Penerbit Universiti Sains Malaysia. pp. 253-309.

Bulbeck D. 2005b. The Guar Kepah human remains. In: Zuraina M, editor. The Perak Man and other prehistoric skeletons of Malaysia. Penang: Penerbit Universiti Sains Malaysia. pp. 383-423. 
10. Changes in human tooth-size and shape with the Neolithic transition in Indo-Malaysia

Bulbeck D. 2011. Biological and cultural evolution in the population and culture history of Malaya's anatomically modern inhabitants. In: Enfield N, editor. Dynamics of human diversity: The case of Mainland Southeast Asia. Pacific Linguistics 627. Canberra: The Australian National University. pp. 207-255.

Bulbeck D, Adi T. 2005. A description and analysis of the Gua Peraling human remains. In: Zuraina $\mathrm{M}$, editor. The Perak Man and other prehistoric skeletons of Malaysia. Penang: Penerbit Universiti Sains Malaysia. pp. 311-343.

Bulbeck D, Kadir RA, Lauer A, Zamri R, Rayner D. 2005. Tooth-sizes in the Malay Peninsula past and present: Insights into the time depth of the indigenous inhabitants' adaptations. Int J Indigen Res 1:41-50.

Bulbeck D, Lauer A. 2006. Human variation and evolution in Holocene Peninsular Malaysia. In: Oxenham M, Tayles N, editors. Bioarchaeology of Southeast Asia. Cambridge: Cambridge University Press. pp. 133-171.

Bulbeck D, Marwick B, O'Connor S et al. 2013. Archaeology of Lake Towuti: Survey and excavation in South Sulawesi. Poster presented at the Society of American Archaeology Annual Meeting, 3-7 April, Honolulu, Hawaii.

Carlson DS, Van Gerven DP. 1977. Masticatory function and post-Pleistocene evolution in Nubia. Am J Phys Anthropol 46:495-506.

Chia S. 2008. Prehistoric sites and research in Semporna, Sabah, Malaysia. Bulletin of the Society for East Asian Archaeology 2, www.seaa-web.org/ bulletin2008/bul-essay-08-01.htm.

Chia S, Arif J, Matsumura H. 2005. Dental characteristics of prehistoric human teeth from Melanta Tutup, Sabah. In: Zuraina M, editor. The Perak Man and other prehistoric skeletons of Malaysia. Penang: Penerbit Universiti Sains Malaysia. pp. 239-251.

Demeter F. 2006. New perspectives on the peopling of Southeast and East Asia during the late Upper Pleistocene. In: Oxenham M, Tayles N, editors. Bioarchaeology of Southeast Asia. Cambridge: Cambridge University Press. pp. 112-132.

Détroit F. 2002. Origine et evolution des Homo sapiens in Asie du Sud-Est: Descriptions et analyses morphométriques de nouveaux fossils. PhD thesis, Museum National d'Histoire Naturelle. Available from: www.dsifilex.mnhn. $\mathrm{fr} /$ get?k=5ZIu9om0ReQJidRUlY9.

Doran GA, Freedman L. 1974. Metrical features of the dentition and arches of populations from Goroka and Lufa, Papua New Guinea. Hum Biol 3:583-594. 
Taxonomic Tapestries

Groves CP. 1976. The origin of mammalian fauna of Sulawesi (Celebes). Z Säugetierk 41:201-216.

Groves CP. 1980. Speciation in Macaca: The view from Celebes. In: Lindberg D, editor. The macaques: Studies in ecology, behavior and evolution. New York: Van Nostrand Reinhold. pp. 84-124.

Groves CP. 1984. Mammal faunas and palaeogeography of the Indo-Australian region. Cour Forsch Inst Senckenberg 69:267-273.

Groves CP. 1985. On the agriotypes of domestic cattle and pigs in the IndoPacific region. In: Misra VN, Bellwood $\mathrm{P}$, editors. Recent advances in IndoPacific prehistory. Leiden: EJ Brill. pp. 429-438.

Groves CP. 1989. A regional approach to the problem of the origin of modern humans in Australasia. In: Mellars P, Stringer C, editors. The human revolution: Behavioural and biological perspectives on the origins of modern humans. Princeton: Princeton University Press. pp. 274-285.

Groves CP. 1995. Domesticated and commensal mammals of Austronesia and their histories. In: Bellwood P, Fox JJ, Tryon D, editors. The Austronesians: Historical and comparative perspectives. Canberra: The Australian National University. pp. 161-173.

Hanihara T. 1994. Craniofacial continuity and discontinuity of Far Easterners in the late Pleistocene and Holocene. J Hum Evol 27:417-441.

Hill C, Soares P, Mormina M, et al. 2007. A mitochondrial stratigraphy for Island Southeast Asia. Am J Hum Genet 80:29-43.

Howells WW. 1973. The Pacific Islanders. London: Weidenfeld \& Nicolson.

Jacob T. 1964. A human mandible from the Anjar urn field, Indonesia. J Natl Med Assoc 56:421-426.

Jacob T. 1967a. Some problems pertaining to the racial history of the Indonesian region. Utrecht: Netherlands Bureau for Technical Assistance.

Jacob T. 1967b. Racial identification of the Bronze Age human dentitions from Bali, Indonesia. J Dent Res 46:903-910.

Joliffe IT. 2002. Principal components analysis. Second edition. New York, NY: Springer.

Manser JM. 2005. Morphological analysis of the human burial series at Niah Cave. PhD thesis. Available from: UMI Dissertation Services, Ann Arbor, MI. 
Matsumura H, Hudson MJ. 2005. Dental perspectives on the population history of Southeast Asia. Am J Phys Anthropol 127:182-209.

Noerwidi S. 2011-12. The significance of the Holocene human skeleton Song Keplek in the history of human colonization of Java: A comprehensive morphological and morphometric study. MA thesis, Museum National d'Histoire Naturelle. Available from: www.hopsea.mnhn.fr/pc/thesis/ M2Noerwidi_5.pdf.

Pardoe C. 1988. The cemetery as symbol: The distribution of prehistoric Aboriginal burial grounds in southeastern Australia. Archaeol Ocean 23:1-16.

Penrose LS. 1954. Distance, size and shape. Ann Eugen 18:337-343.

Pietrusewsky M. 1981. Cranial variation in Early Metal Age Thailand and Southeast Asia studied by multivariate procedures. Homo 32:1-26.

Pietrusewsky M. 2006. A multivariate craniometric study of the prehistoric and modern inhabitants of Southeast Asia, East Asia and surrounding regions: A human kaleidoscope? In: Oxenham M, Tayles N, editors. Bioarchaeology of Southeast Asia. Cambridge: Cambridge University Press. pp. 59-90.

Snell CARD. 1938. Meschelijke skeletresten uit de duin formatie van Java's zudkust nabij Poeger (Z. Banjoewangi). Surabaya: G. Kolff.

Soares $\mathrm{P}$ et al. 2008. Climate change and post-glacial human dispersals in Southeast Asia. Mol Biol Evol 25:1209-1218.

Soares P et al. 2011. Ancient voyaging and Polynesian origins. Am J Hum Genet 88:239-247.

Storm P. 1995. The evolutionary significance of the Wajak skulls. Scripta Geol 110.

Storm P et al. In press. U-series and radiocarbon analyses of human and faunal remains from Wajak. J Hum Evol.

Tayles NG. 1999. The excavation of Khok Phanom Di: A prehistoric Site in Central Thailand. Volume V: The people. London: The Society of Antiquaries.

Tieng FS. 2010. Hoabinhian rocks: An examination of Guar Kepah artifacts from the Heritage Conservation Centre in Jurong. MA thesis, National University of Singapore. Available from: www.scholarbank.nus.edu.sg/bitstream/ handle/10635/20404/FooST.pdf?sequence $=1$.

Turner CG II. 1983. Sundadonty and Sinodonty: A dental anthropological view of Mongoloid microevolution, origin, and dispersal into the Pacific basin, 
Taxonomic Tapestries

Siberia and the Americas. In: Vasilievsky RS, editor. Late Pleistocene and early Holocene cultural connections of Asia and America. Novosibirsk: USSR Academy of Sciences, Siberian Branch. pp. 147-157.

Zuraina M, Pfister L-A. 2005. The Niah collection of 122 skeletons at the University of Nevada. In: Zuraina $\mathrm{M}$, editor. The Perak Man and other prehistoric skeletons of Malaysia. Penang: Penerbit Universiti Sains Malaysia. pp. 155-173. 


\title{
11. Variation in the Early and Middle Pleistocene: The phylogenetic relationships of Ceprano, Bodo, Daka, Kabwe and Buia
}

\author{
Debbie Argue
}

\section{Introduction}

Despite the increased number of hominin fossils available for the period from one million years ago to c.600 ka clarity about their phylogenetic relationships has not emerged. This is because, while studies of each of these hominins typically include comparative analyses with similar fossil material, in most cases this has resulted in controversy as to their affinities and phylogenetic relationships. Variation during this period is explained by some as representing a single species, $H$. erectus. For others it represents multiple taxa among which $H$. erectus is an exclusively Asian species; or a modified version of this in which observed variation is viewed as continual remodelling of the vault and face that does not involve speciation events (Mbua and Bräuer, 2012). As well, the morphological boundaries of $H$. erectus continue to be stretched. Asfaw and others (2002) referred the Daka cranium (Middle Awash, Ethiopia dated c.800 ka years ago) to $H$. erectus despite clear differences in cranial characters from $H$. erectus s.S., and concluded from cladistic analyses that its morphology is consistent with the hypothesis of a widespread polymorphic and polytypic species existing one million years ago representing a single evolving lineage series of Homo erectus fossils in Africa. Ascenzi and others (1996) referred the Ceprano cranium (Italy), at the time thought to be c. 800 ka but recently dated to c. $450 \mathrm{ka}$ (Muttoni et al., 2009), to $H$. erectus while acknowledging differences from $H$. erectus s.s. such as a larger endocranial volume, no sagittal keel or parasagittal depression. Bodo (600 ka) and Kabwe (date unknown) from Africa are viewed as more derived than Early Pleistocene Homo. Kabwe has been placed in a separate species, $H$. rhodesiensis, or as a subspecies of $H$. sapiens, $H$. sapiens rhodesiensis, in recognition of some perceived relatively modern characters; and Bodo has also been placed in $H$. sapiens rhodesiensis.

There are two other hominins known from this period. The Buia cranium from Eritrea (Abbate et al., 1998) dated to 992 ka (Albianelli and Napoleone, 2004) has not been fully described and was unavailable for study at the time this 
research was undertaken. There are, however, morphological descriptions from which similarities and differences with its contemporaries, Ceprano, Daka, Kabwe and Bodo, may be observed. Secondly, ATD6-69 (partial face) and the frontal (ATD6-15) from the same individual, a child, from Gran Dolina, Spain dating to 780-857 ka (Falguèrès et al., 1999) has been placed in a new species, Homo antecessor (Bermúdez de Castro et al., 1997). Few of the characters used in the present study are available for this hominin. It proved quite unstable in the phylogenetic analyses I performed earlier (Argue, 2010) and its relationships indeterminable. I, therefore, do not include it in these analyses.

I use cladistic analyses incorporating Early and Middle Pleistocene fossil crania from Africa and Asia to test existing hypotheses about the phylogenetic relationships of Ceprano, Daka, Kabwe and Bodo to propose an alternative hypothesis for human evolution during the period c.1 Ma-600 ka.

\section{Background}

\section{Daka}

The Daka cranium, BOU-VP-2/66, (Ethiopia), was found in situ in sediments with a basal 40Ar/39Ar age of $1.042 \pm 0.009 \mathrm{Ma}$; the sediments are reverse polarity and their minimum age is therefore estimated to be c.0.8 Ma (Asfaw et al., 2002). The cranium is well preserved although it has some distortion. Its discoverers concluded from cladistic analyses that it is Homo erectus (Asfaw et al., 2002). Manzi and others (2003), however, using a phenetic approach which quantifies overall similarity of single specimens, found that Daka shares the greatest affinities with two fossil specimens from the Koobi Fora region in Africa, KNM-ER 3733 and KNM-ER 3883, which they attributed to H. ergaster, and that Daka is very different from $H$. erectus. They proposed that Daka is best viewed as part of a local African evolutionary lineage spanning 1.8 Ma-c.1 Ma.

\section{Ceprano}

Many fragments of a cranium were found near the town of Ceprano, Italy, in 1994 (Ascenzi et al., 1996). Originally dated to $>700 \mathrm{ka}$ (Ascenzi et al., 1996), further studies have proposed two younger dates. Muttoni and others (2009) and Manzi and others (2010) report that the level that yielded the hominin cranium has an age of c.0.45 Ma; while a date of $0.35 \pm 4$ Ma (Nomade et al., 2011) based on 40Ar/39Ar dating on K-feldspars retrieved from the sediments that hosted the skull has also been proposed. 
Ceprano was at first referred to $H$. erectus, particularly to late $H$. erectus, by which Ascenzi and others (1996) were referring to the Middle Pleistocene fossils Arago, Petralona, and contemporaries which, as they acknowledge, some would attribute to $H$. heidelbergensis. Clarke (2000) undertook a reconstruction of the cranium during 1997 which resulted in a revision of its reported metric values. Although these changes altered a number of characteristics of the cranium, Clarke (2000) retained it in $H$. erectus; this was supported by Ascenzi and others (2000) based upon their comparison of the character states observed on Ceprano with the distinctive features of $H$. erectus listed by Wood (1991: Table 2.11, p.37). Manzi and others (2001), after declaring their confidence in the new reconstruction, calculated phenetic distances using two methods (Unweighted pair group method (UPGMA); Neighbour Joining (NJ)) to generate unrooted phylogenetic trees. The UPGMA method yielded a tree in which Ceprano is grouped with the African Middle Pleistocene sample (Kabwe, Bodo, Saldhana) and the NJ tree shows Ceprano in an isolated position but nevertheless closer to the African Middle Pleistocene group than to Sangiran (Indonesian) and Zhoukoudian (China) H. erectus, Dmanisi, and other Early Pleistocene African crania. Mallegni and others (2003) performed a cladistic analysis using 30 cranial characters yielding eight equally parsimonious trees from which a strict-consensus tree showed Ceprano and Daka in a monophyletic (sister taxa) group with $84 \%$ bootstrap support although they found only one unambiguous synapomorphy (short cranial vault) and one ambiguous synapomorphy (presence of sharply angulated occipital profile) for the clade. They proposed a new species for Ceprano, $H$. cepranensis sp. nov., based upon their assessment that it possesses a unique suite of characters, Beyond a brief discussion of shared characters, they did not engage in a discussion of the apparent close relationship of Ceprano and Daka.

Ceprano, then, has been referred to 'late H. erectus' ( $=H$. heidelbergensis)(Ascenzi et al., 1996); H. erectus (Clarke, 2000; Ascenzi et al., 2000), and specifically not $H$. heidelbergensis (Clarke, 2000); a new species H. cepranensis sp. nov. (Mallegni et al., 2003); and, possibly, H. heidelbergensis (Manzi et al., 2001).

\section{Bodo}

Bodo is a partial cranium (Bodo d'Ar, Ethiopia) estimated to be $600 \mathrm{ka}$ based on biostratigraphic and archaeological considerations (Clarke et al., 1994). In their original announcement, Conroy and others (1976) refrained from making a taxonomic determination. Later, Kalb and others (1982) assigned Bodo to $H$. sapiens rhodesiensis, including it in a taxon with Kabwe (H. rhodesiensis; Smith Woodward, 1921); Stringer (1984) conditionally compared Bodo to H. erectus s.s., although he recognised the possible phylogenetic significance of some $H$. sapiens features of this cranium; Groves (1989) attributed Bodo to a subspecies 
of H. sapiens, as did Adefris (1992) in his dissertation on this fossil (although he preferred the term 'archaic Homo sapiens'); Rightmire (1996) undertook a detailed description and comparative analysis of the Bodo cranium, concluding that it seems most reasonable to group it with Kabwe and similar specimens from the Middle Pleistocene sites in Africa and Europe.

\section{Kabwe}

Kabwe 1 was found during mining operations in the basal wall of a steeply sloping cleft emanating from a cave within a small hillock at Broken Hill, Zimbabwe (then Rhodesia). It has not been dated, and, as it seems to have rolled down the cleft at an unknown time, and was annually inundated by a high water table (Hrdlicka, 1930), so attempts to date it, particularly by using the Electron Spin Resonance method, would be compromised. Further, the hillock no longer exists, having been completely mined. It has not, then, been possible to reliably estimate Kabwe's age. It was originally attributed to a new species, $H$. rhodesiensis by Smith Woodward (1921) who viewed it as quite different from $H$. neanderthalensis and $H$. erectus. Having compared the Broken Hill skull to those of $H$. neanderthalensis, Omo I and II, Hopefield, and OH 9, Rightmire (1976) gave Kabwe a subspecific designation $H$. sapiens rhodesiensis that probably evolved from local groups of $H$. erectus.

Bräuer (1984) assigned Kabwe to 'early archaic $H$. sapiens' ${ }^{1}$ in a group that included Bodo, Hopefield, Eyasi, Ndutu and other African crania, as the cranial vaults are more expanded than $H$. erectus. Groves (1989) placed Kabwe in a subspecies of $H$. sapiens, $H$. sapiens heidelbergensis, that includes the African and European Middle Pleistocene fossils; Kabwe, Bodo, Tighenif and later fossils from Europe and Africa.

Daka, Ceprano, Bodo and Kabwe are, then, each variously attributed to a range of species. The objective is to resolve the phylogenetic position of each so that we may generate hypotheses concerning human evolution during his period.

\section{Materials and methods}

Information about cranial characteristics was obtained from original fossil material and casts of Early and Middle Pleistocene Homo so that cladistic analyses could be performed.

1 The term 'early archaic H. sapiens' is now considered unsatisfactory, being a descriptive category rather than a taxonomic term, and has been generally replaced with $\mathrm{H}$. heidelbergensis; the taxon is considered to comprise similar hominins from Africa and Europe. 
The comparative sample comprises:

- Sangiran 2, 4, 9, 17 and Trinil (H. erectus);

- KNM-ER 1813, OH 24 (Homo habilis; casts);

- KNM-ER 3733;

- KNM-ER 3883;

- Daka;

- Ceprano;

- Bodo; and

- Kabwe (H. rhodesiensis).

I compiled 89 cranial character states (Appendix 1) of which 62 are phylogenetically informative for this set of OTUs (Operational Taxonomic Units). Character states are derived from Lahr (1996), and Schwartz and Tattersall (2002); and Zeitoun (2000) who referred to Weidenreich (1943), MacIntosh and Larnach (1972), Sartono and Grimaud (1983), Grimaud (1982), and Hublin (1978).

Cladistic analysis is widely used in the biological sciences as a methodological approach to phylogenetic reconstruction and has been applied to hominin taxa since the 1970s. It assumes that shared features observed among taxa can be explained by hypotheses of common ancestry that are represented by sets of characters in a hierarchical pattern of taxa (Faith and Cranston, 1991) and is based upon Hennig's (1966) approach to systematics, specifically his approach to descent with modification. Descendants acquire traits transmitted genetically from their ancestors and these are passed on to subsequent descendants (Humphries, 2002). The aim of cladistic analysis is to identify taxa that share a common ancestor by finding, or distinguishing, shared derived character states (synapomorphies) from among the characters in the data set. Cladistic analysis produces possible phylogenetic trees, called cladograms, which are branching diagrams that depict sister group relationships. The cladogram groups OTUs into clusters called clades, and these represent hypotheses about relationships among OTUs. Cladistic analysis is based upon the total number of character changes necessary to support the relationship of OTUs in a tree. The shortest trees are those that account for the observed differences among taxa in the smallest number of evolutionary steps. They are the most parsimonious trees and are generally considered to present the best working hypotheses (after Argue et al., 2009). The phylogenetic trees presented here are derived from my data and analyses.

Before performing a cladistic analysis it seems useful to assess the probability that the phylogenetic trees derived from the data could have arisen by chance alone (Faith, 1991). To test for this I performed a Permutation Tail Probability Test (PTP) in which a ' $\mathrm{p}$ ' value of 0.05 or less would indicate that the null 
hypothesis, that the data are random, is rejected while noting that the meaning of a ' $\mathrm{p}$ ' value of $>0.05$ is controversial (Carpenter et al., 1998; Källersjö et al., 1992; Trueman, 1993; Fu and Murphy, 1999). For this data and taxon set, the PTP value (excluding the outgroup) is $\mathrm{p}=0.01$ and I consider that these data therefore represent a non-random tree structure.

I perform a heuristic search of the cranial data using PAUP* (Phylogenetic Analysis Using Parsimony) Version 4.0b10 for Macintosh (Swofford, 2002), to find the most parsimonious tree or trees. I examine the relative strength of the clades identified by using 1,000 replications of the PAUP bootstrap test. The bootstrap analysis begins by creating a number of pseudo replicate data matrices from the original dataset by resampling the original data matrix and creating a matrix of the same size as the original. Any data series might be represented in any pseudo matrix once, twice, many times, or none at all. The frequency at which a set of clades appear in these reiterations constitutes the bootstrap score. If a particular clade has a high number of characters supporting it, and few characters refuting its monophyly, the chances are that at least some of these will appear in the resampling process and the group will appear in many of the trees generated. If evidence for the monophyly is weak or there is a high level of homoplasy (similar character state in more than one taxon derived from mechanisms other than immediate shared ancestry) in the original matrix, the group might not appear at all, or at low frequency; and the probabilities obtained are not the probability of the reality of clades as such, but reflect the relative support of the clades, given the assumptions in the technique (Wiley and Liebermann, 2011).

The most parsimonious trees found in the initial PAUP search are transposed into MacClade (Maddison and Maddison, 1982). MacClade provides an interactive environment for exploring phylogeny and was developed to help biologists explore relationships between OTUs (Maddison and Maddison, 1982). In MacClade's tree window, phylogenetic trees (cladograms) can be manipulated and alternative hypotheses for an individual taxon, or groups of taxa, may be explored. I, therefore, reproduce the shortest tree produced in the initial analysis (that used PAUP*) in MacClade so that I can test hypotheses that have been presented for each OTU by constraining relevant OTUs and comparing the ensuing tree lengths with the length of the shortest tree. I can test, for example, the likelihood that Daka shared a common ancestor with Ceprano or H. erectus; or if Kabwe and Bodo likely shared a common ancestor.

Clades are further tested using a topology-dependent permutation tail probability test (T-PTP); this tests the support for clades, or sister taxa, shown in the cladogram (Faith and Cranston, 1991; Faith, 1991). The test is defined as the estimate of the proportion of times that a given clade can be found, generated from permuted data that are as short as, or shorter than, the original 
tree. That is, it compares the degree of corroboration for the observed data to that expected by chance alone, so is a test of monophyly of selected nodes. I reject the null hypothesis, that the data have no cladistic structure beyond that produced by chance, at the 0.05 level if fewer than five out of 100 of the trees have a length as short, or shorter, than the cladogram, that is, if the T-PTP result is $\geq 0.05$.

\section{Results}

\section{Shortest trees}

There are three shortest trees 245 steps long (Figure 11.1). In each case, Daka, Ceprano and Bodo form a branch but its configuration varies; in one tree these OTUs form a branch with $H$. rhodesiensis (Tree 3).

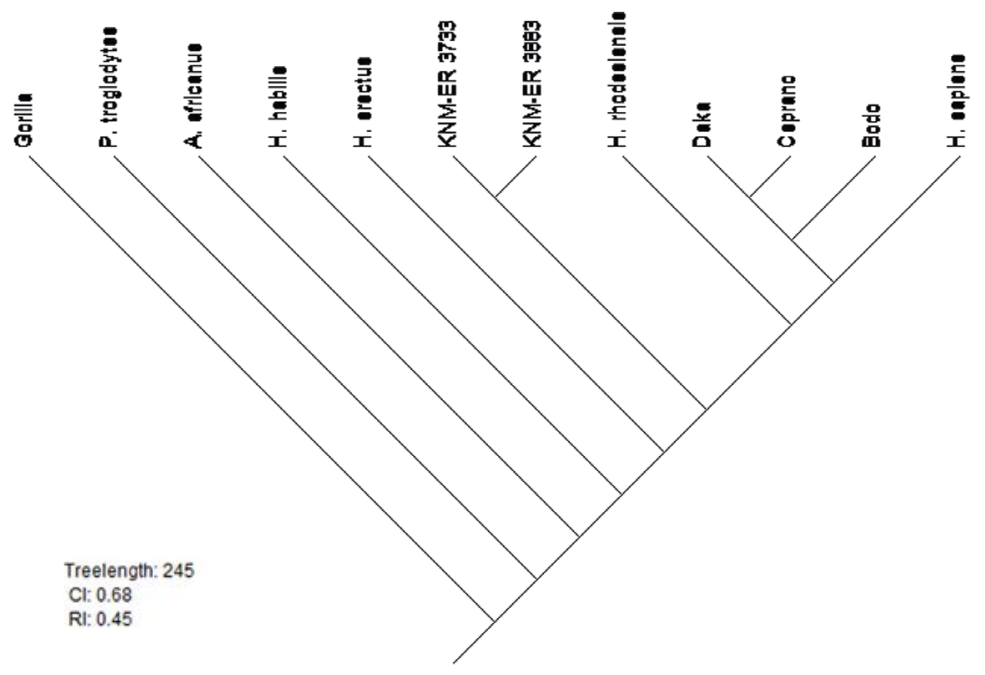

Figure 11.1a: Three shortest trees.

Source: Author's calculations. 


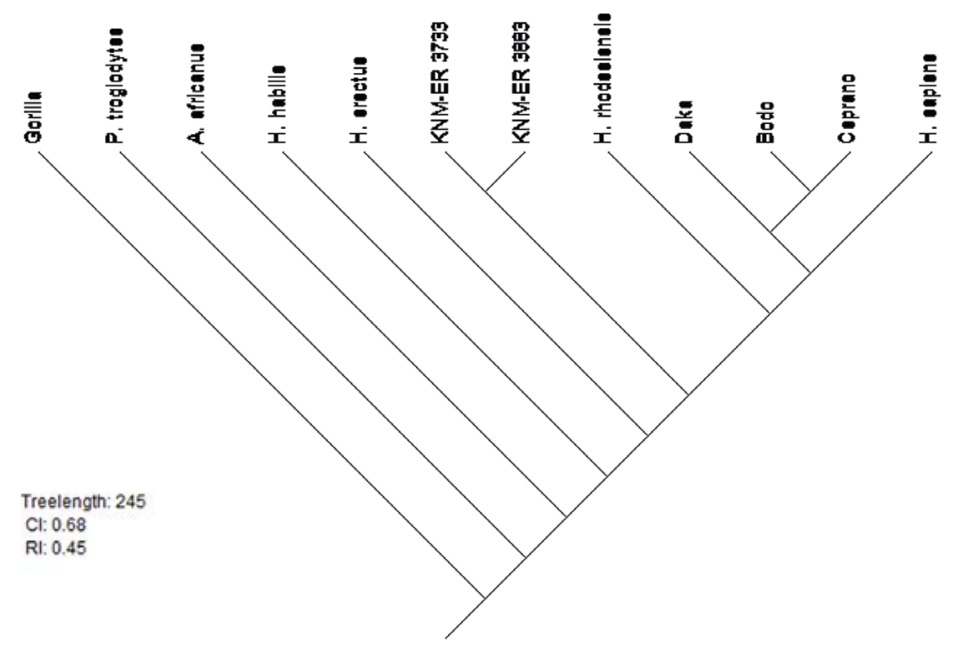

Figure 11.1b: Three shortest trees.

Source: Author's calculations.

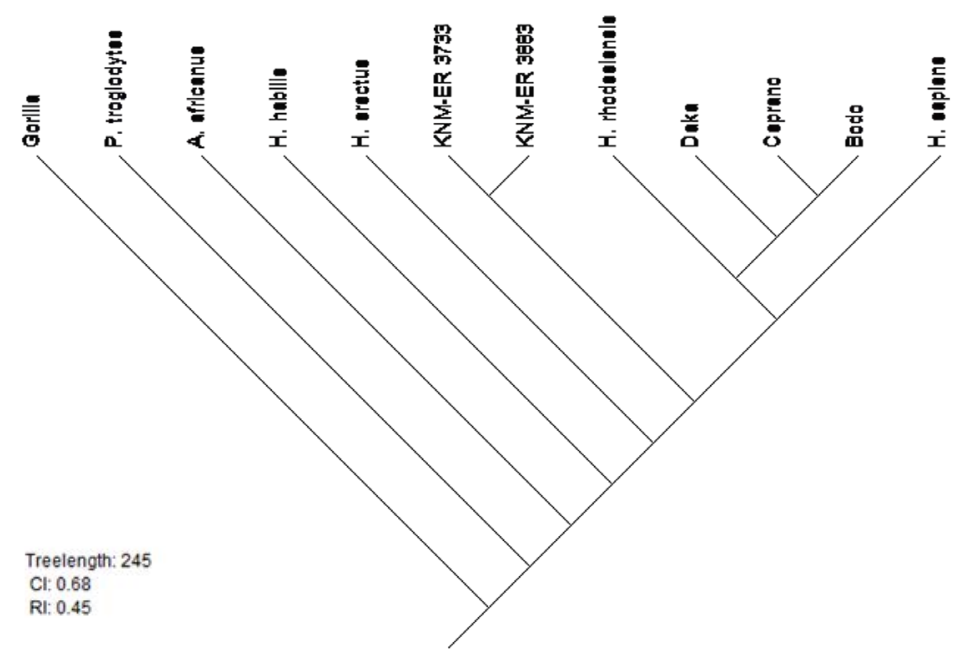

Figure 11.1c: Three shortest trees.

Source: Author's calculations. 


\section{Bootstrap analysis}

The bootstrap analysis (Figure 11.2) shows two clades with $>50 \%$ support. The value for the clade comprising Bodo and Ceprano is 54\%; for the Koobi Fora group it is $61 \%$. Neither of these results reaches the threshold of $70 \%$ (Hillis and Bull, 1993). This would suggest that either there is a high level of homoplasy in the data or evidence for the clades is not strong (or both). The Consistency Index (CI) for these data is 0.68 where a value of 1.0 indicates that there is no homoplasy. This CI suggests that there is indeed likely to be homoplasy in these data but one might also suppose that the support for the clades is not particularly strong.

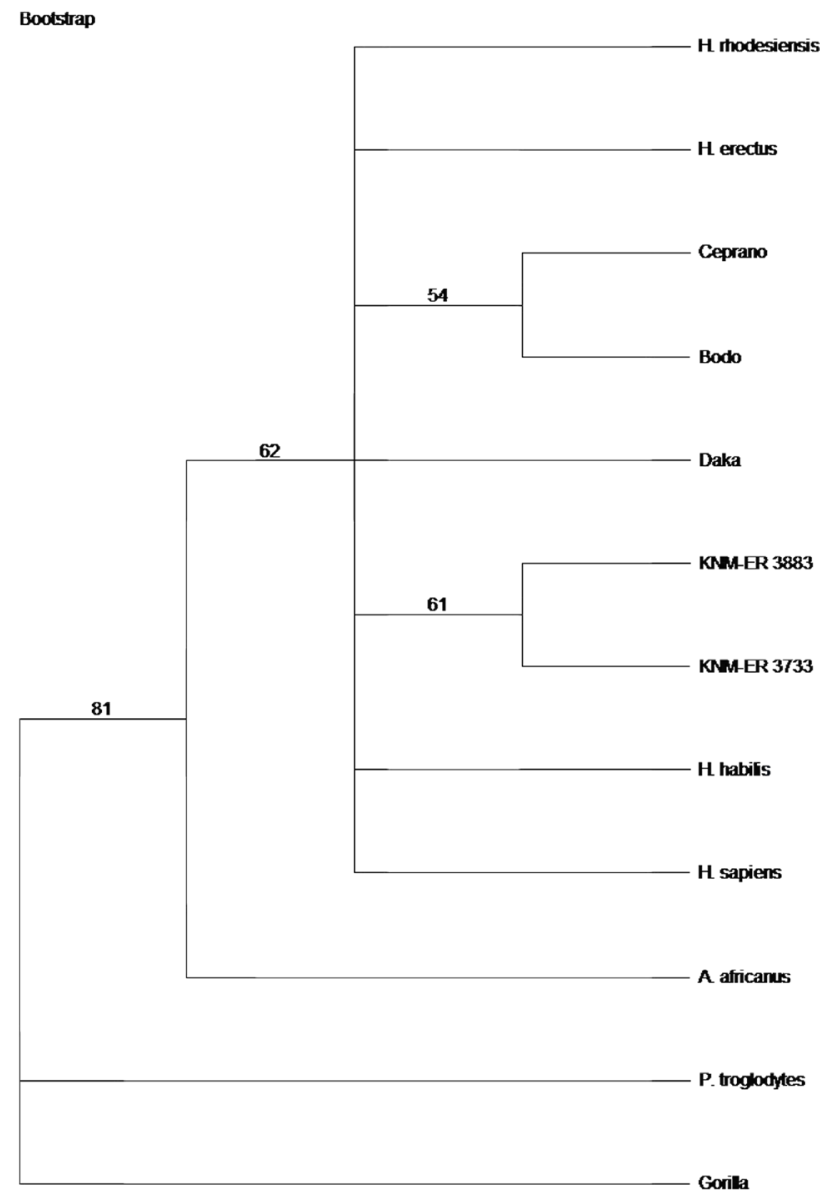

Figure 11.2: Bootstrap analysis.

Source: Author's calculations. 
I had earlier tested our data for randomness using the PTP test (above), which led me to conclude that the data is not random and represents phylogenetic structure. I, therefore, am satisfied that the results provide a valid basis upon which to test hypotheses and I treat the clades as representing phylogenetic relationships. Nevertheless I test for the likelihood that each clade on the shortest tree is monophyletic as opposed to occurring by chance alone.

\section{Testing clades and branches}

\section{Bodo, Daka and Ceprano}

As Bodo and Ceprano form a clade in two of the shortest trees I test the likelihood that this apparent sister taxon relationship occurred by chance alone. The T-PTP result is $\mathrm{p}=0.04$ indicating that Bodo and Ceprano do not group by chance alone.

The clade shares four possible ${ }^{2}$ synapomorphies:

- Post-orbital lateral depression (a depression on the lateral supraorbital region bounded by the temporal line)

- Weak metopic keeling

- Anteroposterior width of mandibular fossa is narrow

- The posterior edge of the tuberculum articular in norma basilaris is arched.

In another of the shortest trees, Ceprano and Daka form sister taxa. The T-PTP for the clade is, however, $\mathrm{p}=0.19$. This would suggest that this clade would come together by chance alone. In fact, the clade shares only two possible synapomorphies: the articular eminence is higher relative to posterior wall of glenoid fossa; and each has an angular torus. In comparison, Mallegni and others' (2003) analysis shows a strongly supported (84\%) Daka-Ceprano clade, notwithstanding that the OTUs share only two synapomorphies: a short cranial vault; and the presence of a sharply angled occipital profile. Based upon our T-PTP result, we would reject Tree 1 (Figure 11.1) as the most parsimonious solution to the data.

The monophyly for Ceprano, Bodo and Daka, however, is not rejected; the T-PTP is $p=0.04$; that is, it is unlikely that this clade would form by chance alone. If we accept the T-PTP result above for Ceprano and Daka, rejecting it as a viable clade within the branch, the most parsimonious solution is that Bodo and Ceprano are sister taxa; and Daka shares a common ancestor with each of them. Ceprano, Bodo and Daka share the following five possible synapomorphies:

2 A particular character state might occur in taxa that are not included in this analysis, so we cannot say categorically that a given state is uniquely synapomorphic for the sister taxa in this study. 
- The frontal edge is convex anteriorly in norma verticalis

- The supraorbital torus is interrupted in the medial zone, forming two 'mono-tori'

- Temporal squama low in relation to vault

- Posterior part of tympanic joins anterior part of mastoid process

- Postglenoid process does not extend laterally beyond extent of tympanic.

\section{Daka, Ceprano, Bodo, H. rhodesiensis}

The T-PTP for the branch comprising Bodo, Ceprano, Daka and H. rhodesiensis is also $\mathrm{p}=0.04$. It shares five synapomorphies:

- Depression at glabella

- Angulation between the pre-glenoid planum and the posterior slope of the articular tuberculum (homoplasy with $A$. africanus)

- The supraorbital margin is thick, rounded and not demarcated from the roof of the orbit

- A pre-glenoid planum precedes the glenoid cavity (homoplasy with $A$. africanus and $H$. erectus)

- A very prominent temporal band on the frontal (homoplasy with the two Koobi Fora hominins).

Before presenting hypotheses for human evolution during this period I test hypotheses previously presented for Daka, Bodo, and Ceprano. In this case, I use the phylogeny in Tree 3 (Figure 11.1) in which Bodo, Ceprano and Daka are on a branch with $H$. rhodesiensis, as the analyses so far would suggest that this is the most parsimonious solution to the data.

\section{Testing other hypotheses for OTUs}

\section{Bodo}

Bodo has been named $H$. sapiens rhodesiensis (Kalb et al., 1982); a subspecies of H. sapiens (Groves, 1989; Adefris, 1992) and, conditionally, H. erectus (Stringer, 1984). The shortest trees in this analysis show Bodo on a branch with, amongst others, $H$. rhodesiensis.

\section{Bodo and $H$. rhodesiensis}

To argue $H$. rhodesiensis subspecies status for Bodo we would expect the tree in which these OTUs are constrained to be as short, or nearly so, as the shortest tree for this set of OTUs. When Bodo is constrained to form a clade with $H$. rhodesiensis, however, the shortest trees length is 253 steps (Figure 11.3). This is 
eight steps longer than the shortest tree $(\mathrm{L}=245)$; and the CI has decreased to 0.66. Such a tree, then, is a less parsimonious explanation of the data. Bodo is unlikely to be a subspecies of $H$. rhodesiensis.

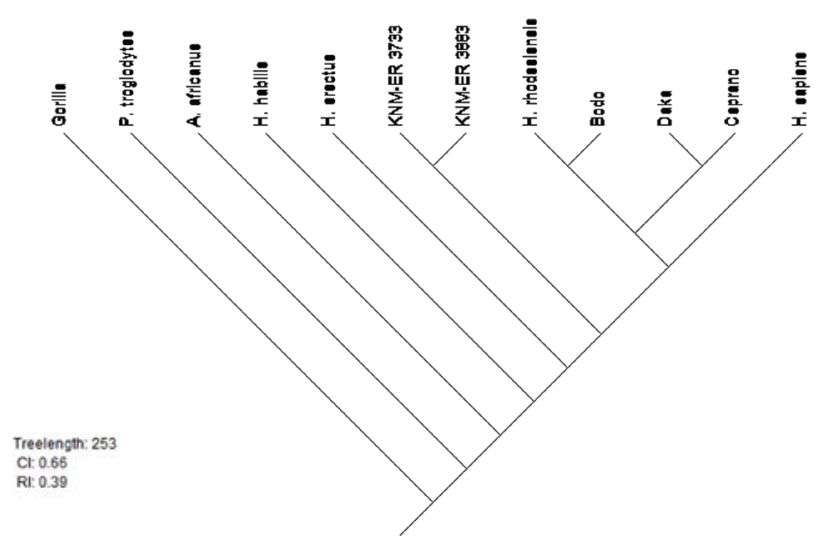

Figure 11.3: Bodo and $\boldsymbol{H}$. rhodesiensis.

Source: Author's calculations.

Bodo and $H$. erectus

The shortest tree in which Bodo and $H$. erectus are constrained to form a clade is $\mathrm{L}=249$ (Figure 11.4), four steps longer than the shortest tree $(\mathrm{L}=245)$ for Bodo. The T-PTP for the constrained clade is $\mathrm{p}=0.18$. This is, therefore, also an unlikely solution for Bodo.

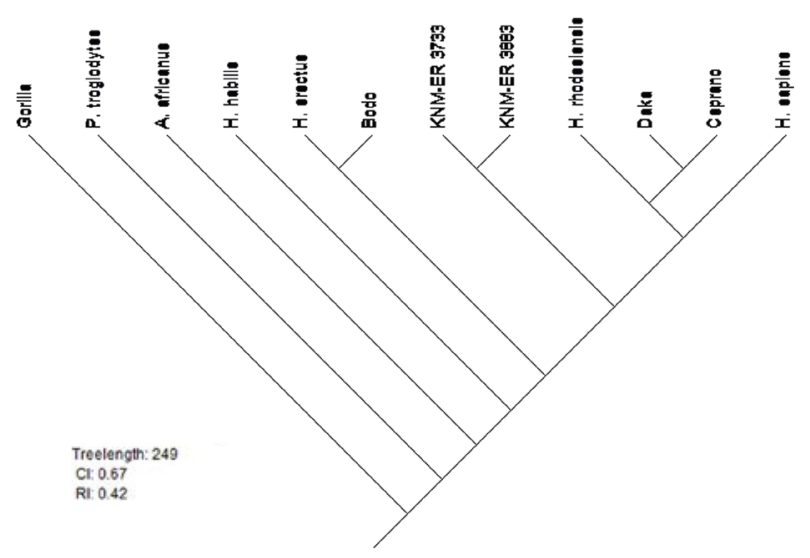

Figure 11.4: Bodo and $\boldsymbol{H}$. erectus.

Source: Author's calculations. 


\section{Daka}

\section{Daka and $H$. erectus}

Asfaw and others (2002) proposed that Daka is H. erectus. When this hypothesis is tested in the present study by constraining Daka to form a clade with $H$. erectus the shortest tree length is 251 (Figure 11.5); this is six steps longer than the most parsimonious tree $(\mathrm{L}=245)$, and the T-PTP is $\mathrm{p}=0.27$; a phylogeny in which Daka and $H$. erectus form sister taxa is a less parsimonious solution for Daka than that identified in the shortest trees.

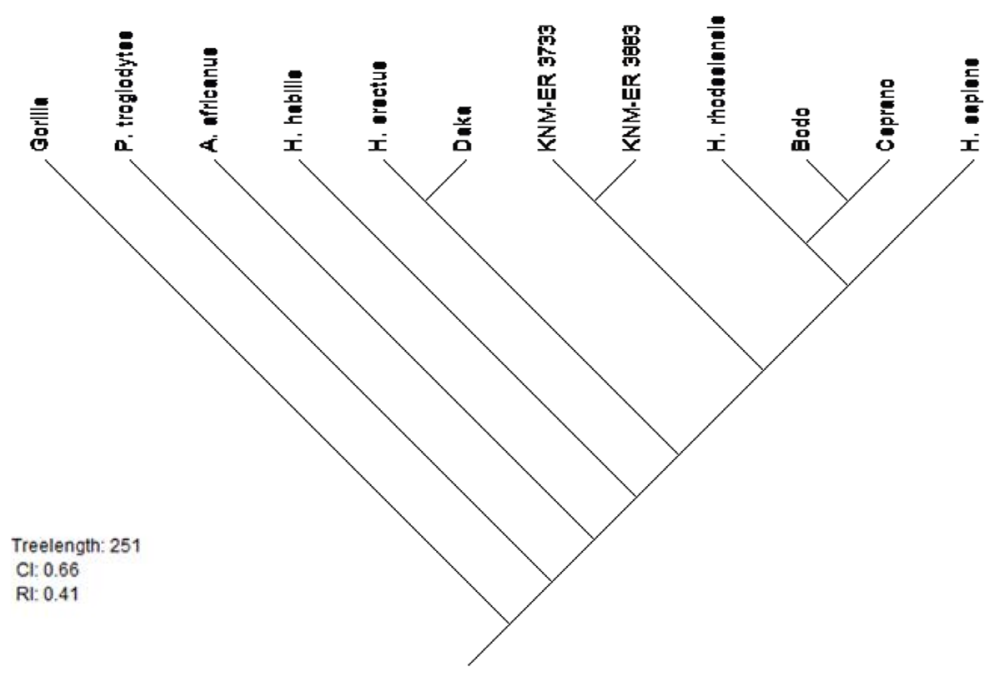

Figure 11.5: Daka and $\boldsymbol{H}$. erectus.

Source: Author's calculations.

\section{Daka and KNM-ER 3733 and KNM-ER 3883}

I explore the possibility for a chronological and anatomical morphocline from the Koobi Fora hominins KNM-ER 3733 and KNM-ER 3883 to Daka/Buia as proposed by Asfaw and others (2002) by testing if it is possible that Daka shared an immediate common ancestor with KNM-ER 3733 and KNM-ER 3883. The outcome (Figure 11.6) is a tree nine steps longer than the most parsimonious; it is most unlikely Daka and the Koobi Fora hominins are phylogenetically closely related. 


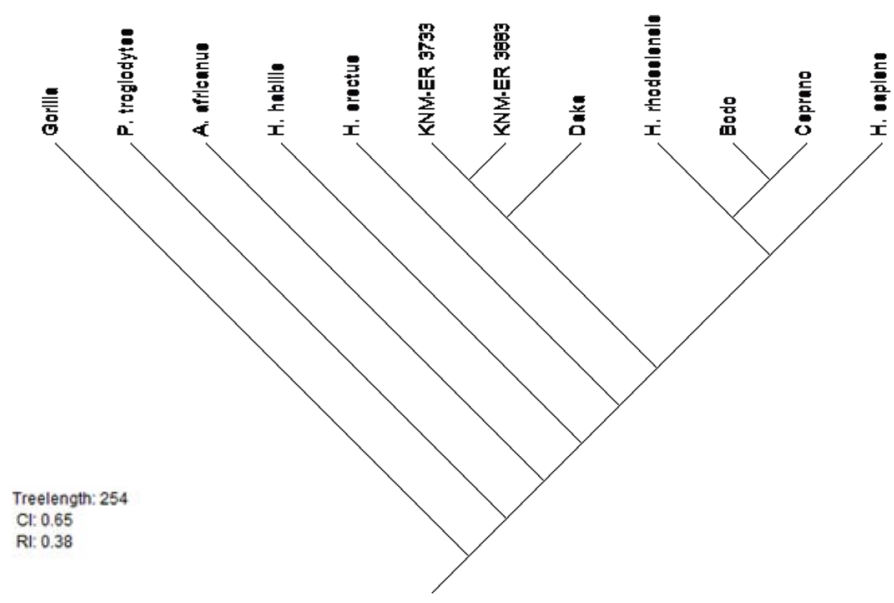

Figure 11.6: Daka and KNMs.

Source: Author's calculations.

\section{Ceprano}

Ceprano and $H$. erectus

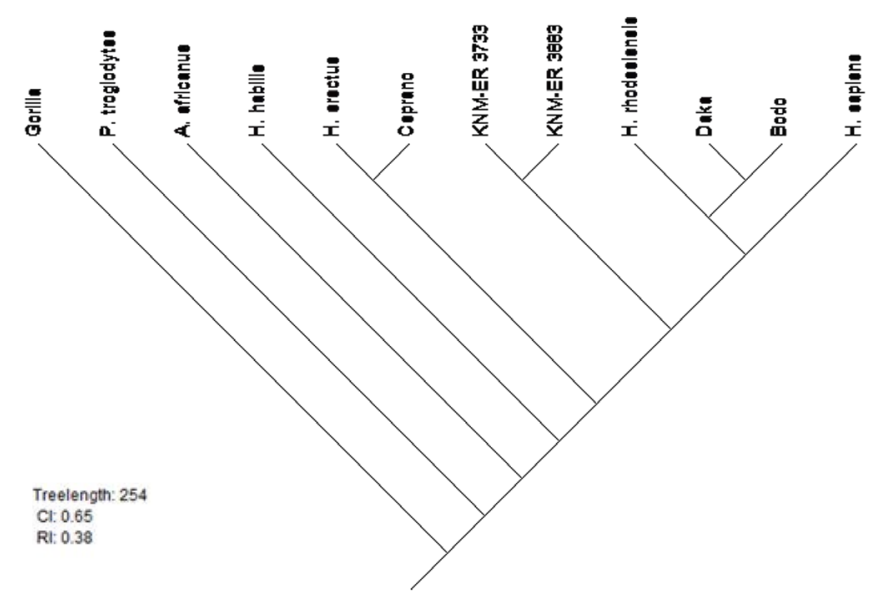

Figure 11.7: Ceprano and $H$. erectus.

Source: Author's calculations.

Ascenzi and others (2000) attributed Ceprano to $H$. erectus based upon a comparison of Ceprano's characteristics with a list of $H$. erectus characteristics 
compiled by Wood (1991). I tested for a possible phylogenetic relationship between Ceprano and $H$. erectus S.s., The shortest tree that includes the clade \{Ceprano, H. erectus\} is 254 steps (Figure 11.7), nine steps longer than the shortest tree $(\mathrm{L}=245)$; it is difficult to argue, then, that Ceprano shared an immediate common ancestor with Sangiran H. erectus.

\section{Buia}

Although Buia is unavailable for study, there is considerable published morphological information (Abbate et al., 1998; Macchiarelli et al., 2004). The cranium is estimated to date from $992 \mathrm{ka}$ (Albianelli and Napoleone, 2004) and is thus close in geological age to Daka (1.042 $\pm 0.009 \mathrm{Ma}$; Asfaw et al., 2002). Buia comprises a cranium, a large part of the facial skeleton, the base (Macchiarelli et al., 2004); and a left symphysis (Bondioli et al., 2006). Preliminary descriptions (Abbate et al., 1998; Macchiarelli et al., 2004) indicate that the braincase is very long $(204 \mathrm{~mm})$ compared to its width $(130 \mathrm{~mm})$, and is relatively high (Abbate et al., 1998).

Buia and Daka share many similarities. While the Buia cranium is longer than Daka (180 mm; Asfaw et al., 2002), both have an endocranial volume (ECV) of 995 cc (Daka: Asfaw et al., 2002; Buia: Macchiarelli et al., 2004). In lateral view the frontal profiles are rounded and rise relatively steeply from the supraorbital sulcus; the occipital profiles are rounded with an incipient bun. In frontal profile, both crania are widest inferiorly and have relatively straight-sided parietal walls but Buia's lateral walls converge inferiorly (Macchiarelli et al., 2004); reminiscent of Ceprano. Both Buia and Daka have reduced post-orbital constriction. The only section of the supraorbital available for Buia, the right lateral half, closely matches the form of the same region on Daka. There are, then, a number of phenetic similarities between these almost contemporaneous Homo that lived $600 \mathrm{~km}$ apart in the Danakil Depression, making it difficult to argue that they are from separate populations. A more detailed comparative analysis may show otherwise, of course, when Buia is available for study.

Buia and Ceprano also share a number of similarities: the parietals converge slightly inferiorly (Buia: Macchiarelli et al., 2004; Ceprano: Ascenzi et al., 1996: 419; pers. obs.); they have a small depression on the same area laterally on the front of the supraorbitals (Ceprano: pers. obs.; Buia: Macchiarelli et al., 2004, Fig 1); on both the frontals rise steeply; supraorbitals are interrupted at glabella (Buia: Macchiarelli et al., 2004); they have reduced post-orbital constriction; mastoid processes are short and broad; there are only modest external occipital protrusions, and slight angular tori. Ceprano has a slightly greater ECV, of $1185 \mathrm{cC}$ (72 cc larger than Buia and Daka). They differ, however, in that the temporal lines on Buia disappear early on the parietals, whereas Ceprano's temporal 
lines continue to asterion; Buia does not have an occipital torus (Macchiarelli et al., 2004), whereas Ceprano does; glabella is in a forward position on Buia (Macchiarelli et al., 2004), while this area is depressed on Ceprano; and Buia has an occipital 'bun' (Abbate et al., 1998, Figure 2b), which is absent on Ceprano.

\section{Discussion}

Identifying relationships between taxonomic units is of critical concern to the study of Homo. Cranial analyses were undertaken so that predictions could be made about the phylogenetic relationships between Early and Middle Pleistocene hominins Ceprano, Daka, Bodo and Kabwe.

Ceprano, Bodo, Daka and Kabwe form a supported branch in which Ceprano and Bodo appear to be the more derived taxa. Groves (1989) had also found Kabwe, Bodo and others fitted a common pattern and did not comprise a western variant of $H$. erectus; he attributed the group to $H$. sapiens heidelbergensis.

I hypothesise that Ceprano, Bodo, Daka and Kabwe form a species for which the prior available name is $H$. rhodesiensis (Smith Woodward, 1921). In this study $H$. rhodesiensis is characterised by an angulation between the pre-glenoid plane and the posterior slope of the articular tuberculum; a depression at glabella; a supraorbital margin that is thick, rounded and not demarcated from the roof of the orbit; a pre-glenoid plane anterior to the glenoid fossa; and a very prominent temporal band on the frontal.

While Buia was unavailable and could not be included in the cladistic analysis, a comparative assessment shows that it is very similar to Daka, and, to a slightly lesser extent, Ceprano. While I would propose from the discussion above that Buia is closely related to Daka at least, further analyses need to be undertaken when this cranium is fully described.

$H$. rhodesiensis thus composed is not closely related to $H$. erectus. $H$. erectus forms a separate lineage in the most parsimonious trees in which Daka, Ceprano and Bodo do not belong. Nor can Daka be shown to belong in the same species as the Koobi Fora hominins. 


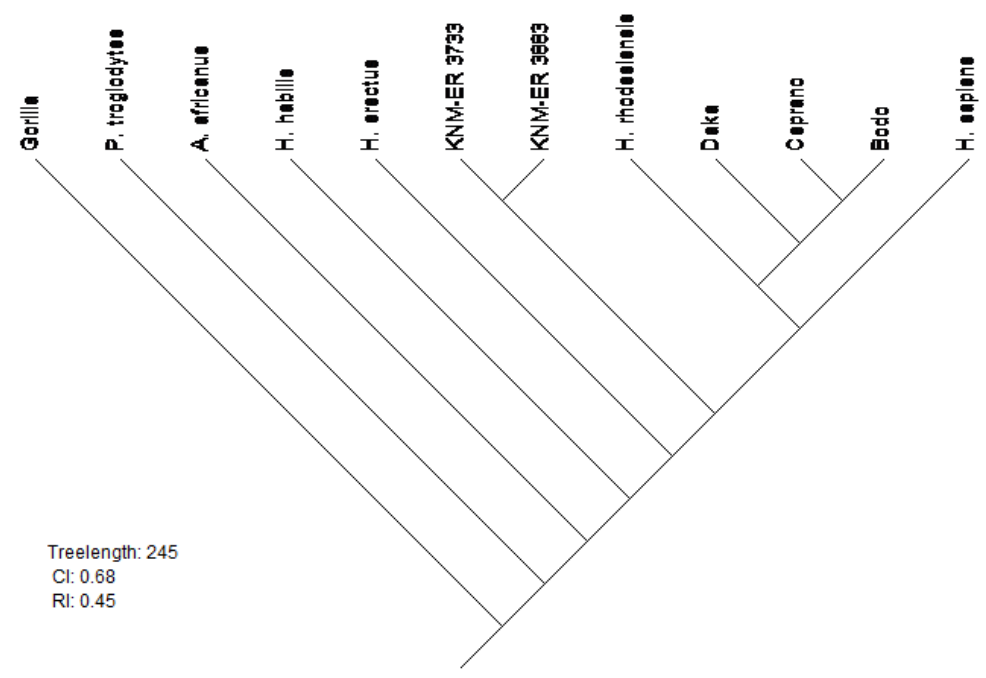

Figure 11.8: Preferred phylogeny.

Source: Author's calculations.

The key development in the evolution of the clade exemplified by Daka, Bodo, and Ceprano is a marked expansion of the vault, and, in Ceprano and Buia, the inferior contraction in the sides of the vault suggesting brain expansion during this period. Brain expansion in Homo is associated with a number of cranial characters: parietal bossing; high contour of the temporal squama; rounding of the occiput; and a relatively steeply sloping frontal (Rightmire, 1996). Kabwe has the first two of these characters, and a relatively large cranium with an ECV of 1300 cc (Holloway et al., 2004: 120). While Ceprano, Daka and Bodo differ in some aspects of cranial shape, they nevertheless represent an evolutionary shift in the overall form of the braincase, a shift we can also observe in Buia. Like Kabwe, vault walls are nearly parallel in Daka, but converge slightly inferiorly in Ceprano and Buia; and postorbital constriction is reduced in all. Ceprano and Daka are more derived than $H$. rhodesiensis in that their frontals rise more steeply, and they have rounded occipitals. Ceprano also has a relatively high temporal squama but does not have parietal bossing. Daka, too, lacks some of the characters associated with cranial expansion, such as a relatively high temporal squama. Although Bodo has a relatively large cranial capacity (1250 cc; Holloway et al., 2004) it does not show some of the other characters associated with an expanded braincase such as parietal bossing, greatest width at the parietals, or reduced post-orbital constriction, although its occipital seems to be rounded and it has a relatively high temporal squama contour. That is, although Bodo, Daka, and Ceprano all show marked cranial expansion in ECVs and related characters, none show all characters. 
Buia shares many characteristics with Daka and Ceprano and I hypothesise that there is a close phylogenetic relationship between them. Further, Buia and Daka are the same age and, arguably, the populations from which they came lived in geographical proximity.

\section{Conclusions}

The paradigm for human evolution in the late Early Pleistocene-Middle Pleistocene comprised a model in which one species, $H$. erectus, is present. As more hominin crania were discovered, for the most part they were placed in this species, requiring an ongoing broadening of the definition of $H$. erectus to accommodate the increasing variation in cranial morphology the newer discoveries presented. This is particularly so for the larger-brained crania Daka, Ceprano, and Bodo.

When these are assessed using cladistic analyses, in which sister-taxon relationships are sought, this group of hominins formed a supported branch that included $H$. rhodesiensis. This species shares a number of synapomorphies, but of equal importance is the evidence for expansion of the brain; and, for the first time, two hominins, Ceprano and Buia, show expansion at the parietals, rather than the prevailing condition in which crania are widest in a lower plane.

$H$. rhodesiensis is well separate from $H$. erectus in the phylogeny. Further, none of the target OTUs could be shown to have shared an immediate common ancestor with $H$. erectus.

The morphological variation in hominins during this period, then, is better explained by speciation than stasis; and the tendency to place new hominins within a framework comprising one species, $H$. erectus, is not supportable.

\section{References}

Abbate E, Albianelli A, Azzaroli A, Benvenuti M, Tesfamariam B, Bruni P, Cipriani N, Clarke RJ, Ficcarelli G, Macchiarelli R, Napoleone G, Papini M, Rook L, Sagri M, Tecle TM, Torre D, Villa I. 1998. A one-million-yearold Homo cranium from the Danakil (Afar) Depression of Eritrea. Nature 393:458-460.

Adefris T. 1992. A Description of the Bodo cranium: An archaic Homo sapiens cranium from Ethiopia. A dissertation in the Department of Anthropology, York University. Michigan, USA: UMI dissertation services. 
Albianelli A, Napoleone G. 2004. Magnetostratigraphy of the Homo-bearing Pleistocene Dandiero Basin (Danakil Depression, Eritrea). Riv Ital Paleontol S 110:35-44.

Argue D, Morwood M, Sutikna T, Jatmiko, Saptomo EW. 2009. Homo floresiensis: A cladistic analysis. J Hum Evol 57:623-629.

Argue D. 2010. The Genus Homo in the Early and Middle Pleistocene of Africa and Europe. PhD thesis, The Australian National University.

Ascenzi A, Biddittu I, Cassoli PF, Segre AG, Naldini E. 1996. A calvaria of late Homoerectus from Ceprano, Italy. J Hum Evol 31:409-423.

Ascenzi A, Mallegni F, Manzi G, Segre AG, Naldini ES. 2000. A re-appraisal of Ceprano calvaria affinities with Homo erectus, after the new reconstruction. J Hum Evol 39:443-450.

Asfaw B, Gilbert WH, Beyenne Y, Hart WK, Renne PR, Wolde G, Vrba ES, White TD. 2002. Remains of Homo erectus from Bouri, Middle Awash, Ethiopia. Nature 416:317-319.

Bermúdez de Castro JM, Arsuaga JL, Carbonell E, Rosas A, Martine I, Mosquera, M. 1997. A hominid from the Lower Pleistocene of Atapuerca, Spain: Possible ancestor to Neanderthals and modern humans. Science 276:1392-1395.

Bondioli L, Coppa A, Frayer DW, Libsekal Y, Rook L, Macchiarelli R. 2006. A one-million-year-old human pubic symphysis. J Hum Evol 50:479-483.

Bräuer, G. 1984. The Afro-European sapiens-hypothesis, and hominid evolution in Asia during the late Middle and Upper Pleistocene. In: Andrews, Franzen, JL. editors: The early evolution of man with special emphasis on Southeast Asia and Africa. Frankfurt am Main: Courier Forschungsinstitut Senckenberg. pp. 145-167.

Carpenter JM, Goloboff PA, Farris JS. 1998. PTP is meaningless, T-PTP is contradictory: A reply to Trueman. Cladistics 14:105-116.

Clarke JD, de Heinzelin J, Schlick KD, Hart WK, White D, Wolde Grabriel G, Walter RC, Suwa G, Asfaw B, Vrba E, H-Selassie Y. 1994. African Homo erectus: Old radiometric ages and young Oldowan assemblages in the Middle Awash Valley, Ethiopia. Nature 264:1907-1909.

Clarke RJ. 2000. A corrected reconstruction and interpretation of the Homo erectus calvaria from Ceprano, Italy. J Hum Evol 39:433-442.

Conroy GC, Jolly CJ, Cramer D, Kalb JE. 1976. Newly discovered fossil hominid skull from the Afar depression, Ethiopia. Nature 275:67-70. 
Taxonomic Tapestries

Faith DP, 1991. Cladistic permutation tests for monophyly and nonmonophylly. Syst Zool 40:266-375.

Faith DP, Cranston PS. 1991. Could a cladogram this short have arisen by chance alone? On permutation tests for cladistic structure. Cladistics 7:1-28.

Falguèrès C, Bahain J-J, Yokoyama Y, Arsuaga JL, de Castro BJM, Carbonell E, Bischoff JL, Dolo J-M. 1999. Earliest humans in Europe: The age of TD6 Gran Dolina, Atapuerca, Spain. J Hum Evol 37:343-352.

Fu J, Murphy RW. 1999. Discriminating and locating character covariance: An application of Permutation Tail Probability (PTP) analysis. Syst Biol 48(2):380-385.

Grimaud, D. 1982. Évolution du parietal de l'Homme fossile, position de l'Homme de Tautavel parmi les hominidés. Thése de 3éme cycle. Muséum National d'Histoire Naturelle (indet).

Groves CP. 1989. A theory of human and primate evolution. Oxford: Clarendon Press.

Hennig W. 1966. Phylogenetic systematics. Urbana, Chicago: University of Illinois Press.

Hillis D, Bull JJ. 1993. An empirical test of bootstrapping as a method for assessing confidence in phylogenetic analysis. Syst Biol 42(2):182-192.

Holloway RL, Broadfield DC, Yuan MS. 2004. The human fossil record, Volume 3. Brain endocasts - the paleoneurological evidence. Somerset, NJ: John Wiley and Sons. pp. 129.

Hrdlicka A. 1930. The skeletal remains of early man. Washington: Smithsonian Institution.

Hublin JJ. 1978. Le torus occipital transverse et les structures associées: Evolution dans le genre Homo. Thése de 3éme cycle, Université P. and M. Curie, Paris IV (inédet).

Humphries CJ. 2002. Homology, characters and continuous variables. In: MacLeod N, Forey PL, editors. Morphology, shape and phylogeny. Systematics Association Special Volume Series 64. London and New York: Taylor and Francis. pp. 8-27.

Kalb J, Jolly CJ, Mebrate A, Tebedge S, Smart CM, Oswald EB, Cramer D, Whitehead P, Wood CB, Conroy GC, Adefris T, Sperling I, Kana B. 1982. Fossil mammals and artefacts from the Middle Awash Valley, Ethiopia. Nature 298:25-29. 
Källersjö M, Farris JS, Kluge AG, Bult C. 1992. Cladistics: What's in a word? Cladistics 9:183-199.

Lahr MM. 1996. The evolution of modern human diversity: A study on cranial variation. Cambridge: Cambridge University Press.

Macchiarelli R, Bondioli M, Chech M, Coppa A, Fiore I, Russom R, Vecchi F, Libsekal Y, Rook L. 2004. The late Early Pleistocene human remains from Buia, Danakil Depression, Eritrea. In: Abbate E, Woldehaimanot B, Libsekal Y, Tecle TM, Rook L, editors. A step towards human origins. The Buia Homo one million years ago in the Eritrean Danakil Depression (East Africa). Riv Ital Paleontol S 110 Supplement:133-144.

MacIntosh NWG, Larnach SL. 1972. The persistence of Homo erectus traits in Australian Aboriginal crania. Archaeology and Physical Anthropology in Oceania 7:1-7.

Maddison WP, Maddison DR. 1992. MacClade: Analysis of phylogeny and character evolution. Version 3.0. Sunderland, Massachusetts: Sinauer Associates.

Mallegni F, Carnieri E, Bisconti M, Tartarelli G, Ricci S, Biddittu I, Segre A. 2003. Homo cepranensis sp nov and the evolution of African-European Middle Pleistocene hominids. Comptes Rendus Palevol 2:153-159.

Manzi G, Bruner E, Passarello P. 2003. The one-million-year-old Homo cranium from Bouri (Ethiopia): A reconsideration of its $H$. erectus affinities. J Hum Evol 44:731-736.

Manzi G, Magri DB, Salvatore M, Palombo MR, Margari V, Celiberti V, Barbieri M, Barbieri, Mu, Melis RT, Rubini M, Ruffo M, Saracino B, Tzedakis PC, Zarattin A, Biddittu I. 2010. The new chronology of the Ceprano calvarium (Italy). J Hum Evol 59:580-585.

Manzi G, Mallegni F, Ascenzi A. 2001. A cranium for the earliest Europeans: Phylogenetic position of the hominid from Ceprano, Italy. Proc Natl Acad Sci 98:10011-10016.

Mbua E, Bräuer G. 2012. Patterns of Middle Pleistocene hominin evolution in Africa and the emergence of modern humans. In: Reynolds S, Gallagher A, editors. African genesis: Perspectives on hominin evolution. Cambridge: Cambridge University Press. pp. 366-422.

Muttoni G, Scardia G, Kent DV, Swisher Carl C, Manzi G. 2009. Pleistocene magnetochronology of early hominin sites at Ceprano and Fontana Ranuccio, Italy. Earth Planet Sci Lett 286:255-268. 
Taxonomic Tapestries

Nomade S, Muttoni G, Guillou G, Robin E, Scardia G. 2011. First 40Ar/39Ar age of the Ceprano man (central Italy). Quaternary Geology 6(5):453-457.

Rightmire GP. 1976. Relationships of Middle and Upper Pleistocene hominids from sub-Saharan Africa. Nature 260:238-240.

Rightmire GP. 1996. The human cranium from Bodo, Ethiopia: Evidence of speciation in the Middle Pleistocene? J Hum Evol 31:21-39.

Sartono S., Grimaud, D. 1983. Les parétaux des Pithécanthropines Sangiran 12 et Sangiran 17. L'Anthropologie 87:475-482.

Schwartz JH, Tattersall I. 2002. The human fossil record: Craniodental morphology of Genus Homo. Volume 2: Africa and Asia. New York: Wiley Liss.

Stringer CB. 1984. The definition of Homo erectus and the existence of the species in Africa and Europe. In: Andrews P, Franzen JL, editors. The early evolution of man with special emphasis on Southeast Asia and Africa. Frankfurt am Main: Courier Forschungsinstitut Senckenberg. pp. 131-143.

Smith Woodward A. 1921. A new cave man from Rhodesia, South Africa. Nature $17: 371-372$.

Swofford D. 2002. PAUP* Version 4.0b10. Distributed by Sinauer Associates, Inc. Smithsonian Institute.

Trueman JWH. 1993. Randomization confounded: A response to Carpenter. Cladistics 9:101-109.

Weidenreich F. 1943. The Skull of Sinanthropus Pekinensus. Palaeontologia Sinica. Pehpei, Chungking. Oxford: Geological Survey of China. pp. 270-272.

Wiley EO, Lieberman BS. 2011. Phylogenetics. theory and practice of phylogenetic systematics. Hoboken, NJ: John Wiley and Sons, Inc. pp. 90-193.

Wood B. 1991. Koobi fora research project, vol. 4: Hominid cranial remains. Clarendon Press, Oxford.

Zeitoun V. 2000. Revision of the species Homo erectus (Dubois, 1893). Use of morphologic and metric data in cladistic investigation of the case of Homo erectus. B Mem Soc Anthro Par 12:1-200. 


\section{Appendix 1. Character states}

\section{1. continuity of post orbital sulcus}

$0=$ absent because of continuity of frontal and supraorbital

$1=$ present but incomplete, interrupted in the medial zone

$2=$ present - complete and with a distinct edge or border

\section{2. postorbital lateral depression}

(a depression on the lateral supraorbital region bounded by the temporal line)

$0=$ absent

$1=$ present

3. depression at glabella in norma facialis

$0=\mathrm{absent}$

$1=$ present

4. shape of frontal edge in norma verticalis

$0=$ linear

$1=$ convex frontwards

5. position of glabella in norma verticalis

$0=$ glabella zone is depressed

$1=$ glabella is neither depressed or protruding

2 = glabella projects beyond the frontal

6. continuity of the supraorbital torus

$0=$ no supraorbital torus

1 = incomplete, interrupted in the medial zone - there are 2 distict tori 'monoorbitares'

$2=$ continuous torus

7. superior surface of orbit margins

$0=$ flow smoothly into frontal squama

$1=$ horizontal posttoral plane from which squama rises posteriorly

$2=$ there is a sulcus between posterior aspect of elevated supraorbital rim and frontal squama 
Taxonomic Tapestries

8. type of orbital arcade - supraorbitals

Where ' $a$ ' is central, ' $b$ ' is middle and ' $c$ ' is lateral:

$0=a>b, b<c$ and $a<c$

$\mathrm{l}=\mathrm{a}>\mathrm{b}, \mathrm{b}<\mathrm{c}$ and $\mathrm{a}>\mathrm{c}$

$2=\mathrm{a}<\mathrm{b}, \mathrm{b}>\mathrm{c}$ and $\mathrm{a}>\mathrm{c}$

$3=a>b, b>c$ and $a>c$

$4=$ no variation in form

The objective is to determine differences in superior-inferior height of supraorbital across the orbit. Measurements were used to determine ' $a$ ', ' $b$ ', 'c' for each specimen.

9. prominence of temporal line on the frontal

$0=$ weak

$1=$ very prominent

10. metopic keeling

$0=\mathrm{absent}$

$1=$ present but weak

$2=$ strong

11. development of the keeling

$0=$ parallel edges

$1=$ wider and flatter posteriorly

$2=$ absent (no keeling)

12. bregmatic eminence

$0=$ absent

$1=$ present

13. upper coronal reinforcement

$0=\mathrm{absent}$

$1=$ present

\section{4. frontal bosse}

$0=$ absent

$1=$ present 
15. obelionic region

$0=$ keeling present

$1=$ no keeling

$2=$ presence of obelionic depression

16. pre-lambdaic depression

$0=$ keeling on 4 th quarter

$1=$ no keeling on 4 th quarter

$2=$ present

17. presence of the temporal band after the coronal suture

$0=$ absent

$1=$ present

18. asterionic process

$0=$ absent

$1=$ present

19. parietal bosse

$0=$ absent

$1=$ present

20. angular tuber

$0=\mathrm{absent}$

$1=$ present

21. curvature of nuchal plane in norma lateralis

$0=$ convex posteriorly

1 = flat to lightly concave posteriorly

22. importance of the occipital torus

$0=$ weak

$1=$ strong

$2=$ no occipital torus

23. extension of external occipital protrusion

$0=$ absent

$1=$ present 
Taxonomic Tapestries

\section{4. extension of the tuberculum linearum}

This refers to the degree of elevation, or relief, at the junction of the superior nuchal line and occipital crest.

$0=$ absent

$1=$ moderate

$2=$ strong

25. medial concavity of the occipital lip to the tuberculum linearum

Is there a depression above where nuchal lines meet?

$0=$ absent

$1=$ depression

26. external occipital crest, where present

$0=a b s e n t$

$1=$ present for whole of nuchal

$2=$ present above inferior nuchal line

$3=$ present below inferior nuchal line

27. occipitomastoid crest

$0=$ absent

$1=$ present

28. height of temporal squama cf vault

$0=$ high

$1=$ low

29. shape of the temporal squama

$0=$ polygon to round

$1=$ triangular

30. strength of supramastoid crest in the region of porion

$0=$ weak

$1=$ strong

31. relation between the supramastoid crest and zygomatic process in lateral view

$0=$ zygomatica forms an angle with supramastoid crest

$1=$ zygomatica is continuous with supramastoid crest 
32. continuity of the supramastoid crest with the inferior temporal line

$0=$ no direct link

$1=$ continuity

33. tuberculum supramastoid anterius

Is there a tubercle where supramastoid crest stops at squamous suture?

$0=$ absent

$1=$ present

34. strength of the mastoid crest

$0=$ weak

$1=$ strong

35. continuity between mastoid crest and superior temporal line

$0=$ no direct link

$1=$ continuity

36. supramastoid sulcus, where present

$0=$ closed posteriorly

$1=$ open posteriorly

37. importance of supramastoid sulcus

$0=$ absent

$1=$ narrow

$2=$ wide

38. convergence of mastoid crest and supramastoid crest

$0=$ divergent anteriorly

$1=$ parallel

39. suprameatum spine

$0=$ absent

$1=$ present

40. section of tympanal in norma lateralis

$0=$ rounded

$1=$ ellipsoid to ovoid 
Taxonomic Tapestries

41. orientation of main axis of tympanal in norma lateralis

$0=$ orientated anteriorly

$1=$ vertical

$2=$ orientated posteriorly

42. thickness of tympanic in norma lateralis (anterior edge of tympanic)

$0=$ weak

$1=\operatorname{strong}(>2 \mathrm{~mm})$

43. contribution of the tympanal to mandibular fossa

$0=$ postglenoid process is strongly involved in the wall

$1=$ the tympanal makes up most of the wall

$2=$ rudimentary or no postglenoid process

44. relative development of mastoid process in norma lateralis

(i.e. does it project below the base of the cranium?)

$0=$ does not project below the base of the cranium

$1=$ projects below base

45. extension of the pre-glenoid planum

(Is there a level surface of bone preceding the mandibular fossa from the articular eminence either for the whole, or at least half, of the width of the eminence?)

$0=$ no pre-glenoid planum precedes the glenoid cavity

$1=$ a pre-glenoid planum precedes the glenoid cavity

46. space between the tympanal and anterior of mastoid process

$0=$ posterior part of tympanal joins anterior part of mastoid process

$1=$ 'split'

2 = wide space

47. anteroposterior width of mandibular fossa

$0=$ narrow

$1=$ wide

48. deepness of glenoid fossa

$0=$ very shallow

$1=$ deep 
49. height of articular eminence relative to posterior wall of glenoid fossa (basal view)

$0=$ slope is shorter

$1=$ similar

2 = higher

50. orientation of mastoid process

$0=$ not orientated inwards

$1=$ orientated inwards

51. deepness of digastric fossa

$1=$ shallow

$2=$ deep

52. size of juxtamastoid eminence

$0=$ no eminence

$1=$ weak

$2=$ strong

53. importance of deepness between entoglenoid formation and tympanic plate

$0=$ fused

1 = groove

$2=$ space

54. anterior wall of glenoid fossa

$0=$ the anterior wall is horizontal

$1=$ oblique

$2=$ almost vertical

55. inferior projection of the entoglenoid process compared to that of the tuberculum zygomaticum anterior

$1=$ entoglenoid projects to a greater extent than the tuberculum zygomaticum anterior

$2=$ entoglenoid is similar to tuberculum zygomaticum anterior in degree of inferior projection

$3=$ entoglenoid is less projected than the tuberculum zygomaticum anterior 
56. relative position of the entoglenoid formation to the tuberculum zygomaticum anterior

$0=$ the entoglenoid formation is at the same level as the tuberculum zygomaticum

$1=$ the entoglenoid formation is posterior to the tuberculum zygomaticum

$2=$ entoglenoid formation is very posterior to the tuberculum zygomaticum

57. inferior projection of the entoglenoid process and the tuberculum zygomaticum compared to the tuberculum articulare

$0=$ very large inferior projection relative to the tuberculum articulare

$1=$ large inferior projection relative to the tuberculum articulare

$2=$ small inferior projection relative to the tuberculum articulare

58. antero-posterior convexity of the tuberculum articular (articular eminence)

$0=$ the tuberculum articular is flat in norma lateralis

$1=$ the tuberculum articular forms a large round arc

$2=$ the tuberculum articular forms a small round arc

59. shape of posterior edge of the tuberculum articular in norma basilaris

$0=$ flat

$1=$ arched

$2=$ sigmoid

60. continuity between the pre-glenoid planum and the posterior slope of the articular tuberclum

$0=$ the two are continuous

$1=$ there is an angulation between them

61. crest on lateral edge of mandibular fossa

$0=$ absent

$1=$ present

62. inferior projection of entoglenoid process compared to the sphenoid border/edge

$0=$ the entoglenoid process projects inferiorly to a greater extent than sphenoid edge

$1=$ the entoglenoid process is equivalent in inferior projection to sphenoid edge $2=$ the entoglenoid process is les projected than sphenoid edge 
63. prominence of entoglenoid formation

$0=$ very prominent

$1=$ not prominent

64. lateral extension of entoglenoid process

$0=$ very extended posteriorly

$1=$ marginally extended backward

$2=$ not extended posteriorly

$3=$ tubercle

$4=$ not extended posteriorly or tubercle

65. does postglenoid process extend out beyond tympanic?

$0=$ doesn't overlap the tympana

$1=$ does overlap the tympana

$2=$ no postglenoid process or rudimentary process

66. profile of nasal saddle and nasal roof

1 = flat nasal bones

2 = slightly raised nasals, forming a curve

3 = nasals forming well-defined curve, ranging in size from medium to large

$4=$ deep angled nasal bones forming a 'pinched nose'

67. relationship of rhinion to nasospinale

$1=$ nasospinale lies in front of rhinion

$2=$ nasospinale is on same plane as rhinion

$3=$ nasospinale lies behind rhinion

68. condition of the margo limitans

$1=$ the margo limitans forms a sill

$2=$ margo limitans forms a smooth curve

$3=$ margo limitans includes a prenasal groove

69. the condition of the facies anterior of maxilla and alveolar process

$1=$ the facies anterior and alveolar process is inflated,

$2=$ the facies anterior and alveolar process is well filled out

$3=$ the facies anterior and alveolar process is sunken

$4=$ the facies anterior and alveolar process forms a flat surface 
Taxonomic Tapestries

70. presence of jugum alveolar

$1=$ there is no jugum alveolar

$2=$ the jugum alveolar forms a narrow ridge

$3=$ the jugum alveolar forms a broad and prominent ridge (width of $1+$ premolar)

71. presence of a sulcus infraorbitalis (i.e. under the infraorbital foramen)

$1=$ there is no sulcus infraorbitalis

$2=$ the sulcus infraorbitalis is narrow

$3=$ the sulcus infraorbitalis is wide

72. zygomaticoalveolar crest (ordered)

$1=$ relatively straight

$2=$ curved

$3=$ forms an arc

4 = forms an arch

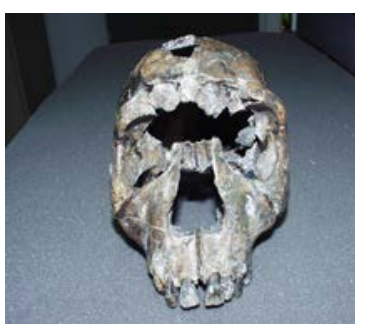

State 2 (curved)

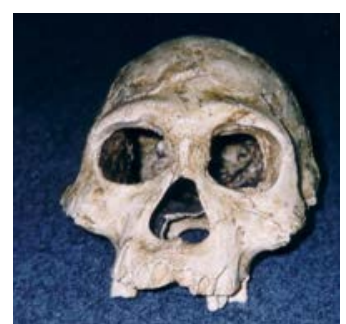

State $3(\operatorname{arc})$

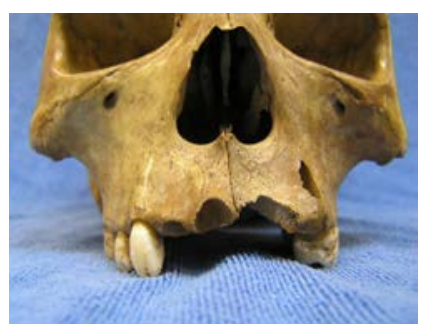

State 4 (arch)

Description: KNM-WT 15000 frontal view 102

Description: D2700 caste frontal view

Description: P1221728

73. shape of naso-alveolar clivus

$1=$ naso-alveolar clivus is convex

$2=$ naso-alveolar clivus is flat

$3=$ naso-alveolar clivus is concave

74. palate surface has low irregular crests or fine ridges arranged in more or less longitudinal direction

$1=$ present

$2=\mathrm{absent}$ 


\section{5. location and direction of orifice of incisive canal}

$1=$ orifice of incisive canal is immediately posterior to incisors

$2=$ orifice of incisive canal is on a plane with canines

$3=$ orifice of incisive canal is on a plane with 1st premolar

$4=$ orifice of incisive canal is on a plane with 2 nd premolar

\section{6. location of zygomatic arch}

$1=$ the zygomatic arch runs below the Frankfurt horizontal

$2=$ the zygomatic arch runs at level of Frankfurt horizontal

$3=$ the zygomatic arch runs above the Frankfurt horizontal

\section{7. condition of the supraorbital margin}

$1=$ the supraorbital margin is thick, rounded and not demarcated from roof of orbit $2=$ the margin is thick with an edged crest not demarcated from roof of orbit $3=$ the supraorbital margin is an edged crest demarcated from the roof of orbit $4=$ the supraorbital margin is thin with an edged crest and demarcated from the roof of orbit

\section{8. condition of infraorbital margin of the orbits}

$1=$ sharp high line dividing the floor of the orbit from the facial portion of the malar $2=$ relatively rounded orbital margin but raised in relation to floor of the orbit 3 = pronounced rounding of the inferior lateral border which is leveled with the floor of the orbit (i.e. lower outside edge for half the lower edge of orbit is rounded but other half of lower orbit not rounded)

\section{9. character of superior fissure}

$1=$ the superior fissure is small and round

$2=$ superior fissure is a slit-like lateral prolongation

$3=$ there is a strut dividing the fissure into 2

80. styloid process

$1=$ present

$2=$ absent

\section{1. tympanic trough}

A coronally oriented long narrow trough along tympanic tube in basal view

$0=$ absent

$1=$ present 
Taxonomic Tapestries

82. sagittal keeling on first half of parietal.

$0=$ absent

$1=$ present

83. presence of external occipital crest

$0=\mathrm{absent}$

$1=$ present

84. presence of glasseri fissure

$0=$ absent

$1=$ present

85. supraorbital torus

$0=\mathrm{absent}$

$1=$ present

86. tuberculum linearum

$0=$ absent

$1=$ present

87. maximum cranial breadth

$0=$ at supramastoid region

$1=$ at parietal region

88. length of nuchal dominates over length of occipital

Determined by comparing measurement for lambda-inion (occipital length) and measurement for inion-opisthion (nuchal length)

$0=$ yes

$1=$ no

89. foramen magnum

$0=$ round

$1=$ oval 


\title{
12. Human evolution in Sunda and Sahul and the continuing contributions of Professor Colin Groves
}

\author{
Michael C Westaway, Arthur Durband and David Lambert
}

\section{Introduction}

In terms of understanding evolutionary processes in the human origins story, much can be gained by employing an approach of splitting the known fossil record into numerous taxonomically recognised species. By focusing on variation in fossil specimens, as defined by differences in characters in both time and space, we can start to explore possible evolutionary relationships among the range of fossil specimens. The opposite approach, of lumping such taxonomically species will potentially obscure interesting differentiation, resulting in the possible loss of understanding for important phylogenetic relationships (Groves, 1989a). Whether such taxonomically recognised species are biologically real or not is exceedingly difficult to establish in the fossil record, however, splitting fossils into divisions based on character traits enables the effective testing of hypotheses regarding the validity of such species.

Approaches in Australian palaeoanthropology have largely been characterised by splitting and lumping. For more than 15 years, the charismatic lumper Alan Thorne had carried the day for the evolutionary story of the Australasian region. His interpretation of the evolution of Homo sapiens in our region evoked an argument for deep geological links with regional Homo erectus. It represented a record of regional continuity anchored to the evidence first discovered in Java some 120 years ago (Dubois, 1894). The model was unlike the earlier variants of the regional continuity brand of human evolution, which proposed a direct 'candelabra' treatment of the fossil record. Thorne proposed that there was some limited gene flow between populations from different regions, however, the crux of his argument was that there was general continuity of traits in the regions. There had not been much modification to this regional pattern from outside. For the colonisation of Sahul, Thorne envisaged that there had been two major migrations into Australia, one derived from Ancient China, the other from Ancient Java. His hypothesis was referred to as the dihybrid model of Aboriginal origins. 
With a background in journalism and a multitude of connections, Thorne delivered a powerful $\mathrm{ABC}$ documentary to the nation on human origins in Sunda and Sahul in 1988, known as 'Man on the Rim'. Together with his American colleague Milford Wolpoff and links forged with Chinese and Indonesian colleagues, he was generally very successful in promoting his model of human evolution for the region on the international stage. His partnerships with Indonesian colleagues had helped him obtain an extensive cast collection (now at the Shellshear Museum, University of Sydney) representative of Sunda, which enabled him to draw his comparisons with the available record from Sahul. He added dramatically to our understanding of the Sahul record, and amassed, through an inspiring two decades of fieldwork, an assemblage of Pleistocene remains from Australia that numbered over 100 individuals, from the internationally significant sites of Kow Swamp and the Willandra Lakes (including Lake Mungo). He held a virtual monopoly over the fossil series, and developed strong links with the Willandra Elders to ensure that research could continue on the series, following the scientific disaster of the Kow Swamp reburial. Thorne for these years appeared to reign supreme, but his position was not to last.

In 1974, Colin Groves, fresh from the Duckworth Laboratory of Physical Anthropology at Cambridge, arrived in Australia. His arrival was in time for some quite significant events relating to research on Aboriginal origins. He was present at the time of the excavation of Mungo Man (WLH 3). This taste of Australian fieldwork was soon after followed by the 'Origins of the Australians' conference held in Canberra at the Australian Institute of Aboriginal Studies. At this conference the mandible of Mungo Man, with his extraordinary pattern of occlusal wear, was exhibited. Macintosh commented at the time that it was morphologically within the range of modern Australians (Macintosh and Larnach, 1976). The Canberra conference defined the parameters for much future debate on the origins of the Australians, a debate that we have moved only somewhat closer to answering today.

From these beginnings at The Australian National University, it was here that Groves was to base much of his interpretations of the fossil record for human origins. His contributions to our understanding of human origins have been of international significance. While there is much of importance in his work to discuss, such as his naming of the species Homo ergaster with Mazák (1975), which has helped to make sense of the confusing morphological diversity that is all too often lumped into Homo erectus, this chapter is restricted to a summary of his contributions to our understanding of human origins in Sunda and Sahul. His work on human origins in Sunda and Sahul did not really begin to emerge in print until 15 years after he first had his feet burnt at Lake Mungo, but many publications strongly (and always politely) argued for replacement 
over regional continuity. This chapter will attempt to tie his work into current research and understanding of human evolution in Sunda and Sahul, and in doing so we hope, shall demonstrate how well his science has held up. While the picture seems far more complicated today compared to the original sketch from 1974, encouragingly a great deal more is now known as a result of a series of new discoveries (some of which are nothing short of spectacular) and the development of improved analytical techniques.

In this chapter we shall consider five major themes that Groves has devoted some thought towards, including i) the question of the taxonomic affinity of the first hominins in Sunda, ii) the first crossing of the Wallace Line by archaic hominins, iii) the evolutionary trajectory of Homo erectus (with a focus on the meaning of late derived erectus), iv) the second crossing of the Wallace Line by Homo sapiens resulting in the subsequent colonisation of Sahul, and v) the important new insights that studies of ancient DNA (aDNA) are contributing to our rewriting of the human evolutionary narrative in Sunda and Sahul. We feel that these represent the key topics in human evolutionary studies on our genus within the region, all being topics that Groves has contributed to.

\section{The first Javan hominins: Is there a case for a pre-erectus taxon in Sunda?}

The possibility of an earlier species being present within the lower units of the site of Sangiran, Java, is a proposition that has quite a long history. Von Koenigswald argued that there were two separate species represented in the fossil record of Java, which he called Pithecanthropus erectus and an earlier species Meganthropus palaeojavanicus (von Koenigswald 1956). Indeed Robinson (1953 and 1955) had suggested that the specimens often associated with Meganthropus were best placed within the genus Paranthropus and identified them as a separate species, Paranthropus palaeojavanicus. Certainly when one considers the hyper robust corpus of Sangiran 6 it is reminiscent of the heavy masticatory apparatus of African Paranthropus, a dentition adapted for processing hardy open woodland vegetation.

A significant comparison of these fossils by Philip Tobias and Ralph von Koenigswald (1964) in Cambridge compared the fossils from the African record (primarily Olduvai) with the Javan specimens. They had a particular focus on those fossils that had been termed Meganthropus. The picture that emerged from the study was an identification of four grades of hominisation, with a suggestion that Meganthropus fitted within a grade similar to that of Homo habilis. Later Tyler (1995) in describing the Sangiran 31 calotte suggested that either the range of Homo erectus needed to be redefined or this fossil represented 
a different species, of which Homo habilis is one that he favoured. The extreme occipital torus is well beyond that of any of the Javan specimens, and a strange region of raised bone has been identified as a sagittal crest (Tyler et al., 1995), a description that has been dismissed by Grimaud-Hervé (2001) as being not possible due to the presence of an angular torus. She suggests that the character may instead be a post-mortem anomaly, the feature perhaps representing raised external compact bone.

A study by Kaifu and colleagues (2005) reviewed this proposition, and identified that the specimens that had in the past been recognised as Meganthropus (Weidenreich 1943) supported two evolutionary propositions. Either there had been a great deal more variability in Homo erectus prior to the Middle Pleistocene, or that there may indeed be another species present. One of the key points that Kaifu had made was that there were a number of characters in the jaw fragments that were more like Homo habilis than Homo erectus.

In an article in Australasian Science in 2008 in relation to the taxonomic affinities of Homo floresiensis, Groves discussed the possibility of a connection between the enigmatic fossil and the earliest known hominins from Java. Specifically he asked:

The question is: can we find traces of its ( There are almost no fossils of the relevant time period anywhere between Africa and Java, but in Java itself there are (mostly rather scrappy) remains from levels somewhat earlier than those from which Homo erectus have come. Most authors have considered that these early Javanese fossils also represent Homo erectus, but recently a joint Japanese and Indonesian team, led by the noted palaeoanthropologist Kaifu, have found that they are actually rather different. This raises a question: if there is something different, something non-erectus, in these early levels, could Homo floresiensis have a hitherto unrecognized ancestor among them? (Groves 2008)

This idea was discussed further by Groves and one of his students (Westaway and Groves 2009), where it was suggested that a process of replacement in the evolution of hominins perhaps was a regular pattern in hominin evolution in Sunda. They suggested that the later erectus extinction event, following the arrival of Homo sapiens, was just the next stage of hominin replacement in Java. It was also suggested in this paper that the infant fossil from Mojokerto, dating to sometime around 1.49 Ma (Morwood et al., 2003), may in fact represent a juvenile of this species.

The presence of pre-erectus-like characters in the early Java series is intriguing. At a time when Sunda was not a chain of islands, a savannah corridor up to $150 \mathrm{~km}$ wide (Bird, Taylor and Hunt, 2005) supported a more open fauna. It is 
not unreasonable to imagine that there may have been pre-erectus hominins in the Early Pleistocene occupying the savannah and coastal plains at times when the sea levels were low. Provisionally such a species has been called Homo modjokertensis (Westaway and Groves 2009). The view that Homo modjokertensis is a real taxon requires the discovery of more complete fossils dating to the early to Middle Pleistocene. There is a lot of uncertainty relating to the earlier Sangiran fossils, and it is perhaps time to revisit Robinson's original proposal that Paranthropus may be present in the early Middle Pleistocene in Sunda. Certainly the dimensions of Sangiran 6 seem to fall closer within the range of Paranthropus than Homo erectus (Figure 12.1a-d). While Sunda is on the edge of the range of the genus Homo, there has been somewhere in the vicinity of 1.5 Mya of hominin evolution. The discovery of Homo floresiensis has exposed palaeoanthropologists to a view that there was much greater diversity in hominin species in Sunda than previously considered. Indeed it has been questioned as to whether Homo floresiensis should in fact continue to be included in the genus Homo (Collard and Wood, 2007), which is a point that we shall return to in the next section. Further studies are required to arrive at a clearer understanding of this diversity.

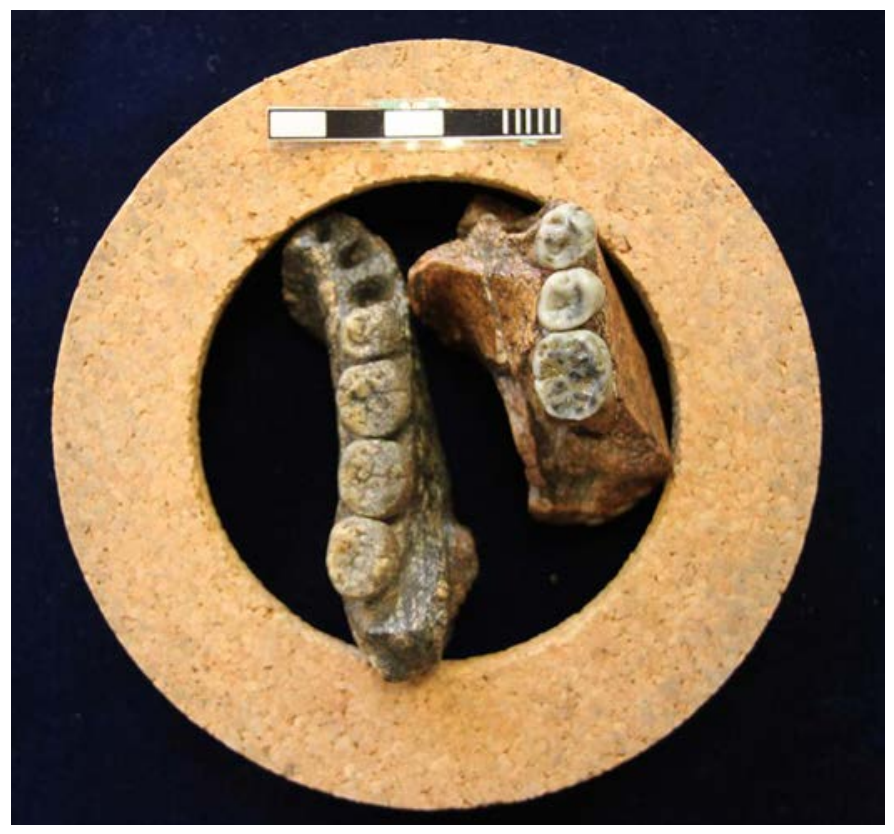

Figure 12.1a: In recent years the Sangiran 6 mandible has been considered by only a few researchers to be outside the range of Homo erectus. The extreme thickness of Sangiran 6 is compared to that of Sangiran $1 b$. 


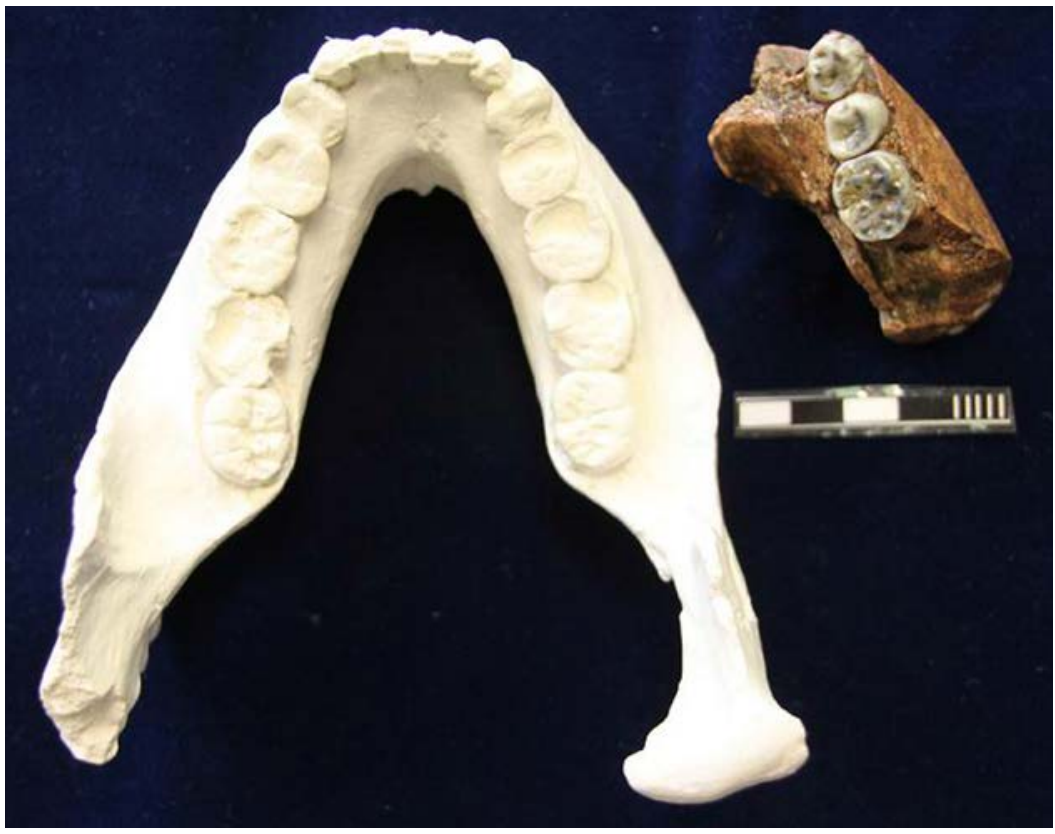

Figure 12.1b: The very thick corpus of Sangiran 6 is similar to that seen in the Peninj Paranthropus mandible.

Source: Photographs taken by Michael Westaway.

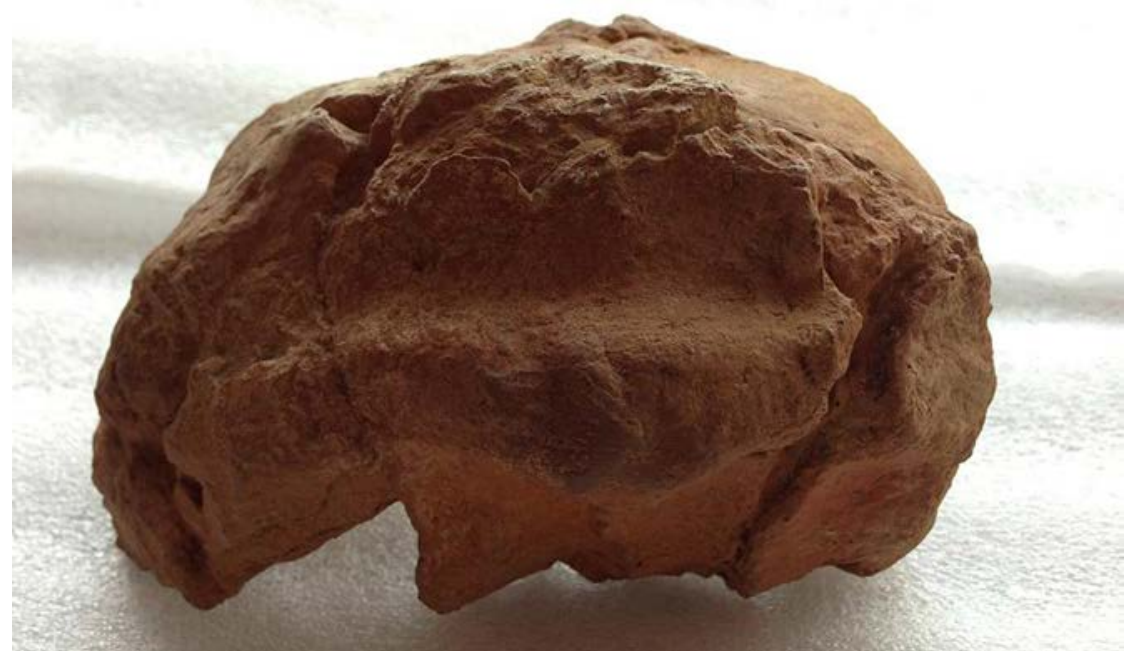

Figure 12.1c: The posterior view of Sangiran 31 (cast) showing the extreme robusticity of the occipital torus.

Source: Photographs taken by Michael Westaway. 


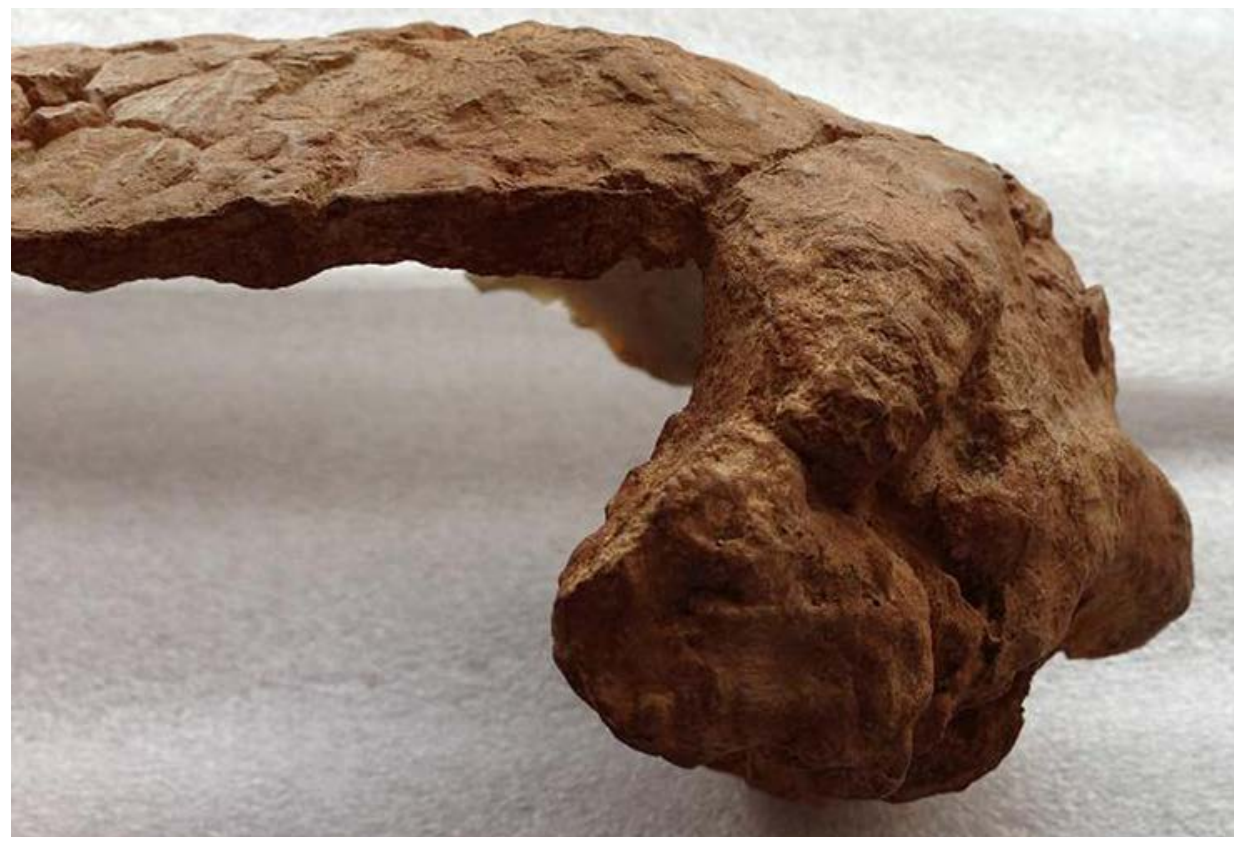

Figure 12.1d: Lateral view of Sangiran 31 (cast) showing the extreme robusticity of the occipital torus.

Source: Photographs taken by Michael Westaway.

\section{Crossing the Wallace Line (1): The puzzle of Homo floresiensis}

The human evolutionary context at the time of Groves' paper 'hovering on the brink' was relatively straightforward. There had been migration into the region by an archaic hominin, Homo erectus, which was later replaced with modern humans. The initial interpretations of the archaeological record from Flores indicated that Homo erectus had made it across the Wallace Line, being present from some $700 \mathrm{ka}$ (Groves, 1996). Groves in this paper discussed evidence from the general palaeontological and zoogeographical record to help build a meaningful context around the stone artefacts from Flores. He suggested that Homo erectus in Flores was part of a general oriental dispersal along the lesser Sunda Chain.

With the discovery of Homo floresiensis the story became far more complicated. Initial interpretations have focused on $H$. floresiensis being derived from $H$. erectus. The principle of island dwarfing has been cited as a possible mechanism of how $H$. erectus may have initially evolved from the larger species (Brown et al., 2004). Revision of the endocranial volume of $H$. floresiensis to $426 \mathrm{cc}$ by 
Kubo et al. (2013) has perhaps made the proposition of dwarfism somewhat more tenable. In their comparison they consider dwarfism from the earlier known hominins from Java, provisionally called here Homo modjokertensis (but lumped by Kaifu and colleagues within Homo erectus). What the most recent study by Kaifu et al. helps establish is that Homo floresiensis may be derived from the earliest hominins known from Sangiran.

Cladistic analyses have suggested that Homo floresiensis is derived from either a Homo rudolfensis or Homo habilis like ancestor, indicating that it is part of a lineage dating back to either the Late Pliocene or Early Pleistocene (Argue et al., 2009). It is important to note at this point that Homo erectus is derived from the much later African species Homo ergaster. The evidence from the post crania also suggests that a pre-erectus hominin is more likely the ancestor for Homo floresiensis. The primitive anatomy of the wrist (Tocheri et al., 2007), the general limb proportions (Holliday and Franciscus, 2009), the pelvis (Jungers et al., 2009a), and the unusual anatomy and proportions of the feet (Jungers et al., 2009b) all seem to support this proposition. Jungers et al. (2009b) make the point that while it is possible that insular dwarfism may have resulted in some reversals to a few plesiomorphic states over a period of $800 \mathrm{ka}$, it is improbable that island dwarfism directed such dramatic change throughout so much of the cranial and postcranial anatomy of Homo floresiensis. One limitation that we face is the absence of fossils representative of the wrist and feet from Homo ergaster and Homo erectus.

It has recently been suggested (Collard and Wood, 2007) that the inclusion of the Late Pleistocene specimens from the site of Liang Bua, Flores, in the genus Homo as a new species, H. floresiensis, is not compatible with the commonly accepted definition of the genus Homo (Wood and Collard, 1999).

\section{Regional continuity in Java: The idea of Homo soloensis}

There has been considerable debate in Europe and Africa regarding the idea of multiple species within the erectus-grade, including such species as Homo antecessor, Homo cepranensis, Homo rhodesiensis and Homo helmei. The idea of intermediate species has been subject to minimal discussion within Sunda. It is possible that the long-term isolation of Java may have led to the formation of new species derived from Homo erectus. 


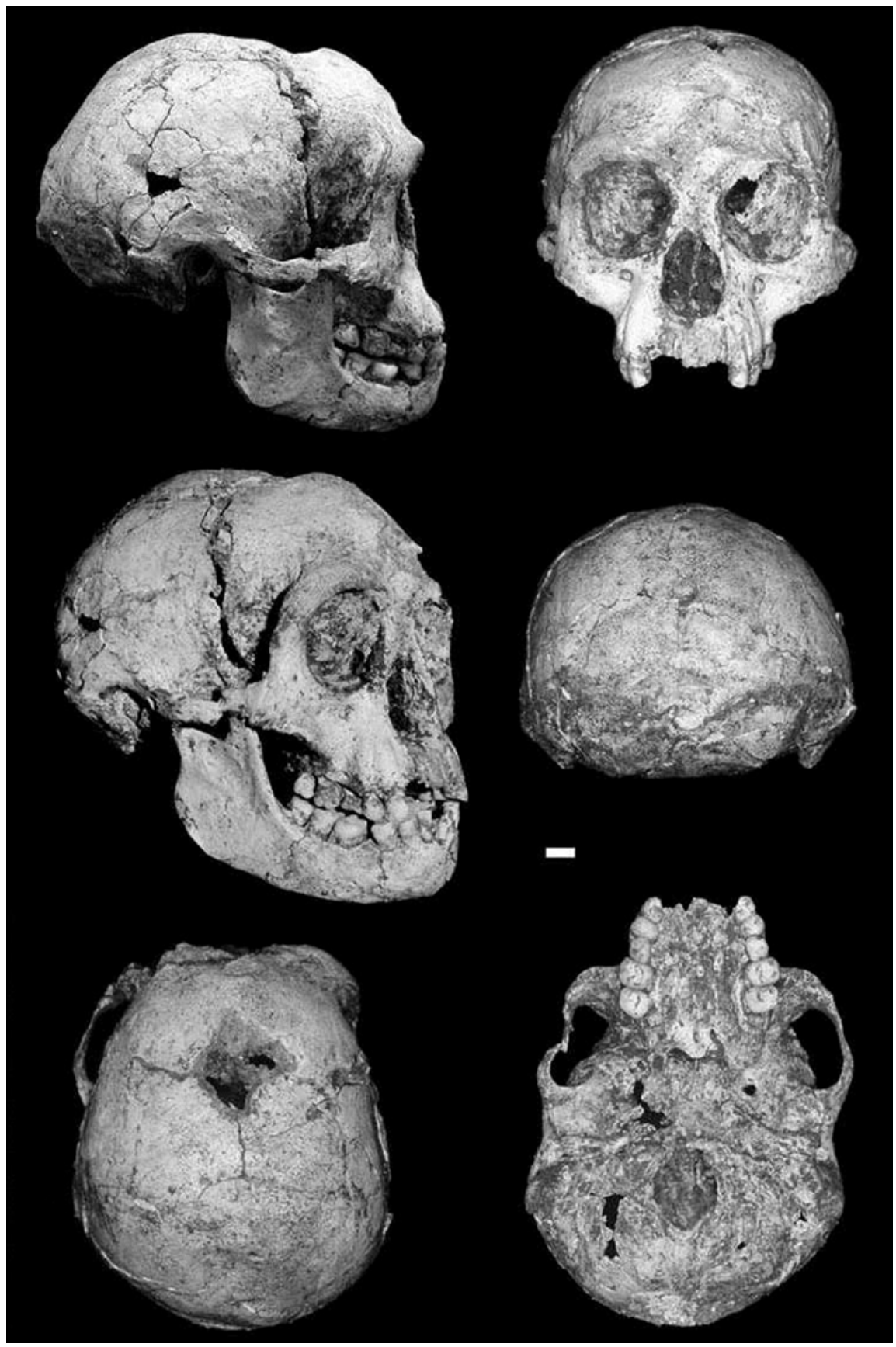

Figure 12.2: Liang Bua 1, the type specimen of Homo floresiensis.

Source: Morwood et al. (2004). 
Alongside discussion around the proposal that archaic Javan Homo erectus (which we called above Homo modjokertensis) had evolved into the diminutive Homo floresiensis, there has also been a less publicised but no less important debate concerning the continuous evolution of Homo erectus in Java. Some workers have suggested that the later surviving individuals from sites like Ngandong and Sambungmacan, often referred to as more 'advanced' Homo erectus (e.g. Santa Luca, 1980; Rightmire, 1990, 1991; Lahr 1996; Anton et al., 2007) or even sometimes as 'archaic' Homo sapiens (e.g. Delson et al. 1977; Bräuer 1992; Frayer et al., 1993), might instead be identified as a new species dubbed Homo soloensis. This species name was coined by Oppenoorth (1932) in his initial descriptions of the earliest hominin material excavated from Ngandong, and has since been reconsidered by more recent authors (e.g. Widianto and Zeitoun, 2003; Zeitoun, 2009; Zeitoun et al., 2010; Durband, 2004, 2007, 2008c, 2009; Durband and Westaway, 2013). Groves (1989a) also recognised the more derived affinities of the later Javan material, referring it to its own chronosubspecies of H. erectus soloensis.

Kaifu and colleagues (2008) provided a detailed analysis of the evolutionary changes that accumulated in the Javan hominin lineage. Those authors recognised 'a continuous, gradual evolution of Javanese $H$. erectus from the Bapang-AG to Ngandong periods' (Kaifu et al., 2008: 578), with the Sambungmacan specimens reflecting a more intermediate morphological condition. These conclusions have been echoed by Zeitoun (2009; Zeitoun et al., 2010), and Durband (2002, 2004, 2007, 2009), who likewise found ample evidence for the accumulation of significant change within the Javanese hominin assemblage. These changes include both morphometric relationships of various cranial elements (e.g. Kaifu et al., 2008) as well as the evolution of several autapomorphic features of the cranial vault and base (Durband, 2002, 2004, 2007, 2008c). Features such as a divided foramen ovale located in a pit, the unique configuration of the mandibular fossa, and a 'teardrop' shaped foramen magnum caused by an opisthionic recess are some of the characters that have been shown to be autapomorphic in Ngandong, with most appearing in Sambungmacan and Ngawi (Durband 2004, 2007, 2008c). The faunal record of Java during this time period is indicative of relative isolation and endemism (de Vos et al., 1994; van den Bergh et al., 1996, 1999, 2001), which would be consistent with the interpretations of the patterns seen in the hominins.

While opinions vary on how to approach the taxonomy of the later Javan material (e.g. Ngandong, Sambungmacan, and Ngawi), it is becoming clear that the evolutionary history of the later Sunda hominins is considerably more complex than it is often portrayed. This evidence, particularly when considered alongside the potential for dynamic change suggested by the earliest Javan fossil material and $H$. floresiensis, suggests that there may have been more changes taking place in Sunda than has previously been appreciated. It would seem reasonable to suggest that further speciation occurred in Sunda and there was not overall stasis within the erectus grade, but in fact significant episodes of divergence at certain points in the Pleistocene within two hominin lineages. 


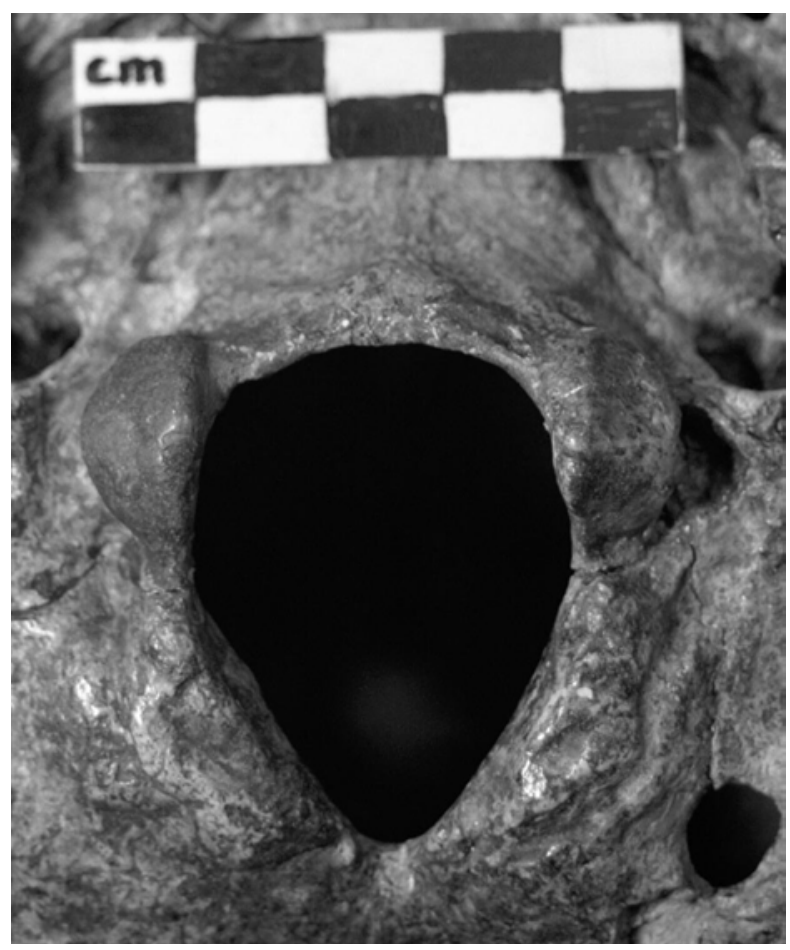

Figure 12.3a: Autapomorphic characters identified in the Ngandong series, including (a) a tear drop shaped foramen magnum (above) and (b) a divided foramen ovale (below).

Source: Photographs taken by Arthur Durband.

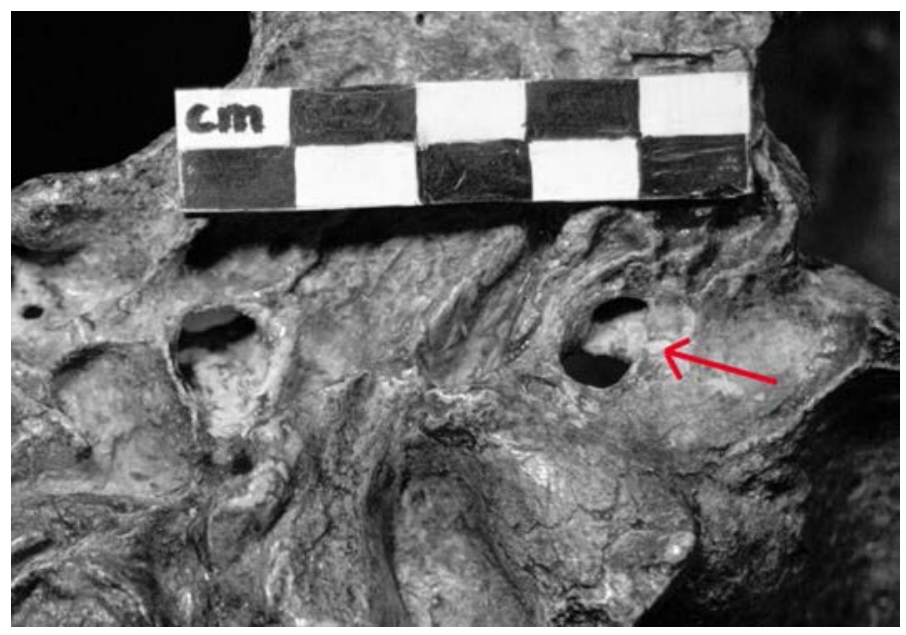

Figure 12.3b 
Taxonomic Tapestries

\section{Crossing the Wallace Line (2): Colonisation of Sahul and morphological variation in Homo sapiens}

The most successful migration through Sunda was that of Homo sapiens. The nature of this migration is now far better understood than it was in 1996, and the complexity of the migration is increasingly being revealed through studies from both ancient DNA (aDNA) and the DNA of modern populations (a topic which will be discussed in further detail in the next section of this paper). The evolution of Homo erectus/soloensis was probably interrupted with the arrival of Homo sapiens in the region, but our understanding of any possible overlap is still imprecise. It is possible that $H$. sapiens migrating into Sunda did not encounter any populations of $H$. erectus/soloensis, as some evidence suggests that they may have become extinct tens of thousands of years earlier (Storm, 2000, 2001 b; see also new dates for Ngandong by Indriati et al., 2011). Certainly the replacement of erectus/soloensis occurred either prior to, or soon after (perhaps a matter of millennia), the arrival of Homo sapiens. It is unclear if Homo sapiens then took the southern route or the northern route to Sahul. The southern route would have brought them into contact with Homo floresiensis, but the earliest evidence on Flores for $H$. sapiens subfossil remains is only early Holocene in age. We still currently lack the evidence necessary in Flores to understand the interaction between these two species. In nearby Timor evidence exists for deep sea fishing activity, identified as that of modern humans, as early as $42 \mathrm{ka}$ (O'Connor et al., 2011).

Homo sapiens developed as part of their cultural repertoire the capacity for long sea journeys, enabling the establishment of a viable population in Australia some 50,000 years ago. While a model identifying a significant genetic contribution from Homo erectus to the origin of the First Australians has been proposed in a number of formats (Thorne, 1976; Thorne and Wolpoff, 1981; Curnoe and Thorne, 2006; Webb 2006), phylogenetic analyses have demonstrated that no such signature can be demonstrated (Westaway and Groves, 2009). Homo erectus has a series of autapomorphic characters distinct to that species, while characters shared between Homo heidelbergensis and Homo sapiens are absent in Homo erectus (Groves and Lahr, 1994). Plesiomorphic retentions in Homo sapiens provide a clearer ancestral link to the earliest anatomically modern fossils from East Africa (Groves, 1989b).

Much of the debate in Sahul on the origins of the First Australians has focused around the meaning behind the Pleistocene robust and gracile fossil series from southeast Australia. Groves (2001) noted that it is expected that much of this variation is the result of evolutionary change over '60 ka' (we prefer a date of $50 \mathrm{ka}$ from available evidence). The suggestion that cranial robusticity 
is representative of adaptation to the climatic stress of the Last Glacial Maximum (LGM) has been the subject of attention by a number of Australian palaeoanthropologists (Wright, 1976; Bulbeck, 2001; Stone and Cupper, 2003; Westaway and Lambert, 2013), although there remains a lack of clarity as to what the actual mechanism for such selection may be. It would seem that in the very important Willandra Lakes series cranial robusticity does not emerge until the approach to the Last Glacial Maximum (Westaway and Groves, 2009). There are five well-dated specimens that support this hypothesis. Currently these include the gracile fossils WLH1 and WLH3 dated to sometime around $40 \mathrm{ka}$ (Olley et al., 2006), and the robust fossils WLH 50 (Grün et al., 2011) and the two fossils WLH 152 and 153 (Webb, 2006). The revised dates on the Kow Swamp cranial series also place this robust series of crania at the peak of the LGM (Stone and Cupper, 2003).

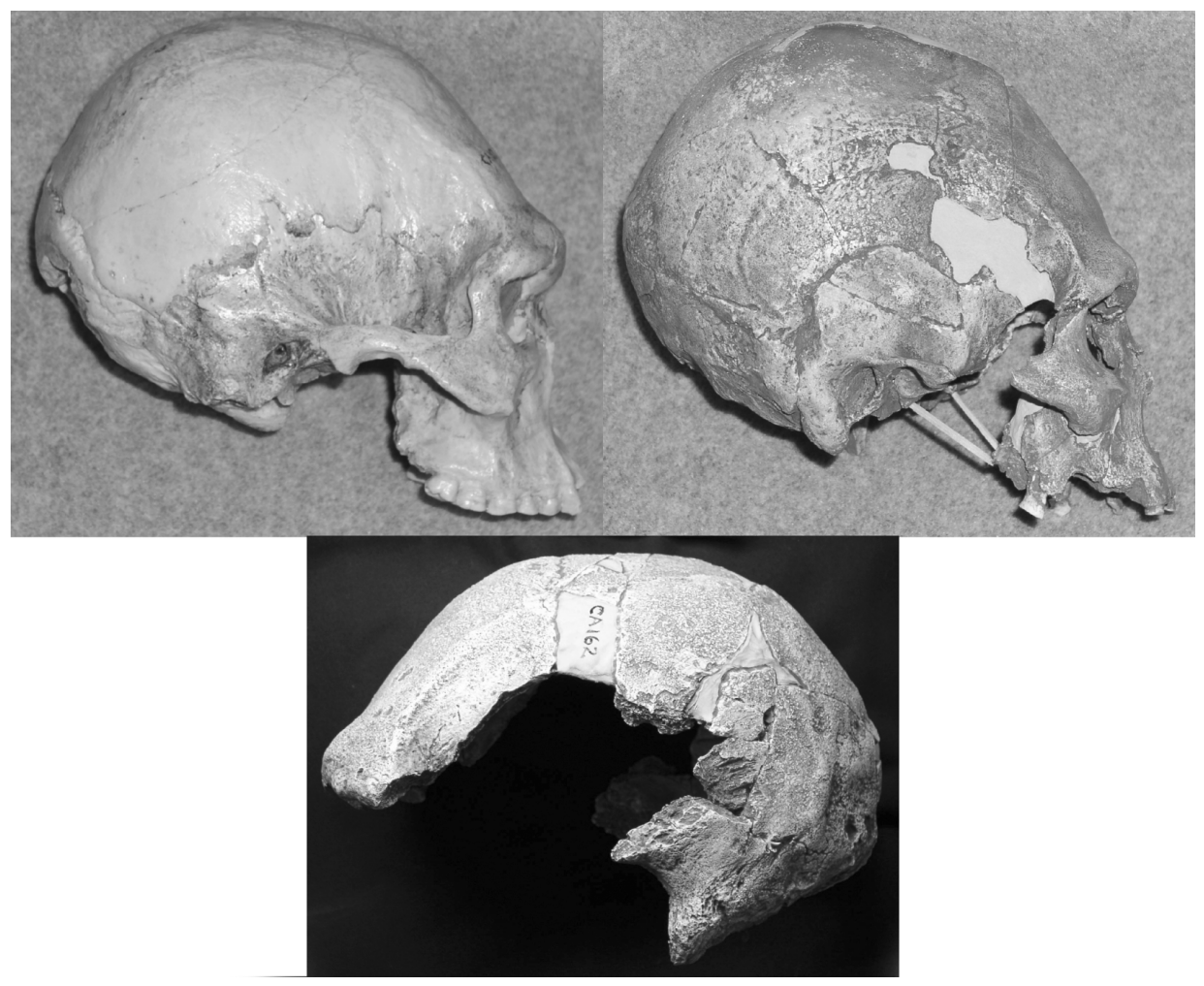

Figure 12.4a: Robust (Cohuna, Kow Swamp 5 and WLH 50) Australian fossils often discussed in the Aboriginal origins debate.

Source: Photographs taken by Arthur Durband. 


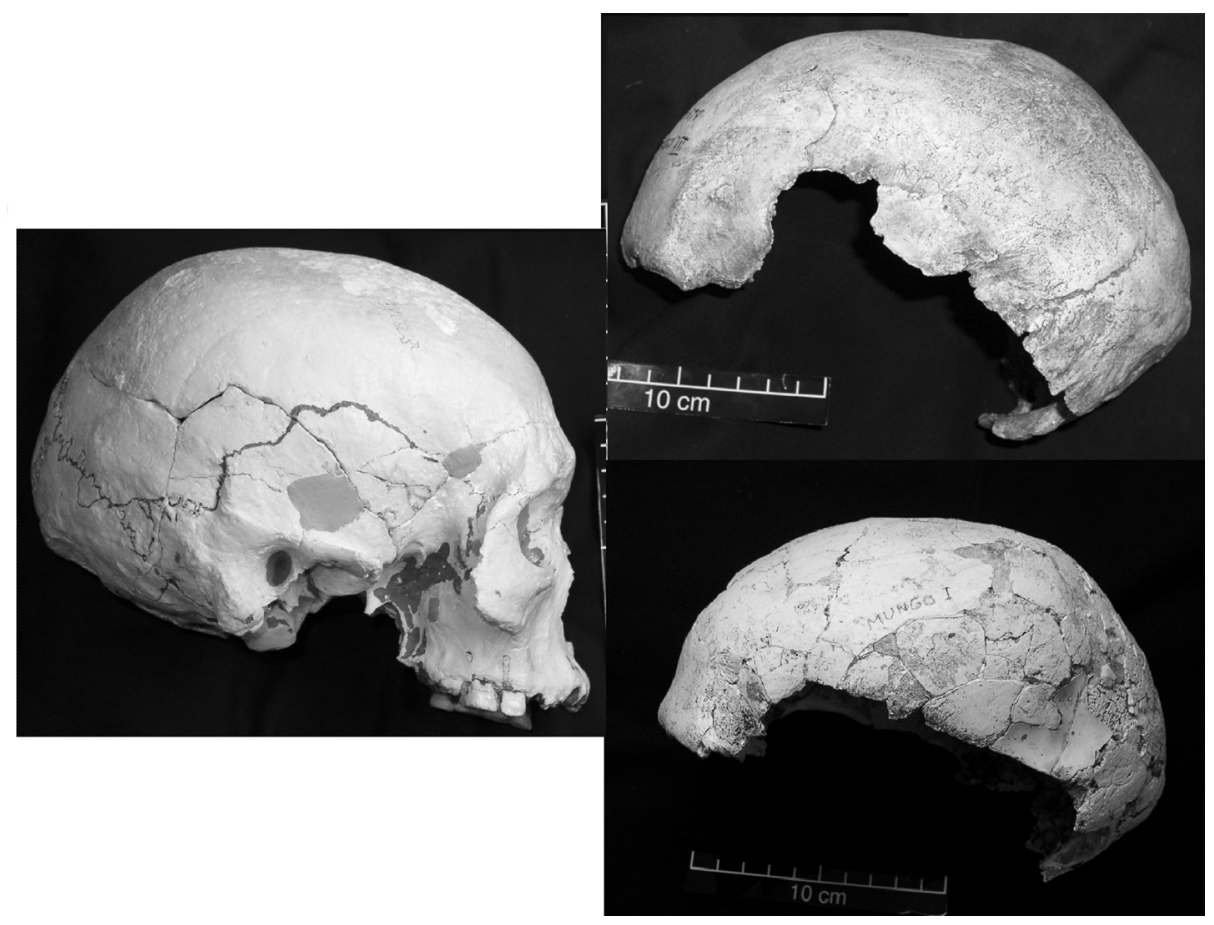

Figure 12.4b: Gracile (Keilor, WLH 3 and WLH 1) Australian fossils often discussed in the Aboriginal origins debate.

Source: Photographs taken by Arthur Durband.

Groves (2001) suggested that increased robusticity was also an artefact of artificial cranial deformation, a prospect that has been demonstrated by a number of workers (Antón and Weinstein, 1999; Durband, 2008ab). Cranial deformation contributed to the appearance of a flattened receding frontal in many of the robust fossils commonly mentioned in this debate; a feature that was initially considered to be a trait inherited from Homo erectus. While it is certainly true that not all of the robust fossils have been artificially deformed, many of the key fossils commonly mentioned by continuity advocates, like Kow Swamp 1, 5, and Cohuna, have been influenced by this cultural practice (Brown, 1989; Durband, 2008ab). Another key robust fossil in the debate, WLH 50, is likely pathological, which has resulted in the increased cranial vault thickness of the individual (Webb, 1990). There does remain some debate regarding the pathological diagnosis of WLH 50 (Westaway, 2006; Curnoe and Green, 2013; Durband and Westaway, 2013).

What would appear to best explain the high degree of cranial variation and the emergence of cranial robusticity is a significant amount of in situ evolution, associated with the climatic amelioration of the LGM, with a very ancient 
example in some regions of Sahul of the cultural practice of cranial deformation. What remains puzzling, however, is the fact that some of the robust fossils in the Australian record, such as WLH 50, WLH 19, Nacurrie 1 and 2, Kow Swamp 5 etc., do bear resemblance to some of the earliest, quite robust fossils from East Africa, such as Herto, Omo I and II and Jebel Irhoud I. This can be extended to early Homo sapiens fossils found outside of Africa as well, such as the fossil Skhul V. When tested phylogenetically (Westaway and Groves, 2009) these robust, circa 100 ka Homo sapiens fossils do sit closely to the more robust specimens from the Willandra Lakes. This suggests a situation where robusticity is present in early Homo sapiens, then a gracile from emerges with the Mungo and Niah individuals, and then we see a return to robust forms around the LGM in the Willandra Lakes.

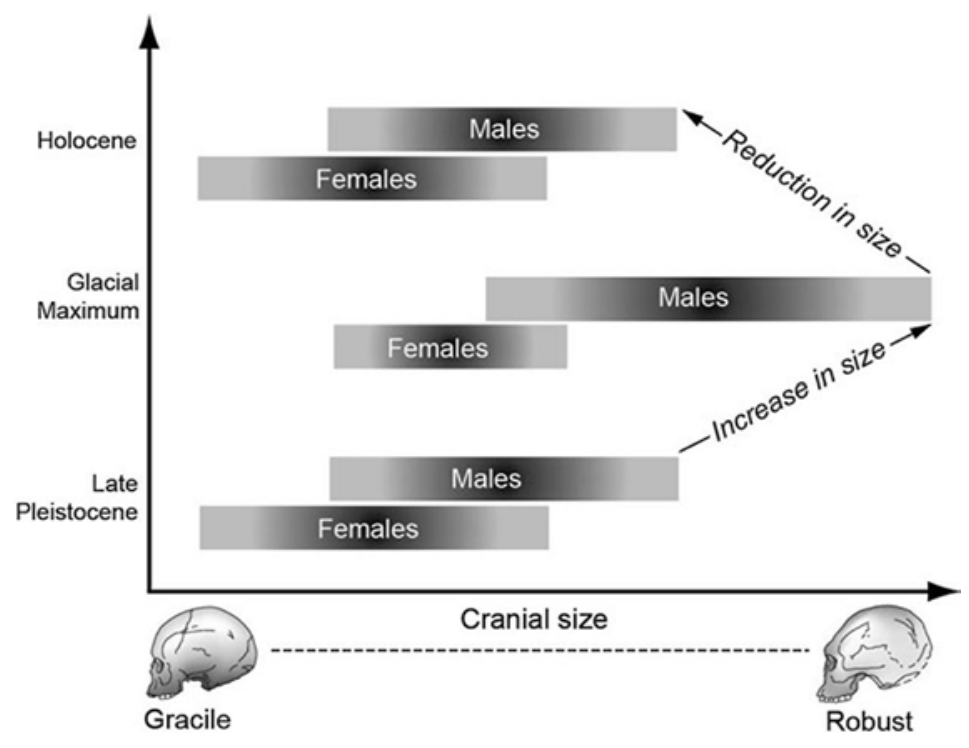

Figure 12.5: Theorised representation of the emergence of cranial robusticity associated with the onset of the Last Glacial Maximum.

Source: Westaway and Lambert (2014).

One of the big questions we now face relates to whether there was significant gene flow into Sahul later in the Pleistocene following the initial colonisation event some $50 \mathrm{ka}$. Oppenheimer (2004) suggested that a secondary migration may in fact explain the appearance of a more robust cranial form in Sahul during the LGM, which is not dissimilar to the earlier models put forward by Thorne. This is a question that is currently the subject of some scrutiny by those interested in the study of DNA. Such a migration has been suggested much later in prehistory, with the identification of gene flow from India occurring in the mid Holocene, said to have coincided with the arrival of the dingo (Pugach 
et al., 2013). This hypothesis will undoubtedly be the subject of reassessment through future studies of both aDNA and modern sampling, which we shall touch upon in the next section.

\section{Revising the record through studies in DNA}

DNA is rewriting our understanding of the complexity of Australia's early population history. It also serves as a catalyst to reconsider the meaning of the diversity in the Australian human fossil and osteological record. Studies on living populations have distinguished unique Y chromosome and mtDNA haplotypes in Aboriginal Australia which indicate that migrations into Australia through Asia predate 50 ka (Keinan et al., 2007; Gutenkunst et al., 2009; van Holst Pellekaan, 2013). However, like all other non-African populations, all Aboriginal Australian mtDNA studies demonstrate that their ancestry can be traced to a single L3 haplotype.

Initial forays into ancient DNA (aDNA) generated much excitement in archaeological/palaeoanthropological circles. The announcement in 2001 by Adcock et al. of the identification of an extinct mitochondrial lineage brought Lake Mungo once again into the global limelight. Their argument suggested that the $40 \mathrm{ka}$ WLH 3 fossil and a later fossil from Kow Swamp (KS 8) contained a non-L3 mitochondrial lineage that was identified as no longer being present in modern populations. This suggested to the authors that two populations had co-existed in Australia, with the WLH 3 mitochondrial genome representing an extinct human lineage (Adcock et al., 2001). In a forum in Archaeology in Oceania, Groves noted that the triumph of the paper, that being of aDNA extraction from such ancient fossils, was overshadowed by what he regarded as the shortcomings of the authors' interpretations. His concerns were over the lack of support for the branch in their cladogram for modern humans and the other potential interpretations of the data (such as the lineage sorting within an ancient population, as opposed to the replacement of a human lineage). In a later publication he discussed with the palaeoanthropologist David Cameron the possibility of contamination in the sequence by nDNA inserts (numts), which may have resulted in the observed mtDNA sequence. They also questioned as to whether the signature represented modern contamination (Cameron and Groves, 2004).

The meaning of the aDNA record from the Willandra series is undergoing a new analysis using next generation sequencing, and a review of this more recent DNA research is providing new insights into the evolutionary past of the first Australians. The identification of archaic DNA of Neanderthals and Denisovans in the DNA of Melanesian populations has revealed that there was indeed 
genetic exchange between the first modern humans in Central Asia and some of the later archaic hominin species during the Late Pleistocene period (Rasmussen et al., 2011). While we have evidence that some limited DNA sequences of Neanderthals and Denisovans were assimilated into H. sapiens, it is feasible that interactions with Homo erectus/soloensis did occur, but no viable offspring resulted. The divergence from Homo erectus was several hundred thousand years earlier than the split between Homo sapiens and Homo neanderthalensis (the recognised common ancestor between the latter two being Homo heidelbergensis, which lived during the later Middle Pleistocene). Low rates of Neanderthal and Denisovan DNA can be interpreted in a number of ways. Perhaps reproductive success was not high and hence it is reasonable to assume that reproductive success would have been even less likely between Homo sapiens and Homo erectus. Current evidence suggests that there is no support for overlap between these two species (Westaway and Groves, 2009; Indriati et al., 2011).

An important component of mtDNA studies from Melanesia (Friedlaender et al., 2005), as highlighted by Davidson (2010 and 2013), is that the genetic evidence indicates two possible migration events, with a separation between the mtDNA of the colonists of north and east Papua New Guinea, with those from southern Sahul. Indeed it would appear that the haplotypes from Melanesia represent earlier haplotypes from those present in southern Sahul (Merriwether et al., 2005). The Australian mt haplogroups S, O, and M42a are not shared with New Guinea on current evidence and this, together with shared haplogroups $\mathrm{P}$ and $\mathrm{Q}$, has been interpreted as indicating separate origins of Australian and New Guinea people, while at the same time suggesting different migration histories of these separate groups of colonisers.

More recent research has identified a genomic signature said to be representative of substantial gene flow between the Indian populations and Australia during the mid Holocene some 4,230 years ago (Pugach et al., 2013). This research group attempted to link these changes with the arrival of the dingo in Australia and the appearance of changes in stone tool technology. However, the latter of these changes have been demonstrated by archaeologists to have occurred much earlier in some regions of Australia (Hiscock, 2008), and are likely to have little relevance to a possible migration from India. The other key issue with the proposed Indian migration is how did such populations enter Australia in the mid Holocene without leaving any trace in island Southeast Asia? While an influx of additional genetic material into Australia during the Holocene possibly did occur, it is still not clear if this left any significant genetic signature. This question will require further review to establish the meaning of any such genetic signature. 
Taxonomic Tapestries

\section{Discussion}

Colin Groves has made a significant contribution to our understanding of human evolution in Sunda and Sahul. One aspect of human evolution in the region that all would seem to agree upon is that resolving many of the questions discussed in the past by Groves and others will only be possible through the discovery of new specimens. Importantly, it also requires a clearer chronological sequence for the fossils, in order to place them reliably in an evolutionary framework. Refining our techniques of analysis is critical to help establish more reliable means of hypothesis testing. An approach that involves splitting fossil specimens into different taxonomically recognised species (or operationally taxonomic units, as Groves prefers) holds a great deal of potential for unravelling the nature of phylogenetic relationships in human evolution. If species are lumped together, and autapomorphies in recognisable specimens are effectively ignored, then we risk the opportunity of identifying examples of speciation within our genus.

In this chapter we have considered a number of key themes in human origins research in the regions of Sunda and Sahul. The taxonomic subdivision of various fossil discoveries of Sunda spanning some 1.5 million years into four separate species (as opposed to two) is an approach that is currently difficult to test phylogenetically, due to the fragmentary nature of the early Sangiran record. As demonstrated by Kaifu et al., it is difficult to establish with certainty if the pre-Grenzbank fossils from Sangiran truly represent a distinct species. Kubo et al. (2013) have recently demonstrated that dwarfism in Homo floresiensis is a less dramatic prospect when we consider this with the earlier Javan hominins, and not the later classic Homo erectus. Previously Kaifu et al. (2005) have raised the possibility that the earlier Javan hominins may in fact represent an earlier species. We envisage that perhaps a more parsimonious explanation for the origins of Homo floresiensis is that it is derived from an earlier pre-erectus hominin. We agree that the pre-Grenzbank fossils probably represent a more likely candidate ancestor for Homo floresiensis, or perhaps a sister group to a close ancestor, than do the later Homo erectus fossils. There are some fossils from the pre-Grenzbank, such as the very large Sangiran 6 that may even represent a different genus, as suggested by Robinson (1953 and 1955). Sangiran 6 is unlikely to represent an ancestor of either Homo floresiensis or Homo erectus. It is probable that it was the gradual divergence between species within these different populations, following the geographic isolation of one population on Flores, which led to the emergence of the new species Homo floresiensis. In this model then Homo modjokertensis was not necessarily a terminal species, and it was also not the ancestor of Homo erectus. The ancestral candidate for Homo erectus was Homo ergaster. We suggest that Homo modjokertensis on Java was eventually replaced by Homo erectus, the timing of which remains unknown. 
Is it reasonable to continue identifying Homo erectus as a distinct species that remained as the same taxon for around 1 Mya-800 ka? Homo erectus continued along its evolutionary trajectory following the extinction of Homo modjokertensis. If the species evolved on Java for $800 \mathrm{ka}$ or more, should we regard the late Homo erectus at the sites of Ngandong, Ngawi and Sambungmacan as a different species? Similar divisions have been made within the transitory grade between Homo heidelbergensis and Homo neanderthalensis. There is an increasing acceptance of evolutionary change within hominin species that did not necessarily lead to the lineage of Homo sapiens. This perhaps requires for consideration the designation of a later species Homo soloensis.

The presence of Homo floresiensis in the lesser Sunda Islands suggests that hominin evolution on the edge of the hominin range was no less stagnant than evolution in other regions closer to the original centre. Perhaps it is time that we begin considering that evolutionary processes in Sunda are as complex as those identified in Africa and Europe, with a model of punctuated equilibrium perhaps being relevant to Pleistocene Sunda. Homo soloensis was eventually replaced by Homo sapiens sometime after 100,000 years ago. Homo floresiensis was replaced soon after the arrival of Homo sapiens in the lesser Sunda Chain, following the arrival of modern people on the eastern side of the Wallace Line, perhaps some 60,000 years ago. It is apparent that our species was likely responsible for the extinction of two hominin lineages in Sunda, although the timing of the disappearance of Homo erectus remains unresolved.

Microevolutionary changes are most likely responsible for the variation that we see within Homo sapiens in Pleistocene Sahul. It would not appear necessary to call upon models that discuss assimilation of Sunda hominins to explain the appearance of cranial robusticity around the time of the Last Glacial Maximum. The emergence of cranial robusticity perhaps has more to do with the onset of glacial conditions in Sahul. DNA studies may be able to assist us in unravelling the gracile and robust debate, by establishing if the variation is simply just reflective of sexual dimorphism. Importantly, DNA is beginning to reveal important new information that is not available from the study of fossil morphology alone. The evidence for genetic exchange between our species and the Late Pleistocene hominins Homo neanderthalensis and the enigmatic Denisovans is an exciting development resulting from such studies.

\section{Conclusion}

We are very fortunate that amongst his diverse taxonomic interests Colin Groves has been able to invest some time into the question of hominin phylogeny in Sunda and Sahul. The discipline in Australia is very much richer as a result. 
In this paper we have suggested a hypothesis for hominin evolution in Sunda and Sahul building on the theoretical approach of Groves. It will be tested, and potentially falsified, through the acquisition of new evidence (both fossil and DNA), the refinement of the chronology of known fossil hominins, and the development of new techniques of phylogenetic analysis on both new and old data.

\section{Acknowledgements}

Thank you very much to the editors for their kind invitation to be part of this important volume. We are grateful to Dr Christine Hertler and Dr Friedemann Schrenk from the Senckenberg, Frankfurt, for providing access to the Sangiran 6 specimen in their collection and allowing me to compare these to casts within the collection. We are also grateful to Dr Dominique Grimaud-Hervé from The Institut de paléontologie humaine, Paris, for allowing MCW access to the cast of Sangiran 31 and for discussions on the possible meaning of its morphology. Professor Mark Collard from Simon Fraser University provided many valuable comments on the possible meaning of the Sangiran 6 mandible, a jaw fragment that we hope to review with Prof Collard in further detail at some stage in the future. The Elders from the Willandra Lakes World Heritage Area have provided ongoing support for our research into the origin of their ancestors, which we are deeply grateful for. Finally, the late Professor Mike Morwood provided the images of Homo floresiensis, he was a very generous and supportive scholar and the discipline of palaeoanthropology in this region has suffered a great loss with his passing.

\section{References}

Adcock GJ, Dennis ES, Easteal S, Huttley GA, Jermiin LS, Peacock J, Thorne A. 2001. Mitochondrial DNA sequences in ancient Australians: Implications for modern human origins. Proc Natl Acad Sci 98(2):537-542.

Anton SC, Spoor F, Fellman CD, Swisher III CC. 2007. Defining Homo erectus: Size considered. In: Henke W, Tattersall I, editors. Handbook of Paleoanthropology. Berlin: Springer-Verlag. pp. 1655-1693.

Antón SC, Weinstein KJ. 1999. Artificial cranial deformation and fossil Australians revisited. J Hum Evol 36:195-209.

Argue D, Morwood MJ, Sutikna T, Jatmiko, Saptomo EW. 2009. Homo floresiensis: A cladistic analysis. J Hum Evol 57:623-629. 
Bird MI, Taylor D, Hunt C. 2005. Palaeoenvironments of insular Southeast Asia during the Last Glacial Period: A savanna corridor in Sundaland? Quat Sci Rev 24(20-21):2228-2242.

Bräuer G. 1992. Africa's place in the evolution of Homo sapiens. In: Bräuer G, Smith, editors. Continuity or replacement: Controversies in Homo sapiens evolution. Rotterdam: AA Balkema. pp. 83-98.

Brown P. 1989. Coobool Creek. A morphological and metrical analysis of the crania, mandibles and dentitions of a prehistoric Australian human population. Terra Australis, 13. Canberra: Department of Prehistory, Australian National University.

Brown P, Maeda T. 2009. Liang Bua Homo floresiensis mandibles and mandibular teeth: A contribution to the comparative morphology of a new hominin species. J Hum Evol 57:571-596.

Brown P, Sutikna T, Morwood MJ, Soejono RP, Jatmiko Wayhu Saptomo E, Awe Due R. 2004. A new small-bodied hominin from the Late Pleistocene of Flores, Indonesia. Nature 431:1055-1061.

Bulbeck FD. 2001. Robust and gracile Australian Pleistocene crania: The tale of the Willandra Lakes. In: Simanjuntak T, Prasetyo B, Handini R, editors. Sangiran: Man, culture, and environment in Pleistocene times: Proceedings of the International Colloquium on Sangiran Solo-Indonesia. Jakarta: Yayasan Obor. pp. 60-106.

Cameron DW, Groves CP. 2004. Bones, stones and molecules. London: Elsevier.

Collard M, Wood BA. 2007. Defining the genus Homo. In: Henke W, Rothe H, Tattersall I, editors. Handbook of Paleoanthropology. Berlin Heidelberg: Springer. pp. 1575-1610.

Curnoe D, Thorne A. 2006. Human origins in Australia: The skeletal evidence. Before Farming [online version] 2006/1 Article 5.

Curnoe D, Green H. 2013. Vault thickness in two Pleistocene crania. J Archaeol Sci 40(2):1310-1318.

Davidson I. 2010. A lecture by the returning Chair of Australian Studies, Harvard University, 2008-09 Australian archaeology as a historical science. $J$ Australian Studies 34(3):377-398.

Davidson I. 2013. Peopling the last new worlds: The first colonisation of Sahul and the Americas. Quatern Int 285:1-29. 
Taxonomic Tapestries

Delson E, Eldridge N, Tattersall I. 1977. Reconstruction of hominid phylogeny: A testable framework based on cladisitic analysis. J Hum Evol 6:263-278.

de Vos J, Sondaar PY, Van Den Bergh GD, Aziz F 1994. The Homo bearing deposits of Java and its ecological context. Cour Forsch Inst Senckenberg 171:129-140.

Dubois E. 1894. Pithecanthropus erectus, eine menschenaehnliche Ubergangsform aus Java. Batavia: Landesdruckerei.

Durband AC. 2002. The squamotympanic fissure in the Ngandong and Sambungmacan Hominids: A reply to Delson et al. Anat Rec 266:138-141.

Durband AC. 2004. A test of the multiregional hypothesis of modern human origins using basicranial evidence from Indonesia and Australia. PhD dissertation, University of Tennessee.

Durband A. 2006. Craniometric variation within the Pleistocene of Java: The Ngawi 1 cranium. Hum Evol 21:193-201.

Durband A. 2007. The view from down under: A test of the multiregional hypothesis of modern human origins using the basicranial evidence from Australasia. Collections in Anthropology 3:651-659.

Durband AC. 2008a. Artificial cranial deformation in Pleistocene Australians: The Coobool Creek sample. J Hum Evol 54(6):795-813.

Durband AC. 2008b. Artificial cranial deformation in Kow Swamp 1 and 5: A response to Curnoe (2007). Homo 59:261-269.

Durband AC. 2008c. Mandibular fossa morphology in the Ngandong and Sambungmacan fossil hominids. Anat Rec 291:1212-1220.

Durband AC. 2009. Southeast Asian and Australian paleoanthropology: A review of the last century. J Anthropol Sci 87:7-31.

Durband AC, Westaway MC. 2013. Perspectives on the origins of modern Australians. In: Smith FH, Ahern J, editors. The origins of modern humans: Biology reconsidered. Wiley-Blackwell.

Frayer DW, Wolpoff MH, Thorne AG, Smith FH, Pope GG. 1993. Theories of modern human origins: The paleontological test. Am Anthropol 95:14-50.

Friedlaender J, Schurr T, Gentz F, Koki G, Friedlaender F, Horvat G, Babb P, Cerchio S, Kaestle F, Schanfield M, Deka R, Yanagihara R, Merriwether DA. 2005. Expanding southwest Pacific mitochondrial haplogroups $\mathrm{P}$ and Q. Mol Biol Evol 22:1506-1517. 
Grimaud-Hervé D. 2001. Taxonomic position of the Sangiran 31 Hominid. In: Simanjuntak T, Prasetyo B, Handini R, editors. Sangiran: Man, culture, and environment in Pleistocene times: Proceedings of the International Colloquium on Sangiran Solo-Indonesia. Jakarta: Yayasan Obor. pp. 46-53.

Groves CP. 1989a. A theory of human and primate evolution. Cambridge: Cambridge University Press.

Groves CP. 1989b. A regional approach to the problem of the origin of modern humans in Australia. In: Mellars PA, Stringer CB, editors. The human revolution: Behavioural and biological perspectives on the origins of modern humans. Edinburgh: Edinburgh University Press. pp. 274-285.

Groves CP. 1996. Hovering on the brink but not quite getting there. Perspect Hum Biol 2:83-87.

Groves CP. 2001. Lake Mungo 3 and his DNA. Archaeol Ocean 36(3):166-167.

Groves, CP 2008. Walking with Hobbits. Australasian Science (March):16-19.

Groves CP, Lahr MM. 1994. A bush not a ladder: Speciation and replacement in human evolution. Perspect Hum Biol 4:1-11.

Groves CP, Mazák V. 1975. An approach to the taxon of Hominidae: Gracile Villafranchian hominids of Africa. Casopsis Pro Mineralogii 20:225-246.

Grün R, Spooner N, Magee J, Thorne A, Simpson J, Yan G, Mortimer G. 2011. Stratigraphy and chronology of the WLH 50 human remains, Willandra Lakes World Heritage Area, Australia. J Hum Evol 60(5):597-604.

Gutenkunst RN, Hernandez RD, Williamson SH, Bustamante CD. 2009. Inferring the joint demographic history of multiple populations from multidimensional SNP frequency data. PLoS Genetics 5(10):e1000695.

Hawks J, Oh S, Hunley K, Dobson S, Cabana G, Dayalu P, Wolpoff MH. 2000. An Australasian test of the recent African origin theory using the WLH-50 calvarium. J Hum Evol 39:1-22.

Hiscock P. 2008. The archaeology of ancient Australia. Routledge, London.

Holliday TW, Franciscus RG. 2009. Body size and its consequences: Allometry and the lower limb length of Liang Bua 1 (Homo floresiensis). J Hum Evol 57(3):223-228.

Hyodo M. 2011. High resolution record of the Matuyama-Brunhes transition constrains the age of Javanese Homo erectus in the Sangiran dome, Indonesia. Proc Natl Acad Sci 108. 
Indriati E, Swisher III CC, Lepre C, Quinn RL, Suriyanto RA, Hascaryo AT, Grün R, Feibel CS, Pobiner BL, Aubert M, Lees W, Antón SC. 2011. The age of the 20 meter Solo River Terrace, Java, Indonesia and the survival of Homo erectus in Asia. PLoS One 6(6):e21562.

Jungers WL, Harcourt-Smith WEH, Wunderlich RE, Tocheri MW, Larson SG, Sutikna T, Awe Due R, Morwood MJ. 2009b. The foot of Homo floresiensis. Nature 459:81-84.

Jungers WL, Larson SG, Harcourt-Smith W, Morwood MJ, Sutikna T, Awe Due R, Djubiantono T. 2009a. Descriptions of the lower limb skeleton of Homo floresiensis. J Hum Evol 57:538-554.

Kaifu Y, Aziz F, Indriati E, Jacob T, Kurniawan I, Baba H. 2008. Cranial morphology of Javanese Homo erectus: new evidence for continuous evolution, specialization, and terminal extinction. J Hum Evol 55(4):551580 .

Kaifu, Y, Baba H, Aziz F, Indriati E, Schrenk F, Jacob T. 2005. Taxonomic affinities and evolutionary history of the early Pleistocene hominins of Java: dentognathic evidence. Am J Phys Anthrop 128:709-726.

Keinan A, Mullikin JC, Patterson N, Reich D. 2007. Measurements of the human allele frequency spectrum demonstrates greater genetic drift in East Asians than in Europeans. Nat Genet 29:1251-1255.

Kubo D, Kono RT, Kaifu Y. 2013. Brain size of Homo floresiensis and its evolutionary implications. Proc $R$ Soc Ser B 280(1760):1-9.

Lahr MM. 1996. The evolution of modern human diversity: A study of cranial variation. Cambridge: Cambridge University Press.

Larick R, Ciochon RL, Zaim Y, Sudijono S, Rizal Y, Aziz F, Reagan M, Heizler M. 2001. Early Pleistocene 40AR/39Ar ages for Bapang Formation hominins, Central Java, Indonesia. Proc Natl Acad Sci 98:4866-4871.

Leigh SR. 1992. Cranial capacity evolution in Homo erectus and early Homo sapiens. Am J Phys Anthrop 87:1-13.

Macintosh NWG, Larnach SL. 1976. Aboriginal affinities looked at in world context. In: Kirk RL, Thorne AG, editors. The origins of the Australians. Canberra: Australian Institute of Aboriginal Studies Press. pp. 113-126.

Merriwether DA, Hodgson JA, Friedlaender FR, Allaby R, Cerchio S, Koki G, Friedlaender JS. 2005. Ancient mitochondrial M haplogroups identified in the Southwest Pacific. Proc Natl Acad Sci 102:13034-13039. 
Morwood MJ, Brown P, Jatmiko, Sutikna T, Wahyu Saptomo E, Westaway KE, Rokus Awe Due, Roberts RG, Maeda T, Wasisto S, Djubiantono T. 2005. Further evidence for small-bodied hominins from the late Pleistocene of Flores, Indonesia. Nature 437:1012-1017.

Morwood MJ, O'Sullivan PO, Susanto EE, Aziz F. 2003. Revised age of Mojokerto 1, an early Homo erectus cranium from East Java, Indonesia. Austral Archaeol 57:1-4.

Morwood MJ, Soejono RP, Roberts RG, Sutikna T, Turney CSM, Westaway KE, Rink WJ, Zhao J-X, Van den Bergh GD, Awe Due R, Hobbs DR, Moore WM, Bird MI, Fifield LK, 2004. Archaeology and age of a new hominin from Flores in eastern Indonesia. Nature 431:1087-1091.

O'Connor S, Ono R, Clarkson C. 2011. Pelagic fishing at 42,000 years before the present and the maritime skills of modern humans. Science 334(6059):11171121.

Olley, J. M., Roberts, R. G., Yoshida, H., \& Bowler, J. M. 2006. Single-grain optical dating of grave-infill associated with human burials at Lake Mungo, Australia. Quaternary Science Reviews, 25(19), 2469-2474.

Oppenheimer S. 2004. Out of Eden: The peopling of the world. London: Robinson Publishing.

Oppenoorth WFF. 1932. Homo (Javanthropus) Soloensis. Een Plistoceene mensch van Java. Wetensch. Meded. Van den Dienst van den Mijnbouw NederlandschIndië, No. 20:49-63.

Pugach I, Delfina F, Gunnarsdóttira E, Kayserd M, Stoneking M. 2013. Genomewide data substantiate Holocene gene flow from India to Australia. Proc Natl Acad Sci 110(5):1803-1808.

Rasmussen M, Guo X, Wang Y, Lohmueller KE, Rasmussen S, Albrechtsen A ... \& Krogh A. 2011. An Aboriginal Australian genome reveals separate human dispersals in Asia. Science 334(6052):94-98.

Rightmire GP. 1990. The evolution of Homo erectus: Comparative anatomical studies of an extinct human species. Cambridge: Cambridge University Press.

Rightmire GP. 1991. The dispersal of Homo erectus from Africa and the emergence of more modern humans. J Anthropol Res 47:177-191.

Robinson JT. 1953. Meganthropus, australopithecines, and hominids. Am J Phys Anthrop 11:1-38. 
Taxonomic Tapestries

Robinson JT. 1955. Further remarks on the relationship between "Meganthropus" and australopithecines. Am J Phys Anthrop 13:429-446.

Rightmire GP. 1994. The relationship of Homo erectus to later middle Pleistocene hominids. Cour Forsch-Inst Senckenberg 171:319-326.

Santa Luca AP. 1980. The Ngandong fossil hominids: A comparative study of a Far Eastern Homo erectus group. Yale Univ Publ Anthropol 78.

Stone T, Cupper ML. 2003. Last Glacial Maximum ages for robust humans at Kow Swamp, southern Australia. J Hum Evol 45(2):99-111.

Storm P. 2000. The evolutionary history of humans in Australasia from an environmental perspective. Anthropol Sci 108:225-244.

Storm P. 200la. Life and death of Homo erectus in Australasia: An environmental approach to the fate of a paleospecies. In: Sémah F, Falguères C, GrimaudHervé D, and Sémah A-M, editors. Origine des Peuplements et Chronologie des cultures Paléolithiques dans Le Sud-Est Asiatique. Paris: Semenanjung. pp. 279-298.

Storm P. 2001b. The evolution of humans in Australasia from an environmental perspective. Palaeogeogr Palaeoclimatol Palaeoecol 171:363-383.

Thorne A. 1976. Morphological contrasts in Pleistocene Australians. In: Kirk RL, Thorne AG, editors. The origin of the Australians. Canberra: AIAS Press. pp. 95-112.

Thorne A, Wolpoff MH. 1981. Regional continuity in Australasian Pleistocene hominid evolution. Am J Phys Anthrop 55:337-349.

Tobias PV, von Koenigswald GHR. 1964. A comparison between the Olduvai hominines and those of Java and some implications for hominid phylogeny. Nature 204:515-518.

Tocheri M, Orr CM, Larson SG, Sutikna T, Jatmiko, Saptomo EW, Rokus Awe Due, Djubiantano T, Morwood MJ, Jungers WI. 2007. The primitive wrist bone of Homo. floresiensis and its implications for hominin evolution. Science 317:1743-1745.

Tyler DE, Krantz GS, Sartono S. 1995. The taxonomic status of the 'Meganthropus' cranial (Sangiran 31) and the 'Meganthropus' occipital fragment III. In: Bower JRF, Sartono S, editors. Evolution and ecology of Homo erectus. Leiden: Pithecanthropus Centennial Foundation, Leiden University. pp. 189-201. 
van den Bergh GD. 1999. The late Neogene elephantoid-bearing faunas of Indonesia and their palaeozoogeographic. A study of the terrestrial faunal succession of Sulawesi, Flores, and Java, including evidence for early hominid dispersal east of Wallace's Line implications. Scripta Geol 117:1-419.

van den Bergh GD, de Vos J, Sondaar PY. 2001. The late Quaternary palaeogeography of mammal evolution in the Indonesian archipelago. Palaeogeogr Palaeoclimatol Palaeoecol 171:385-408.

Van den Bergh GD, de Vos J, Sondaar PY, Aziz F. 1996. Pleistocene zoogeographic evolution of Java (Indonesia) and glacio-eustatic sea level fluctuations: A background for the presence of Homo. Bullindo Pac Pre hi 14:7-21.

Van Holst Pellekaan. 2013. Genetic evidence for the colonization of Australia. Quatern Int 285:44-56.

Von Koenigswald GHR. 1956. Meeting prehistoric man. London: Thames and Hudson.

Webb SG. 1990. Cranial thickening in an Australian hominid as a possible palaeoepidemological indicator. Am J Phys Anthrop 82(4):403-411.

Webb SG. 2006. The first boat people. Cambridge: Cambridge University Press.

Weidenreich F. 1943. The skull of Sinanthropus pekinensis: A comparative study on a primitive hominid skull. Palaeontol Sin NS D 10.

Westaway, M.C. 2006. The Pleistocene human remains collection from the Willandra Lakes World Heritage Area, Australia, and its role in understanding modern human origins. National Science Museum Monographs No. 34. Tokyo: National Science Museum.

Westaway MC, Groves CP. 2009 The Mark of Ancient Java is on none of them. Archaeol Oceania 44:84-95.

Westaway MC, Lambert D. 2014. Origins of the First Australians. In: Smith C, editor. The global atlas of archaeology. New York: Springer.

Widianto H, Zeitoun V. 2003. Morphological description, biometry and phylogenetic position of the skull of Ngawi 1 (East Java, Indonesia). Int $J$ Osteoarchaeol 13:339-351.

Wood BA and Collard M. 1999. The human genus. Science 284:65-71.

Wright RVS. 1976. Evolutionary process and semantics: Australian prehistoric tooth size as a local adjustment. In: Kirk RL, Thorne AG, editors. The origin of the Australians. Canberra: AIAS Press. pp. 265-274. 
Taxonomic Tapestries

Zeitoun V. 2009. The human canopy: Homo erectus, Homo soloensis, Homo pekinensis and Homo floresiensis. BAR International Series 1937. Oxford: John and Erica Hedges Ltd.

Zeitoun V, Detroit F, Grimaud-Herve D, Widianto H. 2010. Solo man in question: Convergent views to split Indonesian Homo erectus in two categories. Quaternary International 223-224:281-292. 
PART IV 



\title{
13. The domestic and the wild in the Mongolian horse and the takhi
}

\author{
Natasha Fijn
}

\section{Introduction}

Against a strong head wind we reached this almost flat plateau, at a height of 6,800 ft., and immediately saw, a few kilometers off, a group of animals galloping away from us at full speed. My Mongolian companion, Namkhajdorj Balgan, recognised them at once with the naked eye as Przewalski wild horses, and subsequent observation with a telescope confirmed beyond any possible doubt that this was what they were ... We followed them for about six or eight miles over quite open ground and observed them by telescope until they disappeared (Kaszab, 1966: 346).

The account above is by a scientist on a joint Hungarian-Mongolian expedition in the summer of 1966. This was the last published sighting of horses in the wild in the scientific literature. The final sighting of this unique horse was actually recorded in 1969 by the Mongolian scientist N. Dovchin (Bouman and Bouman, 1994). There were, no doubt, further sightings by local Mongolian herders travelling with their herds to waterholes in the area. These herding families would have had an intimate knowledge about the habits of the takhi, passed down from one generation to another over the millennia. The location, near the border between China and Mongolia, was sparsely populated and the final retreat for the last Asiatic wild horse population. Mongolian herders called this mountainous location Takhiin Shar Nuruu, which translates as The Yellow Wild Horse Mountain Range. With their knowledge of horses, Mongolian herders would have recognised the significance of this area as a refuge for the takhi.

One of the earliest written references to the takhi was in The Secret History of the Mongols where it describes how Chinggis Khan fell from his horse when it was startled by takhi (Bouman and Bouman, 1994). To Mongolians the takhi is the 'father' of the Mongolian horse. The horse is an inherent part of their identity as herders and as Mongolians. Stamina and strength are prized characteristics in a Mongolian horse and the takhi represents the epitome of these features. The intention of this paper is to re-examine the notions of domestic and wild in relation to the 'domestic' Mongolian horse and the 'wild' takhi from Mongolia, 
not just from a western perspective but also through a cross-cultural lens from living with herders and their herd animals in the Khangai Mountains of Mongolia.

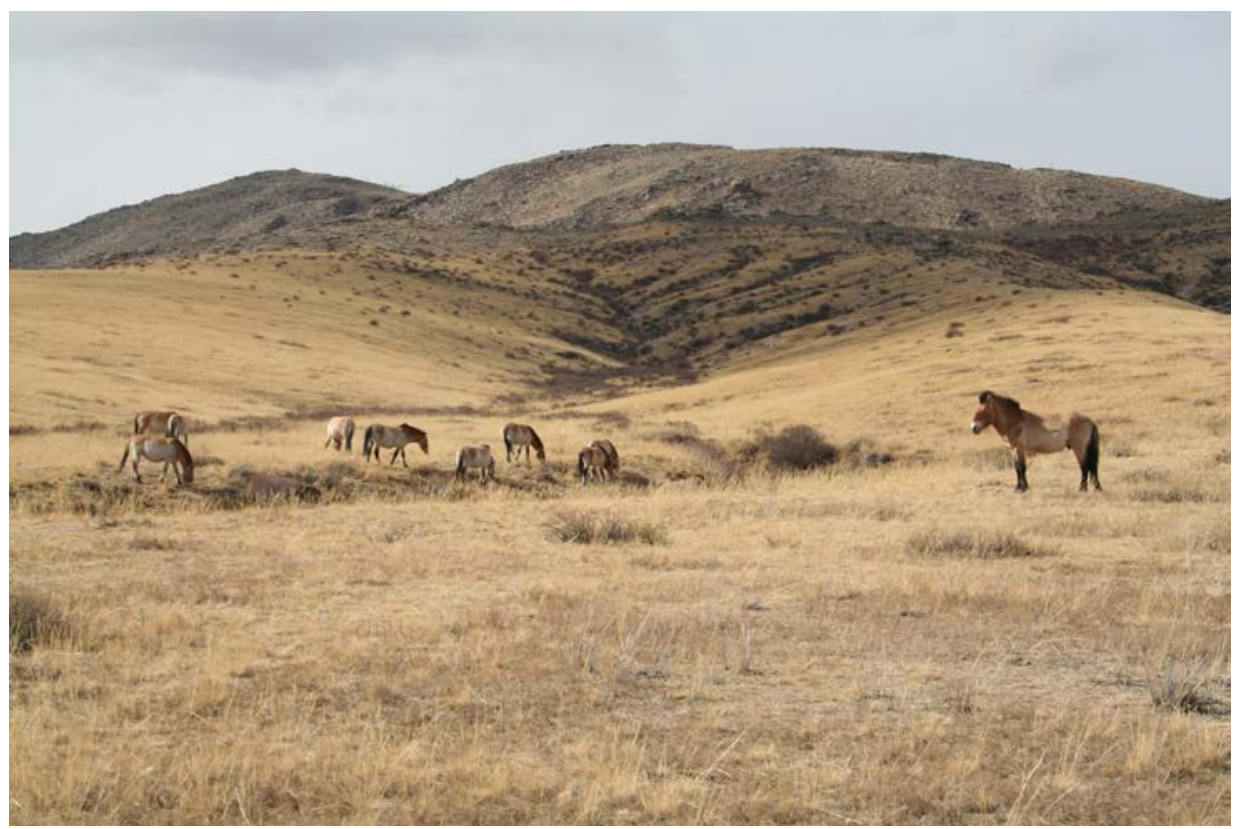

Figure 13.1: Takhi herd with stallion to the right, Hustai Nuruu National Park, 2007.

Source: Photograph by Natasha Fijn

\section{Taxonomy and morphology of wild horse characteristics}

During the Paleolithic, in both present-day France and Spain, humans were painting and etching horses on the walls of caves and making small clay horse figurines. These depictions of the wild horses they hunted bear a remarkable resemblance to the Asiatic wild horse, or Equus przewalskii. The horses had upright manes and 'beards' along the jaw line with light muzzles and underparts (see Figures 4-6 in Mohr, 1971; Figure 2 in Pruvost et al., 2011).

When Linnaeus (1707-1778) formed the classification system for scientific nomenclature, he made no mention of the Asiatic wild horse because such a horse was not yet known to exist according to the current knowledge in Europe (Bouman and Bouman, 1994). A wild horse population, Equus ferus ferus, known 
as the tarpan, was still clinging on to existence on the steppes of the Ukraine when another wild horse population was 'discovered' in 1881 (or made more widely known) through Colonel Przewalski's reports on his explorations into Central Asia. The tarpan was mouse-grey and would turn almost white in the winter to camouflage with its snowy environment. In contrast the Asiatic wild horse varied from rust or dun-coloured to bay (Groves, 1994; see Figures 13.1 and 13.2).

In 1986, Colin Groves recognised two wild horse taxa that survived into historic times, Equus ferus przewalskii Poliakov, 1881, and Equus ferus ferus Boddaert, 1785. Groves outlined key differences in external and cranial morphology between the 'wild type' Przewalski horse and that of the domestic horse from examining museum specimens, photographs, the current literature and descriptive accounts of the horse. These differences were based on a close analysis of the stature, weight, body conformation, head form, body colour, mane and tail, body hair, cranial characteristics and postcranial skeleton (described by Groves and Willoughby, 1981; Groves, 1994; Groves and Grubb, 2011).

More recently, in a revision of the taxonomy of ungulates, Groves concluded that Equus przewalskii should be recognised as distinct; that the domestic horse should retain its historic scientific name Equus caballus; while the extinct tarpan should be known in the scientific nomenclature simply as Equus ferus (Groves and Grubb, 2011). As Groves states, 'it is often convenient to refer to domestic animals by their own scientific name, regardless of the fact that they might, in fact, be of mixed (or hybrid) origin' (2011: 8).

The research by Colin Groves on the taxonomy and the morphology of Equus przewalskii and his interest in domesticated animals was one of the reasons that I began research based in Mongolia. I was initially interested in conducting cross-cultural research in Mongolia to gain a window into the domestication processes in relation to the horse. The research for my doctoral thesis broadened to encompass ethnography about multispecies hybrid communities, both human and nonhuman, including Mongolian herders, horses, cattle (including yak), sheep and goats. Throughout 2005 and during a shorter trip in the spring of 2007 I lived with Mongolian herders in two extended family encampments in the Khangai Mountains. Through daily interaction, while milking and herding, individual herders gain a remarkable knowledge about the reproduction, breeding, communication, social behaviour and ecology of these herd animals. Horses are a particularly significant part of Mongolian herding culture (see Fijn, 2011). ${ }^{1}$

1 To see footage, by the author, of the importance of the horse in relation to horse racing within a winter festival, see: http://khangaiherds.wordpress.com/about/khangai-herds-extra/. 


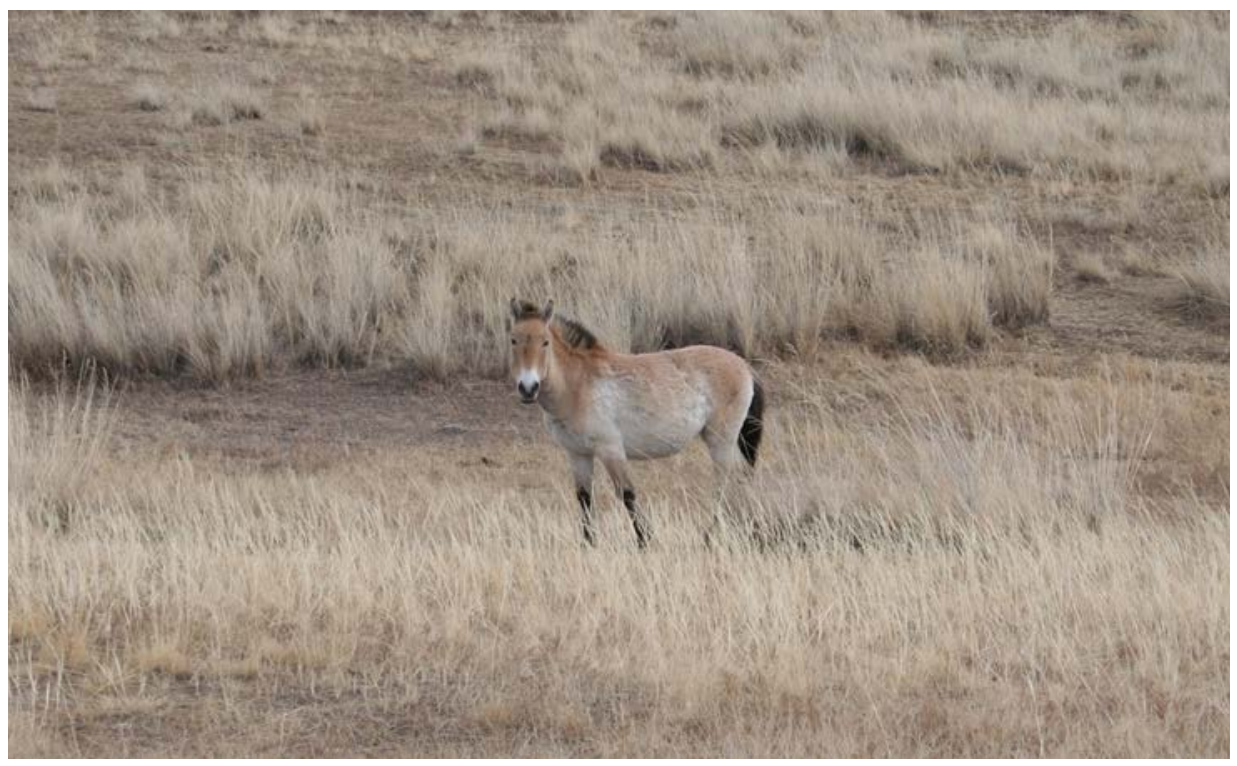

Figure 13.2: Individual takhi at Hustai Nuruu National Park, 2007.

Source: Photograph by Natasha Fijn.

Research in the field was conducted through observational filmmaking, semi-structured interviews and the anthropological technique of participant observation, living in a herding encampment with an extended herding family (which included living amongst herd animals). Within this chapter I return to what initially sparked my interest in Mongolia in the first place, the horse, and through a multidisciplinary, cross-cultural perspective I examine the relationship between the 'domestic' Mongolian horse and the 'wild' takhi (Equus przewalskii) (see Figures 13.1 and 13.2).

\section{The common name for Equus przewalskii}

Human, Mongolian horse and takhi all co-existed in the same environment. Mongolians refer to the predominant breed of horse that is native to Mongolia as Mongol and to the one that is not tamed by humans as takhi. ${ }^{2}$ Historically, Mongolians also distinguished between a darker mountain variety and a lighter steppe variety of takhi. ${ }^{3}$ Colonel Przewalsky, by contrast, mistook sighting

2 Henceforth in this paper I refer to the tame horse (Equus caballus) that co-exists with Mongolian herders as the 'Mongolian horse' and to Equus przewalskii as 'takhi'.

3 This aligns with the views of early twentieth century authors, who named and described two different geographic populations of takhi, recognising them as distinct. 
Mongolian wild asses, or khulan, for wild horses when they galloped off as a herd into the distance. It was only due to good fortune and luck that he happened to be given what became the type specimen, by Kirghiz hunters on the border between Russia and Mongolia.

Many academics working on research relating to the rehabilitation of Equus przewalskii into reserves refer to the horse by the Mongolian name of takhi. Van Dierendonck and Wallis de Vries (1996) state that they prefer the name takhi because Przewalski horse is misleading in that it should not be confused with the domestic Mongolian horse. The Mongolian term takhi recognises the status of this horse as a significant part of Mongolia's cultural heritage. Colonel Przewalski, sometimes spelt Przhevalsky or Prjevalsky, also had his name attributed to a species of gazelle and 80 different plant species. According to Meyer and Brysac, Przewalsky was a ruthless exploiter of the Central Asian peoples he encountered, travelling 'with a carbine [shotgun] in one hand, a whip in the other' (cited in Nalle, 2000: 199-200). The fact that the horse is still commonly referred to as 'Przewalski's horse' denotes a retention of a colonialist and imperialist form of ownership of both the name and the horse itself.

\section{The domestic and the wild}

There is a tendency in the western world to form Cartesian dualistic divisions between nature and culture, male and female, domestic and wild, native and feral. This stems from a historical basis in Judeo-Christian traditions and beliefs where the world is categorised and divided into good and evil, right and wrong, and continues into present-day Western knowledge systems, where this framework can inadvertently persist. This is not to say, however, that a categorisation according to domestic and wild animals should not be made. The intention within this chapter is to avoid viewing the domestic and the wild as 'hyper-separated' and instead think of them along a continuum, where there can be considerable crossover between the two forms. The environmental philosopher Val Plumwood provides a clear perspective on human/nature dualism in saying that this mindset 'conceives the human as not only superior to but as different in kind from the non-human, which as a lower sphere exists as a mere resource for the higher human one. This ideology has been functional for Western culture in enabling it to exploit nature with less constraint, but it also creates dangerous illusions by denying embeddedness in and dependency on nature' (Plumwood, 2012: 15).

Sandor Bökönyi's definition of a domestic animal is representative of earlier views of animal domestication in the following: 'The essence of domestication is the capture and taming by man of animals of a species with particular 
behavioural characteristics, their removal from their natural living area and breeding community, and their maintenance under controlled breeding conditions' (Bökönyi, 1989: 22). Juliet Clutton-Brock recently defined 'true' domestication as the 'keeping of animals in captivity by a human community that maintains total control over their breeding, organization of territory, and food supply' (Clutton-Brock, 2012: 3 emphasis added). These definitions may apply to a categorisation according to a western perspective but this does not apply to a Mongolian herding perspective, nor to the way herd animals live in Mongolia (see chapter by Clutton-Brock, this volume).

The definition is of course correct in relation to how horses are kept in a western scenario, where the territory is decided upon by humans with often only one or two horses within a grassed area bounded by fences, or indoors on their own within a stable. Many are strictly bred according to studbooks through artificial insemination. Thoroughbreds are perhaps a good example of this definition of the domestic, in terms of total human control over their breeding, territory and food supply.

The Mongolian horse is not held in captivity because the land in Mongolia is not fenced and they are free to roam without human-made barriers. They have not been removed from their natural environment, as the grassland steppe habitat was still occupied by wild horses until historic times and it is likely that their ancestors in the Pleistocene roamed over a similar grassland landscape, perhaps even in the same geographical location. Mongolian horses choose where to forage, they protect themselves from predators and even make their own way to new seasonal pastures ahead of the herding encampment. Mongolian horses exist within a social structure that they would naturally adopt, for example, the main herd generally consists of a stallion and up to 25 mares with their young. Herders do not have total control over their breeding, as a stallion can potentially impregnate mares from another herd if he can outcompete another stallion.

In contrast, for 13 generations the entire takhi population were socially disrupted, captured, removed from their natural living area by being transported from Mongolia to Europe and other parts of the world, separated into human controlled breeding communities, or zoos, and maintained under controlled living conditions. Humans had total control of their breeding and organisation of territory because not one individual remained on the grassland steppe of Mongolia. Because the population spent over 90 years in captivity, the takhi required protective enclosures before being released back into reserves

4 For an ethnography related to the breeding of thoroughbreds and horse racing, see Cassidy (2002). 
in Mongolia, as individuals had not learnt how to survive the extremely harsh Mongolian winters without supplementary feed, nor that they could be prey to wolves.

The 'domestic' Mongolian horse is not closely monitored by herders against wolf attack (see Hovens and Tungalaktuja, 2005). During the harsh winter they do not require additional feed but survive on the standing fodder that grows only during the short summer season (see Figure 13.3). When snow covers the ground, Mongolian horses know how to paw through the snow to get at the vegetation beneath. Van Dierendonck and others (1996) and Linklater (2000) found that the behaviour and social structure of the takhi, once they had been rehabilitated back onto the grassland steppe, was remarkably similar to feral horse populations. This is also the case in Mongolian 'domestic' horse herds. I observed that their social organisation was remarkably similar to findings in relation to the reintroduced takhi and to 'feral' horse populations (see Fijn, 2011: 65-69).

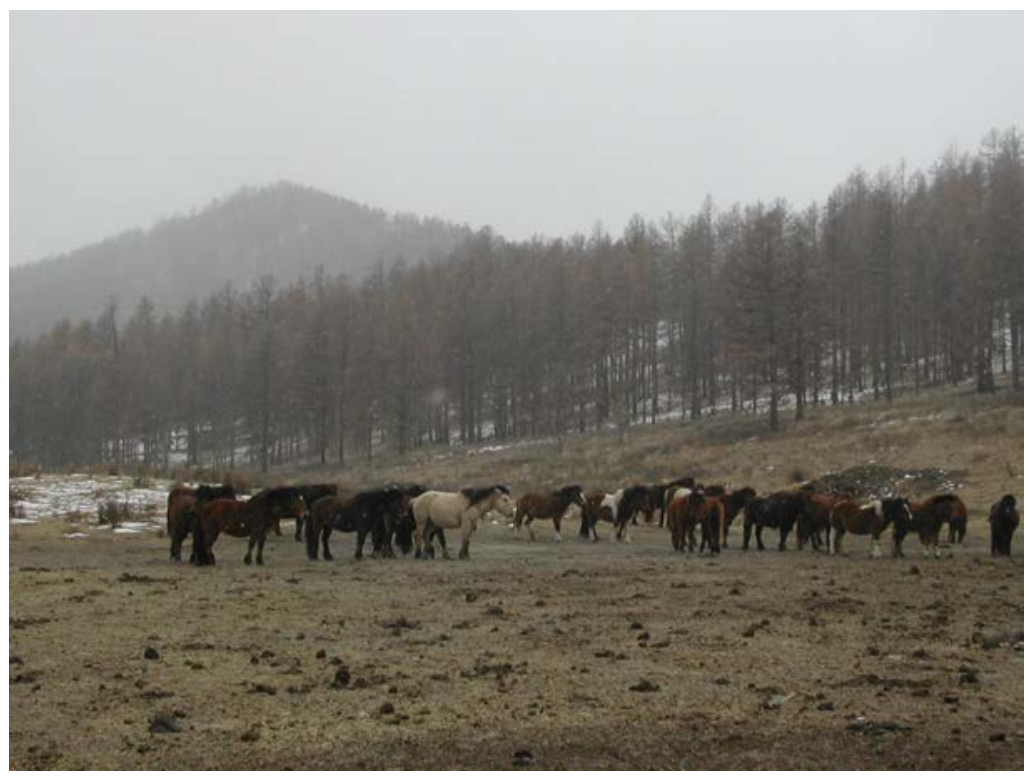

Figure 13.3: A Mongolian horse herd in a snowstorm in spring, Arkhangai Province, 2005.

Source: Photograph by Natasha Fijn.

It seems ironic that, according to the dualistic categorisation of domestic and wild, the way the 'domestic' Mongolian horse exists does not fit the criteria of a domesticated animal, whereas the 'wild' Mongolian horse living within a captive zoo fits the accepted definition of a domestic animal well. It reveals a difference 
in attitude whereby ' $[\mathrm{t}]$ he behaviour of a species is often one of the last areas of their biology to be studied and one of the last aspects to be considered in making management decisions' (Boyd and Houpt, 1994: 267); whereas for Mongolian herders the behaviour of the horse is a priority. I agree with Kaczensky and others' (2007) recommendation that local Mongolian herders need to be more actively involved in the management and conservation of the takhi, including recognising their depth of knowledge in relation to the behaviour and social structure of the horse. Through the takhi's reintroduction back into three separate reserves in Mongolia since 1992, the herds have gradually been given some of their own agency back and, hopefully, will ultimately be released from total human control and management. ${ }^{5}$

In comparison to many rangelands throughout the world, the pastoral ecosystem in Mongolia is relatively intact (see Mallon and Jiang, 2009). The herders, herd animals and their wild counterparts have all co-existed and adapted within a functioning ecosystem for thousands of years. A sign of a healthy ecosystem is if top predators still persist in the landscape and in Mongolia there are still wolves (Canis lupus) and, although endangered, other large predators, such as the Gobi bear (Ursus arctos) and snow leopard (Uncia uncia). Large ungulates still inhabit Mongolia including wild representatives that are related to the domestic animals, such as argali (Ovis ammon), ibex (Capra sibirica) and wild Bactrian camels (Camelus ferus). In many of these cases Mongolia functions as one of the last vestiges for these large mammals that during the Pleistocene would have lived in far greater numbers across large parts of Eurasia (Bedunah and Schmidt, 2000).

\section{A cross-cultural re-examination of the accounts of capturing takhi}

Cultural differences in approach to the human-horse relationship have been evident from ancient and classical history. These differences persist to the present day. There are two main approaches, a co-operative approach based upon understanding the behaviour of the horse, and an alternative approach based on human dominance and equine submission. Social interactions and contact between humans and horses have reflected these differences in approach (Van Dierendonck and Goodwin, 2005: 65).

5 There has been a large body of scientific research focusing on the behaviour and ecology of the takhi after reintroduction into reserves in Mongolia (see King, 2002; King and Gurnell, 2005, 2007; Van Dierendonck and Wallis de Vries, 1996; Van Dierendonck et al., 1996). 
This nicely summarises the difference between a historically Euro-American approach toward horses and a Mongolian herding one. In this section I draw upon my observations of how herders captured and tamed Mongolian horses and integrate these ethnographic details with earlier historic accounts to consider how the recruitment of wild individuals into a tame Mongolian horse herd could potentially occur.

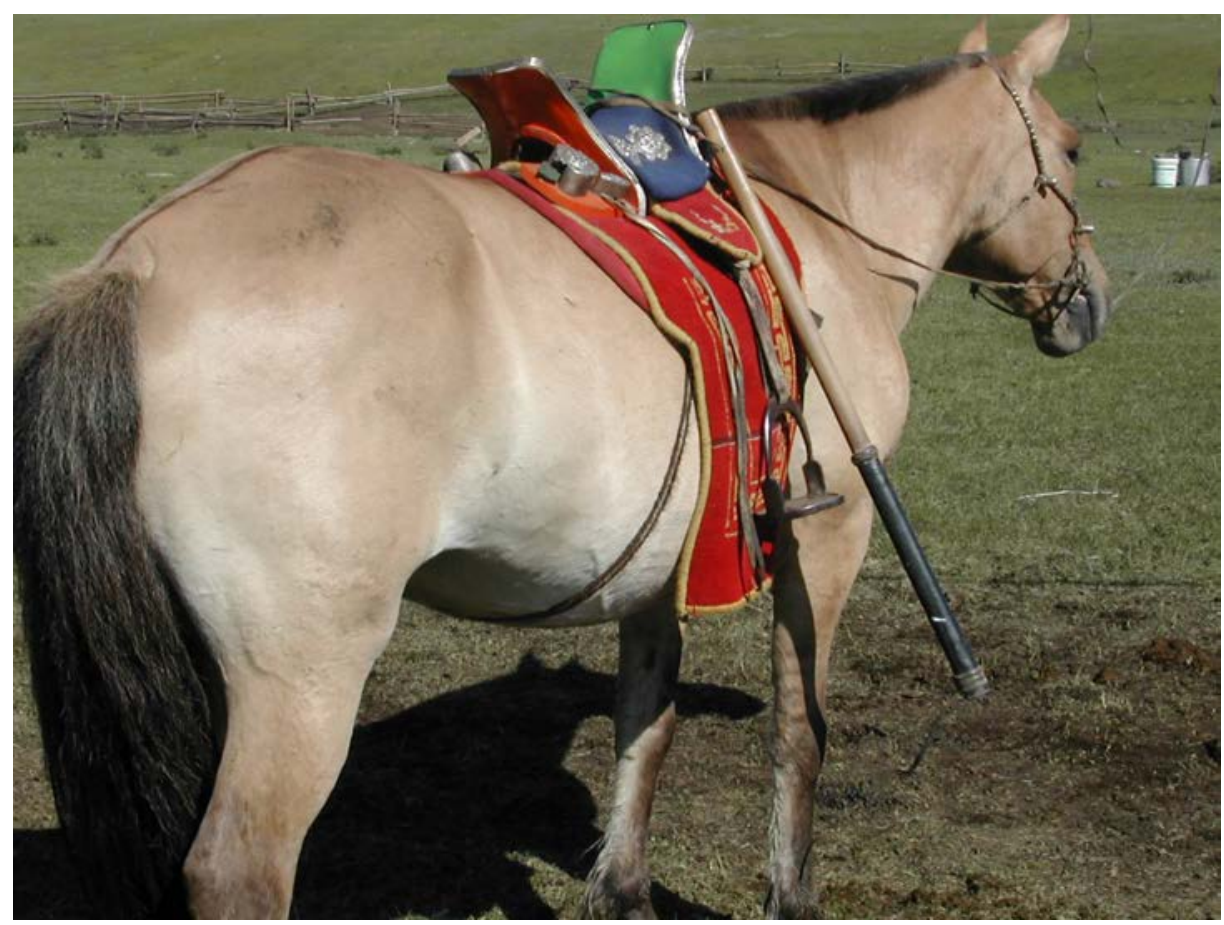

Figure 13.4: A prized Mongolian horse with elaborate saddle and bridle and wild-type characteristics, note the coat colour, stripes on the legs and eel-stripe down the back, 2005.

Source: Photograph by Natasha Fijn.

While in the field, I asked herders about their favourite horses. They were often selected on the basis of their fine appearance, distinctive markings, or quiet behaviour. One particular aspect that was particularly favoured were ancestral, or wild-type, characteristics, reminiscent of ancient cave paintings: a dun coat, dark mane and tail, dark eel-stripe down the back and faint stripes on the upper legs and neck. As early as 1868 Charles Darwin perceptively recognised these features as possible 'wild-type' characteristics in certain breeds of horse. Lusis (1943) described how the 'wild-dun colour' is common in Mongolian domestic horses and how it is always combined to some degree with striping on the legs. Bökönyi noted the resemblance of some domestic horses in Central Asia to the 
takhi, not only in the colouration of the horse but also the shape of the skull. Some Kazakh horses 'faithfully present the colour of the takhi, they have a welldeveloped dorsal stripe ... and they often have stripes on their legs' (1975: 85). From noting these characteristics in the field, I began to consider that perhaps these markings were an indication that the Mongolian horse represents an ancient breed of domestic horse and is evidence of their long association and bond with Mongolian herders; or perhaps even an indication that on rare occasions takhi may have interbred with Mongolian domestic horses and contributed to their genetic heritage (see Figure 13.4).

Bökönyi pointed out that a good motivation for herders to occasionally introduce individuals from a wild herd was to increase the number of herd animals, as the size of the herd is representative of a herding family's wealth. He states, 'even at the end of the last century and the beginning of ours it happened that Mongolian animal breeders would capture Przevalsky foals, admit them to their herds and rear them there: that is to say, they domesticated them' (1974: 85). From observing how herders in Mongolia catch foals with an urgaa, or lasso pole, I can readily envisage how individuals from a wild population could be captured. One way is through herders capturing foals by chasing the takhi herd on horseback until a foal tires, separating the foal from the herd, and then the herder could merely slip the urgaa over the exhausted foal's head. ${ }^{6}$

An account from one of the brothers Gram-Grshimailo, credited as being the first Europeans to see takhi in the wild, related such a scenario:

[T] he Mongols have often attempted to tame [adult] wild horses but always in vain. The wild horse will not accept human contact, is terrified of them and will not allow himself to be used. Wild horses are caught in a fairly simple manner. During the foaling season the Kalmucks [western Mongolians in Russia] take two horses into the desert. As soon as they have found a herd, they chase them until the exhausted foals fall over. These foals are picked up and put into the domesticated herd (quoted in Mohr, 1971: 68).

This technique does correspond with techniques still used by Mongolian herders today, as I have observed herders use a similar technique on a number of occasions by relying on exhaustion to break in their two-year-old horses. One adult herder may ride the mare (or the horse's mother), while a lighter teenager leaps onto the two-year-old bareback, inducing the young horse to buck and gallop alongside the mare until it is too exhausted to attempt to get rid of the rider and becomes calm (also see Fijn, 2011: 144-147).

6 It is general knowledge within the oral history of Mongolian herding families that the two kinds of horse readily interbred in the past. I was informed that they produced 'good stock' but that herders kept their techniques a secret (Ranger at Hustai Nuruu, pers. comm., 13 April 2005). 
Unfortunately, this technique of capturing the foals was misappropriated by European hunters to capture takhi in order to take them to zoos in Europe. The hunters were additionally instructed by Falz-Fein (a wealthy zoo owner who engaged in the business transactions with the hunters) to shoot the mares in the herd before capturing the foals. Falz-Fein was proud of this technique and wrote 'I laid much stress on the animals not being chased before capture, but rather by shooting their mother. As we could not get milking mares from the Mongolians living in the area, we had to buy them in Bijsk and have them covered so they foaled at the same time as the wild mares. In order to feed the wild foals we had to kill the tame ones' (Mohr, 1971: 95-96). Bökönyi regretted such a practice, as 'to kill the mother mares with a view to catch the foals more easily was an appalling procedure indeed ... The killing of the mares put an end to the possibility of a number of further foals being born' (1974: 98).

A Mongolian scientist, S. Dulamtseren, commented that one of the reasons for the extinction of the last population of takhi in the wild was due to the breakdown of the social structure of the herd by these hunters activities (van Dierendonck and Wallis de Vries, 1996). On just one expedition in 1901 the hunters captured 51 foals. Of these, only 28 survived the stressful journey to a European zoo (Bökönyi, 1974). This practice would have been counter to the ethics of Mongolian herders, as they do not kill female animals that are still able to reproduce.

Even though horses are generally able to roam free within their own herd in Mongolia, during the summer season foals are tethered along pegged lines, so that the herders can obtain milk from the mares. ${ }^{7}$ In the instance of the takhi foals, the herder would be able to encourage the foal to feed from a surrogate mare, just as herders do today. Often at least one mare loses her own foal to wolf predation and is encouraged to adopt another, or perhaps even two. The adopted foal is handled many times a day when it is taken to feed from the mare prior to milking and in this way the foal becomes quite tame and easily handled later in life. If a takhi foal grew up within a horse herd, nurtured by a surrogate mare, then the takhi is more likely to integrate with the herd as an adult and subsequently reproduce further (hybrid) offspring.

Bökönyi (1974) provided an archaeological example from kurgans (burial mounds) from the Turkic period in Mongolia. One of the horses sacrificed within the burial mound corresponded with the skull of an interbred horse from a takhi mare and a Mongolian stallion. It would not be a great biological leap for a takhi to breed with a Mongolian horse, as they do produce viable, fertile offspring. A greater biological distance exists between the Mongolian yak

7 To see footage by the author of a young herder catching adult horses with an urgaa, followed by foals and two-year-olds being handled during milking, see: www.khangaiherds.wordpress.com/about/khangai-herdspart-3/. 
and the Mongolian cow, yet I observed how readily they breed within a mixed herd of a yak bull (or bulls), Mongolian cows and yak-cow hybrids (see Fijn, 2011: 87-89). In summary, it is highly probable that throughout history wild horses, in this instance takhi, were on occasion integrated and bred with tame horse herds, specifically Mongolian horse herds.

Bökönyi acknowledged that the takhi may have interbred with tame Mongolian horses in the past, but this 'does not at all reduce their quality as genuine wild horses' (1974: 45) and still means that they are a unique population of horse in their own right. With the inclusion of my ethnographic observations, it is feasible that individuals could have been caught from this distinct population and integrated within the domestic horse population as foals, ultimately contributing to the genetic heritage of the domestic Mongolian horse (see Figure 13.5).

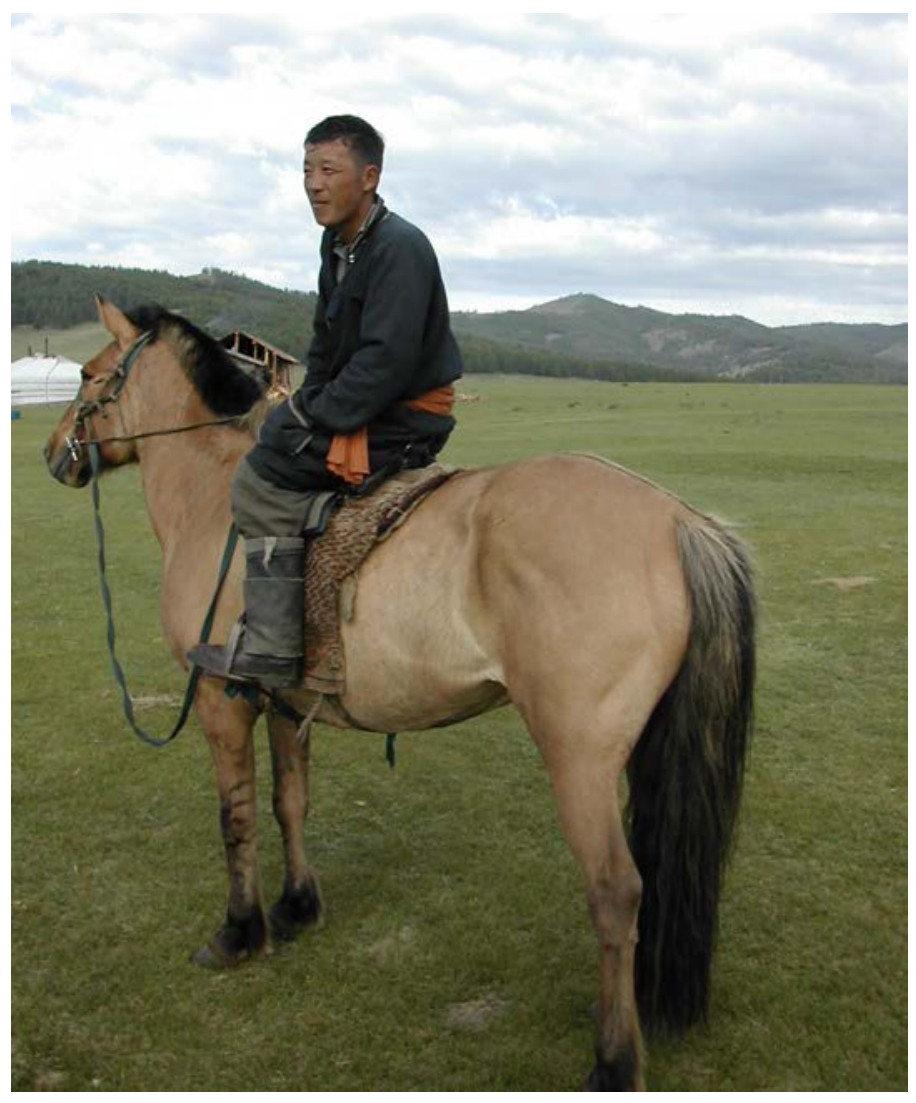

Figure 13.5: Mongolian herder with Mongolian horse, note the coat colour, eel-stripe down the back and stripes on the legs, Bugat Province, 2005. 


\section{Recent evidence from DNA analysis on the domestic and the wild horse}

From the genetic evidence, it is an unlikely scenario that horse domestication sprang up in just one location, but very likely that it occurred in a number of different geographical locations and that wild horses were repeatedly integrated within the domestic sphere even up until recent history when the last wild herds disappeared. To take a parallel hominid example, research on the Neanderthal genome found that Neanderthals have contributed toward the present day genetic ancestry of most humans beyond Africa (Green et al., 2010). Through studies into DNA, scientific ideas of what makes up a species, including humans and domestic animals, are rapidly changing.

Prior to modern day genetics it was thought that Equus przewalskii might represent the original wild ancestral stock from which all domestic horses stem. Through more recent DNA analysis it is now clear that they diverged as a distinct population before horses began to co-exist with humans (Ishida et al., 1995; Wallner et al., 2003). Early studies of their genetics indicate that takhi have a different number of chromosomes $(2 \mathrm{~N}=66)$ in comparison to domestic horses $(2 \mathrm{~N}=64)$ (Ryder, 1994), the difference being due to a simple Robertsonian translocation. They can readily interbreed and produce fertile offspring, whereas in other members of the genus Equus there is far greater chromosomal variation and the hybrid offspring are often infertile (for example, donkeys and horses produce infertile mules).

A large number of mares have contributed to a great variation of mitochondrial DNA in horses, indicating an 'extensive utilization and taming of wild horses' (Vila et al., 2001: 474). Jansen and others concluded perhaps more than 77 successfully breeding mares contributed to the domestic horse, leading them to suggest that 'the horse has been domesticated on numerous independent occasions' (2002: 531). Lindgren and others found that 'the maternal gene pool may have been diversified by the capture of only wild females from local populations (while backcrosses with wild stallions were prevented)' (2004: 335). Cieslak and others (2010) also found multiple introgressions of females adding to the genetic diversity, particularly from the Iron Age onwards. In the instance of Mongolia, this would have meant that once the captured takhi foals became adults, herders bred from takhi females with their Mongolian horse stallion.

Many genetic studies on the horse have focused specifically on the difference between the takhi and the domestic horse but the findings are controversial. Part of the lack of clarity surrounding the results of these analyses is that more than one domestic mare was interbred with takhi while in captivity (see Bökönyi, 1974; Mohr, 1971). This fact has been taken into consideration within 
genetic analyses (see for example, Oakenfull et al., 2000) but little consideration has been given to the likelihood of hybridisation with takhi occurring within the domestic horse population before the takhi disappeared from the grasslandsteppe.

It is interesting that as early as 1995, Ishida and others had tentatively suggested that some gene flow occurred between the ancestral populations of the Przewalski wild horse and the Mongolian native horse. Since then a number of authors have found that there is substantial overlap in terms of their mitochondrial DNA, or the maternal line (see for example, Myka et al., 2003; Vila et al., 2001). Analysis of the nucleotide sequence diversity along the $\mathrm{Y}$ chromosome, or male line, has revealed that the takhi is distinct from the domestic horse, suggesting that incorporation of takhi genes into the Mongolian horse population was by mares, not stallions (Wallner et al., 2003; Lindgren et al., 2004). This could be explained by the Mongolian herding practice of castrating most male horses in their second year, so that they remain tame and easy to handle. The males could have been kept for riding and racing purposes. Only the female takhi would have become reproductive adults and mated with the domestic Mongolian stallion within the herd, producing fertile hybrid offspring. By 2009, Lau and others felt able to state with more certainty that there was a constant flow of female mediated genetic information between takhi and domestic horses, and used the term 'unidirectional hybridisation' to describe interbreeding between takhi and domestic horses.

Mongolian horses show the largest amount of genetic diversity in comparison with other Asian and European horse breeds (Ishida et al., 1995; Tozaki et al., 2003). This diversity means that closely related Japanese and Korean horse breeds are derived from Mongolian horses. The Norwegian Fjord horse resembles the takhi in many physical features (Groves, pers. comm.). Bjørnstad and others suggested a close genetic relationship between the Mongolian and Norwegian horse. They concluded that the 'Mongolian horse has had a major impact on a wide range of breeds, and that Central Asia could have been a centre of dispersal of horses through trading and human migration' (2003: 57). Dispersal of Mongolian horses as far as Western Europe would have occurred particularly during the time of the Mongol Empire when the Khans ruled the largest empire in history (Morgan, 1986). It is, therefore, important to retain this genetic diversity and a robust population of Mongolian horses. The Mongolian horse is unique, as representatives of ancient ancestral stock, and should be valued for its role, not only as a partner in the unprecedented migration during the Khan Empire, but in providing a valuable contribution to the genetics of horse breeds across Eurasia today (see Figure 13.6). 


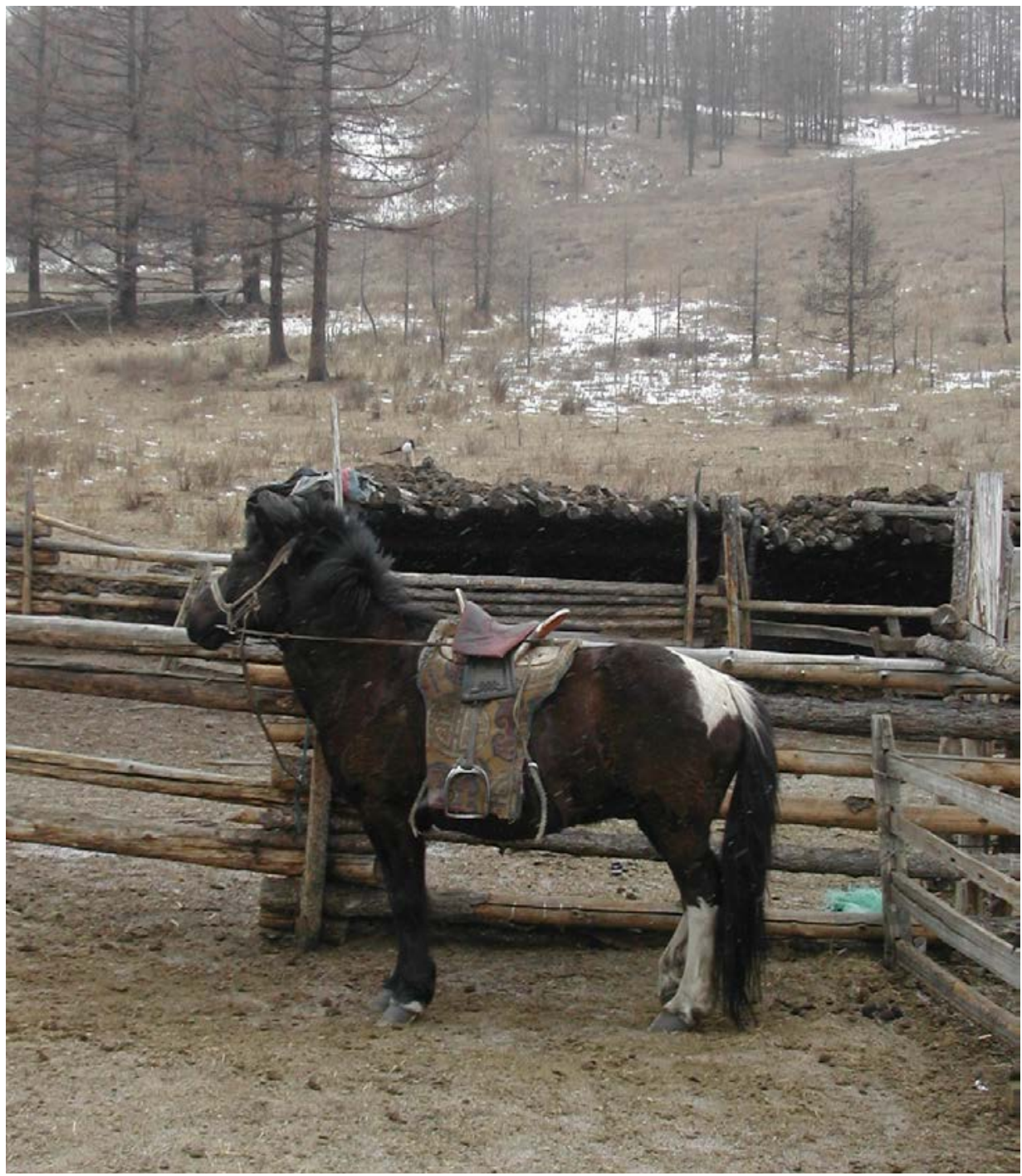

Figure 13.6: A saddled piebald (kharlag) Mongolian horse, Arkhangai Province, 2005.

Source: Photograph by Natasha Fijn.

\section{Conclusion}

The relationship between Mongolian herders and the Mongolian horse is unique. Through Mongolian herders allowing the horse greater agency, in allowing them to behave and live within a social structure that they would adopt of their own 
volition, they are allowing horses greater autonomy. Natural selection can still occur to a notable degree in the Mongolian horse and the population is likely to be more resilient as a result. Mongolian horses have retained their anti-predator behaviour against wolves and an ability to forage on the grassland throughout the seasons, without the dependence found in Euro-American breeds.

To Mongolian herders, the difference between a 'domestic' and a 'wild' animal is not considered so much according to a physiological or morphological condition but relates more to behavioural disposition: domestic animals are tame and associate with humans and the herding encampment, while those that are wild are afraid and choose not to live with humans. King and Gurnell describe how before the takhi were reintroduced into reserves, 'there was no [Western] knowledge about the ecology of takhi in the wild before they became extinct, and so it was not clear how the released animals would cope in their new surroundings' (2005: 278). It would have come as no surprise to Mongolian herders, however, that the reintroduced takhi would be capable of surviving on the grassland steppe, as their horse herds have been successfully doing so for tens of hundreds, if not thousands of years. It took me some months to adjust to life in Mongolia, the takhi also took time to adjust after their forebears had spent 13 generations in captivity in Europe. The takhi population is now thriving and have adapted smoothly to living on the grassland steppe, ${ }^{8}$ just as many horses throughout the world have adjusted to become 'feral' and no longer require an association with humans to survive. Instead of viewing domestic and wild as a hyper-separated dichotomy, these different states should be thought of as being more fluid, where there can be considerable cross-over, or interbreeding, between the two.

Colin Groves is the world expert on the morphology and taxonomy of Equus przewalskii, or the takhi. It should be noted that he encourages those he has mentored to explore different avenues and he readily embraces interdisciplinary research. This has meant that I have not been constrained in my exploration of the relationship of the takhi and the Mongolian horse, through not only the taxonomic and morphological analysis, but also my ethnographic findings from Mongolia, previous historical accounts and the current wealth of scientific literature on the genetics of the horse. This has led me to conclude, in agreement with Colin Groves' previous findings, that the takhi are morphologically and genetically distinct from other horses and merit our conservation. Any conservation project with the goal of reintroducing 'wild' takhi herds back into Mongolia should seriously take into account Mongolian herding knowledge and expertise.

8 Reintroductions to Hustai Nuruu National Park began in 1992. By 2000 the population at this reserve alone consisted of 120 horses (King, 2002). 
Prior to the capture and confinement of the entire takhi population in zoos across the globe, it is highly likely that there was integration of individual takhi within Mongolian horse herds and this would have inevitably influenced the diverse genetic makeup of the native Mongolian horse. This evidence should help to dispel the popular portrayal of the 'origin myth' in relation to animal domestication: the view that the domestication of the horse was a singular instance, occurring at some stage during the Neolithic, and that the scientific goal should be to pinpoint this particular point in time with a specific date. The process of the domestication of the horse from the 'wild' is not a dichotomous one, where a binary line is crossed, but is a fluid, adaptable and ongoing process that still occurs into the present day.

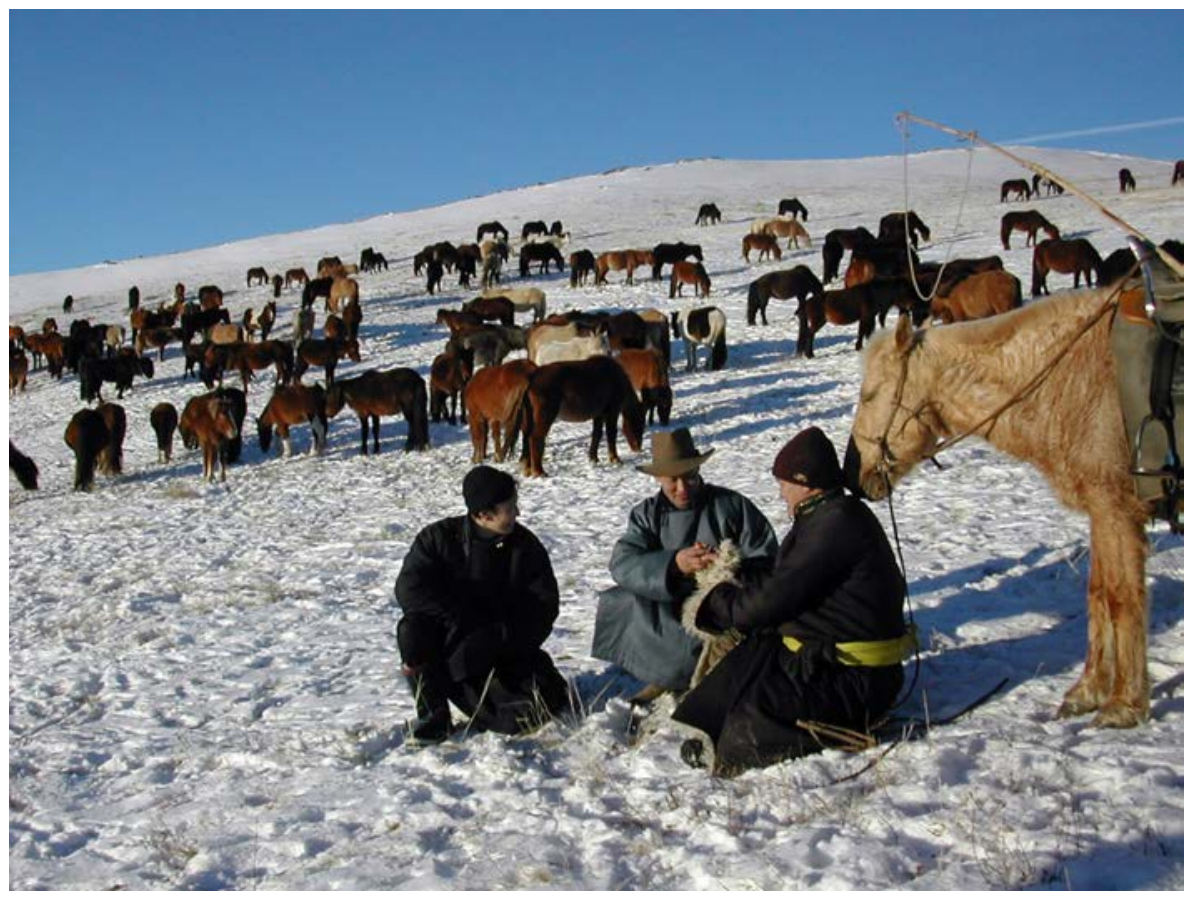

Figure 13.7: Mongolians greeting by passing snuff. Note the colour diversity within one large herd of Mongolian horses.

Source: Photograph by Natasha Fijn.

\section{References}

Bedunah DJ, Schmidt SM. 2000. Rangelands of Gobi Gurvan Saikhan National Conservation Park, Mongolia. Rangelands 22(4):18-24. 
Taxonomic Tapestries

Bjørnstad G, Nilsen NØ, Røed K. 2003. Genetic relationship between Mongolian and Norwegian horses? Anim Genet 34:55-58.

Bökönyi S. 1974. The Przevalsky horse. London: Souvenir Press.

Bouman I, Bouman J. 1994. The history of Przewalski's horse. In: Boyd L, Houpt KA, editors. Przewalski's horse: The history and biology of an endangered species. New York: SUNY. pp. 5-38.

Boyd L, Houpt KA. 1994. Przewalski's horse: The history and biology of an endangered species. New York: SUNY.

Cassidy R. 2002. The sport of kings: Kinship, class and thoroughbred breeding in Newmarket. Cambridge: Cambridge University Press.

Cieslak M, Pruvost M, Benecke N, Hofreiter M et al. 2010. Origin and history of mitochondrial DNA lineages in domestic horses. PLOS ONE 5(12): e15311. doi:10.1371/journal.pone.0015311.

Clutton-Brock J. 2012. Animals as domesticates: A world view through history. Michigan: Michigan State University Press.

Fijn N. 2011. Living with herds: Human-animal coexistence in Mongolia. Cambridge, New York and Melbourne: Cambridge University Press.

Green RE, Krause J, Briggs AW, Maricic T et al. 2010. A draft sequence of the Neandertal genome. Nature 328:710-722.

Groves CP. 1986. The taxonomy, distribution and adaptations of recent equids. In: Meadow RH, Uerpmann HP, editors. Equids in the Ancient World. Wiesbaden: Ludwig Reichert Verlag. pp. 11-65.

Groves CP. 1994. Morphology, habitat and taxonomy. In: Boyd L, Houpt KA, editors. Przewalski's horse: The history and biology of an endangered species. New York: SUNY. pp. 39-60.

Groves C, Grubb P. 2011. Ungulate taxonomy. Baltimore: Johns Hopkins University Press.

Groves C, Willoughby DP. 1981. Studies on the taxonomy and phylogeny of the genus Equus 1. Subgeneric classification of a recent species. Mammalia 45(3):321-354.

Hovens JPM, Tungalaktuja K. 2005. Seasonal fluctuations in the wolf diet in the Hustai National Park (Mongolia). Mammal Biol 70(4):210-217. 
Ishida N, Oyunsuren T, Mashima S, Mukoyama H, Saitou N. 1995. Mitochondrial DNA sequences of various species of the genus Equus with special reference to the phyogenetic relationship between Przewalskii's wild horse and domestic horse. J Mol Evol 41:180-188.

Jansen T, Forster P, Levine MA, Oelke H et al. 2002. Mitochondrial DNA and the origins of the domestic horse. PNAS 99(16):10905-10910.

Kaczensky N, Enkhsaihan O, Ganbaatar O, Walzer C. 2007. Identification of herder-wild equid conflicts in the Great Gobi B strictly protected area in NSW. Erforsch biol Ress Mongolei 10:1-18.

Kaszab Z. 1966. New sightings of Przewalski Horses. Oryx 8(6):345-347.

King SRB. 2002. Home range and habitat use of free-ranging Przewalski horses at Hustai National Park, Mongolia. Appl Anim Behav Sci 78:103-113.

King SRB, Gurnell J. 2005. Habitat use and spatial dynamics of takhi introduced to Hustai National Park, Mongolia. Biol Conserv 124:277-290.

King SRB, Gurnell J. 2007. Scent-marking behaviour by stallions: An assessment of function in a reintroduced population of Przewalski horses (Equus ferus przewalskii). J Zool 272:30-36.

Lau AN, Peng L, Goto H, Chemnick L et al. 2009. Horse domestication and conservation genetics of Przewalski's horse inferred from sex chromosomal and autosomal sequences. Mol Biol Evol 26(1):199-208.

Lindgren G, Backström N, Swinburne J, Hellborg L et al. 2004. Limited number of patrilines in horse domestication. Nat Genet 36(4):335-336.

Linklater WL. 2000. Adaptive explanation in socio-ecology: Lessons from the Equidae. Biol Rev 75:1-20.

Lusis JA. 1943. Striping patterns in domestic horses. Genetica 23(1):31-62.

Mallon DP, Jiang Z. 2009. Grazers on the plains: Challenges and prospects for large herbivores in Central Asia. J Appl Ecol 46:516-519.

Mohr E. 1971. The Asiatic wild horse. London: J. A. Allen \& Co.

Morgan D. 1986. The Mongols. Oxford: Basil Blackwell.

Myka JL, Lear TL, Houck ML, Ryder OA, Bailey E. 2003. Fish analysis comparing genome organization in the domestic horse (Equus caballus) and the Mongolian wild horse (E. przewalskii). Cytogenet Genome Res 102:222225 . 
Taxonomic Tapestries

Nalle D. 2000. Tournament of shadows: The great game and the race for empire in Central Asia. Middle East Policy 7(3):199-200.

Oakenfull EA, Ryder OA. 1998. Mitochondrial control region and 12S rRNA variation in Przewalski's horse (Equus przewalskii). Anim Genet 29(6):456459.

Plumwood V. 2012. The eye of the crocodile. Canberra: ANU E Press.

Ryder OA. 1994. Genetic studies of Przewalski's horses and their impact on conservation. In: Boyd L, Houpt KA, editors. Przewalski's horse: The history and biology of an endangered species. New York: SUNY. pp. 75-92.

Pruvost M, Bellone R, Benecke N, Sandoval-Castellanos E et al. 2011. Genotypes of predomestic horses match phenotypes painted in Paleolithic works of cave art. PNAS 108(46):18626-18630.

Tozaki T, Takezaki N, Hasegawa N, Ishida M et al. 2003. Microsatellite variation in Japanese and Asian horses and their phylogenetic relationship using a European horse outgroup. J Hered 94(5):374-380.

van Dierendonck MC, Bandi N, Batdorj D, Dügerlham S, Munkhtsog B. 1996. Behavioural observations of reintroduced Takhi or Przewalski horses (Equus ferus przewalskii) in Mongolia. Appl Anim Behav Sci 50:95-114.

van Dierendonck MC, Goodwin D. 2005. Social contact in horses: Implications for human-horse interactions. In: de Jong $\mathrm{FH}$, van den Bos $\mathrm{R}$, editors. The human-animal relationship. Assen, The Netherlands: Van Gorcum. pp. 6581 .

van Dierendonck MC, Wallis de Vries MF. 1996. Ungulate reintroductions: Experiences with the takhi or Przewalski Horse (Equus ferus przewalskii) in Mongolia. Conserv Biol 10(3):728-740.

Vila C, Leonard JA, Götherström A, Marklund S et al. 2001. Widespread origins of domestic horse lineages. Science 291(5503):474-477.

Wallner B, Brem G, Müller M, Achmann R. 2003. Fixed nucleotide differences on the $\mathrm{Y}$ chromosome indicate clear divergence between Equus przewalskii and Equus caballus. Anim Genet 34:453-456. 


\title{
14. Rhino systematics in the times of Linnaeus, Cuvier, Gray and Groves
}

\author{
Kees Rookmaaker
}

\section{History inspires innovation}

Most scientists agree that it is imperative to read the literature in their immediate field of interest hot off the press to keep abreast of the latest advances. They build on a more extensive body of knowledge which is the result of past explorations and discoveries by persons working in the same discipline. Generally it is almost irrelevant how the current consensus was reached or which people were responsible for it, unless a discovery or theory represented a major breakthrough. The history of a given subject is of course highly interesting, and any scientist would be advised to pay attention to the lives of their predecessors in their speciality. While for the majority of scientists such historical insight is largely optional, it often appears that students of animal taxonomy have much less choice. Animal and plant biodiversity is so immense that a revision must necessarily take into account all previous studies of the specimens and populations now combined in a certain species or higher ranking group. We are bound to respect the decisions and models of previous generations of taxonomists, although we have every right to fine-tune them or even dismiss them completely.

The historical component of taxonomy is nowadays often as quickly recognised as it is dismissed. Searching old and dusty books, examining skulls and hides in museum storerooms, locating old geographical placenames, understanding obscure concepts of classification, is it really needed to understand the evolutionary species groups? When a bibliographer or historian finds a scientific name which had long remained hidden in some obscure or rarely consulted journal, there is often an immediate call to relegate it to the growing list of 'forgotten names' - names often forgotten merely because the contemporary colleagues of the naturalist who proposed the name had only a partial knowledge of the new literature. Nomenclature may be a part of taxonomy which in its rules has an historical dimension, but taxonomy is one science where history cannot safely be ignored.

Colin Groves is one of those taxonomists who is sensitive to past research. He has shown this in his 2008 book Extended family: Long-lost cousins (a personal look 
at the history of primatology). In the same vein, the present chapter is a personal look, this time mine, at four different phases in the history of the systematic research of the small group of currently existing species of rhinoceros. Given that there are only a handful, or maybe just over a handful of qualifying rhino taxa, the history of the understanding of their relationships is unexpectedly treacherous and complicated, as well as ever changing. As this is a personal look, I have only quoted the most relevant literature in the bibliography. Much has been written about the rhinoceros. In 1983 I bravely published a Bibliography of the Rhinoceros, and was proud to state that I had been able to extract 3,106 references (pleased enough even to count them manually). Continuing ever since to archive the world's output on these animals, the bibliography has now extended to over 18,000 references (fortunately counted by a computer). All these are globally accessible on the Rhino Resource Centre, which provides the references as well as the text on the website: www.rhinoresourcecentre.com, a stable and hopefully not too ephemeral source of information, current as well as historic, on everything related to rhino studies.

Although history does not often allow a saltationary approach, I will focus on just four periods in the story of rhino systematics. This will show how the classification of the living world changed over time, from the mid-eighteenth century to the present.

\section{Rhino systematics in the time of Carl Linnaeus}

\section{Uppsala, Sweden: 1758}

Carl Linnaeus (1707-1778), the famous professor of botany in the small university town of Uppsala, is unlikely ever to have seen a rhinoceros alive. For most of his work on the animal kingdom, he had to depend on occasional specimens in a few collections, and of course on a thorough knowledge of the renaissance literature. Given the enormous scope of his pioneering endeavours to classify all known animals and plants, the results were remarkably fair to the prevailing sentiments of his time. His work was of course highly innovative, which makes it easy to understand that it took him several adjustments along the way to find the right format to fit all available information.

His main work on animals was the Systema Naturae, first published in 1735 and updated through a series of revisions to the most authoritative tenth edition of 1758. Linnaeus masterfully condensed the entire animal kingdom: at first he needed only a pamphlet of just 12 pages, in 1758 expanded to about 800 pages, to 
list all known vertebrates and invertebrates. His list of mammals occupied just 63 pages, nevertheless was remarkably comprehensive. His species were inclusive of all variants, defined strictly morphologically rather than zoogeographically.

This emphasis on morphological and anatomical characters led to some rather surprising results. Because the rhinoceros was known to have incisor teeth, the animal came to be classed together with rodents of the genera Hystrix, Lepus, Castor, Mus and Sciurus, away from other pachyderms or ungulates. But Linnaeus had relied on insufficient evidence, inasmuch as only one of the two species of rhinoceros recognised in his book actually has these incisors. The only type of rhinoceros well-known in his time was the species with a single horn, now known as Rhinoceros unicornis, the Indian or greater one-horned rhinoceros.

There were of course plenty of rumours of rhinos having two horns, both in Asia and in Africa. There were even a number of specimens in European collections where the two horns were still attached to each other and obviously belonged to the same animal. The academic world, for some reason still poorly understood, was reluctant to admit the existence of a second species of rhinoceros, which would have two horns on the nose instead of one. The reasoning at the time was as ingenuous as it was convoluted, with the number of horns being ascribed to climate, age, sex, size, to just about anything except to the possibility that there was more than one species of rhinoceros. In an age when unicorns and dragons were still very much in discussion, this reluctance seems excessive.

Linnaeus was a brave taxonomist. He was certain that there was a rhinoceros species with two horns on the nose, separated from the one with a single horn, but remarkably, he did appear to see the need to explain himself. 'I have seen the complete head of one of these animals', he stated, therefore he could not doubt its existence. However, when we carefully read his paragraphs in the Systema Naturae of 1758, we end up with a species of rhinoceros with two incisors on either side of the jaws, a double horn on the nose, living in India. If Linnaeus actually examined the head which he claimed to have seen, with his extensive knowledge of animal morphology, it must be concluded that he saw a skull of an Indian rhinoceros where a second horn was artificially added to the specimen. If this interpretation is correct, it exonerates Linnaeus, but did nothing to help the study of rhino systematics in the remainder of the eighteenth century. 


\section{Rhino systematics in the time of Georges Cuvier}

\section{Paris, France: 1816-1836}

There were a number of new discoveries in the half century separating the works of Linnaeus and Georges Cuvier (1769-1832), professor of natural history in Paris. The vicinity of the Cape of Good Hope was carefully explored and yielded exhaustive morphological and anatomical descriptions of the resident black rhinoceros by people like Robert Jacob Gordon and Anders Sparrman (Figure 14.1). Travellers in other parts of Asia had long known about the existence of a rhinoceros outside the Indian subcontinent, said to bear either one or two horns on the nose. The evidence soon became overwhelming enough to recognise that changes were needed.

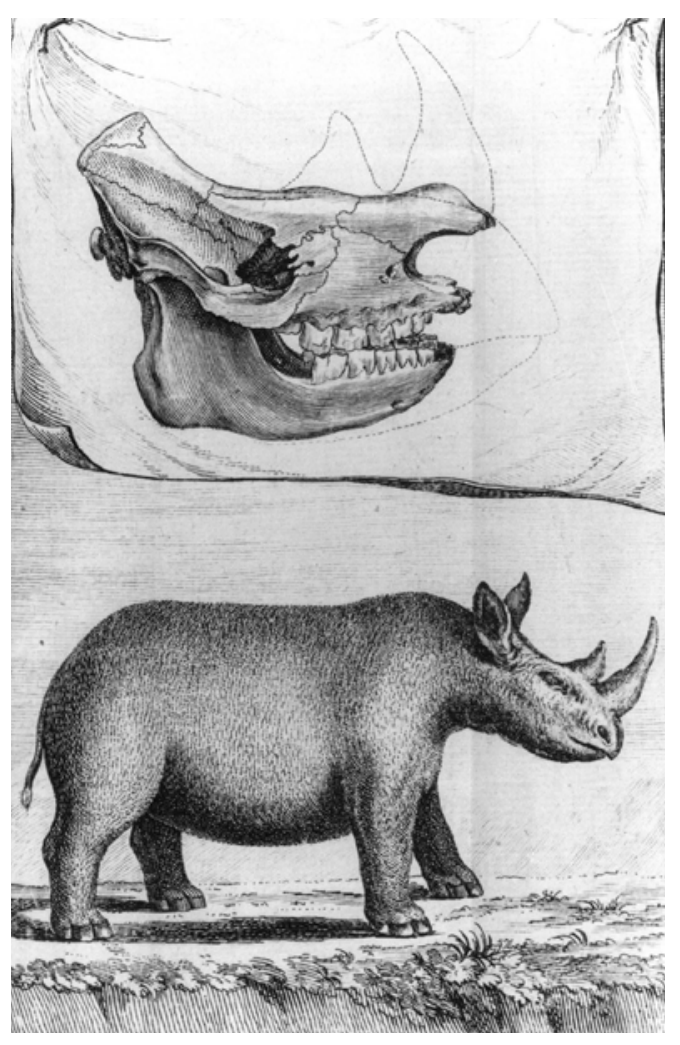

Figure 14.1: Black rhinoceros and skull, sketched by Anders Sparrman after a specimen which he shot in South Africa's Cape Province, December 1775. Published in his Resa till Goda-Hopps-Udden, Stockholm, vol. 1 (1783), plate 5. 


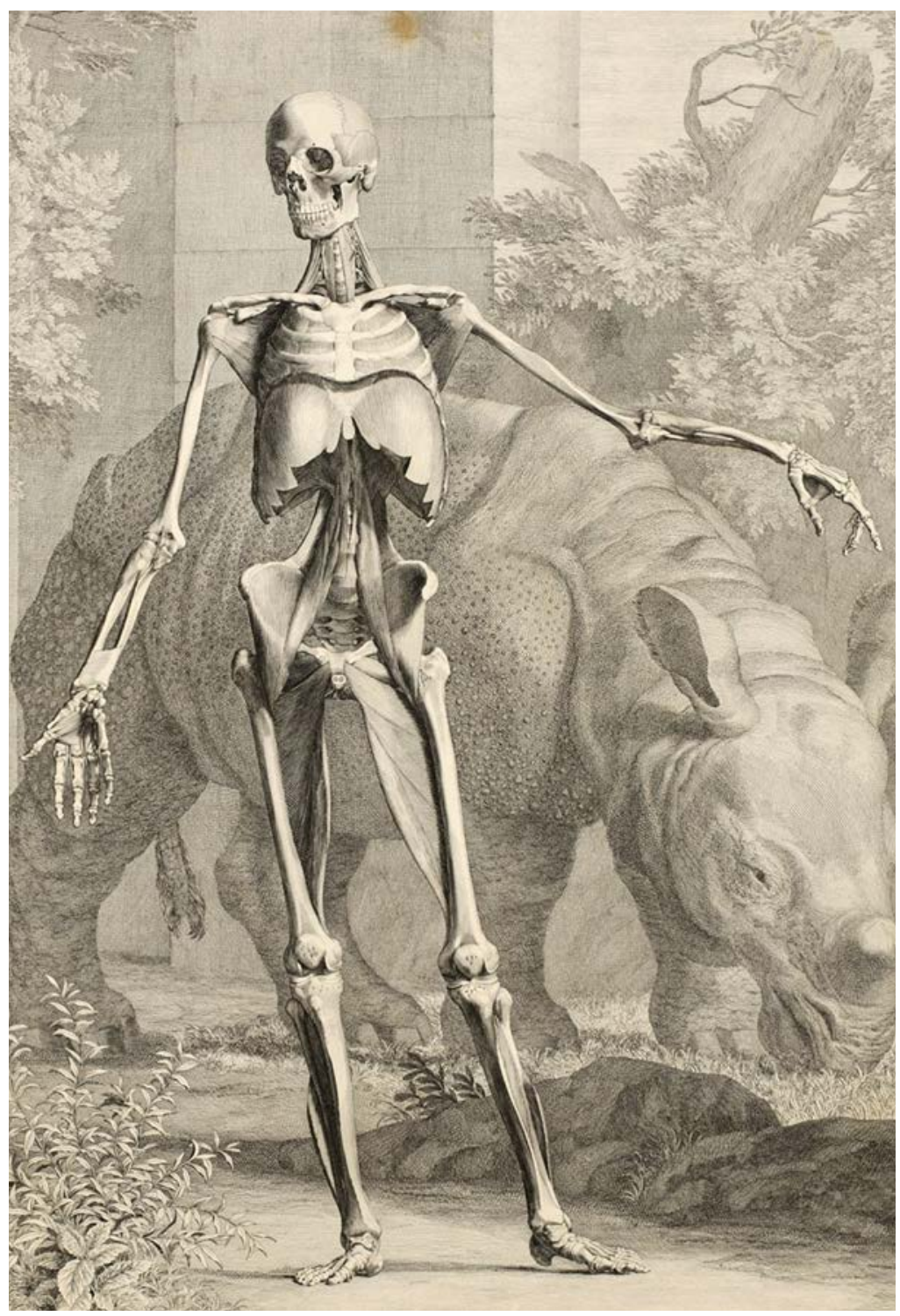

Figure 14.2: The famous Indian rhinoceros 'Clara', shown all around Europe between 1741 and 1758, depicted behind a human skeleton in the anatomical atlas by Bernard Siegfried Albinus, Tabulae sceleti et musculorum humanis corporis (1747), pl. 4.

Source: From Bernard Siegfried Albinus, Tabulae sceleti et musculorum humanis corporis (1747), pl. 4. 


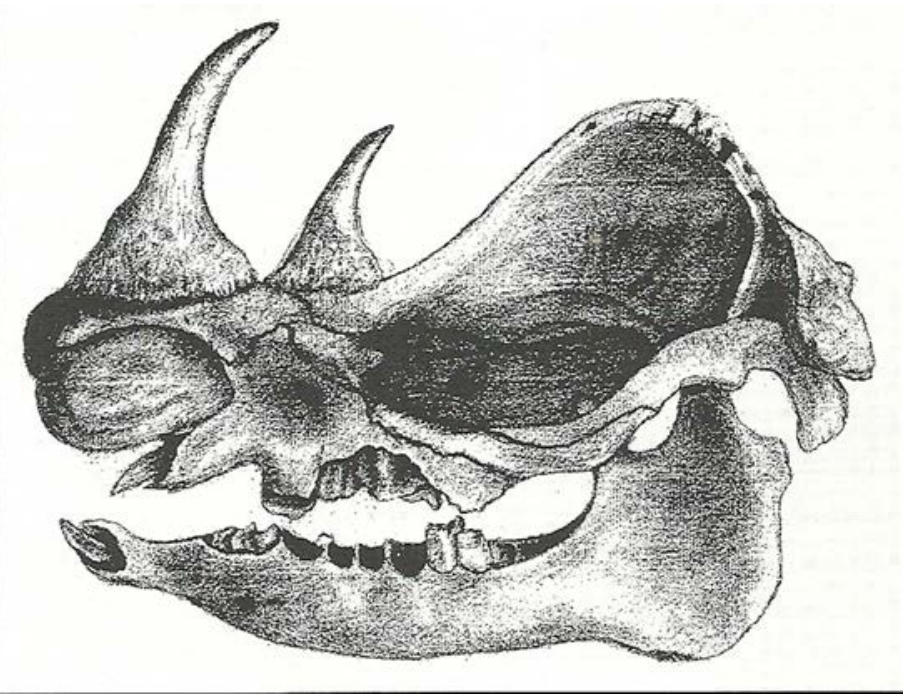

Figure 14.3: A rhinoceros skull drawn by the English physician James Parsons in or near London in the early eighteenth century. It is an Indian rhinoceros (Rhinoceros unicornis) with incisors, indicating that the posterior horn must have been an artificial addition.

Source: Hunterian Library, Glasgow, Av.1.17 folio 13.

William Bell (d.1792), trained as a zoological draughtsman by the great collector John Hunter in London, spent a few months in the British Fort Marlborough on the west coast of Sumatra. Some 10 miles away from the town, he found a rhinoceros, made drawings, collected the skull, and sent all off with a useful description to London, where his work was duly published by the Royal Society. Hence the existence of Rhinoceros sumatrensis could no longer be doubted.

Rhino specimens sent from Java had already convinced Petrus Camper (17221789 ) in the 1780s that this animal really differed from the better known singlehorned rhinoceros. Camper was not only a famous professor of human anatomy, but he was also interested in the morphological structures of the larger mammals like reindeer, orangutan, elephant and rhinoceros. At the end of his life, his studies convinced him that the rhinoceros of Java differed materially from the other species. Although possibly his death kept him from writing a treatise on the subject, he did engage a local artist to show the different types of rhinoceros in an engraving, which he could send to his colleagues at home and abroad.

In southern Africa, the British explorer William John Burchell (1781-1863) had penetrated far enough into the unknown interior to find a new species of rhinoceros, larger than the known kind and showing a broad rather than pointed upper lip. He carried a skull back to the coast together with drawings 
made on the spot where he first saw them. Remarkably, and for reasons still poorly understood, he sent word of his greatest discovery not to one of his academic friends in Britain, but to a professor of natural history in Paris, Henri de Blainville (1777-1850), who duly published his letter and drawing of the new Rhinoceros simus.

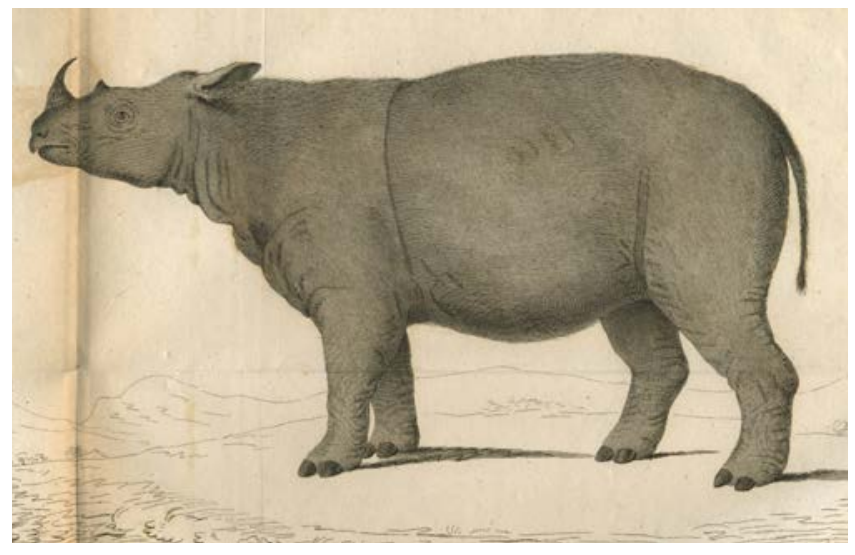

Figure 14.4: The first description of the double horned rhinoceros of Sumatra by William Bell, Surgeon in the Service of the East India Company at Bencoolen. It was published in the Philosophical Transactions of the Royal Society of London in 1793.

Source: From Bell, the Philosophical Transactions of the Royal Society of London in 1793.

Georges Cuvier (1769-1832) was one of the most influential zoologists in Europe in the first quarter of the nineteenth century, where he taught at the university and studied animals in the Jardin des Plantes. When he came to write a general overview of the animal kingdom, it was up to him to evaluate all the different strands of new information which had come to light since the time of Linnaeus. In 1816 he published the first part of his Règne Animal (Animal Kingdom), where, among the pachyderms, he distinguished three living species of rhinoceros: the African two-horned and Indian one-horned types of Linnaeus, to which he added the animal discovered by Bell in Sumatra. We must note the absence of Camper's rhinoceros from Java and Burchell's new African sort, the last of which is explained by the actual date of publication of Cuvier's book, late 1816 rather than 1817 as stated on the title-page. There is still an important role to play by bibliographers to unravel the more intricate puzzles in the development of science.

It must be said that Cuvier appears to have been particularly careful in his definition of the species, not wanting to recognise what in the end might be difficult to separate as a different species on morphological grounds alone. His colleague de Blainville was a little more liberal in a paper published in 1817 where he enumerated three Asian and four African species of rhinoceros. 


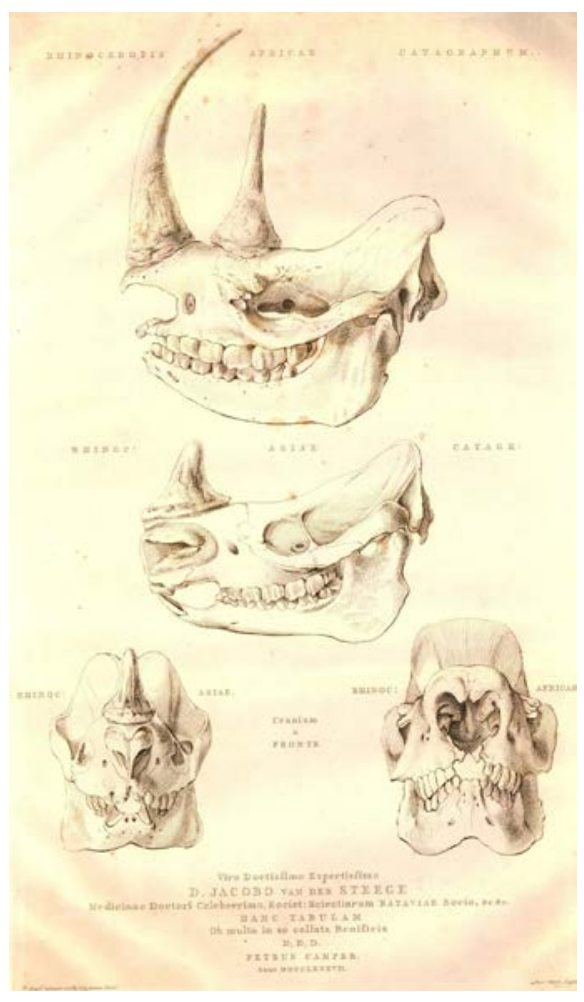

Figure 14.5: Broadside published by the Dutch professor Petrus Camper to show the differences between skulls of a black rhinoceros obtained from the Cape of Good Hope and of a rhinoceros from Java sent to him by Jacob van der Steege. Engraved by Reinier Vinkeles: 'Rhinocerotis Africae Catagraphum', 1787.

Source: British Museum, London.

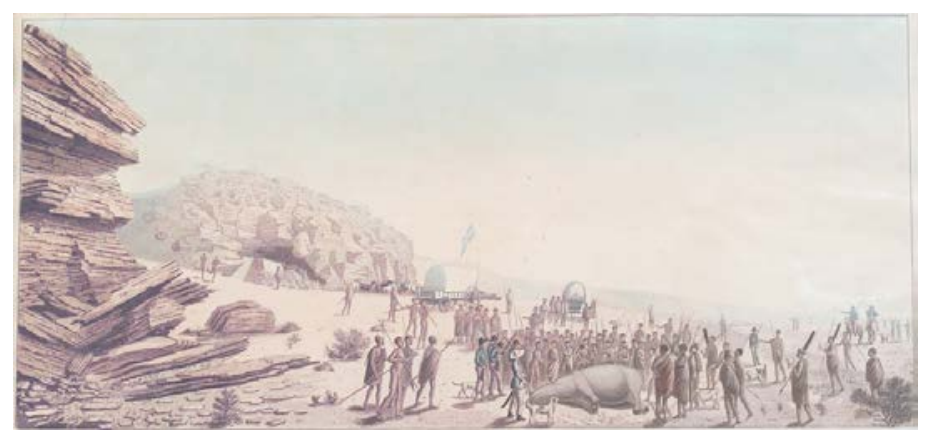

Figure 14.6: Depiction of a rhino hunt at Chué Spring (Heuningvlei) in South Africa by William Burchell in 1812. 
Twelve years later, in 1829, when Cuvier published the second edition of his definitive Règne Animal, he repeated most of the text, but he did add the Javan rhinoceros as a fourth species. He could not do differently, as his brother had described the animal after specimens and a written treatise had been received from Alfred Duvaucel (1793-1824), who had been sent to collect materials on behalf of the museum in Paris. His classification was of course very close to what we would recommend today. I should note, however, the absence of Rhinoceros simus, the white rhinoceros, from his writings, and one wonders why he did not feel inclined to add this as a fifth kind. Maybe the lack of original material at his disposal led to this course of action.

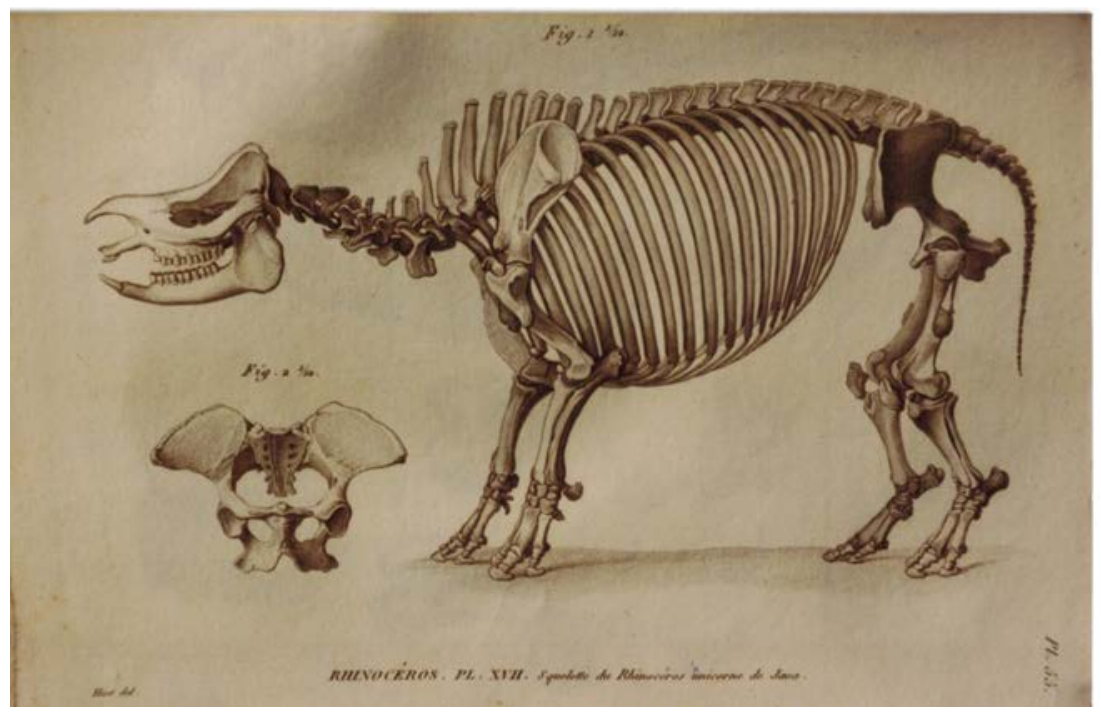

Figure 14.7: Skeleton of the 'Rhinoceros unicorne de Java' in the Paris Museum of Natural History. From Georges Cuvier, Recherches sur les ossemens fossiles (1836), Atlas, pl. 17.

Source: From Georges Cuvier, Recherches sur les ossemens fossiles (1836), Atlas, pl. 17.

\section{Rhino systematics in the time of John Edward Gray}

\section{London, United Kingdom: 1862-1875}

After Cuvier's final edition of the Règne Animal in 1836, the focus of rhino taxonomy definitely shifted to the British sphere of influence. There was a great influx of specimens from all of the range states which had to be diagnosed and 
named. It was a time when new species would be recognised after reading a report in a travel journal or examining just one or even part of a specimen which had just arrived from abroad. Though the aim was obviously to understand the great biodiversity in nature, the result was an array of species and varieties which, if viewed in their totality, was often bewildering.

On 1 June 1835, the British surgeon and naturalist Andrew Smith (1797-1872) was travelling in the African interior near present-day Mafikeng (North-West Province, South Africa) when his hunters alerted him that a different kind of rhinoceros had been shot. Hurrying to the spot to examine this exciting trophy, Smith carefully looked over the animal and that evening, sitting at the campfire, decided to follow the assessment of the assembled crowd. The animal differed from the common black rhino by its greater ferocity and the shape of the horns which were of equal length, and he called it the keitloa. When Smith published his Illustrations of the Zoology of South Africa in 1838, the first instalment started with the new Rhinoceros keitloa, obviously seen as the greatest prize of his expedition into the unknown parts of South Africa.

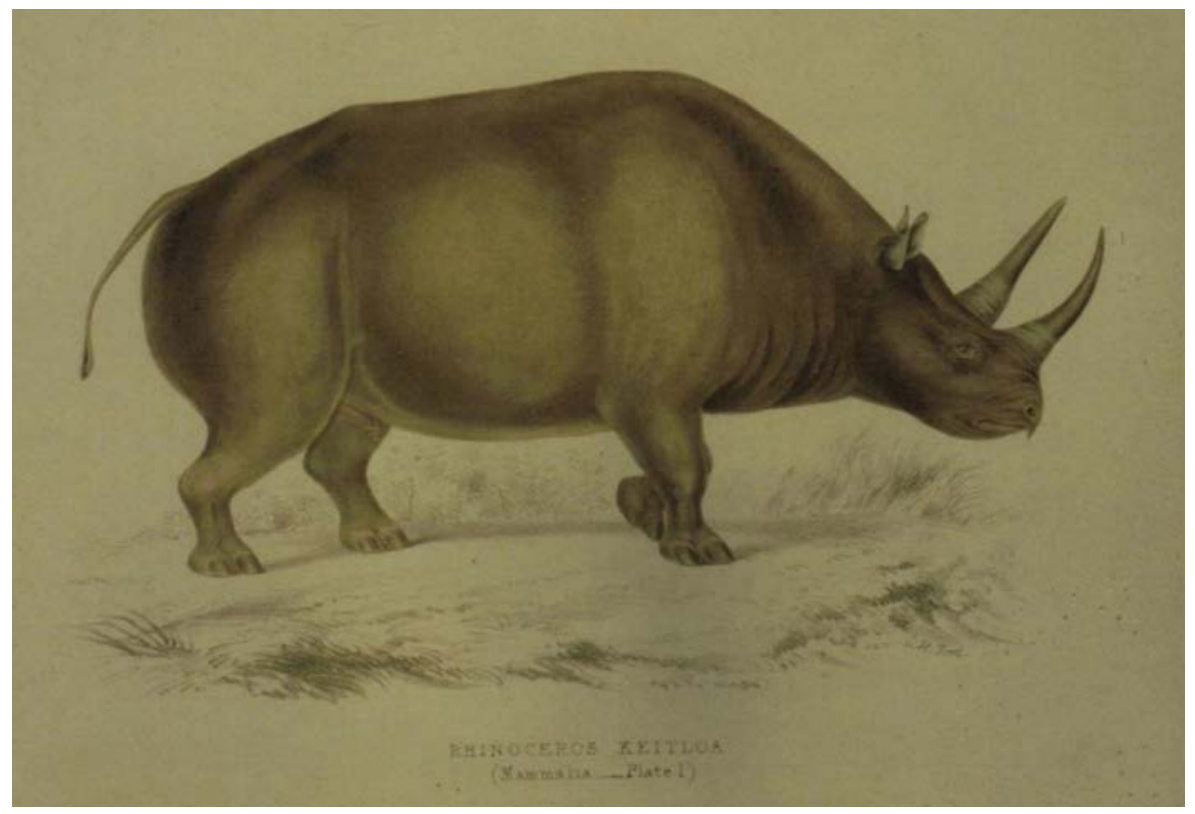

Figure 14.8: Lateral view of black rhinoceros called 'Rhinoceros keitloa' drawn by Gerald Ford for Andrew Smith, Illustrations of Zoology (June 1838), vol. 1, plate 1.

Source: Drawn by Gerald Ford for Andrew Smith, Illustrations of Zoology (June 1838), vol. 1, plate 1. 
The description of this new species of African rhinoceros may not appear particularly momentous, but in a way it opened the flood gates, when an experienced and respected zoologist like Andrew Smith without hesitation was willing to denote horn shape and temperament as characteristics useful enough to warrant specific distinction. In the African bush, this led to widespread speculation and endless discussions. Soon it was not unusual for big game hunters to allude to the existence of six or seven rhino species, all in the southern parts of Africa. Four were almost universally recognised, two types of black (borele and keitloa) and two types of white (mohoohoo and kobaaba). This practice did not remain restricted to the realm of campfire tales, these species were duly named, immortalised and generally accepted from the time of the revisions by John Edward Gray (1800-1875). As the main zoologist in the British Museum, Gray published a series of catalogues of the collections, which were influential and highly regarded. In 1862, Gray had no hesitation to list four African species which he called Rhinoceros bicornis, keitloa, simus and oswellii - and in some ways, he was relatively conservative in his assessment.

In this catalogue of 1862, Gray remained close to the classification of Cuvier by listing the same three species of rhinoceros inhabiting Asia, but he added a fourth one (Rhinoceros crossii) on the basis of an unlocalised strangely shaped horn. However, the time of change had arrived. In a new revision of 1868, Gray had five species of Asian one-horned rhinos as well as one species of Asian twohorned rhino. Edward Blyth (1810-1873) of the Asiatic Museum in Calcutta in 1862 found that skulls differed in broadness and suggested that these characters had specific status. The Secretary of the Zoological Society of London, Philip L. Sclater (1829-1913), compared a two-horned rhino from Chittagong in the London Zoo from 6 February 1872 with another from Malacca which arrived on 2 August 1872. The animals differed, especially in the length of the hairs fringing the ears, and were declared separate species (R. sumatrensis and $R$. lasiotis).

Considering that the above account is a rather watered-down version of the changing taxonomies of rhino species, leaving aside several spurious and even more ill-defined additions to the list, somehow time had come to put some of these distinctions to rest. Maybe it was hardly a coincidence that stabilisation was brought to the field soon after the death of John E. Gray in March 1875. William Henry Flower (1831-1899) had used the extensive collections of the Royal College of Surgeons in London to study the variations in cranial and dental characters. His revision almost miraculously brought new sense to the chaos of conflicting ideas and interpretations. In essence, he reverted back to Cuvier's last views, and recognised just five extant species, in Asia unicornis, sondaicus, sumatrensis, and in Africa bicornis and simus, but was unsure about the status of lasiotis. It was not quite the end to the era of superfluous descriptions and convoluted classifications, but there certainly was a path towards a workable taxonomy. 


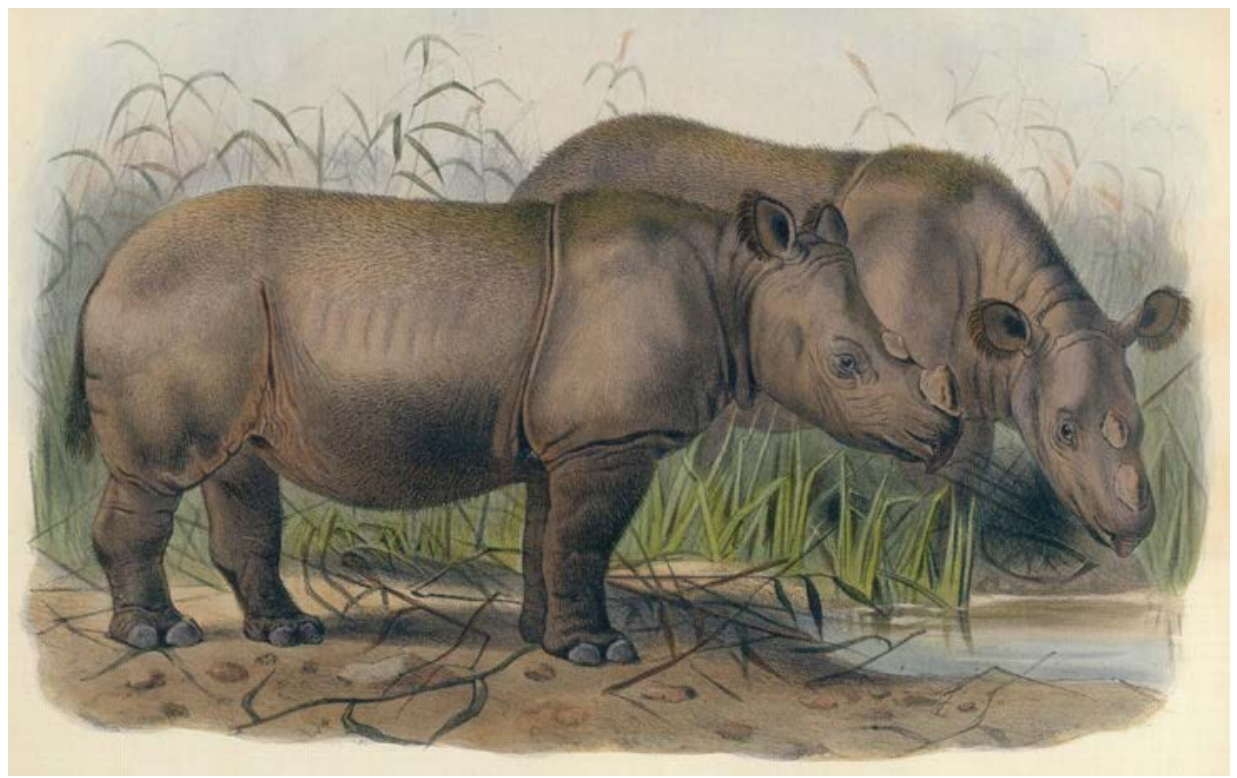

Figure 14.9: Images of the female Sumatran rhino 'Begum' shown in London Zoo from 15 February 1872 to 31 August 1900. She was the type of Rhinoceros lasiotis. From Sclater, On the rhinoceroses now or lately living in the Society's Menagerie (1877), pl. 98.

Source: From Sclater, On the rhinoceroses now or lately living in the Society's Menagerie (1877), pl. 98.

\section{Rhino systematics in the time of Colin Groves}

\section{UK and Australia: From 1965}

The intensity of the debates around rhino systematics in the mid-nineteenth century appears to have scared away any newcomers to the scene. It can truthfully be said that very little change was advocated for just about a century. The only notable exception was the rhinoceros shot by Major Percy Horace Gordon Powell-Cotton (1866-1940) in the Lado Enclave in the central parts of Africa. In this remote and unknown district, he found an animal very much like the white rhinoceros inhabiting regions further south, which differs particularly in the width of the nasal bones. Richard Lydekker (1849-1915) announced the discovery in a short notice tucked away in one of the issues of The Field, a magazine intended for the gentleman interested in field sports. On 22 February 1908 he named the animal Rhinoceros simus cottoni, after the discoverer, using a subspecific epithet, becoming more popular at the time, due to the perceived similarity of the two types of wide-mouthed rhinos. 


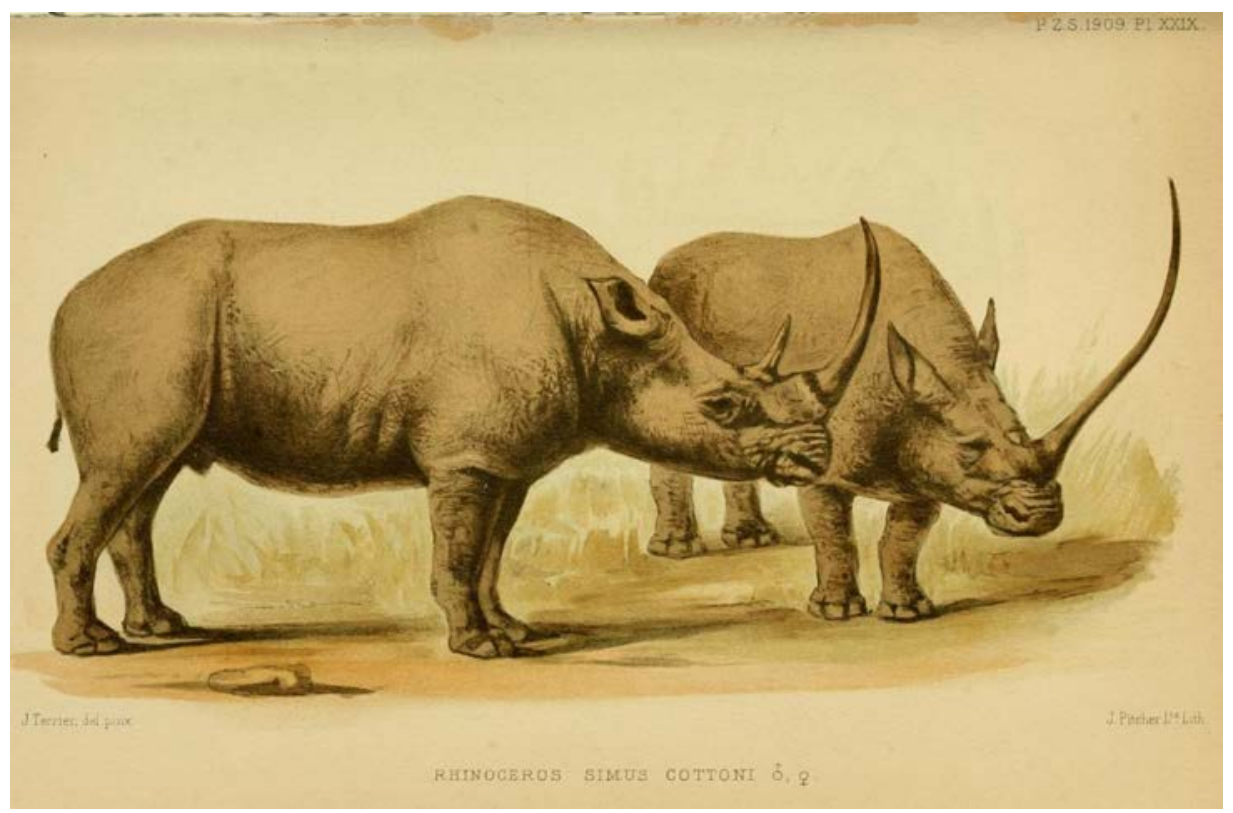

Figure 14.10: Nile rhino from the Lado Enclave in Sudan. Plate drawn by $\mathrm{J}$ Terrier and printed by $\mathrm{J}$ Pitcher. It was used to illustrate the account of this new species by Edouard Louis Trouessart, Le rhinoceros blanc du Soudan (rhinoceros simus cottoni) (1909), plate 1.

Source: From Edouard Louis Trouessart, Le rhinoceros blanc du Soudan (rhinoceros simus cottoni) (1909), plate 1 .

A reasonably stable situation had emerged and remained unchallenged, maybe partly because there was no excitingly new material that warranted a new revision, probably also due to a general lack of interest. In order to compare fossil bones with those of recent African rhinos, Arthur Tindell Hopwood (1897-1969) at the Natural History Museum in London had a fresh look at black rhinoceros systematics. His paper of 1939 had little news to offer, differentiating almost every population examined as a separate subspecies (bicornis, holmwoodi and somaliensis). Inevitably, many new rhino specimens had come to museums and zoos during the century. The African black rhinoceros is widespread and animals from different regions differ in size or colour or temperament or dentition or in a variety of other ways.

The first to undertake a much-needed revision of the species was Ludwig Zukowsky (1888-1965) in Germany, published in Der Zoologische Garten in 1965, which is of course a journal of international rank, but not particularly one where a major taxonomic study would be expected. Zukowsky had been able to compare many living animals during his work in German zoos like Hamburg and Leipzig, to which he added pictures taken in the field and a comprehensive 
survey of literature. Zukowsky's work, although largely ignored, remains in fact one of the major monographs written about a single rhino species. However, he worked in the tradition of taxonomic splitters, who generally used very minor differences to denote new species or subspecies, thereby increasing the number of forms to untenable levels. It is therefore not surprising that Zukowsky recognised 16 subspecies of Diceros bicornis, eight new and others resurrected from older works.

This is where Colin Groves first entered the scene. While pursuing his $\mathrm{PhD}$ studies, he found that the rhinoceros of Borneo differed enough from those of other parts of the range to warrant its description as a new subspecies, which he named after Tom Harrisson (1911-1976), one of those intrepid scholars who combine field work and museum studies. Next, on reading Zukowsky's study of 1965, he was aware that either the book would be totally forgotten and misunderstood, or needed to be put in a context of modern taxonomic theories. With an interest in rhinos which continues to this day, he set out to redress the excessive splitting by Zukowsky and divided the black rhino species in just seven subspecies. It is unfortunate that the international community of conservationists found it hard to cope with this sudden increase in subspecies, from three to seven, as theoretically there had been really no more than three types across the African continent for most of the century. An increase was inevitable though, in view of the fact that the black rhino in eastern and central Africa shows much variation and gradation and sudden morphological changes according to habitats and other patterns.

Groves has made several adjustments to rhino taxonomy during his long career. Together with Claude Guérin, the renowned expert in rhino palaeontology, he looked at data from Indochina and described the material as a subspecies of Rhinoceros sondaicus, correctly resurrecting a forgotten name annamiticus used only once earlier. More recently, while pursuing his belief in the Phylogenetic Species Concept, he has shown that in many ways the two subspecies of white rhino in southern and central Africa differ enough to be separated as species: Ceratotherium simum and Ceratotherium cottoni. This new understanding of their phylogenetic, genetic and biological relationship comes sadly at a time when the last examples in central Africa are being slaughtered by poachers and other opportunists. Ceratotherium cottoni, previously also distinguished in the vernacular as the northern white rhino, really deserves its own name, for which Nile rhinoceros may be one of the better historical choices.

Although the rhino taxonomy proposed by Groves certainly has its critics, there is no published alternative arrangement, which equally takes into account the available museum specimens, genetic material, histories of zoo animals, nomenclatorial rules and a thorough knowledge of the historical as well as current distribution of the rhino species. New insights will certainly come, and taxonomy 
is an evolving field which hopefully one day will become popular again with the increased need to understand global biodiversity. There will always be room for adjustments, but until that time, here is the latest classification of the recent rhinoceroses in Ungulate Taxonomy by Groves and Grubb (2011). Six species are recognised: Rhinoceros unicornis, Rhinoceros sondaicus (three subspecies, one extant), Dicerorhinus sumatrensis (three subspecies, two extant), Diceros bicornis (eight subspecies, four extant), Ceratotherium simum and Ceratotherium cottoni.

\section{Taxonomy in the service of conservation}

One of the reasons to look at the interpretation of rhino diversity over a period of several centuries is to weigh the impact of differing taxonomic interpretations on conservation initiatives. Taxonomy, it is of course recognised, is a field of academic pursuit no different from other scientific disciplines. New facts are constantly added, theories are adjusted, discarded or discovered, and inevitably systematic arrangements will constantly remain in a state of flux. If in 1758 a need had been felt to manage the remaining rhino populations in Africa, there would have been no scientific impediment to translocate anywhere in the continent and breed animals from different regions at will, because only one species was known. If in 1860 similar problems would have been addressed, the managers would have needed to understand a plethora of rather poorly defined species (not even subspecies), which probably would have thwarted the ingenuity of even the best minds given a practical need in the field. And it remains true that changes in systematics can cause any number of awkward or unwanted situations to occur, where animals are translocated to areas outside a range as understood at a given time.

Taxonomy should not obstruct conservation. Conservation should not ignore taxonomy. The goal is to understand biodiversity in all its wonderful facets and to preserve all its elements for future generations. Anybody working for rhino conservation has difficult choices to make on a daily basis. Rhino populations are not just dwindling, they are actively threatened to be wiped out completely. It is a war - to fight people greedily exploiting wildlife, it is a war - to stop encroachments on forest and bush. The possibility that this war will be lost is not unrealistic at all, with ever decreasing resources and ever increasing threats. Maybe the study of taxonomy will soon turn into a study of past biodiversity, gone before it is properly understood. Most people would say that this should not happen, yet only too few are willing to make the sacrifices needed to keep the world stocked with rhinos, and all the other beautiful creatures still precariously kept away from the brink of extinction. 


\section{Acknowledgements}

A long line of people have devoted some of their considerable intellectual or practical expertise to the study and conservation of the rhinoceros. I have had the privilege to meet some and correspond with others, always learning and often enjoying small discoveries in unexpected corners. I acknowledge their expertise and willingness to share their findings. Colin Groves is one of the busy professionals who finds time to guide a younger generation and his advice to me over the years has been invaluable. My wife Sandy and I look back with pleasure on the few times we could meet Colin and Phyll. There is still much to learn about rhinoceros taxonomy, ecology, history, management and conservation, and there is no time to lose as rhinos are under enormous pressure in their wild habitat. In my view, no new study or new conservation project should be undertaken without first understanding what has been done in the distant and recent past in order that we build on the expertise of past generations of dedicated researchers. In the case of the rhinoceros, the Rhino Resource Centre provides an almost unparalled platform which allows access to literature unimpeded by funding or locality, globally available without restriction. I thank all authors who have shared their publications by this means.

\section{References}

Note that all titles are available to view on the website of the Rhino Resource Centre (sponsored by the International Rhino Foundation, SOS Rhino, Rhino Carhire, Save the Rhino International and WWF-Areas).

Bell W. 1793. Description of the double horned rhinoceros of Sumatra. Phil Trans $R$ Soc Lond 1793:3-6, pls. 2-4.

Blyth E. 1862. A memoir on the living Asiatic species of rhinoceros. J Asiatic Soc Bengal 31(2):151-175, pls. 1-4.

Braun A, Groves CP, Grubb P, Yang Qi-Sen, Xia Lin. 2001. Catalogue of the Musée Heude collection of mammal skulls. Acta Zootaxonomica Sinica 26(4):608-660.

Burchell WJ. 1817. Lettre a M. H. de Blainville. In: Blainville HMD de, Lettre de M. W.J. Burchell sur une nouvelle espèce de rhinoceros, et observations sur les différentes espèces de ce genre. Journal de Physique, de Chimie et d'Histoire Naturelle 85:163-168, pl. 1.

Cave AJE, Rookmaaker LC. 1977. Robert Jacob Gordon's original account of the African black rhinoceros. J Zool, Lond 182:137-156, pls. 1-7, figs. 1-2. 
Cuvier G. 1817. Le règne animal distribué d'après son organisation pour servir de base a l'histoire naturelle des animaux et d'introduction à l'anatomie comparée. Paris: Deterville.

Cuvier G. 1829. Le règne animal, 2nd edition. Paris: Deterville et Crochard.

Cuvier G. 1836. Le règne animal, 3rd edition. Bruxelles: Louis Haumann.

Flower WH. 1876. On some cranial and dental characters of the existing species of rhinoceroses. Proc Zool Soc Lond 1876 May 16:443-457, figs. 1-4.

Gentry A, Clutton-Brock J, Groves CP. 2004. The naming of wild animal species and their domestic derivatives. J Archaeol Sci 31:645-651.

Geoffroy Saint-Hilaire E, Cuvier G. 1824. Rhinoceros de Java. In: Geoffroy St. Hilaire E et al. Histoire naturelle des mammifères, vol. 6(45). Paris: Blaise. pp. 1-2, pl. 309.

Gray JE. 1868. Observations on the preserved specimens and skeletons of the Rhinocerotidae in the collection of the British Museum and Royal College of Surgeons, including the description of three new species. Proc Zool Soc Lond 1867:1003-1032, figs. 1-6.

Gray JE, Gerrard E. 1862. Catalogue of the bones of mammalia in the collection of the British Museum. London: Trustees of the British Museum.

Groves CP. 1965. Description of a new subspecies of rhinoceros, from Borneo, Didermocerus sumatrensis harrissoni. Säugetierkundliche Mitteilungen 13(3):128-131.

Groves CP. 1967a. Comment on the proposed decision on the validity of Didermocerus Brookes, 1828. Bull Zool Nomencl 24(5):279.

Groves CP. 1967b. Geographic variation in the black rhinoceros, Diceros bicornis (L, 1758). Z Säugetierk 32(5):267-276, figs. 1-2, tables 1-2.

Groves CP. 1967c. On the rhinoceroses of South-East Asia. Säugetierkundliche Mitteilungen 15(3):221-237, figs. 1-4, tables 1-5.

Groves CP. 1971. Species characters in rhinoceros horns. Z Säugetierk 36(4):238252, figs. 1-22.

Groves CP. 1972. Ceratotherium simum. Mammalian Species no. 8:1-6, figs. 1-5.

Groves CP. 1975. Taxonomic notes on the white rhinoceros Ceratotherium simum (Burchell, 1817). Säugetierkundliche Mitteilungen 23(3):200-212, fig. 1, tables $1-3$. 
Taxonomic Tapestries

Groves CP. 1982a. Asian rhinoceroses: Down but not out. Malayan Naturalist 36(1):11-17, 20-22, figs. 1-4, table 1 .

Groves CP. 1982b. The skulls of Asian rhinoceroses, wild and captive. Zoo Biology 1:251-261, tables 1-4.

Groves CP. 1983. Phylogeny of the living species of rhinoceros. Z Zool Syst Evol 21(4):293-313, figs. 1-11.

Groves CP. 1993a. Bad medicine for wildlife. The Skeptic 13(1):12-14.

Groves CP. 1993b. Testing rhinoceros subspecies by multivariate analysis. In: Ryder OA, editor. Rhinoceros biology and conservation: Proceedings of an international conference. San Diego, USA: San Diego, Zoological Society. pp. 92-100, figs. $1-5$.

Groves CP. 1995a. A comment on Haryono et al.'s Report. Asian Rhinos 2:9.

Groves CP. 1995b. What is wrong with the captive population of Sumatran rhinos? Asian Rhinos 2:12.

Groves CP. 1995c. Why the Cat Loc (Vietnam) rhinos are Javan. Asian Rhinos 2:8-9, fig. 1.

Groves CP. 1997. Die Nashörner - Stammesgeschichte und Verwandtschaft. In: Anonymous. Die Nashörner: Begegnung mit urzeitliche Kolossen. Fuert: Filander Verlag. pp. 14-32, figs. 1-5.

Groves CP. 2003. Taxonomy of ungulates of the Indian subcontinent. J Bombay Nat Hist Soc 100(2/3):341-362.

Groves CP. 2008a. Extended family: Long-lost cousins. A personal look at the history of primatology. Arlington, VA: Conservation International.

Groves CP. 2008b. Review of L.C. Rookmaaker, Encounters with the African rhinoceros. J Mammal 89(6):1570.

Groves CP, Chakraborty S. 1983. The Calcutta collection of Asian rhinoceroses. Rec Zool Surv India 80:251-263, tables 1-2.

Groves CP, Fernando P, Robovsky J. 2010. The sixth rhino: A taxonomic reassessment of the critically endangered northern white rhinoceros. PLoS One 5(4) e9703:1-15

Groves CP, Grubb P. 2011. Ungulate taxonomy. Baltimore: Johns Hopkins University Press. 
Groves CP, Guérin C. 1980. Le Rhinoceros sondaicus annamiticus d'Indochine: Distinction taxinomique et anatomique; rélations phylétiques. Géobios 13(2):199-208, figs. 1-4, tables 1-2.

Groves CP, Kurt F. 1972. Dicerorhinus sumatrensis. Mammalian Species 21:1-6, figs. $1-4$.

Groves CP, Leslie Jr. DM. 2011. Rhinoceros sondaicus (Perissodactyla: Rhinocerotidae). Mammalian Species 43 (887):190-208.

Groves CP, Robovsky, J. 2011. African rhinos and elephants: Biodiversity and its preservation. Pachyderm 50:69-71.

Hillman Smith K, Groves CP. 1994. Diceros bicornis. Mammalian Species 455:1-8, figs. $1-3$.

Laurie WA, Lang EM, Groves CP 1983. Rhinoceros unicornis. Mammalian Species 211:1-6, figs. 1-3.

Linnaeus C. 1758. Systema naturae per regna tria naturae, secundum classes, ordines, genera, species, cum characteribus, differentiis, synonymis, locis. Editio decima, reformata. Holmiae: Laurentii Salvii.

Lydekker R. 1908. The white rhinoceros. Field 22 February 1980 (2878:319).

Prins HHT. 1990. Geographic variation in skulls of the nearly extinct small black rhinoceros Diceros bicornis michaeli in northern Tanzania. Z Säugetierk 55:260-269, figs. 1-3, tables 1-5.

Robovsky J, Fernando P, Groves CP. 2010. Misto peti nosorozcu sest. Novy druk, ktery uz viasne neesistuje. Vesmir 89:368-371, figs. 1-4.

Rookmaaker LC. 1978. Two collections of rhinoceros plates compiled by James Douglas and James Parsons in the eighteenth century. Journal of the Society for the Bibliography of Natural History 9(1):17-38, figs. 1-7

Rookmaaker LC. 1982. The type locality of the Javan Rhinoceros (Rhinoceros sondaicus Desmarest, 1822). Z Säugetierk 47(6):381-382

Rookmaaker LC. 1983a. Bibliography of the rhinoceros: An analysis of the literature on the recent rhinoceroses in culture, history and biology. Rotterdam and Brookfield: A.A. Balkema.

Rookmaaker LC. 1983b. Historical notes on the taxonomy and nomenclature of the recent Rhinocerotidae (Mammalia, Perissodactyla). Beaufortia 33(4):3751, figs. 1-4.

Rookmaaker LC. 1983c. Jamrachs Rhinozeros. Bongo, Berlin 7:43-50, fig. 1 
Taxonomic Tapestries

Rookmaaker LC. 1984. The taxonomic history of the recent forms of Sumatran Rhinoceros (Dicerorhinus sumatrensis). $J$ Malays Branch $R$ Asiatic Soc 57(1):12-25, figs. 1-6.

Rookmaaker LC. 1989. The zoological exploration of Southern Africa 1650-1790. Rotterdam and Brookfield: A.A. Balkema.

Rookmaaker LC. 1998. The sources of Linnaeus on the rhinoceros. Sven Linnesallskap Arsskr 1996/97:61-80, figs. 1-15.

Rookmaaker LC. 1999. Specimens of rhinoceros in European collections before 1778. Sven Linnesallskap Arsskr 1998/99:59-80, figs. 1-7.

Rookmaaker LC. 2003a. The last white rhinoceros in Zimbabwe. Pachyderm 35:100-114, figs. 1-8.

Rookmaaker LC. 2003b. Why the name of the white rhinoceros is not appropriate. Pachyderm 34:88-93, pl. 1.

Rookmaaker LC. 2004. Rhinoceros rugosus - a name for the Indian rhinoceros. $J$ Bombay Nat Hist Soc 101(2):308-310.

Rookmaaker LC. 2005. Review of the European perception of the African rhinoceros. J Zool, Lond 265:365-376, figs. 1-9.

Rookmaaker LC. 2005. The black rhino needs a taxonomic revision for sound conservation. International Zoo News 52(5):280-282.

Rookmaaker LC. 2008. Encounters with the African rhinoceros: A chronological survey of bibliographical and iconographical sources on rhinoceroses in southern Africa from 1795 to 1875: Reconstructing views on classification and changes in distribution. Münster: Schuling Verlag.

Rookmaaker LC. 2010. The sixth living rhino species? International Zoo News 57(3): 171 .

Rookmaaker LC. 201la. A review of black rhino systematics proposed in Ungulate Taxonomy by Groves and Grubb (2011) and its implications for rhino conservation. Pachyderm 50:72-76.

Rookmaaker LC. 2011b. The early endeavours by Hugh Edwin Strickland to establish a code for zoological nomenclature in 1842-1843. Bull Zool Nomencl 68(1):29-40.

Rookmaaker LC, editor. 2013. www.rhinoresourcecentre.com. (accessed 2013). 
Rookmaaker LC, Kraft R. 2011. The history of the unique type of Rhinoceros cucullatus, with remarks on observations in Ethiopia by James Bruce and William Cornwallis Harris (Mammalia, Rhinocerotidae). Spixiana 34(1):133134, figs. 1-8.

Rookmaaker LC, Groves CP. 1978. The extinct Cape rhinoceros, Diceros bicornis bicornis (Linnaeus, 1758). Säugetierkundliche Mitteilungen 26(2):117-126, fig. 1 , tables $1-3$.

Rookmaaker LC, Visser RPW. 1982. Petrus Camper's study of the Javan rhinoceros (Rhinoceros sondaicus) and its influence on Georges Cuvier. Bijdragen tot de Dierkunde, Amsterdam 52(2):121-136, figs. 1-8.

Sclater PL. 1872. Notes on Propithecus bicornis and Rhinoceros lasiotis. Ann Mag Nat Hist (4)10:298-299.

Sclater PL. 1877. On the rhinoceroses now or lately living in the Society's Menagerie. Trans Zool Soc Lond 9:645-660, pls. 95-99, figs. 1-9.

Smith A. 1838. Illustrations of the zoology of South Africa; consisting chiefly of figures and descriptions of the objects of natural history collected during an expedition into the interior of South Africa, vol. 1: Mammalia, part 1. London: Smith, Elder and Co.

Toit $\mathrm{R}$ du. 1987. The existing basis for subspecies classification of black and white rhinos. Pachyderm 9:3-5.

Trouessart E-L. 1908. Le rhinoceros blanc du Bahr-el-Gazal. La Nature, revue des sciences et de leurs applications aux arts et à l'industrie 37:50-53, figs. 1-2.

Trouessart E-L. 1909. Le rhinoceros blanc du Soudan (rhinoceros simus cottoni). Proc Zool Soc Lond 1909 February 16:198-200.

Zukowsky L. 1965. Die Systematik der Gattung Diceros Gray, 1821. Zoologische Garten 30:1-178, figs. 1-8. 



\title{
15. Conservation consequences of unstable taxonomies: The case of the red colobus monkeys
}

\author{
John Oates and Nelson Ting
}

\section{Introduction}

Species are the common primary 'currency' used in biodiversity conservation planning. Regions and ecosystems are often prioritised for conservation action based on measures of species richness and endemism (e.g. Myers et al., 2000; Olson and Dinerstein, 2002), and species judged to be in danger of extinction are usually given special attention (e.g. with focused conservation action plans produced by the International Union for Conservation of Nature's Species Survival Commission (IUCN SSC); see www.iucn.org/about/work/programmes/ species/publications/species_actions_plans/). Such species-based thinking is quite understandable. From long before there was any science of biology or taxonomy, people around the world have recognised sets of similar organisms as distinct entities (and given names to these sets); this 'natural' species concept provided the basis for the work of Linnaeus and those who have followed him. With or without scientific classification, people would recognise horses as different from asses and lions as different from tigers, and factor this recognition into their world view and decision making. When science is brought fully into play in conservation planning, however, a species-based approach can lead to serious difficulties in determining conservation priorities in those cases where a group of organisms has a poorly resolved or unstable species-level classification. Difficulties arise both in establishing relative conservation priorities within that group, and in relation to other groups. Unstable classification also creates problems for communicating information to policy-makers and managers who may have little knowledge of taxonomy.

Among primates, the taxonomy of Africa's red colobus monkeys has been particularly unstable and contentious. A great number of different classifications have been published in the last 45 years, recognising between one and 16 species. Several of these different classifications have been produced by Colin Groves, who has long been interested in this group of monkeys (e.g. Groves, 1989, 2001, 2007). Groves' classificatory changes have been influenced not only by new research findings, but also by his move from using the Biological Species Concept (BSC) as the basis of taxonomic analysis to the Phylogenetic 
Species Concept (PSC). The frequent, and often quite radical, changes in red colobus classifications have led to confusion both among field workers studying behaviour and undertaking surveys, and in conservation assessments published by national and international organisations. This has been particularly problematic because red colobus monkeys are among the most endangered primates in Africa with numerous populations in danger of extinction due to hunting or habitat modification by humans (Oates, 1996). With no consensus on their classification and on which forms are particularly distinct, it has been difficult to designate conservation priorities for this group of primates.

In this chapter we consider some of the causes and consequences of this example of taxonomic instability. For instance, could particular colobus populations, such as the Critically Endangered Tana River red colobus of Kenya and the probably recently extinct Miss Waldron's red colobus of West Africa, have suffered from a lack of sufficient conservation attention in part through their ambiguous distinctiveness? And could the use of different classifications have influenced the relative priority given to different regions of Africa for primate conservation? Finally, using the red colobus example, we consider what taxonomic practices might most beneficially be applied to conservation without a loss of scientific integrity.

\section{Systematics theory and background}

While no evolutionary biologist would debate the importance of the species concept in the development of evolutionary theory, there has been a lack of consensus on how a species should be defined (Frankham et al., 2012). This is one of the reasons why red colobus monkeys have been so difficult to classify. In fact, the taxonomic issues within this group are related to a larger theoretical debate that dominated the field of systematics in the latter half of the twentieth century. A comprehensive review of the history of this debate is beyond the scope of this chapter, but it is worthwhile highlighting some aspects of the debate particularly relevant to the problem we are discussing here.

A major theoretical divide has arisen between the two approaches that have come to be known as Evolutionary Systematics and Phylogenetic Systematics. The former is rooted in the union of evolutionary theory and population genetics that occurred in the 1940s, now known as 'The Modern Synthesis' (Huxley, 1942), while the latter finds its origins in the cladistic approach advocated by Willi Hennig in his book Phylogenetic Systematics, which was translated into English in 1966. One of the major differences between these two taxonomic schools has been in how they have viewed species. Those following Evolutionary Systematics have typically used process-based species concepts (i.e. considering the process leading to population divergence), while those who have supported Phylogenetic Systematics have generally employed pattern- 
based species concepts (i.e. the patterns resulting from divergence). The bestknown process-based species concept is the biological species concept (BSC), and the most commonly cited pattern-based concept is the phylogenetic species concept (PSC).

Usually credited to Mayr (1942), the BSC only applies to sexually reproducing organisms and defines species as 'groups of interbreeding natural populations that are reproductively isolated from other such groups' (Mayr, 1996: 264). Some authors (e.g. Bock, 2004; Coyne and Orr, 2004) have elaborated on this definition to allow for limited gene flow between two species as long as their respective gene pools are protected from one another. Several other species concepts have been formulated as modifications to the BSC, but it has been argued that many of these are redundant (e.g. Evolutionary Species, Mate Recognition Species; Szalay, 1993; Mayr, 1996). In regard to the PSC, Cracraft's (1983) definition is the most commonly accepted: 'the smallest diagnosable cluster of individual organisms within which there is a parental pattern of ancestry and descent'. This has been further refined to a group of populations with shared and fixed character combinations that represent minimal units appropriate for cladistic analysis (Davis and Nixon, 1992; Groves, 2004). In this sense, it is not so much a 'species concept' but a criterion for the diagnosis of species (Mayr, 1996; Goldstein and DeSalle, 2000). In fact, Groves (2012) states that a more appropriate name for the PSC might have been the 'Diagnosability Species Concept'.

Evolutionary Systematics (and thus the BSC and its derivatives) dominated the field of systematics for decades following the Modern Synthesis. However, the BSC has been criticised on several grounds (see Sokal and Crovello, 1970). One of its biggest shortcomings is the difficulty it creates for species diagnosis when populations do not overlap in distribution, precluding complete confidence in whether or not they would interbreed if brought into contact. In such circumstances, species status is typically given to a population when its differences (usually morphological) from other populations exceed the amount of variation seen within a typical species of the larger taxonomic group to which it belongs. Species diagnosis can thus change depending on what traits are compared and what is regarded as 'typical variation' within a species. This subjectivity has led to a great deal of confusion in the classification of many taxa, including the red colobus monkeys, as we outline below. Frustration over this subjectivity, in combination with the rise of molecular phylogenetics, has led to an increasing acceptance of Phylogenetic Systematics and the PSC over the past couple of decades. No one exemplifies this paradigm shift better than Colin Groves himself; his early classifications of red colobus monkeys (and other taxa) were consistent with the BSC, but more recently he has fully adopted the PSC in his classifications and has advocated for its use (Groves, 2001, 2004, 2012). Table 15.1 displays how red colobus classifications have changed over the years, including Groves' classifications. 
Taxonomic Tapestries

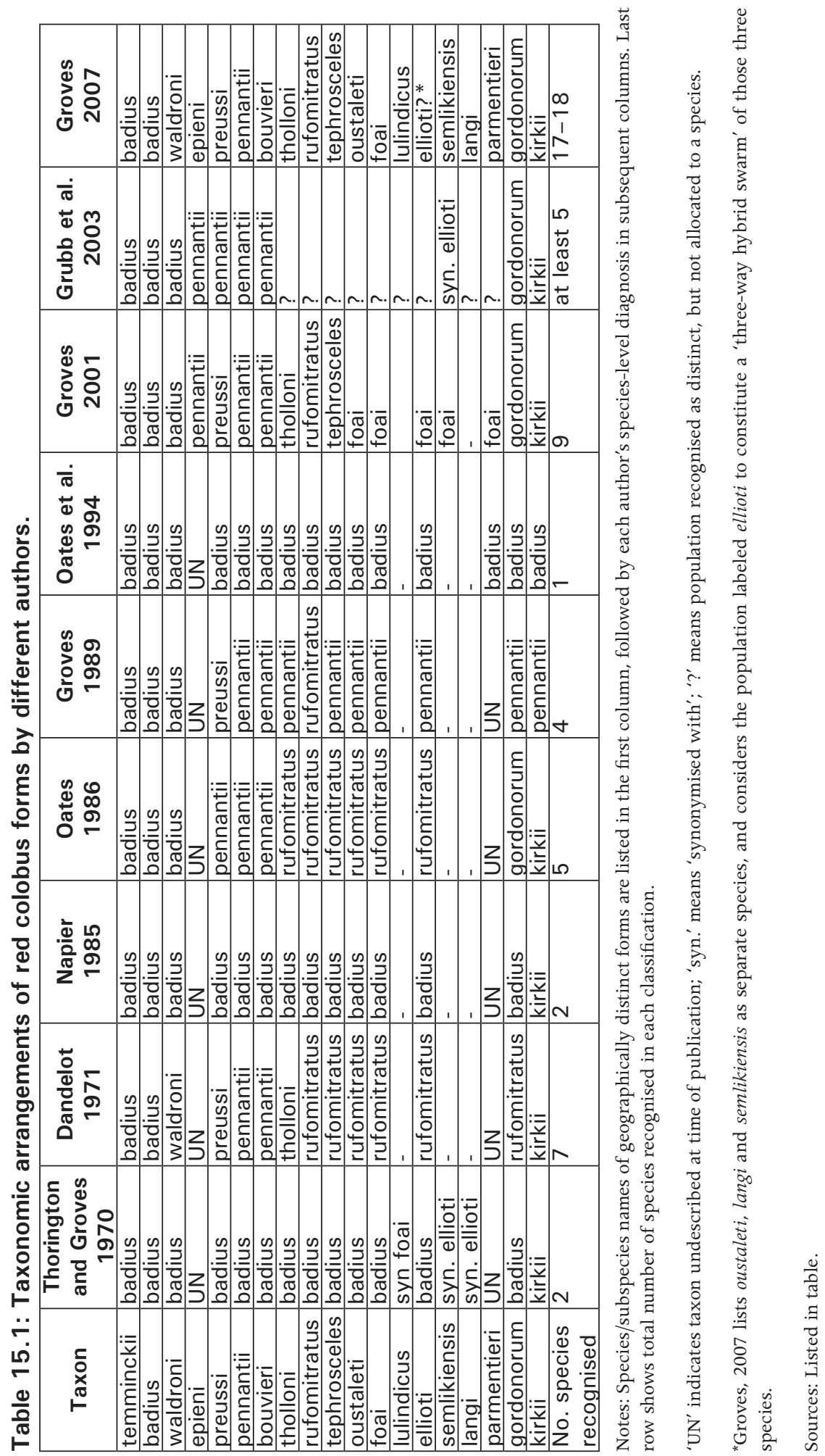




\section{Red colobus monkey distribution and variation}

Red colobus monkeys are commonly regarded as belonging to the subfamily Colobinae of the family Cercopithecidae (Old World monkeys) and they are closely related to the other two living African colobine groups - the olive colobus and the black-and-white colobus. Based largely on pelage differences, 16-18 different forms of red colobus are recognised in many recent classifications (see, e.g. Grubb et al., 2013), distributed across equatorial Africa in a primarily allopatric manner, with the exception being a putative hybrid zone in the eastern Democratic Republic of Congo (Figure 15.1). All populations of red colobus have varying amounts of red, black, white, brown and grey in their pelage, with certain forms showing considerable intra-populational variation, while others are relatively uniform (Kingdon, 1997; Struhsaker, 2010). Red colobus also have a complex and graded vocal system that makes it difficult to classify their vocalisations into discrete categories, unlike the calling array of the blackand-white colobus group (Marler, 1970). Furthermore, their crania display a clinal pattern of size and shape variation across Africa (Cardini and Elton, 2009). These features of red colobus biology have made their classification one of the thorniest issues in African primate taxonomy (Grubb et al., 2003).

Nearly all recently published classifications recognise the same 16-18 different forms of red colobus, with each form regarded as either a subspecies or species; there is thus broad agreement and stability in terms of the recognition of different geographic populations as being taxonomically distinct. The only major exceptions involve populations that occupy the putative hybrid zone in Central Africa. There has been little agreement, however, regarding how many species are present among these 16-18 taxa, and into which species each different form should be classified (see Table 15.1). This is because most classifications of these monkeys have attempted to diagnose species under the BSC, and because the distinct populations are distributed allopatrically objective diagnosis of biological species is extremely difficult, if not impossible. Furthermore, most of the systematic work done has involved comparisons of pelage patterns, which is problematic, given that red colobus coat colour varies at populational and even social group levels. Other research, involving vocalisations or craniometrics, has suffered from incomplete sampling and been confounded by the complex patterns of variation in these monkeys. This has often led to 'giving up' (in the words of Groves, 2001) and a decision to combine all of the red colobus into one species, except sometimes for a few particularly distinct forms. Despite this, most authors have recognised that the level of variation among the different forms does exceed that which is typical for a single primate species under the BSC. 


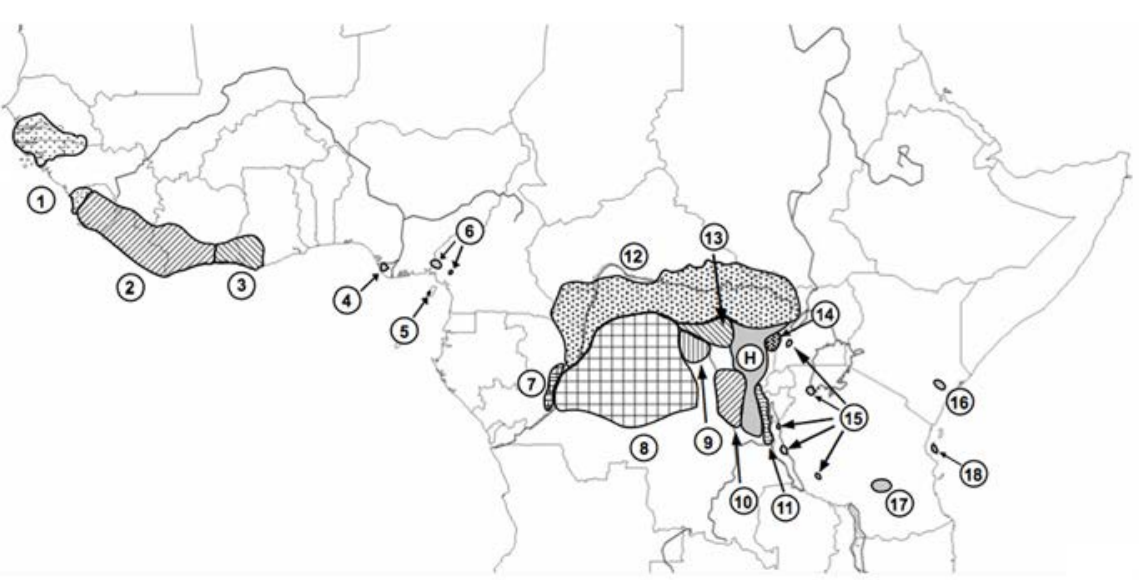

Figure 15.1: Distribution of 18 allopatric populations of red colobus monkeys that have been given taxonomic names of subspecies or species rank. 1, temminckii; 2, badius; 3, waldroni; 4, epieni; 5, pennantii; 6, preussi; 7, bouvieri; 8, tholloni; 9, parmientieri; 10, Iulindicus; 11, foai; 12, oustaleti; 13, langi; 14, semlikiensis; 15, tephrosceles; 16 , rufomitratus; 17, gordonorum; 18 , kirkii. ' $\mathrm{H}$ ' is a putative hybrid population in the eastern Democratic Republic of Congo.

\section{A history of red colobus monkey classification}

Before describing the contentious species-level history of red colobus monkey classification, it is worth noting that the genus-level classification of this group too has changed substantially over the years. Such changes have also in part been caused by paradigm shifts in systematics and likewise may have influenced conservation policy by introducing further confusion. Briefly, most classifications prior to 1980 placed the red colobus monkeys with other African colobines in the genus Colobus. Since then, they have been recognised as (1) the subgenus Piliocolobus within the genus Procolobus, reflecting a close relationship to the olive colobus, or (2) members of a distinct genus, Piliocolobus. These different arrangements result from differences of opinion about what criteria (e.g. morphological variation, genetic variation, time) should be used to diagnose taxa above the species level; there is no current consensus as to which is most appropriate (Goodman, 1996; Groves, 2001).

An important benchmark in the classification of primates in modern times was the publication in 1967 of A Handbook of Living Primates by John and Prudence 
Napier. Napier and Napier followed Verheyen (1962) in recognising just two species of red colobus monkeys, Colobus badius and C. kirkii, which they grouped together in the subgenus Piliocolobus. In the same year, Kuhn (1967) also followed Verheyen in separating $C$. kirkii of Zanzibar from $C$. badius as a monotypic species, and also placed the red colobus in the subgenus Piliocolobus.

Colin Groves, in addition to his doctoral research on gorilla systematics and ecology (Groves, 1966, 1967, 1970a), took an early interest in the systematics of gibbons and leaf-eating monkeys, and co-authored an influential classification of Old World monkeys with Richard Thorington (see also Groves, 1970b). For red colobus, Thorington and Groves (1970) used the classification of Kuhn (1967), but noted that the recognition of several species might be "more in line with taxonomic practice'. In the same volume as Thorington and Groves, Rahm (1970) recognised only one species, Colobus badius, with 14 subspecies, including $C$. b. kirkii, and said that 'no definite answer can be given from the point of view of species and subspecies'. Not long after this, Dandelot (1971) produced a fivespecies classification of red colobus (Colobus badius, C. pennantii, C. rufomitratus, C. tholloni and $C$. kirkii), noting that more extensive research would undoubtedly lead to an increase in the number of species recognised, and suggesting $C$. ellioti, C. preussi and C. waldroni as 'potential' species. Struhsaker (1975) analysed the call repertoires of five different populations generally regarded as subspecies and found $C . b$. preussi to have the most divergent repertoire.

Confusion continued into the 1980s. Extending his earlier analysis of vocalisations to include additional red colobus populations, Struhsaker (1981) identified four clusters of subspecies based on degree of vocal similarity: (1) badius and temminckii; (2) preussi; (3) tholloni, tephrosceles and rufomitratus; and (4) gordonorum and kirkii. Wolfheim (1983) recognised only a single species of red colobus, while P. Napier (1985) retained the two-species arrangement ( $C$. badius and $C$. kirkii) of Kuhn and of Thorington and Groves, citing Verheyen's observation (1962) that kirkii had a relatively small cranial capacity. In an IUCN SSC conservation action plan Oates (1986) - taking account of Struhsaker (1981) - regarded the red colobus monkeys as members of a single superspecies, Procolobus badius, provisionally containing five species: P. badius, P. pennantii, P. rufomitratus, $P$. kirkii and $P$. gordonorum; all the forms found in the central and eastern Congo Basin, together with tephrosceles and rufomitratus of eastern Africa, were grouped together in P. rufomitratus. Groves (1989), however, citing unpublished research by himself and Pierre Dandelot, moved to a fourspecies arrangement, recognising a central species (Colobus pennantii, but which also now included $C$. kirkii), a species restricted to Kenya's Tana River ( $C$. rufomitratus), an Upper Guinea species (C. badius), and $C$. preussi of Cameroon and Nigeria (said to be 'very distinct'). 
In a review of colobine monkey diversity in the mid-1990s, Oates and others (1994) decided to treat all the red colobus as a single species, Procolobus (Piliocolobus) badius, based on the lack of consensus in other classifications. This publication did not contain any new analysis, and did not influence later taxonomic studies, but it did influence conservation listings, as we describe below. Kingdon (1997), by contrast, in a widely used field guide, placed the red colobus in their own genus, Piliocolobus, and used an eight-species classification: P. kirkii, P. gordonorum, P. rufomitratus, P. tholloni, P. oustaleti, P. pennanti [sic], $P$. preussi and $P$. badius.

Since the year 2000, several substantially different taxonomic arrangements of red colobus monkeys have been published, adding to the confusion. The IUCN SSC Primate Specialist Group convened a meeting of primate biologists in Orlando, Florida, in 2000 in an attempt to produce a taxonomic consensus that could be used in conservation planning. This meeting, in which Colin Groves participated, failed to reach a clear consensus on the species-level classification of red colobus. A classification of African primates resulting from the meeting placed the red colobus in the genus Procolobus (subgenus Piliocolobus); it recognised five distinct species ( $P$. badius, $P$. kirkii, $P$. gordonorum, $P$. rufomitratus and $P$. pennantii), and left an additional 5-8 subspecies in a poorly defined 'central assemblage' on which the working group recommended further research to establish relationships (Grubb et al., 2003). This central assemblage of populations is the same group of taxa referred to as $P$. rufomitratus by Oates (1986), except that Grubb and others excluded rufomitratus itself, treating this Tana River red colobus as a separate species. Meanwhile, Groves (2001) had published his influential book Primate Taxonomy, which listed nine species of red colobus, allocated to the genus Piliocolobus: P. badius, P. pennantii, P. preussi, P. tholloni, P. foai, P. tephrosceles, P. gordonorum, P. kirkii and P. rufomitratus.

Later, Groves revised his nine-species classification to a 16-species arrangement by additionally recognising Piliocolobus waldronae, P. epieni, P. bouvieri, $P$. parmientieri, P. oustaleti, P. langi and P. semlikiensis as full species (Groves, 2007). Shortly after this, Ting (2008) presented the results of the first thorough comparison of mitochondrial DNA in red colobus monkeys and proposed instead a five-species arrangement within the genus Procolobus (subgenus Piliocolobus): $P$. badius, $P$. pennantii, $P$. kirkii, P. rufomitratus and $P$. epieni.

Struhsaker (2010), paying special attention to patterns of vocal similarity and difference, recognised seven groups of 'taxa' (badius and relatives, preussi, pennantii, bouvieri, rufomitratus and relatives, gordonorum and kirkii), but was not prepared to allocate these groups, or the populations within them, to named species. In an appendix to Struhsaker's book, Grubb and others (2010) listed 18 subspecies as belonging to a single species, Procolobus badius. 
In the recently published Mammals of Africa, Grubb and others (2013) 'very provisionally' recognise six species: Procolobus badius, $P$. preussi, $P$. pennantii, $P$. rufomitratus, $P$. gordonorum and $P$. kirkii. This is the same arrangement used by Struhsaker (2010), except that these taxa are given species rank, and bouvieri of the Congo Republic is included within P. pennantii.

\section{Effects on conservation planning}

One of the earliest attempts to provide an inventory of threatened species to guide conservation planning was the publication of the Red Data Books by IUCN's Survival Service Commission (known since 1980 as the Species Survival Commission). These publications began to appear in 1966 as loose-leaf datasheet volumes giving information on rare and endangered animals which had come to the attention of IUCN. The first Red Data Book on mammals (Simon, 1966) included 25 species and 22 subspecies of primates judged to be rare or endangered; among these were three red colobus monkeys, listed as Colobus badius kirkii, $C$. b. rufomitratus and C. b. gordonorum. In 1978 Colobus badius preussi was added to the list (Goodwin et al., 1978). In 1980, datasheet publications were superseded by bound volumes, with different volumes covering different groups of taxa, and in 1986 the Red Data Books became the Red List. Table 15.2 compares a selection of IUCN's threat ratings of red colobus taxa from 1978 to 2012.

Table 15.2: Selected threat status listings of red colobus taxa by IUCN.

\begin{tabular}{|l|l|l|l|l|}
\hline Taxon & Red Data Book 1978 & Lee et al.1988 & Red List1996 & Red List2012 \\
\hline temminckii & - & R & EN & EN \\
\hline badius & - & VU & - & EN \\
\hline waldroni & - & EN & CR & CR \\
\hline epieni & UN & UN & EN & CR \\
\hline preussi & EN & EN & EN & CR \\
\hline pennanttii & - & EN & EN & EN \\
\hline bouvieri & - & EN & EN & CR \\
\hline tholloni & - & $\mathrm{K}$ & - & NT \\
\hline rufomitratus & EN & EN & EN & EN \\
\hline tephrosceles & - & VU & - & EN \\
\hline oustaleti & - & $\mathrm{K}$ & - & LC \\
\hline foai & - & $\mathrm{K}$ & $\mathrm{DD}$ & - \\
\hline lulindicus & - & - & $\mathrm{DD}$ & - \\
\hline ellioti & - & $\mathrm{K}$ & - & - \\
\hline semlikiensis & - & - & $\mathrm{DD}$ & - \\
\hline langi & - & - & $\mathrm{DD}$ & - \\
\hline parmentieri & $\mathrm{UN}$ & - & $\mathrm{DD}$ & - \\
\hline gordonorum & $\mathrm{R}$ & $\mathrm{EN}$ & EN & EN \\
\hline kirkii & $\mathrm{R}$ & $\mathrm{EN}$ & EN & EN \\
\hline
\end{tabular}

Notes: $\mathrm{CR}=$ Critically Endangered; DD = Data Deficient; EN = Endangered; $\mathrm{K}=$ Insufficiently Known; LC = Least Concern; NT = Not Threatened; $\mathrm{R}=$ Rare; $\mathrm{UN}=$ Undescribed; $\mathrm{VU}=$ Vulnerable; a dash indicates that the taxon was not given an individual listing. 
During the 1980s two conservation assessments appeared that focused on African primates. The IUCN SSC Primate Specialist Group's Action Plan for African Primate Conservation: 1986-90 (Oates, 1986) made an assessment of the status of every African primate species. The action plan used the five-species classification of red colobus referred to above (see Table 15.1): $P$. badius and $P$. rufomitratus were rated as Vulnerable, $P$. pennantii as Endangered, and P. kirkii and $P$. gordonorum as Highly Endangered. The same species-level classification was followed by Lee and others (1988) in the Threatened Primates of Africa: The IUCN Red Data Book. Lee and others included both species and subspecies; each of the five species was listed as either Vulnerable (P. badius and P. rufomitratus) or Endangered (the remaining three species), and nine subspecies were also given attention through being regarded as of conservation concern. IUCN's 1988 Red List also employed this five species arrangement (IUCN, 1988).

A significant change in the classification of red colobus monkeys for conservation purposes occurred with IUCN's 1996 Red List (IUCN, 1996). Here, all red colobus were lumped into one species, Procolobus badius, with 14 subspecies. The 1996 primate assessments were made by the Primate Specialist Group; Oates and others (1994) is almost certainly the source of the classification employed. Although several subspecies were listed as Endangered or Critically Endangered in the 1996 Red List, the species as a whole was rated as only Near Threatened, based on the new system of threat categories and criteria adopted by IUCN in 1994. The same one-species classification was employed in the revised edition of the Primate Specialist Group's African primate action plan, which appeared in the same year (Oates, 1996).

The IUCN Red List is now published in digital form (www.iucnredlist.org). At the time of writing, the Red List assesses the status of 13 different geographically and taxonomically distinct forms of red colobus, including six species and 10 subspecies (IUCN, 2012). The six species are: Procolobus badius, P. gordonorum, $P$. kirkii, P. pennantii, P. preussi and P. rufomitratus. This arrangement is based in part on IUCN's Global Mammal Assessment of 2008, for which primates were initially assessed at a workshop in 2005; that workshop used Grubb and others (2003) as a primary reference for classification. Grubb and others treat preussi as a subspecies of $P$. pennantii, but the latest Red List elevates this taxon to species level, following Butynski and Kingdon (2013). Of the 13 taxa on the Red List, four are rated as Critically Endangered and seven as Endangered. The taxa foai, lulindicus, ellioti, langi and parmentieri are not individually assessed in the 2012 Red List; they are listed as subspecies of P. rufomitratus which, as a species, is given a rating of Least Concern. The 2012 Red List does not list semlikiensis, following Grubb and others (2003) in treating this taxon as synonymous with ellioti. 
How might changes in classification have affected the attention given by conservationists to the rarest and most threatened of red colobus monkey populations? We will highlight the cases of three forms of red colobus, one probably extinct, one possibly extinct, and one verging on extinction.

Miss Waldron's red colobus of eastern Côte d'Ivoire and western Ghana was referred to as the subspecies Procolobus badius waldroni by Oates (1986), Lee and others (1988) and IUCN (1988). Groves (1989) did not specifically mention waldroni, but also implied that it should be considered as a subspecies of Procolobus badius. The 1996 IUCN Red List gave separate treatments to species and subspecies; all red colobus were treated as one species (Procolobus badius, listed as Near Threatened), while the subspecies P. badius waldroni was listed as Critically Endangered (IUCN, 1996). A few years later, Oates and others (2000) reported that P. b. waldroni was probably extinct, and suggested that even if a few individuals survived, no viable population remained. Subsequently, no reliable record has emerged of any Miss Waldron's red colobus having been seen in the wild, although the remains of a few individuals were found with hunters in Côte d'Ivoire, most recently in 2006 (Oates, 2011). Since 2006, Groves (2007) has elevated this monkey to species status (as Piliocolobus waldronae), and the genetic study by Ting (2008) has also indicated that this might be a reasonable course, confirming the suggestion of Dandelot (1971). We are left to wonder whether recognition of waldroni as a species during the 1980s and 1990s might have directed more conservation attention to this monkey, and averted its extinction. In other words, did taxonomy 'kill' this monkey in the sense used by Morrison and others (2009)?

Bouvier's red colobus is known only from a handful of specimens collected in the nineteenth and early twentieth centuries in the former French Congo (today's Republic of the Congo, or Congo-Brazzaville). Dandelot (1971) classified this monkey as Colobus pennantii bouvieri, based on the similarity of its colour pattern and arrangement of hair on the front of the head to Pennant's red colobus of Bioko. Most subsequent classifications have kept Bouvier's colobus as a subspecies of Pennant's colobus (where that taxon is regarded as a species), or recognised it as one among many subspecies of red colobus in single-species classifications. Exceptions are Ting (2008), who could not confidently place this form into a species because a lack of biomaterials precluded its inclusion in DNA analysis, and Groves (2007), who elevates this form to species rank as Piliocolobus bouvieri, and says that the 'status of this extremely poorly known monkey needs urgent investigation'. The lack of specimens for both morphological and genetic comparative study (and the fact that there have been no substantial scientific observations in the wild) has led this monkey to be seriously neglected. Even the exact locations from where the museum specimens originated are in some doubt, but they seem to lie mostly in the swamp forests on the right bank of the lower Sangha River and near the mouth of the Likouala- 
Mossaka River. A report of red monkeys with light faces and white underparts from the Lefini Reserve in the 1970s (quoted in Groves, 2007) doubtfully refers to this colobus. In the 1996 Red List, bouvieri was rated as an Endangered subspecies of Procolobus badius (IUCN, 1996) and the current Red List includes it as a Critically Endangered subspecies of Procolobus pennantii. Given the lack of any convincing observational reports of this colobus for many decades, there must be a strong possibility that it is extinct; R. Dowsett (pers. comm. to JFO, 1974) noted that monkeys in general are very heavily hunted in this part of Congo, although he added that the area from which bouvieri is known is difficult to access. As with Miss Waldron's colobus we speculate that a clearer taxonomic definition of Bouvier's colobus might have led to it receiving more attention. ${ }^{1}$

The Tana River red colobus of Kenya was listed in the original IUCN Red Data Book as a subspecies, rufomitratus, of the species Colobus badius and rated as Endangered (Simon, 1966). In 1972 the surviving population was estimated at around 1900 individuals (Goodwin et al., 1978). Oates (1986), Lee and others (1988) and IUCN (1988) continued to list the Tana colobus as Endangered, but classified it as a subspecies of Procolobus rufomitratus, a species considered to occupy the Congo Basin and the Western Rift Valley as well as the Tana River, on the basis of the vocal patterns reported by Struhsaker (1981). Kingdon (1997), however, regarded the Tana population as a distinct species, Piliocolobus rufomitratus, a course later followed by Groves $(2001,2007)$ and (using the name Procolobus rufomitratus) by Grubb and others (2003). In 1999-2001, Meikle and Mbora (2004) recorded a total of 613 individuals in the forests along the Tana River, $50 \%$ of the number estimated present in 1994, and referred to the Tana red colobus as 'the most endangered primate species in Africa.' Mbora and Butynski (2009) describe the long-time survival prospects of the Tana colobus as very bleak, especially since the High Court of Kenya ruled in 2007 that the Tana River National Primate Reserve was not properly established by law. However, the current Red List (IUCN, 2012) treats the Tana colobus as the subspecies Procolobus rufomitratus rufomitratus, with the status of Endangered, apparently using an older population estimate of 1,100-1,300 individuals and an assessment that there has not been a significant population decline since 1975.

In addition to the three forms of red colobus we have highlighted, a majority of the remaining 13-15 forms must be regarded as threatened, based on having small, fragmented, and/or rapidly declining populations. Of particular concern are Pennant's red colobus of Bioko Island, the Niger Delta red colobus, and Preuss' red colobus of western Cameroon and eastern Nigeria. Each of these monkeys is rated as Critically Endangered on the current Red List (IUCN, 2012) where they are called Procolobus pennantii pennantii, P. pennantii epieni and

1 Note added in proof: Lieven Devreese (pers. comm.) planned to conduct a field survey to locate any surviving populations of Bouvier's red colobus in the early part of 2015. At the time of writing, no information from this survey was available. 
$P$. preussi respectively - the same classification employed by Grubb and others (2013). Groves (2007) calls these taxa Piliocolobus pennantii, P. epieni and P. preussi.

At least six forms of red colobus monkey could readily be regarded, therefore, as among the most endangered primates in Africa, along with the roloway monkey of Ghana and Côte d'Ivoire, the kipunji of Tanzania, and the mountain and Cross River gorillas. Some combination of these primates has featured for some years, with others, on the list of the World's 25 Most Endangered Primates compiled by the IUCN Primate Specialist Group, Conservation International and the International Primatological Society (see, e.g. Mittermeier et al., 2009). No more than two forms of red colobus (listed as species or subspecies) have ever appeared on this list, however, because of a perceived need (in terms of raising support for primate conservation) to distribute the 25 primates selected as the 'Most Endangered' relatively evenly across Africa, Asia, Madagascar and the Neotropics, as well as across higher taxonomic groups (including strepsirrhines and great apes). This less than objective approach has served to diminish a general awareness of how many red colobus forms are in trouble, and the fact that red colobus often appear on this list as subspecies (in contrast to a large majority of full species occupying the other slots) may also diminish a sense of the crisis faced by these primates.

Differences among red colobus monkey classifications could also potentially affect the prioritisation of areas for conservation. Area-based conservation planning typically compares geographic regions based on their levels of species endemism and/or richness. In general, regions with greater numbers of species, and particularly endemic species, are judged to warrant higher conservation priority and therefore may have a greater chance of being designated for protection efforts. However, levels of species endemism and richness can change depending on what species classification is used, so that a simple change in species concept can alter priority areas for conservation (Agapow et al., 2004). Figures 15.2-15.4 display the distribution of red colobus monkey species according to four different classification schemes. Under a single-species classification (e.g. Oates et al., 1994), there is no area of red colobus species endemism. Using Groves' 2001 nine-species classification (Figure 15.2) East and Central Africa become priority areas for conservation, with six endemic species. Figure 15.3 displays Groves' full application of the PSC to these primates (Groves, 2007) and would give conservation priority to the Congo Basin, which contains nearly half of the red colobus forms. Alternatively, Ting's 2008 classification recognises five species, three of which are endemic to west Central Africa (Figure 15.4). These four different classifications emphasise how differences in taxonomy can create tangible differences in the selection of conservation priority areas. For example, although Myers and others (2000) did not consider the Congo Basin as 
a biodiversity hotspot, Olson and Dinerstein (2002) do consider the Northeastern Congo Basin Moist Forests as a special ecoregion with many endemic species, including 'Piliocolobus oustaleti'.

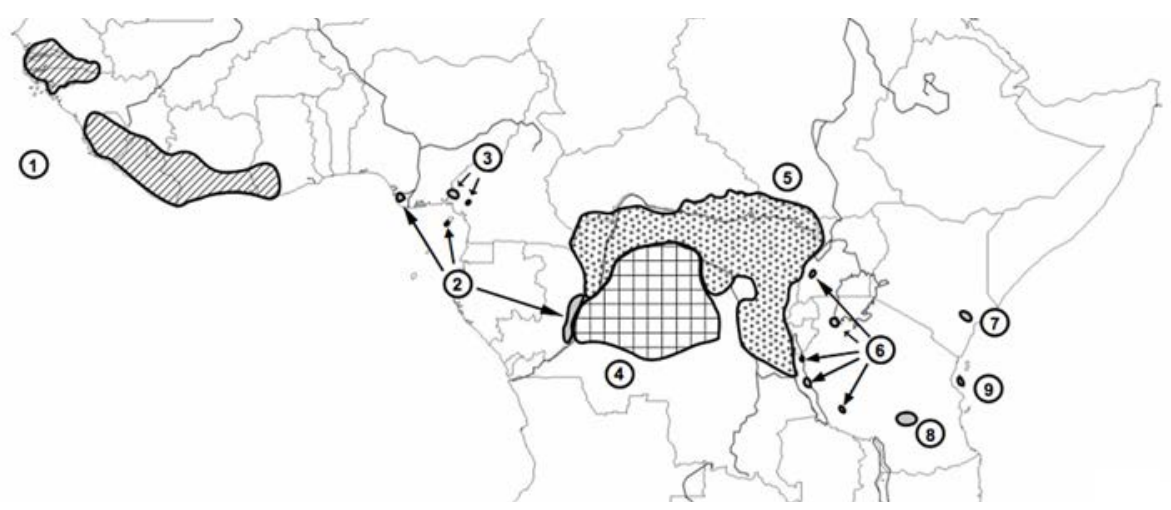

Figure 15.2: Geographical distribution of red colobus according to nine-species arrangement of Groves (2001); $1=P$. badius, $2=P$. pennantii, $3=P$. preussi, $4=P$. tholloni, $5=P$. foai, $6=P$. tephrosceles, $7=P$. rufomitratus, $8=$ P. kirkii, 9 = P. gordonorum.

Source: After Groves (2001); Ting (2008).

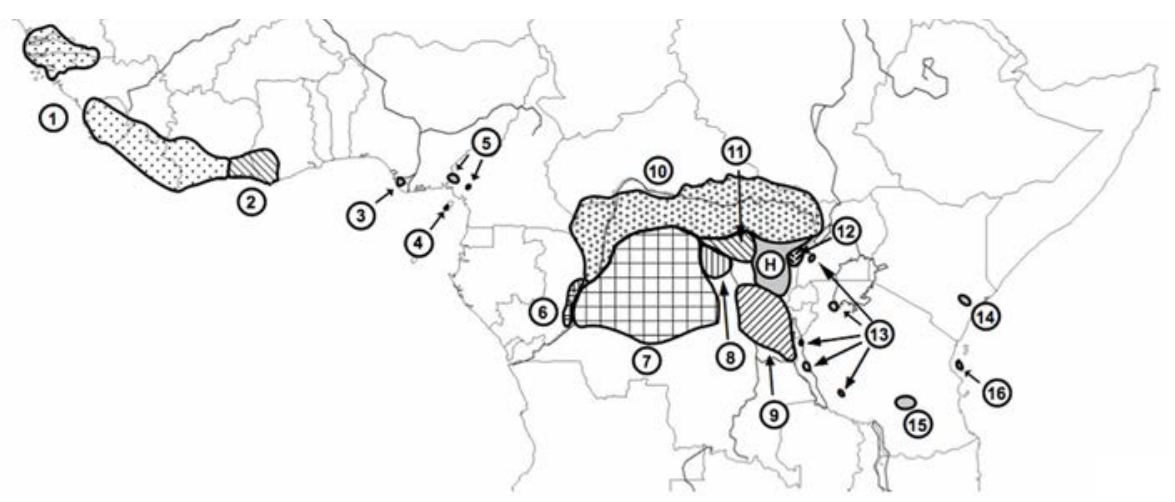

Figure 15.3: Geographical distribution of red colobus according to 16-species arrangement of Groves (2007); $1=P$. badius, $2=P$. waldroni, $3=P$. epieni, $4=$ $P$. pennantii, $5=P$. preussi, $6=P$. bouvieri, $7=P$. tholloni, $8=P$. parmentieri, $9=P$. foai, $10=P$. oustaleti, $11=P$. langi, $12=P$. semlikiensis, $13=$ P. tephrosceles, $14=P$. rufomitratus, $15=P$. gordonorum, $16=P$. kirkii. 


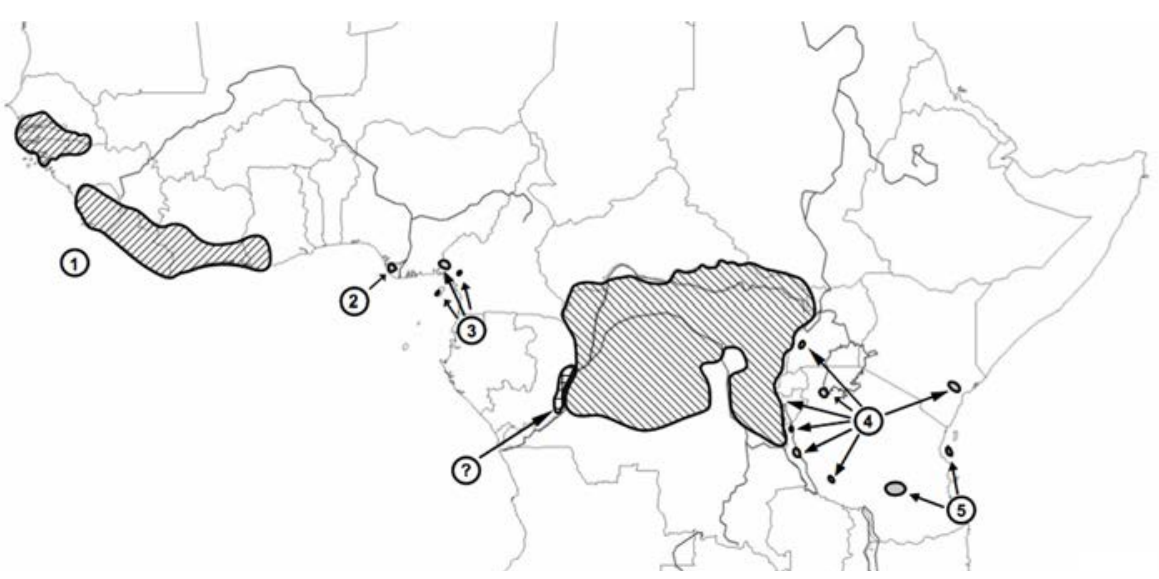

Figure 15.4: Geographical distribution of red colobus according to five-species arrangement of Ting (2008): $1=P$. badius, $2=P$. epieni, $3=P$. pennantii, 4 $=P$. rufomitratus, $5=P$. kirkii; ' ?' is bouvieri which could not be considered in Ting's analysis due to lack of material.

Source: After Ting (2008).

\section{Discussion and conclusions}

The points reviewed in this chapter raise broader issues regarding systematics and conservation biology. It has long been argued that the two fields require better integration if conservation priorities are to be set in the most effective way (e.g. see Rojas, 1992; Dubois, 2003; Mace, 2004; Agapow et al., 2004). Despite progress in this area over the past 20 years, however, large areas of debate remain. One of these is the extent to which conservation concerns should be taken into account when diagnosing taxa. After all, more money and higher levels of protection are commonly directed to endangered populations recognised as distinct species or subspecies. Understanding this, Groves (2001) recognised the Cross River gorilla as the subspecies Gorilla gorilla diehli based more on an appreciation of conservation concern, and as a stimulus to further research, 'than anything else'. However, although a concern for the survival of a population suspected to be more distinctive than is generally recognised can be a useful spur to new taxonomic investigation (which in turn may produce new conservation attention), our view is that elevating populations to higher taxonomic ranks solely due to conservation concern is not valid and can undermine the credibility of instruments such as the Red List in the larger world. 
As we have discussed, different species concepts in the field of systematics lead to different ways of classifying organisms, and most systematists (or at least those who are not strongly wedded to a single concept) would agree that the choice of concept is subjective. In an ideal world, we would all agree on a single species concept that can be applied consistently across all taxa. However, such agreement is very unlikely, and we are thus stuck with a plurality of species concepts. Given this circumstance, we believe it would be sensible to choose species concepts based on their applicability to the particular study organisms, as long as researchers are transparent about which species concept they are using. This would help ensure that taxonomic revisions are due to new data and discoveries rather than to a simple change in species concept, and it would prevent populations being forced into species concepts that are poorly applicable.

Choosing species concepts based on circumstance would also have an effect on conservation planning by generating stable classifications more quickly. For example, the BSC has been argued to be most appropriate for conservation planning purposes because it is process-based, grounded in population genetics, and looks to the present and future (Frankham et al., 2012). While we believe this to be true in theory, conservation decisions have to be made by balancing what is best in theory with what can be implemented in practice. For example, application of the BSC to allopatric populations can be very time and labour intensive and produces subjective classifications. Use of the BSC can therefore be a hindrance to urgent action in these circumstances, especially if multiple types of data are required and the organisms concerned are rare and/or live in remote areas. The red colobus monkeys are an example of this problem. While scientists have spent several decades attempting to delimit BSC boundaries in these monkeys, one form has probably gone extinct (Miss Waldron's red colobus), one may be extinct (Bouvier's red colobus), and several more have declined to precarious states.

Use of the PSC for allopatric populations has advantages because it produces objective and unambiguous classifications (Vogler and DeSalle, 1994; Gippoliti and Groves, 2013). Some have suggested that phylogenetic species are not necessarily evolutionarily meaningful and that the PSC undermines the importance of species in the evolutionary process (e.g. Tattersall, 2007, 2013). While we appreciate these concerns, it is important to point out that the most significant unit of evolution is the population, and the PSC recognises species as populations that have diverged in some manner. Even if this divergence is not enough to produce reproductive isolation, the evolutionary significance of whether or not two populations can potentially interbreed is moot if they are allopatric and will never come into contact. There is thus more recognition of evolutionary theory in the Phylogenetic Species Concept than some acknowledge. 
The use of phylogenetic species does not preclude further research into, and incorporation of, more process-based and adaptive frameworks in conservation, such as grouping certain species together into larger management units or identifying divergent taxa as high conservation priorities (Gippoliti and Groves, 2013).

We consider that the instability in the taxonomic treatment of red colobus has been one factor that has led these monkeys to be relatively neglected in conservation planning compared to some other primates, and that this neglect may have led to a lack of sufficient action to halt the decline and possible extinction of some distinctive populations. Unstable classifications may have caused confusion, and led to less focused conservation action than has been needed. The primary cause of the taxonomic instability has been the inability of scientists to diagnose species in this group according to the Biological Species Concept and the resulting gradual transition to the application of the Phylogenetic Species Concept. Red colobus monkey conservation might have benefitted if the PSC had been applied at a much earlier point. We do not believe that application of the PSC undermines the scientific credibility of either systematics or conservation as long as those using it are transparent regarding its use. While the case of the red colobus is only a single example of an advantage of applying the PSC over the BSC, it is possible that application of the PSC across other taxonomic groups could prevent similar dire situations from arising in other organisms.

We suggest that the application of taxonomy to conservation planning could also be improved if conservation authorities such as the IUCN SSC Primate Specialist Group used standardised species lists updated at regular intervals (e.g. five years); such lists should be accompanied by a clear statement on the species concept used to produce the list. The IUCN Red List would then follow the standardised lists formulated by specialist groups. Meanwhile, normal research in systematics would continue, and its findings be considered during reviews of standard lists.

However, although taxonomic instability may have contributed to the lack of conservation attention given to red colobus monkeys, despite the precarious status of many forms, it is almost certainly not the only factor leading to their neglect. Even though their classification has been highly unstable, red colobus have long featured in some way on the IUCN Red List. We conclude that taxonomy is probably only one factor in their neglect compared to, for instance, great apes and lemurs. Morrison and others (2009) have found that the 'charisma' of animals like red wolves, polar bears and green turtles has meant that there has been no reduction in the conservation efforts devoted to them despite taxonomic research findings that question their species status. Red colobus lack the charisma that great apes gain from their close similarity 
to humans, their intelligence and their size. They lack the 'cuteness' of furry lemurs. Both great apes and lemurs are readily seen close-up in many zoos, and have been the focus of a great deal of media attention. Red colobus, which have never survived very long in captivity, lack all these attributes.

While a case could be made for conservation action to be undertaken largely independently of current taxonomic opinion, as happens today with some particularly charismatic animals, if this course was generally followed then objective conservation planning would be almost impossible. Those organisms less charismatic to the general public would have a low priority for conservation attention. Thus good taxonomy is essential for effective conservation. By dedicating a lifetime to describing biological diversity, Colin Groves has greatly aided conservation efforts in a wide range of taxa. His relatively recent endorsement of the PSC has helped illuminate the issue of the role of taxonomy in conservation and produced a healthy debate.

\section{Acknowledgements}

We thank Tom Struhsaker for first introducing us to red colobus, and for his huge contribution to an understanding of these monkeys' biology. We are also grateful to Eric Delson and Cliff Jolly for stimulating discussions about systematics and taxonomic theory, and to Colin Groves and the late Peter Grubb for many thought-provoking conversations about primate and especially red colobus taxonomy. As we made final edits to this chapter we learned of the death (on 5 July 2014) of Dr Peter Marler. Marler briefly studied red colobus in Uganda's Kibale Forest in 1965 and encouraged Tom Struhsaker - who had been his PhD student - to undertake a more comprehensive study of these monkeys. JFO joined Tom in Kibale in 1970, leading to an affiliation with the Marler lab at Rockefeller University which lasted into the 1980s and was a life-changing experience. Our contribution is therefore dedicated to the memory of Peter Marler.

\section{References}

Agapow PM, Bininda-Emonds ORP, Crandall KA, Gittleman JL, Mace GM, Marshall JC, Purvis A. 2004. The impact of species concept on biodiversity studies. Q Rev Biol 79:161-179.

Bock WJ. 2004. Species: The concept, category and taxon. J Zool Syst Evol Res 42:178-190. 
Butynski TM, Kingdon J. 2013. Procolobus preussi Preuss' red colobus. In: Butynski TM, Kingdon J, Kalina, J, editors. Mammals of Africa. Vol. II: Primates. London: Bloomsbury Press. pp. 134-136.

Cardini A, Elton S. 2009. Geographical and taxonomic influences on cranial variation in red colobus monkeys (Primates, Colobinae): Introducing a new approach to 'morph' monkeys. Global Ecol Biogeogr 18:249-263.

Coyne JA, Orr HA. 2004. Speciation. Sunderland, MA: Sinauer Associates.

Cracraft JL. 1983. Species concepts and speciation analysis. Curr Ornithol $1: 159-187$.

Dandelot P. 1971. Order Primates. Part 3, The mammals of Africa: An identification manual. Washington, DC: Smithsonian Institution Press.

Davis JI, Nixon KC. 1992. Populations, genetic-variation, and the delimitation of phylogenetic species. Syst Biol 41:421-435.

Dubois A. 2003. The relationships between taxonomy and conservation biology in the century of extinctions. C R Biol 326:S9-S21.

Frankham R, Ballou JD, Dudash MR, Eldridge MDB, Fenster CB, Lacy RC, Mendelson JR III, Porton IJ, Ralls K, Ryder OA. 2012. Implications of different species concepts for conserving biodiversity. Biol Conserv 153:25-31.

Gippoliti S, Groves CP. 2013. 'Taxonomic inflation' in the historical context of mammalogy and conservation. Hystrix 23:1-7.

Goldstein PZ, DeSalle R. 2000. Phylogenetic species, nested hierarchies, and character fixation. Cladistics 16:364-384.

Goodman M. 1996. Epilogue: A personal account of the origins of a new paradigm. Mol Phylogenet Evol 51:269-285.

Goodwin HA, Holloway CW, Thornback J. 1978. Red data book. Vol. 1: Mammalia. Revised edition. Morges, Switzerland: IUCN.

Groves CP. 1966. Variation in the skulls of gorillas with particular reference to ecology. PhD thesis, University College London.

Groves CP. 1967. Ecology and taxonomy of the gorilla. Nature 213:890-893.

Groves CP. 1970a. Population systematics of the gorilla. J Zool, Lond 161:287300. 
Taxonomic Tapestries

Groves CP. 1970b. The forgotten leaf-eaters, and the phylogeny of the Colobinae. In: Napier JR, Napier PH, editors. Old World monkeys: Evolution, systematics, and behavior. New York: Academic Press. pp. 555-587.

Groves CP. 1989. A theory of human and primate evolution. Oxford: Oxford University Press.

Groves CP. 2001. Primate taxonomy. Washington, DC: Smithsonian Institution Press.

Groves CP. 2004. The what, why, and how of primate taxonomy. Int J Primatol 25:1105-1126.

Groves CP. 2007. The taxonomic diversity of the Colobinae in Africa. J Anthropol Sci 85:7-34.

Groves CP. 2012. Species concepts in primates. Am J Primatol 74:687-691.

Grubb PJ, Butynski TM, Oates JF, Bearder SK, Disotell TR, Groves CP, Struhsaker TT. 2003. Assessment of the diversity of African primates. Int J Primatol 24:1301-1357.

Grubb PJ, Glander K, Siex K. 2010. Annotated list and measurements of red colobus taxa. Appendix 1.1. In: Struhsaker TT, editor. The red colobus monkeys. Oxford: Oxford University Press. pp. 277-284.

Grubb PJ, Struhsaker TT, Siex KS. 2013. Subgenus Piliocolobus. In: Butynski TM, Kingdon J, Kalina J, editors. Mammals of Africa. Volume II: Primates. London: Bloomsbury Press. pp. 125-128.

Hennig W. 1966. Phylogenetic systematics. Champaign, IL: University of Illinois Press.

Huxley J. 1942. Evolution. The modern synthesis. London: Allen and Unwin.

International Union for Conservation of Nature (IUCN). 1988. 1988 IUCN Red List of threatened animals. Gland, Switzerland: IUCN.

IUCN. 1996. 1996 IUCN Red List of threatened animals. Gland, Switzerland: IUCN.

IUCN. 2012. IUCN Red List of threatened species. Version 2012.2. www. iucnredlist.org. accessed 7 May 2013.

Kingdon J. 1997. The Kingdon field guide to African mammals. San Diego: Academic Press. 
Kuhn H-J. 1967. Zur Systematik der Cercopithecidae. In: Starck D, Schneider R, Kuhn H-J, editors. Neue Ergebnisse der Primatologie. Stuttgart: Gustav Ficher. pp. 25-46.

Lee PC, Thornback J, Bennett EL. 1988. Threatened primates of Africa: The IUCN Red Data book. Gland, Switzerland: IUCN.

Mace GM. 2004. The role of taxonomy in species conservation. Phil Trans $R$ Soc Lond B:Biol Sci 359:711-719.

Marler P. 1970. Vocalizations of East African monkeys. Folia Primatol 13:81-91.

Mayr E. 1942. Systematics and the origin of species. New York: Columbia University Press.

Mayr E. 1996. What is a species, and what is not? Philos Sci 63:262-277.

Mbora DNM, Butynski T. 2009. Tana River red colobus. In: Mittermeier RA et al. Primates in peril: The world's 25 most endangered primates 2008-2010. Primate Conserv 24:15.

Mbora DNM, Meikle DB. 2004. Forest fragmentation and the distribution, abundance and conservation of the Tana River red colobus (Procolobus rufomitratus). Biol Conserv 118:67-77.

Mittermeier RA, Wallis J, Rylands AB, Ganzhorn JU, Oates JF, Williamson EA, Palacios E, Heymann EW, Kierulff MCM, Yongcheng L, Supriatna J, Roos C, Walker S, Cortés-Ortiz L, Schwitzer C. 2009. Primates in peril: The world's 25 most endangered primates 2008-2010. Primate Conserv 24:1-57.

Morrison WR III, Lohr JL, Duchen P, Wilches R, Trujillo D, Mair M, Renner SS. 2009. The impact of taxonomic change on conservation: Does it kill, can it save, or is it just irrelevant? Biol Conserv 142:3201-3206.

Myers N, Mittermeier RA, Mittermeier CG, da Fonseca GAB, Kent J. 2000. Biodiversity hotspots for conservation priorities. Nature 403:853-858.

Napier JR, Napier PH. 1967. A handbook of living primates: Morphology, ecology and behaviour of nonhuman primates. London: Academic Press.

Napier PH. 1985. Catalogue of primates in the British Museum (Natural History) and elsewhere in the British Isles. Part III: Family Cercopithecidae, Subfamily Colobinae. London: British Museum (Natural History).

Oates JF. 1986. Action plan for African primate conservation: 1986-90. Stony Brook, NY: IUCN/SSC Primate Specialist Group. 
Taxonomic Tapestries

Oates JF. 1996. African primates: Status survey and conservation action plan. Revised edition. Gland, Switzerland: IUCN.

Oates JF, Abedi-Lartey M, McGraw WS, Struhsaker TT, Whitesides GH. 2000. Extinction of a West African red colobus monkey. Conserv Biol 14:15261532 .

Oates JF, Davies AG, Delson E. 1994. The diversity of living colobines. In: Davies AG, Oates JF, editors. Colobine monkeys: Their ecology, behaviour and evolution. Cambridge: Cambridge University Press. pp. 45-73.

Olson DM, Dinerstein E. 2002. The Global 200: Priority ecoregions for global conservation. Ann Missouri Bot Gard 89:199-224.

Rahm UH. 1970. Ecology, zoogeography, and systematics of some African forest monkeys. In: Napier JR, Napier PH, editors. Old World monkeys: Evolution, systematics, and behavior. NewYork: Academic Press. pp. 589-626.

Rojas, M. 1992. The species problem and conservation: What are we protecting? Conserv Biol 6:170-178.

Simon N. 1966. Red data book. Volume 1: Mammalia, a compilation. Morges, Switzerland: IUCN.

Sokal RR, Crovello TJ. 1970. The biological species concept: A critical evaluation. Am Nat 104:127-153.

Struhsaker TT. 1975. The red colobus monkey. Chicago: University of Chicago Press.

Struhsaker TT. 1981. Vocalizations, phylogeny, and palaeogeography of red colobus monkeys (Colobus badius). Afr J Ecol 19:265-283.

Struhsaker TT. 2010. The red colobus monkeys. Oxford: Oxford University Press.

Szalay FS. 1993. Species concepts: The tested, the untestable, and the redundant. In: Kimbel WH, Martin LB, editors. Species, species concepts, and primate evolution. New York: Plenum Press. pp. 21-41.

Tattersall I. 2007. Madagascar's lemurs: Cryptic diversity or taxonomic inflation? Evol Anthropol 16:12-23.

Tattersall I. 2013. Species-level diversity among Malagasy lemurs. In: Masters J, Gamba M, Génin F, editors. Leaping ahead: Advances in prosimian biology. New York: Springer. pp. 11-20. 
Thorington RW Jr, Groves CP. 1970. An annotated classification of the Cercopithecoidea. In: Napier JR, Napier PH, editors. Old World monkeys: Evolution, systematics, and behavior. New York: Academic Press. pp. 629647.

Ting N. 2008. Molecular systematics of red colobus monkeys (Procolobus [Piliocolobus]): Understanding the evolution of an endangered primate. $\mathrm{PhD}$ Thesis, City University of New York.

Verheyen WN. 1962. Contribution à la craniologie comparée des Primates: Les genres Colobus Illiger 1811 et Cercopithecus Linné 1758. Ann Musée Roy Afr Centr Ser 8 Sci Zool 105:1-255.

Vogler AP, Desalle R. 1994. Diagnosing units of conservation management. Conserv Biol 8:354-363.

Wolfheim JH. 1983. Primates of the world: Distribution, abundance, and conservation. Seattle: University of Washington Press. 



\title{
16. The phylogenetic species concept and its role in Southeast Asian mammal conservation
}

\author{
Erik Meijaard and Benjamin Rawson
}

\section{Introduction}

Taxonomy may appear a somewhat old-fashioned or even outdated science, but recent heated debate has blown some significant dust off the subject. There is an ongoing dispute between propenents of the Biological Species Concept (BSC) (Zachos, 2013; Zachos et al., 2013) and the Phylogenetic Species Concept (PSC) (Gippoliti and Groves, 2013; Groves, 2013). More precisely the disagreement centres on the perceived implications of the use of either concept for species conservation. Users of the PSC have been accused of causing irresponsible taxonomic inflation and with that dilution of the conservation efforts allocated to each species (Zachos, 2013). The defence of PSC proponents has been that, without the use of the PSC, taxa of potentially significant conservation importance would be overlooked. Such taxa would be ranked as subspecies, and the assumption is that few people or organisations allocate efforts and funding to their conservation. In return, the counterargument has been that subspecies are rarely phylogenetically distinct and do therefore not warrant major conservation efforts (Zink, 2004). The real debate thus appears to be about the best method to allocate an appropriate taxonomic rank to taxa that is in line with their evolutionary distinctness and thus the need to prevent their extinction.

The BSC dates back to the 1930s and remains the most commonly used species concept today. The concept depends on the inference that species are those entities which do not interbreed. When two taxa occur sympatrically (i.e. their ranges overlap) and do not interbreed, the BSC is straightforward to apply. Things get complicated, however, when species occur allopatrically (i.e. no range overlap), because opportunities for interbreeding do not then naturally occur. In fact, many phylogenetic studies indicate a high frequency of gene flow between distinct species, even sympatric ones, with hybridisation often leading to speciation (Bell and Travis, 2005; Mallet, 2007).

As opposed to the BSC, 'the PSC depends on evidence, not on inference' (Groves, 2013: 7). Under the PSC, species are considered to be populations differing by at 
least one taxonomic character from all others, and within each of which there is 'a parental pattern of ancestry and descent' (Cracraft, 1989; Isaac et al., 2004). An absence of interbreeding is not required under the PSC.

Because of its use of evidence (e.g. measurable differences in a sample) rather than inference (e.g. an assumption that two taxa are unlikely to interbreed and produce fertile offspring), the PSC is more likely to lead to taxonomic instability. Two taxa can initially be separated when only a small sample is available, possibly missing some of the variation in the populations of the two taxa (e.g. by not fully sampling a cline). Once more material becomes available, broader variation within either taxon may result in overlap and the conclusion that, after all, the two taxa are not separated as species. Such taxonomic instability concerns conservation organisations that want to be sure that investments in a particular taxon will not be undermined by changes in a species taxonomy.

Taxonomic inflation, or the elevation of many existing subspecies to species level (cf. Isaac et al., 2004), is considered another unwanted side-effect of the use of the PSC (Zachos et al., 2013). With many subspecies being raised to species level, and concommitant shrinking of species' ranges, the list of species of conservation concern would rapidly grow through the use of PSC. It has been argued however that such taxonomic inflation is needed because it was preceeded by irresponsible taxonomic deflation. In the words of BrandonJones and colleagues, 'an increase in recognized species is a desirable reversal of the regrettable trend from about 1920 to 1980, when specific recognition was excessively restrained, with correspondingly reckless subspecific recognition' (Brandon-Jones et al., 2004: 98). A transition from the dominant paradigm of the BSC to the PSC is therefore likely to lead to an increased number of recognised species, an increase of relative threat level at the species level and possibly a reduction in the available conservation resources devoted to each.

We here assess how the application of the PSC has influenced large mammal conservation in Southeast Asia. We look specifically at two groups, the Southeast Asian wild pigs (Suidae) and gibbons (Hylobatidae), because we are most familiar with their conservation through our work as, respectively Chair of the IUCN SSC Wild Pig Specialist Group and Vice-chair of the Section on Small Apes (SSA) of the IUCN SSC Primate Specialist Group. We try to answer three questions: (1) Has conservation attention increased for a taxon since it received full species status? (2) If so, would this increase in conservation attention likely have happened if the species would have remained a subspecies? (3) Has the increase in the recognised number of species in these families led to a detrimental dilution in funding available for all of them. 


\section{Southeast Asian pig taxonomy and conservation}

\section{A history of taxonomic change in Southeast Asian pigs}

Southeast Asia has long been recognised as the center of diversity of wild pig species (Meijaard et al., 2011). At present, 18 extant species of pig are recognised in the family Suidae, the majority of which occur in Southeast Asia. There are two genera in the region, Sus and Babyrousa. Taxonomic revision of the Suidae is ongoing, especially in the Philippines and Indonesia where several taxa are waiting to be described. Even without additional species this is a speciesrich family, reflecting the evolutionary success, ecological versatility, and, considering their endemic presence on a great number of islands, the extensive dispersal ability of pigs.

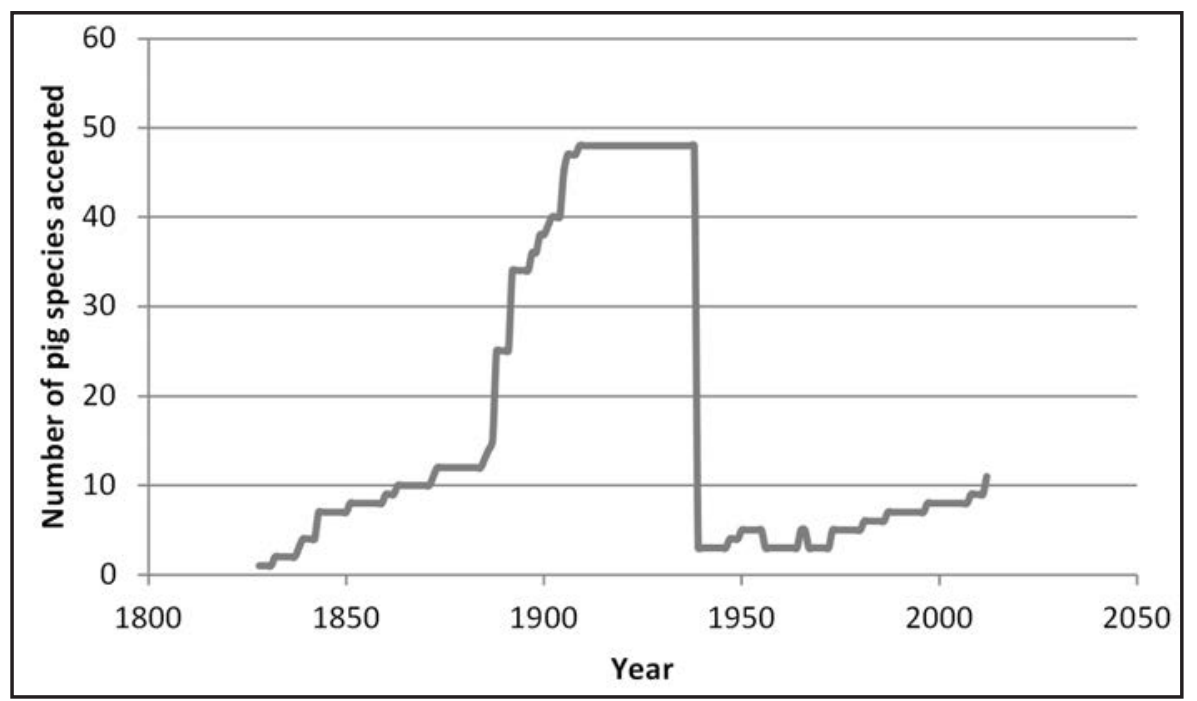

\section{Figure 16.1: Change over time of the number of Southeast Asian pig species described and generally recognised.}

Source: Figure created by authors using authors' own data and data provided in published accounts of species numbers.

The number of Southeast Asian Suidae species has fluctuated greatly over time. In 1758, Linneaus described the first species, Sus scrofa, which ranges over much of the Eurasian landmass, as well as parts of insular Southeast Asia (Meijaard et al., 2011). Following this, there were 80 years of taxonomic stagnation until Sus barbatus, the bearded pig of Sumatra, Borneo and Peninsular Malaysia was described. A general interest in natural history, and specific curiosity about the 
fauna of newly explored parts of Southeast Asia resulted in additional collection of specimens and description of new species (Figure 1). From 1888 onwards, a rapid increase in the number of species was primarily caused by Pierre Marie Heude, a French Jesuit missionary and zoologist based in China. Within the space of a few years, he described some 32 pig species (Heude, 1888, 1892), and by 1909, 48 species of pig had been described in Southeast Asia.

New thinking about what constitues a species, much influenced by evolutionary biologists such as Ernst Walter Mayr, led to major taxonomic lumping of species around the 1940s. The number of pig species in Southeast Asia was reduced to three, and then hovered around the four or five species until the 1980s. A subsequent revision of these taxa by Groves (1981), based on a morphological, ecological and karyological review, reinstated several of the species that had been lumped in the 1940s. This resulted in the following species: Sus scrofa, S. barbatus, $S$. verrucosus, and $S$. celebensis. In addition to these there is the babirusa (Babyrousa babirussa) which Groves did not consider in his 1981 review.

Further application of the phylogenetic species concept led to the recognition of additional species of pig, which in 1993 were officially accepted by the IUCN SSC Pigs, Peccaries and Hippos Specialist Group (Oliver, 1993). In addition to the species above, Sus cebifrons and S. philippensis from the Philippines were now recognised as distinct. The process did not stop there and, in 1997, the Indochinese species S. bucculentus was resurrected (Groves et al., 1997), followed by the separation of the babirusa into three distinct species (Meijaard and Groves, 2002), the description of $S$. oliveri from Mindoro in the Philippines (Groves, 2001 b), and the separation of $S$. ahoenobarbus from Palawan in the Philippines from S. barbatus (Groves, 2001b; Lucchini et al., 2005). These processes have now resulted in 12 suid species in Southeast Asia being recognised by the IUCN.

We note that subsequent work indicates further taxonomic changes, with Sus bucculentus being subsumed into S. scrofa, but S. scrofa itself being split into several distinct species (Groves and Grubb, 2011; Meijaard and Groves, 2013). Sus blouchi from Bawean Island appears to be distinct enough to be allocated to full species level (Groves and Grubb, 2011). Also, an unpublished manuscript found that the pigs from the Sulu Islands in the Philippines were not Sus barbatus, as had been assumed, but a distinct taxon, and in addition, morphological and genetic variation within Sus scrofa indicates consistent differences between, what are presently different subspecies. Finally, recent morphological and genetic studies have indicated that the genus Babyrousa consists of six distinct species rather than the three that are presently recognised (A. MacDonald, pers. comm). These revisions will ultimately result in 15 to 20 recognised species of Suidae in Southeast Asia. 


\section{The impact of taxonomic change on pig conservation}

It is obvious that suid taxonomy is a field in flux. The more we learn about the variation within and between pig taxa and the more we understand the general drivers of such variation, the more likely it has become that taxonomies are revised. Conservation practitioners and scientists generally do not like such taxonomic instability. It interferes with long term conservation planning for species survival and the development of captive breeding and zoo programs. As argued by the opponents of the PSC, the splitting of species leads to a dilution of conservation effort (Zachos et al., 2013). Is this really true however?

The Southeast Asian pig taxa of most conservation concern are the Critically Endangered Visayan warty pig, S. cebifrons, and the Endangered Javan warty pig, S. verrucosus, Mindoro warty pig, S. oliveri, and Togean Babirusa, Babyrousa togeanensis. Three of these (S. cebifrons, S. oliveri and B. togeanensis) were relative recently described using the phylogenetic species concept.

In 1993, the IUCN SSC Pigs, Peccaries and Hippos Specialist Group and other supporting partner agencies (including the Zoological Society of San Diego and, subsequently, the Rotterdam Zoo) devised and initiated a 'Visayan Warty Pig Conservation Programme' with the Philippine Government (Meijaard et al., 2011). Prior to its recognition as a full species, captive populations of Philippine pigs were maintained as single individuals or small groups of animals of mixed origin, and no attempts had been made at captive breeding (Oliver et al., 1993). Since then, two captive breeding and rescue centres for S. cebifrons have been established on Negros Island, and by 2011 at least 87 animals were kept in European zoos alone (Glatston, 2011). The successful breeding programs now require the identification of a safe release site, and this process is ongoing. The species remains highly threatened, but the immediate extinction risk seems to have been averted.

One could argue that the same kind of conservation action could have been undertaken if $S$. cebifrons would have remained a subspecies of $S$. barbatus, where it was originally placed (Groves, 1981). The IUCN presently lists 401 mammal subspecies as threatened, most of which are primates, so it is possible to focus global and local conservation authorities on taxa at the subspecies level. It is doubtful, however, that the Philippine authorities would have been as supportive for the conservation of a subspecies of $S$. barbatus, which also occurs in Indonesia and Malaysia. An interesting comparison for this exists in the Sulu Islands, where there was a locally popular appeal to the Philippine Government to take all due steps to 'eradicate' wild pigs. The government was initially supportive because it treated these populations, which they assumed to be $S$. barbatus, as non-native to the Philippines. Only when studies indicated that the Sulu pig might be an endemic new species to these islands (K Rose 
and P Grubb, unpublished manuscript) were the eradication plans cancelled. The above strongly suggest that recognition of $S$. cebifrons as a full species has played a vital role in preventing its extinction. Another species that appears to have benefited from their recognition as full species is $S$. philippensis, which is now treated as distinct in at least some zoos (e.g. the Amsterdam Zoo).

The two other Endangered species that were only recently elevated to species level appear to have benefited less from this taxonomic change. There are no specific in situ or ex situ programs yet for S. oliveri and B. togeanensis. In fact, the Indonesian Government is presently developing a babirusa action plan, which has retained the original taxonomy that combines the three IUCN-recognised species of babirusa into one. Finally, S. verrucosus blouchi, the Javan warty pig of Bawean Island may be one of the most endangered pig taxa. In anticipation of the taxon being elevated to full species, S. blouchi, as proposed by Groves and Grubb (2011), a survey is presently ongoing to ascertain the status of the taxon. Such conservation activitities had been planned for a long time, and had partly been implemented (Nijman, 2003; Semiadi and Meijaard, 2004), but the recognition that this could be a distinct species has generated renewed efforts to ensure that it will not go extinct.

\section{Gibbon taxonomy and conservation}

\section{A history of taxonomic change in gibbons}

The Hylobatidae have experienced not only a significant increase in the number of species, but an increase in the number of genera over time. Most early authors recognised only one genus in the Hylobatidae, that of Hylobates, with the occassional addition of Symphalangus (e.g. Elliot, 1913; Schultz, 1933). Groves $(1968,1972)$ tentatively recognised three sub-genera, those of Hylobates (which also included the hoolock gibbons), Nomascus and Symphalangus. This approach was later supported to a large degree by genetic evidence (Hall et al., 1998; Hayashi et al., 1995; Roos and Geissmann, 2001; Takacs et al., 2005). Groves (2001a) added a fourth subgenus, Bunopithecus, for the hoolock gibbons, but later changed its name to Hoolock (Mootnick and Groves, 2005). These four subgenera were subsequently raised to generic status (Brandon-Jones et al., 2004; Geissmann, 2002), and are now commonly recognised (e.g. Meyer et al., 2012; Takacs et al., 2005). Groves, therefore played a fundamental role in development of the currently understood systematics of the Hylobatidae at the generic level. 


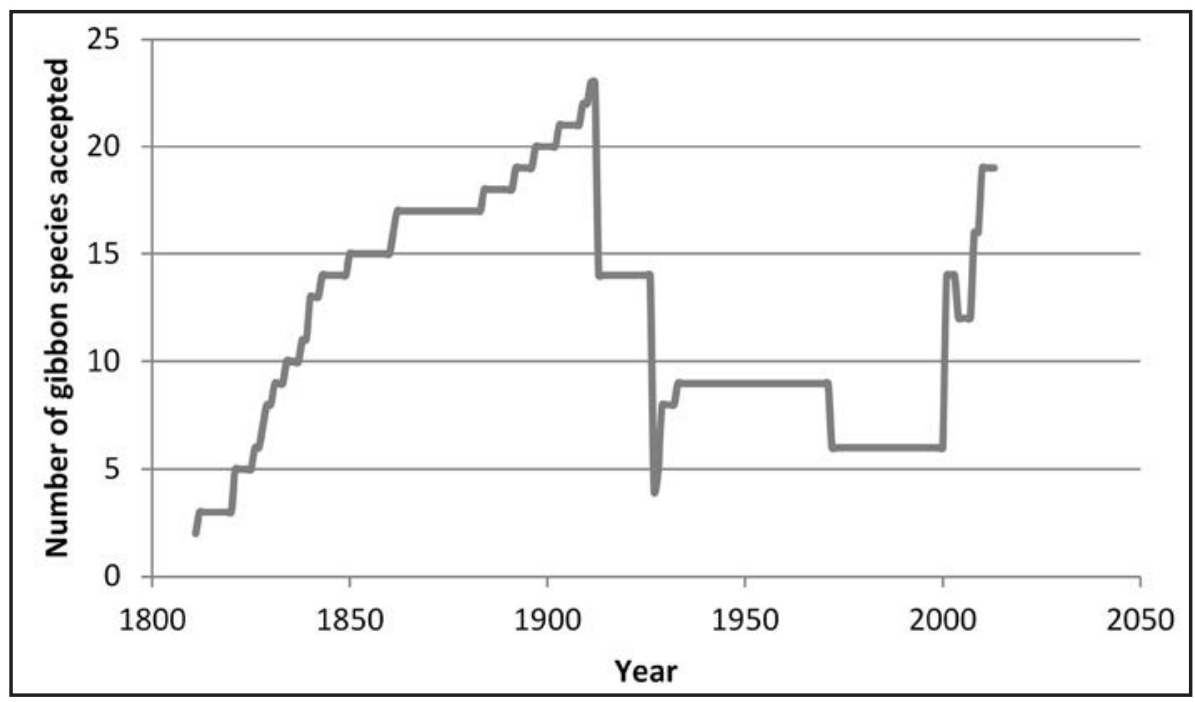

Figure 16.2: Change over time of the number of gibbon species described and generally recognised.

Source: Figure created by authors using authors' own data and data provided in published accounts of species numbers.

Similar to the rapid increase in Suidae species described above, the Hylobatidae experienced a rapid increase in the number of described species between the mid-nineteenth and early twentieth century. From a maximum of 23 species, this was reduced to four by Pocock (1927), revised to seven by Kloss (1929), and subsequently to nine by Schultz (1933). Groves also played a significant role in the species-level taxonomy for the Hylobatidae. His taxonomic review in 1972 reduced the number of species to six (Groves, 1972). In 1967, Groves had already described a second sub-species of the hoolock gibbon, Hylobates hoolock leuconedys from east of the Chindwin River, but it was not until much later that this taxon was elevated to generic and specific status as Hoolock leuconedys (Mootnick and Groves, 2005). Further taxonomic reviews by Brandon-Jones and others (2004), Mootnick and Fan (2011) and Thinh and others (2010) revealed the distinctness of additional gibbon species, and in the latest review of the gibbons, 19 species of Hylobatidae are recognised (Mittermeier et al., 2013). Sixteen of these are listed on the IUCN Red List and three remain unassessed. Of these 16, four are Critically Endangered, 11 Endangered, and one Vulnerable (IUCN, 2013). 
Taxonomic Tapestries

\section{The impact of taxonomic change on gibbon conservation}

While some taxa such as Hylobates klossii, Symphalangus syndactylus and $H$. moloch have undergone no recent taxonomic rearrangements, and as such have not been significantly subjected to changes in priority setting, other taxa have. For example, the raising of the eastern hoolock (Hoolock leuconedys) to specific status (Mootnick and Groves, 2005) and discovery of a population in Assam, India reportedly changed conservation priorities in this area, previously believed to only contain Hoolock hoolock (J. Das, pers. comm.). The discovery of Nomascus annamensis between the distributions of N. gabriellae and N. siki in 2010 (Thinh et al., 2010) has opened up additional funding opportunities for gibbons located in its area of occurrence (Rawson, pers. obs.).

The Cao Vit gibbon (Nomascus nasutus) was until 2004 considered a subspecies of N. concolor (Brandon-Jones et al., 2004; Groves, 2001a), and as such the single remaining population of approximately 129 individuals on the Sino-Vietnamese border would have been considered a low priority compared to healthier populations in China, specifically Wuliangshan and Ailaoshan. However, it has now become the second most threatened gibbon taxon after the Hainan gibbon (Nomascus hainanus) and considerable conservation funding flows to this population as a result.

To further educate discussion about how taxonomic change has impacted gibbon conservation we sent out a survey to all members $(n=53)$ of the IUCN Species Survival Commission, Primate Specialist Group, Section on Small Apes and received 24 responses. All 19 Hylobatidae taxa recognised in Handbook of the mammals of the world, Volume 3: Primates (Mittermeier et al., 2013) were listed by at least one respondent as a taxon they had worked on. The average time that respondents had been engaged in gibbon conservation was approximately 13 years, providing a sufficiently long period of time and sufficient taxonomic coverage to expect to detect changes in relation to taxonomic inflation.

When asked whether taxonomic inflation had led to the recognition of too many gibbon species, responces were split with 33.3\% answering yes, 29.2\% answering no and $37.5 \%$ expressing no firm opinion. However, when asked whether changes in taxonomy had ever changed their conservation priorities, such as focusing on a newly elevated subspecies, the vast majority said it had not ( $\mathrm{n}=24,91.7 \%$ answered 'no' while only $8.3 \%$ answered 'yes'). The most common rationale cited for not changing priorities was that at the population level, changes in taxonomy do not change conservation interventions required. In other words, the units of conservation commonly of interest to gibbon conservationists are smaller than that of species and occur at the site or population level. Several respondents noted that as gibbons are so rare 
and under high threat, taxonomic assessments are not significant drivers for conservation interventions and instead they focus on population conservation irrespective of taxonomic affiliation.

Responses to a question concerning whether funding for gibbons had increased, decreased or remained static were split, with $8.3 \%$ reporting a decrease, $16.7 \%$ an increase, $50 \%$ no change and $25 \%$ did not know. In fact, changes in funding for gibbon conservation in relation to taxonomic inflation are likely confounded by the increased funding being fed into gibbon conservation in general. Important funding mechanisms such as the USFWS Great Ape Conservation Grant (GACF) (which also includes the Hylobatidae in calls for proposals) and the more recent significant investment by the Arcus Foundation have come online during the most recent expansion in the number of gibbon taxa. Between 2007 and 2011, for example, USFWS GACF provided \$25,541,000 for ape conservation, and although the amount specifically allocated for gibbon conservation is unknown, this doubtless represents a significant investment which was not available before the grants inception in 2001. Likewise, the Arcus Foundation has invested at least $\$ 3,500,000$ in gibbon specific conservation since it began funding gibbons in 2007 (H. Rainer, pers. comm.).

From a captive management perspective, there are implications of taxonomic inflation. One significant issue is that splitting of taxa may result in captive populations of previously taxonomically homogenous individuals being assessed as hybrids. For example, raising Nomascus siki and N. leucogenys to species level has resulted in a large number of hybrid animals being held in zoos as founder captive populations did not distinguish these taxa at species level (Petersen and Melfi, pers. comm.). The value of hybrid gibbons from a conservation and reintroduction standpoint is much lower than non-hybrids. A further implication of taxonomic inflation in gibbons is that the increased number of taxa means that zoos, because of limited space, are unable to hold significant collections of all species (either independently or collectively). This is resulting in a triage approach limiting which taxa of gibbons are held in regional collections. Quite simply, as the number of taxa increase, the percentage of taxa which can be incorporated into breeding programs decreases. Moreover, the number of wrongly identified gibbons is likely to have increased.

\section{Discussion}

We have reviewed the impact of the use of the phylogenetic species concept on the conservation of two groups of Southeast Asian mammals, pigs and gibbons. We find that at least for some taxa there appears to have been a clear benefit of being considered full species, in terms of commitment from national governments 
to ensure their survival, generate funding for their in situ protection, develop breeding programs, and raise their global profile. This seems obvious for the gibbons for which major funding from the Arcus Foundation and United States Fish and Wildlife Service has been allocated for their protection. This funding has increased with the increasing threat level to the species, which in turn relates to taxonomy. As an example, under the more conservative 1972 taxonomy which largely follows a BSC, the remaining 129 Nomascus nasutus gibbons would be unlikely to get the same level of attention as they get now. Similarly, for pigs, renewed funding support was sought for Bawean pig (Sus (v.) blouchi) when it became clear that this was likely an endemic species of the island. Similarly, specific programs for Visayan warty pig (Sus cebifrons) were only developed once it became clear that the species was distinct. In contrast, we did not encounter examples in which funding per species or attention to their conservation had decreased following their elevation to species level, although, we recognise that our sample of pigs and gibbons is only a small part of the total number of globally threatened taxa, and possibly not representative.

We cannot fully assess the counterfactual, that whether the same kind of conservation support could have been generated if these taxa had remained as subspecies. Total funding for biodiversity conservation is likely to increase over time, with growing global concerns about species extinction and unsustainable use of natural resources (Leiserowitz et al., 2006; Sachs et al., 2009), and a general recognition that more conservation funding is needed to meet biodiversity targets (McCarthy et al., 2012). These processes could take place independent of whichever taxonomic principles or species definitions are followed. It is unclear whether there is a fixed amount of conservation funding available for all species and that adding species would dilute the funding available for each species. Or alternatively, funding levels could actually increase with the number of threatened taxa that require improved conservation management, in which case an increasing number of species would translate into an increasing amount of focus and funding. At least based on our analysis, the latter rather than the former seems the case, and dilution of conservation funding because of taxonomic inflation does not seem to be a major concern.

Another issue of importance, which was revealed through the feedback from the Section on Small Apes of the Primate Specialist Group, is that most people have been working long-term at the site level and do not really feel that taxonomy has much to do with how they approach conservation. They approach conservation from a broader ecological and management point of view and focus efforts on habitat protection. Changing the status of a subspecies to a species is not perceived to be of much consequence to their work. Again, this would indicate that there is limited harm in applying the more stringent PSG, even if this leads to an increase in the number of species. With an increase in the number of 
species, individual populations and sites generally become more important to that taxon, rather than less important. For example, the recent description of Nomascus annamensis (Thinh et al., 2010) significantly reduced the understood range of both $N$. siki and $N$. gabriellae which it falls between, making at least $N$. siki a much higher conservation priority due to a range reduction with fewer sites containing potentially viable populations.

From a conservation standpoint, the discussion about conservation impacts of the use of a BSC rather than PSC ultimately leads to the question of what is the unit of conservation. The IUCN recognises subspecies as a valid unit of conservation, and indeed has assessed 1,838 subspecies of Animalia and Plantae (no Fungi or Protista have been assessed at the subspecies level) compared with 70,289 taxa assessed at the species level (IUCN, 2013). Thus about $2.6 \%$ of assessed threatened taxa are subspecies. If the analysis is restricted to South and Southeast Asia, there are 302 subspecies assessed by the IUCN, compared with 16,855 species (i.e. $1.8 \%$ of the total). These figures indicate that, although conservation status assessments at the subspecies level exist, such assessments are relatively rare. IUCN status assessments are an important driver of conservation action (Hoffmann et al., 2010; Rodrigues et al., 2006), and considering the relative low uptake of subspecies-level assessments, a precautionary approach would be to err on the side of inflated rather than under-estimated taxonomic diversity.

Finally, there may be good reasons for not underestimating taxonomic diversity. A recent global analysis of avian subspecies showed that $36 \%$ of avian subspecies are, in fact, phylogenetically distinct (Phillimore and Owens, 2006). Interestingly, the authors found significant differences in the proportion of subspecies that are phylogenetically distinct, with Nearctic/Palearctic subspecies showing significantly reduced levels of differentiation. Additionally, the authors found differences between island and continental subspecies, with continental subspecies significantly less likely to be genetically distinct. These results indicate that the overall level of congruence between taxonomic subspecies and molecular phylogenetic data is greater than previously thought. Phillimore and Owens suggest that the widespread impression that avian subspecies are not real arises from a predominance of studies focusing on continental subspecies in North America and Eurasia, regions which show unusually low levels of genetic differentiation (Phillimore and Owens, 2006). These findings are reflected by our own phylogenetic and taxonomic studies in Southeast Asia, which indicate ancient patterns of species diversification in a region that has maintained relative climatic stability compared with the higher latitudinal areas that were significantly affected by glacial cycles (de Bruyn et al., 2014; Meijaard, 2004). In addition, the main islands in the Malay Archipelago (Wallace, 1869) and high geological activity and concommitant topographical changes in the region 
(Meijaard and Groves, 2006) have resulted in much higher speciation rates than in continental North America and Eurasia. Taking into account that taxonomic research in Southeast Asia is practiced by few scientists (Meijaard and Sheil, 2012), and that many taxonomic studies and updates therefore remain pending, we expect there to be significant undiscovered or overlooked taxonomic diversity in Southeast Asia.

In conclusion, our study suggests that the use of a phylogenetic species concept has been beneficial to the conservation of species in the Southeast Asian region. So-called taxonomic inflation in Southeast Asia is needed to ensure that we identify as many evolutionary distinct species of conservation concern as possible. The efforts by Groves and colleagues to recognise distinct taxa using the PSC therefore appears to be warranted in Southeast Asia, where much taxonomic variation remains hidden and conservation needs are higher than anywhere else (di Marco et al., 2014).

\section{Acknowledgements}

Ben Rawson thanks the membership of the IUCN SSC Primate Specialist Group Section on Small Apes membership for their input into discussions on taxonomic inflation and impacts on conservation priorities. We thank Colin Groves for his wonderful mentorship, commitment to good science and conservation, and unfailing willingness to help whenever he can.

\section{References}

Bell MA, Travis MP. 2005. Hybridization, transgressive segregation, genetic covariation, and adaptive radiation. Trends Ecol Evol 20(7):358-361.

Brandon-Jones D, Eudey AA, Geissmann T, Groves CP, Melnick DJ, Morales J, Shekelle M, Stewart T. 2004. Asian primate classification. Int J Primatol 25(1):97-164.

Cracraft J. 1989. Speciation and its ontology: The empirical consequences of alternative species concepts for understanding patterns and processes of differentiation. In: Otte D, and Endler JA, editors. Speciation and its consequences. Sunderland, MA: Sinauer Associates. pp. 28-59.

de Bruyn M, Stelbrink B, Morley RJ, Hall R, Carvalho GR, Cannon CH, van den Bergh G, Meijaard E, Boitani L, Maiorano L, Shoup R, von Rintelen T. 2014. Borneo and Indochina are major evolutionary hotspots for Southeast Asian biodiversity. Systematic Biology 63:879-901. 
Di Marco M, Boitani L, Mallon D, Iacucci A, Visconti P, Meijaard E, Schipper J, Hoffmann M, Rondinini C. 2014. Lessons from the past: A retrospective evaluation of the global decline of carnivores and ungulates. Conserv Biol 28(4):1109-1118.

Elliot DG. 1913. A review of the primates. American Museum of Natural History Monograph series 1. New York: American Museum of Natural History. pp. $1-317$.

Geissmann T. 2002. Taxonomy and evolution of gibbons. Evol Anth 11(S1):2831.

Gippoliti S, and Groves CP. 2013. 'Taxonomic inflation' in the historical context of mammalogy and conservation. Hystrix 23(2): 8-11.

Glatston A. 2011. Regional Visayan warty pig studbook. Sus cebifrons negrinus. Rotterdam, the Netherlands: Rotterdam Zoo.

Groves CP. 1968. The classification of the gibbons (Primates, Pongidae). $Z$ für Säugetierkunde 33:239-246.

Groves CP. 1972. Systematics and phylogeny of gibbons. In: Rumbaugh DM, editor. Gibbon and Siamang, Vol. 1. Basel: Karger. pp. 1-89.

Groves CP. 1981. Ancestors for the pigs. Canberra: Australian National University Press. p. 96.

Groves CP. 2001a. Primate taxonomy. Washington DC: Smithsonian Institution Press. p. 350.

Groves CP. 2001b. Taxonomy of wild pigs of Southeast Asia. Asian Wild Pig News 1(1):2-3.

Groves CP. 2013. The nature of species: A rejoinder to Zachos et al. Mammal Biol - Z für Säugetierkunde 78(1):7-9.

Groves CP, Grubb P. 2011. Ungulate taxonomy. Baltimore, Maryland: Johns Hopkins University Press.

Groves CP, Schaller GB, Amato G, Khounboline K. 1997. Rediscovery of the wild Sus bucculentus. Nature 386(27 March 1997):335.

Hall LM, Jones DS, Wood BA. 1998. Evolution of the gibbon subgenera inferred from Cytochrome b DNA sequence data. Mol Phyl Evol 10(3):281-286.

Hayashi S, Hayasaka K, Takenaka O, Horai S. 1995. Molecular phylogeny of gibbons inferred from mitochondrial DNA sequences: Preliminary report. $J$ Mol Evol 41:359-365. 
Taxonomic Tapestries

Heude PM. 1888. Étude sur les suilliens. Mémoires concernant l'histoire naturelle de l'Empire chinois 2:85-111.

Heude PM. 1892. Étude sur les suilliens, chapitre 4, etc. Mémoires concernant l'histoire naturelle de l'Empire chinois 4(3/4):113-211.

Hoffmann M, Hilton-Taylor C, Angulo A, Bohm M, Brooks TM, Butchart SHM, Carpenter KE, Chanson J, Collen B, Cox NA et al. 2010. The impact of conservation on the status of the world's vertebrates. Science 330(6010):15031509 .

Isaac NJB, Mallet J, Macdonald AA. 2004. Taxonomic inflation: Its influence on macroecology and conservation. Trends Ecol Evol 19(9):464-469.

International Union for Conservation of Nature (IUCN). 2013. IUCN Red List of threatened species. Version 2012.2. www.iucnredlist.org. accessed 10 May 2013.

Kloss CB. 1929. Some remarks on the Gibbons, with the description of a new sub-species. Proc Zool Soc Lond 99(1):113-127.

Leiserowitz AA, Kates RW, and Parris TM. 2006. Sustainability values, attitudes, and behaviors: A review of multinational and global trends. Annu Rev Environ Resour 31: 413-444.

Lucchini V, Meijaard E, Diong CH, Groves CP, Randi E. 2005. New phylogenetic perspectives among species of Southeast Asian wild pig (Sus sp.) based on mtDNA sequences and morphometric data. J Zool 266(1):25-35.

McCarthy DP, Donald PF, Scharlemann JPW, Buchanan GM, Balmford A, Green JMH, Bennun LA, Burgess ND, Fishpool LDC, Garnett ST et al. 2012. Financial costs of meeting global biodiversity conservation targets: Current spending and unmet needs. Science 338(6109):946-949.

Mallet J. 2007. Hybrid speciation. Nature 446(7133):279-283.

Mayr E. 1942. Systematics and the origin of species from the viewpoint of a zoologist. New York: Columbia University Press.

Meijaard E. 2004. Solving mammalian riddles. A reconstruction of the Tertiary and Quaternary distribution of mammals and their palaeoenvironments in island Southeast Asia. PhD thesis, Department of Anthropology and Archaeology, The Australian National University.

Meijaard E, d'Huart JP, Oliver WLR. 2011. Family Suidae (Pigs). In: Wilson DE, Mittermeier RA, editors. Handbook of the mammals of the world, Vol. 2 Hoofed mammals. Barcelona, Spain: Lynx Edicions. pp. 248-291. 
Meijaard E, Groves CP. 2002. Upgrading three subspecies of babirusa (Babyrousa sp.) to full species level. Asian Wild Pig News 2(2):33-39.

Meijaard E, Groves CP. 2006. The geography of mammals and rivers in mainland Southeast Asia. In: Lehman S, and Fleagle J, editors. Primate biogeography. New York: Kluwer Academic Publishers. pp. 305-329.

Meijaard E, Groves CP. 2013. New taxonomic proposals for the Sus scrofa group in eastern Asia. Suiform Soundings 12(1):26-30.

Meijaard E, Sheil D. 2012. The dilemma of green business in tropical forests: How to protect what it cannot identify. Conserv Lett 5(5):342-348.

Meyer TJ, McLain AT, Oldenburg JM, Faulk C, Bourgeois MG, Conlin EM, Mootnick AR, de Jong PJ, Roos C, Carbone L et al. 2012. An Alu-based phylogeny of gibbons (Hylobatidae). Mol Phyl Evol 29(11):3441-3450.

Mittermeier RA, Rylands AB, Wilson DE, editors. 2013. Handbook of the Mammals of the World, Vol. 3 Primates. Barcelona, Spain: Lynx Edicions.

Mootnick A, Groves C. 2005. A new generic name for the hoolock gibbon (Hylobatidae). Int J Primatol 26(4):971-976.

Mootnick AR, Fan P-F. 2011. A comparative study of crested gibbons (Nomascus). Am J Primatol 73(2):135-154.

Nijman V. 2003. Notes on the conservation of the Javan Warty Pig Sus verrucosus blouchi on the island of Bawean. Asian Wild Pig News 3(1):15-16.

Oliver WLR. 1993. Pigs, peccaries, and hippos. Status survey and conservation action plan. Gland, Switzerland: IUCN SSC Pigs and Peccaries Specialist group and IUCN SSC Hippos Specialist Group.

Oliver WLR, Cox CR, Groves CP. 1993. The Philippine Warty Pigs (Sus philippensis and S. cebifrons). In: Oliver WLR, editor. Pigs, peccaries, and hippos. Status survey and conservation action plan. Gland, Switzerland: IUCN. pp. 145-155.

Phillimore AB, Owens IPF. 2006. Are subspecies useful in evolutionary and conservation biology? Proc R Soc Lond B Biol Sci 273(1590):1049-1053.

Pocock RI. 1927. The gibbons of the genus Hylobates. J Zool Ser A Proc Zool Soc Lond 97(3):719-741.

Rodrigues ASL, Pilgrim JD, Lamoreux JF, Hoffmann M, Brooks TM. 2006. The value of the IUCN Red List for conservation. Trends Ecol Evol 21(2):71-76.

Roos C, Geissmann T. 2001. Molecular phylogeny of the major Hylobatid divisions. Mol Phyl Evol 19(3):486-494. 
Taxonomic Tapestries

Sachs JD, Baillie JEM, Sutherland WJ, Armsworth PR, Ash N, Beddington J, Blackburn TM, Collen B, Gardiner B, Gaston KJ et al. 2009. Biodiversity conservation and the millennium development goals. Science 325(5947):15021503.

Schultz AH. 1933. Observations on the growth, classification and evolutionary specialization of gibbons and siamangs. Hum Biol 5:212-255, 385-428.

Semiadi G, Meijaard E. 2004. Survey of the Javan warty pig (Sus verrucosus) on Java and Bawean Island, with English summary and detailed survey results in Indonesian. Bogor, Indonesia: Pusat Penelitian Biologi-LIPI and IUCN SSC Pigs, Peccaries and Hippos Specialist Group.

Takacs Z, Morales JC, Geissmann T, Melnick DJ. 2005. A complete specieslevel phylogeny of the Hylobatidae based on mitochondrial ND3-ND4 gene sequences. Mol Phyl Evol 36(3):456-467.

Thinh VN, Mootnick AR, Thanh VN, Nadler T, Roos C. 2010. A new species of crested gibbon, from the central Annamite mountain range. Vietnamese $J$ Primatol 4:1-12.

Wallace AR. 1869. The Malay Archipelago. Oxford: Oxford University Press. p. 625 .

Zachos FE. 2013. Taxonomy: Species splitting puts conservation at risk. Nature 494(7435):35.

Zachos FE, Apollonio M, Bärmann EV, Festa-Bianchet M, Göhlich U, Habel JC, Haring E, Kruckenhauser L, Lovari S, McDevitt AD et al. 2013. Species inflation and taxonomic artefacts: A critical comment on recent trends in mammalian classification. Mammal Biol - Z für Säugetierkunde 78(1):1-6.

Zink RM. 2004. The role of subspecies in obscuring avian biological diversity and misleading conservation policy. Proc R Soc Lond B Biol Sci 271:561-564. 


\title{
17. Conserving gorilla diversity
}

\author{
Angela Meder
}

\section{Introduction}

Studying gorillas is fascinating for anybody. Not only are they themselves very special animals, but the environment where they live leaves an everlasting impression on people fortunate enough to visit.

In his book Extended Family (Groves, 2008), Colin Groves described how he started to study gorilla skulls in museum collections and how exciting this work was for him. While he examined museum specimens, he remained fascinated by living gorillas and often visited them in zoos. He felt deep empathy for his study animals and did not understand how any researcher could not feel the same. Most impressive for him, however, were the moments when he saw gorillas in the rainforest, even though he did not regard himself as a fieldworker.

When Colin Groves published the results of his $\mathrm{PhD}$ thesis on the taxonomy of the genus Gorilla (Groves 1967, 1970), he became an internationally renowned gorilla expert. A very important aspect of his work was the effect of ecology on morphological diversity; he found clear differences between populations living in different habitats. Thus, it became important to examine as many specimens as possible that had lived under different conditions to truly understand this variation at the population and species levels. But for many populations, the available sample size was very small, which is something Colin has continually tried to improve.

In 1971, Dian Fossey, who was aware of the importance of his studies, invited Colin to examine some mountain gorilla skulls that she had collected in the Virunga Volcanoes. This was a wonderful chance, not only to examine more specimens, but also to see wild gorillas. Although he had been aware of the threats that existed for gorillas before, his visit with Dian Fossey, who constantly had to fight for their conservation, was an important experience that led him to support conservation activities - something that continues to this day. For me and my gorilla conservation work, this type of lifelong dedication gives constant encouragement. 
Taxonomic Tapestries

\section{Gorillas under threat}

Mountain gorillas are the best known of all gorilla populations because they have been studied thoroughly for several decades. On the Virunga Volcanoes, the highest mountains where gorillas live, they range higher than 4,000 $\mathrm{m}$ into the alpine zone. But most gorillas live in lowland rainforests. Regardless of forest type, all gorillas make their homes in wooded environments. The same wooded environments humans have been cutting down since they developed their own civilisations - for construction, firewood, agriculture and for other purposes. This has increased dramatically more recently with dramatic human population growth. Additionally, the international demand for timber and forest goods has furthered rates of deforestation. Thus, even where human population density is very low, logging companies build roads thereby opening the forest to people who would otherwise not have access, to slowly enter and settle down. Foreign companies as well as Africans exploit natural resources to their maximum for short-term gain while thinking very little about long-term consequences (Oates, 1999). Between the 1990s and 2000s, areas suitable for habitation by African apes decreased very fast; the loss of suitable environment appeared highest for Cross River gorillas $(-59 \%)$, followed by eastern gorillas $(-52 \%)$ and western lowland gorillas $(-32 \%)$ (Junker et al., 2012). In some areas, especially around the mountains of the Albertine Rift, the human pressure on the forest is so high that it results in large areas becoming completely deforested, leaving only small forest islands that are strictly protected. This type of large scale tree felling has been ongoing for many decades and from 1960 to 1996 at least $24 \%$ of the eastern gorillas' range was lost (Mehlman, 2007). This is despite scientists such as Emlen and Schaller stating 'above all, the destruction of habitat by forest clearing must be stopped' in a 1960 publication. As a result of this deforestation some gorilla populations survive in small isolated forest islands that are not connected, introducing the new and real threat of surviving in small, isolated and closed populations, which could lead to further speciation.

While the destruction of habitat is a major threat for gorillas throughout their range, there are more, including: hunting for bushmeat and the pet trade; poaching with snares; conflicts between gorillas and people, especially when gorillas raid crops; disease transmission from humans or livestock as well as epidemic diseases (Ebola); war and political instability that may lead to increased hunting, habitat destruction and general lawlessness. All these problems are addressed by many conservation organisations.

In eastern gorillas, two subspecies are distinguished: mountain gorillas and Grauer's gorillas. The mountain gorillas (Gorilla beringei beringei) found in the Democratic Republic of Congo, Uganda and Rwanda are critically endangered. They live in two distinct mountain areas that have been isolated from each other 
and from other gorilla populations for a long time. There are 480 Virunga gorillas and 400 Bwindi gorillas, both populations have been growing continuously over the last two decades, mainly because they are monitored and managed intensely (Gray et al., 2010; Robbins et al., 2011b). Even if the populations are rather small and isolated (and although they face threats like habitat destruction, disease transmission, poaching and political instability), they have very good prospects.

Although the Grauer's gorillas (Gorilla beringei graueri) in eastern Democratic Republic of the Congo are the only gorilla subspecies to be listed as merely 'endangered' according to the IUCN Red List (2014.2) rather than 'critically endangered' like the other species, we should still be extremely concerned about them. It is estimated that there are only a few thousand of them remaining, but their numbers have declined dramatically within the last two decades, mainly because of habitat destruction and hunting - particularly as a side-effect of war (Maldonado et al., 2012). The smallest known population is on Mt Tshiaberimu, a part of the Virunga National Park, and contains less than ten individuals. When George Schaller made the first survey at the end of the 1950s, there were other gorilla populations nearby (Emlen and Schaller, 1960), suggesting a dramatic decline has occurred in the past 60 years. Taxonomically, these gorillas are specialised and different from the surrounding species, therefore Colin Groves has always been very interested in them (Groves and Stott, 1979).

Western gorillas also comprise two subspecies: western lowland gorillas and Cross River gorillas. The less numerous subspecies - and in fact the least numerous gorilla subspecies - is the Cross River gorilla (Gorilla gorilla diehli) found at the Nigeria/Cameroon border and listed as Critically Endangered by the IUCN Red List (2014.2). There are approximately 250-300 individuals living, however, these are distributed in 12-14 small and fragmented populations (Etiendem et al., 2013). The most pressing threats are the destruction or modification of habitat resulting in further isolation of small populations and hunting for the bushmeat and pet trade. Recently, the genetic work of Bergl and Vigilant (2007) found that there is persistent and recent reproductive contact between many of the smaller populations, which is very good news for the conservation of this subspecies as it suggests genetic isolation may not be as large a threat as previously believed.

Yet, the western lowland gorilla (Gorilla gorilla gorilla), the most widely distributed subspecies, is also listed as Critically Endangered (IUCN, 2012). According to the most recent estimate (2008) there are still at least 125,000 individuals in existence (GRASP Scientific Commission, pers. comm. 2009). The most important threats are epidemic diseases (Ebola), destruction of the forest and hunting for the bushmeat and pet trade. As the distribution area of the western lowland gorillas is also affected by deforestation (and bushmeat hunting that often leads to 'empty forests'), there are certainly many small 
isolated populations that are poorly known. The best known population of this subspecies lives in the Ebo Forest in Cameroon that lies in-between the range of the Cross River gorilla and that of the main western lowland gorilla. This one population is quite small, however, with an estimate of only 25 individuals or less (Morgan, pers. comm. 2012).

\section{The problem with small populations}

Traditionally, inbreeding was regarded as the major danger for small populations as limited gene flow results in reduced genetic variability. As early as 1983, Dian Fossey noted certain characteristics that may have been related to inbreeding in Virunga gorillas, but there have not been any signs of inbreeding suppression since then suggesting that this population is not really threatened by inbreeding (Harcourt and Fossey, 1981). Although genetic variation certainly increases individual fitness and population viability, it is possible that populations can survive and recover from reduced population sizes making inbreeding depression less of a concern than it was previously (Strier, 1993).

Despite the ability of some populations to rebound from small numbers, the main reason why it is difficult for very small populations of gorillas to survive is their life history. Both sexes usually look for partners outside of their natal groups. Reaching adulthood, female gorillas generally leave the group they were born in and join a new male. They emigrate only if they encounter another male and they may transfer several times before they settle down in the group in which they will stay (Sicotte, 2001; Stokes et al., 2003). In western gorillas and Grauer's gorillas, male emigration is common, while among mountain gorillas less than $50 \%$ of the males emigrate (Stoinski et al., 2009). If they leave, they either become solitary or in some populations may join all-male groups (Watts, 2000; Yamagiwa et al., 2003; Robbins et al., 2004). Solitary males may travel very long distances to find another group to join (Douadi et al., 2007). Thus, if a large area is completely deforested, it becomes less likely a male will be able to cross it, significantly lowering his chance of finding another gorilla. If this happens, and gorillas do not find suitable partners we will see a futher reduction in population size. In addition, if animals cannot cross among populations then no exchange of genes will be possible further isolating populations. 


\section{Should we select gorilla populations we want to save?}

Some researchers ask the question whether it is necessary at all to save primates (Chapman et al., 2006; Klages, 2010), and although primatologists do not see any reason to question this, it is good to discuss it. The main reasons why primates should be saved are: their role as seed dispersers - they affect ecosystem dynamics; their potential as a flagship species for conservation; as well as ethical reasons. All these reasons apply to gorillas in a special way.

There are many conservation organisations - both big and small, international and local - doing their best to protect gorillas. They all complain that they do not have enough funds to do everything necessary to ensure the survival of the gorilla populations they focus on. Everywhere resources for conservation are limited and, as Martha Robbins and others (2011a) state, 'the channeling of resources toward one species is unavoidably done to the detriment of the conservation for other species. Until sufficient money is made available, conservationists will continue to be faced with the dilemma of devoting more resources to save a few species versus spreading resources too thinly to achieve success with any species.'

To concentrate funds to certain species (or in this case, populations) sounds very reasonable, and indeed the species would be saved, although only a part of it. And that is the exact problem: the species' diversity would be lost. Virunga gorillas are a good example of a population that was saved by large funding investments into conservation efforts - but they are a very specialised population, adapted to extreme heights, which is not typical at all for the eastern gorillas, making findings hard to extrapolate.

I have been working for a small conservation organisation for 22 years now, and our focus has always been to save small gorilla populations at the periphery of their distribution area as they are especially vulnerable. We want to protect them in their natural habitat for what they are - wonderful animals - but also because research can be done and we can learn from them only if we are able to ensure their survival, perhaps not forever, but for as long as possible. This is true for each population, even the smallest ones that contain less than 10 individuals. 


\section{Why is the survival of peripheral populations important?}

Only if we can save all gorilla populations that still exist, will we save the whole lot and preserve the great variation Colin highlighted in his $\mathrm{PhD}$ work. Relict populations at the periphery of the distribution area in particular carry important genes that are lost if these populations are extinguished. In the sense of the biological species concept, this is especially interesting because 'geographically separated populations often exhibit new, fixed character states differentiating them from close relatives, and these are surely "units of evolution" in all meaningful senses' (Groves, 2001).

An especially interesting example is the small gorilla population in Ebo. As it is a relict population in a montane forest area in-between the two western gorilla subspecies, it is very important for our understanding of the evolution and history of this species: 'For quite a number of reasons, therefore, the Ebo Forest gorillas would seem to be a unique and significant population, which should be protected as soon as possible.' (Groves, 2005).

A very well-studied example of the importance of saving the whole diversity of a taxon is the Cross River gorilla. Genetic diversity is not evenly distributed within the Cross River gorilla population; Richard Bergl and others (2008) found three subpopulations that exhibit different levels of genetic variability. They conclude: 'Loss of either peripheral subpopulation would cause the loss of unique alleles, and loss of the Eastern subpopulation would result in a reduction in heterozygosity and a decline in the effective allele number' (Bergl et al., 2008: 855).

\section{What would be lost for research?}

The evolution of primates is not yet fully understood with new studies often providing novel insights and directions for study. For reliable results, it is necessary to know as much as possible about living animals, and especially about their environment. Colin Groves noted in 1970 that morphological differences are connected with ecological differences (i.e. the height in which the respective gorilla population lives). 'Thus in phase with the changes in morphological pattern within each of the three subspecies, there are corresponding gradation in altitude, temperature and rainfall' (Groves, 1970).

Since he wrote this, taxonomic methods have changed fundamentally - genetic methods were added to the repertoire making it possible now to analyse relatedness of different populations irrespective of possible effects of phenotypic plasticity. Colin Groves wrote in 2001: "The coming of "molecular methods" 
has revolutionised our understanding of evolution more than it has taxonomy.' Genetic analysis allows taxonomists to work with noninvasively collected samples - they can even study animal populations that are not represented in museum collections and that no researcher has ever seen (Thalmann et al., 2006, 2011).

Since genetic methods were developed, they have been used for studies with a wide range of subjects. They have helped us to understand dispersal patterns, mating systems, reproductive strategies, and the influence of kinship on social behavior. Genetic analyses can show whether a population lost genetic diversity and whether such a loss was recent or more ancient (Vigilant and Guschanski, 2009). Today, even whole populations can be studied by sampling all individuals (Gray et al., 2010; Robbins et al., 2011b). Like museum material, this genetic material can serve as the basis for the study of many questions.

To fully understand gorilla evolution, however, it is not sufficient to study material stored in museums and gene banks; the direct observation of the animals in interaction with each other and with their environment provides additional invaluable information. In any case, researchers are interested in the conservation of their study subjects - and many of them actively contribute to their protection. In fact, the presence and interest of researchers can be an important factor for the protection of the gorillas (Tranquilli et al., 2011).

\section{What would be lost for the countries and the people?}

Gorillas are charismatic animals that can help to explain the importance of conservation during public awareness campaigns and environmental education. They can draw the attention of local people to the natural resources in their immediate environment. To protect and save these resources is of course not only in the interest of foreign researchers and tourists, but it is important for the future of the countries themselves and the people living there.

For the countries where gorillas live, these animals are not only a flagship species for conservation, but in some cases also an important source of income - particularly where gorilla tourism is practiced. If gorillas become extinct, the authorities may not see any reason to continue the effective protection of the areas where these apes used to live and we would see further loss of forests that are so important to a myriad of wildlife species.

Thus, it is clear that it is not only the gorillas themselves that have to be protected, but also their environment; this cannot be separated because gorillas are not able to survive outside the forest (if they are to survive in a natural 
environment). An important example of how deforestation can create knock on effects that further put wildlife at risk is the danger of mudslides close to mountains. Close to the Virunga Volcanoes, much of the forest on the mountain slopes was cut during the last few decades, and as a result catastrophic mudslides have become common after heavy rains; potentially destroying whole villages. In addition, deforestation further impacts humans as forested areas often act as water catchments and provide many ecosystem services.

\section{What can we do?}

If we want to protect endangered species and preserve them for future generations, surveys are the first step. Such studies have shown in many cases that healthy gorilla populations still survive in remote areas. While a few decades ago a survey always meant a visit to the area, today it is possible to identify potential distribution areas by satellite imaging and remotely sensed data. As Richard Bergl and others (2010) write, by using remotely sensed data 'valuable insights into habitat availability, fragmentation and corridors are possible with relatively small investments of time and money.' These analyses allow survey teams to focus on certain areas in which to conduct transects, during which they map the habitat and identify threats to the forest and the gorillas. Their findings are the basis for planning further research and conservation measures.

To establish protected areas and effectively enforce their conservation is the central gorilla protection activity (Tranquilli et al., 2011). Even local communities have successfully created reserves for gorillas with support of conservation organisations (Bergl et al., 2010). Additional conservation measures can be very different and have to be planned individually for each area. First of all the situation of the gorillas, their habitat and the human population living close to/ in the forest has to be evaluated carefully; this is the basis for the planning of conservation activities.

For some populations, a very special approach may be necessary. In the Virunga Volcanoes, constant monitoring and veterinary management resulted in increased gorilla population growth. According to Robbins and others (2011a), extreme measures were needed to achieve this in addition to conventional conservation efforts. It has to be mentioned, however, that such extreme conservation may influence the natural behavior or life history of a species, potentially disrupting natural selection and introducing new threats. Such measures that are extremely expensive are not possible everywhere of course, but in many areas it is possible to protect gorillas with much smaller financial resources, if the conservation activities are planned carefully and individually, and evaluated constantly. 
Many of the gorilla populations that Emlen and Schaller (1960) found in their survey have disappeared - nobody knows when and how it happened exactly, but in general their habitat was destroyed. The same fate threatens several gorilla populations now in many parts of their range. We may not be able to save all the populations - but we should at least try our best to save them for as long as possible. For research, for conservation of the ecosystem (of which gorillas are an important component), for local human populations and for the gorillas themselves. Even taxonomic studies are certainly much more exciting if living populations are the study subjects instead of extinct ones.

On the other hand, researchers should not ignore the threats to their subjects. Colin Groves has a very clear position: 'More and more, the work of taxonomists and other biologists must be put at the service of conservation' (Groves, 2003). And he himself is the best example for a scientist who takes this responsibility seriously.

\section{References}

Bergl RA, Vigilant L. 2007. Genetic analysis reveals population structure and recent migration within the highly fragmented range of the Cross River gorilla (Gorilla gorilla diehli). Molecular Ecol 16:501-516.

Bergl RA, Bradley BJ, Nsubuga A, Vigilant L. 2008. Effects of habitat fragmentation, population size and gemographic history on genetic diversity: The Cross River gorilla in a comparative context. Am J Primatol 70:848-859.

Bergl RA, Warren Y, Nicholas A, Dunn A, Imong I, Sunderland-Groves J, Oates JF. 2010. Remote sensing analysis reveals habitat, dispersal corridors and expanded distribution for the critically endangered Cross River gorilla Gorilla gorilla diehli. Oryx 46:278-289.

Chapman CA, Lawes MJ, Eeley HAC. 2006. What hope for African primate diversity? Afr J Ecol 44:116-133.

Douadi MI, Gatti S, Levrero F, Duhamel G, Bermejo M, Vallet D, Menard N, Petit EJ. 2007. Sex-biased dispersal in western gorilla (Gorilla gorilla gorilla). Molecular Ecol 16:2247-2259.

Emlen JT, Schaller GB. 1960. Distribution and status of the mountain gorilla, 1959. Zool Sci Contrib N Y Zool Soc 45:41-52. 
Taxonomic Tapestries

Etiendem DN, Funwi-Gabga N, Tagg N, Hens L, Indah EK. 2013. The Cross River gorillas (Gorilla gorilla diehli) at Mawambi Hills, South-West Cameroon: Habitat suitability and vulnerability to anthropogenic disturbance. Folia Primatol 84:18-31.

Fossey D. 1983. Gorillas in the mist. Boston: Houghton Mifflin Co.

Gray M, Fawcett K, Basabose A, Cranfield M, Vigilant L, Roy J, Uwingeli P, Mburanumwe I, Kagoda E, Robbins MM. 2010. Virunga Massif Mountain Gorilla census - 2010 summary report.

Groves CP. 1967. Ecology and taxonomy of the gorilla. Nature 213:890-893.

Groves CP. 1970. Population systematics of the gorilla. J Zool (Lond) 161:287300.

Groves CP, Stott KW. 1979. Systematic relationships of gorillas from Kahuzi, Tshiaberimu and Kayonza. Folia Primatol 32:161-179.

Groves CP. 2001. Primate taxonomy. Washington, DC: Smithsonian Institution Press.

Groves CP. 2003. A history of gorilla taxonomy. In: Taylor AB, Goldsmith ML, editors. Gorilla biology. New York: Cambridge University Press. pp. 15-34.

Groves CP. 2005. A note on the affinities of the Ebo Forest gorilla. Gorilla $J$ 31:19-21.

Groves CP. 2008. Extended family. Arlington, VA: Conservation International.

Harcourt AH, Fossey D. 1981. The Virunga gorillas: Decline of an 'island' population. Afr J Ecol 19:83-97.

International Union for Conservation of Nature (IUCN). 2012. IUCN Red List of Threatened Species. Version 2012.2. www.iucnredlist.org.

IUCN. 2014. IUCN Red List of Threatened Species. Version 2014.2. www. iucnredlist.org.

Junker J, Blake S, Boesch C, Campbell G, du Toit L, Duvall C, Ekobo A, Etoga G, Galat-Luong G, Gamys J, Ganas-Swaray J, Gatti S, Ghiurghi A, Granier N, Hart J, Head J, Herbinger I, Hicks, TC, Huijbregts B, Imong IS, Kuempel N, Lahm S, Lindsell J, Maisels F, McLennan M, Martinez L, Morgan B, Morgan D, Mulindahabi F, Mundry R, N'Goran KP, Normand E, Ntongho A, Okon, DT, Petre C-A, Plumptre A, Rainey H, Regnaut S, Sanz C, Stokes 
E, Tondossama A, Tranquilli S, Sunderland-Groves J, Walsh P, Warren Y, Williamson EA, Kuehl HS. 2012. Recent decline in suitable environmental conditions for African great apes. Divers Distrib 18:1077-1099.

Klages A. 2010. Triage: conserving primates and competing interests. Totem: Uni W Ontario J Anth 18(1):Article 12.

Maldonado O, Aveling C, Cox D, Nixon S, Nishuli R, Merlo D, Pintea L, Williamson EA. 2012. Grauer's gorillas and chimpanzees in eastern Democratic Republic of Congo (Kahuzi-Biega, Maiko, Tayna and Itombwe landscape): Conservation Action Plan 2012-2022. Gland: IUCN SSC Primate Specialist Group, Ministry of Environment, Nature Conservation \& Tourism, Institut Congolais pour la Conservation de la Nature and the Jane Goodall Institute.

Mehlman PT. 2007. Current status of wild gorilla populations and strategies for their conservation. In: Stoinski TS, Steklis HD, Mehlman PT, editors. Conservation in the 21st century: Gorillas as a case study. New York: Springer. pp. 3-54.

Oates JF. 1999. Myth and reality in the rainforest. How conservation strategies are failing in West Africa. Berkeley: University of California Press.

Robbins MM, Bermejo M, Cipolletta C, Magliocca F, Parnell RJ, Stokes E. 2004 Social structure and life-history patterns in western gorillas (Gorilla gorilla gorilla). Am J Primatol 64: 145-159.

Robbins MM, Gray M, Fawcett KA, Nutter FB, Uwingeli P, Mburanumwe I, Kagoda E, Basabose A, Stoinski TS, Cranfield MR, Byamukama J, Spelman LH, Robbins AM. 201la. Extreme conservation leads to recovery of the Virunga mountain gorillas. PLOS ONE 6(6): e19788. doi:10.1371/journal. pone.0019788.

Robbins MM, Roy J, Wright E, Kato R, Kabano P, Basabose A, Tibenda E, Vigilant L, Gray M. 2011 b. Bwindi mountain gorilla census 2011 - summary of results.

Sicotte P. 2001. Female mate choice in mountain gorillas. In: Robbins MM, Sicotte P, Stewart KJ, editors. Mountain gorillas. Cambridge: Cambridge University Press. pp. $59-87$.

Stoinski TS, Vecellio V, Ngaboyamahina T, Ndagijimana F, Rosenbaum S, Fawcett KA. 2009. Proximate factors influencing dispersal decisions in male mountain gorillas, Gorilla beringei beringei. Anim Behav 77:1155-1164.

Stokes EJ, Parnell RJ, Olejniczak C. 2003. Female dispersal and reproductive success in wild western lowland gorillas. Behav Ecol Sociobiol 54:329-339. 
Strier KB. 1993. Viability analyses of an isolated population of muriqui monkeys (Brachyteles arachnoides): Implications for primate conservation and demography. Primate Conserv 14/15:43-52.

Thalmann O, Fischer A, Lankester F, Pääbo S, Vigilant L. 2006. The complex evolutionary history of gorillas: Insights from genomic data. Mol Biol Evol 24:146-158.

Thalmann O, Wegmann D, Spitzner M, Arandjelovic M, Guschanski K, Leuenberger C, Bergl RA, Vigilant L. 2011. Historical sampling reveals dramatic demographic changes in western gorilla populations. BMC Evol Biol 11:85. doi:10.1186/1471-2148-11-85.

Tranquilli S, Abedi-Lartey M, Amsini F, Arranz L, Asamoah A, Babafemi O, Barakabuye N, Campbell G, Chancellor R, Davenport TRB, Dunn A, Dupain J, Ellis C, Etoga G, Furuichi T, Gatti S, Ghiurghi A, Greengrass E, Hashimoto C, Hart J, Herbinger I, Hicks TC, Holbech LH, Huijbregts B, Imong I, Kumpel N, Maisels F, Marshall P, Nixon S, Normand E, Nziguyimpa L, Nzooh-Dogmo Z, Okon DT, Plumptre A, Rundus A, Sunderland-Groves J, Todd A, Warren Y, Mundry R, Boesch C, Kuehl H. 2011. Lack of conservation effort rapidly increases African great ape extinction risk. Conserv Lett. doi: 10.1111/j.1755263X.2011.00211.x.

Vigilant L, Guschanski K. 2009. Using genetics to understand the dynamics of wild primate populations. Primates 50:105-120.

Watts DP. 2000. Causes and consequences of variation in male mountain gorilla life histories and group membership. In: Kappeler PM, editor. Primate males. Cambridge: Cambridge University Press. pp. 169-179.

Yamagiwa J, Kahekwa J, Basabose AK. 2003. Intra-specific variation in social organization of gorillas: Implications for their social evolution. Primates 44:359-369. 


\title{
18. The warp and weft: Synthesising our taxonomic tapestry
}

\author{
Marc F Oxenham and Alison M Behie
}

While this volume has been structured around three key themes, reflecting key research interests of Colin's over the years, what has clearly emerged is the enormous influence Colin has had, at a range of levels and degrees of pervasiveness, on the thinking of many people. Our title, Taxonomic Tapestries, evokes Colin's legacy in a number of ways with Kelley and Sussman's (2007) paper on academic genealogies being particularly relevant in this context. Kelley and Sussman explore a series of ancestor (academic supervisor) and descent (PhD student) lineages in order to document, for the most part, the academic intellectual history of primatology. Indeed, we can all engage in such genealogical detective work either to explore our own intellectual roots, or simply to locate famous ancestors. Both of us, for instance, can directly (in a unilineal fashion) trace our roots back to Hooton and his descendent (student) Washburn, while our respective ancestries diverge quite markedly after that. Colin only needs to go back a single generation to John Napier to locate his illustrious ancestor and perhaps chief intellectual influence, during his formative years, at least. Such formative periods are relevant to our tapestry of influences as we are all shaped to a greater of lesser degree by our subsequent histories and networks of colleagues and acquaintances. The contributions to this volume are clearly illustrative of this point.

In this final chapter we wish to briefly explore a range of additional ideas and questions that have emerged from contributor's approaches to the three meta-themes (the warp if you like) encompassed by this volume: behaviour and morphology; evolution; and conservation. While you, as readers, may have constructed your own framework upon which to engage with the various contributions presented here, we, the editors, have been particularly struck by the following (various strands forming the weft if you like): (1) ways of looking at the universe (incorporating ideas on taxonomy, speciation and evolution); (2) how one actually does taxonomy; (3) the causes of speciation; and (4) the value (and pitfalls) of the phylogenetic species concept (PSC). The main warp and emergent weft go to form a complex tapestry of tightly woven ideas and themes that illustrate the breadth of research interests and influence of Colin Groves. 


\section{Ways of looking at the universe: Species, taxonomy and evolution}

A rather disparate collection of approaches to this theme can arguably be said to characterise the entire set of contributions to this volume, and this is despite the quite specific set of themes authors were asked to address. Far from being a problem, the rich quarry of ideas and positions has been served. We have restricted our discussion of contributions to this emergent theme by selecting those that have a historical basis. Ulrich Welsh provides us with a biography of the German polymath Adolf Remane, who published some 300 papers, including a significant number on primate evolution and dental morphology. He presents the idea that Remane's interests resonate with those of Colin and in exploring some of the influences on research and methodological approaches of Remane, a range of prominent historical figures and themes were explored. The main point being that none of us work in an intellectual vacuum and many of the meta-ideas we cherish may in fact represent the repackaging of theories and approaches that have been circulating for centuries or are currently circulating elsewhere by scientists from a different, possibly unconnected, academic lineage.

Juliet Clutton-Brock provides a very useful perspective on how biologists have viewed their universe by reviewing aspects of the intellectual history of the naming of things, or more specifically, the naming of living organisms. Given the number of chapters dealing with the concept of species, and other taxonomic categories, in one way or another, this chapter provides a very solid context for these discussions (see below for Clutton-Brock's contribution to 'doing taxonomy'). The theme of the recycling of meta-ideas implicit in Juliet's work, is an issue explored in some detail, while in a highly specific sense, in Oxenham's chapter on Lamarck.

As noted, in some instances, ideas ascribed to one prominent scholar can be seen in the work of others that were somewhat less fortunate in terms of the success of their career and subsequent academic traction they received: Oxenham deals with the pre-Darwinian evolutionist Lamarck. Much of his chapter discusses what the author sees as Lamarck's actual views on the processes and mechanisms of evolutionary change, an important aspect of which prefigures some views usually ascribed to Darwin. Moreover, Lamarck's understanding of the nature of species is dealt with in some detail as well, as it was fundamental to his particular evolutionary scheme.

Historical precedents aside, Natasha Fijn provides a very important insight into how we conceptualise difference and similarity. Fijn looks at wild and domestic horses in Mongolia from the perspective of both scientific and cultural taxonomies. Colin is connected in as much as he has worked on horse taxonomy 
in the past (and published on it), and was the author's doctoral supervisor or academic ancestor. Indeed, Fijn states Colin is the world expert 'on the morphology and taxonomy of Equus przewalskii, or the takhi'. In trying to see past the domestic/wild dualism, she poses some interesting questions regarding the role of animal behaviour (and human-animal behavioural interactions) in taxonomic or classificatory determinations (see below for Fijn's contribution to 'doing taxonomy').

Perhaps the least intuitively obvious exploration of how taxonomies inform our understanding of biological and cultural processes comes from the pen of archaeologists Peter Hiscock and Chris Clarkson. They review models seeking to explain the processes involved in the production of what are often seen as various types of lithic artefacts in Mousterian (Neanderthal) assemblages. They assess two of these models in the context of a specific assemblage and argue that tool types, for this assemblage at least, are not simply a function of varying levels of flake retouch (curation) over time, but that different forms are arrested stages in a continuum. They suggest the initial lithic blank form plays a significant role in finished flake form or type. They go on to argue that different models may explain particular artefact assemblages and no one approach fits them all. They caution that simply seeing flake end stage morphology as a function of retouch intensity may lead one to misinterpret past (hominid) behaviour to a significant degree. There is no easy pathway to Neanderthal cognitive abilities and behaviour through lithic artefact form. There is an implicit link here to the nature of things, or in the context of this book, the nature of species. The transformational processes Hiscock and Clarkson discuss with reference to final forms (types of lithic artefact) have analogues in the biological world. Their argument that blank form predicates final form will stir reflections by biologists on canalisation and evolution.

\section{How does one actually do taxonomy?}

While not a main theme in this volume, one contribution deals with the nuts and bolts of taxonomic methodology and principles in a contribution that details the process of naming a new species of Sulawesi rat after Colin (Lenomys grovesi). And what better tribute to Colin?

A further two chapters deal with the operational aspects of taxonomy a little less directly. For instance, Juliet Clutton-Brock directly tackles the issue of defining, or correctly naming, domestic species. This particular approach is quite compatible with Colin's own definition of the Phylogenetic Species Concept. And, yes, we agree the dingoes should have their own name and Canis dingo is more than appropriate! Natasha Fijn's chapter (mentioned above under 
a different thematic heading), read in conjunction with Juliet Clutton-Brock's discussion of domestic species, provides an interesting discourse on the way we see, think about and categorise domestic animals and these two approaches are all the more interesting as they wrote their chapters independent of the content and approach of each other.

Finally, we wish to discuss Kees Rookmaaker's contribution here, even though it is perhaps more at home under the theme (see below) looking at the pros and cons of the PSC. Kees provides us with a history of rhino systematics which forms a solid basis to an understanding of the development of systematics in general. The paucity of recognised rhino species in Linneaus's time, to a slight increase in the time of Cuvier, sees an explosion in recognised forms when otherwise small differences (e.g. horn shape and temperament) were considered sufficient taxonomic signifiers. By the end of the nineteenth century a more considered approach to rhino taxonomy prevailed, a sort of compromise between extreme splitting and lumping as it were. The author then looks at Colin's rather substantive contributions to the taxonomy of rhinos, much in the form of his subscription to the PSC. Kees makes the same link back to the issue of conservation that other chapters have made, with the somewhat dour prediction of the possibility that taxonomy may end up serving the role of a way to study past biodiversity rather than to serve one of its key roles in helping protect current biodiversity. This idea is also alluded to in Angela Meder's chapter (discussed under the theme below) where she addresses the fact that 'while taxonomy is more exciting to study for living rather than extinct animals' the rapid decline of gorillas may not give us that luxury.

\section{Some causes of speciation}

A number of contributions explored, either implicitly or explicitly, mechanisms leading to speciation events, or contributing to morphological change or elevated levels of variation. For instance, Peter Andrews and Richard Johnson in reviewing the fossil evidence for gibbon ancestors find it somewhat lacking. They provide a thoroughly useful discussion of problems with actually identifying last common ancestors, which by definition cannot have homologous characters defining their descendent new species. With respect to the speciation theme Peter and Richard explore three scenarios, or potentially (future) testable hypotheses, for the origins of the hylobatids, but stress that however they came into being it was relatively recent (within the last few million years) and likely in the context of some severe environmental stressor.

This idea of the role of environmental stressors is also pursued by one of us, (AB) along with a number of colleagues, where the possible role of severe weather 
conditions as a variable in speciation events or, minimally, the biogeographic distribution of closely related species of primates (in this instance) is explored. It was found that group size was a key variable in adaptation to severe environments (i.e. frequent severe storms that destroy significant portions of the regular food supply). This, coupled with establishment of energy conservation behaviours by species faced with environmental stochasticity and the resultant stress (e.g. a hurricane wipes out the forest), provides a selective advantage in regions that are at high risk of extreme weather on a somewhat regular basis. Clearly, ecological niches can be characterised by extreme weather, as much as by any other variables.

Angela Meder's chapter focuses on the conservation of gorillas and the fact that due to habitat disturbance and hunting one of the major threats current gorilla populations deal with is small population size. She describes how many of these populations (as small as 10 animals in some instances) are isolated from each other, posing the threat that they may easily die off. However, another risk from this scenario is that they will potentially become further speciated from related species. While Angela notes that recent studies of the Cross River gorilla have shown populations that were once believed to be isolated are in fact exchanging genetic material, it is important to consider that these small, isolated populations could further change gorilla taxonomy.

While not a speciation event per se, David Bulbeck (a former graduate student of Colin's and later colleague) used human tooth size and shape analyses to explore the population history of Indo-Malaysia from the Late Pleistocene through to the modern period. He found a generalised trend in reducing tooth size, but no specific evidence for a reduction in tooth size from the Neolithic into the late Holocene. He favours a migration model, rather than an environmentally based one, whereby newcomers, perhaps originating in Sulawesi, have influenced the dental size and shape history of the region from the late Holocene to modern times.

Another former graduate student, and current colleague of Colin's, Debbie Argue, has also looked at speciation events, this time among a range of Early and Middle Pleistocene hominins. Argue has carried out a cladistic analysis of the Ceprano, Bodo, Daka and Kabwe fossils and presents data in support of placing these specimens into a common species: $H$. rhodesiensis. Colin had previously seen Bodo and Kabwe, at least, as distinct to H. erectus and preferred to see them as $H$. sapiens heidelbergensis. However, Debbie agrees with Colin's earlier work that these specimens, which she now sees as belonging to the same species, are quite distinct to $H$. erectus. She argues that the key evolutionary trait shared by members of this new species is a marked expansion in the cranial vault. Whether Colin would agree with these findings or not, he would be the 
first to applaud the approach which is, after all, in line with his version of the phylogenetic species concept. Standing on the shoulders of giants is perhaps something Debbie is quite proud of in this instance.

Before leaving the emergent theme of speciation, a further past graduate student of Colin's, and now colleague, Michael Westaway (and his associates) stress the importance of Colin's interpretation of the PSC and the resultant definition of more, rather than fewer, species. Minimally, splitting facilitates hypothesis testing as to the validity of such 'split' species, while the opposing approach (lumping) does not. Colin's influence in this regard can be seen in the expansion in the number of recognised hominin species in Pleistocene Southeast Asia, an early 'pre-erectine' species of which may be ancestral to Homo floresiensis. In terms of anatomically modern human variation in the region, the authors see microevolutionary change as key, perhaps in the context of environmental and climatic influences and not ruling out the possibility of more prosaic explanations; sexual dimorphism for instance. They see no role for previously held views of genetic inputs from Homo erectus, or similar such species. Notwithstanding, the new genetic data indicating Neandertal and Denosovan influences seems quite exciting.

\section{The value (and pitfalls) of the phylogenetic species concept (PSC)}

A number of contributors have dealt more or less explicitly with the PSC (with Kees Rookmaaker's chapter, while relevant in this regard, discussed under the theme of 'doing taxonomy' above). The nature of the species concept biologists ascribe to would seem to have important positive and negative ramifications for a range of sub-disciplines, not the least being conservation and parasitic disease control. Robert Attenborough, a long-time colleague of Colin's, explores Colin's version of the Phylogenetic Species Concept, which had led him to split numerous taxonomic units into smaller ones by identifying more species than other operational species concepts might allow. Robert develops an argument for the value of this approach, particularly where seeing more species may be of some practical benefit. He applies this idea to his review of the taxonomy of mosquitoes that have the capacity to infect humans with the malarial parasite and stresses the need to fine tune our taxonomy of these organisms if we are ever to make advances in interrupting the malarial cycle.

John Oates and Nelson Ting draw a detailed and well-argued direct link between the realities of institutionally funded conservation efforts and taxonomy. While 
they are quick to stress that taxonomy needs to be carried out independently of the direct needs of conservation priorities (in order to preserve the scientific rigour and independence of systematics), they stress that:

Species are the common primary 'currency' used in biodiversity conservation planning. Regions and ecosystems are often prioritised for conservation action based on measures of species richness and endemism and species judged to be in danger of extinction are usually given special attention ... [but] unstable classifications can have implications for conservation priorities and policies.

While the authors try and avoid taking sides in terms of subscription to one major approach (BSC vs PSC) over another, they tend to side with taxonomies that are a result of PSC approaches, in as much as the operational practicality of the PSC appears more objective, even if it does tend to lead to a proliferation of taxonomic units rather than a reduction. Notwithstanding, even subscribing to the PSC has its own problems. For instance, the authors note that with respect to red colobus monkey classification, even those who agree on subscribing to the PSC argue over which traits are important in classifying/differentiating this group. At the end of the day, the authors advocate consistency and consensus (and soon!) with regard to colobus monkey systematics, before a lack of such inadvertently leads to more extinction events (see Kees Rookmaaker's similar lament with respect to rhino taxonomy).

Eric Meijaard and Ben Rawson, both previous students of Colin, note the significant and far reaching impact Colin has had on both pig and gibbon taxonomy. Indeed, they argue that his work in this area has made a positive contribution to the conservation of both groups. In general, the authors address the issue of the effect on conservation efforts of greater or lesser taxonomic differentiation. For some Southeast Asian pigs, at least, better identification of endangered species (recognised using the PSC) has been a boon in terms of conservation success. The same can be argued for several species (recognised by Colin) of gibbon. However, interestingly, a survey of those involved in gibbon conservation efforts suggested that taxonomic classifications, per se, were not a driver, or detractor, with respect to conservation as conservation efforts tend to focus on endangered populations and not species or sub-species. One important point, in the context of the current heated discourse over taxonomic instability, is that the authors do not see a trend whereby conservation funds are diluted in the face of taxonomic inflation.

The main purpose of this edited volume was to pay tribute to the incredibly productive career of Colin Groves in the context of a complex tapestry of 
Taxonomic Tapestries

bio-evolutionary themes linked by the common glue of taxonomy. We believe we have been successful in this regard and as editors, are honoured to have the privilege of packaging this tribute to a remarkable scholar: Colin Groves.

\section{References}

Kelley E, Sussman RW. 2007. Academic genealogy on the history of American Field Primatology. Am J Phys Anthrop 132:406-425. 


\section{Index}

aboriginal 185, 193, 195, 197, 198, 200, 202, 207

see also Orang Asli

Aborigine (Australian) 194, 196, 197, 199,

204, 206, 249, 250, 260, 261, 262, 264

adaptation 286

biological 183, 184

in apes 56, 58, 59, 61, 62

in gibbons 52, 53, 54, 61, 63

in gorillas 365,377

in hominins 251, 261

in lemurs 86

in monkeys 85,86

in mosquitoes 143, 144, 146

in takhi 286, 294, 295

of malaria 142

of taxonomy 130

phenotypic 146

pre-adaptation 58

Africa 57, 263, 362

animals 178

conservation $8,322,330,332-3$

hominins in 103, 143, 215-18, 251, 252, 256, 260, 263, 267, 291

malaria 138, 141, 143, 144, 146, 147

primate emigration 56

primate fossils $54,55,57,58,61$

primate taxonomy 321, 325-8, 329, 330, 333

primates $8,53,58,59,322,325,326,327-30$, $332-3,362$

rhinoceros 301, 302, 304-6, 308-13

sub-Saharan 138, 147

see also Central Africa, East Africa, South Africa

afropithecines 56

allopatry 131-5, 137, 138, 140, 159, 176, 325, 326, 336, 345

see also geographic speciation

Alouatta 75, 76, 83, 86, 95

belzebul 76

caraya 76

coibensis 75, 76, 77

guariba 76

macconnelli 76

nigerrima 76

palliata $75-83,85,86$

pigra $75-87$

sara 76

seniculus 76

see also howler monkey
American Museum of Natural History

(AMNH) 13, 47

American Society of Mammalogists 7

ancient DNA, see DNA - ancient

annamiticus 312

Anoiapithecus 57

Anopheles 136-8, 140, 141, 147

annulipes 137

arabiensis 138, 141, 143, 144

bancroftii 137

bwambae 138, 144

clowi 143

coluzzii 139, 142, 144, 146

farauti 137, 138, 142, 143

funestus 141

gambiae 138, 139, 141, 142, 143, 144, 145, 146

hinesorum 138, 143

irenicus 143

koliensis 137, 138, 142, 143

longirostris 137, 143

lungae 137, 143

melas 138, 142, 144

merus 138, 142, 144

punctulatus 137, 138, 139, 142, 143, 146

quadriannulatus 138-9, 143, 144

rennellensis 143

Anophelinae 136

anopheline 8, 129, 136-8, 140, 141, 144, 145,

146

anthropogenic 3, 40, 78, 158

anthropology 5, 95, 129, 282

biological (bio-anthropology) 3, 4, 5, 147, 183, 184

see also palaeoanthropology

anthropophily 141, 142, 143, 144, 145, 146

Aotus 76

apes 58,98

African 53, 54, 59, 362

and gibbons 52, 54, 58, 59-61, 95, 97

and Proconsul 61

conservation 346, 352, 353, 354, 367

deficiency of fossils 54-5

divergence 52, 60

evolution 51, 58

fossil record 53, 54, 58, 59, 60, 62, 99

in China 59

Indian 60

lineage 52, 59, 61, 98

loss of tail 60,61

migration 56, 57

Miocene 56, 57, 58, 59 
modern 56

-monkey split 59-60, 61, 62

morphology of fossils 55-9

Sivalik 98-9

teeth 97,99

uricase gene 62

see also great apes, individual species names, primates

Apidium 95

arboreal 52, 55, 56, 58

arboviruses 136

Archaeolemuridae 99

archaeological

assemblage 106

considerations 217

finds 184, 185, 289

patterns 104

record 255

sites 171

archaeology 103, 108, 264, 265, 375

archaeozoology 171, 177, 178

Arcus Foundation 353, 354

Aristotle 8, 93, 95, 171, 172, 173, 174, 176

Artiodactyla 46, 178

artiodactyls 46, 178

Asia 264

hominins in 51, 215, 216, 264

see also Central Asia, East Asia, North Asia, Southeast Asia

Asian

dogs 179

primate fossils $55,57,58$

primates 52, 63, 333

rhinoceros 301, 302, 305, 309

rodents 46

wildlife 6

see also horses - Asian

Ateles 76

Australasia 249

Australia 6, 155, 249, 205, 267, 310

hominins in 185-7, 193-6, 198, 200, 202, 205, 261-3, 265

mosquitoes in 136, 137, 142,

peopling of 208, 249, 250, 260, 264, 265

see also Aborigine, dingo, Kow Swamp, Lake Mungo, Willandra Lakes

Australian Faunal Region 137

Australian-Indonesian Archaeological

Expedition 37

Australoids 183, 191, 197, 204, 205, 208

Australopithecus 97
Austroasiatic 184

Austronesian 184, 208

autapomorphy 258, 259, 260, 266

Avahi 134

avian 133, 355

see also birds

Babyrousa 347, 348, 349

barrier

anthropogenic 284

behavioural 176

geographic 76, 131

language 97

mating 139

behaviour 135, 373

and domestication 283-4

and food supply 84

animal 3, 5, 375

barrier 176

comparison 78-9, 83

energy conserving 77, 377

hominid 375

influence of weather on 77

Mousterian 124

of Alouatta 75, 77, 78-9, 83

of anopheline 141, 142, 143, 145, 146

of birds 133

of gibbons 51, 54

of horses 281, 285, 286, 287, 293, 294

of lemurs 77

of monkeys 322

of primates 3

of wild dogs 179

processes 110

social 281

study of $7,8,286,322$

understanding of 4

Belize 77, 79, 80, 81, 84, 85, 86, 87

Bell, William 304, 305

bio-anthropology, see anthropologybiological

biological anthropology, see anthropologybiological

biological species 133

biological species concept (BSC) 3, 134, 176, $323,354,355,366,379$

move away from $321,337,346$

origins of 131,345

proponents of 345

shortcomings of 131, 132, 176, 323, 325, 336,337 
birds 130, 136, 140, 142, 159, 161, 173

birds of paradise (Paradisaeidae) 133, 135

'blank-retouch interaction hypothesis' 109,

110,123

Blyth, Edward 309

Borneo 85, 184, 203, 205, 208, 312, 347

see also Indonesia

botany 95, 156, 177, 300

Bougainville 137, 138, 143

brachiation 51, 52, 53, 58

Britain, see United Kingdom

British Museum 46, 171, 309

Bunomys

andrewsi 41

chrysocomus 14, 41

coelestis 46

Bunopithecus 350

hoolock 52

sericus 54

Burchell, William John 304, 305, 306

Burkina Faso 139

camels, Bactrian (Camelus ferus) 286

Cameroon 327, 332, 363, 364

Camper, Petrus 304, 305, 306

Canis

dingo 180, 375

domesticus 175

familiaris 175, 177, 178, 179

lupus 178, 179, 286

lupus arabs 177

poutiatini 177

vertagus 175

see also dingo, dogs, wolves

Cape of Good Hope 302, 306

Capricornis, see serow

capuchin monkeys, see Cebus

Caribbean 77

Cebus 76, 99

Central Africa 325, 333

Central America 76, 80, 82, 83

Central Asia 265, 281, 283, 287, 292

Ceratotherium

cottoni 312, 313

simum 312, 313

Cercopithecidae 96, 325

Cercopithecoidea 99

chimpanzees 55, 56, 97, 98

see also Pan

China 54, 180, 249, 250, 279, 348, 352

fossil deposits 54, 59, 61, 217 hominins in 183, 184, 193, 195, 198, 200,

$$
\text { 202, } 204
$$

modern humans 185, 191, 197, 204

cladistic

analysis 8, 215, 216-19, 230, 232, 256, 323, 377

approach 322

structure 221

taxonomy 130

cladistics 177

Hennigian 132

'coefficient of racial likeness' (CRL) 188

Colobinae 325

colobine 56, 61, 325, 326, 328

see also red colobus monkeys

Colobus 326

badius 326, 327, 329, 332

black-and-white 325

kirkii 326, 327

olive 325,326

pennantii 326, 327, 331

preussi 327

rufomitratus 326, 327

tholloni 326, 327

waldroni 327

see also monkeys, Procolobus, red colobus monkeys

colonisation 84,86

of Mesoamerica 76, 83

of Sahul 249, 251, 260, 263, 265

Congo Basin 327, 332, 333-4

Congo Republic/Republic of the Congo 329, 331,332

conservation, see Africa-conservation, Gorilla-conservation, Groves, Colin-and conservation, pigs-conservation, primate - conservation, rhinocerosconservation, Southeast Asia-conservation Conservation International 333

Costa Rica 79

Côte d'Ivoire 331, 333

creationism 7, 159

culicid 136

Culicidae (Diptera) 136

Culicinae 136

Cuvier, Georges 93, 95, 157, 159, 299, 302, 305, 307, 309, 376

Darwin, Charles 93, 96, 155, 156, 157, 159, $167,172,177,287,374$

Darwinism 96, 130, 156, 157, 163 
see also neo-Darwinian, pre-Darwinian de Blainville, Henri 156, 305

Democratic Republic of Congo 325, 326, 362, 363

Dendropithecus macinnesi 56, 61

Denisovans 264, 265, 267

'diagnosability species concept' 323

Dicerorhinus sumatrensis 313

dihybrid model of Aboriginal origins 249

dingo 176

nomenclature $179,180,375$

origins 180, 263, 265

see also Canis - dingo

Diptera, see Culicidae

divergence 59, 135, 241, 323, 337

in Alouatta 76, 83

in apes 62

in gibbons 51, 52, 59

in Hominidae 59

in hominins 258, 265, 266

in horses 291

in hylobatids 59

in monkeys 62, 327

in orangutans 54, 59-60

population 322, 336

DNA 139

analysis 40, 41, 291, 331

ancient DNA (aDNA) 8, 251, 260, 264

and gibbons 51, 54

and hominin evolution 268

and horses 291-2

and interbreeding 176

and taxonomy 3

collecting 3

Denisovan 264, 265

genomic probes 137

mitochondrial (mtDNA) 59, 75, 205, 208, 264, 265, 291, 292, 328

modern Homo 260, 264

nDNA inserts (numts) 264

Neanderthal 264, 265

research 264

ribosomal (rDNA) 137, 138, 139

sequence use 45

study of 263,264,267, 291

trees 59

dogs 142, 176, 208

classification 173, 175, 177, 178

domestic 177, 179

Thai 179

wild 179,180

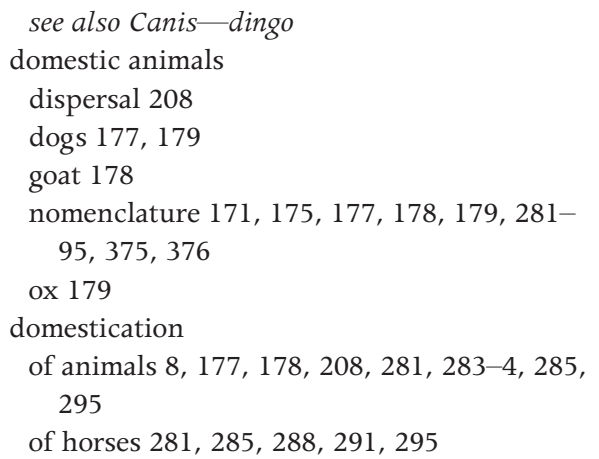

dominant vector species or species complexes (DVS) 141, 142

Dryopithecinae 57

dryopithecine 57, 58, 62

Dryopithecus 57

fontani 99

giganteus 99

mogharensis 96

pilgrimi 99

Duvaucel, Alfred 307

Early Metal Phase (EMP) 184, 186, 187, 188, 197, 199, 203, 204, 207

Java 186, 187, 201, 202, 203, 204, 205, 206, 207

Early Pleistocene 54, 215, 217, 232, 253, 256

East Africa 144, 260, 263, 333

East Asia 208

East India Company 305

ecological species concept 4

Egypt 166, 167, 172, 173

England, see United Kingdom

Equatorial Guinea 141

equids 171,172

Equus 291

africanus 178

asinus 178

caballus 178, 281, 282n.2

ferus 280, 281, 281

przewalskii 280, 281, 282-3, 291, 294, 375

see also horses

Eropeplus canus 22, 29

Ethiopia 215, 216, 217

Eurasia 286, 292, 347, 355, 356

Europe 93, 95, 96, 98, 136, 301, 303, 305, 349

and horses 280, 284, 288, 289, 292, 294

hominins in 218, 256, 267

Medieval 175

primate migration 55, 57 
primates in 57, 59, 62

see also Western Europe

Europeans 174, 180, 288

evolution 373

and ecological species concept 4

anti- 166

biological 8, 156, 322, 348, 380

mosaic 58

of Allouatta 83

of anopheline 144

of apes 51, 53, 58, 59

of dryopithecines 57,58

of gibbons $8,51,54,59$

of gorillas 366, 367

of hominins $3,8,51,54,59,124,205,215$,

$216,218,225,231,232,249-68$

of hylobatids 54

of language 171

of primates 366, 374

phyletic (anagenetic) 158

role of 4

study of human $5,7,8$

understanding of $4,161,367$

evolutionary

advantage 144

'arms race' 144

change 58, 103, 146, 159, 161, 167, 258, 260, 267,374

cost 144

differentiation 139

distinctness 345, 356

framework 266

history 46, 51, 60, 161

interpretations 51

lineage 132, 136, 163, 215, 216

micro change 267,378

narrative 8,251

paradigm 205, 232

pre-evolutionary system 130

process 134, 156, 166, 178, 249, 267, 336

relationships between species 75, 249

scenarios 51

scheme 374

shift 231

significance 51, 60, 336

species groups 299, 323, 336

steps 61,219

success 347

systematics 322,323

theory 130, 131, 155-67, 251, 252, 322, 336, 374,375 traits 377

transition 103

extinction 179

and colobus monkeys 322, 331, 332, 336,

337

and erectus 252, 260

and gorillas 367, 369, 376

and primates 94

and rhinoceros 313

and takhi 289, 294

anthropogenic 158

concerns about 354

events 159, 252, 379

ideas on 158, 164, 166

of hominin lineages 264, 267

of Homo modjokertensis 267

of languages 171

of species 158, 164

of tarpan 281

possible of Lenomys 40

prevention 345,350

threat of 136, 321, 322, 349, 379

First Australians, see Aborigine

Five Predicables, the 174

flies 136

Flores 255, 256, 260, 266

Flower, William Henry 309

Fossey, Dian 5, 361, 364

France 95, 97, 98, 104, 105, 108, 280, 302

frog 133

Gegenbaur, Carl 95

genetic species concept 4, 135

'geno-hype' 3

Geoffroy Saint-Hilaire, Etienne 96

geometric index of unifacial reduction (GIUR)

$111-19,123$

Germany 95, 311

Ghana 331, 333

gibbons 51-63, 85, 95, 97, 327, 346, 350-6, 376,379

adaptation 52, 53, 54, 61, 63

and apes 52, 54, 58, 59-61, 95, 97

behaviour 51, 54

comparison with great apes 51, 53, 54, 59,

61

divergence 51, 52, 59

DNA 51,54

evolution 8, 51, 54, 59

speciation $51,54,61$ 
see also Groves, Colin, Hylobates,

Nomascus, Symphalangus

Gigantopithecus 96, 98, 99

blacki 98

goats 178,281

see also Ovis

Gobi bear (Ursus arctos) 186

Goethe, Johann Wolfgang 93, 95

Gordon, Robert Jacob 302

Gorilla 98, 99, 361-9, 377

adaptation 365,377

conservation 5, 9, 361-9, 377

Cross River (Gorilla gorilla diehli) 333, 335 $362,363,364,366,377$

decline 376

ecology 5

evolution 366, 367

extinction 367, 369, 376

fossils 55

modern 56

mountain (Gorilla beringei) 5, 98, 361-3, 364

skull analysis 5, 97, 361

speciation 362

study of 361

systematics 327

tooth analysis 98, 99

Virunga 363, 364, 365

see also Groves, Colin - and gorilla taxonomy

Gray, John Edward 307, 309

great apes 337,338

African 58

comparison with gibbons 51, 53, 54, 59, 61

conservation $333,337,338,353$

deficiency of fossils 54, 55, 59

divergence 59, 62

lineages 55

modern 56, 58

morphology 53, 58

uricase gene 62

see also apes, primates

Greece 172, 173

Gregory, William King 96, 99

griphopithecines 56

Groves, Colin 5-7, 46-7, 93-6, 155, 171, 183,

$250,373,377,379-80$

and 'diagnosability species concept' 323

and Alouatta taxonomy 76, 77, 86

and Bodo cranium 217, 230, 377

and biological species concept 4, 131, 132, $176,321,323$

and conservation 5, 6, 180,338, 366, 369 and First Australians 260, 262, 264

and gibbon morphology 51, 52, 53

and gibbon taxonomy 327, 350, 351, 379

and gorilla taxonomy 5, 327, 335, 361,

363, 366

and Homo floresiensis 7, 252, 255

and horse taxonomy 171, 281, 294, 374-5

and Javan material 258

and Kabwe cranium 218, 230, 377

and mammal dispersal 208

and mammalian taxonomy 7, 46, 179

and monkey taxonomy 321, 323, 324, 325 ,

$327,328,331,332-3,334$

and pig taxonomy $348,350,379$

and primate taxonomy 46, 93, 366

and phylogenetic species concept 4, 132,

$135,176,321,323,333,356,375,378$

and rhinoceros taxonomy $6,299,310$,

312,376

and Sahul 266, 267-8

and Sulawesi 208

and Sunda 252, 266, 267-8

and taxonomic methods 366-7, 374

and ungulate taxonomy 134, 313

criticism of 167-8

naming of Lenomys grovesi 39, 47, 375

Primate Taxonomy (2001) 75, 76, 93, 328

species concepts 130, 135, 136, 140, 147,

$155,160,167-8$

taxonomic issues 129, 171, 178-9, 373

taxonomy of primates 131

taxonomic contribution to Homo ergaster

7,250

Guatemala 86

Guérin, Claude 312

Guinea 327

Haeckel, Ernst 96

Harrisson, Tom 312

Hennig, Willi 130, 219, 322

see also cladistics - Hennigian

Heude, Pierre Marie 348

Hill, John 46

Hispanopithecus 58, 59

laietanus 57, 60, 61, 62

Holocene

and H. Sapiens in Flores 260

Australian Aborigines 194, 205, 265

craniodental change 184

human migration 183, 263, 265

human skeletal record 8 
human tooth-size transition 183, 191, 194, 197, 199, 203, 204, 205, 206, 208-9, 377 Indo-Malaysia human remains 183-4, 191, 194, 197, 203, 204, 205, 206, 208

Leang Burung 37, 39 sample comparisons 187, 207

Southwest Pacific samples 197

Sulawesi murid species 41

Hominidae 58, 59

hominins 215, 216, 219

adaptation 251, 261

archaic 251, 255, 265

characteristics of 216, 225, 227, 230, 232

divergence 258, 265, 266

DNA and evolution 268

evolution 3, 8, 51, 54, 59, 124, 205, 215, $216,218,225,231,232,249-68$

extinction of lineages 264, 267

fossil availability 215,232

fossil studies 215, 268

fossils in Java 184-7, 191, 193-208, 249, 250-2, 256, 258, 266-7

from Sangiran 256

in Africa 103, 143, 215-18, 251, 252, 256, 260, 263, 267, 291

in Asia 51, 215, 216, 264

in Australia 185-7, 193-6, 198, 200, 202, 205, 261-3, 265

in China 183, 184, 193, 195, 198, 200, 202, 204

in Europe 218, 256, 267

in Sahul 267-8

in Southeast Asia 183-4, 204, 206, 208, 265 , 378

in Sunda 251, 252, 253, 258, 267-8

Javan 251-5, 256, 258, 266

language development 171

Late Pleistocene species 265, 267

lineages 258, 267

phylogeny 230,267

Pleistocene 267, 377, 378

Pleistocene fossils 187, 378

pre-erectus 253, 256, 266

taxonomy 218n.1, 219, 232

see also Laccopithecus, Paranthropus,

Pithecanthropus erectus, Rudapithecus

hominoid 51-63, 94

Homo 98, 99, 215, 218, 229, 230, 231, 232,

253, 256

antecessor 216,256

cepranensis 217,256 habilis 219, 251, 252, 256

helmei 256

modjokertensis $253,256,258,266,267$

neanderthalensis 218, 265, 267

rudolfensis 256

soloensis $258,260,265,267$

Homo erectus 218, 225, 249, 253, 256, 258,

266, 377

'advanced' 258

and H. Floresiensis 255-6, 258, 266, 378

and $H$. soloensis 258,260

and $H$. ergaster 256

as single species 215,232

Bodo fossil 220, 225, 226, 377

Ceprano cranium 215, 217, 220, 225, 228, 229

Daka cranium 215, 216, 220, 225, 227

definition 232

distribution 251

divergence 256

extinction 252, 267

interaction with $H$. sapiens 265

Javanese fossils 252, 256, 258

Kabwe fossil 218, 220, 377

lineage 215, 220, 226, 227, 230, 232, 252, 256, 266-7

migration 255

morphology 215, 228-9, 250, 256, 260, 262

non- 252

phylogeny 232, 251, 260, 267

pre- $251,252,253,256,266$

s.s. $215,217,229$

Sangiran fossils 6, 217, 219, 229, 253

variability 252

Zhoukoudian fossils 217

Homo ergaster 216, 256, 266

characteristics 256

Colin Groves' taxonomic contribution 7, 250

Homo floresiensis 257, 260, 266

characteristics 255-6

discovery of 253, 255

Colin Groves' role in debate about 7, 252

phylogeny 258,267

questions over lineage 253, 255-6, 266, 378

Homo rhodesiensis 221, 225, 230, 231, 232,

256, 377

Bodo cranium 225, 226, 230, 377

Kabwe cranium 215, 217, 218, 219, 230, 377

Homo sapiens 103

and $H$. erectus extinction 252 
and Neanderthals 103, 265

'archaic' 218, 258

Australian fossils 263

DNA assimilation 265

heidelbergensis subspecies 218, 230, 377

interaction with $H$. erectus 265

migration 251, 260, 267

morphology 260, 263

phylogeny 217-18, 249, 267

rhodesiensis subspecies 215, 217, 218, 225

homology 60, 93, 94, 99

Hoolock leuconedys 351, 352

Hopwood, Arthur Tindell 311

horses 178, 321, 374-5, 279-95

Asian 279, 280, 281, 292

behaviour 281, 285, 286, 287, 293, 294

Colin Groves and taxonomy of 171, 281, 294, 374-5

divergence 291

DNA 291-2

domestication 281, 285, 288, 291, 295

in Europe 280, 284, 288, 289, 292, 294

Neolithic domestication 295

see also Equus, Mongolian horse, takhi, tarpan

howler monkey 75, 76, 84, 85, 86

black 84

mantled 81

see also Alouatta

human-induced, see anthropogenic

Hunter, John 304

hybridisation 4, 137, 139, 172, 176, 177, 281, 289-92, 324, 325, 326, 345, 353

Hylobates 52, 99, 350

hoolock 351

klossii 352

lar 53

see also gibbons

Hylobatidae 9, 51, 56, 59, 346, 350, 351, 352, 353

hylobatids 51, 52, 53, 54, 56, 59, 60, 62, 376

ibex (Capra sibirica) 286

India 58, 263, 265, 301, 302, 352

see also rhinoceros - Indian

Indian ape, see Sivapithecus sivalensis

Indo-Malaysia 184-6, 190, 191, 194, 196, 197, 199, 204-8, 377

see also Orang Asli

Indochina 40, 41, 312

Indonesia 47, 250, 252
Australian-Indonesian Archaeological

Expedition to Sulawesi 37

Colin Groves in 6

dog dispersal 208

fossil location 20, 47

Government 350

Holocene remains 183

human migration 208

human remains 185

names 17,18

pig taxonomy 347, 349, 350

Pleistocene deposits 54, 217

West Papua 130

see also Borneo, Flores, Java, Sulawesi

Indonesian National Museum of Natural

History 13

Indopithecus 99

Indriidae 99

insects 135, 140, 161, 173

see also culicid, flies, mosquitoes

interbreeding 3, 131, 132, 135, 176, 291, 292,

294, 323, 336, 345, 346

International Code of Zoological Nomenclature (ICZN) 178, 179

International Primatological Society 333

International Union for Conservation of

Nature (IUCN) 329, 330, 348, 349, 350, 355

Red Data Books 329, 330, 332

Red List of Vulnerable Species 179, 329, 330 , $331,337,351,363$

International Union for Conservation of

Nature Species Survival Commission (IUCN SSC) 321, 327, 329

Wild Pig Specialist Group 346, 348, 349

Peccary Specialist Group 348, 349

Hippo Specialist Group 348, 349

Primate Specialist Group 328, 330, 333, $337,346,352$

invertebrates 94, 135, 156, 301

Iran 6

Italy 58, 215, 216

Ivory Coast, see Côte d'Ivoire

Java 13

hominin fossils 184-7, 191, 193-208, 249, 250-2, 256, 258, 266-7

Lenomys fossils 20

rhinoceros fossils 304-7

see also Indonesia

Java Man, see Pithecanthropus erectus

Javan warty pig 349, 350 
Kalam 133

Kenya 6, 52, 322, 327, 332

kenyapithecines 56

Khangai Mountains 280, 281

Kow Swamp 250, 261, 262, 263, 264

Laccopithecus robustus 59, 61

Lake Mungo 250, 264

see also Mungo Man, Willandra Lakes

Lamarck, Jean-Baptiste 8, 155-68, 374

Last Glacial Maximum (LGM) 261, 262, 263, 267

Late Pleistocene

Australian samples 194

Flores samples 256

hominin species 265,267

Indo-Malaysia samples 54, 186, 208, 377

Java samples 184, 191, 193, 195, 196, 207

lemur 77, 85, 86, 135, 337, 338

ring-tailed (Lemur catta) 84

ruffed (Varecia $v$. editorium) 84

sportive (Lepilemur) 134

white 85

woolly 134

see also Archaeolemuridae, Avahi

Lenomys 13, 20, 22, 27, 29, 42, 43, 47

distribution 17,18

longicaudus 19, 20, 23, 30, 31, 32, 38, 44

Lenomys grovesi $8,37,43,375$

dentary 17, 19, 38, 39, 42, 43-5

distribution 39

existence of 40,46

fossil samples 40,41, 44, 45

Lenomys meyeri $20,22,30,39,45-6$

burrow system 35

dentary 28, 30, 32, 39, 42, 43, 45

description 20-5, 30, 31

distribution 22

fossil samples 13, 16, 17, 18, 36, 38, 40, 41, 44, 45

habitat 34

lampo 19, 20, 23, 26, 29, 30, 31, 38, 42, 44

location of samples 17, 18, 32, 33, 39

modern samples 16, 31, 38, 40, 44, 45

see also Mus meyeri

Linnaean 130, 177, 178

Linnaeus, Carl 171, 172n.1, 174-5, 176-8,

280, 300-2, 305, 321

lumping 133, 136, 249, 348, 376, 378

Lydekker, Richard 99, 310 macaques 84, 208

Madagascar 77, 86, 134, 144, 333

Makassar 13, 186

Malay Archipelago 355

Malaya 184, 185, 186, 187, 197, 203, 205, 207, 208

see also Indo-Malaysia, Orang Asli

Mammalia 174

mammalian

diversity 39

taxonomy 7, 134

marsupials 46

Maxomys

hellwaldii 39, 40, 41

musschenbroekii 40, 41

surifer 40, 41

Mayr, Ernst Walter 130, 131, 132, 133, 176, 323, 348

Mazák, Vratislav 7, 250

Medieval 159, 175

Meganthropus palaeojavanicus 251, 252

Melanesia 264, 265

Mendelian genetics 130

Mesoamerica 75, 76, 83

Mesopotamia 172, 173

Mexico 75, 79, 81, 86

Middle East 144

Middle Pleistocene 232, 252, 377

fossils 8

Homo fossils 216-32, 265

hylobatids fossils 54

Paranthropus fossils 253

primate fossils 55

Miocene 54, 55, 56, 57, 58, 59, 61, 62, 63

mitochondrial DNA, see DNA - mitochondrial

Moluccas 137, 138, 142

Mongolian horse 279-95, 374

Mongoloid 183, 191, 197, 197

monkeys 52, 53, 59, 61, 62, 75, 327, 332, 33

New World 8

Old World 56, 62, 325, 327

see also Aotus, Cebus, howler monkeys, red

colobus monkeys, spider monkeys

monotremes 46

mosaic evolution, see evolution-mosaic

mosquitoes $8,136,140,141,143-7,378$

see also anopheline, Culicidae

Mousterian 103, 104, 106, 108, 110, 122-5, 375

mtDNA, see DNA - mitochondrial

Mulvaney, DJ 13, 37 


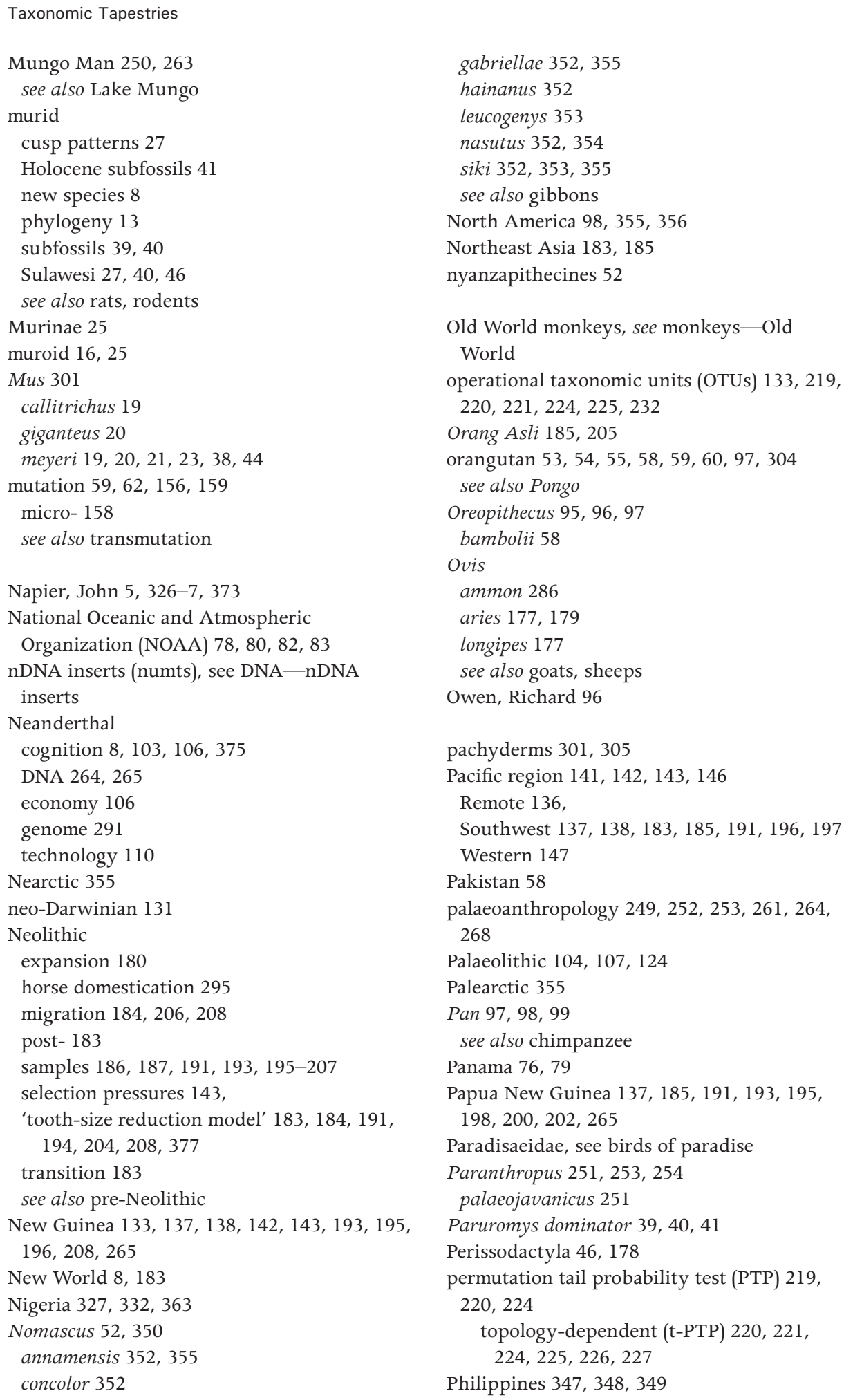


phyletic (anagenetic) evolution, see

evolution - phyletic

phylogenetic analysis 268

phylogenetic analysis using parsimony

(PAUP*) 220

phylogenetic species 336, 337

phylogenetic species concept (PSC) 4, 138,

$140,155,323,336-7,345-56$,

acceptance of 323

application of 8, 133, 135, 337, 345-56

Colin Groves' support for 132, 176, 312,

323, 333, 338, 375, 376, 378

criteria 134, 147

criticism of 135, 345, 349

definition 132, 323,

pitfalls of 132, 336, 346, 373, 376, 378, 379

review of application $346,353,356$

value of 132, 133, 336, 337, 373, 376, 378, 379

Pierolapithecus 57

pigs 138, 142, 347

Bawean 354

conservation 8, 347, 349, 353, 354, 379

endangered 349, 350, 354, 379

extinction 349-50

migration 208

Mindoro warty 349

Philippine 349

Sulawesi warty 208

Sulu 349

Sumatran bearded 347

taxonomy 347, 348, 349, 379, 379

Togean Babirusa 349

Visayan warty 349,354

see also Babyrousa, Javan warty pig, Suidae, Sus

Piliocolobus 326, 327, 328, 331, 332, 333, 334 see also red colobus monkeys

Pithecanthropus erectus 251

Pleistocene 98, 258, 284, 286

Australian samples 250, 260

hominin fossils 187,378

Indo-Malaysia samples 191, 194

Java samples 191, 194, 207

post- 184

Sahul 263, 267

Sunda 267

terminal 186, 208

see also Early Pleistocene, Late Pleistocene,

Middle Pleistocene

plesiomorphic 256, 260
Pliocene 256

Polynesians 206

Pongo 95, 98, 99

see also orangutan

Powell-Cotton, Major Percy Horace Gordon 310

pre-adaptation, see adaptation-

pre-adaptation

pre-Darwinian 95, 129, 374

pre-Neolithic 184, 187, 191, 196, 197, 198,

199, 200, 202, 204, 205, 206

primate $56,57,61$

African 8, 53, 58, 59, 322, 325, 326, 327-30, $332-3,362$

African emigration 56

African fossils 54, 55, 57, 58, 61

African taxonomy 321, 325-8, 329, 330, 333

and hominoids 51

Asian 52, 63, 333

Asian fossils 55, 57, 58

behaviour 3

colonisation 76

conservation 7, 8, 322, 330, 333, 337, 349, 365

distribution 377

endangered 322, 329, 330, 332, 333, 349

European 57, 59, 62

European migration 55, 57

evolution 366, 374

extinction 94

interbreeding 132

interrelationships 95

Mesoamerican 76

Middle Pleistocene fossils 55

morphology 52, 53, 94, 95, 97, 99

relation to humans 5

Southeast Asian 346

speciation 87

systematics 94,96

taxonomy 5, 131, 134, 321, 325, 326, 328

see also Groves, Colin, International Union

for Conservation of Nature Species

Survival Commission-Primate Specialist

Group, and individual species names

primatology 8, 46, 94-7, 299-300, 365, 373

principal-components analysis (PCA) 31, 43,

44, 45, 190, 191

Procolobus 326, 328

badius 324, 326, 327, 328, 329, 330, 331,

$332,334,335$

gordonorum 327, 328 
kirkii 327, 328

oustaleti 328

pennantii 324, 326, 327, 328, 329, 330, 332, 334,335

pennantii pennantii 332

preussi 328

rufomitratus 324, 326, 327, 328, 329, 330, $332,334,335$

rufomitratus rufomitratus 332

tholloni 328

see also colobus, red colobus monkeys

Proconsul 61

heseloni 52, 58

proconsulids 55, 56, 57, 59

Przewalski horse, see Equus przewalskii

Przewalski, Colonel 281, 283

\author{
Ramapithecus 99 \\ Rangwapithecus gordoni 52 \\ rats $7,13,20,25,33,34,375$ \\ see also Lenomys, Paruromys, Rattus, rodents \\ Rattus \\ bontanus $40,41,46$ \\ foramineus 41 \\ hoffmanni 39, 40, 41 \\ mollicomulus 46 \\ rattus 40,41 \\ tanizumi 40, 41 \\ red colobus monkeys 8, 321-38, 379 \\ Bouvier's 331, 332, 336 \\ Miss Waldron's 322, 331, 332, 336 \\ Niger Delta 332 \\ Pennant's 331, 332 \\ Preuss' 332 \\ Tana River 322, 328, 332 \\ see also Colobus, Piliocolobus \\ Red Data Books, see International Union for \\ Conservation of Nature - Red Data Books \\ Red List, see International Union for \\ Conservation of Nature - Red List of \\ Vulnerable Species \\ Remane, Adolf 8, 93-9, 374 \\ Rhino Resource Centre 300 \\ rhinoceros \\ and Cuvier 302-7 \\ and Gray 307-10 \\ and Linnaeus 300-1, 376 \\ Colin Groves' work with 6, 47, 310-13 \\ conservation 8,313 \\ research into existing species 300 \\ systematics $300-13,376$
}

taxonomy 300, 376, 379

see also annamiticus, Ceratotherium,

Dicerorhinus, pachyderms, ungulates

Rhinoceros

bicornis 309, 311

crossii 309

holmwoodi 311

keitloa 308, 309

lasiotis 310

oswellii 309

simus 305, 307, 309, 310, 311

somaliensis 311

sondaicus 312, 313

sumatrensis 304

unicornis 301, 304, 313

ribosomal DNA, see DNA-ribosomal

rodents $8,16,25,46,301$

see also individual species names, murid, rats

Romer, AS 96

rotifers 94

Royal College of Surgeons 309

Royal Society 304

Rudapithecus hungaricus 57, 62

Rukwapithecus fleaglei 52

Russia 283, 288

Rwanda 6, 362

Saguinus 76

Sahul 8, 249-68

scala natura, see scale of being

scale of being (scala natura) 159, 160, 165, 166

'scraper reduction model' 104, 109

serow (Capricornis) 135

sexual dimorphism 16, 267, 378

sheep 177, 178, 179, 281

see also Ovis

Simpson, GG 96

'Sinodont' 183

Sivalik pongids 98, 99

Sivapithecus

himalayensis 99

sivalensis 59, 60

Smith, Andrew 308, 309

snow leopard (Uncia uncia) 286

Soejono, RP 37

Solomon Islands 137, 138, 142, 143

South Africa 302, 306, 308

South America 75, 76, 77, 83, 136

South Asia 355

Southeast Asia 8, 58, 63, 179, 183-4, 265, 347-8, 355-6 
conservation $8,345-7,353$

hominins 183-4, 204, 206, 208, 265, 378

pigs 346, 347-9, 379

primates 346

Spain 60, 216, 280

Sparrman, Anders 302

speciation 140, 215, 232, 258, 266, 345, 355

allopatric 159

causes $373,376-8$

in gibbons $51,54,61$

in gorillas 362

in howler monkeys 75-87

'incipient' 139, 140

mechanisms 8, 75, 134

role of natural disasters $75-87$

understanding 3, 373

Species Survival Commission, see

International Union for Conservation of

Nature-Species Survival Commission

spider monkeys 53, 56

see also Ateles

'splitting' 129, 133, 135, 136, 249, 266, 312,

$349,353,376,378$

sub-Saharan Africa 138

Suidae 8, 346, 347, 348, 351

see also pigs

Sulawesi 17

human fossils $184,185-8,198,200-5,207-$ 9, 377

rodents $8,13-47,375$

see also Indonesia

Sunda 8, 249-68

Sunda Shelf 40, 41

'Sundadont' 183

Sus 347

ahoenobarbus 348

barbatus 347, 348, 349

blouchi 348, 350, 354

bucculentus 348

cebifrons 348, 349, 350, 354

celebensis 208, 348

oliveri $348,349,350$

philippensis 348, 350

scrofa 347, 348

verrucosus 348, 349, 350

see also pigs

Symphalangus 99, 350

syndactylus 52, 352

see also gibbons

'synthetic evolutionary theory' 96

\section{Taeromys}

celebensis 29,41

punicans 41

Taiwan 180, 208

takhi 8, 279-95, 375

tamarins, see Saguinus

Tanzania 6, 52, 333

tarpan 281

Tarsius 95

taxonomic impediment 3, 5

taxonomy

adaptation of 130

and DNA 3

cladistic 130

mammalian 7, 134

of African primates 321, 325-8, 329, 330, 333

of hominins 218n.1, 219, 232

of Indonesian pig 347, 349, 350

of pigs $347,348,349,379,379$

of primates 5, 131, 134, 321, 325, 326, 328

of rhinoceros 300, 376, 379

see also Groves, Colin, operational taxonomic units, zoological taxonomy

Tempe Depression 17, 22, 29, 40, 46

Thailand 186, 187, 204

Thorne, Alan 183, 249, 250, 263

Timor 260

translocation 86, 291, 313

transmutation 156, 157, 159

see also mutation

typological species concept 131

Uganda 138, 338, 362

ungulates 46, 47, 132, 134, 281, 286, 301

see also Artiodactyla, pachyderms,

Perissodactyla, rhinoceros

United Kingdom 46, 95, 305, 307-9, 310

United States 14, 46, 47, 287

United States Fish and Wildlife Service

(USFWS) 353, 354

unweighted pair group method (UPGMA) 217

Vanuatu 136, 137, 142

vertical-lateral evolutionary model 162

Vietnam 55, 140, 204, 352

Virunga gorillas 363, 364, 365

Virunga National Park 363

Virunga Volcanoes 361, 362, 368 


\section{Taxonomic Tapestries}

Wallace Line 251, 255, 260, 267

warty pig, see Javan warty pig, pigs

West Africa 322

West Papua 130

Western Europe 172, 292

wild dog, see dingo

Willandra Lakes 250, 261, 263, 264

see also Lake Mungo

Wolpoff, Milford 250

wolves 176, 177, 178, 180, 285, 286, 289, 294, 337

see also Canis lupus

Yucatan 77, 83, 86

Zimbabwe 208

zoology 5, 94, 95, 156-7, 173, 304, 305, 309, 348, 349

Zoological Society of London 309

zoological taxonomy 133, 156, 177, 178, 179

zoophily 143, 144, 145, 146

Zukowsky, Ludwig 311-12 